The Urban Book Series

Daniel Baldwin Hess

Tiit Tammaru Editors

Housing Estates

in the Baltic

Countries

The Legacy of Central Planning in

Estonia, Latvia and Lithuania

Springer Open 


\section{The Urban Book Series}

\section{Editorial Board}

Fatemeh Farnaz Arefian, Bartlett Development Planning Unit, University College London, London, UK

Michael Batty, Centre for Advanced Spatial Analysis, University College London, London, UK

Simin Davoudi, Planning \& Landscape Department GURU, Newcastle University, Newcastle, UK

Geoffrey DeVerteuil, School of Planning and Geography, Cardiff University, Cardiff, UK

Andrew Kirby, New College, Arizona State University, Phoenix, AZ, USA

Karl Kropf, Department of Planning, Headington Campus, Oxford Brookes

University, Oxford, UK

Karen Lucas, Institute for Transport Studies, University of Leeds, Leeds, UK

Marco Maretto, DICATeA, Department of Civil and Environmental Engineering, University of Parma, Parma, Italy

Fabian Neuhaus, Faculty of Environmental Design, University of Calgary, Calgary, AB, Canada

Vitor Manuel Aráujo de Oliveira, Porto University, Porto, Portugal

Christopher Silver, College of Design, University of Florida, Gainesville, FL, USA

Giuseppe Strappa, Facoltà di Architettura, Sapienza University of Rome, Rome,

Roma, Italy

Igor Vojnovic, Department of Geography, Michigan State University, East Lansing, MI, USA

Jeremy W. R. Whitehand, Earth \& Environmental Sciences, University of

Birmingham, Birmingham, UK 
The Urban Book Series is a resource for urban studies and geography research worldwide. It provides a unique and innovative resource for the latest developments in the field, nurturing a comprehensive and encompassing publication venue for urban studies, urban geography, planning and regional development.

The series publishes peer-reviewed volumes related to urbanization, sustainability, urban environments, sustainable urbanism, governance, globalization, urban and sustainable development, spatial and area studies, urban management, transport systems, urban infrastructure, urban dynamics, green cities and urban landscapes. It also invites research which documents urbanization processes and urban dynamics on a national, regional and local level, welcoming case studies, as well as comparative and applied research.

The series will appeal to urbanists, geographers, planners, engineers, architects, policy makers, and to all of those interested in a wide-ranging overview of contemporary urban studies and innovations in the field. It accepts monographs, edited volumes and textbooks.

\section{Now Indexed by Scopus!}

More information about this series at http://www.springer.com/series/14773 
Daniel Baldwin Hess · Tiit Tammaru Editors

\section{Housing Estates in the Baltic Countries}

The Legacy of Central Planning in Estonia, Latvia and Lithuania

䌼 Springer Open 


\section{Editors}

\author{
Daniel Baldwin Hess \\ Department of Urban and Regional \\ Planning, School of Architecture \\ and Planning \\ University at Buffalo, State University \\ of New York \\ Buffalo, NY, USA
}

\author{
Tiit Tammaru (D) \\ Department of Geography, Centre for \\ Migration and Urban Studies \\ University of Tartu \\ Tartu, Estonia \\ OTB - Research for the Built Environment \\ Delft University of Technology \\ Delft, The Netherlands
}

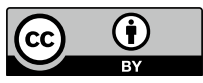

ISSN 2365-757X

The Urban Book Series

ISBN 978-3-030-23391-4

https://doi.org/10.1007/978-3-030-23392-1
ISSN 2365-7588 (electronic)

ISBN 978-3-030-23392-1 (eBook)

(C) The Editor(s) (if applicable) and The Author(s) 2019. This book is an open access publication.

Open Access This book is licensed under the terms of the Creative Commons Attribution 4.0 International License (http://creativecommons.org/licenses/by/4.0/), which permits use, sharing, adaptation, distribution and reproduction in any medium or format, as long as you give appropriate credit to the original author(s) and the source, provide a link to the Creative Commons license and indicate if changes were made.

The images or other third party material in this book are included in the book's Creative Commons license, unless indicated otherwise in a credit line to the material. If material is not included in the book's Creative Commons license and your intended use is not permitted by statutory regulation or exceeds the permitted use, you will need to obtain permission directly from the copyright holder.

The use of general descriptive names, registered names, trademarks, service marks, etc. in this publication does not imply, even in the absence of a specific statement, that such names are exempt from the relevant protective laws and regulations and therefore free for general use.

The publisher, the authors, and the editors are safe to assume that the advice and information in this book are believed to be true and accurate at the date of publication. Neither the publisher nor the authors or the editors give a warranty, express or implied, with respect to the material contained herein or for any errors or omissions that may have been made. The publisher remains neutral with regard to jurisdictional claims in published maps and institutional affiliations.

This Springer imprint is published by the registered company Springer Nature Switzerland AG

The registered company address is: Gewerbestrasse 11, 6330 Cham, Switzerland 
We affectionately dedicate this book to the memory of Rein Ahas, our patient teacher, mentor, and friend.

We also dedicate our work to those who designed, constructed, and have resided in housing estates in Estonia, Latvia and Lithuania. From them, we have learned much about communal living, urban progress and social change. 


\section{Preface}

In this book, we further our scholarly engagement of housing and cityscapes by extending the research presented in our previous book, Housing Estates in Europe: Poverty, Ethnic Segregation, and Policy Changes (D. B. Hess, T. Tammaru, and M. van Ham, eds., Springer, 2018). The fortunes of modernist housing estates continue to be topical, and this new book therefore takes a more-in-depth look into the various challenges related to them. Our research would not have been possible without Daniel Hess' academic stays in Tartu, Estonia, funded first by a Fulbright Scholar Award and second by a Marie Skłodowska-Curie international fellowship.

With Estonia as our home base, we sought to consolidate and deepen our understanding of modernist housing estates based on events and examples in the Baltic countries. We began by staging two seminars (both titled Past, Present, and Future of Socialist Housing Estates: Exploring Research Needs in the Baltic States) in October, 2016, first in Vilnius, Lithuania (and held at the Lithuanian Social Research Centre, with organisation assistance from Donatas Burneika and Marija Dremaite) followed by Riga, Latvia (and held at the Faculty of Architecture at Riga Technical University, with organisation assistance from Sandra Treija). The seminars provided opportunities for scholars to present up-to-date research related to housing estates and to engage with us in discussions about gaps in scholarly knowledge and research needs. We thus considered the advantages of a vertical scheme to research about housing estates, allowing a deep dive into housing estates in the Baltic countries [that differed from the horizontal research scheme in our first book about housing estates, in which the geographic research was large (14 case studies, from Birmingham to Moscow and from Helsinki to Athens) but the scope was limited to poverty, ethnic segregation, policy, and attendant topics] and thus the concept for this Baltic-focused book was born.

In the Baltic countries, we found an endlessly fascinating site for studying the triumphs and failures of housing estates. Centrally planned housing constitutes a significant segment of the housing stock in the Baltic countries (and a majority segment of the housing stock in larger Baltic cities). New housing opportunities introduced into the housing market - an important phenomenon in the economy of these post-socialist places - tend to emphasise the weaknesses and challenges of 
older housing, and this is a significant occurrence in Estonia, Latvia and Lithuania, as new housing is continuously added during the third decade of the post-transition era. It thus becomes more important to know how to maintain the status of housing estates in the Baltic countries and prevent their further deterioration (both physical and social). Through our work on this book, we therefore seized opportunities to assess the current status of housing estates (deeply informed by knowledge about their historical formation) and to measure changes since 1990 in their physical condition and social status. The chapters herein delve into influencing forces for housing estates in the Baltic countries, and also explore how housing estates themselves in Estonia were influencers (since their planning and design won important USSR awards). We especially wanted to characterise the trajectory of housing estates in various Baltic settings and in various conditions related to their establishment in the decades following World War II. Chapters in this book also explore particular characteristics of Baltic housing estates in significant detail, such as the (unfulfilled) promise in the original design of nearby and convenient service networks that supported the primary residential function of these modernist districts. This book thus offers a timely overview of the current status of large housing estates in Estonia, Latvia and Lithuania, their trajectories, and future outlook, which we have summarised in seven takeaway lessons.

The book would not have been possible without contributions from author teams from throughout the Baltic countries (and stretching to Finland, the Netherlands, Norway, Scotland and the United States). We are indebted to Brendan Seney for his assistance in preparing the final manuscript; for tireless English-language editing from Susan June; and assistance with the book manuscript from Alex Bitterman, Emily Moll, Kelley Mosher, Joshua Wilcox and Sydney Zuckerman. Our research approach was developed through extensive conversations with Kadri Leetmaa and Anneli Kährik. Our progress benefitted from presentations of work-in-progress by Daniel Hess at the Dorpater Dozentenabend Lecture Series at the University of Tartu (in Tartu, Estonia, December 2017). During the effort to produce this edited volume, Daniel Hess was Visiting Scholar and Director in the Centre for Migration and Urban Studies, University of Tartu.

The research leading to this work has received funding from the European Union's Horizon 2020 research and innovation programme under Marie Skłodowska-Curie grant agreement number 655601. Support also came from three grants from the Estonian Research Council: Institutional Research Grants IUT2-17 on Spatial Population Mobility and Geographical Changes in Urban Regions, PUT PRG306 Understanding the Vicious Circles of Segregation. A Geographic Perspective, Infotechnological Mobility Observatory, and RITA-Ränne. The European Research Council funded this research under the European Union's Seventh Framework Programme (FP/2007-2013)/ERC [Grant Agreement No. 615159] (ERC Consolidator Grant DEPRIVEDHOODS, Socio-spatial inequality, deprived 
neighbourhoods, and neighbourhood effects). Delft University of Technology University supported this research through the Visiting Professors programme of the Faculty of Architecture and the Built Environment.

Buffalo, USA

Daniel Baldwin Hess

Tartu, Estonia

Tiit Tammaru

January 2019 


\section{Contents}

\section{Part I Introduction}

1 Modernist Housing Estates in the Baltic Countries: Formation, Current Challenges and Future Prospects. . . . . . . . . . . . 3 Daniel Baldwin Hess and Tiit Tammaru

\section{Part II Context and Vision}

2 A Turbulent Political History and the Legacy of State Socialism in the Baltic Countries . . . . . . . . . . . . . . . . . . 31

Allan Puur, Martin Klesment and Luule Sakkeus

3 The Rise and Demise of the Soviet-Made Housing Shortage in the Baltic Countries Michael Gentile

4 The Exceptional Design of Large Housing Estates in the Baltic

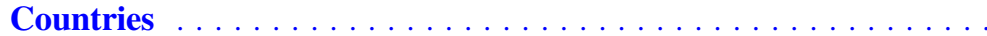

Marija Drèmaitè

5 Baltic Crossings: Soviet Housing Estates and Dreams of Forest-Suburbs . . . . . . . . . . . . . . . . . . . . . 95 Laura Berger, Sampo Ruoppila and Kristo Vesikansa

6 Mass Housing and Extensive Urbanism in the Baltic Countries and Central/Eastern Europe: A Comparative Overview . . . . . . . . 117 Miles Glendinning

Part III Housing the Masses: Establishing Socialist-Modernist Housing Estates in the Baltic Countries

7 Architectural Transcendence in Soviet-Era Housing: Evidence from Socialist Residential Districts in Tallinn, Estonia Daniel Baldwin Hess and Pille Metspalu 
8 Socialist Ideals and Physical Reality: Large Housing Estates in Riga, Latvia

Sandra Treija and Uǵis Bratuškins

9 Living in a Large Housing Estate: Insider Perspectives from Lithuania

Viltė Janušauskaitè

Part IV Exploring the Socio-Demographic and Ethnic Characteristics of Previous and Current Housing Estate Dwellers

10 Socio-economic and Ethnic Trajectories of Housing Estates in Tallinn, Estonia.

Anneli Kährik, Karin Kangur and Kadri Leetmaa

11 Residential Change and Socio-demographic Challenges for Large Housing Estates in Riga, Latvia

Zaiga Krišjāne, Māris Bērziņš, Guido Sechi and Jānis Krūmiņš

12 Soviet Housing Estates in Vilnius, Lithuania: Socio-ethnic Structure and Future(-Less?) Perspectives

Donatas Burneika, Rūta Ubarevičienė and Aušra Baranuskaitė

\section{Part V Complexities of Built Environments in Housing Estates}

13 Incomplete Service Networks in Enduring Socialist

Housing Estates: Retrospective Evidence from Local

Centres in Estonia.

Kadri Leetmaa and Daniel Baldwin Hess

14 Collectivist Ideals and Soviet Consumer Spaces:

Mikrorayon Commercial Centres in Vilnius, Lithuania and Tallinn, Estonia

Matas Šiupšinskas and Epp Lankots

15 Between Community and Private Ownership in Centrally

Planned Residential Space: Governing Parking in Socialist

Housing Estates.

Tauri Tuvikene

\section{Part VI Imagining the Future Lives of Housing Estates}

16 State-Subsidised Refurbishment of Socialist Apartment

Buildings in Estonia

Kalle Kuusk and Jarek Kurnitski 
17 Retrofitting Soviet-Era Apartment Buildings with 'Smart City' Features: The H2020 SmartEnCity Project in Tartu, Estonia . Rein Ahas, Veronika Mooses, Pilleriine Kamenjuk and Raimond Tamm

Index 


\section{Editors and Contributors}

\section{About the Editors}

Daniel Baldwin Hess is Professor and Chairperson of the Department of Urban and Regional Planning in the School of Architecture and Planning at the University at Buffalo, State University of New York. He earned a doctoral degree in urban planning from the University of California, Los Angeles. While this book was in progress, he was Visiting Scholar and Director of the Centre for Migration and Urban Studies at the University of Tartu, Estonia, where he was a Marie Skłodowska-Curie International Fellow funded by the European Commission. His research addresses interactions between housing, transportation, land use and other public concerns, and he develops new pathways for understanding the complex socio-economic and ethnic landscape of cities and spatial inequalities. In his scholarship, he explores metropolitan form and urban planning practice and policy, sometimes interactively and sometimes separately, but always as a means to improve city functions and urban life. He is a former Fulbright Scholar at Tallinn University of Technology in Estonia, a National Endowment for the Humanities Fellow at Columbia University and winner of an Eisenhower Fellowship. He is co-editor of the journal Town Planning Review (Liverpool University Press) and co-editor of the book Housing Estates in Europe: Poverty, Ethnic Segregation, and Policy Challenges (Springer Publishing 2018).

Tiit Tammaru is Professor of Urban and Population Geography at the Department of Geography, University of Tartu. He leads the development of longitudinal linked censuses and registers data for urban and population geographic studies in Estonia. He was trained in human geography and received a doctoral degree from the University of Tartu in 2001. Since then, he has worked as a Lecturer, Researcher, Senior Researcher and Professor at the Department of Geography, University of Tartu. He has also worked as a Guest Researcher at the Department of Geography, University of Utah, 
and Department of Geography, Umeå University. Currently, he is a Visiting Professor at the Neighbourhood Change and Housing research group at the Department OTBResearch for the Built Environment, Faculty of Architecture and the Built Environment, Delft University of Technology. He is co-editor of the book Housing Estates in Europe: Poverty, Ethnic Segregation, and Policy Challenges (Springer Publishing 2018).

\section{Contributors}

Rein Ahas Mobility Lab, Department of Geography, University of Tartu, Tartu, Estonia

Aušra Baranuskaitė Institute of Human Geography and Demography, Lithuanian Social Research Centre, Vilnius, Lithuania

Laura Berger Department of Architecture, Aalto University, Helsinki, Finland

Māris Bērziṇš Department of Human Geography, University of Latvia, Riga, Latvia

Uǵis Bratuškins Faculty of Architecture, Riga Technical University, Riga, Latvia

Donatas Burneika Institute of Human Geography and Demography, Lithuanian Social Research Centre, Vilnius, Lithuania

Marija Drèmaitė Department of History, Vilnius University, Vilnius, Lithuania

Michael Gentile Department of Sociology and Human Geography, University of Oslo, Oslo, Norway

Miles Glendinning Scottish Centre for Conservation Studies, University of Edinburgh, Edinburgh, Scotland

Daniel Baldwin Hess Department of Urban and Regional Planning, University at Buffalo, State University of New York, Buffalo, New York, USA

Viltė Janušauskaitė Department of History, Vilnius University, Vilnius, Lithuania

Anneli Kährik Centre for Migration and Urban Studies, University of Tartu, Tartu, Estonia

Pilleriine Kamenjuk Mobility Lab, Department of Geography, University of Tartu, Tartu, Estonia

Karin Kangur Centre for Migration and Urban Studies, University of Tartu, Tartu, Estonia 
Martin Klesment School of Governance, Law and Society, Estonian Institute for Population Studies, Tallinn University, Tallinn, Estonia

Zaiga Krišjāne Department of Human Geography, University of Latvia, Riga, Latvia

Jānis Krūmiņš Department of Human Geography, University of Latvia, Riga, Latvia

Jarek Kurnitski Department of Civil Engineering and Architecture, Nearly Zero Energy Buildings Research Group, Tallinn University of Technology, Tallinn, Estonia

Kalle Kuusk Department of Civil Engineering and Architecture, Nearly Zero Energy Buildings Research Group, Tallinn University of Technology, Tallinn, Estonia

Epp Lankots Institute of Art History and Visual Culture, Estonian Academy of Arts, Tallinn, Estonia

Kadri Leetmaa Centre for Migration and Urban Studies, University of Tartu, Tartu, Estonia

Pille Metspalu Centre for Migration and Urban Studies, University of Tartu, Tartu, Estonia

Veronika Mooses Mobility Lab, Department of Geography, University of Tartu, Tartu, Estonia

Allan Puur School of Governance, Law and Society, Estonian Institute for Population Studies, Tallinn University, Tallinn, Estonia

Sampo Ruoppila Department of Social Research, University of Turku, Turku, Finland

Luule Sakkeus School of Governance, Law and Society, Estonian Institute for Population Studies, Tallinn University, Tallinn, Estonia

Guido Sechi Department of Human Geography, University of Latvia, Riga, Latvia Matas Šiupšinskas Department of History, Vilnius University, Vilnius, Lithuania Raimond Tamm Tartu City Government, Tartu, Estonia

Tiit Tammaru Centre for Migration and Urban Studies, University of Tartu, Tartu, Estonia

Sandra Treija Faculty of Architecture, Riga Technical University, Riga, Latvia

Tauri Tuvikene Centre for Landscape and Culture, School of Humanities, Tallinn University, Tallinn, Estonia 
Rūta Ubarevičienė Institute of Human Geography and Demography, Lithuanian Social Research Centre, Vilnius, Lithuania;

Faculty of Architecture and the Built Environment, Department of Urbanism, Delft University of Technology, Delft, The Netherlands

Kristo Vesikansa Department of Architecture, Aalto University, Helsinki, Finland 


\section{Part I \\ Introduction}




\title{
Chapter 1 \\ Modernist Housing Estates in the Baltic Countries: Formation, Current Challenges and Future Prospects
}

\author{
Daniel Baldwin Hess $\mathbb{D}$ and Tiit Tammaru $\mathbb{D}$
}

\begin{abstract}
This opening chapter of the book Housing Estates in the Baltic Countries: The Legacy of Central Planning in Estonia, Latvia and Lithuania presents seven important takeaway messages distilled from the chapters of this volume that, taken together, provide a comprehensive overview of the formation, current challenges and future prospects of large housing estates in the Baltic countries. Modernist housing built between the 1960s and the early 1990s forms a large share of the housing stock in the capital cities of the Baltic states. Their sheer size suggests that various methods of reconstruction, rather than downsizing or even demolition, would be among the ideal strategies for their future development. Today, reconstruction of these districts and housing contained therein is mainly the responsibility of private owners, since the public sector relinquished most of the housing sector in the early 1990s. Private apartment owners, organised into building-based flat-owners' associations, often lack the ability to undertake comprehensive renovation of apartment buildings and regeneration of surrounding neighbourhoods. For viable solutions to emerge, the public sector must again assume a prominent role. A comprehensive renovation strategy must be structured to include urban space even larger than individual apartments or apartment buildings and encompass (a) improving the physical environment of the apartment buildings and neighbourhoods; (b) enhancing the social mobility and social integration of the inhabitants (since many possess an ethnic minority background); and (c) facilitating integrated connectivity between housing estates and surrounding metropolitan space through transport, jobs, services and various other activities.
\end{abstract}

Keywords Housing estates • Baltic countries - Central planning • Retrofitting • Urban regeneration - Sustainable city

\footnotetext{
D. B. Hess $(\bowtie)$

Department of Urban and Regional Planning, University at Buffalo, State University of New York, New York, USA

e-mail: dbhess@buffalo.edu

T. Tammaru

Centre for Migration and Urban Studies, University of Tartu, Tartu, Estonia

e-mail: tiit.tammaru@ut.ee

(C) The Author(s) 2019

D. B. Hess and T. Tammaru (eds.), Housing Estates in the Baltic Countries,

The Urban Book Series, https://doi.org/10.1007/978-3-030-23392-1_1
} 


\subsection{Introduction}

In the decades immediately following World War II, modernist apartment buildings within large housing estates were constructed in European cities to meet crushing housing demand. The construction of modernist housing estates was widespread in the centrally planned countries of Europe ruled by Communist parties, and the Baltic countries were no exception. Following World War II, housing estates began to shape the physical configuration of cities-especially their spatial layout and housing stocks - with profound effects that are still visible today (Hess et al. 2018a). Housing estates also maintained a place of prestige in Soviet cities until the collapse of the Union of Soviet Socialist Republics (USSR) (Hess et al. 2018a). Although nearly three decades have passed since the disintegration of the Soviet Union, Soviet-era housing still forms a significant share of the housing stock in major cities. The relative position of Soviet-era housing estates on the housing ladder has declined, while the position of central city neighbourhoods and suburbs has risen. In this book, we explore in significant detail the formation of Soviet-era housing estates and analyse their trajectories of change in order to better understand and to better address contemporary challenges.

Today, many people perceive socialist housing estates as obsolete and socially stigmatised, and the initially envisioned lifespan of apartment buildings - approximately 30 years - has now been exceeded (Ahas et al. 2019). Since nearly all housing units and apartment buildings require renovation, one option would be to completely demolish mid-twentieth-century housing estates and construct replacement housing to satisfy today's lifestyles and building standards, an approach announced in a large-scale khrushchëvki demolition project in Moscow (Gunko et al. 2018). But since the number of people living in housing estates is large and since apartments in housing estates are privately owned, the cost to demolish and built replacement housing is three to four times higher than comprehensive renovation. Consequently, it is virtually impossible to demolish housing at such large scales (Ahas et al. 2019; Kuusk and Kurnitski 2019). In Tallinn, for example, such a demolition programme would affect nearly $60 \%$ of city dwellers. Various renovation options are thus a more realistic way forward, especially since the structural condition of the apartment buildings is generally satisfactory and renovation is needed mainly for other features of the apartment buildings, especially reducing energy consumption, regulating indoor climates, rehabilitating facades and reinforcing balconies (Kuusk and Kurnitski 2019).

Modernist housing estates have attractive features that may be improved further through various renovation strategies. For example, apartment buildings dating from the era of state socialism provide affordable housing and they are often located close to city centres and/or are well connected to city centres through public transport. Through renovation, their physical appearance can be significantly improved. People living in housing estates could benefit from investments in community social infrastructure, including schools. In order to achieve better outcomes, we emphasise that individual apartment-based and apartment 
building-based renovation (as is the norm today) should continue, and area- or neighbourhood-based renovation should be introduced to stabilise the development trajectory of neighbourhoods and reverse the downward spiral of neighbourhoods. For this to happen, the public sector must again assume a role, ideally helping to manage the complex socio-spatial structures that have evolved in the do-it-yourself urbanism framework prevalent since the 1990s which has produced both successes and eclectic outcomes (Kuusk and Kurnitski 2019). Instead of demolishing them, we can finally complete large housing estates (Tammis 2017) by enhancing various envisaged elements that were unfinished under socialism-including mixed uses and activities, embedded services networks and employment opportunities contained within - to enhance the long-term potential of housing estates.

This book draws together various perspectives that address the complexity of challenges that Soviet-era modernist housing estates face today in the Baltic countries. We begin by clarifying the motivations for establishing housing estates in the post-World War II era to seek a better understanding of the USSR housing system in which housing estates became a hallmark. We explore the social and ethnic landscapes and built environments of housing estates, and we consider various renovation strategies to prepare housing estates for their future lives in the context of a shift from a highly state-controlled and socialist housing system to a neo-liberal market-oriented system (Hess et al. 2018a). The Baltic countriesEstonia, Latvia and Lithuania-form a unified region in many respects, and the three nations were simultaneously occupied by the Soviet Union from World War II until 1991, when the USSR disintegrated (cf. Drèmaitè 2019). While recent books have provided a pan-European view of socio-spatial changes (Tammaru et al. 2016) and the role of large housing estates in such changes (Hess et al. 2018b), this book provides an in-depth exploration of large housing estates in the Baltic countries, focusing on their formation, trajectories of change and future prospects. We have distilled the following seven synthetic takeaway messages from the ensuing chapters in this book.

Lesson 1: The formation of housing estates in Eastern Europe and Soviet Union, including the Baltic countries, was somewhat delayed compared to Western Europe. Housing estates nonetheless became key elements of the residential cityscape. Most Baltic cities were situated on relatively flat land, and the addition of modernist residential towers added vertical planning to horizontal urban space, allowing cities to grow in a new dimension.

Lesson 2: Although socialist societies were closed, ideas and knowledge about urban planning travelled across the Berlin Wall and through the Iron Curtain. Ideas that were critical to planning large housing estates in the Baltic countries were obtained from architects' study trips, most often to neighbouring Nordic countries. Two forces consequently combined in the Baltic countries in the decades following World War II: international modernism and Soviet socialism.

Lesson 3: A shift from Garden City and City Beautiful inspirations in Stalinesque guise (through the 1950s until the mid-1960s) to a Concrete City orientation (from the mid-1960s through the 1980s) took place in the physical configuration of housing estates. This phenomenon can be attributed to an abrupt 
political shift that prioritised attention towards housing needs and industrialised the construction industry.

Lesson 4: Housing estates in the Soviet Union were a vast experiment in socio-spatial organisation of cityscapes. They embodied an egalitarian ideology in which massive residential spaces structured the everyday lives of people in relation to the neighbourhoods in which they lived. Deliberate socio-spatial mixing, however, did not necessarily lead to joint activities of ethnic and socio-economic groups.

Lesson 5: A shift from a more communal to individualistic lifestyle took place over time in housing estates. In the early decades of the Soviet Union, shared public space (outdoors, and within community areas) was maximised and individual space (indoors, within apartments) was minimised. As the residential density of housing estates increased, architects expanded the size of individual apartments in subsequent projects to maximise the comfort of occupants.

Lesson 6: Housing estates that were located at a certain distance from city centres in places of abundant land are, relatively speaking, more advantageously located today as cities have sprawled since then. They are usually well connected to city centres via public transport.

Lesson 7: There are four potential ways to consider the next stage for housing estates: (a) do-nothing, (b) downsize, (c) demolish (and replace) and (d) renovate. Since the apartment buildings in housing estates consume a substantial share of the total housing stock and since individual apartments are mostly owner-occupied, demolition is a difficult option. With time, the do-nothing approach has gradually given way to building-based renovation. The next step would be more comprehensive renovation coordinated by the public sector; this would help improve building-level management and finally complete housing estates relative to the original aims of the housing programme under which they were conceived and planned.

The remainder of this introductory chapter will elaborate on these takeaway messages in greater detail.

Lesson 1: The formation of housing estates in Eastern Europe and Soviet Union, including the Baltic countries, was somewhat delayed compared to Western Europe. Housing estates nonetheless became key elements of the residential cityscape. Most Baltic cities were situated on relatively flat land, and the addition of modernist residential towers added vertical planning to horizontal urban space, allowing cities to grow in a new dimension.

The starting point for the formation of large housing estates in the USSR can be attributed to the 1957 Communist Party Congress (Hess et al. 2018a). Industrialisation subsequently triggered employment-based migration to cities and new housing units were built at breakneck speed in vast planned residential districts (Burneika et al. 2019; Kährik et al. 2019; Krišjāne et al. 2019). Amid a USSR occupation from the 1940s until 1991 and forced industrialisation that fueled urbanisation-due in part to migration from other parts of the Soviet Union-the demand for post-World War II housing was acute, especially in the capital cities of Tallinn (Estonia), Riga (Latvia) and Vilnius (Lithuania). See Fig. 1.1. The cities underwent profound changes, since urbanisation had been only modest before 
1 Modernist Housing Estates in the Baltic Countries ...

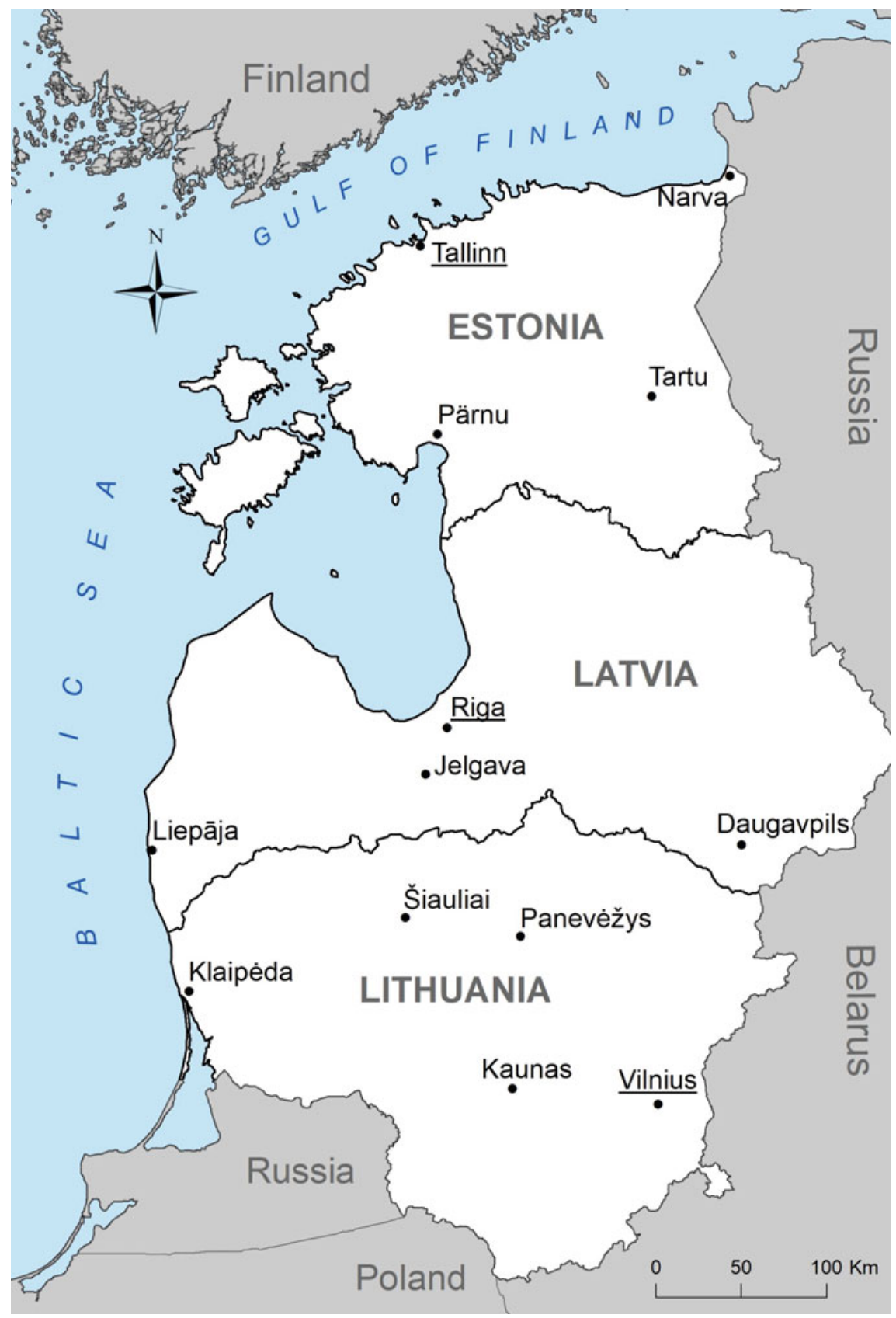

Fig. 1.1 Location of Estonia, Latvia and Lithuania and their capital cities and key urban centres. Source Figure prepared by Annika Väiko 
World War II (Puur et al. 2019). The spatial structure of Baltic cities was relatively simple at that time: historic medieval towns were surrounded by late nineteenthand early twentieth-century neighbourhoods of worker housing and villas. In the Soviet years, an ample layer of modernist housing was added, forming the most important segment of the housing stock.

Post-World War II urbanisation in Estonia, Latvia and Lithuania was strongly linked to in-migration from other parts of the Soviet Union, and these mainly Russian-speaking (now) ethnic minorities became the majority urban population in many cities, especially in Estonia and Latvia (Puur et al. 2019; Hess et al. 2012; Leetma et al. 2015). For example, the population of Tallinn increased by $70 \%$ between 1959 and 1989 and the share of Russian speakers increased to almost 50\% of the city's population (Kährik et al. 2019). The respective share is higher in Riga (Krišjāne et al. 2019) and lower in Vilnius, where Poles form the third largest ethnic group (Burneika et al. 2019). This migration produced demand for new housing, resulting in reshaped cityscapes and, notably, the addition of planned modernist estates to house workers and their families (Fig. 1.2). When the USSR disintegrated in $1991,61 \%$ of the population of Tallinn and $74 \%$ of the population of Riga lived in large housing estates built since the 1950 s. By $2011,58 \%$ of the population in Tallinn, $75 \%$ of the population in Riga and $67 \%$ of the population in Vilnius lived in large housing estates (see Fig. 1.3).

Within the vast Soviet Union housing programme, Baltic housing estates were usually ambitious and often original, and architects in Estonia, Latvia and Lithuania challenged the rigid standard housing guidelines that were enforced since the 1960s in the USSR. There was an ambition to give new residential districts a sense of uniqueness. With a 'westward gaze' towards architectural and town planning innovation in Western Europe and even North America, Baltic architects and city planners aimed to design housing estates with a sense of dignity, especially in the capital cities (Berger et al. 2019; Hess and Metspalu 2019; Metspalu and Hess 2018). The smaller industrial towns were often planned in a more uniform fashion. Two housing estates in the Baltic countries were awarded the prestigious Soviet Union State Prize for urban residential design: Žirmūnai (Lithuania) in 1968 and Väike-Õismäe (Estonia) in 1986 (Drèmaitè 2019). The Lenin Prize, the highest award in the Soviet Union, was bestowed in 1974 upon Lazdynai in Vilnius.
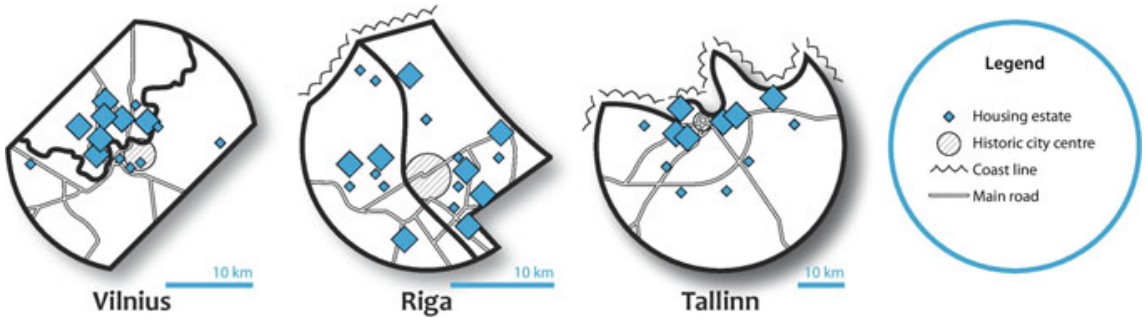

Fig. 1.2 Metropolitan distribution of housing estates in Tallinn, Estonia; Riga, Latvia and Vilnius, Lithuania. Source Figure prepared by Raivo Aunap 
Fig. 1.3 Share of residents living in housing estates in the Baltic capital cities, 1989 , 2000 and 2011

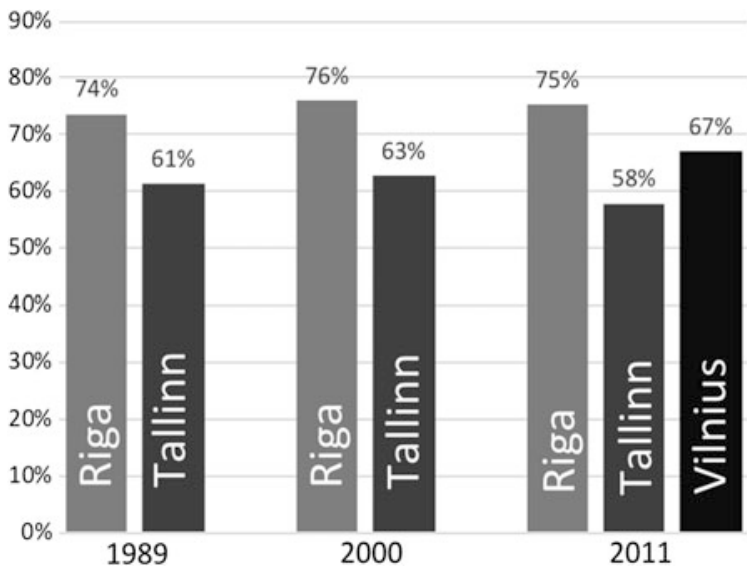

However, architects in the Baltic countries also had to surrender to the pressures of mass construction of low-cost housing, limiting the creativity of architects.

The Soviet system provided a unique opportunity to experiment with new models of city planning that was embraced by architects (Hess and Metspalu 2019). A centrally planned economy and government ownership of all land and industry, including the construction sector, permitted a grand-scale approach to the processes of industrialisation, employment-driven migration and urbanisation (Burneika et al. 2019; Kährik et al. 2019; Krišjāne et al. 2019). The rapid expansion of housing in post-World War cities in the Baltic countries thus dramatically altered the region's traditional cityscapes. But the initial estate-based housing programmes were delayed in the Eastern Bloc (compared to Western Europe), mainly due to Communist Party leader Joseph Stalin's preference for expensive grand architecture (also known as Stalin Baroque), a general emphasis on heavy industry under central planning and, accordingly, a low priority assigned to housing construction (Berger et al. 2019; Gentile 2019). However, construction of housing estates continued through the early 1990s - a longer duration in the Eastern Bloc compared to Western Europe-due to intensive urbanisation (Fig. 1.4).

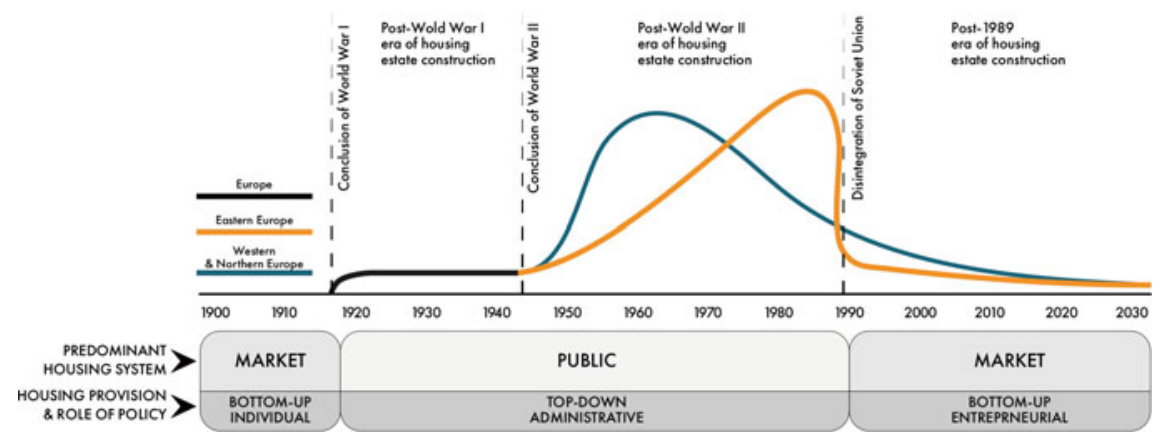

Fig. 1.4 Growth and decline of housing estate construction in Eastern and Western Europe 
Apartments were centrally allocated to residents queued in housing lists, and rents were generously subsidised (Gentile 2019). The waiting period for a new apartment lasted for years, and acquiring a flat was considered an immense achievement for families, especially in the 1960s and 1970s (Janušauskaite 2019). When apartments in newly built housing estates in Soviet cities were allocated to occupants, preference was given to migrants, usually arriving through 'organised channels' of migration from the other Soviet Republics and needing apartments immediately upon arrival (Krišjāne et al. 2019). Despite the addition of seemingly endless apartment buildings in brand-new urban neighbourhoods, people were crowded into an inadequate number of apartments with meager per-capita living space. The allowed living space according to SNiP (a Russian acronym for Construction Norms and Rules), excluding kitchen and bathroom, was defined as 9 $\mathrm{m}^{2}$ per person (cf. Gentile 2019), while the minimum provision was set to $4 \mathrm{~m}^{2}$ (Treija and Bratuškins 2019).

The main spatial element of housing estates became mikrorayon (Treija and Bratuškins 2019) which were further organised into makrorayons or housing estate districts. The number of people living in a typical mikrorayon ranged between 5,000 and 15,000 people, while the size of housing estate districts varied even more, between 30,000 and 100,000 people in the Baltic countries (Burneika et al. 2019; Kährik et al. 2019; Krišjāne et al. 2019) and even more greatly elsewhere in the Soviet Union and Eastern Europe, especially in larger cities such as Moscow, St. Petersburg, Kiev or Bucharest (French and Hamilton 1979). Usually sited on greenfields where developable space was available, land use separation and other urban planning techniques were employed to create master-planned 'modernist' residential space that was thought at the time to be an improvement over traditional city form. Also, in these peripheral areas, necessary urban infrastructure could be provided with a reasonable investment (Treija and Bratuškins 2019).

Lesson 2: Although socialist societies were closed, ideas and knowledge about urban planning travelled across the Berlin Wall and through the Iron Curtain. Ideas that were critical to planning large housing estates in the Baltic countries were obtained from architects' study trips, most often to neighbouring Nordic countries. Two forces consequently combined in the Baltic countries in the decades following World War II: international modernism and Soviet socialism.

Housing estates arose in the decades following World War II in Estonia, Latvia and Lithuania to meet desperate housing needs, but Baltic housing estates were distinguished from housing estates elsewhere in the Soviet Union, even though all were built under the same strictly controlled and centrally administered Soviet system. It was compulsory to follow the USSR norms for housing estates in the Baltic countries, especially those norms related to the design of apartment buildings; nonetheless, a detectable Western influence on town planning, especially from Nordic countries, was absorbed by the Baltic countries during the Soviet years (Hess and Metspalu 2019). Furthermore, the Baltic countries served as a bridge that allowed these 'imported' ideas to travel further to the East, and Nordic housing 
estates consequently became exemplars for housing estates throughout the USSR (Šiupšinskas and Lankots 2019).

Architects from Estonia, Latvia and Lithuania reproduced concepts especially from Finnish (notably Pihlajamäki and Tapiola, near Helsinki) and Swedish (notably Vällingby, near Stockholm) housing estates, with design inspiration especially evident in Estonia owing to its close links with Finland (Šiupšinskas and Lankots 2019). In fact, Finnish housing estates were inspired by the Swedish model for new suburban high-density residential settlements, which itself was based on ideas from British and American inter-war urban planning, including the Garden City concept, neighbourhood residential planning and post-War 'New Towns' (Berger et al. 2019; Hall 2014) (Fig. 1.5). Thus, two forces combined in the Baltic countries in the decades following World War II: international modernism and Soviet socialism. The outcome has been labelled 'socmodernism' (a term proposed by Crowley), a specific version of Modernism distinguished from Western Modernism (Drèmaitè 2019).

In many European countries, including the United Kingdom, France and the Netherlands, the focus of post-World War II housing expansion was social housing (and not necessarily within housing estates) and did not appeal to Soviet planners (Šiupšinskas and Lankots 2019). In contrast, however, the combination of egalitarian social aims and elaborate spatial planning considerations for housing estates captured the attention of architects and urban planners of the Soviet Union. There was a perception that social housing was intended for low-income and working-class people (or social groups who relied on state support for housing), but socialist leaders were in search of models of equal housing for everyone. Such housing models were readily found in the social-democratic Nordic countries. Housing was at the very heart of Nordic welfare systems (Andersson and Kährik 2016). In fact, Vällingby, a Stockholm housing estate established in 1954, strongly reflected the planned welfare state of mid-twentieth-century Europe (Wassenberg 2013) since the social-democratic environment required that affordable housing be ubiquitous, accessible to all people and spatially coherent (Fig. 1.5). Housing estates thus became spatial manifestations of the socialist ideology in the Soviet Union and Eastern Europe (Kährik and Tammaru 2010; Kovács and Herfert 2012).

How did Soviet-era architects in the Baltic countries learn, as early as the 1950s, about housing estate design outside of the Soviet Union, given the conditions in the Soviet Union of control, censorship and isolation? A specific policy of collaboration and friendship with the Soviet Union offered an important corridor for exchange of ideas for Estonia, and meaningful contact between Finland and Estonia was maintained through most of the operable years of the Soviet Union, especially since the Khrushchëv Thaw (Berger et al. 2019; Kalm 2012). The first official delegation to Finland took place in June 1959 and it consisted of 21 specialists from Latvia, Estonia, Lithuania and the city of Leningrad (Drèmaite 2019). The Association of Finnish Architects made its first excursion to Tallinn in 1962 (Berger et al. 2019). Knowledge was also shared through professional journals, books and exhibitions. Although the division between the Western World and the Eastern Bloc was remarkable during the Cold War, there was considerable mutual exchange- 

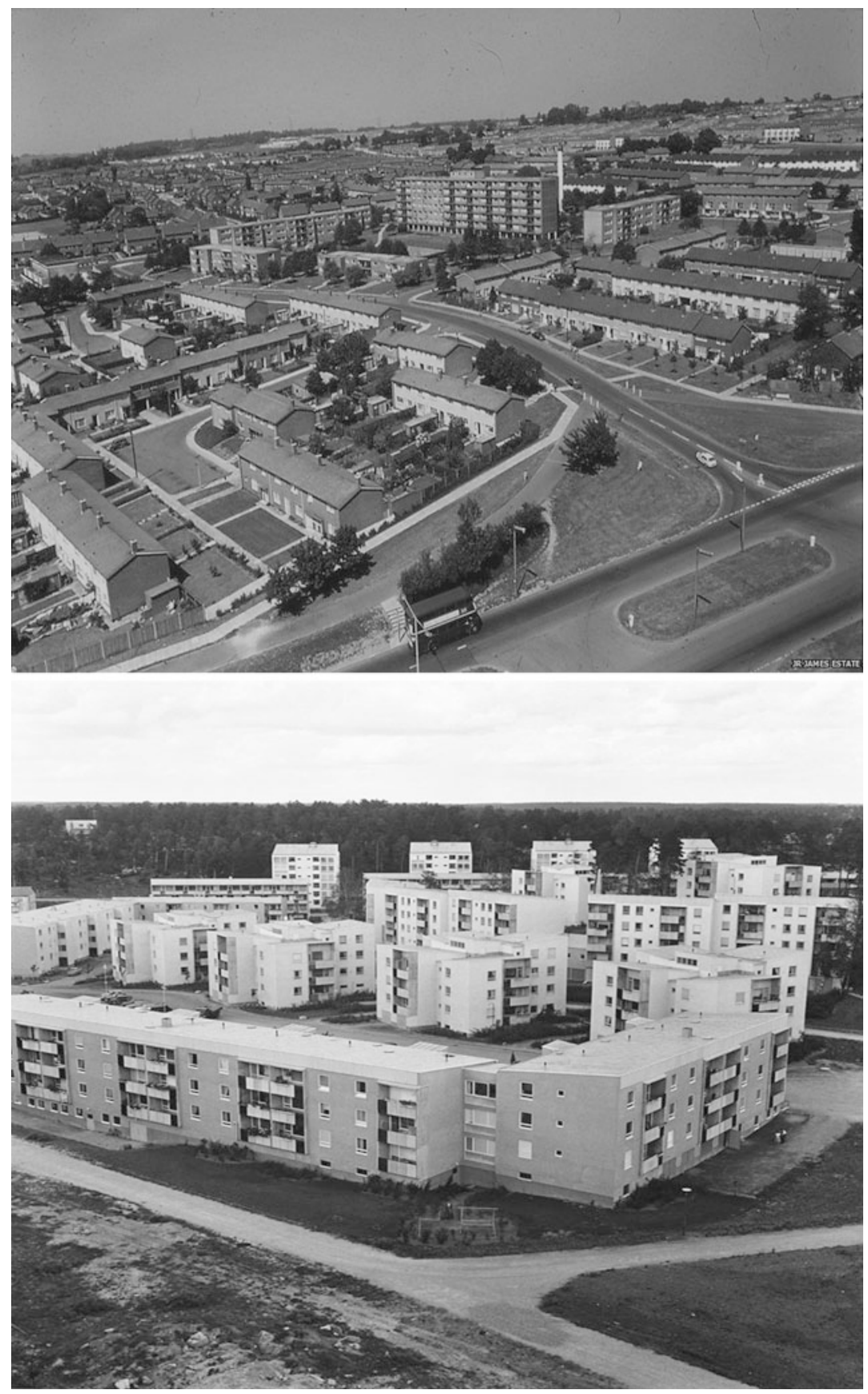

Fig. 1.5 Views of Stevenage 'New Town' (upper panel) and Vällingby (lower panel). Source Wikimedia Commons 
despite significant institutional and political barriers - in both directions between Estonia and Finland between the late 1950s and the 1970s, a period coinciding with rapid production of housing estates.

Estonia, due to its membership in the Soviet Union, was in a more restricted position for international engagement and was consequently a greater beneficiary than Finland of this exchange. Estonians interacted with visiting Finnish architects, visited Finland (and other countries) on a restricted basis on official study trips, co-hosted architectural exhibitions and acquired Western magazines [especially the French publication L'architecture D'aujourd'hui (translated: Architecture of Today] and other literature about architecture and city planning (Drèmaitè 2019; Hess and Metspalu 2019). These international publications from Finland and Sweden (and beyond) became a 'window to the west' for Estonians, and the relationship between the two countries could be described as a 'hinge-point' of architectural influences between 'Western' and 'socialist' countries during the Soviet years (Berger et al. 2019; Hess and Metspalu 2019). Mutual exchange was made easier when regular ferry service between Helsinki and Tallinn was restored in 1965 and the sight of Finnish visitors in Estonia became more common; still, it was not an easy exchange for Estonians, as travel permits were required (Berger et al. 2019). Thus, Estonia and Finland were in the nexus of Baltic cooperation that linked urban ideas across the Iron Curtain.

With great influence on architecture, city building and city planning from Finland, however, the built works in the Baltic countries-including apartment buildings, housing estates and other aspects of the residential sector-were of lower quality in physical aspects than built works in Finland. The outcome is a cityscape that integrates Western ideas and the specific context of the Soviet system, producing an atmosphere in which housing estates exhibiting characteristics of the 'Soviet West' and reflecting 'Baltic exceptionalism' are evident (Drèmaite 2019; Glendinning 2019). Socialist ideology and standardised designs and construction came from the East. This ideology, with its vigorous focus on equality and related apartment building models and spatial planning rules, often led to monotonous architecture, unwelcoming public space and unending repetition of housing estates (Hess and Metspalu 2019). Town planning ideas and physical form of housing estates came from the North along with a stronger attachment to the landscape. Despite being restricted by rules and serial housing, some independent architectural thinking was allowed that shaped the formation of large housing estates in the Baltic republics (Hess and Metspalu 2019). In housing estates from the 1950s and 1960s (e.g. the first plan of Mustamäe), architectural influences in Estonia from Finland are noticeable - including references to organicism, use of natural materials and naturalistic site layout that emphasised existing landscape features-but distance to Western models was maintained and a certain 'Soviet' touch was added from the outset, especially a greater degree of standardisation (Berger et al. 2019). In later decades, the Soviet influences became more prominent as each new housing estate became denser compared to previous projects. Still, the architecture in the Baltic countries was less grandiose and there was a stronger link to nature compared to many other cities in the USSR and Eastern Europe (Glendinning 2019). 
Lesson 3: A shift from Garden City and City Beautiful inspirations in Stalinesque guise (through the 1950s until the mid-1960s) to a Concrete City orientation (from the mid-1960s through the 1980s) took place in the physical configuration of housing estates. This phenomenon can be attributed to an abrupt political shift that prioritised attention towards housing needs and industrialised the construction industry.

Khrushchëv-era housing marking the initiation of mass housing construction in the Soviet Union in the 1950s and early 1960s tends to possess features that suggest how apartment buildings were inspired by the (a) Garden City movement and (b) 'neighbourhood unit' concept first introduced by the American planner Clarence Perry in 1929, originating with the seminal 1943 County of London Plan by Forshaw and Abercrombie (Berger et al. 2019). Hence, the origins of Soviet urban planning ideals emanate from ideologically opposite contexts (the United States and Great Britain). Key features of built environments included low-rise apartment buildings, human-scaled design, small and compact neighbourhoods focused around elementary schools, harmony with nature, natural building materials, landscape elements and mature trees, and protected pathways and convenient walkability. High-quality materials were used in the design of buildings and other structures.

Garden City principles broadly and strongly influenced designs and plans for modernist housing estates in Sweden and Finland (Vaattovaara et al. 2018). Nordic countries became an inspiration in the Soviet Union for the design of large housing estates. The first state-sponsored study trip in 1957 was perfectly timed with initiation of the design for one of Tallinn's first large housing estates, Mustamäe, and visiting Soviet architects' experience in Tapiola (and other residential projects near Helsinki) left a lasting impression for planners and designers, as evidenced by their notes in excursion reports (Berger et al. 2019; Hess and Metspalu 2019; Metspalu and Hess 2018). Housing estates in heavily treed districts in Tallinn (Mustamäe), Riga (Āgenskalna Priedes) and Vilnius (Lazdynai) were inspired by the natural landscape retained in the design of Tapiola and the Finnish concept of the 'forest-suburb' (Berger et al. 2019; Drèmaitè 2019).

By the late 1960s, however, many of the charming features of housing estates had been abandoned for the sake of efficiency. The refinement of mass construction techniques allowed housing estates established during the 1970s and 1980s to become larger and denser and to feature taller high rises (16 storeys are the highest in the Baltic cities, but apartment buildings are taller elsewhere in the former Soviet Union and Russia). We refer to the latter as the 'Concrete City' housing estate model. There were fewer 'protected' places within housing estates (formed by apartment building placement) and landscaping was virtually absent, in sharp contrast to the earlier heavily treed housing estates. Concrete slabs were practically the only visible material, with occasional brick structures. This design evolution is visible, for example, in the differences between two housing estates in Tallinn: Mustamäe (construction began in 1962) and Lasnamäe (construction began in 1973). In short, the relentless demand for new housing is reflected in the addition of apartment buildings that grew significantly larger during the Soviet years 
(beginning with 3- to 4-storey simple khrushchëvki and mushrooming to 16-storey apartment towers towards the end of the Soviet period) (Fig. 1.6).

The shift from the Garden City to the Concrete City was due in part to (a) political conditions creating strict regulations imposed on city planning from the Soviet system (aimed at industrialising the construction industry and improving quality while reducing costs) and (b) high immigration to the Baltic countries during the peak Soviet years, when tens of thousands of migrants (mainly from Russia, Belarus and Ukraine) required housing quickly, and this large and urgent demand for housing decreased the quality of built environments that designers and planners were ultimately able to deliver in housing estates. The Third Congress of Soviet Architects in 1961 identified the problem of monotony, lack of aesthetics and lack of creativity in use of standardised designs. Likewise, despite censorship, architects and even the general public regularly published articles in the popular press in the 1970s about their dissatisfaction with housing estates (Metspalu and Hess 2018). Although there was valid and public criticism of housing estates by the late 1960 s and early 1970 s, people with decision-making capability did not react (Wassenberg 2013), and unlike in Western Europe (Fig. 1.4), housing estate construction continued with abandon until the dissolution of the Soviet Union. Economic considerations were prioritised and housing construction had to support economic needs in a cost-efficient manner (Drèmaitè 2019).

The requirement to house large numbers of people in apartments, and the obligation to follow strict building norms and employ standardised designs,

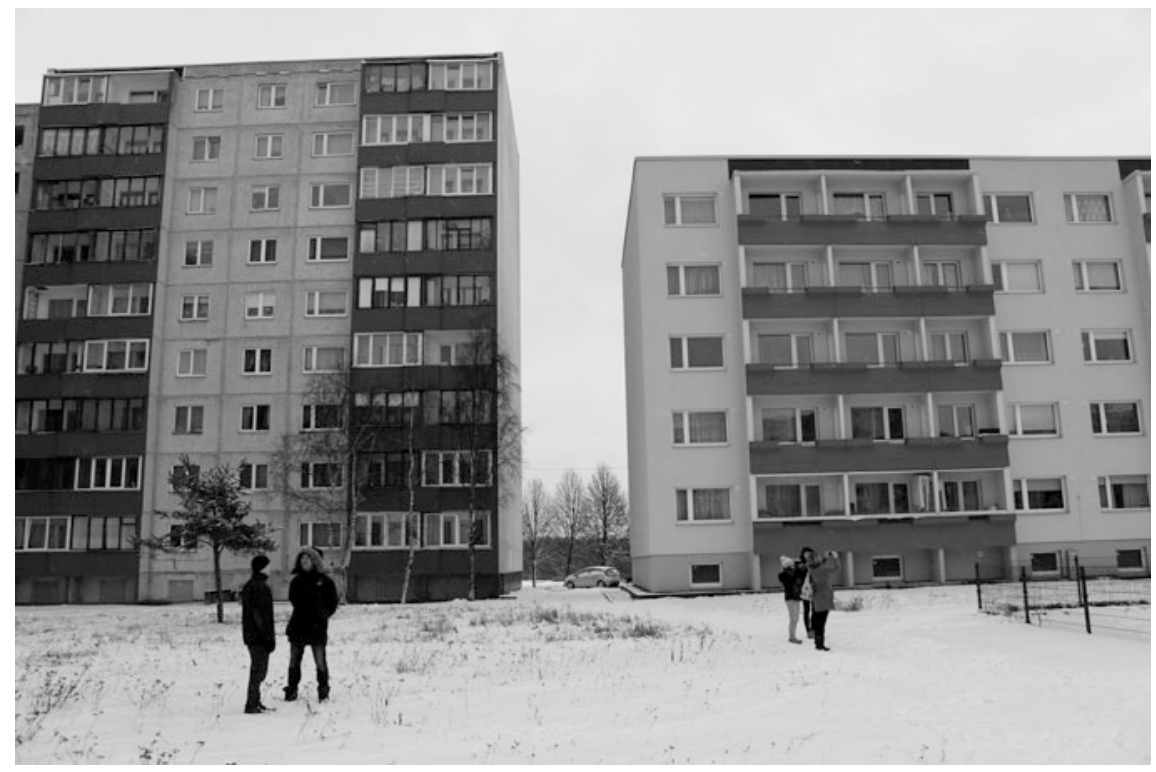

Fig. 1.6 View of Lasnamäe, Tallinn, Estonia. Source Annika Väiko 
presented challenges for architects. In the early years of the housing estate movement, some of the best architects in the Baltic countries were willing to attempt to meet the challenges, and they were generally employed in Soviet housing institutes (Dremaite 2019). Even though Baltic architects had opportunities to participate in official state-sponsored study trips to view architecture and city planning abroadand they visited Nordic housing estates such as Tapiola and desired to emulate them - they returned to the Baltic countries and built Concrete City housing estates in response to the demands of the system in which they worked. Consequently, in the Baltic countries, there was potential for high-quality urban environments in housing estates, realised only in early attempts and in occasional small projects but not sustained during the predominant era of large housing estate construction.

Lesson 4: Housing estates in the Soviet Union were a vast experiment in socio-spatial organisation of cityscapes. They embodied an egalitarian ideology in which massive residential spaces structured the everyday lives of people in relation to the neighbourhoods in which they lived. Deliberate socio-spatial mixing, however, did not necessarily lead to joint activities of ethnic and socio-economic groups.

During the Soviet era, the maintenance costs of apartments in housing estates were subsidised generously by the state and apartments were therefore financially affordable for everyone who acquired apartments through the central housing allocation system (Treija and Bratuškins 2019). Socio-economic segregation in housing estates according to occupation during the Soviet years was virtually nonexistent; this was an outcome of socialist egalitarianism and the centralised housing system (Gentile 2019; Marcińczak et al. 2015; Tammaru et al. 2016). Everyone from a factory janitor to a factory director was intended to live nearby in harmony in socialist apartment buildings (although housing queues were an inherent barrier to smooth operation of the housing system). Housing estates thus served as classical meeting places for various social and ethnic groups. Nevertheless, even during Soviet times, there was a low level of social integration between people from different ethnic and socio-economic status groups, with infrequent intermixing with nongroup members in daily life. The main vectors of segregation in the Baltic countries ran across ethnicity, social origin (people of rural origin versus intelligentsia) and social position (white-collared employees versus workers) (Janušauskaitė 2019).

A parallel system of local-language (Estonian, Latvian, Lithuanian) and Russian-language education contributed to ethnic segregation in the Baltic countries (Tammaru et al. 2017). In mikrorayon within large housing estates, local-language and Russian-language kindergartens and schools are often found side by side, sorting children into different education institutions and socio-ethnic networks. Hence, ethnic divides existed in large housing estates, dual mikrorayons emerged, and architects designed larger mikrorayons (12,000 inhabitants instead of 6,000 inhabitants) to accommodate a dual society and ensure that all families could benefit from socialist-modernist town planning (Bruns 2007; Leetmaa and Hess 2019). 
People from 'higher' white-collar socio-economic groups felt that they (and members of their peer group) possessed a special or unique status and were socially distinct from 'others' living in housing estates (Janušauskaite 2019). Large apartment buildings typical of modernist housing estates provide space for people to avoid others if they choose to do so. It is remarkable that activity-based avoidance and self-segregation were phenomena of daily social life in the Soviet Union, where socio-spatial differences between people were small. Through daily practices, people tried to emphasise the high social status of their family, their neighbours or their neighbourhood (reflecting a natural human tendency to try to make oneself feel 'special'). Also, people were critical of their neighbours' children (behaviour in the neighbourhood, performance in school) if they thought others were part of a lower social class (Janušauskaitè 2019).

Despite avoiding firsthand contact with people they perceived to be different from themselves, individuals in the Soviet Union lived a 'neighbourhood-based life' and this occurred intentionally and by design of housing estates. A neighbourhood-based life was consistent with socialist ideology, and modernist housing estates provided various opportunities for emphasising a community-based socialist life (while the factory was the centre of work life) (Janušauskaite 2019). In fact, people derived their own 'local identity' from housing estates in which they lived (Janušauskaite 2019) and tended to conduct daily life within their mikrorayon or small residential unit, generally avoiding travel out of their neighbourhood. Vällingby in Stockholm was among the first neighbourhoods that applied the integrated ABC - an acronym for Arbete-Bostad-Centrum or Workplace-HousingCentre-concept developed by Sven Markelius in 1945 in the spirit of British New Towns, and it was eagerly applied in planning mikrorayon service centres in Baltic housing estates, including ABC-5 in Tallinn, Žirmūnai in Vilnius and Imanta in Riga (Šiupšinskas and Lankots 2019).

A strongly localised orientation for people's everyday lives was consistent with Soviet Union control over the populace. Subversive and anti-communist ideas should not spread, and Soviet Union propaganda should be available (in so-called 'Red Corners' planned within community facilities and schools in mikrorayon) to emphasise socialist ideology. Certain restrictions existed in printing and distributing maps in Soviet Union cities (for fear that the maps might fall into enemy hands and reveal state secrets), further limiting people's knowledge of cities beyond their immediate surroundings (Hess and Hiob 2014; Jagomägi and Mardiste 1994). To help its original residents navigate the built environment of Annelinn in Tartu, Estonia (constructed between 1969 and 1973) - and to aid them in overcoming the repetitive architecture without printed maps - the designers provided a crude depiction of the physical form of the mikrorayon as a building façade mural that still exists today (see Fig. 1.7). Nevertheless, the built environment of housing estates constituted places of memory and formed people's cognitive maps of neighbourhoods (Šiupšinskas and Lankots 2019). Soviet society was closed, and the form of the city - especially regarding residential planning in large housing estates-reinforced it. 


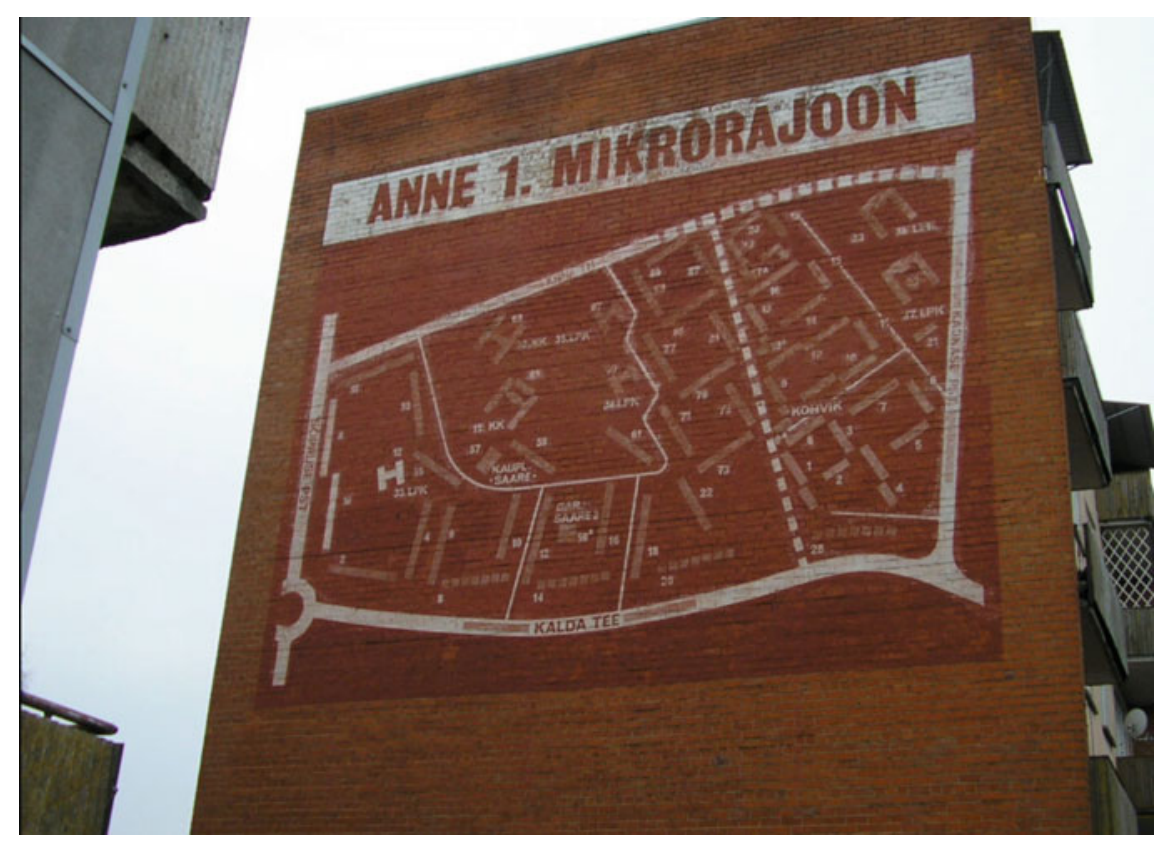

Fig. 1.7 A map of Annelinn appears as building façade artwork in Tartu, Estonia. Source Image by Daniel Baldwin Hess

Lesson 5: A shift from a more communal to individualistic lifestyle took place over time in housing estates. In the early decades of the Soviet Union, shared public space (outdoors, and within community areas) was maximised and individual space (indoors, within apartments) was minimised. As the residential density of housing estates increased, architects expanded the size of individual apartments in subsequent projects to maximise the comfort of occupants.

There was popular excitement about new apartment buildings in the 1950s. These first-generation buildings contained significant improvements over the existing housing stock, with basic comfort facilities inside apartments. The design of housing estates initially emphasised ample shared communal space outside individual apartments - within schools, child care centres, Culture Halls, social clubs, saunas, shared dining, sports and recreation-in which individual Soviets were envisioned to maximise their participation in socialist life. In the first generation of standardised housing, apartments were small (Treija and Bratuškins 2019), while service networks and community space in housing estates were intended to be rich. With abundant services in every superblock and mikrorayon, people were expected to spend a great deal of time away from their apartment, participating in a structured socialist life. Daily services such as kindergartens, schools, food shops, canteens, clubs, housing unit administration services, sports 
Fig. 1.8 Changing paradigm of private versus public space in apartment buildings and housing estates

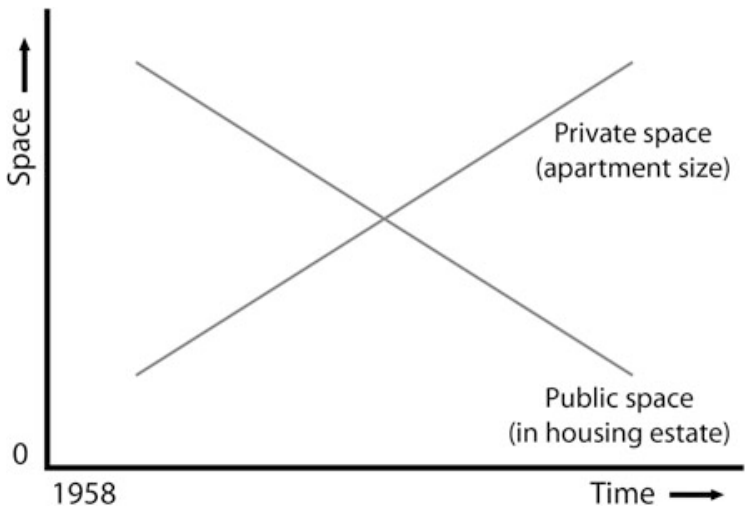

fields and playgrounds had to be located within the boundaries of a given mikrorayon and no further than 400 metres from any residence (Dremaitè 2019). Large employers often provided space for leisure activity in Culture Halls. In reality, however, these service networks were undersupplied, and there was a chronic shortage of nearby commercial opportunities (Leetmaa and Hess 2019; Metspalu and Hess 2018; Šiupšinskas and Lankots 2019).

In later-generation standardised housing, when it was evident that services could not be supplied at levels suggested in housing estates norms (subscribing to socialist doctrine), individual apartments within apartment buildings were designed to be larger. For example, a communal one-bedroom apartment only $45 \mathrm{~m}^{2}$ in size was the most common, and it constituted $51 \%$ of the dwellings in the large Lithuanian housing estate Karoliniškès (Janušauskaitè 2019). In the more spacious apartments, toilet and bath were separated, and comfort amenities increased in number both within apartments and apartment buildings; for example, interior trash receptacles and elevators were installed in apartment buildings taller than five storeys (Treija and Bratuškins 2019). Architects attempted to improve on standardised designs by enlarging the interior space of apartments and creating flexible configurations of interior space in dwellings to provide families with greater comfort (Dremaite 2019). Plans were drafted for experimental series of apartment buildings in which apartments were equipped with corner balconies, larger service rooms and larger kitchens (Drèmaite 2019). Consequently, older housing estates now possess cramped apartments but more human-scaled exterior space (such as the older parts of Kengarags in Riga, Mustamäe in Tallinn and Lazdynai in Vilnius), while later-period Soviet-era housing estates have larger apartments but repetitive and monumental exterior space not appropriately scaled for pedestrians (such as Plavnieki in Riga, Lasnamäe in Tallinn and Justinskes in Vilnius) (Fig. 1.8).

Lesson 6: Housing estates that were located at a certain distance from city centres in places of abundant land are, relatively speaking, more advantageously located today as cities have sprawled since then. They are usually well connected to city centres via public transport. 
Housing estates originally built at a considerable distance from city centres (where sufficient un-built land could be assembled to accommodate the significant space needs of a housing estate) were often poorly connected by transport to city centres and worksites (Hess 2018). Even when the actual distance from a city centre was not great, the perceived distance was much longer (Janušauskaitė 2019). Distance from the city centre is important in the current trajectory of change in housing estates, and housing estates closer to city centres are often more attractive than those more distant (Burneika et al. 2019; Kährik et al. 2019; Krišjāne et al. 2019). The perceived distance has shortened owing to improved transport and sprawl of cities resulting from suburbanisation (Janušauskaitè 2019). However, the quality of housing estates often improves with distance from the city centre, and the age of housing estates decreases with distance from the city centre (Burneika et al. 2019). Urban locations that once seemed remote - as Baltic cities have evolved and grown in size - now provide relatively reasonable access to city centres, as surrounding metropolitan space has expanded. For example, 1970s-era housing estates in Vilnius are now considered to be well located and to possess attractive community and social infrastructure (Burneika et al. 2019).

Public transport and automobile transport have vastly improved since socialist times in Baltic cities, with better connections to city centres. The socialist system was a virtually carless society (for the average resident), but Soviet-era planners always had lofty aspirations for urban grandiosity and therefore built wide and spacious roads unwittingly capable of accommodating today's significantly higher traffic volumes (Hess 2017). Housing estates were rather grand places with large infrastructure and generous space between buildings, and the 'extra space' is now available for other uses, including automobile parking (Tuvikene 2019). Another important element of the improved relative location pertains to services: new commercial outlets have been added to housing estates, especially shopping centres within or adjacent to residential districts. This has improved the comfort and convenience of living in housing estates because they now contain fitness centres and swimming pools, schools (for all levels), cinemas and shopping malls. These additions to housing estates have helped shift the urban form of Baltic cities in part from compact to sprawling, as many of these new services are provided in automobile-friendly (more than pedestrian-friendly) environments.

Lesson 7: There are four potential ways to consider the next stage for housing estates: (a) do-nothing, (b) downsize, (c) demolish (and replace) and (d) renovate. Since the apartment buildings in housing estates consume a substantial share of the total housing stock and since individual apartments are mostly owner-occupied, demolition is a difficult option. With time, the do-nothing approach has gradually given way to building-based renovation. The next step would be more comprehensive renovation coordinated by the public sector; this would help improve building-level management and finally complete housing estates relative to the original aims of the housing programme under which they were conceived and planned.

There are various ways to envision the future of large housing estates. In many cities, especially in the United States and Western Europe, demolishing large tower 
blocks has been an important urban revitalisation tactic since the destruction of the Pruitt-Igoe housing estate in St. Louis, Missouri in 1972 (Hess et al. 2018a). Similar debates have surfaced in the public agenda in Eastern Europe since the fall of the Iron Curtain. Challenges with physical environments due to a gradual decline and natural wear and tear (Janušauskaite 2019) and risks related to socio-economic downgrading (Burneika et al. 2019; Kährik et al. 2019; Krišjāne et al. 2019) propelled prominent urban researcher Ivan Szelényi (1996) to predict the swift deterioration of housing estates into ghettoes. So far, such predictions have not been fulfilled. Furthermore, because of the very prominent role of socialist apartment buildings in the housing sector, complete demolition has not been an option. For the very same reason-high importance and dominant role in Baltic capital city's housing stocks - the do-nothing approach is not an option. Hence, the most reasonable way forward must address the gradual decline of modernist housing (so that it can compete with new housing continuously added to the housing stock) and the renovation of the existing housing stock.

Individual apartments in the large housing stock within modernist housing estates are mostly in private hands, and most apartment owners have joined building-based flat-owners' associations (Tuvikene 2019). The reason for the large-scale privatisation in the 1990s was twofold. First, it represented a symbolic break with the totalitarian regime in which nearly all properties, including housing, were in common ownership. The second reason was pragmatic. After regaining independence, the Baltic countries faced severe economic challenges and there were no public funds available for housing maintenance (Liepa-Zemeša and Hess 2016). The result is a poorly managed housing stock. Lack of understanding about the legal relations between landowners, managers and apartment owners as well as a lack of knowledge about their mutual rights and responsibilities creates frustration and passivity with regard to maintaining and improving housing and its environs (Treija and Bratuškins 2019).

The second outcome is closely related to the first and fits under the umbrella term 'do-it-yourself urbanism': every apartment owner has acted within her or his best abilities; however, their poorly coordinated efforts-owing to a weak management system - have led to an eclectic appearance of apartment buildings (Kuusk and Kurnitski 2019). In addition to individual apartment owners, flat-owners' associations have undertaken joint renovation efforts, usually to improve overall energy efficiency. Although most modernist apartment buildings were built during a period of cheap energy, contemporary energy efficiency concerns are often important to inhabitants since heating costs today are comparatively high (Lihtmaa et al. 2018). However, flat-owners' association funds often permit only single renovation measures that typically neglect the complexity of problems involved, including the need to invest in ventilation, leading to a deterioration of indoor climate. Financial support may be acquired for apartment building renovation from European funds for improving energy efficiency (KredeEx in Estonia, JESSICA in Latvia and Lithuania). The focus of European support is on improving the overall energy efficiency of the building envelope as well as ventilation and indoor air quality, aiming at nearly zero-energy buildings (nZEB) (Ahas et al. 2019; Kuusk 
and Kurnitski 2019). When comprehensive renovation of apartment buildings is undertaken - an exception rather than a rule-retrofitted Soviet-era apartment buildings can be quite attractive. This practice also maintains the socially mixed ownership structure, contributing to lower levels of residential segregation than newly built apartment buildings where the socio-economic structure of residents is more homogenous (Kährik and Tammaru 2010). In short, positive outcomes in apartment building renovation are possible, but they require efforts that go beyond the individual flat owners' abilities and call for better coordination and management.

The SmartEnCity initiative in Tartu and Estonia is a promising example of what can be accomplished by moving from an apartment building-based to area-based approach in revitalising modernist housing neighbourhoods within an integrated sustainability and 'smart city' framework. It includes retrofitting apartment buildings; modernising public and private transportation systems; adapting neighbourhoods to new lifestyles; establishing new uses and activities; and focusing on place-making (Ahas et al. 2019). It also addresses apartment buildings, their surroundings, the people who inhabit them, and connectivity through integrated planning and holistic revitalisation (cf. Wassenberg 2018). It focuses not solely on profit - currently the main feature of the heavily market-based housing sector in the Baltic countries (Tammaru et al. 2018) — but instead on people, seeking ways to improve quality of life, solidarity and well-being (Ahas et al. 2019). Financial schemes for such renovation programmes are complex and beyond the reach of single flat-owner associations, but assistance can be provided through pan-European energy efficiency programmes such as KredEx and JESSICA, enhanced by other funding sources such as municipal governments, private banks and stakeholder involvement (Ahas et al. 2019; Kuusk and Kurnitski 2019).

More can be done, however. While 'smart city' interventions are attractive, the addition of common space, improved sanitary facilities and especially elevators to apartment buildings in older housing estates is crucial (Kuusk and Kurnitski 2019), making life more comfortable especially for the elderly and families with children. These tactics could also increase the attractiveness of housing estates among these two large population groups.

Model interventions can be designed for specific Soviet-era apartment building types and then replicated. For 1-464 series apartment buildings, there are four areas of specific concern: the spatial layout of apartments is rigid; repartitioning interior building space could create new apartment sizes for various household types; additional communal space is needed; and people underestimate the large effort required for comprehensive renovation (Kuusk and Kurnitski 2019). Both the quality and speed of the retrofitting process can be improved by introducing new technological innovations, such as using prefabricated modules for renovating building facades. According to Kuusk and Kurnitski (2019), using prefabricated panels with factory-installed windows can reduce the renovation time for external walls from 6 months to 2 weeks. Since the apartment buildings are standard, renovation practices that take advantage of prefabrication can be very time-efficient. 
Western European experience suggests that policies facilitating social mobility and ethnic integration are crucial for residents of large housing estates (Bolt 2018). Although ethnic and social challenges in large housing estates in the Baltic countries are not comparable to those in Western Europe, certain similarities exist: (1) ethnic minorities are over-represented in large housing estates in the Baltic countries; and (2) while the social mix of housing estate residents is still high in Riga and Vilnius, the first signs have appeared of poverty concentration in housing estates in Tallinn (Burneika et al. 2019; Kährik et al. 2019; Krišjāne et al. 2019). In housing estates that are less centrally located, connectivity enhancements are critical for integrating housing estate residents through transport improvements and access to activities (Hess et al. 2018a). The key lesson from Western Europe is that it is easier to invest in built environment improvements than socially based improvements, causing the revitalisation strategies to be skewed to infrastructure and other physical aspects (Hess et al. 2018a; Wassenberg 2018).

When districts are renovated holistically like in Estonia's SmartEnCity, rather than a flat-by-flat or a building-by-building approach, there is a potential for accumulated benefits for other parts of the city (with better results from central locations), while area-based improvements are most appreciated locally. The key benefits of the area-based SmartEnCity renovation include energy efficiency, energy performance, sustainable mobility, integrated infrastructure and sharing programmes (bicycles, laundry) (Ahas et al. 2019). In short, many modern ideas about urban life - including equity, sustainability, ecological footprints, communal life and the sharing economy - align well with the underlying principles of housing estates, offering a glimmer of hope for a productive future for housing estates (Hess and Metspalu 2019).

In-migration of young people is needed to demographically balance the age structure of housing estates. This could also enhance inter-generational cooperation for aspects of daily life such as childcare. True, housing estates are generally not attractive to young people with sufficient resources to live in older gentrified neighbourhoods or new suburbs (Kährik et al. 2019). Gentrifiers are usually drawn to central city neighbourhoods with historic housing (pre-World War II wooden tenement buildings) and not to apartments in standardised prefabricated buildings (Hess 2011). However, real estate prices in gentrifying or gentrified neighbourhoods are rising beyond the reach of average young families. Real estate price escalation related to the revitalisation of inner-city neighbourhoods could produce a spillover effect for modernist housing estates as families in search of housing turn their attention there. Gentrification of central city places suggests that the reputation of neighbourhoods can undoubtedly change with time.

It is therefore important to understand the conditions necessary for young families to move by choice to large housing estates. Housing estates do indeed have appealing aspects (Tammis 2017; Ouředníček 2016; Marin and Chelcea 2018; Kovács et al. 2018) and certain differentiations between the appeal of housing estates are now evident (Kovács et al. 2018; Temelová et al. 2011). Many (young) people looking to lessen their 'ecological footprint' find they can do so in housing estates with small, renovated energy-efficient apartments. Housing estates possess 
various features appealing to ecologically minded people: nearby playgrounds and greenspace (within walking distance); community gardens; shops and services in proximate commercial nodes; and efficient public transport connections (making it possible to live without a car or at least reduce daily driving). Walkability within housing estates reflects the urban compactness inherent in their design. Renovation programmes that focus on the needs of people and on new urban lifestyles may also lure younger generations (Ahas et al. 2019). Enhancing community engagement, grass-roots advocacy groups (Tammis 2017) and other collective initiatives could also help to improve the fortunes of housing estates.

Acknowledgments We are grateful to all authors in this volume for their valuable input to this introductory chapter. We are especially indebted to Michael Gentile, Kadri Leetmaa, Anneli Kährik, Sampo Ruoppila, Donatas Burneika, Maris Bērziņš and Zaiga Krišjāne. Raivo Aunap provided cartographic assistance and Annika Väiko provided editorial support. The research leading to this work has received funding from the European Union's Horizon 2020 research and innovation programme under Marie Skłodowska-Curie grant agreement number 655601. Support also came from four grants from the Estonian Research Council: Institutional Research Grant IUT2-17, Personal Research Grant PUT PRG306, RITA-Ränne and Infotechnological Mobility Observatory. The European Research Council funded this research under the European Union's Seventh Framework Programme (FP/2007-2013)/ERC (Grant Agreement No. 615159) (ERC Consolidator Grant DEPRIVEDHOODS, Socio-spatial inequality, deprived neighbourhoods and neighbourhood effects).

\section{References}

Ahas R, Mooses V, Kamenjuk P, Tamm R (2019) Retrofitting Soviet-Era apartment buildings with 'Smart City' features: The H2020 SmartEnCity project in Tartu, Estonia. In: Hess DB, Tammaru T (eds) Housing estates in the baltic countries: the legacy of central planning in Estonia, Latvia, and Lithuania. Springer, Dordrecht, The Netherlands

Andersson R, Kährik A (2016) Widening gaps: segregation dynamics during two decades of economic and institutional change in Stockholm. In: Tammaru T, Marcińczak S, Van Ham MSM (eds) Routledge, London, pp 110-131

Berger L, Ruoppila S, Verikansa K (2019) Baltic crossings: Soviet housing estate and dreams of forest-suburbs. In: Hess DB, Tammaru T (eds) Housing estates in the baltic countries: the legacy of central planning in Estonia, Latvia, and Lithuania. Springer, Dordrecht, The Netherlands

Bolt G (2018) Who is to blame for the decline of large housing estates? An exploration of socio-demographic and ethnic change. In: Hess DB, Tammaru T, van Ham M (eds) Housing estates in Europe: poverty, segregation, and policy challenges. Springer, Dordrecht, The Netherlands

Bruns D (2007) Tallinna peaarhitekti mälestusi ja artikleid. Eesti Arhitektuurimuuseum, Tallinn

Burneika D, Ubarevičienė R, Baranauskaitė A (2019) Soviet housing estates in Vilnius, Lithuania: socio-ethnic structure and future(-less?) Perspectives. In: Hess DB, Tammaru T (eds) Housing estates in the baltic countries: the legacy of central planning in Estonia, Latvia, and Lithuania. Springer, Dordrecht, The Netherlands

Dremaite M (2019) The exceptional design of large housing estates in the baltic countries. In: Hess DB, Tammaru T (eds) Housing estates in the baltic countries: the legacy of central planning in Estonia, Latvia, and Lithuania. Springer, Dordrecht, The Netherlands

French RA, Hamilton FEI (1979) The socialist city: spatial structure and urban policy. Wiley, London 
Gentile M (2019) The rise and demise of the Soviet-made housing shortage in the baltic countries. In: Hess DB, Tammaru T (eds) Housing estates in the baltic countries: the legacy of central planning in Estonia, Latvia, and Lithuania. Springer, Dordrecht, The Netherlands

Glendinning M (2019) Mass Housing and 'Extensive Urbanism' in the Baltic Countries and Central and Eastern Europe: A Comparative Overview. In: Hess DB, Tammaru T (eds) Housing estates in the baltic countries: the legacy of central planning in Estonia, Latvia, and Lithuania. Springer, Dordrecht, The Netherlands

Gunko M, Bogacheva P, Medvedev A, Kashnitsky I (2018) Path-Dependent development in mass housing in Moscow, Russia. In: Hess DB, Tammaru T, van Ham M (eds) Housing estates in Europe: poverty, segregation, and policy challenges. Springer, Dordrecht, The Netherlands

Hall P (2014) Cities of tomorrow: an intellectual history of urban planning and design since 1880. Wiley, Chicester

Hess DB (2011) Early 20th-century tenement buildings in Estonia: building blocks for neighborhood longevity. Town Plan Archit 35(2):110-116

Hess DB (2017) Decrypting fareless public transport in Tallinn, Estonia. Case Stud Transp Policy 5(4):690-698

Hess DB (2018) Transport in Mikrorayons: accessibility and proximity to centrally planned residential districts during the socialist era, 1957-1989. J Plan Hist 17(3):194-204

Hess DB, Hiob M (2014) Preservation by neglect in Soviet-era town planning in Tartu Estonia. J Plan Hist 13(1):24-49

Hess DB, Metspalu P (2019) Architectural Transcendence in Soviet-Era Housing: Evidence from Socialist Residential Districts in Tallinn, Estonia. In: Hess DB, Tammaru T (eds) Housing estates in the baltic countries: the legacy of central planning in Estonia, Latvia, and Lithuania. Springer, Dordrecht, The Netherlands

Hess DB, Tammaru T, Leetmaa K (2012) Ethnic difference in housing in post-Soviet Tartu, Estonia. Cities: Int J Urban Policy Plan 29:327-333

Hess DB, Tammaru T, van Ham M (2018a) Lessons learned from a Pan-European study of large housing estates: origin, trajectories of change, and future prospects. In: Hess DB, Tammaru T, Van Ham M (eds) Housing estates in Europe: poverty, segregation, and policy challenges. Springer, Dordrecht, The Netherlands

Hess DB, Tammaru T, van Ham M (eds) (2018b) Housing estates in Europe: poverty, segregation, and policy challenges. Springer, Dordrecht, The Netherlands

Jagomägi J, Mardiste H (1994) Maps and mapping in Estonia. GeoJournal 33(1):81-90

Janušauskaitė V (2019) Living in a large housing estate: insider perspectives from Lithuania. In: Hess DB, Tammaru T (eds) Housing estates in the baltic countries: the legacy of central planning in Estonia, Latvia, and Lithuania. Springer, Dordrecht, The Netherlands

Kalm M (2012) An apartment with all conveniences was no panacea: mass housing and the alternatives in the Soviet period in Tallinn. Architektura and Urbanizmus 46(3-4):194-207

Kovács Z, Egedy T, Szabó B (2018) Persistence or change: divergent trajectories of large housing estates in Budapest, Hungary. In: Hess DB, Tammaru T, van Ham M (eds) Housing estates in Europe: poverty, segregation, and policy challenges. Springer, Dordrecht, The Netherlands

Kovács Z, Herfert G (2012) Development Pathways of Large Housing Estates in Post-socialist Cities: An International Comparison. Hous Stud 27(3):324-342. https://doi.org/10.1080/ 02673037.2012 .651105

Krišjāne Z, Bērziņš M, Sechi G, Krūminšs J (2019) Residential change and socio-demographic challenges for large housing estate in Riga, Latvia. In: Hess DB, Tammaru T (eds) Housing estates in the baltic countries: the legacy of central planning in Estonia, Latvia, and Lithuania. Springer, Dordrecht, The Netherlands

Kuusk K, Kurnitski J (2019) State-Subsidized refurbishment of socialist apartment buildings in Estonia. In: Hess DB, Tammaru T (eds) Housing estates in the baltic countries: the legacy of central planning in Estonia, Latvia, and Lithuania. Springer, Dordrecht, The Netherlands

Kährik A, Kangur K, Leetmaa K (2019) Socio-Economic and ethnic trajectories of housing estates in Tallinn, Estonia. In: Hess DB, Tammaru T (eds) Housing estates in the baltic countries: the 
legacy of central planning in Estonia, Latvia, and Lithuania. Springer, Dordrecht, The Netherlands

Kährik A, Tammaru T (2010) Soviet prefabricated panel housing estates: areas of continued social mix or decline? The Case of Tallinn. Hous Stud 25(2):201-219. https://doi.org/10.1080/ 02673030903561818

Leetmaa K, Hess DB (2019) Incomplete service networks in enduring socialist housing estates: retrospective evidence from local centres in Tallinn, Estonia. In: Hess DB, Tammaru T (eds) Housing estates in the baltic countries: the legacy of central planning in Estonia, Latvia, and Lithuania. Springer, Dordrecht, The Netherlands

Leetmaa K, Tammaru T, Hess DB (2015) Preferences Towards Neighbor Ethnicity and Affluence: Evidence from an Inherited Dual Ethnic Context in Post-Soviet Tartu, Estonia. Ann Assoc Am Geogr 105(1):162-182

Liepa-Zemeša M, Hess DB (2016) Effects of public perception on urban planning: evolution of an inclusive planning system during crises in Latvia. Town Plan Rev 87(1):71-92

Lihtmaa L, Hess DB, Leetmaa K (2018) Intersection of the global climate agenda with regional development: unequal distribution of energy efficiency-based renovation subsidies for apartment buildings. Energy Policy 119:327-338

Marcińczak S, Tammaru T, Novák J, Gentile M, Kovács Z, Temelová J, Valatka V, Kährik A, Szabó B (2015) Patterns of socioeconomic segre-gation in the capital cities of fast-track reforming postsocialist countries. Ann Assoc Am Geogr 105(1):183-202

Marin V, Chelcea L (2018) Housing Estates in Bucharest, Romania: A Viable Housing Provider in Europe's Densest Capital City. In: Hess DB, Tammaru T, van Ham M (eds) Housing estates in Europe: poverty, segregation, and policy challenges. Springer, Dordrecht, The Netherlands

Metspalu P, Hess DB (2018) Revisiting the role of architects in planning large-scale housing in the USSR: the birth of three large housing estates in Tallinn, Estonia. Plan Perspect 33(3):335-361

Ouředníček M (2016) The relevance of "Western" theoretical concepts for investigations of the margins of post-socialist cities: the case of Prague. Eurasian Geogr Econ 57(4-5):545-564. https://doi.org/10.1080/15387216.2016.1256786

Puur A, Klesment M, Sakkeus L (2019) A turbulent political history and the legacy of state socialism in the baltic countries. In: Hess DB, Tammaru T (eds) Housing estates in the baltic countries: the legacy of central planning in Estonia, Latvia, and Lithuania. Springer, Dordrecht, The Netherlands

Szelényi I (1996) Cities under socialism and after. In: Andrusz G, Harloe M, Szelényi I (eds) Cities after socialism. Blackwell, Oxford

Šiupšinskas M, Lankots E (2019) Collectivist Ideals and Soviet Consumer Spaces: Mikrorayon Commercial Centres in Vilnius, Lithuania and Tallinn, Estonia. In: Hess DB, Tammaru T (eds) Housing estates in the baltic countries: the legacy of central planning in Estonia, Latvia, and Lithuania. Springer, Dordrecht, The Netherlands

Tammaru T, Marcińczak S, Aunap R, Van Ham M (2017) Inequalities and segregation across the long-term economic cycle: an analysis of south and north European cities. IZA discussion paper 10980

Tammaru T, Marcińczak S, van Ham M, Musterd S (2016) Socio-Economic segregation in European capital cities: east meets west. Routledge, New York/London

Tammaru T, van Ham M, Janssen H, Marcinczak S, Aunap R (2018) Relationship between income inequality and residential segregation between socioeconomic groups. Reg Stud

Tammis T (2017) City unfinished. Urban planning visions and spatial scenarios of Tallinn, EKA, Tallinn

Temelová J, Novák J, Ouředníček M, Puldová P (2011) Housing estates after socialism: various trajectories and inner differentiation. Urban Stud 48(9):1811-1834. https://doi.org/10.1177/ 0042098010379279

Treija S, Bratuškins U (2019) Social ideals and physical reality: large housing estates in Riga, Latvia. In: Hess DB, Tammaru T (eds) Housing estates in the baltic countries: the legacy of central planning in Estonia, Latvia, and Lithuania. Springer, Dordrecht, The Netherlands 
Tuvikene T (2019) Between community and private ownership in centrally planned residential space: governing parking in socialist housing estates. In: Hess DB, Tammaru T (eds) Housing estates in the baltic countries: the legacy of central planning in Estonia, Latvia, and Lithuania. Springer, Dordrecht, The Netherlands

Vaattovaara M, Joutsiniemi A, Kortteinen M, Stjernberg M, Kemppainen T (2018) Experience of a preventive experiment: spatial social mixing in post-world war II housing estates in Helsinki, Finland. In: Hess DB, Tammaru T, van Ham M (eds) Housing estates in Europe: poverty, segregation, and policy challenges. Springer, Dordrecht, The Netherlands

Wassenberg F (2013) Large housing estates: ideas, rise, fall and recovery. IOS Press, Amsterdam, TU Delft

Wassenberg F (2018) Beyond an ugly appearance: understanding the physical design and built environment of large housing estates. In: Hess DB, Tammaru T, van Ham M (eds) Housing Estates in Europe: poverty, segregation, and policy challenges. Springer, Dordrecht, The Netherlands

Open Access This chapter is licensed under the terms of the Creative Commons Attribution 4.0 International License (http://creativecommons.org/licenses/by/4.0/), which permits use, sharing, adaptation, distribution and reproduction in any medium or format, as long as you give appropriate credit to the original author(s) and the source, provide a link to the Creative Commons license and indicate if changes were made.

The images or other third party material in this chapter are included in the chapter's Creative Commons license, unless indicated otherwise in a credit line to the material. If material is not included in the chapter's Creative Commons license and your intended use is not permitted by statutory regulation or exceeds the permitted use, you will need to obtain permission directly from the copyright holder.

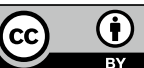


Part II

Context and Vision 


\title{
Chapter 2
}

\section{A Turbulent Political History and the Legacy of State Socialism in the Baltic Countries}

\author{
Allan Puur, Martin Klesment and Luule Sakkeus
}

\begin{abstract}
This chapter provides a survey of the political, socio-economic and demographic development of the Baltic countries. It is meant to give readers a general understanding of the setting in which large urban housing estates were built from the 1960s to the 1980s. The chapter begins with an account of the history of the Baltic countries, including their emergence as independent nations, their incorporation into the USSR and their reappearance on the world map in 1991. The second section analyses the modernisation of the Baltic economies, the Soviet strategies for industrialisation and their impact on the housing sector. The Baltic region enjoyed somewhat higher living standards and exhibited greater openness to Western influences than other union republics, which made Estonia, Latvia and Lithuania attractive to economic migrants from other parts of the USSR. The analysis also shows that the Baltic countries experienced demographic modernisation earlier than other regions of the USSR. A high demand for labour is driven by Soviet strategies for economic development, and slow population growth in the host countries, particularly in Estonia and Latvia, contributed to the persistence of high levels of immigration throughout the post-war decades. Due to their large numbers, migrant workers significantly transformed the composition of the urban population in the Baltic countries. Through a combination of factors, including the housing allocation mechanism, immigrants gained privileged access to new accommodation, and they became over-represented in the housing estates. This development connects the future of the housing estates with the integration of immigrants who settled in the region during the Soviet era.
\end{abstract}

\footnotetext{
A. Puur $(\bowtie) \cdot$ M. Klesment · L. Sakkeus

School of Governance, Law and Society, Estonian Institute for Population Studies,

Tallinn University, Tallinn, Estonia

e-mail: puur@tlu.ee

M. Klesment

e-mail: klesment@tlu.ee

L. Sakkeus

e-mail: luule.sakkeus@tlu.ee

(C) The Author(s) 2019

D. B. Hess and T. Tammaru (eds.), Housing Estates in the Baltic Countries,

The Urban Book Series, https://doi.org/10.1007/978-3-030-23392-1_2
} 
Keywords Housing estates • Economic development - Demography • Baltic countries

\subsection{Introduction}

This chapter provides a discussion of the political, socio-economic and demographic development of the Baltic countries. The introductory chapter is meant to give readers a general understanding of the setting in which large urban housing estates were built during the decades following World War II. The features that are common to the development of Estonia, Latvia and Lithuania will be outlined as well as the characteristics that distinguish them from one another.

Estonia, Latvia and Lithuania are situated on the eastern coast of the Baltic Sea. Although frequently described as tiny, the territory of the smallest Baltic country, Estonia, exceeds that of Denmark, the Netherlands or Switzerland. If the Baltic States were a single country, its combined area would comprise 175 thousand $\mathrm{km}^{2}$ and rank ninth among the member states of the European Union. However, the Baltic countries are sparsely populated; in the EU context, only Sweden and Finland possess lower population density.

While there have been several individual studies of Estonia, Latvia and Lithuania published since the 1990s (Plakans 1995; Raun 2001; Kiaupa 2002; Mäesalu et al. 2004; Bleiere et al. 2006), relatively few comparative accounts of the development of the Baltic countries are accessible to an international reader. To a significant extent, this chapter draws on the groundbreaking work of Romuald Misiunas and Rein Taagepera (2nd edition 1993) on the Baltics under Soviet rule. A survey of the economic history of the Baltic States, compiled by Kahk and Tarvel (1997), and two more recent treatises by Andres Kasekamp (2010) and Andrejs Plakans (2011) were valuable resources used for the chapter. These materials have been complemented by evidence from studies pertaining to the economic history and demography of Estonia, Latvia and Lithuania.

\subsection{The Long Road to Nation-Statehood, Loss and Restoration of Independence}

Although linked by spatial proximity, the ancestors of modern-day Estonians, Latvians and Lithuanians are linguistically diverse peoples. Estonians speak a Finno-Ugric language akin to Finnish, while Latvian and Lithuanian are the only surviving strands of the Baltic family of Indo-European languages. During the Northern Crusades, lands that would subsequently become modern Estonia and Latvia were subjugated to German and Danish conquerors. Invaders established themselves as a ruling elite that baptised, colonised and gradually enserfed the 
indigenous population. By contrast, Lithuanians succeeded in establishing their own political entity, which in 1386 joined in dynastic union with neighbouring Poland. This union with Poland led to the gradual Polonisation of the Lithuanian nobility, although they maintained a distinct sense of identity.

The early sixteenth century witnessed the emergence of an important cultural boundary within the Baltic region. The Reformation spread rapidly to the territory of modern Estonia and Latvia. Although Protestantism (in the form of Calvinism) gained some adherents in Lithuania, the southern part of the Baltic region remained Catholic. A major political realignment was prompted by a Muscovian push towards the Baltic Sea in 1558. In response, feudal rulers and merchant cities of the region began to seek foreign protection. At the beginning of the seventeenth century, wars were fought between Sweden and Poland-Lithuania for control of the region. The conflict ended in 1629, when most of the territory of Livonia was ceded to Sweden, with the exception of Latgale in south-eastern Latvia, which remained under Polish rule. The cultural division between the Lutheran north and Catholic south became a lasting feature of the Baltic region.

The next major shift in the political configuration of the region occurred with Russia's renewed attempt to gain access to the Baltic Sea. As a result of the Great Northern War (1700 to 1721), Sweden lost the provinces of Estland and Livland to Russia. Tsar Peter the Great regarded the area as Russia's 'window to the West', offering the local nobility generous terms of surrender and reinstating their former privileges, which had been curtailed under Swedish rule. During the first partition of the Polish-Lithuanian Commonwealth in 1772, Russia annexed Polish Livonia (Latgale). During the second partition of Poland in 1793, Russia gained parts of the Lithuanian State, and during the third partition in 1795, the remainder fell under Russian rule. That same year, the Duchy of Courland was annexed to Russia and was granted the same autonomy as given earlier to the provinces of Estland and Livland. Together, the three formed Russia's Baltic provinces. With the third and final partition of Poland-Lithuania, Russia had gained control over almost the entire territory of the modern Baltic States. Only Memel (present-day Klaipeda) remained under Prussia (Germany) until after World War I.

Within the Russian Empire, the three Baltic provinces and the Lithuanian lands remained distinct from each other and from other areas of the Empire. As elsewhere in Europe, the Enlightenment gradually started to challenge existing societal arrangements. From 1816 to 1819, the Baltic provinces of Estland, Livland and Courland became the first regions of the Russian Empire to abolish serfdom, although peasant ownership of land only started to increase in the $1860 \mathrm{~s}$. Lithuanians and Poles revolted against Russian control from 1830 to 1831, and again from 1863 to 1864, both attempts failed and resulted in repression by Tsarist authorities and implementation of forced Russification a couple of decades earlier than in the remaining parts of the region. The late nineteenth century witnessed the awakening of national consciousness throughout the region (Hroch 2000). The persecution of Roman Catholics by Tsarist authorities turned a struggle for religious equity into one facet of the Lithuanian national awakening movement, unlike its other Baltic counterparts. In tandem with socio-economic modernisation, 
the growth of national consciousness prepared the ground for Estonian, Latvian and Lithuanian nation-states. An opportunity was presented by the collapse of the old empires during the turmoil of World War I. On 16 and 24 February 1918, respectively, Lithuania and Estonia declared independence. A Latvian declaration followed on 18 November.

The practical organisation of the new states would begin only after the armistice in the West that ended the German occupation of the Baltics. However, the Red Army invaded the newly independent countries in November 1918. It quickly seized large parts of Estonia and Lithuania and almost all of Latvia, and installed puppet governments headed by local Bolsheviks. In 1919, the fortunes of war turned against the invaders. By the spring of 1919, the Estonian territory had been cleared, although hostilities continued until a peace treaty was negotiated with Soviet Russia in February 1920. With support from Estonia and Poland, Latvia succeeded in achieving control over its territory in early 1920. In Lithuania, German troops blocked the advance of the Red Army towards Kaunas and the Polish army repelled them from Vilnius in 1919. Lithuania and Latvia signed peace treaties with Soviet Russia in July and August 1920, respectively. The establishment of Lithuanian independence was confounded by pressures from a newly formed Polish state for a return to a Polish-Lithuanian union. The situation was aggravated by conflicting claims over Vilnius; in 1920, the historical capital of Lithuania was seized by the Poles, resulting in strained relations between the two nations throughout the interwar period. In 1923, Lithuania took control over Memel (present-day Klaipeda), which had been separated from East Prussia by the Treaty of Versailles and had become a mandated territory of the League of Nations.

Having successfully defended their independence, the Baltic States faced the challenge of nation building. They needed to reform their political, social and economic systems in conformity with their newly achieved status as modern states. From 1919 to 1922 , all three countries conducted land reforms, which proved more radical in Estonia and Latvia by abolishing the large estates owned by Baltic-German barons. Liberal constitutions were adopted and democratic legislatures elected in all three countries, which later, as in a number of nations in interwar Europe, gave way to more authoritarian rule. However, the forms of authoritarianism in the Baltics were mild and did not significantly hinder the social and cultural advancement that had begun with the achievement of independence.

The Baltic countries strove to maintain neutrality in foreign relations by signing non-aggression pacts with both the USSR and Germany. Unfortunately, these efforts proved futile with the rise of Stalin in the USSR and Hitler in Germany. In March 1939, Germany re-annexed Memel (Klaipeda). Furthermore, in August 1939, Nazi Germany and the USSR concluded the treaty known as the MolotovRibbentrop Pact. The treaty had a secret protocol that divided Eastern Europe into spheres of interest, with Estonia, Latvia, Finland, Romanian Bessarabia (Moldova) and eastern Poland included in the Soviet sphere, and the rest of Poland and Lithuania ceded to Germany. After the annihilation of Poland, Germany and the USSR traded Lithuania for a larger share of Poland, leaving all three Baltic countries to the Soviet Union. In September and October 1939, the latter demanded 
to station its military bases in the region. In June 1940, the Soviets took over the Baltic countries, and after installing puppet governments and staging so-called elections, annexed Estonia, Latvia and Lithuania to the USSR as union republics.

From 1941 to 1944 (in western Latvia until May 1945), the Baltic countries were occupied by Nazi Germany. The second Soviet occupation commenced in the fall of 1944, and lasted nearly 50 years. In the 1940s and early 1950s, a new regime was introduced and forced Sovietisation on all facets of society. After Stalin's death in 1953, terror subsided and the Baltic peoples gradually accustomed themselves to the new conditions, which could be characterised as a state of dependence. Unlike the Soviet satellite states of Eastern Europe, the Baltic countries, particularly Estonia and Latvia, evolved within the strict dictates of central administration and growing pressures for Russification from the 1970s onwards.

After 1985, taking advantage of the liberalisation of the regime by Soviet leader Mikhail Gorbachev, aspirations towards the restoration of independence gathered force in all three Baltic countries. The coordinated actions of Baltic popular movements hastened democratisation within the USSR and undermined the foundations of the Soviet Empire. On 23 August 1989, the 50 ${ }^{\text {th }}$ anniversary of the Molotov-Ribbentrop Pact, a two-million-strong human chain stretched from Tallinn to Vilnius (Fig. 2.1). The next couple of years brought gradual

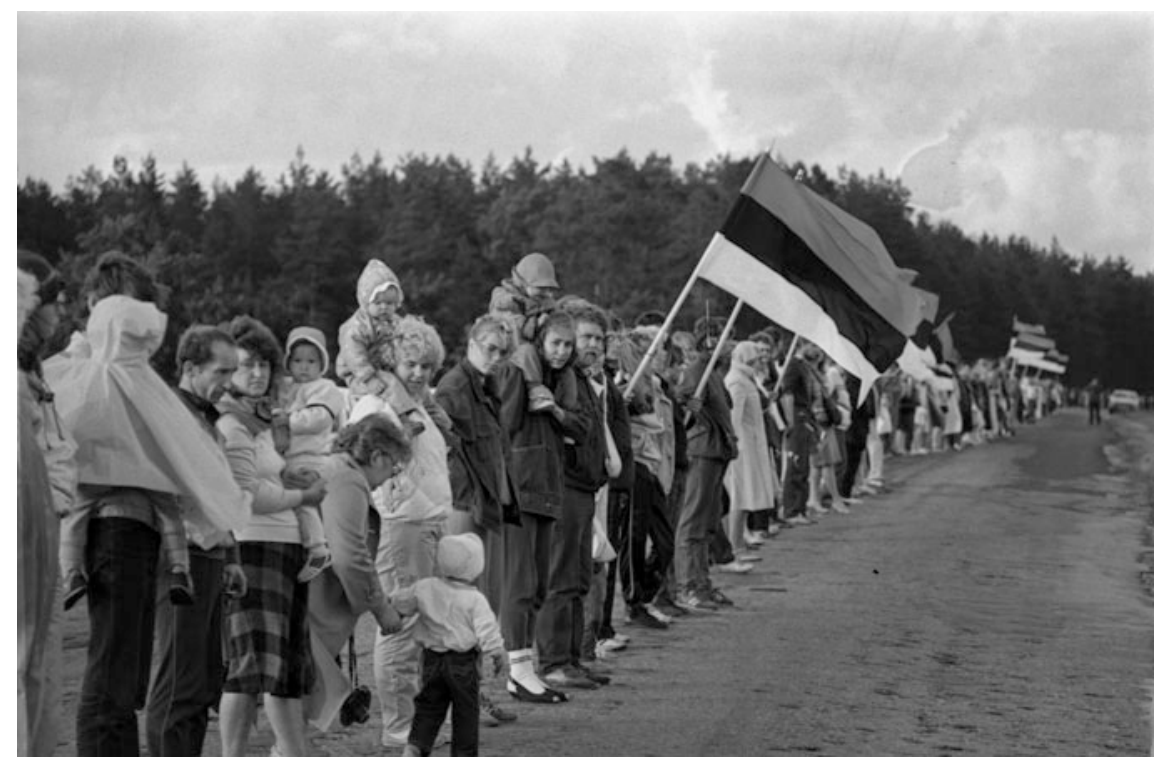

Fig. 2.1 The Baltic Way or Baltic Chain was a $675-\mathrm{km}-$ long human chain that spanned the length of the three Baltic States on 23 August 1989, to commemorate and draw attention to the secret clause of the Molotov-Ribbentrop Pact of 1939. This agreement between Nazi Germany and the Soviet Union had placed the Baltic States within the Soviet Union's sphere of influence and anticipated the annexation of these countries. The secret clause was denied by the Soviet Union up until 1989. Source H. Leppikson, National Archives of Estonia, EFA.250.0-139849. Photo permission obtained from National Archives of Estonia 
advancement towards increased autonomy for the Baltic countries. Finally, following the failed putsch of Communist hardliners in Moscow in August 1991, authorities in Estonia, Latvia and Lithuania seized the opportunity to declare full independence. A wave of international recognition followed, and in September 1991, the Baltic States were admitted to the United Nations. Despite a relatively disadvantaged starting position, Estonia, Latvia and Lithuania have made remarkable progress in the decades following the restoration of independence. Achievements in the political arena are reflected in stable democracies in all three Baltic nations and their membership in the European Union and the North Atlantic Treaty Organisation.

\subsection{Socio-Economic Development}

Within the Russian Empire, the economies of the Baltic region were primarily agricultural. Modernisation of the agricultural sector was impeded by the persistence of the manorial system, which was based on peasant labour (Kahk and Tarvel 1997). Up until the end of the nineteenth century, approximately half of the farmers in the provinces of Estland and Livland still remained landless; in Lithuania, the proportion was smaller. A re-orientation to dairy farming, facilitated by an expanding railway network that allowed easier access to the Russian market, brought a major change in agriculture (Kõll 1994).

Tsarist policy led to intense industrialisation in the Baltic region at the end of the nineteenth and beginning of the twentieth centuries. Riga became one of the most important industrial centres and port towns of the Russian Empire. Large industrial enterprises were also established in Tallinn and other urban areas. Transport infrastructure (railways and ports) boosted external trade traffic through the Baltics and laid the foundations for the development of heavy industry in major Baltic cities. The textile and chemical industries and machine building became important sectors of Baltic economies. While the region experienced a notable increase in industrial output, production was mainly based on imported raw materials and served the needs of the internal Russian market. Tariffs protected local industries from international competition.

The outbreak of World War I and the German advance into the Baltic region led to the evacuation of many industries and industrial workers to Russia. Riga lost substantial industrial capacity, and, as a result, the employment structure of Latvia became much more agricultural than it had been before the war (Karnups 2012). During the first years of independence, the Baltic countries attempted to revive pre-war heavy industry in hope of exporting to the Russian market (Pihlamägi 1999), but Soviet Russia placed limits on imports and the policy to revive heavy industry failed. As a result, the Baltic countries were required to re-orient their economies towards Western markets. To illustrate the scale of re-orientation, 
90\% of Estonian exports prior to World War I went to the Russian market. By 1920, this figure had fallen to $32 \%$, and in 1924, it was just over five percent (Valge 2006).

The agricultural sectors of the Baltic States were significantly transformed by land reforms that were carried out in the newly independent countries from 1919 to 1922. Lands of the former nobility were in large part confiscated and redistributed to peasants (Kahk and Tarvel 1997). For a considerable part of the rural population of Estonia, Latvia and Lithuania, this was the first opportunity to own land. Agricultural production in the Baltic countries during the interwar years also featured a successful co-operative movement. Co-operative associations were established to provide farmers with credit and also to give them assistance with machinery, marketing and exports. Agricultural output, particularly of dairy and meat products, became one of the most important exports of the Baltic economies during the interwar period. Following the Great Depression, the economic policy of the Baltic States in the 1930s resembled that of many other European countries, including a higher degree of state control over foreign trade and more state regulation of industry and agriculture (Kõll and Valge 1998). Some industries, such as oil shale in Estonia, were prioritised. Such state intervention in economic affairs can also be described as corporatism, with the state creating a number of government-controlled monopolies that regulated output and export.

The incorporation of the Baltic States into the Soviet Union once again dramatically altered the economic and social structure of the region. The politics of the USSR demanded the eradication of private ownership of the means of production. Nationalisation of banks and large- and medium-sized enterprises started in 1940 the first year of Soviet occupation - and was then extended to land and private housing that exceeded a certain amount of space (Mertelsmann 2006). The USSR had already implemented a strategy of heavy industrialisation and collectivisation of agriculture during the interwar period. This was now applied to the Baltic republics. At the end of the 1940s, farmers were forced to join collective farms for fear of being labelled as 'kulaks'. Large-scale deportations served to spread terror among those who were tempted to oppose the new regime (Misiunas and Taagepera 1993). However, collective farms were often small, and only in the 1950s did they start to be merged into more viable production units. During the early post-war years, the reorganisation of agriculture was disastrous to productivity, and output dropped to much lower levels than before collectivisation (Raun 2001; Kahk and Tarvel 1997).

Industrialisation of the Baltic countries during the Stalinist period was not solely an economic consideration but also a measure that quickly changed the composition of the population (Lewis and Rowland 1979). Under the pretext that the local workforce was insufficient, hundreds of thousands of workers, specialists and administrators from other parts of the USSR were brought to the Baltic countries and employed in the rapidly expanding industries. In Estonia, the chemical industry became one of the prioritised branches, partly capitalising on pre-war oil shale production. The metal and textile industries and machine building were also targeted. In Latvia and Lithuania, machine building, metal-working and electronics 


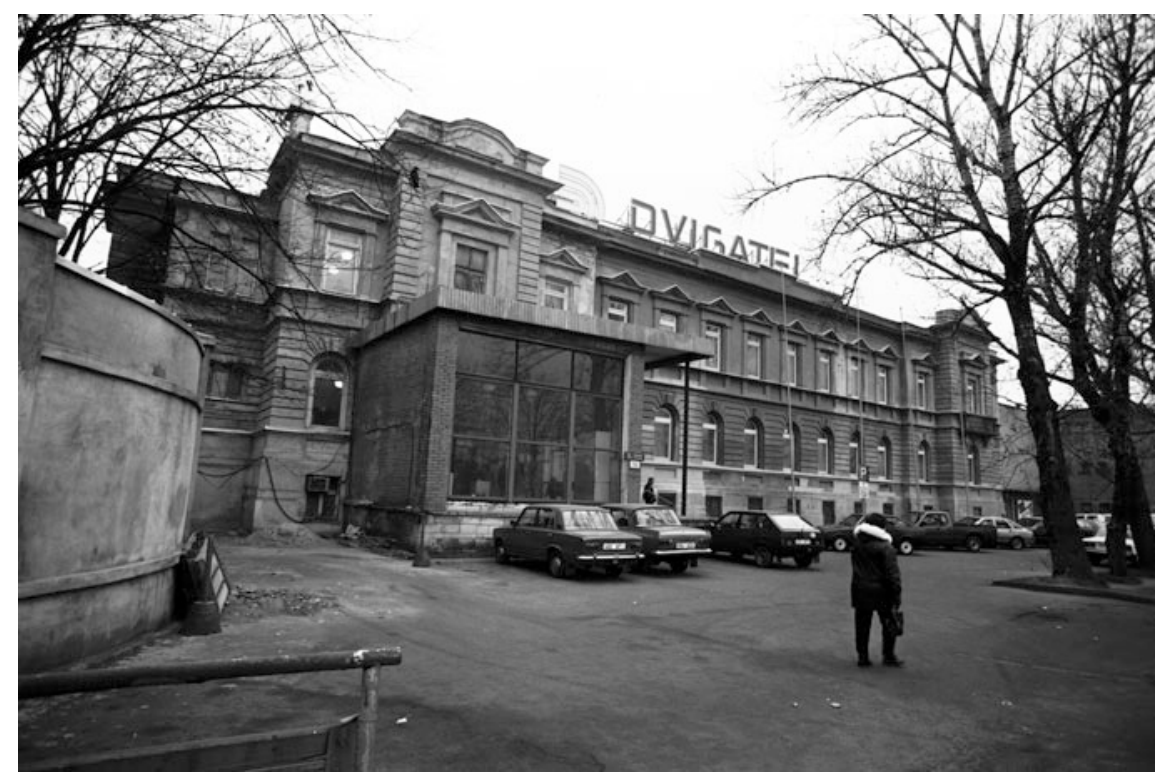

Fig. 2.2 The administrative building of the 'Dvigatel' plant, founded in 1897 to produce railway equipment. During the Soviet era, the plant specialised in machine building for strategic and military purposes. Like other all-union enterprises controlled directly by Moscow, 'Dvigatel' served as a major migration channel for workers from other parts of the Soviet Union. Source V. Puhm, National Archives of Estonia, EFA.251.0-156490. Photo permission obtained from National Archives of Estonia

were among the prioritised industries. Figure 2.2 depicts the factory complex 'Dvigatel' in Tallinn, Estonia that produced machinery for USSR atomic and chemical industries. Soviet industrialisation exerted a profound influence on Baltic cities, producing remarkably rapid rates of urban growth. However, despite the arrival of large numbers of new urban dwellers, relatively little housing or new infrastructure was constructed in the Baltic cities in the late 1940s and 1950s, which resulted in deficiencies in both areas throughout the early post-war decades.

After the death of Stalin, the period known as the 'Khrushchëv Thaw' brought some decentralisation of administration. In the Baltic countries, more decision-making freedom was given to local leaders, bringing a relative improvement in branches of the economy that more directly served the needs of the population. Agricultural enterprises in the Baltic republics achieved a high output and diversity of production that made them success stories of collective farming in the Soviet Union (Järvesoo 1973). Both agricultural and industrial outputs rapidly increased during the Thaw and pre-war living standards were reached in the 1960s. At the end of the 1960s, Estonia's national income was estimated to be $44 \%$ higher than the USSR average, Latvia's $42 \%$ and Lithuania's 15\% (Misiunas and Taagepera 1993). 
Between the mid-1960s and the 1980s, management of the economy was re-centralised in Moscow, but at the same time, more autonomy was given to enterprises ('self-management') in order to increase their accountability for results. In an environment of soft budget constraints and the continuous need to meet yearly production plans, increasing output by attracting more labour was often considered to be the solution. This strategy was supported through large-scale housing construction, which gained momentum in the 1960s and continued until the late Soviet period. Hallmarks of this period include large panel estates that can be found in all Baltic cities. In the context of state socialism, in which the housing market was suppressed, the provision of accommodation was an important fringe benefit that enterprises could offer to their employees, thus strongly guiding individuals' employment and migration decisions (Gentile and Sjöberg 2013). This system favoured enterprises within the economy's prioritised sectors, which were under the direct control of Moscow (heavy industry, defence). Enterprises in these sectors were better equipped with resources for housing construction.

Compared to the Thaw period, industrial growth rates declined: the five percent annual growth that occurred at the end of the 1970s was only half of what it had been during the second part of the 1950s (Misiunas and Taagepera 1993). Economic growth stagnated even further in the 1980s, and for the average consumer, a deficit of goods became reality. Despite large numbers of new dwellings constructed in the 1970s and 1980s, the demand for housing continued to exceed the supply, particularly for subgroups of the population not employed in prioritised sectors. Still, in the context of the Soviet Union, the Baltic region featured comparatively higher living standards than other union republics.

After the dissolution of the USSR and regained independence of the Baltic States, a series of profound reforms were carried out in the 1990s to transition from a centrally planned system to a market economy. Economic reforms and privatisation of state enterprises were most radical in Estonia, while in Lithuania the transformation was slower and more gradual (Norkus 2012). According to the most recent statistics, in Estonia and Lithuania, per capita GDP adjusted for purchasing parity is $75 \%$ of the EU average, and somewhat lower (64\%) in Latvia. These figures rank Lithuania and Estonia fourth and fifth, respectively, and Latvia seventh among the Eastern European member states of the EU (Eurostat 2017).

In the housing sector, all three countries implemented large-scale privatisation of dwellings to sitting tenants along with the restitution of housing to pre-war owners. As a result, an overwhelming majority of dwellings became owner-occupied and home-ownership rates surged. With respect to housing supply, the diversity and quality of new dwellings have markedly improved since 1990. However, Soviet-era panel estates still house the majority of urban dwellers in Baltic cities. 


\subsection{Demographic Development, Urbanisation and Ethnic Composition}

In the context of the Russian Empire, Baltic peoples were forerunners with respect to demographic modernisation. The earliest divide that distinguished Estonians, Latvians and Lithuanians demographically from other nations under the Tsar's rule relates to the emergence of the so-called Western European marriage pattern, characterised by a relatively late age at marriage and a high proportion of people who would never marry (Hajnal 1965). In the late nineteenth century, the mean age at first marriage for women was 25 to 26 years in the provinces that later became modern Estonia, Latvia and Lithuania.

The change in the marriage pattern paved the way towards a more radical development, controlled marital reproduction. Early demographic modernisation in the Baltic countries is corroborated by evidence from the Princeton European Fertility Project, which analysed the decline of fertility in Europe since the nineteenth century (Coale et al. 1979; Coale and Watkins 1986). The dates as of which a sustained decline in marital fertility could be observed were 1888 for Estonia, 1892 for Latvia and 1895 for Lithuania. These dates closely resemble estimates for Western Europe, with those of Germany (1888), England and Wales (1892), and Scotland (1894) occurring during the same period. In Russia and Ukraine, a sustained fertility decline began 20-30 years later. Likewise, death rates in the Baltic region were lower than in European Russia in the late nineteenth century (Rashin 1956). According to the earliest estimates, life expectancy in the provinces of Estland, Livland and Courland was 39 years for men and 43 years for women in the early 1880s. These figures show that life expectancy in the Baltic provinces exceeded that in Prussia and Bavaria but lagged somewhat behind France, England and Wales, and the Scandinavian countries (Rothenbacher 2002).

In the three Baltic countries, the interwar period of independence was shaped by the continuation of demographic trends that had started in the second half of the nineteenth century. In Estonia and Latvia, fertility decreased below replacement levels in the late 1920s and early 1930s, which is often regarded as the endpoint of the transition from large to small families. In a comparative perspective, the emergence of below-replacement fertility during the interwar years places Estonia and Latvia in the same category as most countries of Northern and Western Europe (Katus 1994). Although progress towards a modern demographic regime was also underway in Lithuania, fertility levels remained higher in the latter country. From the early 1920s to the late 1930s, Baltic mortality declined rapidly, narrowing the gap between more advanced countries of Western Europe. Life expectancy in Estonia and Latvia climbed more quickly than in France; in the late 1930s, Latvia slightly surpassed the latter country (Vallin et al. 2017). Trends in infant mortality suggest that similar progress occurred in Lithuania.

In regard to urbanisation, Latvia appeared to be the most advanced of the three Baltic countries during the interwar period. In the late 1930s, 37\% of Latvians were urban residents. Even during the Tsarist era, Riga had developed into an unofficial 
capital for the entire Baltic region and was the third largest urban centre in the Russian Empire after Moscow and St. Petersburg. During the same period in Estonia, the proportion of urban residents was somewhat lower (33\%), and in Lithuania they comprised only $23 \%$ of the total population.

The loss of independence and incorporation into the USSR in $1940 \mathrm{had}$ far-reaching demographic consequences for the Baltic countries. It has been estimated that from 1939 to 1945 , the combined losses inflicted by political terror, deportation, war, mobilisation, evacuation, flight to the West and border changes affected $25 \%$ of the pre-war population of Estonia, $30 \%$ of Latvia and $15 \%$ of Lithuania (Misiunas and Taagepera 1993). In the Baltic region, armed conflict did not cease with the end of World War II. Fighting against the Soviet occupation continued in the late 1940s and early 1950s, with the greatest intensity in Lithuania. In the latter country, an estimated 33,000 were killed on both sides (Burauskaite and Morkus 2002); in Estonia and Latvia, the number of victims was much smaller. The largest post-war deportation was carried out in the Baltic countries in March 1949, with a total of 95,000 people 're-settled' in remote regions of the USSR (Strods and Kott 2002).

However, notwithstanding the large losses caused by the war and Sovietisation, the Baltic countries experienced remarkably rapid population growth during the post-war decades (Table 2.1). Between the 1959 and 1989 censuses, the population increased $31 \%$ in Estonia, 28\% in Latvia and 36\% in Lithuania. In fact, even higher growth rates have been reported for the late 1940s and 1950s, but the dubious reliability of population statistics for the period prior to the first post-war census (1959) warrants caution with regard to their use. By the late 1980s, the population

Table 2.1 Total, urban and rural population, Baltic States, 1959-2017 (in thousands)

\begin{tabular}{|c|c|c|c|c|c|c|c|c|c|}
\hline \multirow[t]{2}{*}{ Year } & \multicolumn{3}{|c|}{ Estonia } & \multicolumn{3}{|l|}{ Latvia } & \multicolumn{3}{|c|}{ Lithuania } \\
\hline & Total & Urban & Rural & Total & Urban & Rural & Total & Urban & Rural \\
\hline 1959 & 1,197 & $\begin{array}{l}676 \\
(56 \%)\end{array}$ & $\begin{array}{l}521 \\
(44 \%)\end{array}$ & 2,080 & $\begin{array}{l}1,076 \\
(52 \%)\end{array}$ & $\begin{array}{l}1,004 \\
(48 \%)\end{array}$ & 2,697 & $\begin{array}{l}1,026 \\
(38 \%)\end{array}$ & $\begin{array}{l}1,671 \\
(62 \%)\end{array}$ \\
\hline 1970 & 1,356 & $\begin{array}{l}881 \\
(65 \%)\end{array}$ & $\begin{array}{l}475 \\
(35 \%)\end{array}$ & 2,352 & $\begin{array}{l}1,435 \\
(61 \%)\end{array}$ & $\begin{array}{l}917 \\
(39 \%)\end{array}$ & 3,119 & $\begin{array}{l}1,558 \\
(50 \%)\end{array}$ & $\begin{array}{l}1,561 \\
(50 \%)\end{array}$ \\
\hline 1979 & 1,464 & $\begin{array}{l}1,017 \\
(69 \%)\end{array}$ & $\begin{array}{l}448 \\
(31 \%)\end{array}$ & 2,503 & $\begin{array}{l}1,664 \\
(66 \%)\end{array}$ & $\begin{array}{l}839 \\
(34 \%)\end{array}$ & 3,391 & $\begin{array}{l}2,035 \\
(60 \%)\end{array}$ & $\begin{array}{l}1,357 \\
(40 \%)\end{array}$ \\
\hline 1989 & 1,566 & $\begin{array}{l}1,119 \\
(71 \%)\end{array}$ & $\begin{array}{l}447 \\
(29 \%)\end{array}$ & 2,667 & $\begin{array}{l}1,851 \\
(69 \%)\end{array}$ & $\begin{array}{l}815 \\
(31 \%)\end{array}$ & 3,675 & $\begin{array}{l}2,487 \\
(68 \%)\end{array}$ & $\begin{array}{l}1,188 \\
(32 \%)\end{array}$ \\
\hline $2000^{1}$ & 1,370 & $\begin{array}{l}923 \\
(67 \%) \\
\end{array}$ & $\begin{array}{l}447 \\
(33 \%) \\
\end{array}$ & 2,377 & $\begin{array}{l}1,618 \\
(68 \%)\end{array}$ & $\begin{array}{l}759 \\
(32 \%)\end{array}$ & 3,484 & $\begin{array}{l}2,332 \\
(67 \%)\end{array}$ & $\begin{array}{l}1,152 \\
(33 \%)\end{array}$ \\
\hline 2011 & 1,294 & $\begin{array}{l}879 \\
(68 \%)\end{array}$ & $\begin{array}{l}415 \\
(32 \%)\end{array}$ & 2,070 & $\begin{array}{l}1,404 \\
(68 \%)\end{array}$ & $\begin{array}{l}666 \\
(32 \%)\end{array}$ & 3,043 & $\begin{array}{l}2,031 \\
(67 \%)\end{array}$ & $\begin{array}{l}1,012 \\
(33 \%)\end{array}$ \\
\hline 2017 & 1,316 & $\begin{array}{l}899 \\
(68 \%)\end{array}$ & $\begin{array}{l}415 \\
(32 \%)\end{array}$ & 1,950 & $\begin{array}{l}1,333 \\
(68 \%)\end{array}$ & $\begin{array}{l}618 \\
(32 \%)\end{array}$ & 2,848 & $\begin{array}{l}1,911 \\
(67 \%)\end{array}$ & $\begin{array}{l}937 \\
(33 \%)\end{array}$ \\
\hline
\end{tabular}

Source With the exception of 2017, data are obtained from Estonian, Latvian and Lithuanian censuses; population increase in Estonia between the 2011 census and 2017 is an artefact resulting from a change in statistical methodology. The Lithuanian population was enumerated in 2001 
reached 1.566 million in Estonia, 2.667 million in Latvia and 3.675 million in Lithuania.

Although the growth rates appear fairly similar for the three countries, the factors contributing to the increase varied significantly. As noted above, Estonia and Latvia had already reached below-replacement fertility levels and a relatively limited excess of births over deaths in the 1930s. Unlike the forerunners of the fertility transition in Northern and Western Europe, Estonia and Latvia witnessed no baby boom in the decades following World War II; in the 1950s and for most of the 1960s, Estonia and Latvia had fertility rates persistently below replacement level. It has been hypothesised that the absence of a baby boom arose from a combination of low fertility attained during the pre-war period and the harsh societal conditions that prevailed in the region during the immediate post-war decade (Katus and Puur 2003). As a consequence, in Estonia and Latvia, the population increase during the Soviet period was driven by large-scale in-migration from other regions of the USSR, mainly from Russia. Between 1959 and 1989, positive net migration directly accounted for $54 \%$ of population growth in Estonia and $60 \%$ in Latvia. A large part of the natural increase also stems from the youthfulness of migrants. In Estonia, for instance, this characteristic was responsible for more than three-fourths of the excess of births over deaths observed during the period.

In accord with its somewhat later demographic modernisation, Lithuania exhibited persistently higher fertility levels than its northern neighbours. At the turn of the 1950s, the total fertility rate in Lithuania was still three children per woman (Stankuniene and Jasilioniene 2008). Despite a gradual decline, fertility in Lithuania continued to exceed the replacement level over the following decades, until ultimately converging with that of Estonia and Latvia around 1980. In Lithuania, the persistence of replacement-level fertility well into the late 1970s implied a considerable excess of births over deaths throughout the entire Soviet period. Although net migration was positive in Lithuania as well, it made a relatively minor contribution to total population growth. Between the 1959 and 1989 censuses, migration accounted for only one-fifth of the growth, while natural increase was responsible for the remaining four-fifths.

In the late 1960s, the long-running similarity in family patterns between Estonia, Latvia and Lithuania, and the countries of Western Europe drew to a close (Coale 1994). The latter countries experienced a shift away from the trend towards earlier family formation that characterised the 1940 and 1950s. By contrast, in the Baltic region, a decrease in the mean age of marriage and childbearing persisted well into the 1970s and 1980s, leading to a convergence of family formation patterns in the Baltics with those of Eastern Europe (Katus et al. 2008). Several researchers have drawn attention to the role of housing allocation in encouraging early family formation (Ni Bhrolchain 1993; Speder 2005). Since the birth of a child increased the number of family members and the dwelling density, the system provided a strong incentive to start childbearing sooner rather than later. From another perspective, the housing shortage severely limited the autonomy of young people and prolonged their dependence on their parents. In a survey conducted in the capital city of 
Estonia in the 1980s, about half of the respondents had lived with their parents or their partner's parents following marriage (Vikat 1994).

As noted in the previous section, the post-war decades featured remarkably rapid urbanisation in the Baltic region. At the time of the 1959 census, the share of urban dwellers surpassed pre-war levels by $24 \%$ in Estonia and by 15 in Latvia and Lithuania. As a result, Estonia overtook Latvia with respect to the proportion of urban residents. As revealed by evidence presented in Table 2.1, urbanisation continued in the 1960s and 1970s. Lithuania experienced particularly rapid urban growth: the urban population increased by more than $50 \%$ in the 1960 s and by more than $30 \%$ in the 1970s. This enabled Lithuania to close much of the previous gap with the other Baltic countries in terms of urbanisation. By the last Soviet census (1989), the proportion of the urban population had reached $68 \%$ in Lithuania, 69\% in Latvia and $71 \%$ in Estonia. In the latter countries, the decline in the rural population slowed down in the 1980s. In Estonia, the reversal of urban-rural migration flows was driven by favourable housing and employment conditions offered by wealthy enterprises in the agricultural sector (Tammaru 2001).

Varying contributions of migration and natural increase had important implications for the ethnic composition of the Baltic countries (Table 2.2). Before World War II, the proportion of the titular ethnic group was $88 \%$ in Estonia, $76 \%$ in Latvia and $84 \%$ in Lithuania, excluding the areas of Vilnius and Klaipeda (Zvidrinsh 1995). As a result of wartime repatriation of Germans and Swedes, Nazi extermination of Jews and Gypsies, and the transfer of border regions of Estonia and Latvia to the Russian Federation, the proportion of titular groups had increased throughout the region. In the following decades, however, the trends in ethnic composition diverged across the countries. In Estonia and Latvia, the combination of low fertility among the native population and large-scale in-migration resulted in a marked decrease in the proportion of titular groups. In the late 1980s, Estonians constituted $62 \%$ of the total population of Estonia, while in Latvia, the share of Latvians had fallen to $52 \%$. In both countries, the non-titular ethnic groups were concentrated in urban areas, including the capital cities; in both Tallinn and Riga, post-war migrants and their descendants outnumbered the titular groups. Outside the capital cities, high concentrations of non-titular ethnic groups had emerged in the industrial regions of north-eastern Estonia and eastern Latvia. By contrast, the large natural increase among Lithuanians sustained by their higher fertility rates prevented a major shift in the proportion of titular and non-titular groups in Lithuania. From 1959 to 1989 , the share of Lithuanians remained close to $80 \%$, with no significant increases or decreases. Another characteristic specific to Lithuania was a sizeable Polish minority concentrated in Vilnius and the surrounding areas.

Within the cities of the Baltic region, particularly Estonia and Latvia, the housing allocation mechanism of the Soviet era produced residential segregation along ethnic lines (Hess et al. 2012). Russian-speaking immigrant workers from other parts of the Former Soviet Union, who frequently arrived through organised channels of migration, were to a large extent recruited by enterprises in the prioritised sectors of the economy which had sufficient resources to provide their employees with accommodation. Immigrants also needed housing immediately 
Table 2.2 Ethnic composition of the population, Baltic States, 1959-2011 (in thousands)

\begin{tabular}{|c|c|c|c|c|c|c|}
\hline $\begin{array}{l}\text { Country/ethnic } \\
\text { group }\end{array}$ & 1959 & 1970 & 1979 & 1989 & 2000 & 2011 \\
\hline \multicolumn{7}{|l|}{ Estonia } \\
\hline Estonians & $\begin{array}{l}893 \\
(75 \%)\end{array}$ & $\begin{array}{l}925 \\
(68 \%)\end{array}$ & $\begin{array}{l}948 \\
(65 \%)\end{array}$ & $\begin{array}{l}963 \\
(62 \%)\end{array}$ & \begin{tabular}{|l|}
930 \\
$(68 \%)$
\end{tabular} & \begin{tabular}{|l|}
903 \\
$(70 \%)$
\end{tabular} \\
\hline Russians & $\begin{array}{l}240 \\
(20 \%)\end{array}$ & $\begin{array}{l}335 \\
(25 \%)\end{array}$ & $\begin{array}{l}409 \\
(28 \%)\end{array}$ & $\begin{array}{l}475 \\
(30 \%)\end{array}$ & $\begin{array}{l}351 \\
(26 \%)\end{array}$ & $\begin{array}{l}326 \\
(25 \%)\end{array}$ \\
\hline Others & $64(5 \%)$ & $96(7 \%)$ & $\begin{array}{l}107 \\
(7 \%)\end{array}$ & $\begin{array}{l}128 \\
(8 \%)\end{array}$ & $89(6 \%)$ & $65(5 \%)$ \\
\hline \multicolumn{7}{|l|}{ Latvia } \\
\hline Latvians & $\begin{array}{l}1,298 \\
(62 \%)\end{array}$ & $\begin{array}{l}1,342 \\
(57 \%)\end{array}$ & $\begin{array}{l}1,344 \\
(54 \%)\end{array}$ & $\begin{array}{l}1,388 \\
(52 \%)\end{array}$ & $\begin{array}{l}1,371 \\
(58 \%)\end{array}$ & $\begin{array}{l}1,285 \\
(62 \%)\end{array}$ \\
\hline Russians & $\begin{array}{l}556 \\
(27 \%)\end{array}$ & $\begin{array}{l}705 \\
(30 \%)\end{array}$ & $\begin{array}{l}821 \\
(33 \%)\end{array}$ & $\begin{array}{l}906 \\
(34 \%)\end{array}$ & \begin{tabular}{|l}
703 \\
$(30 \%)$ \\
\end{tabular} & $\begin{array}{l}557 \\
(27 \%) \\
\end{array}$ \\
\hline Others & $\begin{array}{l}239 \\
(11 \%)\end{array}$ & $\begin{array}{l}317 \\
(13 \%)\end{array}$ & $\begin{array}{l}338 \\
(13 \%)\end{array}$ & $\begin{array}{l}373 \\
(14 \%)\end{array}$ & $\begin{array}{l}303 \\
(13 \%)\end{array}$ & $\begin{array}{l}228 \\
(11 \%)\end{array}$ \\
\hline \multicolumn{7}{|l|}{ Lithuania } \\
\hline Lithuanians & $\begin{array}{l}2,151 \\
(79 \%)\end{array}$ & $\begin{array}{l}2,507 \\
(80 \%)\end{array}$ & $\begin{array}{l}2,712 \\
(80 \%)\end{array}$ & $\begin{array}{l}2,924 \\
(80 \%)\end{array}$ & $\begin{array}{l}2,907 \\
(84 \%)\end{array}$ & $\begin{array}{l}2,561 \\
(84 \%) \\
\end{array}$ \\
\hline Russians & $\begin{array}{l}231 \\
(9 \%)\end{array}$ & $\begin{array}{l}268 \\
(9 \%)\end{array}$ & $\begin{array}{l}303 \\
(9 \%)\end{array}$ & $\begin{array}{l}344 \\
(9 \%)\end{array}$ & $\begin{array}{l}220 \\
(6 \%)\end{array}$ & \begin{tabular}{|l|}
176 \\
$(6 \%)$
\end{tabular} \\
\hline Poles & $\begin{array}{l}230 \\
(9 \%)\end{array}$ & $\begin{array}{l}240 \\
(8 \%)\end{array}$ & $\begin{array}{l}247 \\
(7 \%)\end{array}$ & $\begin{array}{l}258 \\
(7 \%)\end{array}$ & $\begin{array}{l}235 \\
(7 \%)\end{array}$ & $\begin{array}{l}200 \\
(7 \%)\end{array}$ \\
\hline Others & $99(4 \%)$ & $\begin{array}{l}113 \\
(4 \%)\end{array}$ & $\begin{array}{l}129 \\
(4 \%)\end{array}$ & $\begin{array}{l}149 \\
(4 \%)\end{array}$ & $\begin{array}{l}121 \\
(3 \%)\end{array}$ & $\begin{array}{l}106 \\
(3 \%)\end{array}$ \\
\hline
\end{tabular}

Source Estonian, Latvian and Lithuanian censuses. The 1959-1970 figures are based on present (de facto) population; 1979-2011 figures are based on permanent population

upon arrival, which usually gave them priority on waiting lists. Through a combination of factors, immigrants had privileged access to new accommodation and became concentrated in the newly developed housing estates, as shown in Fig. 2.3. In contrast, the host population was over-represented in older dwellings with limited amenities and in single-family homes (Kulu 2003).

As elsewhere in Central and Eastern Europe, the demise of state socialism had immediate repercussions on the demographic regime in the Baltic region. In the early 1990s, fertility rates began a steep decline and life expectancy dropped in all three countries, tipping the balance between births and deaths to the negative (Katus et al. 2009; Vallin et al. 2017). In regard to migration, a significant number of post-war migrants who had settled in Estonia, Latvia and Lithuania during the Soviet period left the countries upon the restoration of independence (Sakkeus 1994). Censuses taken at the beginning of the twenty-first century revealed depopulation in the region: between 1989 and 2000, the population had decreased five percent in Lithuania, 11\% in Latvia and $13 \%$ in Estonia. The decline was more pronounced in urban areas, resulting in a slight reduction in the share of the urban 


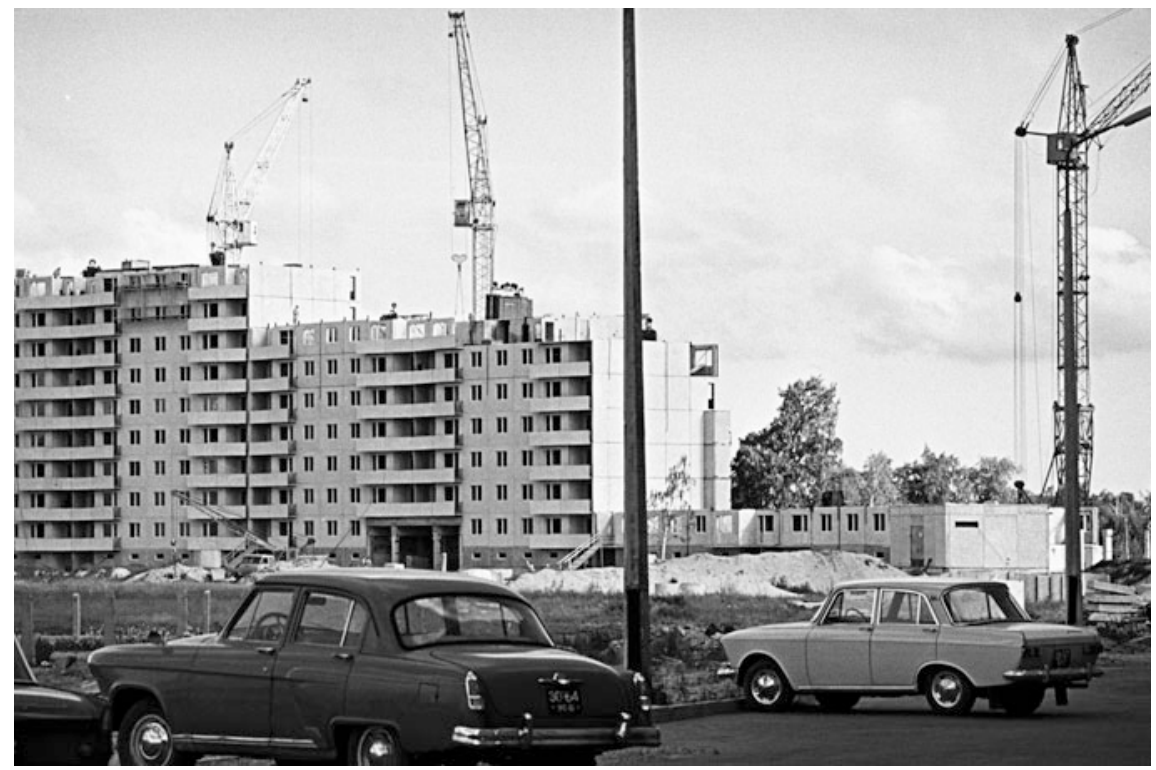

Fig. 2.3 Housing construction in Väike-Õismäe, a housing estate in the western part of Tallinn, in the 1970s. By the 1989 census, Estonian-speakers constituted a minority ( $46 \%$ of residents) in this area. In 2011, their proportion had fallen to 42\%. Source V. Gorbunov, National Archives of Estonia, EFA.204.0-104440. Photo permission obtained from National Archives of Estonia

population in all three countries. At the same time, increased out-migration and the lower fertility rates characteristic of the ethnic minority groups contributed to a recovery in the proportion of the titular groups. In 2000, the percentages of Estonians, Latvians and Lithuanians was 68, 58 and 84 in their respective countries. Due to their relatively slow integration and limited proficiency in host-country languages inherited from the Soviet era, Russian-speaking immigrants in the Baltic region proved less successful in adapting to the new economic realities; their unemployment rates were higher and their earnings somewhat lower than the national average (Lindemann 2013).

Since the turn of the century, the Baltic countries have made further progress in their demographic development. Life expectancy has risen rapidly and the gap between Northern and Western Europe has been reduced, particularly for women (Eurostat 2017). Fertility rates have also increased in all three countries; according to estimates, Estonian and Lithuanian women born in the late 1970s can be expected to give birth to 1.8-1.9 children on average (Myrskylä et al. 2013). Notwithstanding the positive shifts, as the smaller generations born after 1990 begin to prevail in the childbearing age groups, the excess of deaths over births will likely persist. Against that backdrop, recent migration trends have revealed interesting diversity among the countries. While net migration has remained negative in Latvia and Lithuania, Estonia has exhibited a negative to positive reversal in net migration 
from 2015 to 2016, plausibly driven by somewhat higher living standards in the country (Tammur et al. 2017). In regard to spatial distribution, suburbanisation trends have gained momentum in all three countries. Despite an overall decline, municipalities surrounding large urban centres, particularly the capitals, have witnessed considerable population growth (Dahs 2017). The proportions of ethnic groups have changed relatively little since the beginning of the century, except in Latvia, where the share of the titular group has continued to increase. According to recent statistics, ethnic Latvians constitute $62 \%$ of the total population of Latvia.

\subsection{Conclusion}

This chapter provided a survey of political, socio-economic and demographic developments in the Baltic countries. After having been ruled by a succession of foreign overlords, Estonia, Latvia and Lithuania emerged in 1918 as modern independent nations. However, during the course of World War II, the Baltic countries were incorporated into the USSR as union republics. Following the period of Nazi occupation, Soviet rule resumed and continued for nearly half a century, until the Baltic people seized the opportunity to restore their independence in 1991.

Such discontinuity had a major impact on the economic, social and demographic development of Estonia, Latvia and Lithuania. Due to their well-developed infrastructure, the Baltic countries hosted the development of a number of large-scale industrial enterprises during the post-war decades, a process that stimulated rapid urbanisation and led to substantial labour migration to the region. In addition, a more Western-oriented lifestyle and better living standards made the Baltic countries an attractive destination for migrants from other parts of the USSR. In Estonia and Latvia, a combination of large-scale in-migration and the small natural increase among the native populations resulted in a dramatic change in ethnic composition, transforming Estonians and Latvians into minority groups within their capital cities. In Lithuania, the higher fertility of the titular group effectively counterbalanced the impact of migration on the ethnic structure. From the 1960s to the late Soviet period, construction of large housing estates continued in the cities of the Baltic region. However, long waiting lists and a shortage of housing persisted, and compared with Western Europe, the quality of the new construction left much to be desired. A concentration of immigrant workforce in prioritised sectors of the economy, in combination with the administrative housing allocation mechanism, provided new arrivals with privileged access to new accommodation and led to an overrepresentation of immigrants in the housing estates of the state socialist era.

After regaining their independence, the Baltic countries were confronted with new challenges. Compared with the Soviet satellite states of Central Europe, Estonia, Latvia and Lithuania could afford less generous social safety nets and policies to protect the population from the adverse effects of the transition. Despite emerging trends towards suburbanisation and gentrification, housing estates built 
between the 1960s and 1980s still accommodate a large share of the urban population and shape the urban milieu in Baltic cities. However, residential mobility processes and shifts in the population mix of housing estates suggest that certain important changes may be underway. Recent studies on Estonia, a forerunner of market reforms in the Baltic region, suggest a moderate degree of social degradation; for example, there is an increasing concentration of residents with low socio-economic status in many housing estates (Tammaru et al. 2016). The following chapters of this book provide new evidence of this phenomenon throughout the Baltic region. The comparative perspective underlying the analyses offers insight not only into existing patterns but also into the mechanisms that shape social and ethnic outcomes for Soviet-era housing estates in the Baltic countries.

Acknowledgements The preparation of this chapter was supported by Estonian Research Council (grant PRG71).

\section{References}

Bleiere D, Butulis I, Felmanis I, Stranga A, Zunda A (2006) History of Latvia: the twentieth century. Jumava, Riga

Burauskaite B, Morkus P (2002) Resistance to the occupation in Lithuania: 1940-1990. The Genocide and Resistance Research Centre of Lithuania, Vilnius

Coale AJ, Anderson BA, Härm E (1979) Human fertility in Russia since the nineteenth century. Princeton University Press, Princeton (NJ)

Coale AJ, Watkins SC (eds) (1986) The decline of fertility in Europe. Princeton University Press, Princeton (NJ)

Coale AJ (1994) Nuptiality and fertility in USSR republics and neighbouring populations. In: Lutz W, Scherbov S, Volkov A (eds) Demographic trends and patterns in the Soviet Union before 1991. Routledge, London, New York, pp 3-17

Dahs A (2017) Role of socioeconomic factors and regional policy in the demographic development of Latvia. Doctoral thesis. Latvijas Universitāte, Riga

Eurostat (2017) Statistical database [electronic resource]. European Commission, Luxembourg. http://ec.europa.eu/eurostat/data/database

Gentile M, Sjöberg Ö (2013) Housing allocation under socialism: the Soviet case revisited. Post-Sov Aff 29(2):173-195

Hajnal J (1965) European marriage patterns in perspective. In: Glass D, Eversley D (eds) Population in history. Essays in historical demography. Edward Arnold, London, pp 101-143

Hess DB, Tammaru T, Leetmaa K (2012) Ethnic differences in housing in post-Soviet Tartu, Estonia. Cities 29(5):327-333

Hroch M (2000) Social preconditions of national revival in Europe: a comparative analysis of the social composition of patriotic groups among the smaller European nations. Columbia University Press, New York

Järvesoo E (1973) Progress despite collectivization: agriculture in Estonia. In: Ziedonis A, Taagepera R, Valgemäe M (eds) (1973) Problems of mininations. Baltic perspective. California State University, San Jose, pp 137-149

Kahk J, Tarvel E (1997) An economic history of the Baltic countries. Almqvist \& Wiksell International, Stockholm

Karnups VP (2012) Economic and financial developments in Latvia (1920-1940). The Bank of Latvia XC. Riga, The Bank of Latvia, pp 26-44 
Katus K (1994) Fertility transition in Estonia, Latvia and Lithuania. In: Lutz W, Scherbov S, Volkov A (eds) Demographic trends and patterns in the Soviet Union before 1991. Routledge, London, New York, pp 89-111

Katus K, Puur A (2003) Baltic region: Estonia, Latvia and Lithuania. In: Katus K, Puur A (eds) Unity and diversity of population development: Baltic and South-Caucasian regions. Estonian Interuniversity Population Research Centre, Tallinn, pp 49-158

Katus K, Puur A, Sakkeus L (2008) Family formation in the Baltic countries: A transformation in the legacy of state socialism. J Balt Stud 39(2):123-156

Katus K, Puur A, Sakkeus L, Põldma A (2009) Fertility development in the Baltic countries since 1990: A transformation in the context of long-term trends. Finnish yearbook of population research XLIV, pp 7 - 32

Kasekamp A (2010) A history of the Baltic States. Palgrave MacMillan, Basingstoke, New York

Kiaupa Z (2002) The history of Lithuania. Baltos lankos, Vilnius

Kulu H (2003) Housing differences in the late Soviet city: the case of Tartu, Estonia. Int J Urban Reg Res 27(4):897-911

Kõll AM (1994) Peasants on the world market: agricultural experience of independent Estonia, 1919-1939. Almqvist \& Wiksell International, Stockholm

Kõll AM, Valge J (1998) Economic nationalism and industrial growth: state and industry in Estonia 1934-1939. Almqvist \& Wiksell International, Stockholm

Lewis RA, Rowland RH (1979) Population redistribution in the USSR: its impact on society, 1897-1977. Praeger Publishers Inc, New York

Lindemann K (2013) Structural integration of young Russian-speakers in post-Soviet contexts: Educational attainment and the transition to the labour market. [Ph.D. thesis]. Tallinn University (Dissertations in Social Sciences 68), Tallinn

Mertelsmann O (2006) Der stalinistische umbau in Estland. Von der markt- zur kommandowirtshcaft. Verlag Dr. Kovač, Hamburg

Misiunas RJ, Taagepera R (1993) The Baltic States, years of dependence, 1940-1990. Expanded and updated edition. University of California Press, Berkeley, Los Angeles

Mäesalu A, Lukas T, Laur M, Tannberg T, Pajur A (2004) History of Estonia. Avita, Tallinn

Myrskylä M, Goldstein JR, Cheng Y-HA (2013) New cohort fertility forecasts for the developed world: rises, falls, and reversals. Popul Dev Rev 39(1):31-56

Ni Bhrolchain M (1993) East-West marriage contrasts, old and new. In: Blum A, Rallu J (eds) European population II. Demographic dynamics. John Libbey Eurotext, Paris, pp 461-479

Norkus Z (2012) On Baltic Slovenia and Adriatic Lithuania. A qualitative comparative analysis of patterns in post-communist transformation. CEU Press, Budapest

Pihlamägi M (1999) Eesti industrialiseerimine: 1870-1940 [Industrialisation of Estonia: 1870-1940]. Teaduste Akadeemia Kirjastus, Tallinn

Plakans A (1995) The Latvians: a short history. Hoover Institution Press, Stanford University, Stanford, CA

Plakans A (2011) A concise history of the Baltic States. Cambridge University Press, Cambridge, New York

Rashin A (1956) Naselenie Rossii za 100 let, 1811-1913 [Population of Russia over 100 years, 1811-1913]. Gosudarstvennoje statisticheskoe izdatelstvo, Moscow

Raun T (2001) Estonia and the Estonians. Hoover Institution Press, Stanford University, Stanford, CA

Rothenbacher F (2002) The European population, 1840-1945. Palgrave MacMillan, Basingstoke, New York

Sakkeus L (1994) The Baltic States. In: Ardittis S (ed) The politics of East-West migration. MacMillan Press, London, pp 68-85

Stankuniene V, Jasilioniene A (2008) Lithuania: fertility decline and its determinants. Demogr Res 19(20):705-742

Speder Z (2005) The rise of cohabitation as first union and some neglected issues of recent demographic developments in Hungary. Demogr Engl Edition 48:77-103 
Strods H, Kott M (2002) The file on operation 'Priboi': A re-assessment of the mass deportations of 1949. J Balt Stud 33(1):1-36

Tammaru (2001) Linnastumine ja linnade kasv Eestis nõukogude aastatel [Urbanisation and urban growth in Estonia during the Soviet period]. Dissertationes Geographicae Universitatis Tartuensis 13. Tartu University Press, Tartu

Tammaru T, Kährik A, Mägi K, Leetmaa K (2016) The 'market experiment': increasing socio-economic segregation in the inherited bi-ethnic context of Tallinn. In: Tammaru T, van Ham MM, Musterd S (eds) Socio-economic segregation in European capital cities: east meets West. Routledge, London, pp 333-357

Tammur A, Puur A, Tammaru T (2017) Is there a migration turnaround taking place in Estonia? Migration trends in 2000-2015. In: Tammaru T, Kallas K, Eamets R (eds) Estonian human development report 2016/2017. Estonia at the age of migration. Eesti Koostöö Kogu, Tallinn, pp 33-40

Valge J (2006) Breaking away from Russia: Economic stabilization in Estonia 1918-1924. Almqvist \& Wiksell International

Vallin J, Jasilionis D, Meslé F (2017) Does a turbulent history lead to turbulent life expectancy trends? Evidence from the Baltic States. Hist Methods: A J Quant Interdiscip Hist 50(4): 191-209

Vikat A (1994) Family formation in Estonia. Finnish Demographic Society, Helsinki

Zvidrinsh P (1995) Recent changes of ethnic structure in the Baltic states. In: Lundh C (ed) Demography, economy and welfare. Scandinavian Population Studies 10. Lund University Press, Lund, pp 336-350

Open Access This chapter is licensed under the terms of the Creative Commons Attribution 4.0 International License (http://creativecommons.org/licenses/by/4.0/), which permits use, sharing, adaptation, distribution and reproduction in any medium or format, as long as you give appropriate credit to the original author(s) and the source, provide a link to the Creative Commons license and indicate if changes were made.

The images or other third party material in this chapter are included in the chapter's Creative Commons license, unless indicated otherwise in a credit line to the material. If material is not included in the chapter's Creative Commons license and your intended use is not permitted by statutory regulation or exceeds the permitted use, you will need to obtain permission directly from the copyright holder. 


\title{
Chapter 3 \\ The Rise and Demise of the Soviet-Made Housing Shortage in the Baltic Countries
}

\author{
Michael Gentile
}

\begin{abstract}
This chapter reviews the factors underlying the rapid emergence and subsequent narrowing of the Soviet-made housing shortage (i.e. the rise and slow demise of underurbanisation) in the Baltics, corroborating the analysis with findings from archival research on housing construction and allocation in the Latgalian city of Daugavpils between 1945 and 1991. It is suggested that the dynamics of the housing shortage, and the way the Soviet authorities attempted to tackle it, acted as a powerful alternative source of housing and socio-spatial differentiation, and that tracing the priorities assigned by economic planners to the different actors involved in housing construction facilitates the decoding of the Baltic residential landscapes. The chapter starts by portraying the roots of housing shortage, including the radical suppression of market forces and the housing nationalisation shock of the post-WWII years. It then discusses housing construction, housing tenure forms and housing allocation, and describes the specific experience of Daugavpils within these areas in order to shed light on the overall context of residential differentiation in the Baltics.
\end{abstract}

Keywords Housing construction - Housing allocation • Housing shortage $\cdot$ Soviet Union · Latvia • Underurbanisation

\subsection{Introduction}

Throughout the years of the Soviet occupation (1940-1941 and 1944-1991), housing was in constant short supply in the Baltics. What is defined as a shortage of housing is relative, of course. If the developing countries are used as benchmark for comparison, then the Soviet experience may be regarded as a success. If, on the other hand, the Soviet housing experience is gauged against that of the developed capitalist economies in Western Europe and North America, it clearly leaves much

M. Gentile $(\bowtie)$

Department of Sociology and Human Geography, University of Oslo, Oslo, Norway

e-mail: michael.gentile@sosgeo.uio.no

(C) The Author(s) 2019

D. B. Hess and T. Tammaru (eds.), Housing Estates in the Baltic Countries,

The Urban Book Series, https://doi.org/10.1007/978-3-030-23392-1_3 
to be desired. This chapter uses the case of the Latgalian ${ }^{1}$ city of Daugavpils to shed light on the way the Soviet housing programme slowly fought back a crisis that was largely of its own making. The main emphasis will be on Soviet housing construction and allocation practices within a context that has been characterised by 'underurbanisation', and it will be shown that both aspects were subject to the economics of prioritisation that permeated the hierarchy of industrial actors within the urban economy. The chapter starts by portraying the roots of the endemic Soviet housing shortage, including the radical suppression of market forces and the housing nationalisation shock of the post-WWII years (earlier elsewhere in the Soviet Union). It then discusses housing construction, housing tenure forms and housing allocation, and proceeds by elaborating on the specific experience of Daugavpils within these areas in order to shed light on the overall context of residential differentiation in the Baltics.

\subsection{Nationalisation and Market Suppression}

During the early years of the Soviet occupation of the Baltics, two main urban transformation processes took place at the same time. First, like elsewhere in the Soviet Union following the Bolshevik revolution, most housing had to be expropriated, nationalised and redistributed. In the case of housing, this usually meant that sitting owners became tenants and, unless they were able to find enough persons to share their dwelling within a short time, complete strangers were assigned floor space within the dwelling, imposing cohabitation with strangers and transforming the previous independent housing unit into a kommunalka, or communal apartment (Sawicki 1977; Gentile and Sjöberg 2013). Kommunalki were the standard housing predicament for the majority during the early decades of Soviet power, both within the Baltics and elsewhere in Soviet space (Bater 1980; Andrusz 1984; French 1995). Even with the advent of mass housing construction in the late 1950s, communal living within newly built apartments remained frequent for many years - an independent dwelling for a single household signalled privilege until sometime in the 1970s (Gentile and Sjöberg 2013).

The second main transformation had to do with post-war reconstruction. The building stock of many cities was left severely damaged by artillery and bombardment. The reconstruction effort targeted the affected areas (often city centres, industrial areas and train stations) in the immediate post-war years (Gentile and Sjöberg 2010a), focusing on the restoration of industrial production capacities; housing was not prioritised until after Nikita Khrushchëv denounced Stalin's 'excesses' during the so-called secret speech he gave before the All-Union

\footnotetext{
${ }^{1}$ Latgale is the south-eastern region of Latvia. It is known for its distinct regional and linguistic identity.
} 
Assembly of the Communist Party in 1956. By that time, the roots of what later became known as underurbanisation were already firmly in place.

\subsection{An Underurbanisation Crisis}

The Soviet housing crisis has been subject to numerous overlapping and complementary explanations. These include the poor starting point, the reduction in supply caused by the civil war and the two world wars, Stalin's preference for cost-ineffective grand architecture (also known as 'Stalin Baroque'), the general emphasis on heavy industry under central planning and, accordingly, the relative low priority assigned to housing construction. All of these aspects are more or less explicitly captured by the influential underurbanisation thesis proposed by Konrád and Szelényi (1974) during the 1970s and refined as a plastic model of urban growth under socialism by Murray and Szelényi (1984). In short, the underurbanisation model proposes that, following a communist revolution, three or four main stages of urban growth will likely take place. At an early stage, slight (or at times rather significant) deurbanisation will result from the direct or indirect application of anti-urban policies, including the violent removal of parts of the resident bourgeois population. At the next stage, most socialist polities are assumed to move either in a Maoist direction of decentralised industrialisation-leading to a situation of zero-urban growth - or in line with a strategy of rapid industrialisation partly decoupled from growth in other spheres of urbanity, leading to 'underurbanisation'. Underurbanised societies are thus characterised by a combination of plentiful industrial employment opportunities and inadequate urban infrastructures, including insufficient housing resources. This results in severe overcrowding within cities, as well as in substantial commuting (Murray and Szelényi 1984) and in diverted migration towards poorly serviced fringe settlements (Sjöberg 1992; Gentile 2004). Because the social and material deprivation caused by underurbanisation may lead to urban unrest, and in order to prevent rural population loss, most socialist polities restricted migration to cities (Matthews 1986; Sjöberg 1994; Buckley 1995). This migration control system, known as the propiska system in the Soviet Union and as the hukou system in China, was implemented to varying degrees of efficacy, yet it did not stop urban-bound migration, nor did it prevent commuting from outside of the administrative boundaries of controlled cities (Sjöberg 1992; Buckley 1995). In sum, underurbanisation implies a sustained gap between the low rate of urbanisation and the high rate of industrialisation. However, the logic of underurbanisation was unsustainable in the long run. Over time, most if not all of the economically advanced Soviet-style economies increased their prioritisation of consumption and housing. This is the stage Murray and Szelényi (1984) referred to as that of socialist intensive urbanisation, which arguably corresponds to the 1980s in the Baltics. By this time, however, a modest but very specific form of suburbanisation emerged in the surroundings of the region's major cities, as people started following newly created agricultural jobs, leaving an 
increasingly degraded urban environment behind them (Tammaru 2001). Despite this slight relief, Baltic cities left the Soviet Union with heavy baggage of urban imbalances inherited from decades of underurbanisation.

\subsection{Housing Construction}

The Soviet economy was thus characterised by an obstinate shortage of housing, the production and allocation of which generally favoured those employed within the economy's prioritised sectors, meaning heavy industry and defence. While the city administration bore the overall responsibility for housing construction, in practice this task was partly outsourced to the industrial enterprises that were present under its jurisdiction (Di Maio 1974; Lewis and Sternheimer 1979; Shomina 1992). This 'industrial' share of the urban housing burden is commonly known as the vedomstvennyi (departmental) sector in Russian, and the share of this sector in the total housing construction was substantial, particularly in heavy industrial cities, where it dominated completely (Shomina 1992; French 1995). However, the vedomstvennyi sector was not uniformly endowed with the resources needed to provide sufficient housing to its workers-for whom it was an important fringe benefit given its short supply (Gentile and Sjöberg 2010a, b). Two important aspects were central to the enterprises' ability to house their workers: (a) the enterprise formal subordination within the centrally planned system (enterprises under direct Moscow control were better-off), and (b) the priority of its productive activities (heavy industry and military-industrial activities being at the top). In practice, the production activities of Moscow-controlled enterprises belonged to the prioritised branches, meaning that enterprise subordination is a good proxy for economic priority.

The ensuing hierarchical stratification of the industrial sphere meant that some enterprises were in a better position to build housing - more of it, and sometimes of better quality and in better locations - than others (French 1995). The mechanism sustaining this is the differentiated enforcement of budget discipline, meaning that while some (low priority) enterprises were subject to strict budgets and penalties for non-compliance, other (prioritised) enterprises enjoyed elastic budgets allowing them to overspend without having to fear the consequences (Gentile and Sjöberg 2006, 2010b). This is the main principle of the so-called soft budget constraint, which lies at the core of Janos Kornai's economics of shortage approach to understanding central planning (see Kornai 1992).

Concordantly, housing construction under Soviet times resulted in uneven geographies of housing provision - in inequalities in location quality, neighbourhood infrastructure (including the quality and degree of completion of housing estates), and in the maintenance of the dwellings themselves. Such inequalities were produced and sustained by the cumulative effect of the housing shortage and of the diverse economic priorities enjoyed by the range of actors involved in housing construction at different points in time. The resulting pattern was an urban 
landscape of priorities, i.e. a spatio-temporal projection of priorities onto the urban landscape. At the macro-level, these priorities favoured some cities at the expense of others (Sjöberg 1999), whereas at the micro-level, they favoured certain neighbourhoods (Gentile and Sjöberg 2006, 2010b). In short, the landscape of priority was also a landscape of housing inequalities between and within cities, the physical canvas confronting the socialist system in its improbable endeavour to create a new urban society free from the socio-spatial inequalities associated with the capitalist archenemy. One of the main obstacles preventing the achievement of this goal was the extent to which the construction of different mikrorayony (neighbourhood units) was completed. High priority industry-associated mikrorayony were typically completed more rapidly, including most of the auxiliary infrastructure, whereas the little that was built by low-priority enterprises usually was a constant work in progress, unless it was embedded within an existing mikrorayon (or a mikrorayon largely built under the auspices of an organisation that enjoyed higher priority).

\subsection{Housing Tenure}

The Soviet housing system was largely based on the idea of housing as a universal right that was to be achieved through near-universal public rental at heavily subsidised rates that did not even cover the costs of (poor) maintenance (Andrusz 1984). Rental contracts were both permanent and inheritable (Sawicki 1977), which meant that they were essentially comparable to private property, albeit subject to certain limitations that are in fact not uncommon within the private sphere of market economies (e.g. the right to sublet was heavily restricted). Typically, public rental housing was either 'owned' and managed by the city (by the local Soviets, to be precise), or by the various subjects (factories or industrial enterprises) of individual branch ministries, whose housing stock was intended to be almost exclusively for the benefit of their own workers (Di Maio 1974). ${ }^{2}$

However, the demand for public rental housing greatly exceeded its supply, which is why the Soviet authorities tolerated and at times even encouraged alternative solutions. For this reason, alongside the public rental sector, the Soviet city hosted a substantial cooperative sector and an ideologically unpalatable private sector as well (Sawicki 1977; Andrusz 1984). The 'private sector' mostly consisted of unsubsidised single-family homes built to low construction standards, and it was usually not connected to the city's utility infrastructures (Alexandrova et al. 2004). Much of this sector occupied residual land that was not needed or useable for other purposes, and in some cases it may have been present on land that was earmarked

\footnotetext{
${ }^{2}$ Industrial enterprises that managed their own housing resources were typically expected to hand over a certain share (e.g. 10\%) of all new housing construction to the city administration (Andrusz 1984, p. 174).
} 
for the future expansion of existing industrial enterprises, implying that the threat of future demolition and resettlement was constantly present (Domański 1992, 1997).

The cooperative sector differed in that a substantial investment on behalf of the resident was required (Andrusz 1984). According to some of the literature, the social class structure of the residents of the cooperative sector appears to have been skewed towards the middle strata and higher (Bater 1980; Dremaite 2014, p. 200). The cooperative sector also appears to have been a reservoir for improved housing design types (Drèmaite 2014, pp. 200-203), although other studies suggest this might not always be the case owing to the characteristics and limitations of the local construction industry (Gentile and Sjöberg 2010b; Sommer 2012).

\subsection{Housing Allocation}

Throughout the Soviet Union, housing was allocated based on established norms of housing provision. An important distinction was the one between 'living space' and 'general utilisable space', with the former referring solely to the floor space of the rooms contained in a specific dwelling unit, thus excluding the kitchen, bathroom and auxiliary spaces such as corridors or windowless storage rooms (the ratio between living space and general utilisable space is approximately 2:3 in standardised apartments). The per capita norm was established using the living space criterion, meaning that rooms in kommunalki and in private apartments were assigned equal value. The general norm was set at $9 \mathrm{~m}^{2}$ as early as in 1922 (Sosnovy 1959; Sawicki 1977). At the time, this was a very ambitious target: by the time of Khrushchëv's 'secret' speech in 1956, the mean living space per capita was below $4 \mathrm{~m}^{2}$ in many of the USSR's major cities, meaning that things got worse, not better, during the years of forced industrialisation (i.e. forced underurbanisation) under Joseph Stalin.

Because housing was in short supply, and heavily subsidised, demand greatly exceeded supply. As a result, price rationing was replaced by waiting lists and administrative decision-making (Frolic 1972; Morton 1980). Because actual need was the core guiding principle in allocation, citizens were admitted into the waiting list(s) based on the characteristics of their current housing situation; in practice, this meant that only those who had less than a certain amount of living space (irrespective of whether it was located in a private apartment or in a kommunalka) were given the opportunity to join the waiting list. In most cities, the lower limit was close to $5 \mathrm{~m}^{2}$ of living space per capita, ${ }^{3}$ with variations depending on local context: for example, in Leningrad — known as the kommunalka capital of the USSR the limit was set at a mere $4.5 \mathrm{~m}^{2}$ during the late 1960s (Di Maio 1974, p. 119). In Daugavpils, the limit was set at $5 \mathrm{~m}^{2}$, but for cooperatives, it rose to 7 .

\footnotetext{
${ }^{3}$ According to Morton (1980, p. 240) this figure could have been as low as $3 \mathrm{~m}^{2}$.
} 
Once admitted into the waiting list, the house hunt was stalled for years. Exactly for how long depended on, among other things, the particular waiting list that one was admitted to. The main waiting list was the so-called general list (obshchaya ochered'), but there were also particular lists for 'young specialists', for different types of special merit, for cooperative apartments, for people with particular health problems, for people living in absolutely terrible conditions, and so forth. Some of these waiting lists moved faster than others, with the general list typically moving the slowest. The ministerial subjects had their own lists, controlled by the labour union, but all allocation decisions were approved at meetings held by the city executive committee (Di Maio 1974; see Gentile and Sjöberg 2013). Accordingly, this means that considerations relating to social merit were embedded in the housing allocation process by means of differentially functioning waiting lists (Morton 1984, p. 77). Moreover, the degree of one's association to heavy industry or defence influenced the number of dwellings - as well as their physical and locational qualities - that were within one's reach (Szelényi 1983). On top of that, there is agreement in the literature that informal and illegal practices mattered as well, although the extent of these practices is not very well known as their very nature makes them largely undocumentable beyond the anecdotal level (Matthews 1978; Domański 1997; Morton 1984; Alexeev 1988; Gentile and Sjöberg 2013). Illegality in housing allocation could take various paths: in the form of bribes or favours, through side payments upon the exchange of apartments, and through the exercise of power and influence by party officials and/or high-level representatives of prioritised industries or organisations (see Gentile and Sjöberg 2013). Taken together, all these aspects imply that Soviet housing allocation contained several steps that could have potentially contributed to social and, above all, socio-professional residential segregation. In the case of the Baltics, Moldova, the Caucasian and the Central Asian Republics, the strong connection between ethnic background and employment (and thus housing) resulted in distinct patterns of ethnic segregation (Mežs et al. 1994; Kulu 2003). However, the general lack of detailed data on segregation patterns under socialism means that we must rely on case studies using large territorial units to describe very broad (and moderate) patterns of segregation (for an overview, see French 1995). Alternatively, it is possible to infer past segregation patterns based on patterns that existed during the 1990s and 2000s, assuming low residential mobility.

\subsection{Housing Construction in Soviet Daugavpils}

This section describes the housing situation in Daugavpils (current pop. $\approx 85,000$ ), Latvia's second city, as a basis for an overall assessment of the Soviet housing system in the Baltics and in the Soviet Union. Like most cities in the Baltics, Daugavpils' population has been contracting since 1992, when it peaked at approximately 128,000 , but its current population of less than 85,000 reflects the city's particularly acute and prolonged economic and demographic decline. During 
the Soviet occupation, Daugavpils had a mixed economic base, with a handful of large industrial enterprises (the Chemical Fibre Plant or ZKhV, the Elektroinstrument tool factory, the Lokomotiv train locomotive repair works, and the Motovelotsep driving chains factory) and a number of small- or mid-sized factories within mainly construction, light manufacturing and food processing. In addition, it hosted several important military installations, including a secret airbase just outside the city. Many of these functions were located within the early nineteenth century Dinaburg fortress, which was a large closed-off (under Soviet times) territory in close proximity to the city centre. All of these actors were involved in the provision of housing to some extent, but not all were able to make substantial contributions because of the diverse budgetary circumstances that surrounded their activities (Gentile and Sjöberg 2010b).

While Daugavpils' experience, like that of any other city, is heavily contextual, the way the city developed its housing sphere sheds light on most of the aspects covered by the literature discussed above. The case study will start by using Daugavpils to illustrate the underurbanisation thesis (Murray and Szelényi 1984), followed by an analysis of the overall spatio-temporal trends in housing construction in the city. From here, the discussion will move to the outcome of the allocation process at different points in time, synthesising some of the major findings presented in Gentile and Sjöberg (2013).

At the core of the underurbanisation thesis is the observation that the rate of industrialisation under socialism - particularly during the earlier decades-proceeded faster than the rate of urbanisation (Konrád and Szelényi 1974; Murray and Szelényi 1984). Figure 3.1 illustrates how the gap between industrial employment and the cumulative Soviet-built housing supply expanded and later receded in Daugavpils. After a short stage of deurbanisation (which included deportations to Siberia), and until the mid-1950s, there was hardly any new housing construction at all, and efforts were made to restore the city's damaged production capacity. From the mid-1950s and until the mid-1960s, the city experiences a period of rapid industrial growth. While Khrushchëv's mass housing programme started more or less at the same time, it was not able to keep up with the breakneck speed of industrial employment growth, causing underurbanisation and an acute housing shortage. Employment in industry reached a stable level (whereas it continued expanding within the tertiary sector) around 1965, at which point the housing sector slowly started catching up, even though it was not until the 1980s that intensive socialist urbanisation would take place. Even so, by the time of the demise of Soviet power in 1991, Daugavpils remained the most overcrowded city in the Latvian SSR with a mere $16.8 \mathrm{~m}^{2}$ of total floor space per capita in 1990; by contrast, in Riga and Liepāja, respectively, Latvia's capital and third city, the corresponding figures were of 18.1 and $20.3 \mathrm{~m}^{2}$ (Centrālā Statistikas Pārvalde 2017). This clearly changed upon the country's re-independence, as emigration and natural population decline reduced Daugavpils' population by more than a third, rapidly turning an underurbanisation-related housing crisis into an urban shrinkage crisis of notable magnitude. 


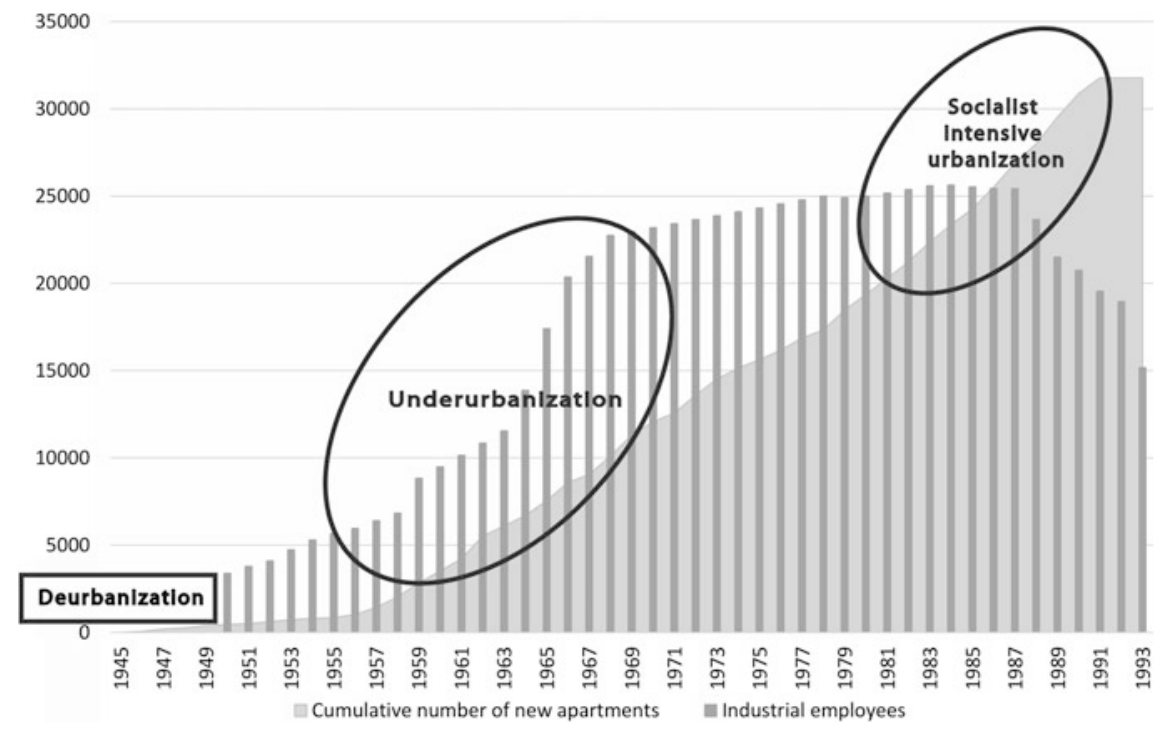

Fig. 3.1 Cumulative number of apartments built in Daugavpils (1945-1993) and number of industrial employees (1950-1993). Source Employee statistics were collected from the following documents retrieved from the Latvian National Archives (LNA), regional section in Daugavpils: LNA 26: 1: 41, LNA 39: 1: 41, LNA 136: 1: 41, LNA 83: 1: 41, LNA 136:1: 41, LNA 136: 1: 41, LNA 150:1:41, p. 85, LNA 157: 1: 41, p. 46, LNA 190: 1: 41, p. 44, LNA 199: 1: 41, p. 33, LNA 206: 1: 41, p. 11, LNA 218: 1: 41, p. 30, LNA 21: 1: 56, p. 1, LNA 37: 1: 56, p. 2, LNA 58: 1: 56, p. 2, LNA 265: 1: 41, p. 3, LNA 170: 1: 56, LNA 241: 1: 56; LNA 285:1: 56, LNA 37: 4: 56, LNA 93: 4: 56, LNA 146: 4: 56, LNA 323: 4: 56, LNA 421: 4: 56, LNA 531: 4: 56, p. 58, LNA 626: 4: 56, pp. 13-14, LNA 703: 4: 56, pp. 61-62, LNA 798: 4: 56, pp. 40-41, LNA 56: 1: 943 , pp. 8-9, LNA 56: 4: 1010, pp. 9-10, LNA 56: 4: 1127, pp. 10-11, LNA 56: 4: 1207, pp. 21-22, LNA 56: 4: 1327, pp. 13-14, LNA 56: 4: 1388, pp. 15-16, LNA 56: 4: 1481, pp. 95-96, LNA 56: 4: 1497, pp. 69-71, LNA 56: 4: 1584, LNA 36: 4: 1615, p. 47, LNA 56: 1a: 23, p. 7. Apartment data are available in Gentile and Sjöberg (2010a)

Until 1956, housing construction in Daugavpils was virtually nil. The impact of Khrushchëv's secret speech, in which he denounced Stalinism, is clearly visible in the number of apartments built starting from 1957 and onwards (Fig. 3.2).

During the period of Soviet occupation, approximately $43 \%$ of all new apartments were built on behalf of the organisation that was formally mainly responsible for this task, i.e. the city administration. However, the degree of the latter's participation in housing construction varied over time. During the meagre Stalin years, ${ }^{4}$ the little that was constructed was funded through departmental sources and, especially, the military. When Khrushchëv's housing programme took off in 1957, the city administration played an important role, but its relative presence in the mass housing programme started declining rather soon, reaching a new minimum in the

\footnotetext{
${ }^{4}$ From an urban planning and architecture perspective these years lasted until 1956 although Stalin
} died in 1953 . 


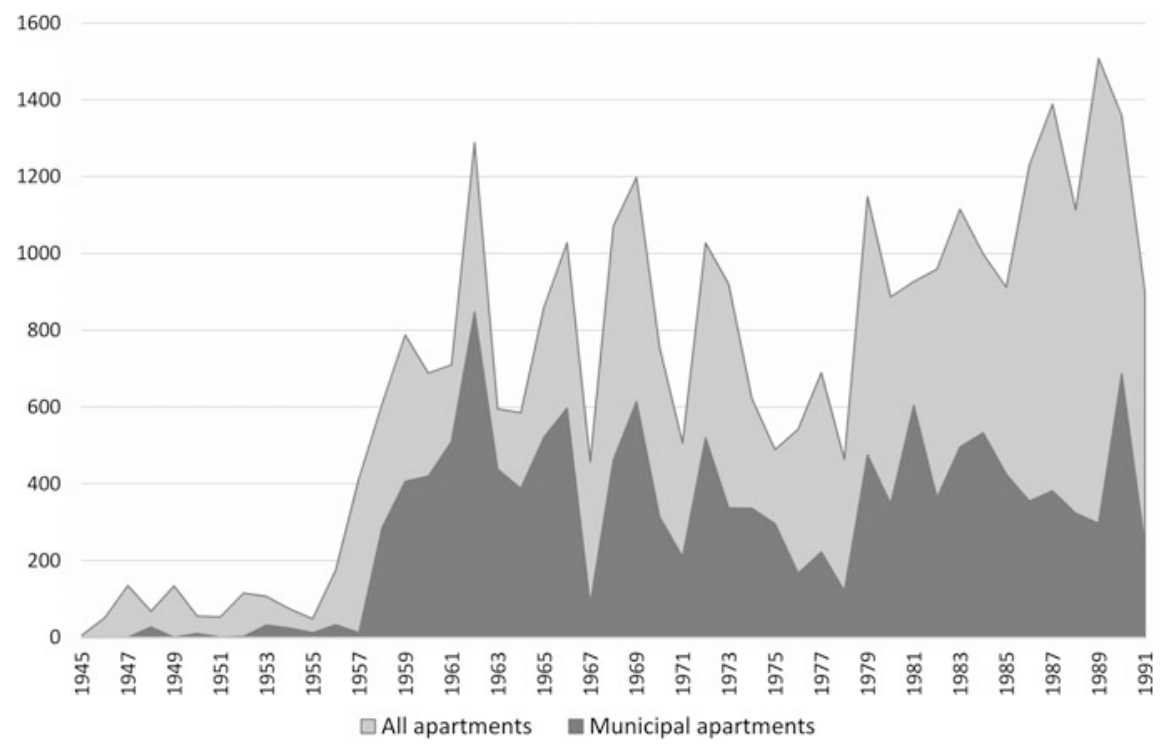

Fig. 3.2 Year-on-year construction of new apartments (number of units) in Daugavpils, in total (light) and by the city administration (dark). Source Documents retrieved from the Latvian National Archives, regional section of Daugavpils, details of sources available in Gentile and Sjöberg (2010a)

late 1970s. Between 1976 and 1979, only about a third of all completed dwellings consisted of municipal apartments, and while this share rose somewhat throughout the remaining years of Soviet power, departmental actors dominated the scene during the 1980s.

However, as discussed above, different departmental actors were endowed with different resources and budget constraints, placing them in unequal positions with respect to their ability to produce new dwellings for their workers. Figure 3.3 presents the overall employment statistics for Lokomotiv, contrasting them to the number of apartments built by the enterprise from 1950 until the end of the Soviet period. Lokomotiv was a high priority male-dominated enterprise under the direct subordination of the Moscow-level Ministry of Transport. Echoing city-wide (and Union-wide) trends, the enterprise's production of housing remained low during the Stalin years, but it increased rapidly during the years of Khrushchëv's power (1958-1964), by which time there was approximately one apartment built for every four workers. Considering that full apartments were seldom allocated to single households at the time, it is reasonable to assume that a fair share of the enterprise's workers was sheltered in enterprise-provided housing. Starting from the 1970s, however, the ratio between number of workers and (cumulative) enterprise-built housing started increasing again, particularly from the 1980s onwards, and by 1991, it had reached almost two-thirds. However, this does not mean that two-thirds of the enterprise dwellings were occupied by its workers: first of all, many of them will 


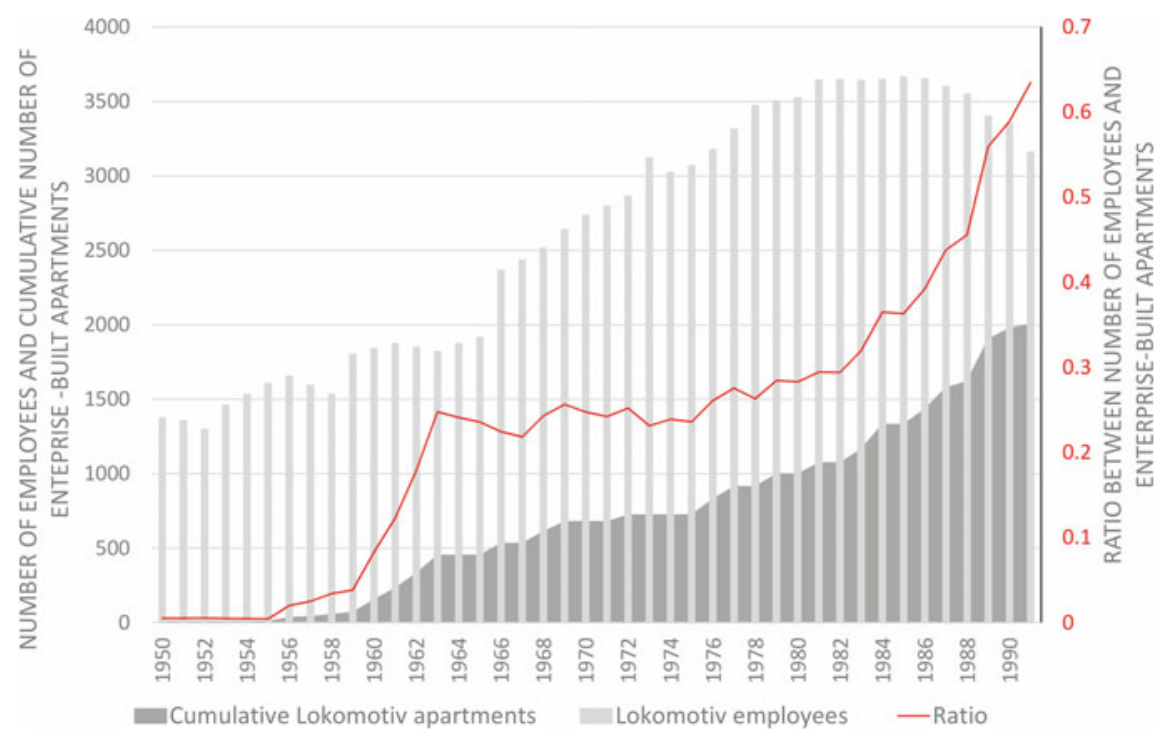

Fig. 3.3 Cumulative number of apartments built by Lokomotiv (1950-1991) and year-on-year number of employees. Sources For the employee data, see Fig. 3.1. The sources for the apartment data are available in Gentile and Sjöberg (2010b)

have retired by then, and second, eviction was only possible upon termination of employment under certain (restrictive) circumstances, meaning that the connection between employment and enterprise housing residence was flexible and incomplete (Sawicki 1977, pp. 112-113). All told, this indicates that the share of non-workers residing in Lokomotiv housing must have risen over time.

The housing story of the Chemical Fibre Plant (Zavod Khimicheskogo Volokna or $\mathrm{ZKhV}$ ) and of its mainly female workers is somewhat different. First of all, the enterprise's own subordination fluctuated between Moscow (Union-level) and joint Moscow-Riga control (Union-Republic level), signalling its relatively weaker status in the priority hierarchy. Second, unlike Lokomotiv, which expanded gradually throughout the Soviet period, ZKhV was quickly assembled starting from 1963, and it counted almost 7000 employees just a few years later. However, it reached its maximum workforce size already in 1968 and started shrinking immediately thereafter; even so, it remained the city's largest employer until the early 1990s.

Figure 3.4 compares ZKhV's workforce size and cumulative apartment output from 1963 until 1991. Unlike Lokomotiv, ZKhV started off with a 'big bang' in terms of employment, yet very little housing was constructed by the enterprise for its own workers until the late 1960s, indicating that its workers were expected to seek shelter through other channels, including the city administration's general waiting list. Moreover, certain features of $\mathrm{ZKhV}$ suggest that the plant was at least partly supposed to offset the sex-based imbalance caused by the prevalence of 'male' workplaces in Daugavpils. The implicit assumption was that the female 


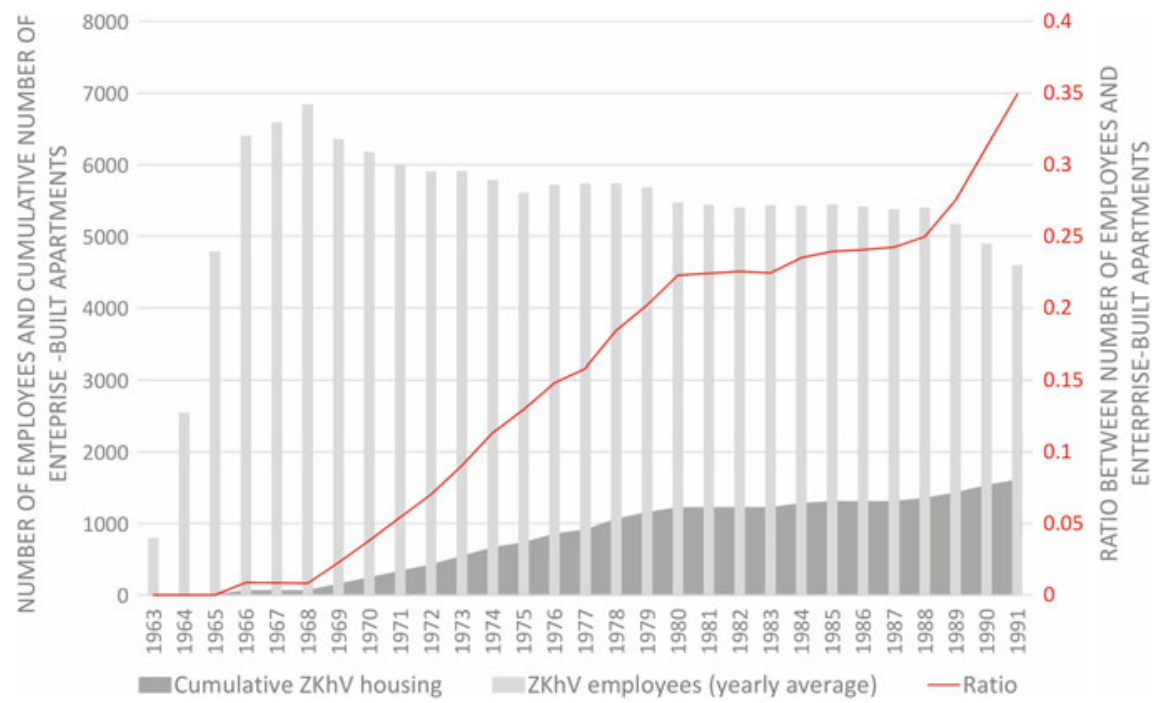

Fig. 3.4 Cumulative number of apartments built by Zavod Khimicheskogo Volokna (1963-1991) and year-on-year number of employees. Source For the employee data, the figures were retrieved from the Latvian National Archive (LNA), Daugavpils regional section, LNA 206: 1: 41, p. 11, LNA 218: 1: 41, p. 30, LNA 21: 1: 56, p. 1, LNA 37: 1: 56, p. 2, LNA 58: 1: 56, p. 2, LNA 265: 1: 41, p. 3, LNA 170: 1: 56, LNA 241: 1: 56; LNA 285:1: 56, LNA 37: 4: 56, LNA 93: 4: 56, LNA 146: 4: 56, LNA 323: 4: 56, LNA 421: 4: 56, LNA 531: 4: 56, p. 58, LNA 626: 4: 56, pp. 13-14, LNA 703: 4: 56, pp. 61-62, LNA 798: 4: 56, pp. 40-41, LNA 56: 1: 943, pp. 8-9, LNA 56: 4: 1010, pp. 9-10, LNA 56: 4: 1127, pp. 10-11, LNA 56: 4: 1207, pp. 21-22, LNA 56: 4: 1327, pp. 13-14, LNA 56: 4: 1388, pp. 15-16, LNA 56: 4: 1481, pp. 95-96, LNA 56: 4: 1497, pp. 6971, LNA 56: 4: 1584, LNA 36: 4: 1615, p. 47, LNA 56: 1a: 23, p. 7. The sources for the apartment data are available in Gentile and Sjöberg (2010a)

workers at $\mathrm{ZKhV}$ would have found their partners among the male employees of the prioritised enterprises that were prolific contributors to the city's housing stock. This was a well-known labour market (or rather, 'labour balancing') strategy in cities dominated by heavy industry or mining (Filtzer 1992), ${ }^{5}$ but the Daugavpils data suggest that the phenomenon was present in other contexts, too. This is because, unlike Lokomotiv, the $\mathrm{ZKhV}$ contributed very little to the overall housing stock, and despite the prolonged decrease in the enterprise's workforce since 1968, the ratio between the latter and the total number of units built by the enterprise only surpassed 0.25 in 1988 . However, this mainly had to do with the accelerated pace of workforce shrinkage experienced by $\mathrm{ZKhV}$ during the last years of Soviet power.

The different sizes of the $\mathrm{ZKhV}$ and Lokomotiv quantitative outputs were not the only housing-related inequality facing the workers of these enterprises. As Örjan

\footnotetext{
${ }^{5}$ Filtzer (1992, p. 64) also suggests that this strategy was less successful in cities dominated by heavy industry or mining because the high wages paid in these branches meant that a single (male) income was sufficient to sustain a household.
} 
Sjöberg and I have shown elsewhere (Gentile and Sjöberg 2010b), ZKhV and Lokomotiv also differed in the qualitative characteristics of the dwellings that they were able to supply. Specifically, whereas the ZKhV's apartments were mainly clustered in a peripheral neighbourhood of dubious environmental quality (Ķīmiķu ciemats or Chemical Settlement, named in honour of the enterprise), Lokomotiv was able to present apartments enjoying prime locational qualities, e.g. in the vicinity of an intended socialist 'new centre' that challenged the bourgeois ambiance of the old city centre, as well as next to the centrally located, aesthetically appealing, ideologically suspect and quadri-confessional 'Church Hill'.

While Lokomotiv and ZKhV serve as useful illustrations to decipher the Soviet urban landscape of priority in its Baltic guise, it is necessary to highlight that these two enterprises certainly do not represent opposites on the priority scale: they are just large enough to facilitate a fruitful comparison. If, instead, we were to scrutinise the housing geographies of the low-priority enterprises - for example, the meat combine or the local clothing factory-then the differences would become even clearer. The clothing factory had a maximum of almost 1400 workers on its payroll in 1968, but it produced almost no housing at all during the entire Soviet period. Importantly, it was not able to produce fully equipped mikrorayony, forcing its worker-residents (like those of numerous other low-priority entities) to live in unfinished and under-serviced mikrorayon fragments in perpetuity. Similarly, other low-priority enterprises contributed almost nothing to the city housing stock, although when they did, their apartments tended to have good locations, suggesting that they may have been earmarked for the upper strata of these enterprises' management (Gentile and Sjöberg 2010b). While it is not possible to determine exactly how large a share of the population residing in Soviet-era apartment blocks that was not able to enjoy the privilege of living in a fully equipped mikrorayon, data from the Latvian National Archive (see Gentile and Sjöberg 2010a) show that 10.7\% of all apartments built between 1945 and 1991 were constructed using the funds of low-priority enterprises, most of which arranged in mikrorayon fragments, as none of the low-priority enterprises ever succeeded in completing a full mikrorayon. Of course, this does not mean that the rest of the Soviet-built housing is organised in well-functioning mikrorayony, as the quality of the mikrorayony varies, but it does give an idea of the share of apartments that simply does not conform with the notion - any notion - of the integrated and spatially just socialist housing estate. For example, the meat combine, with approximately 1000 employees by the end of the Soviet period, worked on its own mikrorayon in the isolated neighbourhood of Križi (Fig. 3.5), but it only succeeded in completing six five-storey blocks between the early 1960s and 1991, with no auxiliary facilities whatsoever: given the housing shortage, new apartments were prioritised before anything else. Three more apartment blocks were being built in the early 1990s, but they were never completed and their empty carcasses continue scarring the local landscape. 


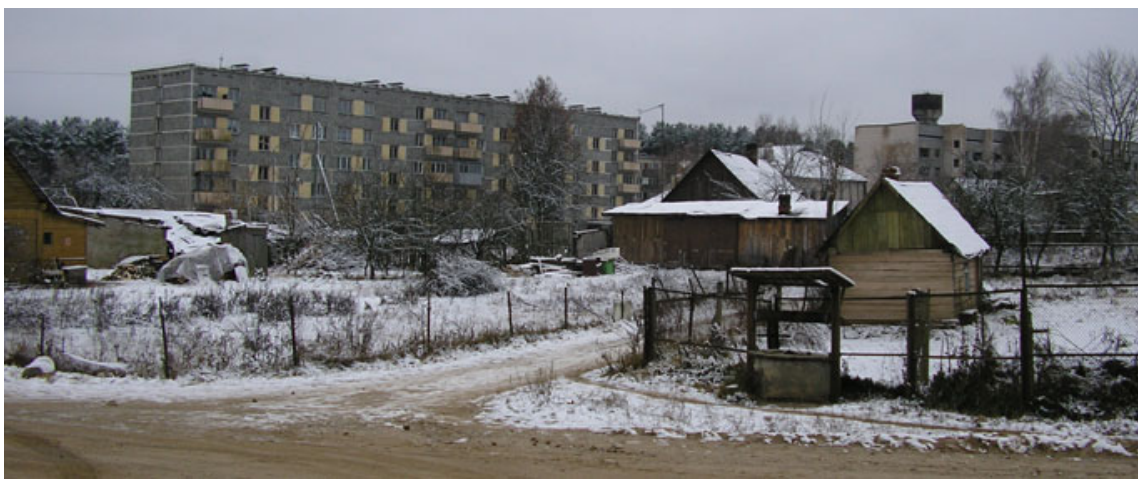

Fig. 3.5 Križi, an unfinished and isolated mikrorayon in Daugavpils. A well for the residents of the single-family housing is visible in the foreground. Source Michael Gentile

\subsection{Housing Allocation in Soviet Daugavpils}

Daugavpils suffered from a rather severe housing shortage, and although this shortage hit different socio-professional groups unequally depending on the place of employment of the person(s) in need of housing, it nevertheless influenced most of the population. Even those lucky enough to work (or have a household member working) at high priority enterprises likely had to experience one of the Soviet waiting lists. However, we know from the literature discussed earlier in this chapter that some people were more equal than others before the altar of housing allocation. This section describes the factors associated with the outcome of the allocation process in terms of assigned living space per household member, as well as the determinants of the amount of time spent waiting. The figures refer to allocation decisions that include both the assignment of (parts of) new apartments and the (re-) allocation of living space located within communal apartments.

Table 3.1 reports the mean per capita living space allocated at four different points in time, representing different stages or periods of the Soviet occupation. In terms of the Murray-Szelényi model, 1953 and 1970 denote, approximately, the beginning and endpoint of the underurbanisation stage, whereas 1980 and, especially, 1990 represent 'socialist intensive urbanisation'. The means refer to the full set of housing allocation decisions made, or in the case of departmental housing, confirmed at the gorispolkom meetings of these particular years (for 1990, owing to the high number of decisions, only the first 4 months are included); this gives a total of about 3500 decisions. All figures are reported and discussed more thoroughly in Gentile and Sjöberg (2013). The selection of indicators included in the analysis is limited by the actual information contained in the archive documents, which was not always very detailed and frequently hard to decipher. Thus, a meaningful discussion is possible in relation to gender (inferred from the applicant's name), workplace type and the applicant's type of occupation. Moreover, in most cases, it 
Table 3.1 Living space (sq. m per capita) allocated in Daugavpils in 1953, 1970, 1980 and 1990 $($ Jan-Apr). n.a $=$ not available (incomplete data)

\begin{tabular}{|c|c|c|c|c|}
\hline & 1953 & 1970 & 1980 & 1990 \\
\hline \multicolumn{5}{|l|}{$\operatorname{Sex}$} \\
\hline Male & 7.06 & 9.07 & 10.74 & 12.29 \\
\hline Female & 7.34 & 9.67 & 11.37 & 12.12 \\
\hline \multicolumn{5}{|l|}{ Surname background } \\
\hline Slavic & 7.06 & 9.35 & 11.03 & 12.17 \\
\hline Baltic & 6.07 & 9.33 & 11.07 & 12.25 \\
\hline Other & 9.01 & 8.65 & 10.78 & 11.31 \\
\hline \multicolumn{5}{|l|}{ Type of workplace } \\
\hline $\begin{array}{l}\text { Municipal and state administrative, excluding part } \\
\text { organs and law enforcement }\end{array}$ & 6.38 & 9.24 & 10.57 & 11.97 \\
\hline Non-priority industry & 6.97 & 8.36 & 10.21 & 11.77 \\
\hline Priority industry & 6.94 & 8.44 & 11.11 & 12.47 \\
\hline Law enforcement, military, political organs & 7.73 & 8.80 & 11.33 & 11.04 \\
\hline Unreported workplace & - & 10.56 & 11.97 & 12.82 \\
\hline \multicolumn{5}{|l|}{ Type of occupation } \\
\hline Unskilled & 6.29 & 8.73 & 10.42 & 11.68 \\
\hline Some skills required & 8.13 & n.a. & 10.14 & 11.96 \\
\hline Higher education required & 8.86 & n.a. & 11.37 & 11.85 \\
\hline Management & 11.62 & n.a. & 12.10 & 12.12 \\
\hline Total mean & 7.11 & 9.28 & 10.98 & 12.20 \\
\hline
\end{tabular}

Data source Gentile and Sjöberg (2013) (based on archive data assembled from multiple sources from the Latvian National Archive, Daugavpils regional section)

was possible to distinguish between people with surnames that sound 'Baltic' versus 'Slavic' (e.g. Bērzin̄š vs. Ivanov), ${ }^{6}$ allowing for the analysis of possible ethnic discrimination processes (there is a widespread belief - and also some hard evidence - in Latvia that Russians were favoured in the housing allocation process, see Mežs et al. 1994). While this is a highly imperfect proxy for ethnic background, the literature on housing markets emphasises how the ethnic associations of particular names may cause discriminatory practices (see, for example, Carpusor and Loges 2006; Andersson et al. 2012).

The first and most important trend revealed by Table 3.1 is that, over time, the amount of living space allocated increased significantly for all categories, rising from just over $7 \mathrm{~m}^{2}$ in 1953 to over 12 in 1990 . While there were some differences

\footnotetext{
${ }^{6}$ Baltic-sounding names are defined as names that suggest that the bearer is of full or partial Lithuanian, Latvian or Estonian descent. However, no Estonian-sounding surnames appeared in the studied materials. In a few cases it was not possible to establish the surname origin - either because it was unclear or because it was not legible in the document; such cases were excluded from the analysis.
} 
Table 3.2 Shares of housing beneficiaries with Baltic-sounding surnames and share of Latvians and Lithuanians in the total population of Daugavpils

\begin{tabular}{l|l|l|l|l|l}
\hline & 1953 & $1959 / 1960$ & 1970 & $1979 / 1980$ & $1989 / 1990$ \\
\hline $\begin{array}{l}\text { Share of housing beneficiaries } \\
\text { with Baltic-sounding surnames } \\
(\%)\end{array}$ & 9 & 6.2 & 16.4 & 10.5 & 14 \\
\hline $\begin{array}{l}\text { Latvian and Lithuanian share } \\
(\%) \text { of city population }\end{array}$ & 18 & 15.2 & 12.1 & 13.4 & 14.4 \\
\hline
\end{tabular}

Sources Gentile and Sjöberg (2013) (based on archive data assembled from multiple sources from the Latvian National Archive, Daugavpils regional section and Soviet census data). The $18 \%$ share of Latvians and Lithuanians in 1953 is an estimate based on the shares present during earlier and the subsequent 1959 census

between men and women (in both directions), gender clearly had little or no effect on the housing allocation decision. Having a Slavic-sounding surname, on the other hand, was associated with a better outcome in 1953-7 $\mathrm{m}^{2}$ versus only 6 for applicants with Baltic-sounding surnames: at such low levels, this a $1 \mathrm{~m}^{2}$ difference matters. ${ }^{7}$ Even so, in a multivariate setting (reported in Gentile and Sjöberg 2013), this differential appears to be explained by other factors, most notably those related to professional status. Yet the fact remains: in the years of Stalinhood, Balts were allocated smaller dwellings, and members of this group may have noticed this and drawn their own conclusions about their being discriminated against (after all, social status was not supposed to influence the allocation decisions).

As to workplace type, moderate differences in allocation outcome were present at an early stage, but they too decreased over time. Interestingly though, it was those employed within law enforcement, the military and the political organs that benefited the most. From 1970 and onwards, a category of beneficiaries emerges whose workplace happens to have been 'forgotten' in the official allocation decisions. This particular category happened to be the most successful, even in 1990. However, what appears to have mattered most is the type of occupation of the applicant, reflecting social status within Soviet society. In 1953, people in managerial occupations received almost twice the amount of living space compared to workers in unskilled occupations, and even though this gap was significantly reduced over the years of Soviet power, it remained in place in 1990.

While the findings from Table 3.1 suggest that little or no ethnic (surname) discrimination took place within the housing allocation process in Daugavpils, the matter cannot be dismissed entirely. Indeed, Table 3.2 shows that Latvian- and Lithuanian-sounding (i.e. Baltic) surnames were generally under-represented among the allocation decisions when compared to these two groups' relative shares of Daugavpils' total population, even though the opposite is true for 1970. This suggests that the process of admitting people into the waiting list favoured

\footnotetext{
${ }^{7}$ The "Other" surname background group (e.g. Georgian, German, Turkic, etc., sounding names) is too small, so its apparent advantage in 1953 is probably due to chance.
} 
outsiders, i.e. immigrants from (mainly) Russia and Belarus. Direct discrimination or purposeful Russification is thus neither confirmed nor refuted, but the outcome of the process nevertheless meant that Latvians and Lithuanians became under-represented in state-owned dwellings - especially within housing estatesand over-represented within the 'private sector', as was the case elsewhere in the Baltics (see, e.g. Hess et al. 2012).

In Table 3.3, mean waiting times in years are reported for all allocation decisions made in 1970, 1980 and 1990 (the data coverage was insufficient for 1953 and 1960). As with the allocation of living space, the trend appears to be towards both improvement and increasing fairness, yet the differences between different groups are more revealing and somewhat more resistant to time-but less so to testing in a multivariate setting [Gentile and Sjöberg (2013) do this for 1980 and 1990]. Thus, even though differences between men and women may be 'explained' by socio-occupational status, they in turn lead back to the Soviet gender-based labour market segmentation that systematically 'placed' women in lower skilled jobs (Filtzer 1992; Katz 2001). In other words, gender-based discrimination in the labour market was exacerbated by its consequences within other spheres, in this case housing allocation. A similar line of reasoning might hold in relation to the fact that

Table 3.3 Mean number of years spent waiting for new accommodation once admitted into the housing waiting list

\begin{tabular}{|c|c|c|c|}
\hline & 1970 & 1980 & 1990 \\
\hline \multicolumn{4}{|l|}{ Gender } \\
\hline Male & 5.22 & 5.43 & 4.26 \\
\hline Female & 6.22 & 5.78 & 4.52 \\
\hline \multicolumn{4}{|l|}{ Surname origin } \\
\hline Slavic & 5.43 & 5.35 & 4.33 \\
\hline Baltic & 6.25 & 5.85 & 4.60 \\
\hline Other & 4.77 & 5.57 & 4.93 \\
\hline \multicolumn{4}{|l|}{ Type of workplace } \\
\hline $\begin{array}{l}\text { Municipal and state administrative, excluding party organs and } \\
\text { law enforcement }\end{array}$ & 6.30 & 5.97 & 4.32 \\
\hline Non-priority industry & 5.58 & 6.01 & 5.08 \\
\hline Priority industry & 5.03 & 6.55 & 5.14 \\
\hline Law enforcement, military, political organs & 3.00 & 2.80 & 3.50 \\
\hline Unreported workplace & 4.25 & 3.47 & 3.38 \\
\hline \multicolumn{4}{|l|}{ Type of occupation } \\
\hline Unskilled & n.a. & 6.51 & 4.84 \\
\hline Some skills required & n.a. & 6.32 & 4.88 \\
\hline Higher education required & n.a. & 4.58 & 3.63 \\
\hline Management & n.a. & 3.03 & 4.45 \\
\hline Total mean & 5.51 & 5.57 & 4.40 \\
\hline
\end{tabular}

Source Gentile and Sjöberg (2013) (based on archive data assembled from multiple sources from the Latvian National Archive, Daugavpils regional section) 
people with Baltic surnames generally spent more time on the waiting list than their Slavic-sounding counterparts, although the gap narrowed over time. Even so, as in the case of living space allocation, the length of the waiting times appears to have been influenced by the applicant's workplace and occupation type, suggesting the presence of meritocratic principles alongside systemic 'impurities' such as bribery and the plain exertion of political 'clout' (as the shorter waiting times for the unreported workplaces would suggest). Needless to say, higher socio-occupational status and working within the 'right' spheres also gave a ticket to faster progress in the Soviet house hunt.

\subsection{Conclusion}

This chapter reviewed the factors underlying the widening and subsequent painfully slow narrowing of the Soviet housing shortage in the Baltics, corroborating the analysis with findings on housing construction and allocation in Daugavpils. While the absence of market allocation prevented the formation of socio-economic spatial differentiation patterns based on price rationing, the dynamics of the housing shortage, and the way the Soviet authorities attempted to tackle it, were a powerful alternative source of socio-spatial differentiation in their own right. Two aspects were especially important in this respect: shortages and priorities. Because cities hosted hierarchically arranged multiple branch-subordinated economic agents (enterprises enjoying different budgetary leeway), many of which actively engaged in housing construction and de facto urban planning, prioritised enterprises were in a better position to house their workers and to embrace (or seize) relatively comprehensive urban planning tasks. Put differently, such enterprises were able to produce full mikrorayony, better serviced, better located and perhaps even better built. At the other end of the priority scale, we have enterprises that were unable to play the housing card to attract workers; such enterprises were typically within light industry or the 'non-productive' sphere, and women overwhelmingly staffed them. And in between these two extremes, a wide range of actors did the best they could, resulting in a diverse urban landscape of priorities in which architectural homogeneity (based on the limitations of the local construction industry) concealed noteworthy differences in the locational and qualitative assets of housing, and where the forthright inequalities of market-based housing allocation were replaced by the oblique outcome of a need-based system maintained by demi-Kafkaesque bureaucracies. Accordingly, the Soviet housing estates-the essence of socialist standardisation and alleged socio-spatial justice - were in fact unequal on various accounts: they differed by size, by degree of completion and endowment with auxiliary functions, by locational quality (i.e. in relation to the city centre, to various urban amenities and to employment opportunities), and, to some extent, by physical quality. This situation was shared not only within the Baltic region, but also well beyond, and it represents the starting point for the introduction of market reforms. The latter, in turn, have structured the Baltic cities' socio-economic 
residential segregation patterns during the past three decades along the lines of the 'socialist' housing differentiation patterns heritage, and they will continue doing so in the foreseeable future.

\section{References}

Alexandrova A, Hamilton E, Kuznetsova P (2004) Housing and public services in a medium-sized Russian city: case study of Tomsk. Eurasian Geogr Econ 45(2):114-133

Alexeev M (1988) The effect of housing allocation on social inequality: a soviet perspective. J Comp Econ 12(2):228-234

Andersson L, Jakobsson N, Kotsadam A (2012) A field experiment of discrimination in the Norwegian housing market: gender, class, and ethnicity. Land Econ 88(2):233-240

Andrusz G (1984) Housing and urban development in the USSR. SUNY Press, New York

Bater J (1980) The soviet city. E. Arnold, London

Buckley C (1995) The myth of managed migration: migration control and market in the Soviet period. Slav Rev 54(4):896-916

Carpusor A, Loges W (2006) Rental discrimination and ethnicity in names. J Appl Soc Psychol 36 (4):934-952

Centrālā Statistikas Pārvalde (2017) Table A_MAG07. Housing stock by statistical region, city and district at the end of the year, 1990-2009, downloaded from the Centrāla Statistikas Pārvalde electronic database at http://data.csb.gov.lv/. Accessed 11 Nov 2017

Di Maio A (1974) Soviet urban housing: problems and prospects. Praeger, New York

Domański B (1992) Social control over the milltown: industrial paternalism under socialism and capitalism. Tijdschrift voor Economische en Soc Geogr 83(5):353-360

Domański B (1997) Industrial control over the socialist town: benevolence or exploitation?. Praeger, New York

Dremaite M (2014) Architecture and housing in Soviet Lithuania. DOM Publishers, Berlin

Filtzer D (1992) Soviet workers and de-stalinization - the consolidation of the modern system of soviet production relations 1953-1964. Cambridge University Press, Cambridge

French RA (1995) Plans, pragmatism and people: the legacy of Soviet planning for today's cities. UCL Press, London

Frolic BM (1972) Decision making in Soviet cities. Am Polit Sci Rev 66(1):38-52

Gentile M (2004) Former closed cities and urbanisation in the FSU: an exploration in Kazakhstan. Eur Asia Stud 56(2):263-278

Gentile M, Sjöberg Ö (2006) Intra-urban landscapes of priority: the Soviet legacy. Eur Asia Stud 58(5):701-729

Gentile M, Sjöberg Ö (2010a) Soviet housing: who built what and when? The case of Daugavpils, Latvia. J Hist Geogr 36(4):453-465

Gentile M, Sjöberg Ö (2010b) Spaces of priority: the geography of Soviet housing construction in Daugavpils, Latvia. Ann Assoc Am Geogr 100(1):112-136

Gentile M, Sjöberg Ö (2013) Housing allocation under socialism: the Soviet case revisited. Post-Sov Aff 29(2):173-195

Hess DB, Tammaru T, Leetmaa K (2012) Ethnic differences in housing in post-Soviet Tartu, Estonia. Cities 29(5):327-333

Katz K (2001) Gender, work and wages in the Soviet Union: a legacy of discrimination. Palgrave, Basingstoke and New York

Konrád G, Szelényi I (1974) Social conflicts of underurbanisation. In: Brown A, Licari J, Neuberger E (eds) Urban and social economics in market and planned economies: policy, planning, and development, vol 1. Praeger, New York, pp 206-226 
Kornai J (1992) The socialist system: the political economy of communism. Oxford University Press, Oxford

Kulu H (2003) Housing differences in the late Soviet city: the case of Tartu, Estonia. Int J Urban Regional Res 27(4):897-911

Lewis C, Sternheimer S (1979) Soviet urban management, with comparisons to the United States. Praeger, New York

Matthews M (1978) Privilege in the Soviet union: a study of elite life-styles under communism. Allen \& Unwin, London

Matthews M (1986) Poverty in the Soviet Union: the life-styles of the underprivileged in recent years. Cambridge University Press, Cambridge

Mežs I, Bunkše E, Rasa K (1994) The ethno-demographic status of the Baltic states. GeoJournal 33(1):9-25

Morton H (1980) Who gets what, when and how? Hous Sov Union Sov Stud 32(2):235-259

Morton H (1984) Housing in the Soviet Union. Proc Acad Polit Sci 35(3):69-80

Murray P, Szelényi I (1984) The city in the transition to socialism. Int J Urban Reg Res 8(1):90107

Sawicki SJ (1977) Soviet land and housing law: a historical and comparative study. Praeger, New York

Shomina E (1992) Enterprises and the urban environment in the USSR. Int J Urban Reg Res 16 (2):222-233

Sjöberg Ö (1992) Underurbanisation and the zero urban growth hypothesis: diverted migration in Albania. Geogr Ann Ser B Hum Geogr 74(1):3-19

Sjöberg Ö (1994) Rural retention in Albania: administrative restrictions on urban-bound migration. East Eur Q 28(2):205-233

Sjoberg Ö (1999) Shortage, priority and urban growth: towards a theory of urbanisation under central planning. Urban Stud 36(13):2217-2236

Sommer S (2012) Soviet housing construction in Tartu: the era of mass construction (1960-1991), Master's thesis, Department of Geography, University of Tartu, Tartu. Available for download at http://cmus.ut.ee/wp-content/uploads/2013/09/2012-magister-Sille-Sommer.pdf. Accessed 10 Nov 2017

Sosnovy T (1959) The Soviet housing situation today. Sov Stud 11(1):1-21

Szelényi I (1983) Urban inequalities under state socialism. Oxford University Press, Oxford

Tammaru T (2001) Suburban growth and suburbanisation under central planning: the case of Soviet Estonia. Urb Stud 38(8):1341-1357

Open Access This chapter is licensed under the terms of the Creative Commons Attribution 4.0 International License (http://creativecommons.org/licenses/by/4.0/), which permits use, sharing, adaptation, distribution and reproduction in any medium or format, as long as you give appropriate credit to the original author(s) and the source, provide a link to the Creative Commons license and indicate if changes were made.

The images or other third party material in this chapter are included in the chapter's Creative Commons license, unless indicated otherwise in a credit line to the material. If material is not included in the chapter's Creative Commons license and your intended use is not permitted by statutory regulation or exceeds the permitted use, you will need to obtain permission directly from the copyright holder. 


\title{
Chapter 4 \\ The Exceptional Design of Large Housing Estates in the Baltic Countries
}

Marija Drèmaitė

\begin{abstract}
This chapter discusses Baltic (mostly Lithuanian) mass housing estates as winners of Soviet urban planning and housing competitions; the role of the architect in the field of standardised design; and Western architectural influences in Soviet Baltic housing estate design. In the field of industrialised and standardised housing construction, the role of architects and one-off design is of special interest, because industrialisation and standardisation in Soviet mass housing brought tension between planners of standardised large housing estates and master architects who drew up unique designs for public buildings. Despite the Communist Party declaring in 1955 the importance of mass housing, the Soviet Union's most prestigious state award - the Lenin Prize - was only ever conferred upon one model site: the Lazdynai large housing estate in Vilnius, Lithuania, in 1974. This chapter thus focuses on the involvement and experimentation of Baltic architects in the planning of standardised housing estates; on professional acknowledgment and on the fulfilment of ideological requirements.
\end{abstract}

Keywords Microrayon · Lazdynai - Mass housing $\cdot$ Baltic modernism

\subsection{Introduction}

Reflecting the current interest in regional differences in large processes and phenomena, peripheral histories open up the possibility of seeing other dimensions, local variations and regional adaptations, and are able to change the established narrative frames. Comparative research in post-war mass housing has shed new light on uniformity and standardisation processes by adopting a more focused approach towards regional differences in the former Socialist countries, especially in the areas of East-West technological relations, the appropriation and rejection of Soviet directives, and the importance of local expertise (Kalm and Ruudi 2005;

\footnotetext{
M. Drèmaitè $(\bowtie)$

Department of History, Vilnius University, Vilnius, Lithuania

e-mail: marija.dremaite@gmail.com

(C) The Author(s) 2019

D. B. Hess and T. Tammaru (eds.), Housing Estates in the Baltic Countries,

The Urban Book Series, https://doi.org/10.1007/978-3-030-23392-1_4
} 
Ritter et al. 2012). In a book on prefabrication and the organisation of Soviet industrial construction (Meuser and Zadorin 2015), the authors not only included an analysis of changes in Soviet mass housing production, describing three generations of mass housing and their special characteristics, but also summarised the changing discourse in socialist mass housing studies, moving away from uniformity and standardisation to regional differences. In a comparison of two dissimilar Soviet regions analysed in two recent studies of mass housing - Central Asia (Meuser 2016) and the Baltic Republics (Drèmaite 2017) — regional differences (and reasons for these differences) were discussed. Baltic modernist architecture was perceived as a manifestation of design excellence throughout the entire USSR: the Baltic region was sometimes called 'the inner abroad' or the 'Soviet West' owing to its Western-influenced architectural designs.

In this context, the possibility that the design of large housing estates in the Baltic region was considered exceptional within the Soviet Union has been addressed by several researchers, particularly in light of the Baltic States' relations with - and orientation towards - Western and International Modernism (Maciuika 1999; Ojari 2004; Cinis 2007). A comparison of Baltic and Nordic housing architecture was a particular focus of the Nordic-Baltic research network, which highlighted the important role played by Nordic Modernism in developing Baltic Modernism during the Soviet period (Caldenby and Wedebrunn 2010, 2013). Recent papers discussing specific Estonian aspects of mass housing have emphasised the criticism of mass housing (Kurg 2009), which led to alternative house design solutions (Kalm 2012a), and the role of architects in designing large housing estates (Metspalu and Hess 2018).

This chapter will further explore the role of the architect and the individualised design approach in the field of mass housing, where construction has been largely regulated by standardisation and the economy. David Crowley saw the division between standard and original as one of the most fundamental features shaping the nature of Socmodernism (a term proposed by Crowley) and distinguishing it from Western Modernism (Crowley 2009, pp. 246-258). He proposed dividing post-war socialist architecture into 'Socmodernism 1' and 'Socmodernism 2' based on this distinction. In his conception, 'Socmodernism 1' met the demands issued by Soviet leader, Nikita Khrushchëv, as early as 1954 to supply inexpensive, unembellished industrialised buildings, largely but not only for the sphere of housing. In this sphere architects were expected to behave as technocrats; they were required not to produce buildings but types, with the result that housing design was removed from the sphere of art to engineering (Crowley 2009, pp. 246-247). This thesis is supported by Richard Anderson who also noted that the architectural profession underwent a process of differentiation during this [Khrushchëv's industrialisation] period as it devolved into two principal spheres: 'those who worked primarily in the field of serialized production and those who worked on unique buildings' (Anderson 2015, p. 250).

The tension between serialised and unique design became a long-standing feature of Soviet architectural production. As Mart Kalm put it: 'Standardised designs were already in extensive use during the Stalinist period but became an obsession 
during Khrushchëv's Thaw, when economical building practices became the focus of attention. [...] The more the state demanded standardised designs, the more architects became irritated and felt oppressed by the restrictions' (Kalm 2012b, p. 39).

These observations suggest the hypothesis that regional differences in the standardised architecture of large housing estates could be introduced by local experts proposing unique architectural solutions. It is therefore important to examine how Baltic architects pursued more individualised solutions; how ideological requirements were imposed during this particular period; and how architects proposed solutions for improvement. It is also important to establish how certain professional (or even national ethnic) aspirations were cloaked in a 'correct' Soviet rhetoric and whether there existed alternative ways of securing official acknowledgement of a project.

The main source of material for this chapter is constituted by my interviews with Lithuanian architects Vytautas Čekanauskas and Vytautas Brèdikis. It should be noted, however, that these interviews were conducted in the period between 2006 and 2016, when the architects had been able to reflect on their designs in light of the passage of time and under different political circumstances. I am therefore grateful to John V. Maciuika, who shared his findings from the personal interviews which he conducted with the same architects in 1992.

Archival research was conducted in the Russian State Archives for Literature and Arts in Moscow (RGALI), where the files of the Lenin and Soviet State Prize Committees are stored. Fairly detailed records were kept of each section meeting, though some handwritten corrections on the machine-typed text suggest possible omissions and revisions. Original designs for Lithuanian large housing estates held by the Lithuanian State National Archives, the Vilnius Regional State Archives, and the Lithuanian Archives of Literature and Art were also consulted.

Other materials reviewed for this paper were carefully selected from the All-Union professional journal (Архитектура CCCP-Architecture of the USSR) and the local Lithuanian journal (Statyba ir Architektura-Construction and Architecture). Information about housing in the Soviet period can be found in the descriptive summaries of the 'architectural achievements' of the Soviet period in Estonia (Volkov and Kruusimagi 1972; Volkov 1987), Latvia (Zakamennijs 1966; Krastinš et al. 1987) and Lithuania (Budreika 1971; Minkevičius 1987).

\subsection{A New Type of Apartment Building and a New Type of Soviet Neighbourhood}

After 1955, Nikita Khrushchëv's construction reforms related to industrialisation and standardisation affected the entire system of Soviet architecture. Planning became the responsibility of two government ministries; Gosplan and Gosstroi, each accountable to the USSR Council of Ministers. Gosplan, the State Planning 
Committee, was responsible for national and regional economic planning, which includes investment in construction. Gosstroi, the State Construction Committee, was established in 1955 as the Soviet Union's principal national institution controlling regional and city planning and construction processes. Gosstroi was involved in every phase of the construction process, from planning to general contracting. The system included more than a dozen specialised research and design institutes as well as scores of local design centres. As with their economic counterpart, Gosplan and Gosstroi were replicated at the Soviet republic level in the form of 15 state construction committees, one in each constituent republic (Ruble 1993, p. 239).

Following the Communist Party's 1957 promise to provide every Soviet family with an individual apartment (Decree No. 931, 1957), the development of residential zones became a critical urban planning issue. The restructuring of the Soviet housing construction industry focused on two issues in particular: industrial production of standardised housing types and the creation of a new model of residential district known as the microrayon. Both undertakings were subject to strict regulation by the State Committee of Civil Construction and Architecture (Gosgrazhdanstroi), which was subordinate to Gosstroi.

For many years, the introduction of large-panel house production (known by its Russian acronym, KPD) and the adoption in 1955 of regulations [known as the Construction Norms and Rules (known by its Russian acronym, SNiP)] served as the means for controlling residential design. In the period from 1955 to 1991, the SNiP rules dealing with mass housing were thoroughly revised only four times: in 1957, 1962, 1971 and 1985, resulting in very slow changes in mass housing design (Meuser and Zadorin 2015, p. 21). In 1956, Gosstroi organised an architectural competition for drawing up new types of design for three-, four- and five-storey houses with small apartments. Based on 217 entries, Gosstroiproekt developed model designs which were finally recommended by Gosstroi for universal roll-out and were used for the majority of mass housing designed between 1958 and 1963 (Meuser and Zadorin 2015, p. 168).

State planning institutes in the Soviet Baltic Republics considered Gosstroiproekt's housing series no. 1 as the basis for local designs. Estonprojekt architects in Tallinn, under chief architect Mart Port, designed Estonia's housing series No. 1-317 in 1956 (Ojari 2004, p. 67), and the Lietprojektas group in Vilnius, under chief architect Gediminas Valiuškis, developed local designs (series No. 1-318) for two-, three-, four- and five-storey buildings in 1958 (Peras 1958, p. 34). Another All-Union design (by Giprostroiindustrya) became the basis for the series I-464, the most widespread industrial series both in Soviet mass housing and in the Baltic cities (Meuser and Zadorin 2015, p. 193). I-464 was particularly subject to multiple improvements and local modifications.

Industrialised housing construction was accompanied by a new type of urban planning, the microrayon (micro-district), a Soviet version of the basic neighbourhood unit (Dremaite 2010; Kosenkova 2013). The model of the Soviet microrayon was developed after the architectural competition of Socialist countries in 1960 for the development of the south-western area of Moscow. The event had an 
important mission: to develop new methods for grouping and arranging multi-unit apartment buildings. The 1960 competition was crucial towards affecting changes in residential urban planning, abandoning the system of constructing housing along the perimeter of a city block in favour of a more freestyle arrangement of multi-unit apartment houses.

The competition also focused on social planning, introducing a tiered system of public, cultural and consumer services (Osnovy sovetskogo gradostroitelstva 1967, pp. 168-242). Tiers were based on the estimated needs of 1000 inhabitants and were defined by frequency of use: daily use sites, periodic use facilities (visited two to three times per week), and episodic use facilities, used twice or three times monthly (Fig. 4.1). The core unit of the microrayon was a group of residential buildings for 2000 inhabitants, further grouped into a microrayon with 900012,000 inhabitants. Services usually accessed on a daily basis included kindergartens, schools, food shops, canteens, clubs, housing unit administration services, sports fields and playgrounds. These were all located within the boundaries of a given microrayon, and no further than $400 \mathrm{~m}$ from any one home. All first-tier public buildings were expected to follow standard designs and consist of prefabricated parts. Second-tier facilities, such as cinemas, libraries, department stores and healthcare facilities, were to be built for the larger residential area (made of several microrayons) and intended to be used periodically. Once these new types of large-scale residential districts began to emerge, management and financing had to be transferred from enterprises to municipal authorities and local governments, who then became responsible for both planning and construction. This was perhaps the most significant change in the modernisation of Soviet urban planning.

\subsection{Prefabricated Mass Housing and Microrayons Are Introduced to the Baltic Republics}

In all three Baltic republics, the major state planning institutes were tasked with planning standard residential construction and 'anchoring it in place', i.e. adapting standardised designs to a specific building plot. Departments of standardised design were established at state planning institutes. The first large-panel residential district plan, prepared in 1959 at the Vilnius Urban Construction Design Institute, demonstrated an attempt to arrange buildings on a more open plan, including diagonal placement. Designed by architect Laimutė Elena Bergaitė-Burneikienè, this new residential quarter for drill factory workers consisted of five-storey, elongated rectangular series I-605A (Giprostroiindustrya) buildings with 80 units per structure (Fig. 4.2). Similarly, Tallinn's second prefab housing district, Mustamäe, was constructed with series I-464 apartment blocks (Ojari 2004, p. 67). Designed in 1959 by the State Design Institute Estonprojekt (architects Voldemar Tippel, Toivo Kallas and Lidia Pettai), it followed the principles of freeform planning and standardised design. It was divided into nine microrayons to 


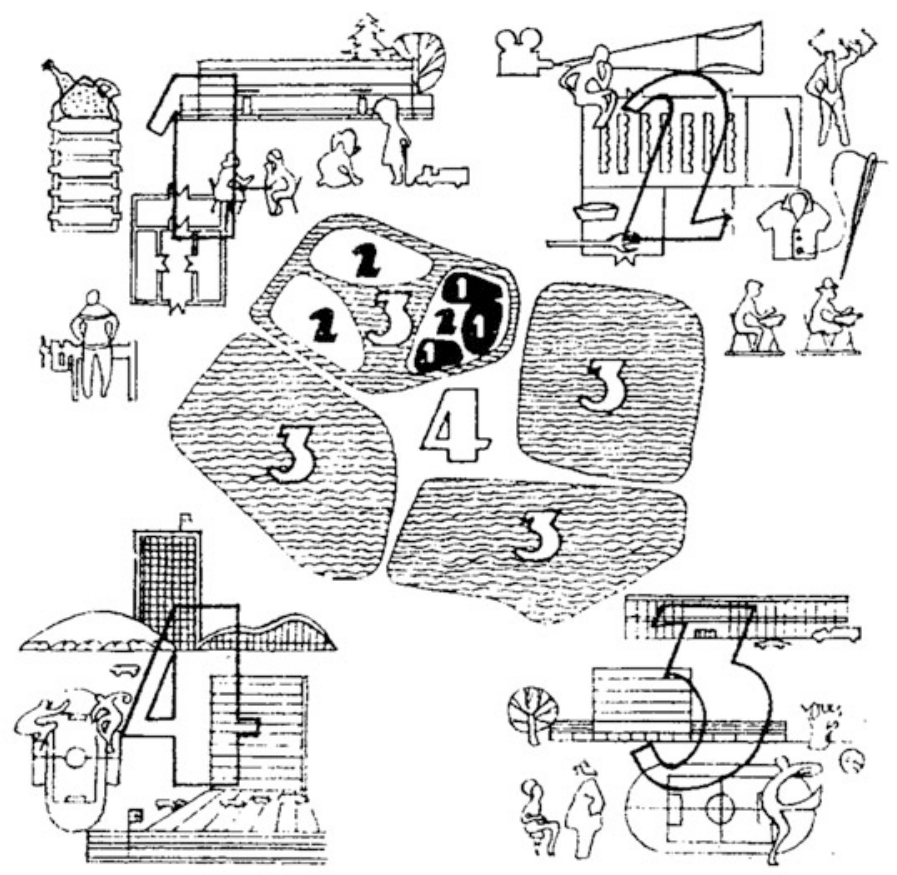

19 pav. Pakopinè kultürinio-buitinio aptarnavimo sistema tarybiniame mieste, suskirstytame i mikrorajonus:

1 - gyvenamụjụ namụ grupé (2000 gyventoju), 2 - mikrorajonas (6-10 tūkst. gyventoju), $3-$ gyvenamasis rajonas (25-50 tükst. gyventojų), 4 - miestas"

Fig. 4.1 Schematic of a tiered system of public cultural and consumer services in a Soviet city: 1 . A group of homes (2000 residents). 2. Microrayon (10,000 residents). 3. Residential area (40,00050,000 residents). 4. A city. Source Minkevičius (1964), p. 40

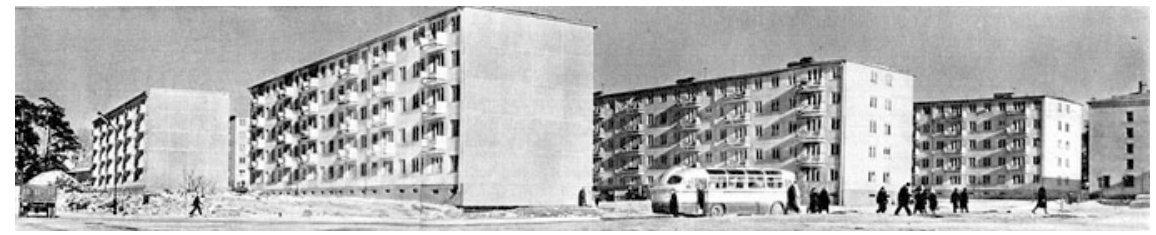

Fig. 4.2 The first prefabricated large-panel buildings (series) built in Vilnius in 1959. Source Naujoji tarybu Lietuvos architektūra (New Architecture of Soviet Lithuania) (1964). Vilnius: Mintis, p. 4 
accommodate 60,000 residents. Each microrayon was arranged around one school, four to six nursery schools and a network of services ranging from post offices to public saunas, all of which would be within walking distance of the residential blocks. Later, custom designed high-rises and apartment buildings were built in Mustamäe.

Āgenskalna Priedes was the first large-scale housing estate in Riga. The first construction stage, with five-storey standard brick houses (locally adapted series No. 1-316), started in 1959 and was completed in 1961 (architect Nikolajs Rendelis). A residential area, a restaurant, commercial buildings and public service facilities were also provided. The second stage of the development started in 1961 with five-storey series I-464-A panel houses. The district retained its historical name. There was an area with several high dunes and clusters of pine trees; however, the dunes were levelled in the construction process and natural features of the district were destroyed (Krastiņš 2013, pp. 83-91).

The three examples mentioned above show that in the first stage of implementing the new directives, standards in prefabricated housing construction and urban planning were followed with little experimentation. Architects recalled that 'architects were hardly involved' (V. E. Čekanauskas, interviewed by John V. Maciuika, 1992), and that work in standardised planning was perceived as neither desirable nor creative (V. E. Čekanauskas, personal communication, December 11, 2006; V. Brèdikis, personal communication, August 2, 2011). In Lithuania, for example, such tasks were delegated to recent graduates who, in turn, hoped to escape their new duties as soon as possible and progress to individualised design. It is also noteworthy that the planning of new microrayons was often delegated to female planners, with comments to the effect that the composition of a microrayon was governed by standards, thus lacking architectural innovation.

By 1961, the Third Congress of Soviet Architects boasted of enormous productivity (165 million $\mathrm{m}^{2}$ of residential floor space created in 1959-1960) but it also took note of significant shortcomings, including 'a lack of creativity in the use of standard designs’ (Архитектура СССР, 1961, no. 6, pp. 3-5). As Dmitry Zadorin has noted, scientific studies have repeatedly attempted to combat the monotony; but the economy was the real reason why all Soviet cities of that era were full of five-storey buildings arrayed in extremely regular patterns (Meuser and Zadorin 2015, p. 167). The architect Albertas Cibas, an official with the Lithuanian Gosstroi, called for measures to attract the best and most experienced architects to work on standardised designs, providing them with a degree of creative liberty, particularly in the adaptation of standard designs for certain sites (Архитектура СССР, 1961, no. 7, p. 7). Decree No. 903 'On Improvement of Design Practice in the Field of Civil Construction, Planning and Construction of Cities', issued by the Soviet Communist Party's Central Committee and Council of Ministers in 1963, indeed encouraged the transfer of responsibilities to regional and local levels. Local design institutes and State building concerns now had an opportunity to implement slight modifications. This all led to experimentation in housing design and microrayon planning. 


\subsection{Experimental Design: The Growth of Local Expertise and the Role of Architects}

In such negotiations, the word 'experimental' played a key role as it had been validated by the 'scientific technological revolution'. David Crowley has noted that architects and designers who could characterise their work as 'experimental' (meaning that an experimental building would provide technical know-how for the rest of the building sector) could bolster their credentials as technical specialists and draw on greater resources and enjoy greater freedoms (Crowley 2009, p. 252).

Indeed, experimental design became a very effective way of introducing improvements to the Soviet residential housing system. The Vilnius Urban Construction Design Institute established a special office for this purpose in 1960. The planning for Burbiškès - a new neighbourhood of Vilnius, which was never constructed-provides an example. Burbiškès was the first mass housing project entrusted to a new generation of young architects-Vytautas Čekanauskas, Vytautas Brèdikis, Jaunutis Makariūnas, Algimantas and Vytautas Nasvytis, who were born in the 1930s and graduated in the mid-1950s - in hopes that they would develop fresh ideas. From 1961 to 1962 , their task was to draw up plans for a residential district in southern Vilnius comprising 30,000 residents, incorporating a three-tier internal organisational structure (Fig. 4.3).

It is important to note that several architects of this group had already earned a reputation as promoters of new ideas. The Nasvytis brothers had designed the breakthrough modernist interior of the Neringa café in Vilnius in 1959. Čekanauskas and Brèdikis had designed the Composers' Union Hall and housing complex with a Nordic touch in 1960. They came from a field of architecture that was valued by the informal hierarchy of the profession. It is also important to

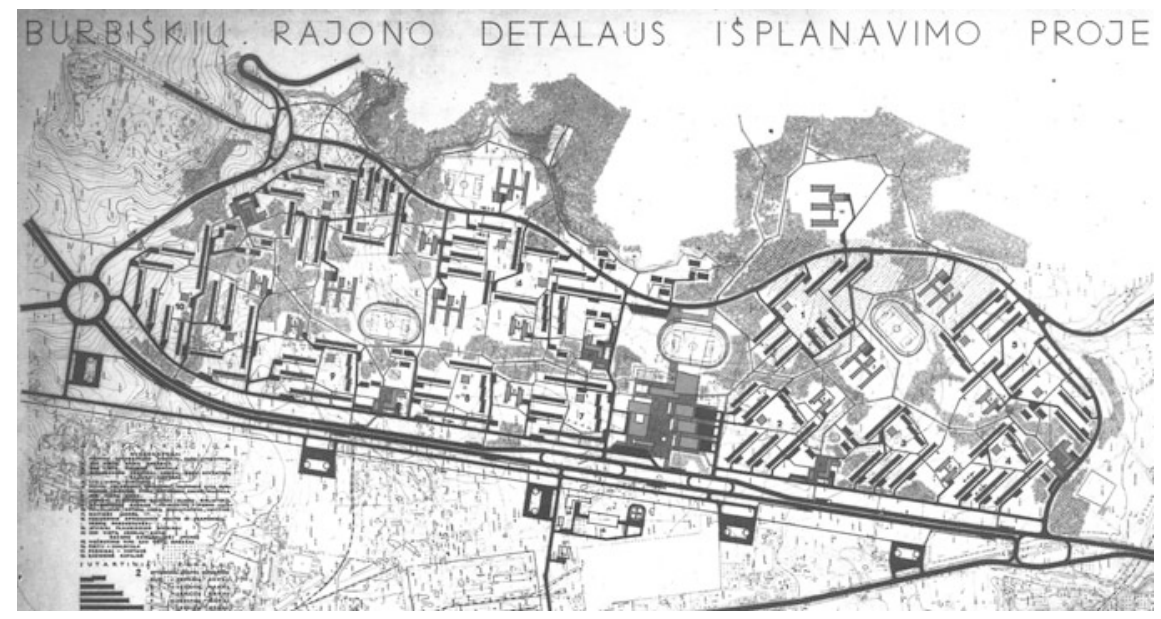

Fig. 4.3 Detailed plan of Burbiškès residential area in Vilnius, 1962. Private collection 
understand the idealism and ambition of the group. According to architects, they wanted to change the standard five-storey residential buildings - to design structures that could be placed on complex terrain and arranged in various different vertical and horizontal combinations, not simply placed in long rows on flat fields. Vytautas Čekanauskas recalls: 'We referred to these [pre-fab panel] buildings simply as "bricks" because of their slab shape and unsightly nature. We wanted to improve these buildings by changing those horrible Russian designs' (V. E. Čekanauskas, personal communication, December 11, 2006).

Architects, working at the same Vilnius Urban Construction Design Institute, supported the ideas of Čekanauskas and Bredikis. Between 1960 and 1965, a group of young architects - Gediminas Valiuškis, Enrikas Tamoševičius and the Nasvytis brothers - drew up the first experimental plans for apartment units and in 1961, organised an internal mini-competition. Vytautas Nasvytis, Jaunutis Makariūnas and Algirdas Jasinskas developed an improved version of the standard I-464 series house, with apartments that could be divided using light sliding partitions or room dividers that also served as closets, allowing for different configurations of each apartment (Figs. 4.4, 4.5, 4.6 and 4.7). However, the price for $1 \mathrm{~m}^{2}$ increased by 5$6 \%$, and the Vilnius factory producing the concrete elements refused to make changes. The Chairman of the Lithuanian Union of Architects complained: 'This is a strange situation - on the one hand, architects are criticised for design flaws, yet on the other hand, their improvements are not accepted.' (Union of Architects Chairman's report 'Architects' tasks in the CPSU Programme' at the Board Plenum, February 2, 1962, Lithuanian Archives of Literature and Art, f. 87, ap. 1, c.

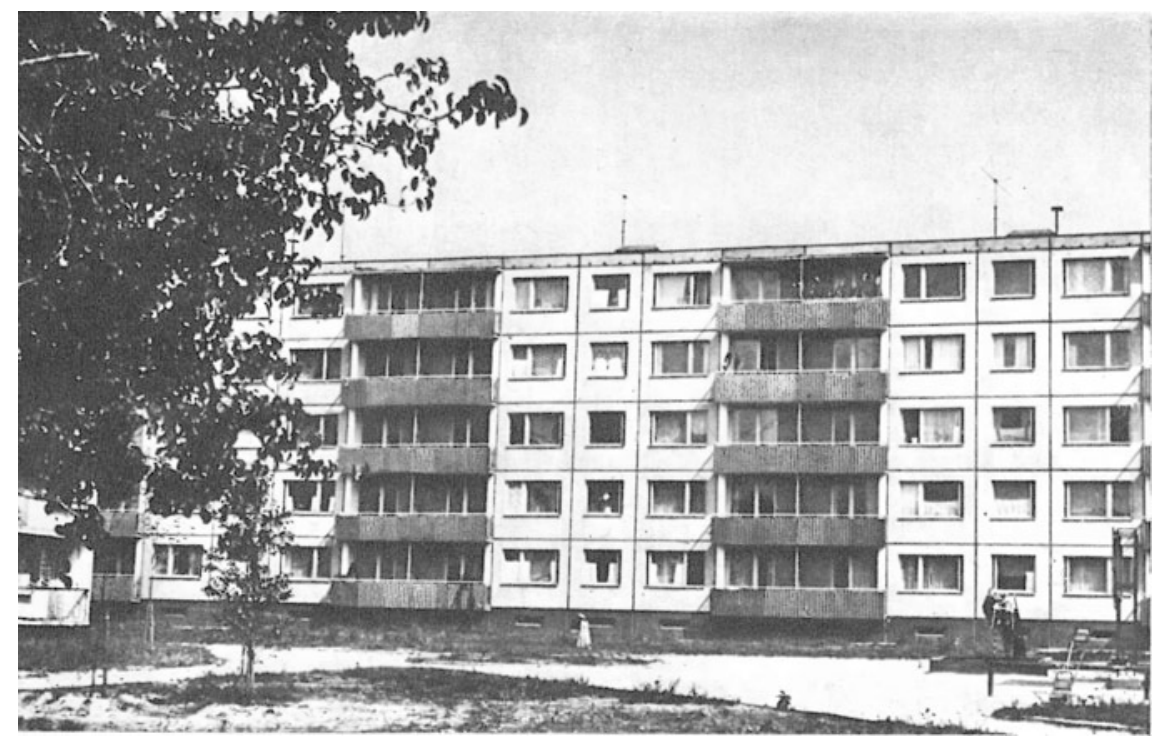

Fig. 4.4 An experimental large-panel apartment house (containing 75 units) based on standard series I-464. Source Žiburkus (1969), unpaginated 

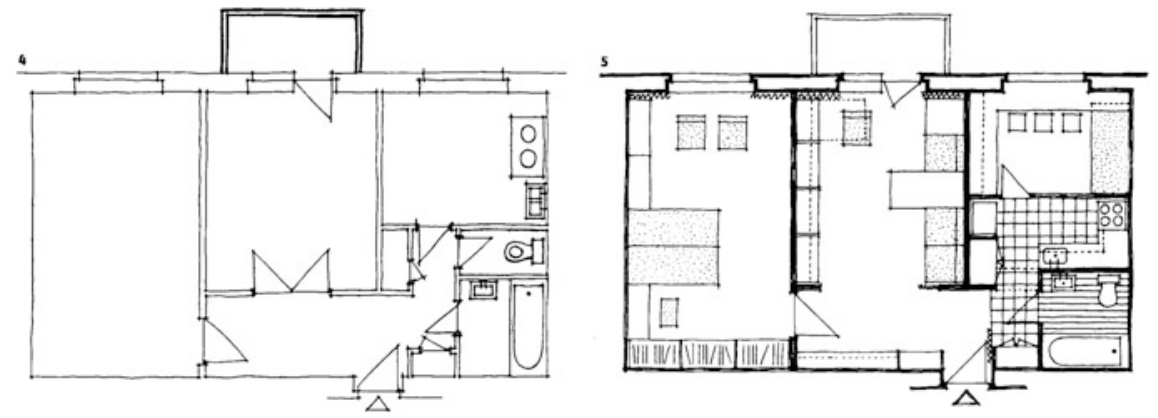

Fig. 4.5 An experimental apartment plan (right panel) compared to the standard apartment design (left panel). Architect Vytautas Nasvytis, 1961. Source Domov, 1967, no. 5, p. 22

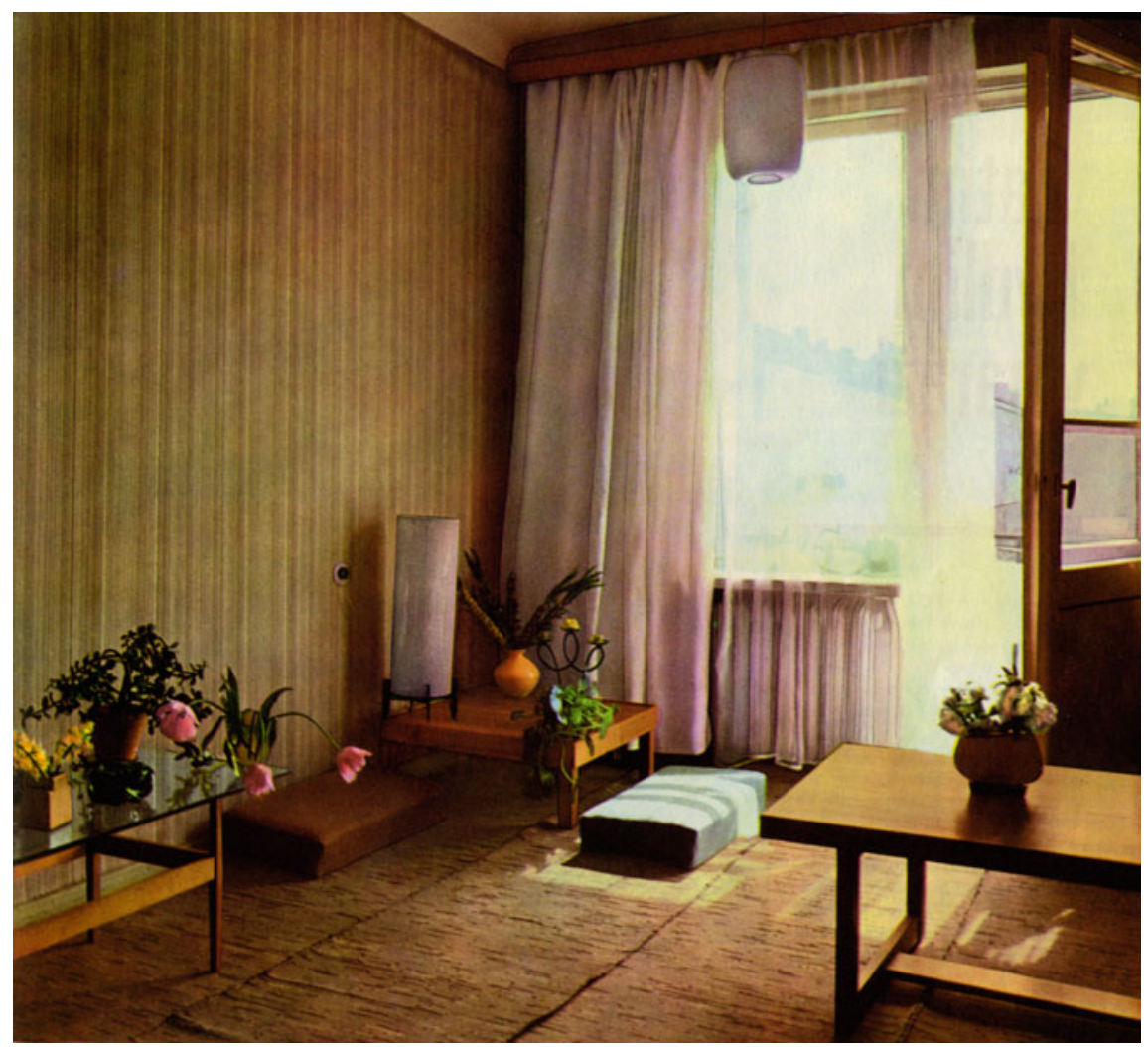

Fig. 4.6 Interior of an experimental apartment, architect Vytautas Nasvytis, 1961. Source Domov, 1967 , no. 5 , p. 23 

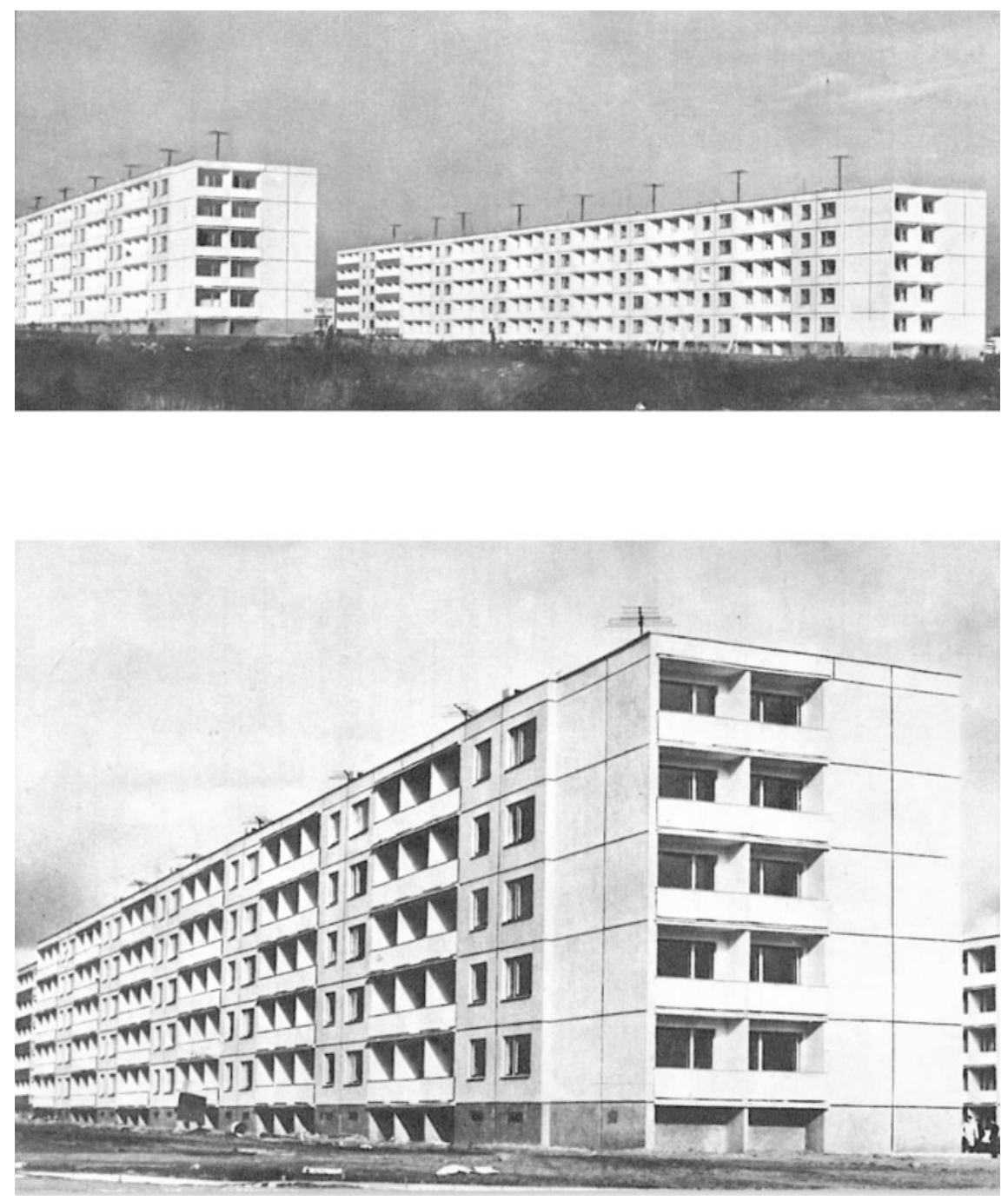

Fig. 4.7 An improved five-storey panel apartment building of the I-464-LI series (Krūminis group). Source Žiburkus (1969), unpaginated

363, 1.9-10). The detailed and meticulously planned Burbiškès project was never built; however, it provided architects with the experience they needed to engage more boldly in future experimentation with residential housing design.

Architect Bronius Krūminis, at the Urban Construction Design Institute, designed a second-generation series (I-464-LI, 1967) intended only for use in Lithuania. Krūminis started his career in the mid-1950s at the Vilnius Scientific Restoration Workshop and was responsible for the restoration of Trakai Lake Castle, an important historical national monument. However, harsh criticism from 
Moscow, for Lithuanians 'rebuilding feudal castles', put an end to these activities. The architect was demoted to work at the Department of Standard Design in Vilnius. However, even in his work there, one can detect his aesthetic approach and architectural ambition. He and his team-Algimantas Umbrasas, Vidas Sargelis and engineer Vaclovas Zubrus - developed the 'Lithuanian series' in close cooperation with Čekanauskas and Brèdikis, who from 1962 to 1963 designed Lazdynai, another large housing estate in Vilnius. In 1967, based on a standard wall length of $3.20 \mathrm{~m}$, they designed five-, nine- and twelve-storey prefabricated large-panel houses, with better apartment planning and loggias instead of balconies, also allowing the possibility of constructing houses on sloped terrain. The construction of these houses was temporarily halted in Lazdynai because the infrastructure was not yet ready, but went ahead in Žirmūnai, another large housing district. We will see later that Žirmūnai benefited greatly from these houses.

In 1970, Krūminis' group designed an experimental series - for construction in Lithuania between 1971 and 1975-which served as the basis for the 1973 third-generation $120 \mathrm{~V}$ panel housing series, distinguished by more façade relief detail, corner balconies and larger service rooms and kitchens. This new series can be seen as reflecting the architects' desire to make apartment planning more convenient and to bring greater volumetric diversity to their buildings. Within the constraints of standardised planning, his efforts constituted small steps toward architectural diversity in large housing estates. However, the lack of diversity was highlighted again in Decree No. 392, 'On Measures to Improve the Quality of Residential and Civil Construction', which was adopted in 1969 by the Soviet Council of Ministers and the Communist Party Central Committee and aimed to achieve greater architectural expressiveness, introduce unique cityscapes, and imbue residential areas with a stronger sense of local identity.

By the late 1970s and early 1980s, it was possible to see many more manifestations of regional identity and an increasingly individualistic approach to design in the building series designed exclusively for the coastal city of Klaipèda (Krūminis, Sargelis, Zubrus and Jonas Stanislovaitis, an engineer with the Klaipeda Panel Building Factory, series 1-120-PSS, 1980). These incorporated a central pattern of corner balconies and enclosed terraces with red brick walls-considered to be typical of the Klaipèda region - conceptually developed by architect Gytis Tiškus. Another innovation in mass-produced apartment construction was the introduction of an $11 \mathrm{~m}^{2}$ hall leading to a terrace, heated attics and more spacious kitchens $\left(8.67 \mathrm{~m}^{2}\right)$.

Architects also transferred their innovation into the realm of design competitions, hoping to obtain the coveted 'experimental project' status. An attempt at improving the quality of standardised designed apartment blocks was made in Estonia in 1971, when the minimum residential design standards were eased. The ensuing architectural competition produced a series of apartment blocks made from local materials, which were called 'Masso houses' after the architect Miia Masso. These buildings — often unplastered red brick buildings — can be encountered all across Estonia (Väljas and Lige 2015, pp. 61-62). 
In 1982, Krūminis' group also submitted an experimental design for a brick residential building that included a new floor plan for apartment units and the possibility of joining living rooms with the entrance hall, along with kitchens equipped with electric stoves. In this way, each unit could have about $30 \mathrm{~m}^{2}$ of combined space without violating any regulations on total apartment unit living space. The architects also proposed three different construction type options: brick support walls, prefabricated and monolithic construction. More and more buildings were constructed using brick, incorporating an increasing diversity of composition. Proposals were made to design a series of residential buildings suited specifically to the three Baltic republics, incorporating materials typically found in the region. However, the great majority of experimental designs were never utilised, or were implemented with considerable modifications, usually hopelessly simplified.

\subsection{Nordic Influence}

The influence of Nordic design is often emphasised in analyses of Baltic design of the Soviet period. Mart Kalm noted that when new residential districts were built among trees in existing pine forests, Tapiola was frequently cited as an inspiration - this happened in Āgenskalna Priedes in Riga, Mustamäe in Tallinn and Lazdynai in Vilnius (Kalm 2012b, p. 38). Triin Ojari also noted that Mustamäe, with its central multifunction shopping and entertainment centre, was akin to Vällingby and Tapiola (Ojari 2004, p. 69). Indeed, as opportunities for tourist travel and foreign exchange programmes increased in the late 1950s, the Soviet Architects' Union began to organise professional delegations that included several representatives from each of the Baltic republics, dispatched on fact-finding missions to both the socialist and 'capitalist' countries.

The favourable Soviet view of Scandinavia as a whole - friendly relations with Finland and Sweden in particular - the progressive approach to residential construction in these countries, and the proximity of the Baltic republics to Scandinavia all led to the Nordic region becoming a benchmark for Baltic modernists, with Finland the most frequently visited country for study trips. Estonia developed the closest relationship with Finland not only because of the closely related language but because of the direct ferry line which opened in the 1960s.

The first official fact-finding delegation to Finland, in June 1959, consisted of 21 specialists from Latvia, Estonia, Lithuania and the city of Leningrad (Materials on the visits of the Soviet architects to foreign countries, 1959, RGALI, f. 674, op. 3, d. 1598, p. 30). Mart Kalm believes that in their memoirs, architects slightly exaggerated the Nordic impact because they wanted to look more western. But, from the recollections of the Lithuanian architects, one can sense that Finnish Modernism really changed their understanding of the essence of architecture. Vytautas Čekanauskas, a member of the group recalled: 'There, we really felt the architecture' (V. E. Čekanauskas, personal communication, December 11, 2006). In 1960, three missions to Finland were organised, including 90 Soviet architects with one 
delegation made up exclusively of nearly 30 Lithuanian architects (Materials on the visits of the Soviet architects to foreign countries, 1960, RGALI, f. 674, op. 3, d. 1625, p. 68). A new directive issued by the Central Tourist Excursion Bureau on 31 January 1959 made foreign travel easier to organise for local trade union administrations in the republics, facilitating continuing visits by Lithuanian architects to Finland in 1961, 1963, 1964, and in later years.

The visiting Lithuanian architects brought home strikingly emotional impressions. Many of them referred to Finland as a symbol of modern architecture that influenced their later work. The Nasvytis brothers asserted that they embraced 'a Finnish-Nordic way of thinking, perceived through the works of Ervi, Aalto, and others' (Mačiulis 2007, p. 102). Čekanauskas remembered the trip having a lasting impression on him. Seeing the suburb of Tapiola and meeting its architect Ervi was, for Čekanauskas, an indescribable event (V. E. Čekanauskas, interviewed by John V. Maciuika, 1992). Vytautas Bredikis recalls: 'good, humane architecture ... a masterful harmony of buildings and nature' (V. Brèdikis, personal communication, August 2, 2011). Documents from personal archives show that many who visited Finland admired works by Alvar Aalto and Reima Pietilä, and used Finnish Modernism as inspiration. Architects admitted that the materials and design processes they used, as well as the composition of their designs within their natural context, all changed after their foreign trips.

\subsection{Recipients of Architectural Excellence Awards: Žirmūnai, Lazdynai and Väike-Õismäe}

\subsection{1 Žirmūnai}

Soviet architectural awards had a strong ideological and didactic role. With the introduction of the USSR State Prize (which was lower in rank to the Lenin Prize) in 1966, one can observe a more equal distribution of prizes among the Soviet Republics and the introduction of a more diverse functional typology of architecture among political monuments and significant public buildings, which were the only types previously to receive awards. The D-18 microrayon of the Žirmūnai residential area-built between 1962 and 1964 in Vilnius, Lithuania-became the first Soviet housing development to receive the USSR State Prize for urban residential design in 1968. It was also the first mass housing estate to receive an award at the first Soviet-wide review of the country's architecture, organised in 1967 in Moscow. From a field of 167 designs submitted for state recognition, the first prize was awarded, by unanimous decision, to the D-18 microrayon. The press signalled it as a turning point in Soviet architecture (Barkhin 1968, p. 5). Politically this recognition was aimed at finding models to be followed in developing Soviet mass housing architecture.

A young urban planner, Birutė Kasperavičienè (1926-1976), began designing new residential microrayons in Vilnius in 1956, and designed the first new 
industrial town, Elektrènai, for 4000 residents in Soviet Lithuania in 1960. In her later D-18 project, Kasperavičiene preserved the natural downhill of the river bank. She had the benefit of using the improved standard house I-464 series, which was developed at the Vilnius Urban Construction Design Institute. Žirmūnai became an experimental site where some of the modernist ideas were introduced; for example, the new nine-storey panel house for single persons (architect Enrikas Tamoševičius) along with the shopping and service centre of the microrayon (a standard design modified by architect Aleksandras Aronas) that was decorated with public art (Figs. 4.8 and 4.9).

When Žirmūnai was nominated for the USSR State Prize in 1968, the award committee noted that the planning of the site was not exceptional. However, they singled out the improvement in designs of standard five-storey houses: 'The site's value stems from a successful implementation of mass housing using a creative approach' (USSR State Prizes, April 1968, RGALI, f. 2916, op. 2, d. 396, p. 167). The committee expressed their belief that the development of the standardised building series would benefit mass housing throughout the country (particularly if the director of the panel factory was involved). Accordingly, a proposal was made to make awards to the structural engineer and the producer of panel housesarchitect Bronius Krūminis and structural engineer Vaclovas Zubrus, representing the developers of the standard I-464 series, and Šmuelis Liubeckis, the director of the Vilnius Factory of Panel Construction - in addition to Kasperavičienè, the planner. It was explicitly stated that Žirmūnai served as proof 'that industrial housing can be diverse: it can have its own character and it can avoid becoming a

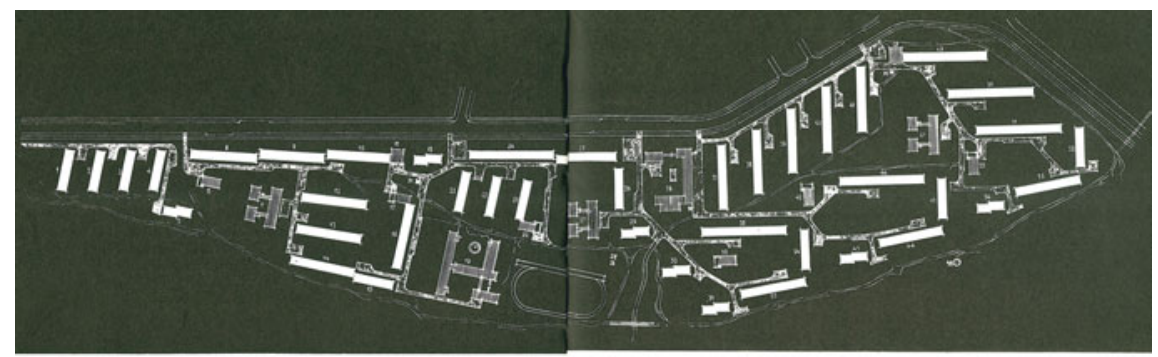

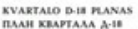
miN of CIT noox D.18.

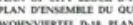

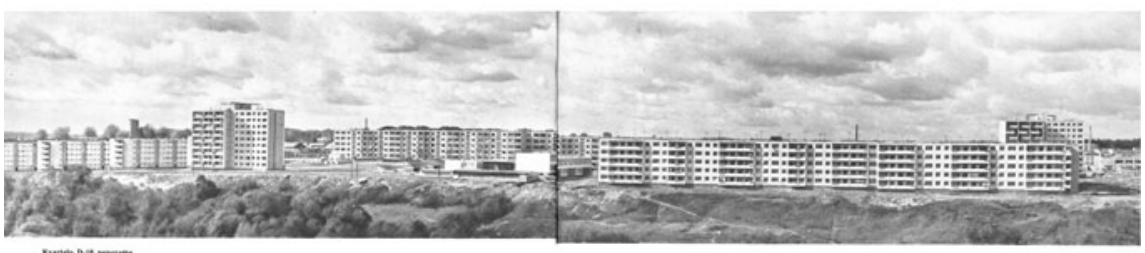

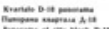

-

Figs. 4.8, 4.9 Plan and view of D-18 microrayon of the Žirmūnai residential area, 1964. Source Žiburkus (1969), unpaginated 
[nationwide] cliché' (USSR State Prizes for the year 1968, October, RGALI, f. 2916, op. 2, d. 397, p. 15).

After Žirmūnai, almost all new industrial cities and significant new mass housing residential areas were awarded the USSR State Prize: Navoii (new industrial town, 1969), Togliatti (new industrial town, 1973), Zelenograd (new architectural complexes, 1975), Shevchenko (new industrial town, 1977), Troparevo (residential area in Moscow, 1980), Pobeda (residential area in Dnepropetrovsk, 1983), VäikeÕismäe (residential area in Tallinn, Estonian SSR, 1986), and residential areas of Eastern Minsk (Belarussian SSR, 1989). It was not until 1974, however, that the Lenin Prize, the Soviet Union's highest award, was conferred on a large mass housing estate. Lazdynai, a new suburb of Vilnius, was said to represent a qualitatively different modernist town planning concept in the Soviet space.

\subsubsection{Lazdynai}

Planning for Lazdynai, a large housing estate for 40,000 residents, grouped into four microrayons, started in 1962 (constructed in 1967-1973). Vytautas Brèdikis and Vytautas Čekanauskas were commissioned to design the estate. It was not a routine commission, although they already had experience with planning Burbiškès. But by 1962, these young architects were already promising in the field of custom design. They emphasised that they were not regular planners of large housing estates and were capable of presenting innovative ideas: 'We were naturally influenced by the aim of making it [Lazdynai] different—of making it better' (V. Brèdikis, interviewed by John V. Maciuika, 1992, p. 8). In later interviews (1992, 2006, 2011), they spoke about the considerable influence on their designs of Finnish (Tapiola), Swedish (Vällingby, Årsta) and modern French (Toulouse-Le Mirail) suburban projects. Both Brèdikis and Čekanauskas highlighted three features they considered most important in differentiating Lazdynai from other Soviet large housing estates (Fig. 4.10).

The first one was the naturally hilly and well-forested site-features that would be preserved in the final landscape design. This was closely connected to the second component - improvements to the I-464 series five- and nine-storey buildings (with Bronius Krūminis, see above), by adding twelve-storey towers. The architects advocated the placement of five- and nine-storey housing blocks perpendicularly across the sloping terrain to create a unique silhouette for the new community: 'We wanted to draw up a special design for each of the buildings, but it was not possible then-we could not build two-storey cottages, for example. Of course, we modified the standard series here, in Lithuania, but the rules and norms were from Moscow' (V. Bredikis, interviewed by John V. Maciuika, 1992, p. 15). Čekanauskas believed that for Lithuania, it was a great opportunity to design its own housing series I-464-LI: 'Who else in the Soviet Union could design their own series except Moscow and Leningrad?' (V. E. Čekanauskas, interviewed by John V. Maciuika, 1992, p. 15). Though the production of these new types of building was a challenge 


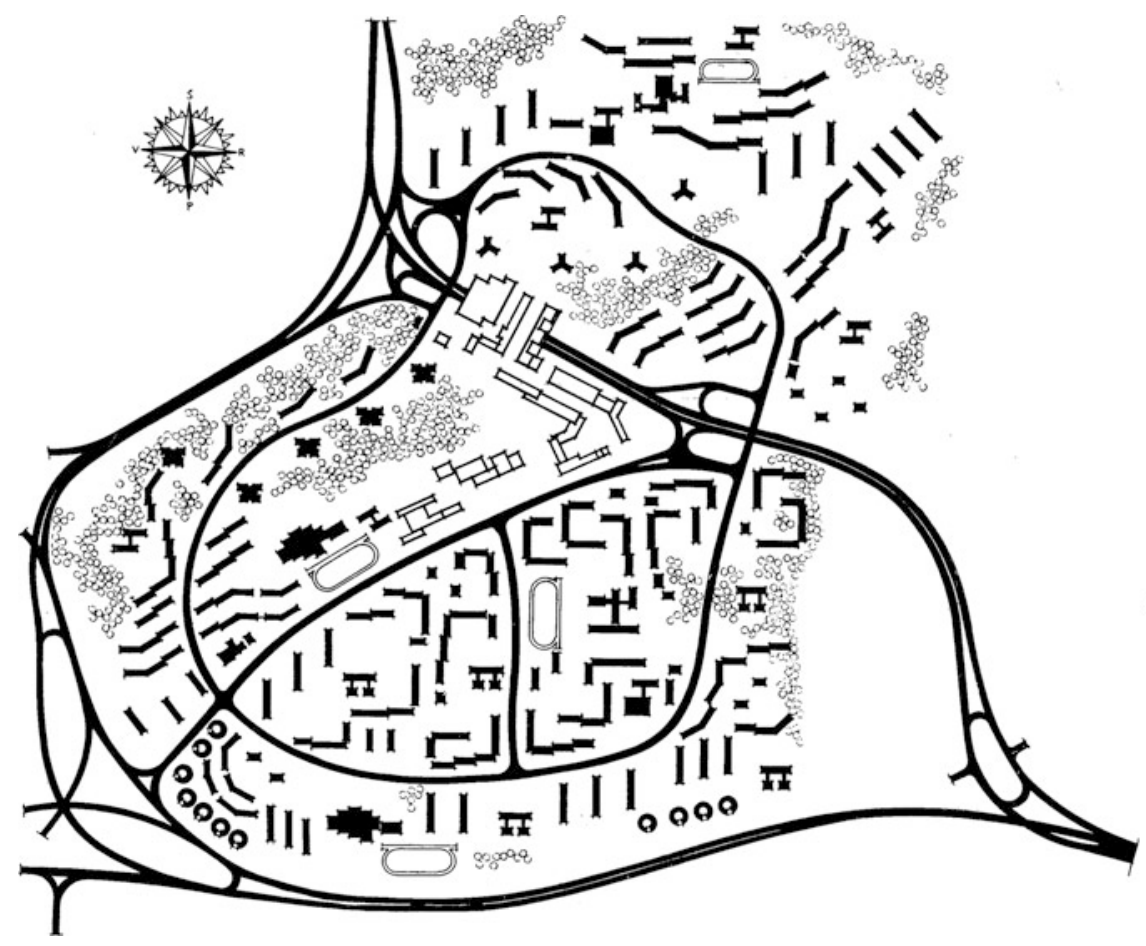

Fig. 4.10 Master plan for Lazdynai, 1967. Source Balčiūnas (1983), p. 3

for the Vilnius Panel Construction Factory, the architects believed that institutional nationalism (strong personal connections between architects and local Communist Party and municipal leaders) played a role when the need arose to defend the innovative designs at Gosstroi: 'we managed to persuade the producers' (V. Brèdikis, interviewed by John V. Maciuika, 1992, p. 8) (Figs. 4.11, 4.12 and 4.13).

Although planners were committed to adapting the standard design in public buildings, the centres of the three microrayons were each given a unique layout complete with public art. After two standard schools were constructed, young architect Česlovas Mazūras introduced an original terraced approach (while still using prefabricated components) that incorporated the sloping terrain and used different materials (red brick in combination with concrete panels).

The third component, highlighted by Čekanauskas, was the integrated construction of the environment, infrastructure and landscape design. He was impressed by the landscape design of the new Swedish housing suburbs (from books, since he did not visit Sweden) and stated that the low density of houses, together with the landscape design, made Lazdynai different to Russian large housing estates where incorporation of these features was never completed. He also often used the phrase 'good taste' in his interviews (1992, 2006) (Figs. 4.14, 4.15 and 4.16). 

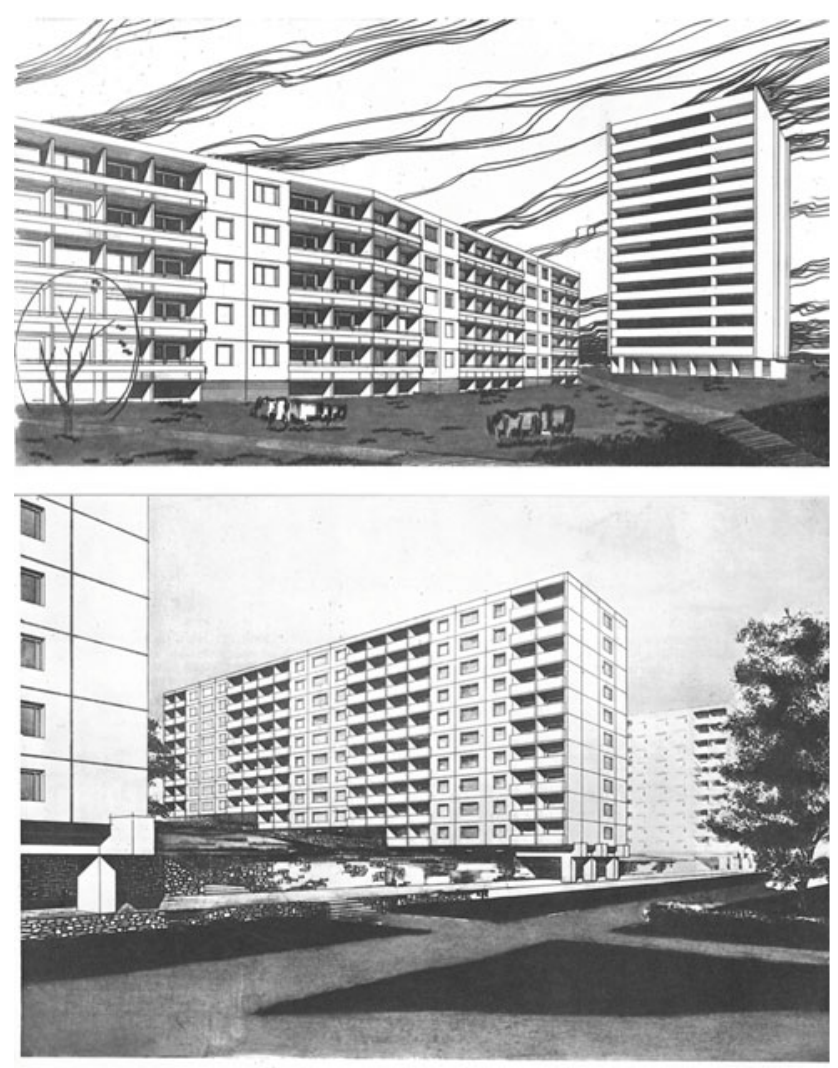

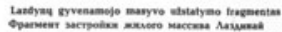

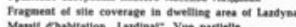

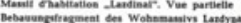

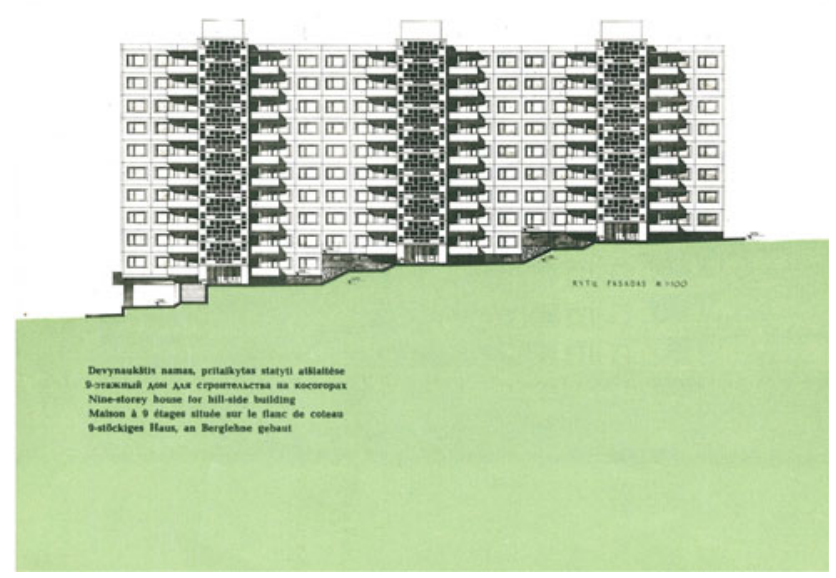

Figs. 4.11, 4.12, 4.13 Improved five- and nine-storey panel building series I-464-LI. Source Žiburkus (1969), unpaginated 
Figs. 4.14, 4.15, 4.16 Views of Lazdynai in the 1980s.

Source P. Petkevičius,

Balčiūnas (1983), p. 6, 10, 14
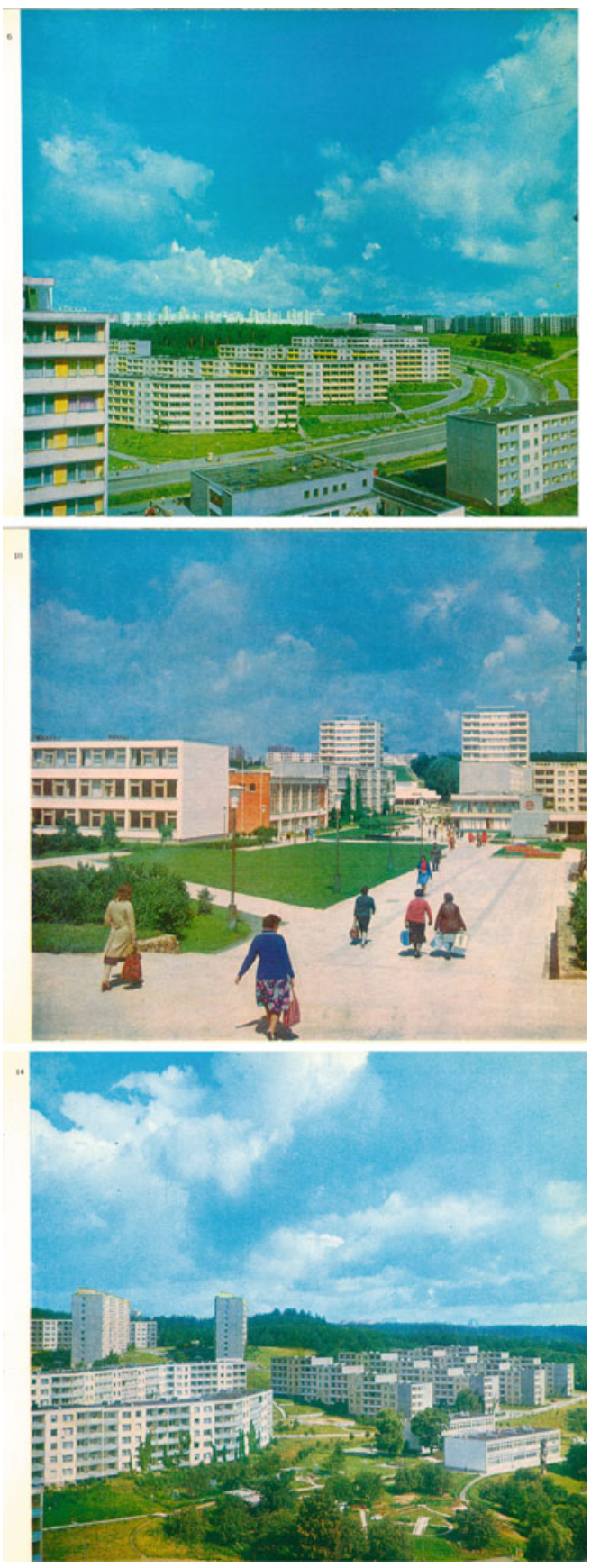
The nomination of Lazdynai for the Lenin Prize in 1974 proceeded smoothly at the Architectural Section and at the Plenary (Lenin Prizes for 1974, April, RGALI, f. 2916, op. 2, d. 751, c. 28-29), since the uniqueness of the site was confirmed by Gosstroi and the Architectural Section members' visit to Lazdynai (including a helicopter tour) (Lenin Prizes for 1974, February, RGALI, f. 2916, op. 2, d. 781, c. 30; Lenin Prizes for 1974, April, RGALI, f. 2916, op. 2, d. 750). Even the large number of individuals nominated to receive the award - six in total, since several officials, such as the Senior Architect of Vilnius city and the head of the construction unit, were also included - provoked little in the way of discussion. Thus, Lazdynai became the first mass housing urban design to be recognised with the most prestigious Soviet national prize. Clearly, the district's design had been overseen by two very talented architects, with many other specialists (nearly 150) contributing to the details. Politically, Lazdynai was used to demonstrate that panel construction is still valid - and does not require major changes — only a touch of 'landscape design'.

\subsubsection{Väike-Õismäe}

The Väike-Õismäe district in Tallinn, Estonia was designed between 1968 and 1969 and built from 1971 to 1975 (architects Mart Port and Malle Meelak) for 45,000 residents. It had already received attention during the process of its design; it was widely featured in the press as a forward-looking design and was even presented as a Soviet achievement in residential planning in the well-known special issue of an international architectural journal dedicated to Soviet architecture (L'Architecture d'au jourd'hui, 1970, pp. 60-61). It was then regarded as a fantasy come true-a Modernist utopian urban space with a geometric plan that could only be perceived from high above (Väljas and Lige 2015, p. 169). Its novelty was perceptible in the new type of planning - the architects refused the traditional division of the area into three microrayons and organised the entire residential area around the central pond, following the idea of a circular town. The green belt around the central pond was reserved for pedestrian and cycle traffic, schools and child care centres. The main road encircling Väike-Õismäe was for public transport and vehicle traffic. The inner circle of the street was planned as quadrangular blocks of nine-storey apartment houses. Sixteen-storey tower blocks were located adjacent to the bus stop and low-rise local supermarkets with customer service buildings. The outer circle of the main street consisted of five-storey apartment houses (Lankots 2010, p. 44). VäikeÕismäe was the only fully completed large housing estate of the three large housing areas that were built in Tallinn from the 1960s to the 1990s. It was also well known for its experimental character. However, it only received the State Prize in 1986 (the area was completed in 1984), when all its novelty was already dated and its shortcomings had become apparent, such as the difficulty for residents in orientating themselves and monotony of houses. 
The three large housing estates which received awards well reflect novelties and experimentation in planning ideology of the period in which they were built. Žirmūnai can be viewed as an ideological representation of creative approach to planning in large housing district, which should have encouraged other planners and builders to experiment. Lazdynai and Väike-Õismäe can be seen as real visions, involving a lot of effort from well-known architects, with the aim of creating an architecturally distinctive housing area.

\subsection{Conclusion}

The recognition that Baltic urban planners received in the late Soviet period can be viewed in two ways. Though a considerable role was played here by the 'good reputation' earned by the designs of Žirmūnai and Lazdynai, Baltic approaches to microrayon design in general were notable within the general Soviet context for their architectural originality. First and foremost, these districts were small in size and constructed in suburbs well chosen for their natural characteristics with the attempt to give each new neighbourhood a sense of uniqueness, drive improvements in industrialised housing construction and assembly as well as environmental clean-up projects. It could be said that these efforts became the defining characteristics of Baltic residential urban planning. With one eye on the West, Baltic architects, planners and engineers tried to bring a certain level of dignity to otherwise standardised Soviet large housing estates.

It is evident that Baltic architects sought to avoid standardised designs, which immediately devalued any creative aspect of the planning process. Standard designs quickly became obsolete, both technically and morally. For all practical purposes, their designers remained unknown to the public at large. It is also evident that, although architects in many Soviet Republics began to shun mass construction projects and conceded the initiative to engineers, the design of mass housing in Lithuania and Estonia was always overseen by professional architects. Despite standardisation and the very limited choice of materials and building types, there were attempts to improve the living environment of mass-produced architecture. Such efforts were made easier by the existence of professional relationships developed between designers, the Communist Party and local administration officials, and the heads of construction material enterprises. Nevertheless, a stagnant bureaucracy and construction industry ensured that most experimental projects remained in the desk drawers and archives of planning institutions, even as clusters of mass-constructed apartment buildings encircled most Baltic cities and towns.

Acknowledgements This research was funded by grant no. S-MOD-17-21 from the Research Council of Lithuania. The author also expresses appreciation to the Juozas Sidas Foundation at Vilnius University, Faculty of History. 


\section{References}

Anderson R (2015) Russia. Reaktion books, London

Balčiūnas V (1983) Lazdynai. Mokslas, Vilnius

Barkhin M (1968) Смотр достижений советской архитектуры [Review of Soviet architectural achievements]. Архитектура СССР 1968(1):5-20

Budreika E (1971) Architektura Sovetskoi Litvy (Architecture of Soviet Lithuania). Stroiizdat, Leningrad (in Russian)

Caldenby C, Wedebrunn PO (eds) (2010) Living and dying in urban modernity. Royal Danish Academy of Fine Arts, School of Architecture, Copenhagen

Caldenby C, Wedebrunn PO (eds) (2013) Survival of modern. From cultural centres to planned suburbs. Royal Danish Academy of Fine Arts, School of Architecture, Copenhagen

Cinis A (2007) Signs of modernism in the architecture of Soviet Latvia between 1960-1980. In: Kervanto-Nevanlinna A (ed) Industry and modernism. Companies, architecture, and identity in the nordic and Baltic Countries during the high-industrial period. Studia Fennica Historica 14, Finnish Literature Society, Helsinki, pp 172-183

Crowley D (2009) Socmodernism and the architecture of leisure in Eastern/Central Europe in the 1960s and 1970s. In: Helme S (ed) Different modernisms, different avant-gardes: problems in Central and Eastern European Art after World War II. Proceedings of the Art Museum of Estonia, Tallinn, pp 246-258

Drèmaite M (2010) The (Post-)Soviet built environment: soviet-western relations in the industrialised mass housing and its reflections in Soviet Lithuania. Lith Hist Stud 15:11-26

Drèmaitė M (2017) Baltic modernism. Architecture and housing in Soviet Lithuania. Dom Publishers, Berlin

Kalm M (2012a) An apartment with all the conveniences was no panacea: mass housing and the alternatives in the Soviet Period Tallinn. Arch Urban J Arch Town Plan Theory 47:189-202

Kalm M (2012b) Baltic modernisms. In: Ritter K, Shapiro-Obermair E, Steiner D, Wachter A (eds) Soviet modernism 1955-1991. Unknown history. Park Books, Zuerich, pp 33-45

Kalm M, Ruudi I (eds) (2005) Constructed happiness: domestic environment in the Cold War Era, (2005). Estonian Academy of Arts, Tallinn

Kosenkova YL (2013) Представления о целостном организме города в период изменения творческой направленности советской архитектуры. In: Kazakova OV (ed) Эстетика оттепели: новое в архитектуре, искусстве, культуре. Российская политическая энциклопедия (РОССПЭН), Москва, pp 15-76

Krastinš̌ J (2013) Āgenskalna Priedes a late 1950s Housing project in Riga: surviving pine trees in the city. In: Caldenby C, Wedebrunn PO (eds) Survival of modern. From cultural centres to planned suburbs. Royal Danish Academy of Fine Arts, School of Architecture, Copenhagen, pp 92-101

Krastinš J, Strautmanis I, Buka O, Asaris G (1987) Architektura Sovetskoi Latvii (Architecture of Soviet Latvia). Stroiizdat, Moskva (In Russian)

Kurg A (2009) Architects of the Tallinn School and the critique of Soviet Modernism in Estonia. J Arch 1:85-108

Lankots E (2010) Väike-Õismäe. In: Caldenby C, Wedebrunn PO (eds) Living and dying in urban modernity. Royal Danish Academy of Fine Arts, School of Architecture, Copenhagen, pp 4446

Maciuika JV (1999) East block, west view: architecture and lithuanian national identity. Tradit Dwell Settlements Rev XI(1):23-35

Mačiulis A (2007) Architektai Algimantas ir Vytautas Nasvyčiai [Architects Algimantas and Vytautas Nasvytis]. Vilniaus dailès akademijos leidykla, Vilnius

Metspalu P, Hess DB (2018) Revisiting the role of architects in planning large-scale housing in the USSR: the birth of socialist residential districts in Tallinn, Estonia, 1957-1979. Plan Perspect 33(3):335-361. https://doi.org/10.1080/02665433.2017.1348974 
Meuser P (2016) Seismic modernism. Architecture and housing in Soviet Tashkent. DOM Publishers, Berlin

Meuser P, Zadorin D (2015) Towards a typology of Soviet mass housing. Prefabrication in the USSR 1955-1991. Dom Publishers, Berlin

Minkevičius J (1964) Miestai vakar, šiandien, rytoj (Cities of yesterday, today, and tomorrow). Valstybinè politinès ir mokslinès literatūros leidykla, Vilnius

Minkevičius J (1987) Architektura Sovetskoi Litvy (Architecture of Soviet Lithuania). Stroiizdat, Moskva (in Russian)

Ojari T (2004) Elamispind. Modernistlik elamuehitusideoloogia ja Mustamäe [Floor space. The modernist residential housing ideology and Mustamäe]. Kunstiteaduslikke Uurimusi/Stud Art Arch 13(2):42-70

Osnovy sovetskogo gradostroitelstva Tom 2 [Principles of town planning in the Soviet Union Vol. 2] (1967) Stroiizdat, Moscow

Peras J (1958) Daugiabutis gyvenamas namas (Multi-apartment house). Valstybinè politinès ir mokslinès literatūros leidykla, Vilnius

Ritter K, Shapiro-Obermair E, Steiner D, Wachter A (eds) (2012) Soviet modernism 1955-1991. Unknown history. Park Books, Zuerich

Ruble BA (1993) From khrushcheby to korobki. In: Brumfield WC, Ruble BA (eds) Russian housing in the modern age: design and social history. Cambridge University Press, Cambridge, pp 232-270

Väljas M, Lige CD (2015) Elav Ruum: sajand Eesti arhitektuuri/Space in motion: a century of Estonian Architecture. Museum of Estonian Architecture, Tallinn

Volkov L (1987) Architektura Sovetskoi Estonii (Architecture of Soviet Estonia). Stroiizdat, Moskva (in Russian)

Volkov L, Kruusimagi Y (1972) Architektura Sovetskoi Estonii (Architecture of Soviet Estonia). Stroiizdat, Moskva (in Russian)

Zakamennijs O (1966) Laikmetiga arhitektura padomju Latvija (Contemporary Architecture of Soviet Latvia). Liesma, Riga (parallel text in Latvian and Russian)

Žiburkus J (ed) (1969) Vilniaus namų statybos kombinatas (Vilnius house building factory). (1969). Ministry of Construction of the Lithuanian SSR, Vilnius

Open Access This chapter is licensed under the terms of the Creative Commons Attribution 4.0 International License (http://creativecommons.org/licenses/by/4.0/), which permits use, sharing, adaptation, distribution and reproduction in any medium or format, as long as you give appropriate credit to the original author(s) and the source, provide a link to the Creative Commons license and indicate if changes were made.

The images or other third party material in this chapter are included in the chapter's Creative Commons license, unless indicated otherwise in a credit line to the material. If material is not included in the chapter's Creative Commons license and your intended use is not permitted by statutory regulation or exceeds the permitted use, you will need to obtain permission directly from the copyright holder. 


\title{
Chapter 5 \\ Baltic Crossings: Soviet Housing Estates and Dreams of Forest-Suburbs
}

\author{
Laura Berger, Sampo Ruoppila and Kristo Vesikansa
}

\begin{abstract}
Finland and Estonia had unusually close connections for a Western and a Soviet state following the Khrushchëv Thaw. This chapter addresses the question of how Finnish architecture and planning influenced the development of multifamily housing, including large housing estates, in Soviet Estonia. The chapter shows how information on architecture and planning was exchanged through travel, professional publications, architecture exhibitions and personal contacts. However, inspiration drawn from Finnish examples could influence Soviet Estonian multifamily housing only selectively. The influences, which mainly refer to Finnish modernism from the 1950s and the 1960s, can be identified solely in individually designed and constructed housing projects, which offered more flexibility and room for individual architects to express their visions. Such projects could be developed, for instance, by collective farm construction companies (KEK), not as large state-led projects. Soviet planners borrowed, in many ways, planning ideas from the West, for example, the principle of the mikrorayon, which was applied in the large housing estates. To Estonians, it was particularly the Finnish concept of the 'forest-suburb' that came to be idealised. The development of large housing estates was nonetheless dictated by the Soviet state bureaucracy and extensive use of mass construction technology, especially standardised precast buildings, created a monotonous built environment. Yet some Finnish influence can be recognised in Tallinn's first large housing estate's shopping and service centres, designed and built as separate projects.
\end{abstract}

Keywords Architectural influences - Modernism - Multifamily housing • Finland · Estonia - Soviet Union

\footnotetext{
L. Berger $(\bowtie) \cdot$ K. Vesikansa

Department of Architecture, Aalto University, Helsinki, Finland

e-mail: laura.berger@aalto.fi

K. Vesikansa

e-mail: kristo.vesikansa@ aalto.fi

S. Ruoppila

Department of Social Research, University of Turku, Turku, Finland

e-mail: sampo.ruoppila@utu.fi

(C) The Author(s) 2019

D. B. Hess and T. Tammaru (eds.), Housing Estates in the Baltic Countries,

The Urban Book Series, https://doi.org/10.1007/978-3-030-23392-1_5
} 


\subsection{Introduction}

This chapter addresses the question of how Finnish architecture and planning influenced multifamily housing, including housing estates, in Soviet Estonia. The relationship between the two countries could be described as a 'hinge-point' of architectural influences between a 'Western' and a 'socialist' country during the Soviet era (see Kalm 2002a; Hallas-Murula 2006; Metspalu and Hess 2018). The connection can be partly explained by close cultural and linguistic ties and partly by Finland's ambiguous political status in between Western powers and the Soviet Union. Finnish architecture had influence in Estonia since nation building strengthened in both countries at the turn of the twentieth century. At the time, many known Finnish architects, such as Eliel Saarinen and Armas Lindgren, designed notable buildings in Estonia, and Saarinen won the competition for Tallinn's first general plan in 1913. During the interwar period, international modernism, referred to as functionalism in Finland and Estonia, was popular and played a significant role in developing architectural identity in both countries. World War II interrupted the architectural exchange. Unlike the Baltic states, Finland retained its independence after the war, but was obliged to sign the Agreement of Friendship, Cooperation and Mutual Assistance with the Soviet Union, lasting from 1948 to 1992 . For Finns, the collaborative policy of friendship was a distinct strategy to solve challenging security problems: to accommodate the interests of a big and sometimes threatening neighbour to a certain extent, in order to maintain peace and remain sovereign (Forsberg and Pesu 2016). One consequence of this collaborative policy of friendship was that Finland represented a less antagonistic, nearby territory for the Soviet Union. For Estonians, it provided an important corridor of interaction and exchange with a 'Western' country, even though under restrictive surveillance by the Soviet Union.

To answer our main question on Finnish influences on modernist multifamily housing in Soviet Estonia, we outline three sub-themes: the transfer of architectural and planning information; the special interests of Estonians; and the Finnish influence on the development of multifamily housing in Soviet Estonia. We begin by setting the international context and conclude by discussing the limited space of architectural expression in Soviet Estonia, including what it meant for developing housing estates.

This chapter draws on various types of literatures, such as histories of architecture, planning and construction technology in the Soviet Union, Finland and Soviet Estonia. It brings together topics that have tended to remain separately discussed (e.g. Ritter et al. 2012; Ward 2012; Meuser and Zadorin 2015), regardless of the inherent relatedness, concerning mass housing in particular. Our reading has benefitted greatly from Estonian studies on architectural and planning history (Kalm 2002a; Ojari 2000, 2004a; Hallas-Murula 2006). We have also used selected first-hand materials such as the Finnish Architectural Review, the Estonian Ehitus ja arhitektuur and epoch exhibition catalogues from the Museum of Finnish Architecture (MFA). In addition to the literary sources, we interviewed two Finnish 
architects, Juhani Pallasmaa (born 1936) and Markku Komonen (born 1945), who were among the focal persons networking with Soviet Estonian architects. From Estonia, we consulted the architectural historians Mart Kalm (born 1961) and Triin Ojari (born 1974).

\subsection{Addressing Persistent Housing Demand}

The lack of sufficient and adequate housing was a persistent problem in industrialising and urbanising Europe since the second half of the nineteenth century. While large-scale social housing construction had begun in certain large cities, such as Berlin, Vienna and Amsterdam, after World War I, the housing shortage remained an extensive problem. The situation was worsened by the destruction of World War II. The collapse in construction and residential overcrowding further deepened with the post-war 'baby boom'. Consequently, by the 1950s, meeting housing needs and improving dwelling conditions was high on governmental agendas throughout Europe (Wassenberg et al. 2004; Hall et al. 2006).

In the search for models of healthy urban and housing environments, a particularly influential planning concept was the 'Garden City' (1898), coined by Ebenezer Howard, proposing new developments outside the overcrowded cities. In practice, this and other similar ideas led to increasing development of garden suburbs. Nonetheless, it was the interwar period's radical modernist ideas, debated by the influential members of the Congrès Internationaux d'Architecture Moderne (CIAM), that provided longstanding concepts of what a future city would look like (e.g. Mumford 2000). The free-standing high-rise blocks and strictly delineated separation of land uses (dwelling, work, recreation and transportation) were however implemented on a large scale only after World War II (Wassenberg et al. 2004; Hall et al. 2006). Another influential concept was 'the neighbourhood unit', a residential development area with designated services. This was first introduced by the American planner Clarence Perry in 1929 and spread widely after its adoption in the seminal County of London Plan by Forshaw and Abercrombie in 1943 (e.g. Hurme 1991, 19-39). Last but not least, the development of new construction materials, prefabrication and standardisation played a significant role in the introduction of a novel urban morphology all around Europe (e.g. Hankonen 1994; Meuser and Zadorin 2015).

There were, however, notable differences in how quickly different countries began to implement new ideas. Many West European countries embarked on estate-based housing programmes immediately after World War II, whereas the Eastern Bloc and especially the Soviet Union delayed housing investments further, due to priority being given to industrial development (Hall et al. 2006, 66). This difference can be illustrated by comparing the capitals of Soviet Estonia and Finland. In Tallinn, state-led construction focussed only on the redevelopment of the most badly damaged part of the city centre, one workers' housing district (Pelgurand) and some smaller areas of workers' housing near the heavy industries 
(Ruoppila 2004). Self-construction of single-family houses was also allowed. In Helsinki, in addition to reconstruction following war damage, and distributing lots for the construction of single-family houses, the municipality had initiated the development of several new multifamily housing areas, following the law on state-subsidised housing loans (ARAVA) in 1949. These areas include Ruskeasuo, Maunula, Herttoniemi and parts of Käpylä, all reflecting the Swedish influence on Finnish architecture and planning, regarding the building types, their positioning in the landscape and the overall appearance of the buildings (Hannula and Salonen 2007, 28-31). This touches on the dissemination of architectural influences from the West. Finns followed developments in Swedish architecture and planning closely, and many Finnish architects had been working in Sweden during and after World War II. Swedish planners had adopted the rapidly spreading concept of neighbourhood units from Great Britain and the USA. The early Swedish examples of post-World War II housing developments are the Årsta district in Stockholm (1943-53) and Norra Guldheden in Gothenburg (1944-47) (Hurme 1991, 55-63).

\subsection{From Mikrorayons to Grand Ensembles to Paper Architecture}

The death of Stalin in March 1953 and his replacement by Nikita Khrushchëv brought a major change in urban, social and cultural development in the Soviet Union. The improvement of living standards was raised as a main goal after severe neglect throughout the Stalin years. Increasing the housing supply was a pressing concern, followed by the need to improve production technology and urban planning.

The turning point in Soviet city building was Khrushchëv's almost 2-h-long address titled 'On the wide-scale introduction of industrial method: improving the quality and reducing the cost of construction' given at the All-Union Building Industry Conference in December 1954. Forty $(2012,151)$ describes how a young architect, Georgei Gradov, had daringly written a 100-page letter to Khrushchëv, informing him of the shortcomings of the Soviet construction industry. Consequently, 'on no other occasion has a head of a state delivered such a lengthy and informed speech about concrete', writes Forty (ibid.). Khrushchëv criticised the appreciation of form over function, namely spending state funds on the 'architectural excess' of the decorative Stalinist style. However, he also criticised the constructivist architects of the 1920s and 1930s for prioritising architecture and design. Instead, stated Khrushchëv, mass production, standardisation and new technologies were to set the new guidelines for all construction (Anderson 2015, 216).

Khrushchëv saw an opportunity to learn about and selectively apply Western innovations to improve living standards in the Soviet Union. In housing and planning matters, this meant a growing interest in mainly French mass-production technology, as well as Swedish, Finnish and British planning ideas (Ward 2012, 510). As part of catching up, professional study trips were organised from and to 
the Soviet Union. Soviet planning professionals made a first visit to Britain in 1955 , followed by several return visits, culminating in a tour that the Soviet Union organised for British visitors in 1960 (Ward 2012, 512). Architecture and planning literature was also actively translated into Russian, and Soviet magazines like Arhitektura SSSR introduced projects from foreign countries, including France, Czechoslovakia, Poland, UK and the Nordic countries (Caldenby and Wolodarski 1973, 34-35). Regarding industrial building methods, the Soviet Union commissioned the French firm Raymond Camus et Cie to develop precast concrete factories in Tashkent and Baku in 1958, making the Camus panels available in the USSR (Meuser and Zadorin 2015, 114; Anderson 2015, 221). According to Anderson $(2015,220)$, the organised spreading of Western planning ideas and the adoption of novel technologies enabled the Soviet Union to literally jump-start housing construction.

In 1957, the leadership of the Soviet Union made a remarkable political promise to end the housing shortage within a maximum of twelve years (Smith 2009, 26). Even though that bold promise would fail, by the end of Khrushchëv era, this 'first rank social reform, which gave Soviet citizens the right to expect better housing conditions within the foreseeable future, was well on the way' (ibid., 26). Moreover, in 1961 the communist party declared that by the end of the $1970 \mathrm{~s}$ 'every family, including the newlyweds, will have a comfortable apartment conforming to the requirements of hygiene and cultured living' (ibid., 28). Consequently, state funding for housing construction was increased, and construction further centralised, including a full-scale implementation of the industrialised building methods, such as precast panels. The first experimental mikrorayon (1956-59) had been constructed in Novye Cheremuski in Moscow, and this was chosen as the model unit to be copied all over the Soviet Union (Anderson 2015, 222).

Soviet city building had taken a new direction during the Khrushchëv era, but construction volumes were at a peak during the Brezhnev period (1964-82), transforming the built environment. Between 1960 and 1975, no less than two-thirds of the total population in the Soviet Union was allocated improved housing with district heating (Bater 1980, 97; Beyer 2012, 261). Under Brezhnev, a new generation of prefabricated systems was developed, and standardisation was taken further. Whereas the projects realised during the 1950s and 1960s had been based on type series, each with specific building components, between 1969 and 1972, the Moscow Scientific Research Institute of Experimental Design developed an 'open typification', which allowed building elements to be mass-produced as interchangeable sets of components. 'Open typification' enabled the construction of 9- to 25-storey buildings (Anderson 2015, 254). Such tower blocks, or 'grand ensembles', executed in Moscow and other large cities, were characteristic of the Brezhnev era. By 1991, industrialised housing comprised $75 \%$ of all Soviet housing stock (Meuser 2012, 274).

Mass housing in the Soviet Union was a task for the State, which determined the amount and location of new buildings. Official Design Institutes were responsible for the entire planning process and the State Building Concerns of the construction 
job. Consequently, architects working in the Design Institutes needed to comply largely with the standardised designs (Meuser and Zadorin 2015, 13). Nonetheless, architects had local influence in how the housing estates were shaped (Metspalu and Hess 2018). Moreover, different state agencies, including construction companies of collective farms, could also commission individually designed apartment buildings (Kalm 2012a, 198-201; Caldenby and Wolodarski 1973, 133-136). Architects working for the state were also allowed to do extra projects, typically private houses but occasionally also small apartment blocks (Kalm 2002a, 239, 2004; Metspalu and Hess 2018, 356).

Some architects also produced so-called paper tigers, projects categorically too artistic or whimsical to ever be realised. Towards the end of the Soviet period, this turned into an entire phenomenon referred to as 'paper architecture', as the discontented younger generation of architects took a rebellious stance in pushing the limits between art and architecture, rejecting functional demands, and embracing narrative and expression instead. Such a reflection of new pride in the profession has been considered to anticipate glasnost and perestroika within architecture (Klotz 1988, 7). The beginning of 'paper architecture' has been dated to 1981, when Mikhail Belov and Max Kharitonov, later well-known professionals, won the competition for an exhibition house sponsored by the periodical Japan Architect. 'Paper architecture' has since been described as 'sublimation of despair', an ultimate escape from the harsh realities dictated by the Soviet building industry (Anderson 2015, 286).

\subsection{Crossing the Baltic Sea}

With the Khrushchëv Thaw, the connections between Finland and Estonia were also gradually restored. The first Soviet Association of Architects (Sojuz Arhitektorow SSSR) study trip to Finland, with 14 Estonians among the group, was made in 1957. Estonian architects subsequently visited Finland almost annually (Hallas-Murula 2006, 127). An excursion report published in the Estonian periodical Ehitus ja arhitektuur (Construction and architecture) lists a wide range of contemporary buildings, such as offices, hospitals, university buildings, hotels and various kinds of housing, visited by Estonian architects (Mirov 1965). In addition, some excursions concentrated on specific topics, such as hospitals (Luts and Avarsoo 1967). Ehitus ja arhitektuur reveals that building engineers likewise built relationships and became familiar with contemporary developments in Finland (e.g. Jürisoo and Malmet 1966). According to Mart Kalm, during the Soviet years, architects were required to note international travels in their official curriculum vitae. Based on this information, Kalm has calculated that as many as half of the members of the Estonian Architects' Union visited Finland during the 1960s (Kalm interview).

In addition to travel, architecture periodicals were an important source of information. The Finnish Architectural Review (Arkkitehti) was ordered for the 
Estonian Academy of Sciences library in 1958, and the Swedish Architectural Review (Arkitektur) the following year (Kalm 2002b, 66). Importantly, periodicals provided information and images from the very latest projects. As Finnish modern architecture was highly regarded at the time the connections were re-established, Estonian architects were also able to learn about Finnish architecture from international publications. According to Kalm (2002a, 414), the projects presented especially in Finnish and Danish architecture periodicals played an important role as idealised educational material at the Estonian Academy of Arts, which was the only school of architecture in Soviet Estonia, until the end of the 1970s.

Two Finnish housing estates stand out among those most documented in publications during this era. These are Tapiola (the first stage built 1952-56), which was an early realisation of the neighbourhood unit concept, and Pihlajamäki (195965), where prefabrication was first used on a large scale. It appears that Tapiola (see Fig. 5.1) and Pihlajamäki (see Fig. 5.2), the best-known examples of Finnish 'forest-suburbs', also remained the housing estates that Estonians visited most frequently, even decades after their completion.

Tapiola was developed as a model community in the rapidly growing Helsinki region. The development was initiated, unusually for the time, by large non-governmental organisations (Hurme 1991, 105). Its development was preceded by distribution of an influential anti-urban pamphlet Homes or barracks for our children by von Hertzen (1946), which presented the prevalent Swedish examples Norra Guldheden and Friluftsstaden, as well as American greenbelt cities, as ideals for new housing areas. Moreover, the planner of Tapiola, Otto-Iivari Meurman, had just published his influential book on detailed planning (1947), to be used for decades to come in teaching urban planning in Finland. Meurman's work combined ideas of garden cities, the neighbourhood principle and functional separation, all of which were implemented in Tapiola. Notably, the area pays homage to the Swedish and American exemplars: buildings and curving routes are positioned carefully in the landscape, and the high-quality architecture was realised synchronously with well-designed green areas. The buildings were designed by leading Finnish architects of the time, including Alvar Aalto, Aarne Ervi, Viljo Revell, and Kaija and Heikki Siren. The Tapiola civic centre, designed by Ervi, closely follows ideas promoted by the CIAM after World War II, such as the balance between commercial and public spaces (Lahti 2006, 119-129). The latest construction technology was also utilised: the experimental blocks of flats made of precast panels, designed by Ervi and Revell in 1953-54, were among the first in the country (Hytönen and Seppänen 2009, 36, 212).

The planning of the Pihlajamäki housing estate in northern Helsinki drew much on the ideals and experience of Tapiola, but the ideas of standardisation and prefabrication were developed further, and the architectural expression was more ascetic. The plan was drawn by Olli Kivinen, who had previously worked in Meurman's office. The City of Helsinki, which was the landowner, assigned the development to two construction companies, HAKA and SATO, of which, in particular, the latter used precast panels. In contrast to a variety of housing types in Tapiola, Pihlajamäki has essentially two types of residential buildings: long 

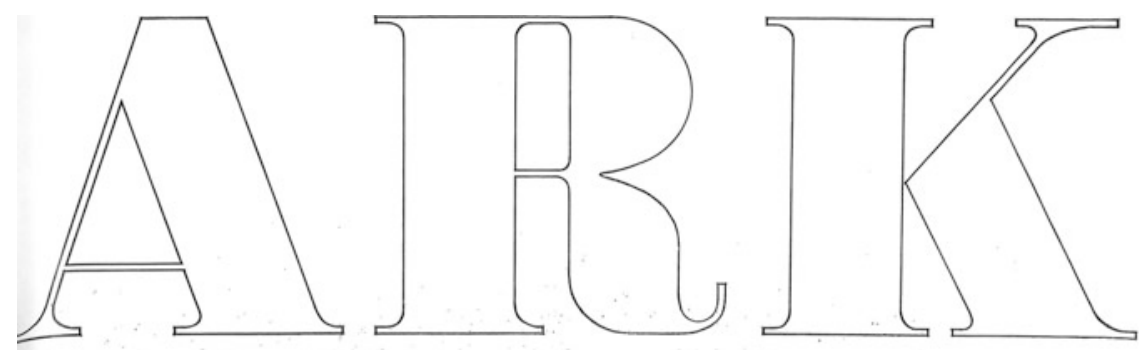

A R K K TEHTI ARKITEKTEN $12 / 1961$

TAPIOLAN KESKUSTA

HAGALUNDS CENTR

TAPIOLA CENTRE

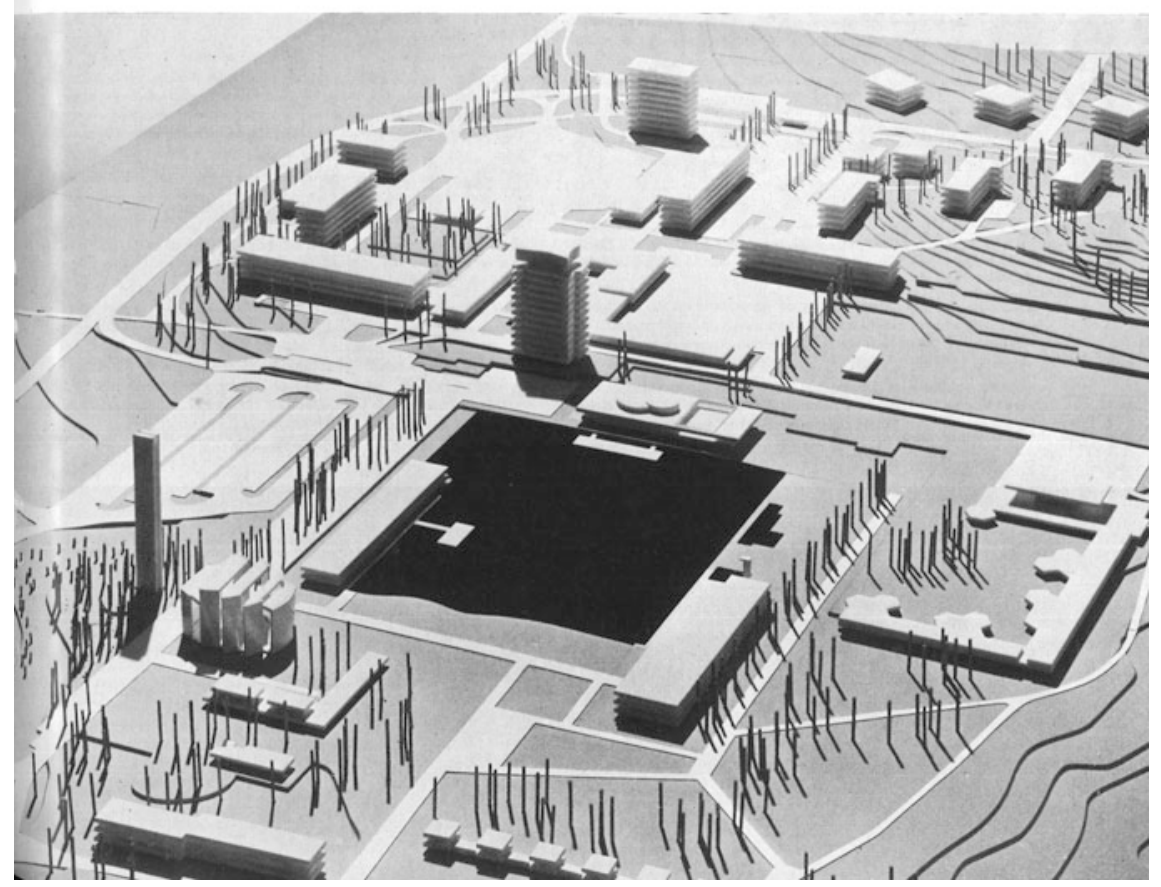

Fig. 5.1 Cover of the Finnish Architectural Review 12/1961 illustrating Tapiola Centre by Aarne Ervi. Source Finnish Architectural Review, used with permission

4-storey buildings following the landscape, and tall tower blocks located on the highest point of the hill. The commercial services are mainly located in the area's own shopping centre (Hurme 1991, 144-163).

As a single work, Tapiola was presumably the most influential piece of Finnish modernism for Estonian architects. Putatively, all Estonian architects travelling to Helsinki from the mid-1950s to the 1970s visited it (Hallas-Murula 2006, 140). 


\section{A R K K I T E II T I A R K I T E K T E N 10-11/1964}

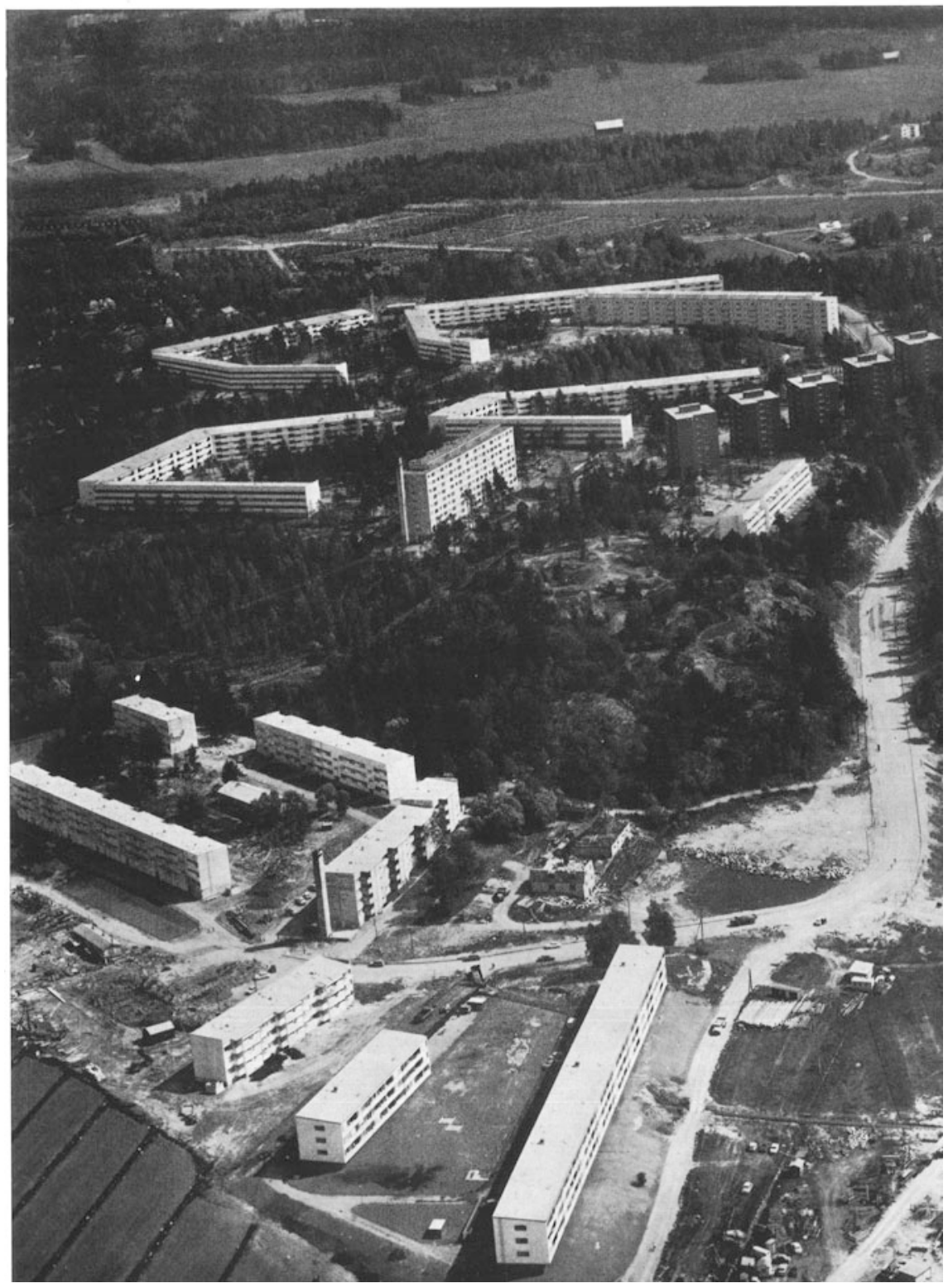

Fig. 5.2 Cover of the Finnish Architectural Review 10-11/1964 illustrating Pihlajamäki estate. Source Finnish Architectural review, used with permission 
In the published excursion reports, Tapiola was described very positively. For instance, Raul-Levroit Kivi (1960) emphasised the variety of building types, how they were freely positioned into the forest, and the relationship between grass fields, decorative plants, hedges, paved pathways, resting places and playgrounds. He also commented on the different types of finishes on the facades, the open balconies and rational kitchens. According to Kivi, characteristics of Finnish building culture were good taste, functionality and perhaps above all, the good quality of construction, which was something architects working in the Soviet Union could only dream about (Kivi 1960, cited in Hallas-Murula 2006, 140-141). Tallinn's chief architect, Dmitri Bruns, paid close attention to the planning; the deliberate contrast between the terraced houses and the towers, and how the streets followed the natural landscape, with no separate pavements (Bruns 1961, cited in Hallas-Murula 2006, 141). Both Hallas-Murula (ibid. 141-143) and Kalm (interview) refer to the connection with nature and the preservation of old trees between the buildings as something specific. This marks a difference in planning traditions between the countries. In Estonia, the idea of 'open planning', or positioning free-standing apartment blocks in an existing landscape, was first introduced in the architectural competition for Tallinn's Mustamäe district in 1958 (Ojari 2000, 55-59). In Finland, taking the landscape into account had been an integral part of planning since the 1930s. An interesting point is that Estonians seemed not to lose interest in Tapiola over time but continued to refer back to it when it was no longer considered topical in Finland. An example is Voldemar Herkel's (1967) article on Finnish single-family and terraced houses, referring mostly to buildings from Tapiola.

The Finnish Association of Architects made its first excursion to Tallinn in 1962. Three years later, a passenger ferry connection between Tallinn and Helsinki was restored, making Finnish visitors a common sight in central Tallinn. According to Ojari $(2004 b, 25)$, the writings and memories of the era illustrate the personal and warm-hearted relationships between Finnish and Estonian architects. ${ }^{1}$ The meetings depended mostly on Finns travelling to Tallinn, because Estonians needed to obtain permission to travel, which was politically controlled and often painstakingly difficult to get (e.g. Pedak 1999). In 1968 Väinö Tamm received a scholarship to study in Finland, and also worked at the office of Erkki and Kirsti Helamaa, reflecting a personal relationship transforming into a work opportunity (Hallas-Murula 2006, 130). This, however, remained a rare example, as the Soviet authorities did not allow close contacts to be established until the years of perestroika and glasnost.

When the Finns visited, they brought over not only much-valued professional journals, but also Finnish weekly magazines, books, and even pencils and sketching paper, which were scarce in Soviet Estonia, Pallasmaa noted in our interview.

\footnotetext{
${ }^{1}$ Among the key persons in keeping the contacts were on the Finnish side, Erkki Helamaa (19242014), Veijo Martikainen (born 1925), Kirmo Mikkola (1934-86), Juhani Pallasmaa (born 1936), and Markku Komonen (born 1945); and on the Estonian side, Edgar Johan Kuusik (1888-1974), Valve Pormeister (1922-2002), Mart Port (1922-2012), Tõnis Vint (born 1942), Leonhard Lapin (born 1947), and Vilen Künnapu (born 1948) (Lapin 1996, 134; Kalm 2002b, 67; Hallas-Murula 2006, 127; Komonen and Pallasmaa interviews).
} 
Most of all, he recalls smuggling art books. Whatever the material was, it was often hidden because of a risk of border control officials confiscating almost anything Western as suspicious (Lapin 1996, 98-100). At the time, foreign contacts were so valuable among Estonians that the Finnish architects likely did not understand that there might have been competition for friendships among their Estonian colleagues (Kalm interview).

Another significant method of passing the information was exhibitions, which typically presented canonised architectural examples, offering an idealised image. Furthermore, these, too, provided a legitimate reason to travel, in their part strengthening the collegial exchange. The first exchanged exhibitions, organised in 1960 and 1961, focused on applied arts and design (Kalm 2002b, 66). In 1966, an exhibition on the restoration of Tallinn's old town was held at the Museum of Finnish Architecture (MFA). As part of the occasion, 13 Estonian architects travelled to Finland and organised a follow-up seminar for students from both cities. The same year, representatives of the Finnish Association of Architects and its standardisation department travelled to Tallinn, bringing with them Finnish building standard catalogues. In 1968, an exhibition focusing on modern Finnish architecture was sent to Tallinn (Hallas-Murula 2006, 129).

The difference in the contents of the exhibitions and to whom they were directed is noteworthy. The exhibitions sent out by MFA aimed to present the best achievements of Finnish architecture, hence focusing on new buildings and individual architects, and often also circulated elsewhere in the Soviet Union, including Leningrad, Moscow and other Baltic republics (Čeferin 2006). In contrast, the architectural exhibitions brought from Soviet Estonia to Finland represented, for a long time, only traditional styles, and were exhibited only in Helsinki. ${ }^{2}$ It was, however, possible to introduce recent Estonian architecture as part of the wider Soviet context. When MFA and the Soviet Association of Architects organised an exhibition of the latest architecture in the Soviet Union (Neuvostoliiton nykyarkkitehtuuria 1973), two Estonian projects were included. These were a commercial centre (Peep Jänes 1963-70) and Tallinn Polytechnic Institute (Uno Tölpus, Henno Seppman and Olga Kontšajeva 1958-71), both located in Mustamäe. All in all, as a form of exchange, exhibitions are illustrative of how contacts between institutions created opportunities for travel, the transmission of professional materials, and the development of personal contacts.

The beginning of the 1980s marked, in many ways, a considerable change in the direction of interests. The new generation of Estonian architects had taken a critical stance with regard to the Soviet system, in particular mass housing, and post-war modernism overall. They also broke away from the ideals of the previous generation, including the tendency to look up to Finnish or Danish architecture (Kalm 2002a, 414). The group emphasised that architecture was art, and many became known as visual artists alongside their architectural profession. Instead of Finnish

\footnotetext{
${ }^{2}$ The lists of exhibitions held at the MFA and circulated internationally can be found at: http:// www.mfa.fi/vaihtuvat-nayttelyt and http://www.mfa.fi/kiertonayttelyt-ulkomailla.
} 
modernism, they drew inspiration from American postmodernism, the Soviet avant-garde of the 1920s, and the interwar Estonian functionalism and cultural heritage. These architects had been virtually excluded from the large state-led projects and had no interest in complying with those rules. However, many of them worked with the design bureau of the collective farms (EKE Projekt), which enabled architecturally more ambitious projects, such as a large cooperative housing complex in Pärnu (Toomas Rein 1972-87) (Kalm 2007, 360-367). The single-family houses had also become an increasingly popular alternative for mass housing since the 1970s (Ruoppila 2004), and therefore homeowners were only too happy to see ambitious designs (Kalm 2012b, 41).

Before the 1980s, the Finnish Architectural Review had not paid much attention to contemporary projects in Soviet Estonia, except for the Tallinn Song Festival Stage (1957-60), an immense suspended canopy (Kotli 1963). The international breakthrough for the new generation, however, received help from the Finns. They became known as the 'Tallinn School' (Kurg 2009), a name coined by Markku Komonen, the editor of the Finnish Architectural Review. In 1980, the periodical published Leonhard Lapin's seminal article presenting the new generation of Estonian architects (Lapin 1980). In 1983, the group organised the exhibition '10 architects from Tallinn', which Komonen imported to Finland the following year. This involved, among other things, Komonen smuggling the exhibition manuscript from Estonia to Finland, as he recalled in an interview. ${ }^{3}$ The exhibition (Komonen 1984) was displayed in Helsinki, Rovaniemi, Kotka, and Jyväskylä in 1984, followed by Riga (1985), Moscow (1986), Kiel (1989), Zurich (1990), and Stockholm (1990) (Hallas-Murula 2006, 178).

A novel tactic of escaping the dull Soviet reality that hampered the realisation of architectural expression was participating in international architectural competitions. To make this possible, the Finns visiting Tallinn were asked not only to import a variety of materials, but also to smuggle the drawings out of the country, and to send the competition entries from Finland. At times, the information reached the ears of the Soviet authorities if the Estonian entries received awards (Lapin 1996, 98-100). One example was the West Coast Gateway competition for a monument to immigrants in Los Angeles (1989). Juhani Pallasmaa was a member of the jury, and he remembers having been utterly dumbfounded upon realising who the architect behind the entry winning the second prize was: 'God damn it, that's Künnapu's work! I recognised it immediately. That was how Künnapu made his breakthrough'.

The Finnish Architectural Review published another two issues on Estonian architecture later in the 1980s (Arkkitehti 4-5/1987 and 7/1989). In addition, another famous competition entry for the Arctic Centre in Rovaniemi, Finland, by Vilen Künnapu, Ain Padrik, and Lennart Meri (then an ethnologist, later president) was published on the cover of the periodical (Arkkitehti 2-3/1984).

\footnotetext{
${ }^{3}$ One architect, Jüri Okas, left the group, and consequently, the name of the exhibition was 'Nine architects from Tallinn'.
} 


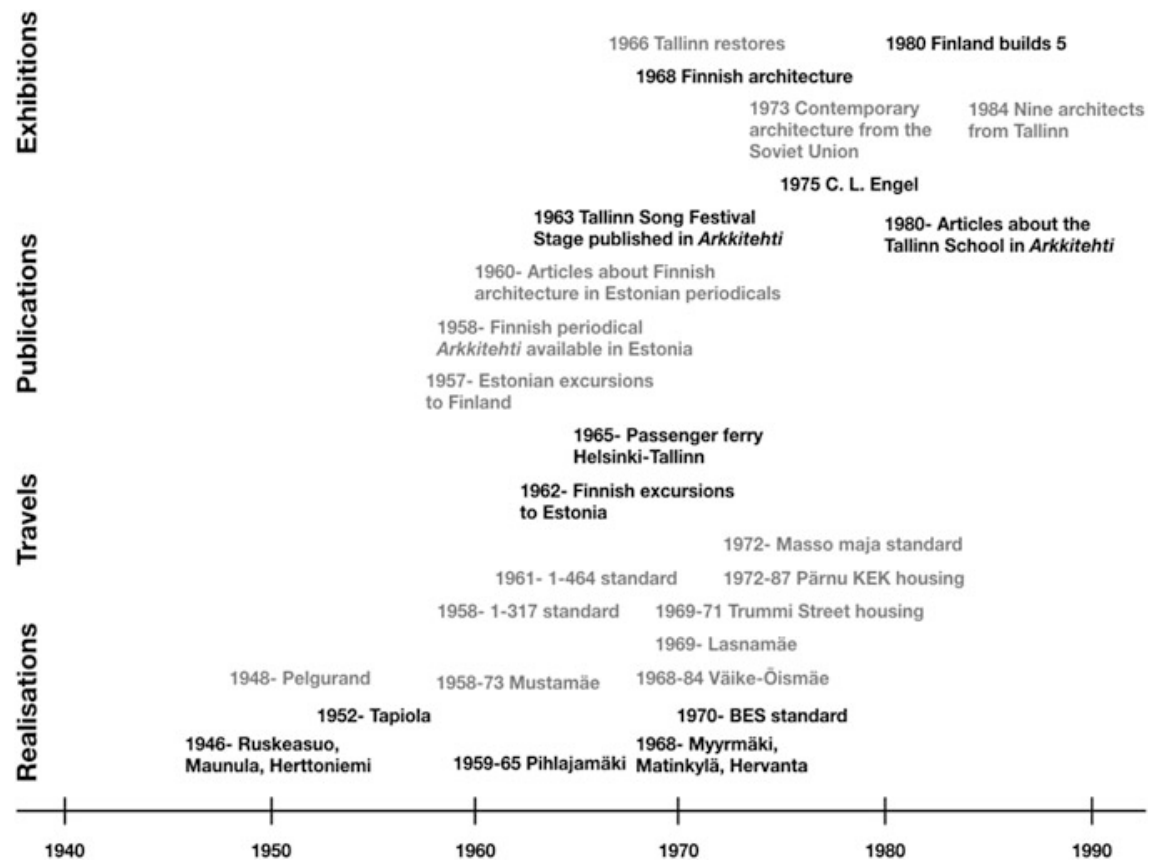

Fig. 5.3 Timeline illustrating architectural exchange and housing development in Finland and Soviet Estonia (Finnish contributions marked in black, Soviet Estonian in grey)

In the context of information exchange, Finnish television, which was increasingly watched in Northern Estonia from the 1960s onwards, is worth mentioning as an important uncensored window to the Western lifestyle and consumption (Høyer et al. 1993, 200), including the changing ideals of the built environment. Finland's role as the closest Western neighbour, the formation of friendships and its overall influence as a nearby reference point also went far beyond architects' circles.

A timeline connecting various points of architectural exchange and housing development in Finland and Estonia is presented in Fig. 5.3.

\subsection{Variations in Standardisation}

In developing multifamily housing, and especially housing estates, standardisation and industrial construction techniques played a crucial role. Nonetheless, due to the political and economic differences between the countries, the standards developed from different premises. In Finland, standardisation was actively promoted by real estate development and construction companies, but also by the Finnish Association of Architects. The state authorities also regarded this development as beneficial for the national economy. The first experimental prefabricated apartment 
blocks were realised in Tapiola in 1954. From the late 1950s, construction companies began to establish their own factories, making it possible to realise entire residential districts, for instance in Pihlajamäki. A next step was the introduction of an open system called BES (betonielementtisysteemi) as a national standard in 1970. This was a joint initiative of the Finnish Ministry of Housing and the concrete industry, in order to speed up housing production. BES enabled components produced by different factories to be used in the same project. BES soon became the dominant system, and the highest peak of housing construction was reached in the mid-1970s (Hankonen 1994, 139-223; Hytönen and Seppänen 2009, 19-133, 208-227). After this, more varied alternatives were developed, but still relying on the same structural principles.

In Estonia, the models of standardised apartment buildings closely followed the Soviet models. The first widely used standard 1-317 was developed by Estonian architects working for the local Design Institute Eesti Projekt (1956-58), following a standardised model outlined in Moscow (Ojari 2004a, 48). This Estonian version of the so-called khrushchëvka had slightly narrower volume than the original model to allow more natural light, which was crucial in the northern setting (Kalm 2002a, 329-331). The khrushchëvka were built extensively over the next decade. In 1961, the Tallinn building company was established to produce precast panels according to the Soviet 1-464 standard, based on the Camus system that had been purchased for the Soviet Union a few years earlier (Kalm 2002a, 342). Most of the Mustamäe and Õismäe housing estates were constructed using the 1-464 standard. By the time Lasnamäe was developed, in the 1980s, several open typification systems had been developed in Moscow and Leningrad, but in Tallinn the production of the precast panels did not change significantly. In the shadow of Soviet standards, Estonian architects attempted to develop more flexible systems, but few of them got built. One exception was a standardised apartment block, which architect Miia Masso managed to get into small-scale production in 1972 (Kalm 2002a, 342). The extensive construction of mass-produced apartment blocks in Tallinn was driven by industrialisation, urbanisation and immigration from the other Soviet republics. By the end of the Soviet period, two-thirds of Tallinn's inhabitants were settled in mass-produced apartment blocks (Ruoppila 2004).

\subsection{Finnish Influences on Estonian Multifamily Housing}

Both Kalm (2002a, 316-326; 353-368; 375-388) and Hallas-Murula (2006, 131173) offer comprehensive analyses of the influence of Finnish architecture on Soviet Estonia. Hallas-Murula considers the influence as predominantly Finnish, Kalm as Scandinavian, yet transmitted through Finland in particular. Drawing on Hallas-Murula and Kalm, at least three different phases of Finnish influence can be recognised: the organic architecture of the late 1950s and the early 1960s; the so-called cornice architecture, which became popular in the mid-1960s; and the neo-functionalism of the 1970s. Organic architecture strove to position buildings in 
the landscape and to use natural materials. Typical of 'cornice architecture' were simplified, horizontal volumes and broad cornices, and neo-functionalism was characterised by abstract, geometric forms. Most of the projects to which Hallas-Murula and Kalm refer are public and semi-public buildings or single-family houses. In other words, smaller scale projects allowing greater architectural freedom in comparison to the standardised solutions that characterised the large housing estates.

Nevertheless, Kalm (2002a) and Hallas-Murula (2006) also refer to certain multifamily housing projects that have drawn on influences from Finnish architecture. The earliest post-war example given by Kalm (2002a, 342) is an experimental apartment block built on Gonsiori Street in central Tallinn (1960), as the Estonian architects aimed to design better-quality standardised solutions for mass housing. According to Kalm (ibid.), the floor plans were based on apartment blocks in the Roihuvuori district in Helsinki, designed by the Finnish architect Esko Korhonen in 1954-60. A tangible inspiration, if not even a copy of Tapiola, has been identified in the type-planned single-family house series IE-1 and RE-1, presented in 1967 (Hallas-Murula 2006, 151). Later multifamily houses inspired by Finnish architectural models include, for instance, Toomas Rein's terraced buildings in Vändra (1969-79) and Pärnu (1972-87). These have been analysed to draw inspiration from Alvar Aalto's works, as well as more generally from 1960s Finnish housing architecture, characterised by strip windows and contrast between white walls and dark window frames (Hallas-Murula 2006, 154-157). Raine Karp's Trummi Street housing complex in Tallinn (1969-71), which consists of a row of terraced houses and three apartment blocks (see Fig. 5.4) developed for Academy of Sciences employees, was inspired by the part of Pihlajamäki designed by Lauri Silvennoinen, as well as Viljo Revell's architecture in general (Kalm 2004).

Regarding Tallinn's large housing estates, the question of Finnish and more widely Western influences is most interesting in the earliest one, Mustamäe (195873), developed when Soviet planning was taking a new direction (see Fig. 5.5). In this case, the Western influences, namely the British and French planning principles, as well as interest in new residential districts in Sweden (Vällingby 1949-58, Farsta 1953-61) and Finland (Tapiola, first phase 1952-56), were transmitted through Moscow (Ojari 2000, 53-54). The International Union of Architects' (UIA) congress on the construction and reconstruction of cities, organised in Moscow in 1958 was of primary importance. This was used by Khrushchëv to proclaim the principles of 'open planning' and mikrorayons (Glendinning 2016, 633; Ojari 2000). These principles were also introduced as requirements in the planning competition for Mustamäe, held the same year. The Soviet 'calculative rationality' reduced the British idea of varied housing typology significantly: $80 \%$ of all housing units were to apply the 1-317 standard as 4-5 floor apartment blocks, which were the most economical to produce. The novelty of open planning principles was reflected in unsatisfactory competition entries (Ojari 2000, 55-59). Consequently, the local Design Institute Eesti Projekt was assigned to work on the 


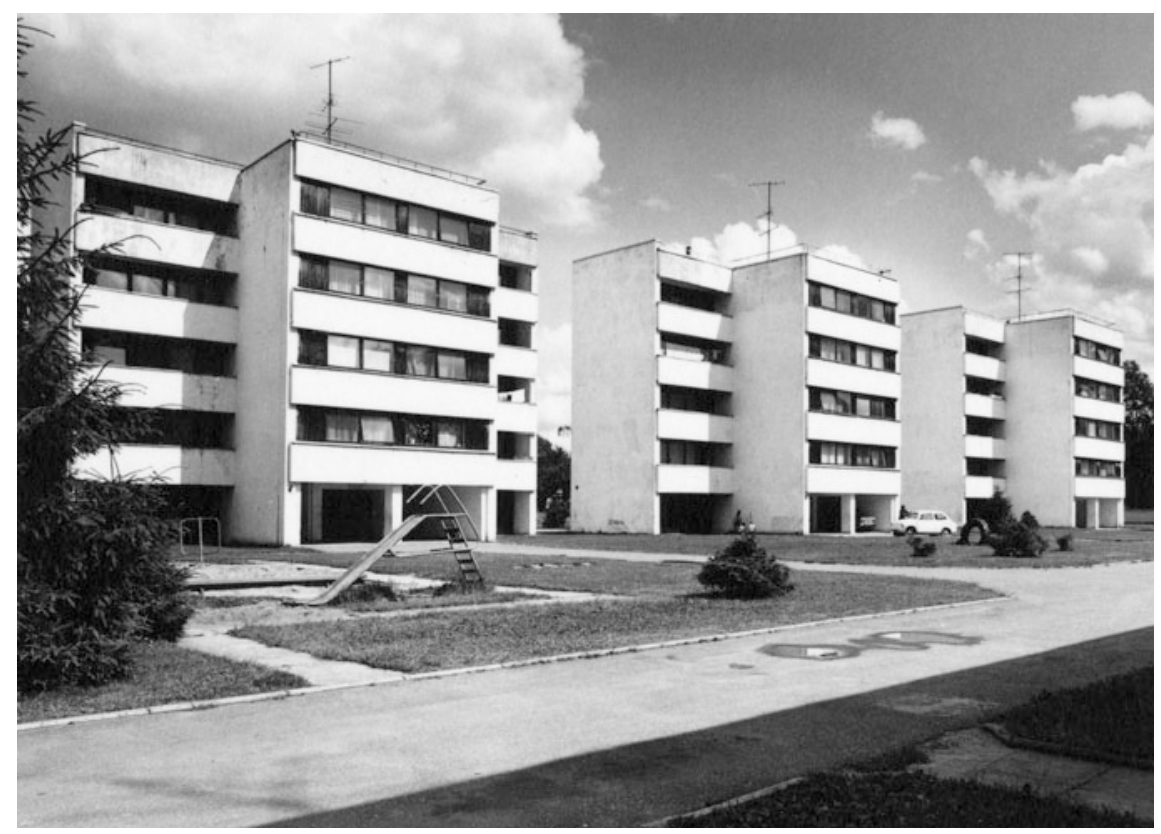

Fig. 5.4 Apartment blocks for the Estonian Academy of Sciences employees in Trummi Street, Tallinn (Raine Karp 1969-71) represent individually designed housing. Source Museum of Estonian Architecture, used with permission

Mustamäe plan. The planning team consisted of architects Voldemar Tippel, Toivo Kallas and Lidia Pettai, and engineer Aleksander Prahm, with whom Tippel had also participated in the Moscow conference and who were awarded the shared second place in the competition. According to Ojari (ibid. 59), the Western influence was recognised in the project, but the planners also took some distance to underline Soviet ideology. Before the construction started in 1962, the 1-464 precast buildings replaced the 1-317 standard in Mustamäe.

The use of standardised models significantly limited the possibilities to apply Nordic ideas. However, the Swedish and Finnish influences have been identified in Mustamäe's shopping and service centres (Lankots and Sooväli 2008), which were buildings that were developed as separate projects and in which architects had more freedom. In particular, Raine Karp's unrealised Mustamäe civic centre project (1964, 1972) bore a resemblance to Tapiola centre (Kalm 2002a, 346). Moreover, the Mustamäe V mikrorayon's commercial centre (Peep Jänes 1963-70) is a prime example of Finnish-inspired 'cornice architecture'. Indeed, Kalm (2002a, 368) argues that it was developed on the basis of Finnish suburban shopping centres. 


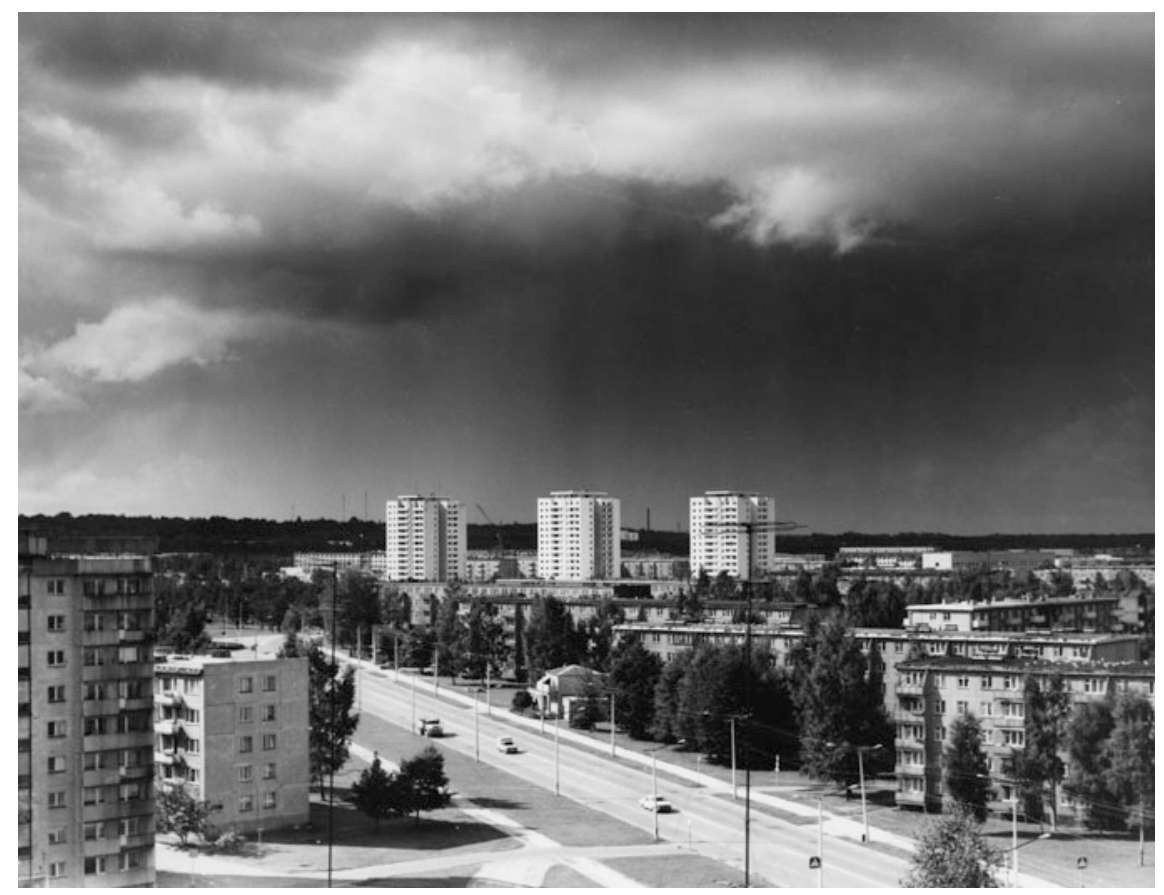

Fig. 5.5 The first mikrorayons of Mustamäe estate in Tallinn (1958-73) consist of 4- to 5-floor apartment blocks built with 1-464 standard. Source Museum of Estonian Architecture, used with permission

\subsection{Discussion and Conclusion}

The main question in this chapter was how Finnish architecture and planning influenced the development of multifamily housing, including large housing estates, in Soviet Estonia. To answer this question, we have provided an account of the ways in which architectural and planning information was transferred between the countries, what was of interest especially to Estonians, and what kind of influence it potentially had in developing multifamily housing in Soviet Estonia.

The connection between Finland and Estonia was restored in the late 1950s as a part of the Khrushchëv Thaw. Finland was one of the model countries to which the Soviet Union paid attention in terms of new town planning ideas (Ward 2012, 510). The difference between Finland and a number of other Western countries, such as the UK (Ward 2012), was that the connections did not fade as the Soviet Union's progressivity transformed into the conservatism of the Brezhnev era. To the contrary, the restoration of a direct passenger ferry connection between Helsinki and Tallinn in 1965 marked a steady flow of Finns to Tallinn. One reason was the collaborative policy of friendship between Finland and the Soviet Union, 
which allowed for cooperation to a certain extent, regardless of the different political and economic systems.

Information was exchanged most importantly through travel, professional publications and architecture exhibitions. Personal contacts played a pivotal role for several reasons. As meticulously monitored Soviet citizens, Estonians needed an acceptable reason to travel, which required contacts and an institutional invitation letter. The Finnish architects travelling to Estonia, for whom the journey was easy to make, were able to bring useful and inspiring materials, which were otherwise scarce in the Soviet Union. Finnish and other Western projects were also known through international journals and books, available in a few professional libraries, and through relatively rare exhibitions.

According to the architecture historians Hallas-Murula (2006) and Kalm (2002a), Estonians took a strong interest in Finnish modernism of the 1950s and the 1960s. The idea of carefully placing modern buildings in the natural surroundings was often perceived to be particularly Finnish, as were some stylistic details of the era. Professional publications and exhibitions enforced these interpretations. At the time, modernist residential projects were associated with progress and hope practically all over the world. Notably, Kalm (2002a, 326) has interpreted that Finnish modern architecture helped Estonians to re-establish their own architectural identity, distinct from other Soviet republics. Simultaneously, Estonians looked back to the country's own functionalist architecture from the interwar period, which created the neo-functionalist tendency in the 1970s.

In terms of residential areas, the most important Finnish references have been the Tapiola and Pihlajamäki districts in the Helsinki metropolitan area, both representing early Finnish housing estates located in natural surroundings, the forest-suburbs. In particular, Tapiola was visited and referenced by Estonian architects even decades after its completion. The travel reports written on the basis of the excursions were, however, often accompanied by pessimism that similar solutions or quality could not be transferred to the context of Soviet Estonia, at least not in housing estates.

In the mid-1960s, the planning paradigm changed internationally towards large and dense housing estates, referred to in Finland with the term 'compact city'. Finnish examples, such as Myyrmäki, Matinkylä and Hervanta, do not seem to have raised interest among Estonians. They rather continued to look back to buildings and estates that were no longer the most topical in Finland. Internationally, the progressive ideals of the 1950 s, associated with mass housing, also started to fade, and during the 1960s the question of production quantities was emphasised. Intriguingly, by looking at aerial photos, the differences between the spatial pattern and architecture of 1970s housing estates in Finland and those in Estonia are less striking than one might presume. Nonetheless, major differences persisted in building quality, landscaping, service provision and post-construction maintenance. Moreover, in Finland, monotonous large housing estates received grave public criticism, and the development gradually turned towards more varied housing areas in the late 1970s. In Estonia, the product of the Soviet housing construction machine did not change much up to the end of the Soviet period. 
To return to the main question of how Finnish architecture and planning influenced Soviet Estonian multifamily housing and housing estates, the answer is that it did so selectively, but only in housing projects in which architecture mattered. The common feature of such projects was that they were individually designed and constructed, in contrast to state-led mass housing. In the case of multifamily houses, these were commissioned by housing cooperatives, the collective farm construction companies (KEK), or equivalent independently operating state agencies. Such projects allowed for more flexibility and room for individual architects to express their ambitions. In terms of the large housing estates, this was possible only in smaller structures, such as the shopping and service centres, the centres of collective life in the mikrorayons. As this chapter has shown, this situation was not caused by a lack of inspiration, information or skills. It was the harsh logic of the Soviet housing production machine, dictated by advancements in mass construction technology. The prefabrication systems, sadly, had a greater role in transforming the built environment than the architects and their visions.

\section{References}

Anderson R (2015) Russia: modern architectures in history. Reaktion Books, London

Bater J (1980) The soviet City. Edward Arnold, London

Beyer E (2012) The Soviet Union is an enormous construction site. In: Ritter K, et al. (eds) Soviet modernism 1955-1991. Unknown history. Park Books, Zurich, pp 257-271

Bruns D (1961) Tapiola. In: Eesti NSV Arhitektuur, artiklite kogumik. Tallinn, pp 46-50

Caldenby C, Wolodarski A (1973) Byggande i Sovjetunionen. Statens institut för byggnadsforskning

Čeferin P (2006) Branded: the museum of Finnish architecture and the international promotion of Finnish architecture. In: Blomstedt $\mathrm{S}$ et al (eds) Suomen rakennustaiteen museo/Finlands arkitekturmuseum/Museum of Finnish Architecture 1956-2006. Helsinki, The Museum of Finnish Architecture, pp 38-54

Forsberg T, Pesu M (2016) The 'finlandisation' of Finland: the ideal type, the historical model, and the lessons learnt. Dipl Statecraft 27(3):473-495

Forty A (2012) Concrete and culture: a material history. Reaktion Books, London

Glendinning M (2016) Cold-war conciliation: international architectural congresses in the late 1950s and early 1960s. J Arch 21(4):630-650

Hall S, Murie A, Knorr-Siedow T (2006) Large housing estates in their historical context. In: Kempen Van et al (eds) Restructuring large housing estates in Europe. The Policy Press, Bristol, pp 63-84

Hallas-Murula K (2006) Suomi-Viro: Arkkitehtuurin yhteinen vuosisata. Viron Arkkitehtuurimuseo, Tallinna

Hankonen J (1994) Lähiöt ja tehokkuuden yhteiskunta. Otatieto Oy, Gaudeamus

Hannula P, Salonen M (2007) Rakennukset kertovat - perustietoa asukkaille. Helsingin kaupunginosayhdistysten liitto ry, Helsinki

Herkel V (1967) Soome väikeelamus. Ehitus ja arhitektuur 1/1967, 48-51

Høyer S, Lauk E, Vihalemm P (eds) (1993) Towards a civic society: the Baltic media's long road to freedom. Baltic Association for Media Research/Nota Baltica Ltd., Tartu

Hurme R (1991) Suomalainen lähiö Tapiolasta Pihlajamäkeen. Suomen tiedeseura, Helsinki

Hytönen Y, Seppänen M (2009) Tehdään elementeistä: suomalaisen betonielementtirakentamisen historia. SBK-Säätiö \& Betonitieto Oy, Jyväskylä 
Jürisoo U, Malmet J (1966) Ehitusalastest ekskursioonidest Soome. Ehitus ja arhitektuur 1/1966, 26-33

Kalm M (2002a) Eesti 20. sajandi arhitektuur/Estonian 20th century architecture. Sild, Tallinn

Kalm M (2002b) Sauna-party at the summer cottage: Soviet Estonians play at being Western. In: Korvenmaa P, Laaksonen E (eds) Universal versus Individual: The architecture of the 1960's. Alvar Aalto Academy, Jyväskylä, pp 53-75

Kalm M (2004) Kolm nuppu ja lint: Helsingi Pihlajamäelt Tallinna Trummi tänavale. Maja 1-2 (2004):57-62

Kalm M (2007) The oasis of the industrialised countryside in Soviet Estonia. In: Kervanto Nevanlinna A (ed) Industry and modernism. Companies, architecture, and identity in the Nordic and Baltic Countries during the high-industrial period. Finnish Literature Society, Helsinki, pp 352-371

Kalm M (2012a) 'An apartment with all conveniences' was no panacea. Mass housing and the alternatives in the Soviet Period in Tallinn. Arch Urban J Arch Town-Plan Theory 47:189-202

Kalm M (2012b) Baltic modernism. In: Ritter K et al (eds) Soviet modernism 1955-1991. Unknown history. Park Books, Zurich, pp 32-45

Kivi RL (1960) Arhitekti muljeid Soomest. Kunst ja Kodu, nr. 3

Klotz H (1988) Paper architecture. New projects from the Soviet Union. Rizzoli, New York

Kotli A (1963) Tallinnan uusi laululava. Arkkitehti 1-2 (1963)

Kurg A (2009) Architects of the Tallinn School and the critique of Soviet modernism in Estonia. J Arch 14(1):85-108

Lahti J (2006) Arkkitehti Aarne Ervin moderni. Kaupunkisuunnittelu pääkaupunkiseudulla. Taidehistoriallisia tutkimuksia 34. Helsinki

Lankots E, Sooväli H (2008) ABC-keskused ja Mustamäe mikrorajoonide identiteetid. Kunstiteaduslikke Uurimusi/Stud Art Arch 17(4):88-109

Lapin L (1980) Funktionalismi Eestin uudessa arkkitehtuurissa. Arkkitehti 3(1980):53-58

Lapin L (1996) Pimeydestä Valoon. Viron taiteen avantgarde neuvostomiehityksen aikana. Otava, Helsinki

Luts K, Avarsoo E (1967) Soome haiglatest. Ehitus ja arhitektuur 4(1967):24-29

Metspalu P, Hess DB (2018) Revisiting the role of architects in planning large-scale housing in the USSR: The birth of three large housing estates in Tallinn, Estonia. Plan Perspect 33(3):335361. https://doi.org/10.1080/02665433.2017.1348974

Meurman O-I (1947) Asemakaavaoppi. Otava, Helsinki

Meuser P (2012) Serial housing construction in the Soviet Union: an architectural-historical approach. In: Ritter K et al (eds) Soviet modernism 1955-1991. Unknown history. Park Books, Zurich, pp 273-283

Meuser P, Zadorin D (2015) Towards a typology of Soviet mass housing. Prefabrication in the USSR 1955-1991. DOM Publishers, Berlin

Mirov B (1965) Arhitekti tähelepanekuid Soome reisilt. Ehitus ja arhitektuur 1(1965):41-43

Mumford E (2000) The CIAM discourse on urbanism, 1928-1960. The MIT Press, Cambridge and London

Neuvostoliiton nykyarkkitehtuuria (1973) (Exhibition catalogue). Neuvostoliiton arkkitehtiliitto and Suomen rakennustaiteen museo

Ojari T (2000) Modernismi parameetrid: Mustamäe kujunemisest. Kümme. Eesti Arhitektuurimuuseumi Aastaraamat. Eesti Arhitektuurimuuseum, Tallinn, pp 49-64

Ojari T (2004a) Elamispind. Modernistlik elamuehitusideoloogia ja Mustamäe/Floor space. The modernist residential housing ideology and Mustamäe. Kunstiteaduslikke Uurimusi/Stud Art Arch 13(2):42-65

Ojari T (2004b) Soome märgid Nõukogude ajas. Maja 1-2(2004):22-27

Pedak K (1999) Eesti-Soome suhetest ja pisut ka arhitektuurist. In: Karu K (ed) EAL 1921-1996: fragmente Eesti arhitektuurelust. Solnessi Arhitektuurkirjastuse OÜ, pp 90-91

Ritter K, Shapiro-Obermair E, Steiner D, Wachter A (eds) (2012) Soviet modernism 1955-1991. Unknown history. Park Books, Zurich 
Ruoppila S (2004) Processes of residential differentiation in socialist cities. Literature review on the cases of Budapest, Prague, Tallinn and Warsaw. Eur J Spat Dev, refereed article no 9, $24 \mathrm{pp}$.

Smith MB (2009) Khrushchëv's promise to eliminate the urban housing shortage. In: Ilic M, Smith J (eds) Soviet state and society under Nikita Khrushchëv. Routledge, Oxon, pp 26-45 von Hertzen H (1946) Koti vaiko kasarmi lapsillemme. WSOY, Porvoo

Ward SV (2012) Soviet communism and the British planning movement: rational learning or utopian imagining? Plan Persp 27(4):499-524

Wassenberg F, Turkington R, van Kempen R (2004) High-rise housing estates in Europe. In: Turkington et al (eds) High-rise housing in Europe. DUP Science, Delft, pp 1-14

Open Access This chapter is licensed under the terms of the Creative Commons Attribution 4.0 International License (http://creativecommons.org/licenses/by/4.0/), which permits use, sharing, adaptation, distribution and reproduction in any medium or format, as long as you give appropriate credit to the original author(s) and the source, provide a link to the Creative Commons license and indicate if changes were made.

The images or other third party material in this chapter are included in the chapter's Creative Commons license, unless indicated otherwise in a credit line to the material. If material is not included in the chapter's Creative Commons license and your intended use is not permitted by statutory regulation or exceeds the permitted use, you will need to obtain permission directly from the copyright holder.

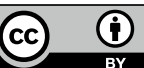




\title{
Chapter 6 \\ Mass Housing and Extensive Urbanism in the Baltic Countries and Central/ \\ Eastern Europe: A Comparative Overview
}

\section{Miles Glendinning}

\begin{abstract}
This chapter provides a comparative overview of the post-war housing programmes of the Central and Eastern European post-war socialist states, arguing that they, like the Baltics, were in some ways distanced from the highly standardised orthodoxies of mainstream Soviet mass housing. With the aim of underlining the extreme diversity of the political/organisational and architectural solutions of mass housing within Central and Eastern Europe, the chapter demonstrates that while public housing was generally dominant in most parts of the region, this concealed wide variations, from the programmes of Poland and East Germany, dominated from the late 50 s by large, powerful cooperatives, to the highly decentralised, even anarchic system in Yugoslavia and the prominence of home-ownership in both Hungary and Bulgaria. Architecturally, the conservative policies of street-façade monumental architecture that prevailed in Ceaușescu's Romania contrasted very strikingly with the idiosyncrasies that sprouted elsewhere, ranging from the sinuous and extraordinarily long 'falowiec' (wave-form) blocks of Gdańsk and Poznań to the wildly variegated design solutions of the various 'blok' sections of Novi Beograd. The chapter compares these varied patterns closely with those of the Baltics, to demonstrate that the latter were not alone within the socialist bloc in their individuality and intermittently 'western' sensibilities.
\end{abstract}

Keywords Prefabrication - Mass housing $\cdot$ Multi-storey flats $\cdot$ Modernism • City planning

M. Glendinning $(\bowtie)$

Scottish Centre for Conservation Studies, University of Edinburgh, Edinburgh, Scotland e-mail: m.glendinning@ed.ac.uk

(C) The Author(s) 2019

D. B. Hess and T. Tammaru (eds.), Housing Estates in the Baltic Countries,

The Urban Book Series, https://doi.org/10.1007/978-3-030-23392-1_6 


\subsection{Mass Housing in the Baltics and the USSR: A Contextual Overview}

This chapter provides a comparative overview of the post-war housing programmes of the Central and Eastern European post-war socialist states, aiming to create a context against which to judge the claims of the special, uniquely 'westward looking architecture' of 'Baltic modernism' (to quote the title of Marija Dremaitè's recent book) (Drèmaitè 2017: 313-5). The recent work by Philipp Meuser and other writers in researching the standard designs, and design discourses, within the Soviet Union has helped dispel the notion that these type-plans were a matter of shoddy homogeneity, and has highlighted the place-specific character of housing in Soviet cities and regions, including Tashkent and Leningrad as well as the Baltic republics. (Meuser 2015) To complement this, my chapter will focus on socialist Central and Eastern Europe, with the aim of underlining the extreme diversity of the political/ organisational and architectural solutions of mass housing within the region.

What were the characterising features of mass housing in the Baltics as opposed to the predominant patterns in the USSR as a whole? With the latter, four broad defining aspects can be pointed to, albeit with considerable simplification: first, the strong, indeed binary polarisation of the organisation of housing between departmental (vedomstvenni) and municipal (Soviet) housing provision, with both private and cooperative housing tolerated only intermittently. Second, the concept of a grand, all-embracing hierarchy of planning, from the union level right down to the individual urban community unit (mikrorayon) and, ultimately individual apartment block, and including the 'urban' development of collectivised rural settlements. Thirdly, stemming from the plentiful supply of state-owned land, an approach to urban design, dubbed 'extensive urbanism' ('extensive Stadtentwicklung') that combined modernist mikrorayon planning with a vast spaciousness and grand 'magistrale' road layouts; and fourthly, under the post-1953 reaction against Stalinism, an intense focus on housing standardisation, type planning and mass production (spearheaded by the renowned ' $\mathrm{SNiP}$ ', or 'housing norms and regulations'), and prefabricated concrete panel construction (Bernhardt 2005).

The Baltic states shared much of this system, but with significant divergences. Organisationally, the forcible character of the Soviet takeover resulted in an unusually high percentage of public housing held by local Soviets as opposed to state enterprises, and-ironically, in view of the long-standing traditions of individual family houses in the Baltics - an unusually low proportion of private housing (Kalm 2002). Architecturally, the relatively short-lived ascendancy of Stalinist Socialist Realism and the persistence of nationalist sentiments ensured that the post-war years saw escalating attempts to offset Soviet extensive urbanism with a 'regional' approach to architectural design, including 'folk' or 'vernacular' sub-trends - although the latter were by no means confined to the Baltic republics, but emerged in an even more emphatic manner in the mass housing of Tashkent and of Central Asia. More generally, designers in the Baltics, as 'the little Soviet West', outdid those of other republics in their eager embrace of the growing cultural and 
architectural exchanges with Western countries from the late 1950s onwards, especially Finland and the rest of Scandinavia (Drèmaite 2017: 76). Yet the Baltics also reflected the centralising aspects of the Soviet system of standardisation, including $\mathrm{SNiP}$ or the definition of housing space in terms not of numbers of dwellings or rooms but of aggregate 'living space' ('zhilaia ploshchad'). In Estonia, for example, local variants of key Soviet types were faithfully developed, beginning in 1956 with design institute Estonprojekt's I-317 adaptation of the standard khrushchëvka, by Mart Port and others (Ojari 2004); and the principles of extensive urbanism were reflected in the concentration of the housing drive in Tallinn into three mega-projects, Mustamäe, Väike-Õismäe and Lasnamäe, roughly corresponding to the 1960s, 70s and 80s.

Central and Eastern Europe, as we will see in this chapter, echoed the divergences and exceptionalism of the Baltic republics' housing in an even more exaggerated way, not least through their very diversity of socialist tenures and architectural design. For example, alongside the sharp Soviet departmental/Soviet split, other tenures were equally prominent, including housing associations, cooperatives, private construction and the famous Yugoslav 'self-managing communities of interest'. Within planning and the built environment, there was a prominent use of prefabricated concrete construction and standardised building types, as in the Baltics and the rest of the USSR, but, in general, on a less overpowering scale; in general, new housing developments were normally related to existing urban fabrics (Zarecor 2017: 9). Overall, the affinity between the core satellites of the USSREast Germany, Poland, Czechoslovakia, Bulgaria, Hungary-was especially strong, while Romania and Yugoslavia followed a much more idiosyncratic pattern.

\subsection{The Satellite States: From Dissidence to Decomposition}

At the centre of the Soviet satellite system was the group of states which remained under Soviet domination from World War II right up until 1989: East Germany (the German Democratic Republic, or GDR), Poland, Hungary, Czechoslovakia and Bulgaria. Overall, these states shared the Soviet system's typical organisational features, of central planning, oral decision-making culture, secrecy and concern with propaganda - a system within which the environment, including mass housing, was both an outcome and a source of state power- as evinced in the elaborate propaganda exploitation of housing 'spectacles' and 'milestones', such as the close interlinking of the completion and naming of Budapest's prestige Havanna development with the 1978 World Federation of Democratic students Congress in Cuba (Urban 2009: 5, 49, 259). These nations also, however, mostly shared a common background of susceptibility to popular unrest against Soviet hegemony, leaving mass housing output drives very often filling a palliative role in the wake of 
unsuccessful uprisings or political liberalisations-for example in post-1956 Hungary. (Ferkai 2005: 56-8; Campbell and Hall 2015: 23).

In central Europe, long-established traditions of municipal power and authority, very different to the Russian situation, also often obstructed the onward march of 'democratic centralism' - for example in Hungary, where the post-war creation of a regional 'Greater Budapest' and the intervention of numerous Soviet-style ministries and industries drastically curbed the housing powers of Budapest's City Council; or even in the GDR, where local authorities retained some significant planning and housing authority, especially in the large cities targeted for planned growth from the 1950s onwards (Molnár 2013: 45-58; Bernhardt 2005: 104-119; Bernhardt and Reif 2009). In some of the more rural countries in the region, such as Bulgaria, there was very little prior history of communism, and low-density, single-storey village type housing was prominent, whereas the GDR and Czechoslovakia featured a strong and entrenched urban proletariat. These disparities in the degree of backwardness in urban development were reflected in sharp differences in the scope of modernising reconstruction, but all the satellite states showed, in principle, a common ethos of universalism within social and economic policy, avoiding sharp differences of private and public or collective life. (Hannemann 1996: 111; Sillince 1990: 477-82)

How, then, was the specific provision of mass housing organised within this at times uncertain bloc of state socialist countries? Overall, as in the USSR, a pyramidal hierarchy, operating through command planning, prevailed. But tenurially speaking, there was significant variety. Despite the general stress on planned industry in all satellite bloc countries, the relative importance of enterprise housing varied widely; municipal authorities played an especially strong role in Hungary, Poland and Czechoslovakia. Overall, however, there was a rather early shift away from standard Soviet tenurial solutions in the region, with many countries shifting sharply away from direct state production altogether, as early as the 1970s in Hungary and Bulgaria and following in the 1980s in Czechoslovakia and Poland. The two overwhelming beneficiaries of the swing away from state command production were the cooperatives, and outright private building. In Poland, the shift to co-op building began especially early and grew rapidly: they were initially boosted under Władysław Gomułka from 1956, reaching 22\% of total output by 1961-5 and subsequently higher still (Donnison 1965: 91-3, 109; Sillince 1990: 62-77, 173, 477-82; Tsenkova 2009: 42; Wynn 1984: 236). Unlike their precarious role in the USSR, including the Baltics, co-ops in Poland operated in effect as local agencies of the state and frequently built on a very large scale, both quantitatively and architecturally, with land allocations guaranteed by the central government social housing agency, the Construction Directorate of Workers' Estates. (Marmot 1981: 180; Rietdorf 1976: 146). In the GDR, a very similar socialist co-op system got seriously underway early, as a response to the 1953 popular uprisings, whereas in Czechoslovakia, Hungary and Bulgaria, the big shift to co-ops came slightly later, in Czechoslovakia in 1958-9 with a $40 \%$ state subsidy, and in Bulgaria from the 
mid-1960s, as part of a radical expansion of state-sponsored house building from $20 \%$ of all new housing in 1961-5 to 50\% in 1977 (Sillince 1990: 37-9, 90-04, 183, 330-43, 475; Deutsche Bauakademie 1968: 9-14; Jordan March 1967a; Jordan April 1967b; Balchin 1996: 245-51, 272-6).

As in the case of the USSR, outright private enterprise building played a surprisingly large role in the housing production of the socialist countries, but here steadily increasing, rather than reducing, in importance-with the aid of long-term loans from the state (Tsenkova 2009: 42-4). There was, however, a significant division between countries where the subsidised private sector was dominated by individual detached houses in villages and country towns, as in Poland or Bulgaria, and those where it was integrated with the urban flat building programme. Hungary strongly emphasised the latter during the post-1956 years of 'goulash communism' under the liberal János Kádár regime, culminating in large-scale 1970s multi-storey Budapest developments such as Havanna (1978), where $30 \%$ of the flats were owner-occupied from the start. To some extent, given the strongly universalistic and totalitarian character of the system, arguably more important than details of tenure was the overall level of state-sponsored production, with its sharp differences in peaks and troughs. Here the two chief alternatives were an early production peak in the 1960s and early 1970s, and a later peak in the 70s and 80s. The former was exemplified by Hungary, where the determined attempts in the post-1956 period to win the loyalty of better-off workers via a 15-year, 1961-75 mass programme (Rietdorf 1976: 76; Ferkai 2005: 56-8; Sillince 1990: 39, 66, 90-104, 459-82; Balchin 1996: 245-51). In the GDR, by contrast, the housing programme continued building up almost to the end of socialist rule in 1989, with a per capita maximum far above that of the other satellite states, and achieved 10 years later than them. This was largely the personal achievement of Erich Honecker, appointed SED party leader in 1971, who immediately launched a vast building drive, codified in 19735 , and revolving around a system of 'complex housing construction', under which the state planning commission set central housing targets for execution on an agency basis by local governments (Volkseigene) and cooperatives on sites centrally allocated by the Bezirke, or administrative provinces. The achievements of this programme were celebrated and exaggerated in highly choreographed spectacle events - the supposed 'millionth', 'two-millionth' and 'three-millionth' dwelling completions. (Wynn 1984: 220-47; Sillince 1990: 337; Angermann and Hilse 2014: 117-8; Honecker 1981: 302-16; Urban 2009: 256-9; Fiedler and Georgen 2008: 40; Rietdorf 1976: 106).

\subsection{Housing Architecture in the Satellite States}

Architecturally, the satellite states relatively closely echoed Soviet patterns, in a way that differed sharply from the US-Western European relationship, albeit with a considerable diversity of interpretation, that reflected the ideology of 'socialist 
competition' and echoed the official rhetoric of unified planning, design and building. This system was restrainedly celebrated in Werner Rietdorf's illustrated overview book of 1975, which picked out Hungary as 'exemplary' in design consistency (Bernhardt and Reif 2009; Marmot 1981). Although the Soviet fixation with living space was only more loosely reflected in these countries, with housing size more generally expressed in square metres per dwelling rather than per inhabitant, the overall assumption that the task was to build relatively basic shelter and small flats for very low rents, very often as part of wider building programmes of enterprises - was very similar to the Soviet Union (Donnison 1965). Common with the Baltics and the remainder of the Soviet Union, too, was the sharp late-1950s swing from Stalinist to post-Stalinist housing solutions, including the reliance on standardisation and industrialised building, and the planning emphasis on modernist 'extensive urbanism', mikrorayon layouts and avoidance of large-scale redevelopments (Bernhardt 2005: 111; Sillince 1990: 7).

The far shorter hegemony of Stalinism in these countries, however, guaranteed a subtly different chronological trajectory, within which the place of CIAM modernism was somewhat less problematic overall. In Czechoslovakia, Germany, and Hungary, 'Neues Bauen' architecture had put down deep roots at various points in the interwar years, and in all three countries, especially Czechoslovakia and Hungary, the years 1945-8 saw an initial blossoming of modernist experiments under a generally liberal left-wing umbrella, in fields as diverse as 'type' design, neighbourhood unit planning, and Existenzminimum small dwelling design. In the Baltics, by contrast, these years witnessed an immediate shift to Socialist Realism, especially in nomenklatura apartments, such as the stately four-storeyed classical ensemble designed in 1946 by Edgar Velbri for academics on Rävala Avenue, Tallinn, containing five-room apartments (and even servant quarters!) (Mumford 2009: 239-41; Zarecor 2011: 17-51; Gzell 1995; Lankots 2004) After a brief early 1950s ascendancy of Stalinist Socialist Realism, exemplified in projects such as the Stalinallee in Berlin or Nowa Huta in Poland, by 1955 the pendulum was swinging back again, reflecting Khrushchëv's denunciations of Stalinism in the USSR.

In this phase, the parallelism of developments in the Baltics and CEE was especially marked. From 1957, Soviet architects, including many from the Baltics, launched enthusiastically into visits to Finland and other Scandinavian countries, a particular focus of emulation being the Tapiola satellite town outside Helsinki; the neighbourhood-planning formulae of Scandinavia (and Britain) were also the focus of growing enthusiasm. The impact on the Baltics was both immediate and enduring. At the first of Tallinn's large prefabricated housing districts, Mustamäe, a 1958-9 competition-winning master plan by $\mathrm{T}$ Kallas, $\mathrm{M}$ Port and V Tippet employed an open-plan mikrorayon layout for the first time in Estonia. As built (1962-73), Mustamäe was dominated by five-storey khrushchëvki, arranged in nine mikrorayons, and including one explicitly 'Scandinavian' feature: the so-called ABC mikrorayon centres, inspired by the 1950s Swedish 'Arbete-Bostad-Centrum' centres, such as Vällingby. (Metspalu and Hess 2018; Lankots and Söövati 2008). The Baltic 'aura' of the new Scandinavian connection continued throughout the 1960s and early 70s, notably in the Vilnius district of Lazdynai, 1962-73, laid out 
by two ambitious young architects, Vytautas Brėdikis and Vytautas Čekanauskas, as the first of a series of peripheral developments. Standard 5, 9 and 12 storey blocks (series 'I-461-LI') were picturesquely disposed on a wooded site in four mikrorayons - three of which, unusually, were provided with well-equipped centres from the outset (Drèmaite 2017: 168-179). Similarly, German, Polish and Czechoslovak housing architects looked to Scandinavia and Britain for new-town and community planning, while embracing the cause of industrialised building and assiduously visiting prefabricated developments in Sweden, Denmark and France (Hannemann 1996: 58; Bernhardt 2005: 115; Topfstedt 1996; Dufaux and Fourcault 2004: 103-5; Gzell 1995). In Hungary, the turmoil of 1956 obstructed any immediate architectural 'thaw', and it was only slightly later, around 1958, that the first attempts were made to lay the ground for fully fledged modernism in Hungarian housing, above all in the Óbuda experimental development in Budapest, a domestic echo of the 1957 Berlin Interbau and Scandinavian precedents in its intended role as a prototype for modernist community planning, housing architecture and interior furniture and fittings (Molnár 2013: 78, 117; Branczik and Keller 2011; Branczik 2012).

In Eastern Europe, the post-war urbanist conceptions of modern housing naturally echoed the Soviet formula of 'extensive urbanism', albeit in a somewhat smaller scale and more diluted form - as documented, for example, in Rietdorf's book (whose front cover illustrates Lazdynai) (Rietdorf 1976: 260-71; Zarecor 2011). Although also reflecting Scandinavian and British neighbourhood-unit planning, the Eastern European version of extensive urbanism was also close to the French grand ensemble concept (Molnár 2013: 45-58; Hannemann 1996: 67; Moravčíková et al. 2011). In almost all cases, this approach was linked integrally to industrialised building, and, just as with Mustamäe in Estonia, the first really large-scale development in any country was often also its first large industrialised building development: for example, Kelenföld in Budapest or Hoyerswerda in the GDR, the latter anticipating a succession of East German Grosssiedlungen, such as Erfurt-Nord, Karl Marx Stadt, Rostock or Berlin-Marzahn (Architects' Journal March 1967; Ferkai 2005: 64-7; Hannemann 2004; Rietdorf 1976: 120; Bernhardt 2005). Correspondingly, there was a marked reluctance to demolish existing housing stock - in contrast to the vast 'slum-clearance' projects of Britain and the USA. This reluctance was fully shared by the Baltics, where, for instance, a succession of grandiose rebuilding plans for the decayed Tartu inner-suburb of Supilinn remained unrealised, even as the giant new Annelinn housing zone was developed on the city's south-east edge. As Tallinn's City Architect (1960-80), Dmitri Bruns, recalled, 'big complexes like Mustamäe were built on virgin land because the housing crisis was so deep that redevelopment was out of the question' (Hess and Hiob 2014; interview with Dmitri Bruns by MG 29-5-2011).

At what level of scale the building of grands ensembles shaded into the building of entire new towns or even satellite towns is unclear, whichever period we look at: but normally the key factor was the involvement of a large-scale enterprise: the first projects of very large-scale developments were already underway in the Socialist Realist period in the early 50s as in the case of Nowa Huta or Stalinstadt; but it was 
only after the shift from Socialist Realism to extensive urbanism in the late 50s, and the move to industrialised building, that the scale of development really ramped up - a movement in which the Baltic states participated only on a modest scale, for example in Lithuania with new towns such as the 4,000-inhabitant Elektrènai, built for power-plant workers in the 1960s with a housing stock of prefabricated slabs, and Sniečkus, a forest new-town for nuclear power station workers, built in 1975-89 on a grandiose, butterfly-plan three-mikrorayon layout. (Drėmaite 2017: 109-115) In many CEE cases, the 'new towns' were not completely new, but, rather, massive and semiautonomous satellites dwarfing existing settlements, as in the case of Halle-Neustadt, where a completely autonomous 'Stadt der Chemiearbeiter' was constructed beside the existing 'Altstadt', with the full panoply of Extensive Urbanist planning (Fig. 6.1), including a main magistrale and serried lines of towers (Hannemann 1996: 64; Hannemann 2004; Topfstedt 1996: 44; Angermann and Hilse 2014: 97-8; Diener 2012; Rietdorf 1976: 120-1).

Most CEE states had no comprehensive equivalent to the USSR's modernist 'rural urbanisation' strategy, within which the Baltics played a leading role, through showpiece collective farms, bristling with apartment blocks and public buildings, sometimes designed in a highly individualistic manner that contrasted with the standardisation of urban housing. For example, at Juknaičiai, Lithuania, the Central Settlement of the 25th CPSU Congress Soviet Farm was developed from 1964 under the forceful chairmanship of Zigmas Dokšas as a highly landscaped

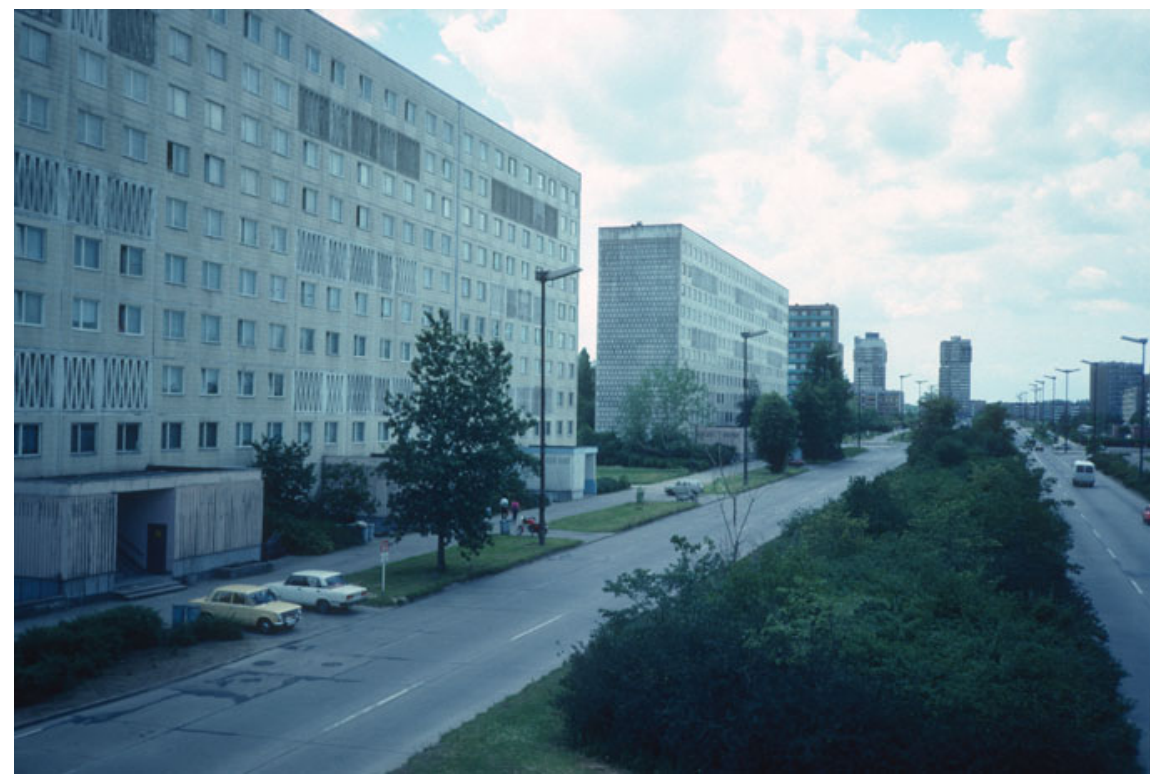

Fig. 6.1 Chemiearbeiterstadt Halle-Neustadt, East Germany: a GDR showpiece of Extensive Urbanism. This view shows Wohnkomplex I, comprising 5233 flats built in 1964-8 Source M Glendinning, 1990 
showpiece, with apartment blocks with exaggerated gabled roofs, and lavish central institutions (Drèmaitė 2017: 136-145). Likewise, in Estonia, farm centres were developed in the form of urban complexes featuring arrays of parallel three- to four-storey prefabricated apartment blocks - for instance in a 1970s plan by architect Valve Pormeister for the central settlement of the Kurtna experimental poultry farm (Kalm 2008; Topfstedt 1996; Rietdorf 1976: 112-25; Deutsche Bauakademie 1968: 281-93; Drèmaitė 2017: 138).

In Eastern Europe as in the Soviet Union, the drive for industrialised building was integrated into the drive for 'extensive urbanism', but the impulse towards large load-bearing panel industrialisation was nowhere quite as single-minded as the Soviet Union - with the arguable exception of East Germany during the Honecker 'dash for numbers' in the 70s and 80s. Despite post-1957 efforts at inter-state coordination under the aegis of the CMEA (Comecon), what was almost entirely absent in the satellite states was a direct equivalent to the massive, early Soviet boom in prefabricated building during the Khrushchëv years, especially in 1957-60. In Czechoslovakia, to be sure, the first experimental 'panelaks' began to appear in Prague, Bratislava and elsewhere from 1956, with later, experimental industrialised schemes such as an aluminium-panel-clad slab block at Invalidovna in Prague; and in East Germany, large-scale production got seriously underway with the founding of the first Baukombinaten and the 1957 commencement of Hoyerswerda, trumpeted as 'the first industrially built town in the GDR'. (Donnison 1965: 110; Zarecor 2011: 289-93; Moravčíková et al. 2011: 20-3, 46-9; Jordan April 1967b; Pugh 2015) But in general, the shift to industrialised building was generally more belated than in the USSR. Hungary, with its strong emphasis on single family owner-occupied housing, began prefabricated construction only in 1961 but thereafter rapidly accelerating, with four house building combines and concrete factories inaugurated in the 1960s, including three built with Soviet help by 1965 , and one built as a joint venture with Larsen \& Nielsen in 1968: the first major prefabricated development, Kelenföld, used a Soviet system (Fig. 6.2). In East Germany, while the ideological facade of Honecker's campaign was provided by the much showcased 'million' milestones, its technical kernel was an East German variant on the Soviet quest for unified systems: the WBS (Wohnbauserie) 70, which tried to simplify the range of types that had proliferated since Hoyerswerda into a single 'family' (Fig. 6.3) (Sebestyén 1965; Molnár 2013: 79; Ferkai 2005: 65-66; Architects' Journal March 1967: 713-715; Angermann and Hilse 2014: 91; Hannemann 1996: 82-92; Hannemann 2004; Wynn 1984: 220246; Rietdorf 1976: 106, 252-4).

\subsection{Divergences from Orthodox Modernism}

No sooner was the industrialised building campaign fully established, in the mid-1960s, then a growing clamour began, especially along architects such as Bruno Flierl in the GDR, against its supposed 'monotony'. These criticisms came 


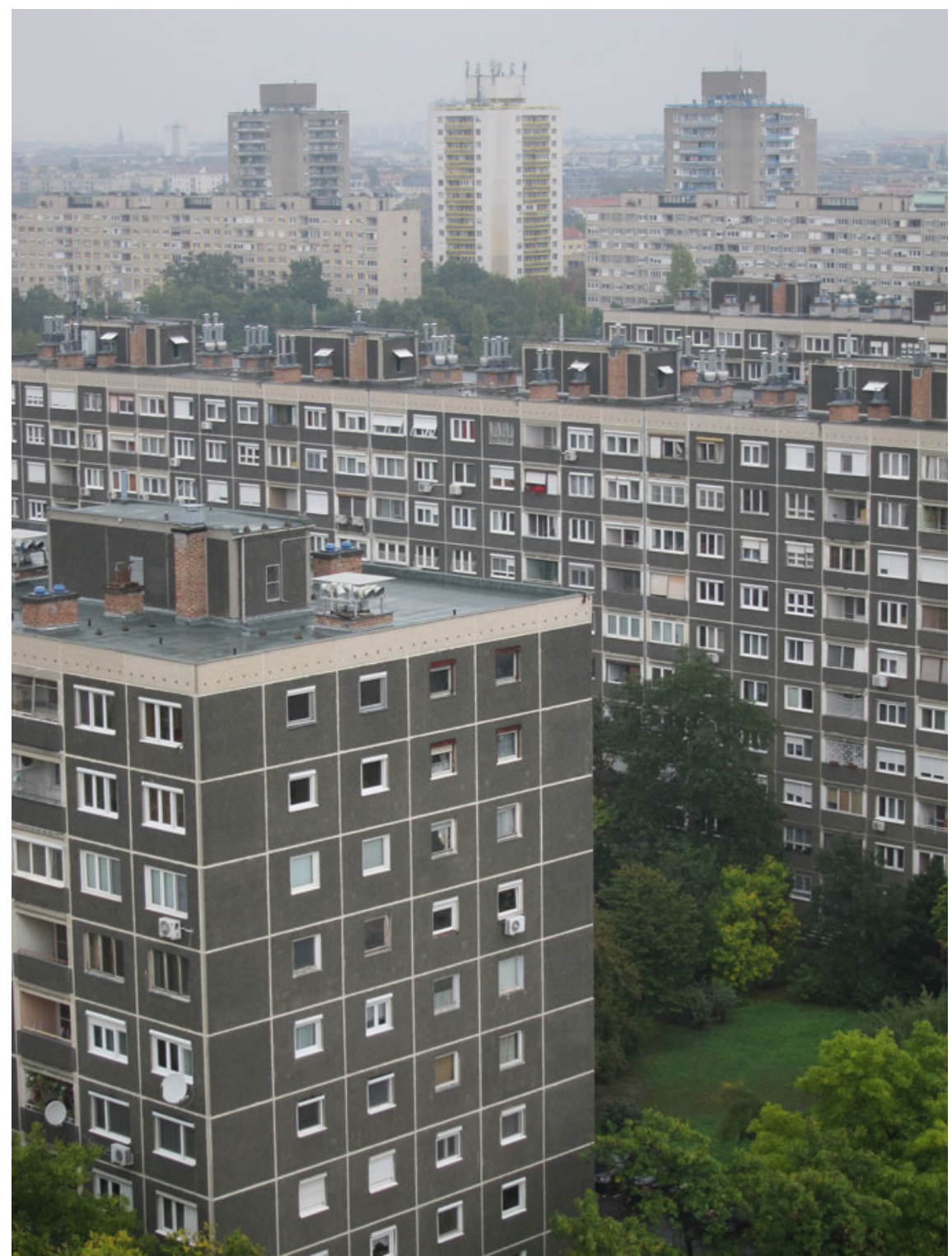

Fig. 6.2 Kelenföld, Budapest: pioneering prefabricated blocks built from 1965 using a Soviet spin-off of the Camus system Source M Glendinning, 2015 


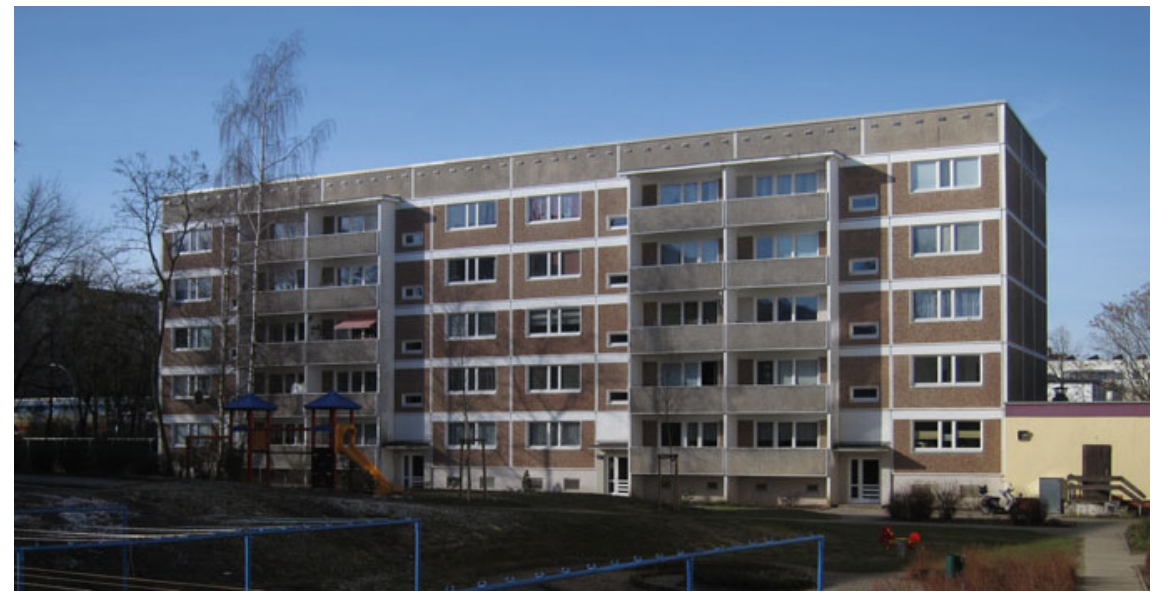

Fig. 6.3 Koszaliner Str. 1-7, Neubrandenburg, East Germany: the first built example of the GDR's WBS 70 standard large-panel prefabricated concrete series, constructed in 1973 (and designated a heritage monument in 1984) Source M Glendinning, 2017

somewhat earlier than their equivalents in the Baltics and the rest of the Soviet Union. In Tallinn, for instance, the late $70 \mathrm{~s}$ saw growing newspaper criticisms of the unfinished state of Väike-Õismäe, and by the late-1980s a fully fledged polemical campaign of 'Stop Lasnamäe!' was underway (Urban 2011: 68-71; Pugh 2015: 87-101; Moravčíková et al. 2011: 54-57; Metspalu and Hess 2018: 17-18). One of the favourite remedies for standardised 'monotony' advocated by late Soviet designers was to promote 'experimental', non-standard projects, partly exempted from the exigencies of SNiP, including 'monolithic' tower blocks built in in situ rather than large-panel concrete, with more flexible plans and individualistic 'sculptural' profiles. Here Lithuania played a leading role, in the 1980 s 'monolitas' programme in Vilnius, whose earliest examples were the towers that studded the skyline of Lazdynai from 1980, designed by architect Česlovas Mazūras (Drèmaitè 2017: 185-9).

In the CEE countries, the architectural responses to the criticisms of orthodox modernism were often somewhat more exaggerated than those in the Baltics, or the rest of the Soviet Union for that matter. One common response was a shift to more 'urban' and dense forms, and more flexible, conglomerate-like planning-for example, in Budapest's Újpalota (1970-5), with its linear arrangement along two colliding planes, with a landmark tower at the intersection. Beyond these, a limited range of more utopian initiatives proposed more extreme solutions, whether megastructural, as in the vast linear 'Strip' development advocated in Budapest by Elemér Zalotay, or the projects of Oskar Hansen in Poland, which combined innovative high density forms with attempts at participatory social input (Ferkai 2005: 67-71; Hryniewicz-Lamber 2004; Molnár 2013: 92; Branczik 2012: 190-191; Kedziorek and Stanek 2012). Although Zalotay's Strip was never 
constructed, from the mid-1960s a group of Polish designers actually built something not far removed from it in scale, in the form of the 'Falowiec' (Wave) projects - enormously long 11 or 12 storey slab blocks of a very unusual, undulating ground plan and featuring balcony rather than the more usual Soviet-style 'sectional' staircase plan. The main group of Falowiec blocks was in the northern suburbs of Gdańsk, in the Przymorze development, built by a single, giant cooperative, the PSM Przymorze (Fig. 6.4). The Falowiec sector of Przymorze, begun in 1964, was put out to competition, with winner Stanisław Różański acting as project design leader within the Gdańsk city design collective, 'Miastoprojekt': 1966-7 saw construction of the first two Falowiec blocks, while the culmination was an immense 'kolos' (colossus) of 16 sections and over $800 \mathrm{~m}$ length (1970-3). The only Baltic equivalent to these vast, curved forms in the landscape is the huge circle of Tallinn's Väike-Õismäe, with its flanking 5 and 9 storey slabs and landmark clumps of 16-storey towers-a 38,000-inhabitant development planned from 1968 by Mart Port, with Malle Meelak, and built 1972-6; but its 'macro-rayon' plan was far more regular in character (Interviews of Dmitri Bruns and Mart Port by MG, 29 May 2011).

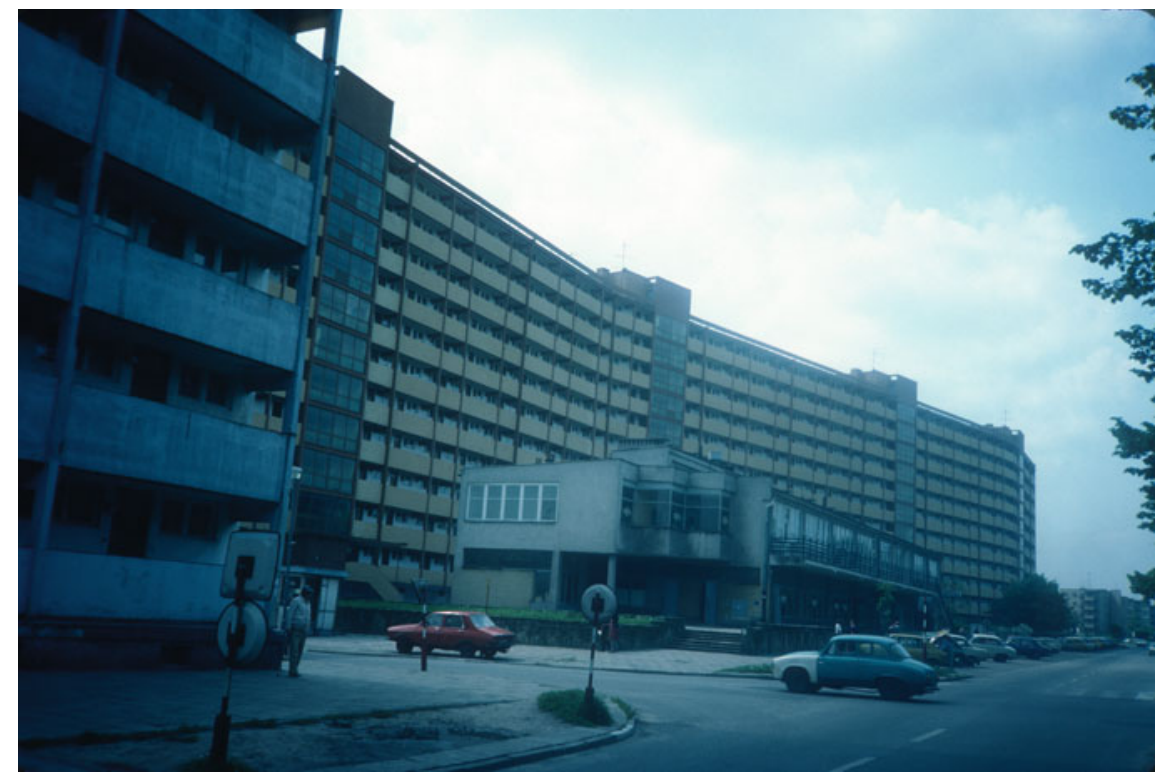

Fig. 6.4 Ul. Piastkowska, Przymorze, Gdańsk, Poland: 11-storey 'Falowiec' slab block built in 1966-7 by the PSM Przymorze cooperative (designers, Miastoprojekt city design collective) Source M Glendinning, 1983 
In historic urban settings, a calculatedly 'contextual' approach had been developed in many places long before that point, with some roots in Stalinist Socialist Realism. With the general post-

Stalinist switch to modernist architecture and planning, slightly different approaches to housing reconstruction of war-devastated, ex-German, Polish cities were attempted, as in the case of Wrocław's Nowy Targ, where a complex succession of plans and proposals was followed by a 'conditional reconstruction' (from 1956), employing modernist blocks of roughly the same scale as the previous buildings, and laid out in a combination of street, courtyard and modern open-plan layouts (www.smpiast.pl/ospoldzielni.html; Friedrich 2010). In East Germany, contextual variants of the WBS 70 were designed for specific locations-a programme not matched anywhere in the USSR, even in the Baltic states, where inner-city projects generally used slab blocks similar to the peripheral estates (Fig. 6.5) (Sillince 1990: 4-7, 114-9; Urban 2009; Angermann and Hilse 2014: 2123, 38-56, 97-8; Deutsche Bauakademie 1968: 284-291).

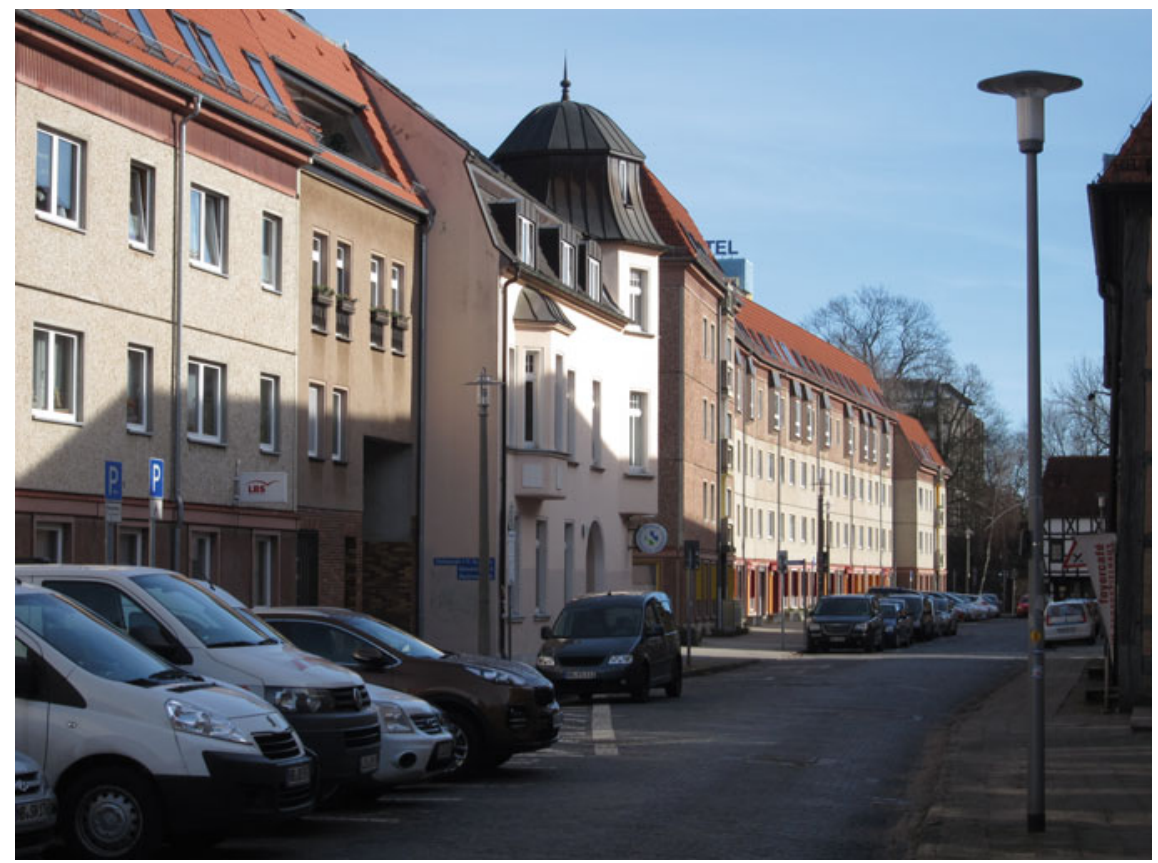

Fig. 6.5 Pfaffenstrasse, Neubrandenburg: 'contextual' WBS 70 Plattenbau developments of the mid-1980s in an Altstadt setting Source M Glendinning, 2017 


\subsection{Socialist Exceptions: Mass Housing in Romania and Yugoslavia}

Whereas the satellite bloc countries all followed relatively similar policies and architectural patterns, and attempted to reflect Soviet precedent in one way or another, in Romania and Yugoslavia, completely different, and wildly diverse, patterns prevailed. (Sillince 1990: 360-386)

In Romania, the overall trajectory of housing production, especially in the late socialist years, was towards ever greater state centralisation and 'systematisation', whereas in Yugoslavia, the mass housing programme was shaped by an escalating national ethos of decentralisation and incessant reorganisation, amounting eventually almost to anarchy. In the 1940s Romania, rather like Bulgaria, was an overwhelmingly agrarian society with almost no 'communist proletariat'. In response, a very tight Stalinist control was established from the beginning by communist leader (1944-65) Gheorghe Gheorghiu-Dei, combined with a strategy of rapid forced urbanisation and population growth, combined with conservation of agricultural land. But this was combined with a growing estrangement from Moscow, beginning in 1952 and deepening during the Khrushchëv 'thaw', which he combated with a recipe of socialist nationalism, announcing in 1964 the 'calea romaneasca spre comunism'. After Gheorghiu's death in 1965, Nicolae Ceauşescu gradually emerged as leader, being recognised by the 1970s as 'conducator' and promoting an ideology of 'comunismului national' (Zahariade 2011: 14-25, 40-44; Rietdorf 1976: 182).

In both the organisation and architecture of mass housing, Romania underwent a succession of fluctuations that set it strikingly apart from every other socialist regime. State expenditure was overwhelmingly focused on industry, with housing seen as a low priority. In the immediate post-war years, there was a strong emphasis on the building of private housing. However, by the late 1980s, in stark contrast to neighbouring Hungary, private building in Romania had dropped to almost nil. Architecturally, Romania was unusual in experiencing a rather shorter ascendancy of orthodox international modernism, with socialist realism only really abating from around 1958-9, and a distinctive Romanian counter-reaction against modern urban planning already underway by 1966 . The initially very low early post-war pace of apartment building quickened rapidly from around 1957. Here, a penchant for the monumentality of grand magistrales and squares remained unusually prominent (Sillince 1990: 135-152; Rietdorf 1976: 185-189; Tsenkova 2009: 39-42; Zahariade 2011: 45-48). Even at the height of straightforward modernism in Romania, in the late 50s and early 60s, spectacle-building along great boulevards was ubiquitous. In some cases these built on existing ensembles, such as Bucharest's Grivița project of 1958-65, including the classical Piaţa Gării de Nord, while others were quite new, such as Piaţa 3 Decembrie, with its cluster of monumental buildings at a busy street junction; by 1969, the Cartierul Floreasca featured a kvartal layout with densely filled street blocks (Sillince 1990: 150; Laurian 1965: 364; Ionescu, et al. 1969; Zahariade 2011: 30-36, 49). 
In much the same way that Soviet planning was based on a totalising, hierarchical concept for the national territory as a whole, including rural as well as peri-urban development, its Romanian counterpart, 'systematisation' (sistematizare), did much the same - uniquely in the CEE states - but with very different built results. As early as the early 1950s, the term was already being bandied about in debates about the planning of Bucharest, within which it meant little more than methodical spatial planning, but it was only following a 1966 speech by Ceauşescu, in which he called for greater economy and land use and for efforts to diversify housing to avoid monotony, that systematisation began to take on specific, and increasingly idiosyncratic, architectural form. Just as Khrushchëv had denounced Socialist Realism as wasteful in the mid-50s, so Ceauşescu's critique focused on the damaging effects of waste-only, in this case, of land, rather than building resources. He vigorously condemned modern functionalist grands ensembles as both profligate of land and architecturally monotonous. Reflecting these critiques, national planners drew up a systematisation programme in 1972, and a general systematisation law followed in 1974, synthesising all previous acts. This was to be a total national strategy of urban concentration, curbing urban peripheral sprawl and reorganising rural villages, with some picked out for modern planned development and others for abandonment and, even, demolition. Within the cities, a 1975 'streets law' mandated that open-plan modernist street layouts should be infilled with additional blocks, and new developments were designed in open street-block layouts incorporating curved, segmental or chamfered elements. In 1985, Ceaușescu proclaimed that within five years, $90-95 \%$ of the inhabitants of Bucharest would live in apartments, and increasing efforts began to clear away 'wasteful' low-density parts of the capital, and substitute taller, standard type blocks (Zahariade 2011: 3662; Tsenkova 2009: 39; Sillince 1990: 135-152; Ciolacu 2015; Marin 2011).

\subsection{The 'Ongoing Revolution': Self-management and Monumentality in Yugoslavia}

Like Romania, Yugoslav policy was dominated by a determination to promote equalisation of disparities across the whole country-but in almost all other respects, its post-war planning and housing policies could hardly have been more different (Mrduljaš and Kulić 2012: 6-10). Tito's Yugoslavia combined a highly assertive external self-projection as a redoubt of nonalignment with a multinational internal structure and a dominant, all-pervasive organisational discourse of incessant, decentralising reorganisation and its architectural outcomes were among the most spectacular and individualistic in post-war Europe-eclipsing even the most flamboyant Soviet efforts, Baltics included.

In geopolitical and economic terms, post-war Yugoslavia experienced around 35 years of relative strength and prosperity, framed by years of crisis and impoverishment. Politically and architecturally, Yugoslavia differed radically from its 
neighbours, not only in its strongly multinational, and multi-ethnic character, but in the idiosyncratic interpretation of socialism favoured by Tito and the Yugoslav leadership. They took to an extreme the Marxist and Leninist concept of the 'withering away of the state', as a prescription for radical devolution of power within society to ever more complex participatory structures, combined with constant constitutional reorganisation, amounting to a 'revolucija koja teče' (ongoing revolution). Within this decentralised system, however, there were embedded highly centralised elements, above all the dominant figure of Tito himself; departmental enterprises also played a surprisingly prominent role in Tito's Yugoslavia, with organisations such as the Yugoslav National Army (JNA) or Jugoturbina able to act as 'first among equals' within the self-management system (Sillince 1990: 402; Mrduljaš and Kulić 2012: 18).

Yugoslavia's post-war housing history fell into three successive phases of increasingly radical devolution and complexity. The first phase comprised the early post-war years, up to 1952, when the country was battling with the economic hardships stemming from the break from Stalin and the Soviet economic embargo, and housing output only averaged around 5,000 per annum. During this time, the system was at its closest to the Soviet satellite bloc countries, but even then, the first moves towards decentralisation were under way. From 1956-7, centralised budget allocation was removed, and a 'social fund' was established, tasked with building rental housing financed by percentage contributions from all work organisations. (Wynn 1984: 156-160; Sillince 1990: 37, 402-4; Mrduljaš and Kulić 2012: 11-14, 406). The third phase of Yugoslav mass housing (1963-72) went further still in the direction both of the market and of decentralisation, abolishing the communal housing authorities and devolving responsibility for housing to commercially-funded 'self-managed enterprises'. In 1972, yet another housing reform enshrined the role of the 'self-managing community of interest' (samoupravna interesna zajednica), a category that included not only employee enterprise housing but a bewildering variety of community groups: by 1986 , over 600,000 people were involved in SIZ decision-making (Hegedüs et al. 2013: 130, 245; Tsenkova 2009: 40-42; ETH Studio Basel 2012: 187-8; Wynn 1984: 156-63; Architects' Journal April 1967: 997; Balchin 1996: 242-3; Sillince 1990: 402-28; Mrduljaš and Kulić 2012: 18-19, 188; Interviews by M Glendinning with D and M Marusić, and A Stjepanović, 7 July 2014).

In built-form terms, the complexity and fluctuations of the Yugoslav housing organisational system were reflected in an exceptionally variegated architectural landscape, resembling Western mass housing architecture more than the orderly, hierarchical mikroayons and rayons of the USSR, including all three of the Baltic States. In Yugoslavia, owing to the break with Russia, socialist realist housing had hardly any time to establish itself, and a reaffirmation of international modernism was signalled dramatically by the Zvezdara Hill project of 1953-5, with its cluster of slender, reinforced-concrete-frame towers, styled with 'winged' roofs-ostentatiously embracing western modernism just like designs such as Lazdynai, but a decade earlier. The building of idiosyncratically styled reinforced-concrete towers of ever greater scale continued to characterise Yugoslav cities in the 1960s and 70s 
- rather earlier than the monolithic Soviet craze exemplified by the sculptural monolith towers of Vilnius - but filling the same landmark role (Dremaite 2017: 185-9). Some were designs of extreme eccentricity, such as the Rudo (Eastern Gate) project in Belgrade, built 1967-76 as a spectacular group of three sail-like 28 storey towers arranged in a radiating triangular grouping, almost like a gigantic expo pavilion, designed by Vera Ćirković and others (Mitrović 1975: 19).

At a relatively early date, however, Yugoslav designers also embarked on a new design trend of medium-rise, conglomerate mega-developments, often on city outskirts, as, for example, at Split III - an approach for which there were few if any equivalents in the Baltic states. In some instances, massive towers were integrated into a dense, medium-rise base, as at the JNA-sponsored, megastructural Banjica development in South Belgrade (from 1966), designed by Mirjana Lukić. In strong contrast with the Soviet industrial prefabrication tradition, Yugoslav housing designers also developed a complex discourse of system building and prefabricated construction, orientated not towards mass systematisation but towards flexibility and open systems - exemplified by the 'IMS' system, developed from 1957 (Blagojević 2012: 3-4, 240; Mitrović 1975: 20-25; interviews D and M Marusić, 7 and 8 July 2014; Wynn 1984: 162-170; Architects' Journal April 1967; Mrduljaš and Kulić 2012: 175-188, 277-300, 410-416).

\subsection{Novi Beograd: Planning by 'Blok'}

Innovative and sometimes startling as these individual projects were, they were all overshadowed, within the Yugoslav planning and housing world, by the spectacular prestige, and architectural diversity, of Novi Beograd (New Belgrade) Yugoslavia's equivalent to Brasilia as a unifying new capital-first planned in 1948 but mostly stalled until 1956, Novi Beograd was very much the personal brainchild of Tito. Organisationally, a range of special central state and governmental enterprises was established to pursue its development, along with the JNA, which consistently played a self-consciously 'progressive' and 'experimental' role in Yugoslav housing design in general. Novi Beograd was a single vast, concentrated zone of elite housing, dedicated to the upper professional, military and government strata of Yugoslav socialist society (LeNormand 2014; Interview D and M Marusić, 7 July 2014; Mrduljaš and Kulić 2012: 36, 296-8; Blagojević 2012: 232-7).

In its orthogonal, linear layout, Novi Beograd, like Brasilia, presented a potent combination of 'motor age' grid planning with strong elements of stately symmetry - a spectacle-driven approach in distinct contrast to the more informal formulae of Soviet extensive urbanism, as seen especially in the Baltics in estates such as Lazdynai in Vilnius. Laid out on a north-west/south-east axis, its constituent elements were 'blocks' (blokovi), each 'blok' being much larger than a Brasilia superquadra, but similar in density (300 persons per hectare) (Mrduljaš and Kulić 2012: 163). The only equivalent to this in the Baltics was the original proposal for Tallinn's last and greatest mega-project, Lasnamäe, designed by Eestiprojekt in 
1970 and largely built in the 80 s: the original linear plan was centred around two parallel expressways.

In Novi Beograd, in a further expression of the 'participatory' and 'experimental' aspirations of Yugoslav socialism, public competitions were used for the urban design of each stage of development. As a result, the successive phases of Novi Beograd were stamped with an exaggeratedly individualistic character, more extreme than anything in the Baltics and fully up-to-date with contemporary 'conglomerate' or 'Brutalist' design trends in Western Europe. The years from 1966/7 onwards saw a veritable explosion of high density 'blok' projects in the central zone of Novi Beograd, mostly JNA-funded, highly variegated in architectural approach but featuring certain common elements, such as a Brasilia-like arrangement of open, columned ground floors including local shops, cafes and community facilities. (Mitrović 1975: 20-25; Mrduljaš and Kulić 2012: 297-8; interview D and M Marusić, 7 July 2014; Blagojević 2012: 232-40).

In 1977, the vertical culmination of Novi Beograd was built: Blok 33, or the 'Western Gate', matching Rudo on the East, designed by Mihajlo Mitrović and comprising two 32-storey office and residential towers crowned by a circular observation pavilion (140 m high) and linked by a high-level bridge, to form a 'gate' like image. By that stage, however, to the south-west, another, even more extreme phase of Novi Beograd was under construction, from 1971: blocks 61-64, comprising two parallel arrays of 40 stepped, clustered blocks of up to 20 storeys, all on a gigantic scale, filling four complete blokovi and containing 3,228 apartments - a concept hardly matched by anything in Moscow or Leningrad, let alone the Baltic states. The initial urban design concept was by architect Josip Svoboda, who claimed, rather quirkishly, to have been inspired by the traditional urban fabric of the Stradun, Dubrovnik's main pedestrian street. And right next door, to the south-east, was an equally extremist project: Blocks 44,45 and 70 , comprising a sea of nearly 90 tower blocks varying from 8 to 17 storeys, for higher income owner-occupation (Mrduljaš and Kulić 2012: 305-7; interviews D and M Marusić, 7 and 8 July 2014).

\subsection{Conclusion}

The flamboyant diversity of Novi Beograd vividly symbolised the pride and spectacle of Tito's Yugoslavia. All the more catastrophic, therefore, was the eventual decline and fall of the entire 'Yugoslav experiment', in the rampant inflation of the 1980s (peaking at $132 \%$ in 1986), which drained away the lending capital from enterprises' housing funds and foreshadowed the disintegration and civil war of the 1990s (Hegedüs et al. 2013: 280; Sillince 1990: 4, 22, 420).

And overall, the somewhat exaggerated policy fluctuations and spectacle-driven character ofmass housing in both Yugoslavia and Romania, however different from each other, both provide a vivid contrast with the Baltic republics, whose post-war housing may have lacked flamboyant fireworks, but instead, in the 1983 words of a 
group of Lithuanian architects, stressed 'the avoidance of grandeur and grandiosity, and a connection with nature'-in the process building up an enduring legacy for the post-socialist era (Drèmaitè 2017: 315).

\section{References}

Angermann K, Hilse T (2014) Altstadtplatten. BUV, Weimar

Architects' Journal (1967) Archit J 713-715. 22 March 1967

Architects' Journal (1967) Archit J 995-998. 26 April 1967

Balchin P (ed) (1996) Housing policy in Europe. Routledge, London

Bauakademie D (1968) Projekiert, Gebaut, Bewohnt. VEB Verlag für Bauwesen, Berlin

Bernhardt C (2005) Planning, urbanisation and urban growth in the socialist period. J Urban Hist 104-119. November 2005

Bernhardt C, Reif H (2009) Sozialistische Städte zwischen Herrschaft und Selbstbehauptung. Steiner, Stuttgart

Blagojević L (2012) The residence as a decisive factor. A\&U, XLVI 3-4:240

Branczik M (2012) Planning of standardised housing types in Hungary. A\&U 3-4:182-185

Branczik M, Keller M (2011) Korszerü lakás az óbudai kísérlet. Budapesti Történeti Múzeum, Budapest

Campbell JA, Hall JA (2015) The world of states. Bloomsbury, London

Ciolacu T (2015) Urban planning in Romania under the effect of Systematisation. In: DOCONF 2015 conference, October 2015. BME University, Budapest

Diener A (2012) Heimatgefühle im Pflasteblock. Frankfurter Allgemeine Zeitung, 16 August 2012

Donnison DV (1965) Housing policies in Eastern Europe. Trans Bartlett Soc 3:1964-1965

Drèmaitė M (2017) Baltic modernism: architecture and housing in Soviet Lithuania. DOM, Berlin

Dufaux F, Fourcault A (eds) (2004) Le monde des grands ensembles. Creaphis, Paris

ETH Studio Basel (2012) Belgrade, formal/informal. Scheidegger \& Spiess, Zürich

Ferkai A (2005) Housing estates. City Hall, Budapest

Fiedler T, Georgen M (2008) Die Geschichte der Deutschen. DTV, Munich

Friedrich J (2010) Neue Stadt in altem Gewand_-der Wiederaufbau Danzigs 1945-1960. Böhlau, Cologne

Gzell S (1995) Outline of postwar urban planning in Poland. Plan Hist 13(2):6-11

Hannemann C (1996) Die Platte. Vieweg, Braunschweig

Hannemann C (2004) Architecture as ideology: industrialisation of housing in the GDR. Humboldt Universität zu Berlin, Stadt-und Regionalsoziologie. Working papers 2A, January 2004

Hegedüs J, Lux M, Teller N (2013) Social housing in transition countries. Routledge, Abingdon

Hess DB, Hiob M (2014) Preservation by neglect in Soviet-era town planning in Tartu, Estonia. J Plan Hist 13(1):24-49

Honecker E (1981) Aus meinem Leben. Dietz Verlag, Berlin

Hryniewicz-Lamber G (2004) Late modern buildings in a historic town centre. In: DOCOMOMO-US, DOCOMOMO-international 2004 conference proceedings, New York, 2004, pp 275-281

Ionescu G, Derer P, Theodorescu D (1969) Arhitectura în România, perioada anilor 1944-1969. Editura Academiei Republicii Socialiste România, Bucharest

Jordan J (1967a) Industrialised building in Eastern Europe: German democratic republic. Arch J 677-680. 15 March 1967

Jordan J (1967b) Industrialised building in Eastern Europe: Czechoslovakia. Arch J 961-3. 19 April 1967

Kalm M (2002) Eesti 20. Sajandi arhitektuur. Sild, Tallinn 
Kalm M (2008) Is urban life in the countryside good? the central settlements of collective farms in the Estonian SSR. Kunstiteaduslikke Uurimusi 2008(4):61-87

Kedziorek A, Stanek $€$ (2012) Architecture as a pedagogical object. A\&U 46(3-4):252-262

Lankots E (2004) Classes in a classless society. Kunstiteaduslikke Uurimusi 2004(2):11-41

Lankots E, Söövati H (2008) ABC centres and identities of Mustamäe mikrorayons. Kunstiteaduslikke Uurimusi 4:88-116

Laurian R (1965) Urbanismul. Editura Tehnică, Bucharest

LeNormand B (2014). Designing Tito's capital — urban planning, modernism and socialism in Belgrade. University of Pittsburgh Press, Pittsburgh

Marin V (2011) Civil society and mass housing in post-communist Bucharest. In: DOCOMOMO conference, Edinburgh

Marmot AF (1981) Polish housing policies. Hous Rev

Metspalu M, Hess DB (2018) Revisiting the role of architects in planning large-scale housing in the USSR: the birth of socialist residential districts in Tallinn, Estonia, 1957-1979, Plan Perspect 33(3):335-361. https://doi.org/10.1080/02665433.2017.1348974

Meuser P (2015) Die Aesthetik der Platte. DOM, Berlin

Mitrović M (1975) Modern Belgrade architecture. Jugoslavija, Belgrade

Molnár V (2013) Building the state — architecture, politics and state formation in postwar central Europe. Routledge, Abingdon

Moravč́́ková H et al (2011) Bratislava Atlas Sidlisk. Slovart, Bratislava

Mrduljaš M, Kulić V (eds) (2012) Unfinished modernisations. UHA, Zagreb

Mumford E (2009) CIAM and the communist bloc. J Arch 14(2):239-241

Ojari T (2004) Floor space: the modernist residential housing ideology and Mustamäe. Kunstiteaduslikke Uurimusi 2004(2):42-70

Pugh E (2015) From national style to rationalised construction. J Soc Arch Hist 2015(3):87-108

Rietdorf W (1976) Neue Wohngebiete sozialistischer Länder. VEB Verlag für Bauwesen, Berlin

Sebestyén G (1965) Large panel buildings. Akadémiai Kiadó, Budapest

Sillince J (ed) (1990) Housing policies in East Europe and the Soviet Union. Routledge, Abingdon

Topfstedt T (1996) Die nachgeholte Moderne. In: Dolff-Bonekämper G, Kier H (eds) Städtebau und Staatsbau im 20. Jahrhundert. Munich 42-8

Tsenkova S (2009) Housing policy reforms in post-socialist Europe. Physica, Heidelberg

Urban F (2009) Neo-historical East Berlin. Ashgate, Farnham, 2009:5, 249, 259

Urban F (2011) Tower and slab. Routledge, Abingdon

Wynn M (ed) (1984) Housing in Europe. Croom Helm, London

Zahariade AM (2011) Arhitectura în proiectul comunist: România 1944-1989. Simetria, Bucharest Zarecor K (2011) Manufacturing a socialist modernity. Pittsburgh University Press, Pittsburgh

Zarecor KE (2017) What was so socialist about the socialist city? J Urban Hist 2017:9

Open Access This chapter is licensed under the terms of the Creative Commons Attribution 4.0 International License (http://creativecommons.org/licenses/by/4.0/), which permits use, sharing, adaptation, distribution and reproduction in any medium or format, as long as you give appropriate credit to the original author(s) and the source, provide a link to the Creative Commons license and indicate if changes were made.

The images or other third party material in this chapter are included in the chapter's Creative Commons license, unless indicated otherwise in a credit line to the material. If material is not included in the chapter's Creative Commons license and your intended use is not permitted by statutory regulation or exceeds the permitted use, you will need to obtain permission directly from the copyright holder. 
Part III

Housing the Masses: Establishing Socialist-Modernist Housing Estates in the Baltic Countries 


\title{
Chapter 7
}

\section{Architectural Transcendence in Soviet-Era Housing: Evidence from Socialist Residential Districts in Tallinn, Estonia}

\author{
Daniel Baldwin Hess $(i)$ and Pille Metspalu
}

\begin{abstract}
In Central and Eastern Europe and the Former Soviet Union, housing estates are often associated with inhumane architecture, unwelcoming public space and unending repetition, outcomes that have been attributed to strict design requirements in a rigid centralised system. Due to the uniformity and standardisation of residential housing produced during socialist times, both the design process and its master - the architect - are believed to have played only minor roles in shaping townscapes. This study, situated in the large housing estates of Tallinn, Estonia, challenges these assumptions using analyses of archival material. The study also explains - through first-hand interviews with senior architects who were key players in building socialist cities - the relations between strict Soviet regulations and vital elements of the city building process, including creativity, power and artistry. Analysis of primary source materials highlights an oversimplification of socialist modernism, which suggests more nuanced explanations for town planning outcomes that differ from what strict adherence to Soviet guidelines would have produced. Findings also suggest that regulations issued in Moscow for USSR-wide site planning played a less important role than previously assumed in town planning outcomes in Estonia. International modernist city planning ideals, combined with local expertise (and a willingness to push boundaries yet remain within the political system), strongly influenced town planning practice in the Soviet 'West'.
\end{abstract}

Keywords Architecture - City planning - Housing estate - Mikrorayon •

Modernism • Socialism • Soviet Union • Tallinn, Estonia • USSR

D. B. Hess $(\square)$

Department of Urban and Regional Planning, University at Buffalo,

State University of New York, Buffalo, NY, USA

e-mail: dbhess@buffalo.edu

P. Metspalu

Centre for Migration and Urban Studies, University of Tartu, Tartu, Estonia

e-mail: pille@hendrikson.ee

(C) The Author(s) 2019

D. B. Hess and T. Tammaru (eds.), Housing Estates in the Baltic Countries,

The Urban Book Series, https://doi.org/10.1007/978-3-030-23392-1_7 


\subsection{Introduction}

State socialism provided unique opportunities to experiment with new models of city planning. Centrally planned systems - and government ownership of all land and industry - permitted a grand-scale approach to urbanisation and a mechanism for promoting rational use of human and industrial assets, improving lives and reducing costs. Through central planning, state socialist governments sought to reorder society and plan new urban territory during rapid urbanisation, industrialisation, employment-driven migration and military consolidation (Domański 1997; Ericson 1988; Hess et al. 2018; Ofer 1977; Shomina 1992). Much power resided in central government decision-making. With land in state ownership, the development process occurred under central authority, and a powerful single-party system controlled land development decisions to promote the expansion of industrial strength and military might.

Vast housing estates - residential complexes dominated by high-rise block apartment buildings - were established between the 1960s and the 1990s to respond to crushing demand for urban housing due to employment-based migration triggered by industry and military expansions. They were critical components of modern, planned cities for housing socialist lives in industrial-utopian centres (Gentile et al. 2012; Kovács and Herfert 2012; Power 1997; Wassenberg 2004). Architects charged with planning new housing estates had great power to shape cities, demonstrating that city planning was a centrepiece of central economic planning (Liepa-Zemeša and Hess 2016).

The peculiarities of town planning (and resulting urban form) during state socialism have intrigued scholars for decades. A number of contemporary studies have retrospectively critiqued socialist urban systems, particularly policies leading to the formation of mikrorayons, or comprehensively planned residential districts composed of standardised buildings (Hatherley 2015; Lizon 1996; Stanilov 2007; Turkington et al. 2004; Wassenberg 2004). While previous research has highlighted the role of central planning and socialist principles in shaping modernist housing estates that are prevalent throughout Central and Eastern Europe (CEE) and the Former Soviet Union (FSU), this chapter, drawing upon on first-hand information gained from interviews with architects from the socialist period, reconsiders several dogmatic notions about urban planning under socialism. We argue that positioning local architects as mere executors of higher political commands controlling city planning oversimplifies the formation of modernist housing estates in socialist cities. Our findings suggest more powerful western influences on large housing estate design than previously assumed and demonstrate the existence of independent architectural thought in the Baltic republics.

The chapter is organised as follows. The following sections describe the socialist framework for city planning that produced mikrorayons as a novel urban form. We synthesise the contemporaneous urban planning system and the role of socialist architects, and we conduct a detailed empirical analysis of three residential districts in a capital city in the former Soviet space. We distil from the analysis key themes 
related to contact that facilitated knowledge acquisition about international modernism and the role of architects in the Soviet city building process. Our concluding thoughts emphasise how, contrary to conventional wisdom, architects had more power than the Soviet system suggests and were able to embrace opportunities to create unique building environments.

\subsection{Mikrorayons: Centrepieces of Socialist Urban Form}

During the Soviet era, city planning was part of the production process. Egalitarianism and a lack of differentiation across urban space were driving objectives; no residential area should be more appealing than any other because of style, size or location (Hausladen 1987). Equality, a key ideological feature of socialist residential planning, was vigorously expressed in Soviet housing estates and mikrorayons through predefined and universal maximum (walking) distances to schools, bus stops, shops and parks. Everyone was, in theory, meant to have comparable access to comparable assets and amenities. The architectural ensembles composing mikrorayons and residential housing estates were meant to be socialist modernist and, owing to influences from Le Corbusier, free from historical references (Berman 1982; Boyer 1994; Charley 2004; Zhuravlyev and Fyodorov 1961). As a result, many projects denied their immediate context, instead of relying on serial implementation of predetermined standardised forms (Choay 1970).

The first apartment houses built using prefabricated panel walls (in the 1960s) took advantage of industrial production to orchestrate residential building more cheaply. This was followed by improved standard designs, introduced in the USSR in the mid-1970s and used widely by the 1980s (Andrusz 1987; Meuser and Zadorin 2016). Each housing unit included 'modern' conveniences-kitchens, washrooms and toilets, central heating, large windows. As the design process matured and mechanisms within it advanced during subsequent iterations, the height of residential buildings increased and the size of individual dwelling units expanded (Lehmann and Ruble 1997; Smith 1996).

Considered to be a highlight of modern city planning, enormous housing estates included apartments (at high density, in standardised high-rise blocks) with modern conveniences in mixed-use settings containing schools, everyday services, day care, and recreational and socialisation opportunities. Usually, one housing estate consisted of several mikrorayons, which were designated by central authority according to housing requirements that were calculated proportional to the needs for workers in enterprises. Site selection for large housing estates was usually designated in general town plans prepared for up to 25-year horizons.

Within new residential districts, site planning was conducted at the district or mikrorayon level with detailed planning projects that were magnificent in size and comprehensive in scope, covering street networks, architectural elements, access and transport and greenery (Port 1969). Strict norms dictated the living space that was allowable for each family, and housing units were allocated according to need 
(based on family size) with rent computed proportional to income (with large state subsidies).

\subsubsection{The Role of Socialist Architects in City Planning}

Important decisions about urban growth and housing policy occurred at high levels in the USSR, and local authorities were involved in mundane decisions, primarily in site selection for new housing districts that were prescribed by Soviet administrators (Tosics 2004).

City planning in USSR republics - and especially the addition of vast residential housing estates - was firmly based on administrative norms and instructions issued by supervising authority and directed by the communist party. Trained architects undertook all city planning duties. General plans and detailed plans for mikrorayons were, as a rule, prepared by professional teams whose members possessed various backgrounds (engineers, traffic specialists, landscape architects, etc.).

Soviet density norms became instruments of town planning and predefined access to workplaces, services, and recreational facilities and the distribution of funds for construction (Yanitsky 1986). Standard high-rise apartment block designs developed in Moscow were adapted locally in state design institutes (Bunkśe 1979; interview with J. Lass, 2016). Through site design in particular, architects created an ensemble - composed of residential buildings, service structures, pathways and roads, and open space - that forms the long-lasting effect of mikrorayons on urbanisation. Local governments were only partly in charge of the location and site design of housing estates (the level of control differed depending on the city or the sister republic) (interview with J. Lass, 2016). Such weak contributions to city planning have often been described in scholarly literature as follows: 'the majority of the housing units were prefabricated apartment blocks, and the architect's role was reduced to site planning for a limited number of housing types' (Lizon 1996, 106). Given the large number of inarguable directives to be followed in city planning under socialism, it was suggested that 'the discipline of urban planning has abolished itself in favor of fulfilling guidelines' (Meuser and Zadorin 2016, 145). It is likewise argued that, throughout the Soviet Union, 'since the building forms of the standard designs were predetermined, this meant that the urban design concept was greatly diminished to the extent of fulfilling guidelines' (Meuser and Zadorin 2016, 153).

The actual power resting within the hands of local architects is consequently debatable, since the state suggested the location for residential space, dictated its volume, and furnished land and financing (Meuser and Zadorin 2016). This notion has been periodically captured in scholarly literature: 'architects, as employees in mammoth state design offices, had no say in the actual design and were reduced to draftspeople whose role was to draw site plans of the predesigned blocks of slabs and point towers to house a maximum number of residents picked from long waiting lists and crowded into a cookie-cutter housing estate' (Lizon 1996, 109). 
Second- and third-generation standardised apartment towers were designed to be sectional and interchangeable and could be assembled in various forms but always in large quantities (Meuser and Zadorin 2016); the requirements for standardisation and prescribed repetition itself implies modest emphasis on artistry and individuality. However, with a fast-paced and vast expansion of housing supplies in cities of CEE and the FSU, architects who planned modernist housing estates had great power to shape city form, and their effects have been long lasting, since few residential districts have been demolished or significantly changed and most are fully occupied.

\subsection{Research Strategy}

To explore the role of architects in practice, we turn to primary sources from the 1960s, 1970s and 1980s to gather key decision-making information about the formation of residential districts in Tallinn, Estonia (Metspalu and Hess 2018). We use official planning documents and, importantly, semi-structured interviews with critical informants. Personal interviews carried out in Tallinn and Tartu with senior architects (D. Bruns, Tallinn Chief Architect, 1960-1980; I. Raud, Eesti Projekt, 1969-1989 and Tallinn Chief Architect 1989-1991; O. Zhemchugov, Eesti Projekt, 1970-1977; J. Lass, Estonian State Building Committee, 1982-1990; R. Kivi, Eesti Projekt, 1969-1972 and Tartu Chief Architect 1972-1991; P. Männiksaar, Architect, Tartu District Executive Committee, 1981-1993), now at the end of their professional careers, give us access to their observations which seldom appear in written form because of censorship during Soviet times. Primary source interviews and review of archival documents-plans and planning documents, including original protocols and memos and contemporaneous newspaper and magazine articles - allow us to assemble a meaningful picture of planning practice related to large socialist housing estates. We also review various materials published in Estonian Socialist Republic newspapers and weekly magazines.

\subsection{An Ensemble of Mid-Twentieth Century of Housing Estates in Tallinn, Estonia}

The socialist industrialisation process was accompanied by fast urbanisation throughout the USSR and particularly in the Baltic states, the western periphery of communism. Due to various factors shaping socialist urbanisation (Bater 1980; French 1987, 1995; Lewin and Elliott 2005), cities in the Baltic States are uniquely preserved. Apart from certain scholarship about Lithuania (Dremaite 2013; Rimkutè 2014; Maciuika 1999), a lack of reliable written material exists about state socialist residential planning theory as implemented in planned developments in the Baltic States. 
As a site for our empirical inquiry, we select Estonia, the smallest of the three Baltic States, where there is comparatively less literature on residential housing formation than in other parts of Europe (Kährik and Tammaru 2010). During the Soviet occupation, several hundred thousand Russian speakers emigrated to or were settled in Estonia, and all Estonian cities experienced population growth between 1944 and 1991 (Tammaru 2001; Kulu 2003). In the 1950s and subsequent decades, there was strong demand for new housing in Estonia, especially in the capital city Tallinn, as Estonians moved from the countryside to towns and Russian-speaking immigrants arrived to support various USSR enterprises. During Soviet times, approximately $76 \%$ of housing units in Tallinn were state-subsidised rental units (a higher share than elsewhere in CEE) and by the end of Soviet occupation, about two-thirds of the population lived in large prefabricated housing estates (Kalm 2002). Each city in Estonia had a master plan, which reserved space for future detailed site planning (Bruns 2007; Port 1983; interviews with R. Kivi, 2013; P. Männiksaar, 2013).

Today, housing estates in Tallinn offer bold visual symbols of the socialist past. Prefabricated panel buildings do not suffer from a bad reputation and have not experienced ghettoisation predicted following the dissolution of the Soviet Union (Sild 2014; Szelényi 1996). However, official policy within the housing sector sometimes reinforced social separation and exclusion (Hess et al. 2012; Leetmaa et al. 2015). Housing in mikrorayons is often unpopular, and many families are driven by a desire to escape the drab environments of Soviet-era housing estates and relocate when possible to new or renovated upscale dwellings or detached homes in the growing suburbs (Tammaru et al. 2009).

In Tallinn, three large mikrorayon-based residential districts-Mustamäe, VäikeÕismäe and Lasnamäe-were constructed successively and at comparable distances from the city centre (see Fig. 7.1). The districts depict an evolution of town planning ideology during the Soviet decades and reflect a maturation of the mikrorayon concept and requirements for larger per person living space in apartments (Andrusz 1987).

\subsubsection{Mustamäe: A Cautious Test of Socialist Residential Planning Principles}

To liquidate the housing shortage in an optimistic period of 10-12 years, the communist party launched an ambitious housing construction programme in the USSR in 1957 (Bruns 2007). Following directives from Moscow, site selection for the first large housing estate in Tallinn was immediately initiated.

The winning design by T. Kallas, M. Port and V. Tippel served as a guiding conceptual plan for Mustamäe (Tammaru et al. 2009) (see Fig. 7.2). In 1959, the plan was elaborated in a detailed planning project in which key planning principles -mikrorayons composed of large residential building blocks and schools, kindergartens, shops within walking distance-were for the first time expansively 


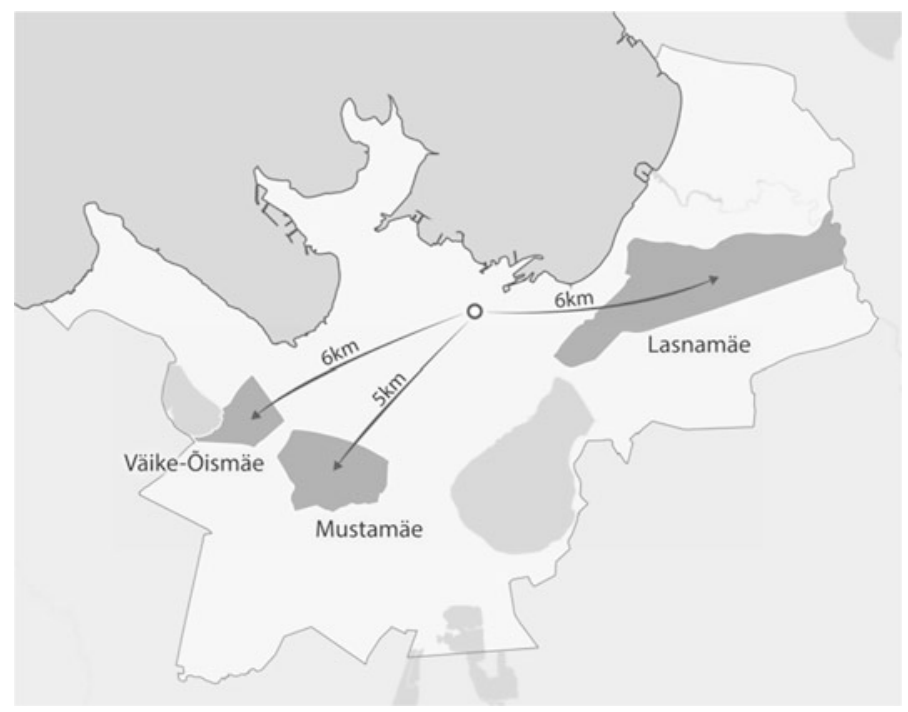

Fig. 7.1 Location of large housing estates in Tallinn, Estonia

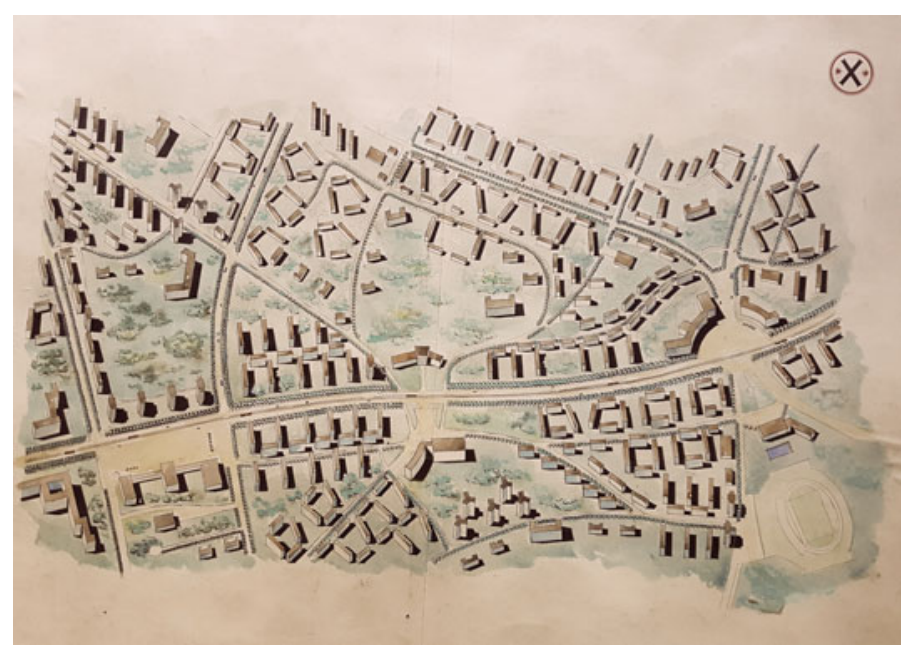

Fig. 7.2 Mustamäe architectural competition entry by Group X. Original drawing, 1958. Source Museum of Estonian Architecture, used with permission

realised in Estonia (see Fig. 7.3). Later, in the 1960s and 1970s, new detailed planning projects were compiled to provide additional residential space in Mustamäe for Tallinn's rapidly increasing population.

The plan offers the first attempt in Estonia at free-form planning, considered novel at the time, in which large residential buildings are distributed freely and do 


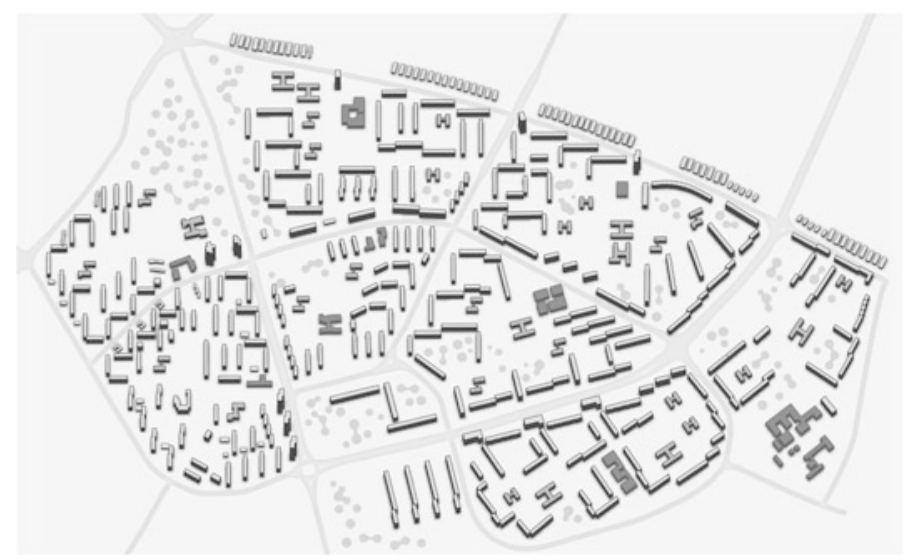

Fig. 7.3 Mustamäe concept plan, 1959. Source Drawing by S. Samuel (2016) based on original plans

not follow traditional street rights-of-way, producing more sunlight and open space between buildings (Estonprojekt 1959). A number of features in the planning concept can be identified as characteristic of Finnish and Swedish modernist residential planning, where building blocks are harmoniously attuned with surrounding landscapes. Foreign influences in city planning can be attributed to the Khrushchëv thaw (McCauley 1995; Peirumaa 2004), which made possible organised study trips for Baltic professionals to capitalist countries and limited distribution of international city planning and architectural literature. More than half of the members of the Estonian Architects' Union visited Finland during the 1960s, following an inaugural trip in 1957, coinciding with the formation of concepts for Mustamäe (Dremaite 2013; Kalm 2002). Architects who had the chance to visit capitalist countries openly popularised western ideas upon their return by writing articles and columns in newspapers.

Adhering to a density norm of $9.5 \mathrm{~m}^{2}$ per inhabitant, the total residential space in Mustamäe was $538,000 \mathrm{~m}^{2}$, embodied in 9 mikrorayons. A majority of buildings $(88 \%)$ were five storeys high and a small share $(4 \%)$ was high-rises. Within every mikrorayon, several elementary schools and one high school (or gymnasium) were planned; in addition, two cinemas, a library, hospital, four canteens, a restaurant and four saunas were required. Shops and service centres (hairdressers, laundry, etc.) within so-called $\mathrm{ABC}$ centres were evenly distributed within a radius of $500 \mathrm{~m}$ of residences. Greenery was preserved in a surrounding forest park, and each mikrorayon included sports facilities and playgrounds. A network of pedestrian paths connecting major destinations was carefully planned. Public transport played an important role; in addition to trolleybuses and buses, a tram was planned, and the location of stops was integrated with the pedestrian network. Garages and shops were designed in the proximity of major thoroughfares to avoid heavy traffic in mikrorayon interiors. Commercial and community centres, with various attractions (including dance halls, fashion studios and sports centres) were planned as 
organising foci in the southern part of the district at the intersection of major radial thoroughfares. The plan stresses unique designs - avoiding standard Soviet projects - for important community assets like a cultural centre, department store, market hall and hotel.

The construction of Mustamäe occurred between 1962 and 1973. Major shortcomings in the operation of the district appeared when certain features were not built, including a centrally located business and community centre and several 16to 22-storey tower blocks. A lack of recreational facilities, greenery development and landscaping were evident immediately after construction (Port 1969).

\subsubsection{Väike-Õismäe: Aerial Architecture in a 1970s Makrorayon}

A detailed planning project for Väike-Õismäe was completed in 1968, overseen by architects M. Port and M. Meelak, and a redevelopment enhancement plan was subsequently issued in 1974, adding services and amenities (but none were actually built).

According to Soviet building regulations, the area should have originally been divided into three or four mikrorayons. However, during the detailed planning project, several alternative solutions were proposed (see Fig. 7.4) which disregarded the central principles of mikrorayon formation and abolished the strict population normative. In the end, the architectural team courageously devised a novel makrorayon approach instead:

'The makrorayon concept evolved quite unexpectedly when we tried to avoid the usual shortcomings of a traditional mikrorayon-based approach. The main logic is quite simple: the street is fringed with buildings on both sides, radial avenues are unneeded, the traffic operation scheme is more simple, and the required street length is halved. To avoid monotony, the buildings are grouped in various combinations; 9-storey buildings are interspersed with "freely placed" 16-storey highrises'. (Port 1969, 35-37)

The district was planned as a makrorayon with a compositional focus on a broad encircling street, which was, characteristic to socialist-modernist urban form, impressive when viewed from above (see Fig. 7.5) (Hess 2017). The outer parts of the oval contained mostly five-storey buildings and the inner part mostly nine-storey buildings (with occasional 16-storey high-rises) (Port 1969) (see Fig. 7.6). The circular layout is punctuated by an artificial lake at its core. Schools and childcare centres are situated symmetrically around the centre. Due to natural circumstances (location on a limestone plateau), green space is restricted in size. According to the plan, the total residential space is $357,000 \mathrm{~m}^{2}$ for 37,750 occupants [adhering to a density norm of $9.5 \mathrm{~m}^{2}$ per resident (initially) and $12 \mathrm{~m}^{2}$ (after full implementation). Car parking spaces were planned for 5,050 vehicles (norm of 170 cars per 1,000 people). Following the norms, 75 groceries and 12 shops for 


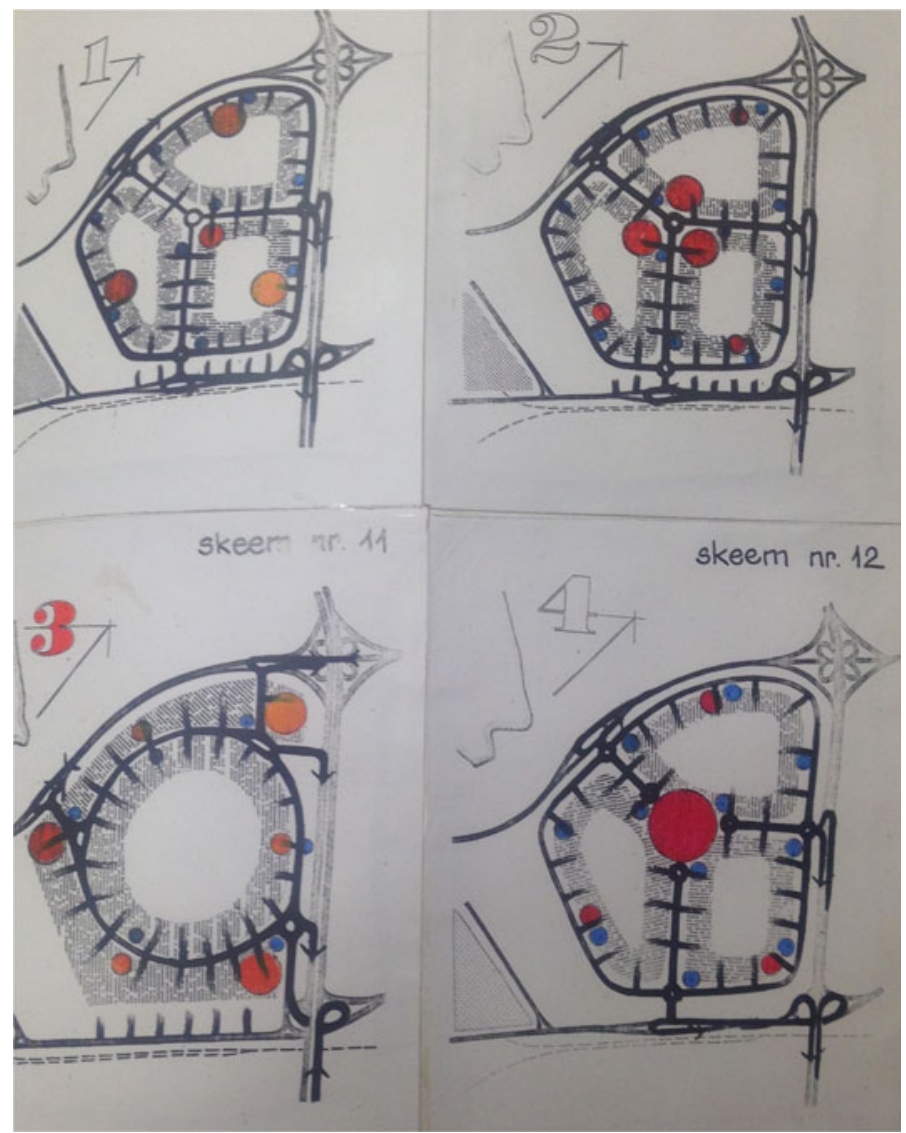

Fig. 7.4 Original drawings for Väike-Õismäe detailed planning project, 1968. The drawings represent alternative transportation network schemes; option 3 , which configures the district as a single makrorayon, was the selected option. Source Tallinn City Government Archives, used with permission

other goods were planned, as well as 3 canteens, 30 beauty salons and community centres. Only $25 \%$ of these planned services were ultimately built.

Construction of the Väike-Õismäe makrorayon began in 1973. Despite the fact that in Väike-Õismäe, USSR building regulations were creatively interpreted-for example, a single makrorayon instead of three mikrorayons, pedestrian crossings not separated from vehicles, etc. - the architectural team was awarded the Prize of Architecture of the USSR Council of Ministers in 1976 (Port 1983). Some parts of the original plan were never implemented (such as large communal car parks between dwelling groups). Deficits in shops and services were severe: only three grocery shops were built, which resulted in constant queues, and only two of three planned community centres were constructed. 


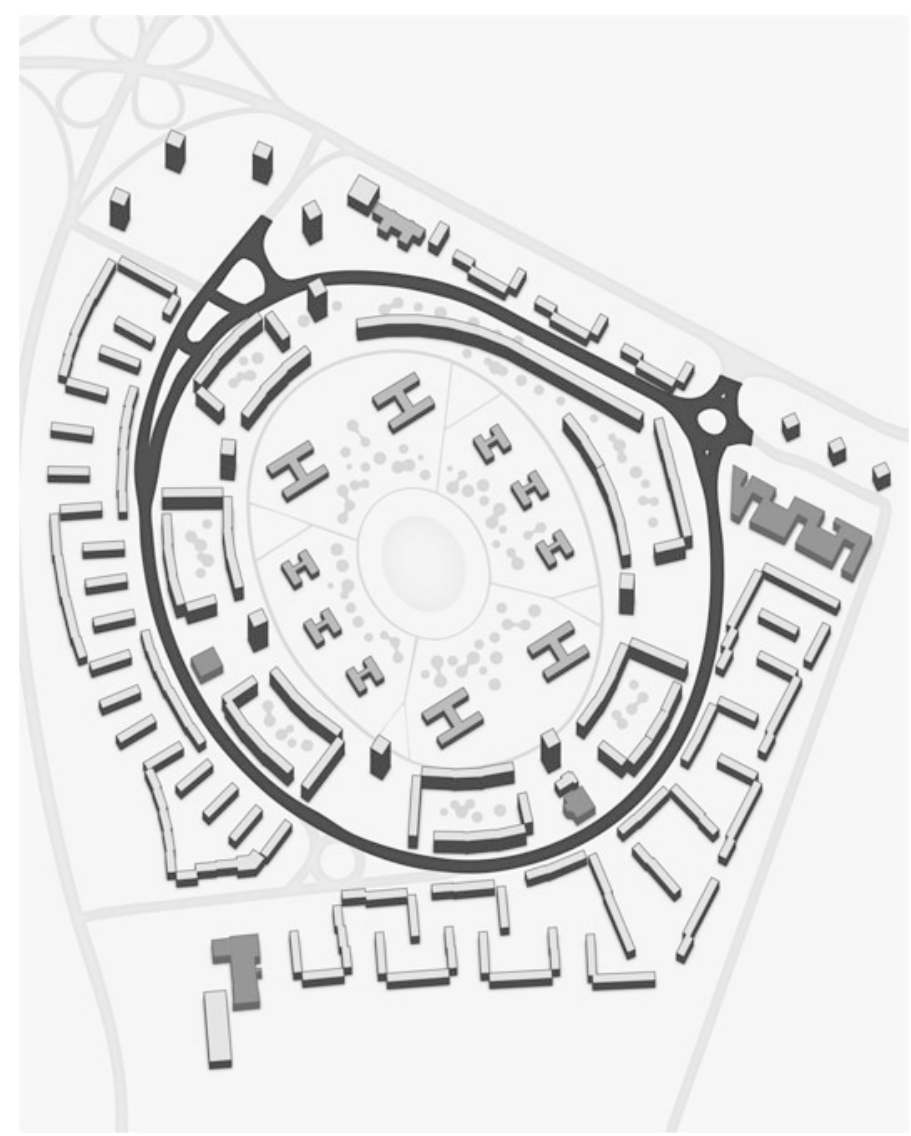

Fig. 7.5 Väike-Õismäe concept plan, 1968. Source Drawing by S. Samuel (2016) based on original plans

\subsubsection{Lasnamäe: Soviet Megalomania, Built to Only Half Completion}

An all-union design competition for Lasnamäe, an enormous residential area, took place in 1969 (Port 1983). The winning design (one of four submitted) produced by M. Port, M. Meelak, O. Zhemchugov, H. Karu and R. Võrno became the basis for the detailed planning project prepared in 1970 by the State Planning Institute Eesti Projekt (see Fig. 7.7). In 1979, an updated general plan was issued to increase residential densities and provide better connections to neighbouring industrial zones.

The guidelines issued by Tallinn City officials and prepared by the city architect's office in 1970 established additional principles for detailed planning: the general structure should be based on makrorayons (25,000 to 30,000 inhabitants) 


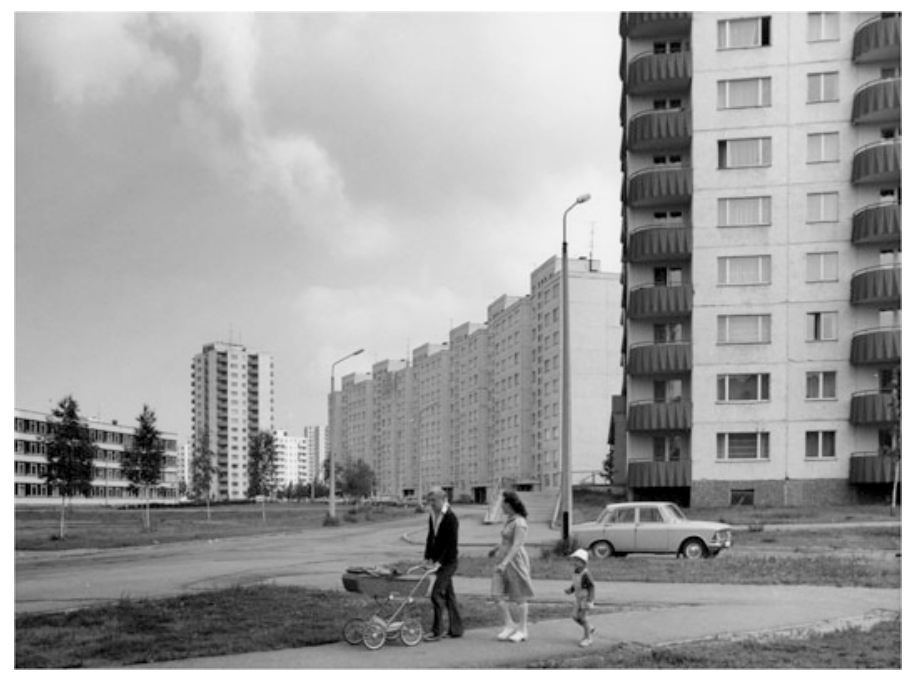

Fig. 7.6 Graceful curves in Väike-Õismäe, Tallinn, Estonia. Photo by Johannes Külmet. Source Museum of Estonian Architecture, used with permission

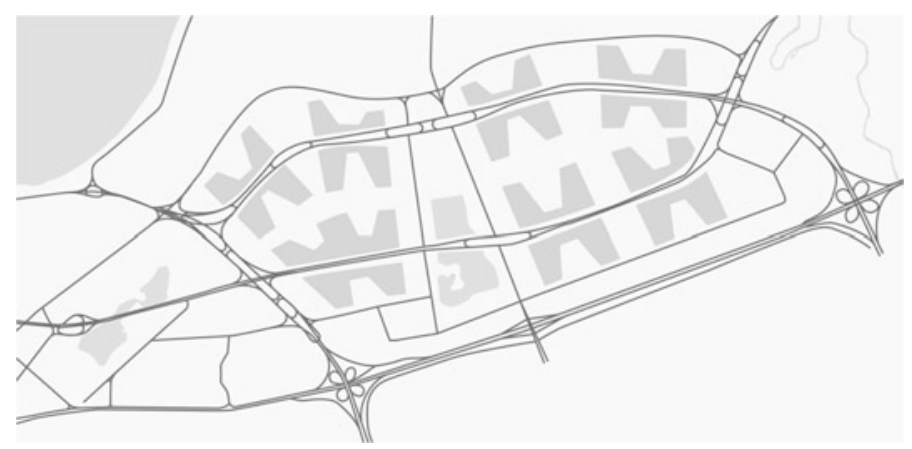

Fig. 7.7 Lasnamäe concept plan, 1970. Source Drawing by S. Samuel (2016) based on original plans

with administrative and business centres; residential building arrangements should form inner courtyards for wind protection; expressive exterior 'gateways' should be composed; buildings of citywide importance should be included and a pedestrian esplanade should top the limestone cliff (see Fig. 7.8) (Eesti Projekt 1970). The backbone of the detailed plan included two key east-west thoroughfares, one of them sunken (7 $\mathrm{m}$ deep), making possible flyover bridges and permitting higher traffic speeds below while enhancing safety for pedestrians (Hess 2017). Pedestrian precincts were planned as landscaped boulevards planted with trees, running parallel to the motorways and crossing the traffic lanes via footbridges near community centres and parking lots (see Fig. 7.9). All community centres adjoin pedestrian 

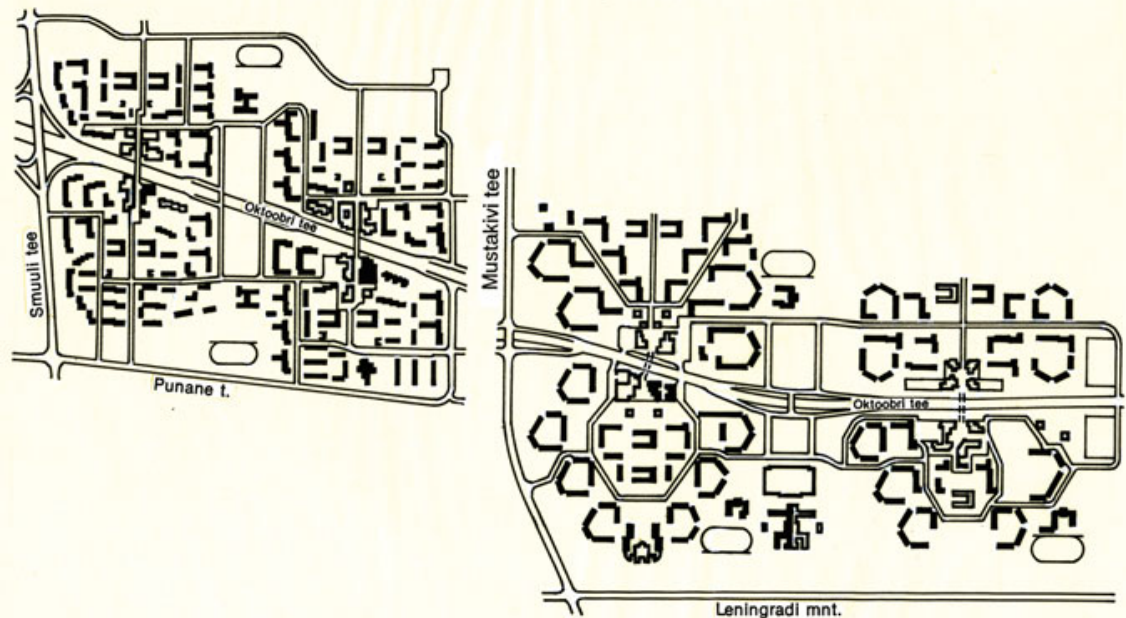

Fig. 7.8 The plan for a housing estate at Lasnamäe (Tallinn, Estonia) centres on four Mikrorayons. Source Museum of Estonian Architecture, used with permission

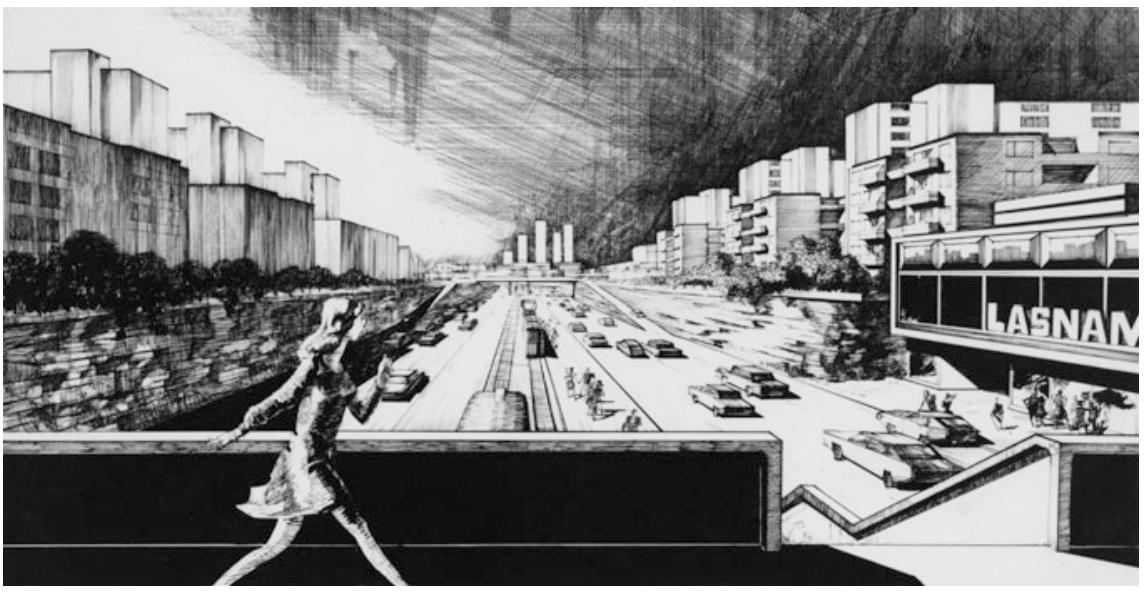

Fig. 7.9 A sketch of a pedestrian overpass providing access to the commercial centre of Lasnamäe, Tallinn. Source Museum of Estonian Architecture, used with permission

streets. In addition to five large sports halls, a cultural-memorial centre was planned on the edge of the limestone cliff. Housing is concentrated around the centres within a radius of $500 \mathrm{~m}$. Each mikrorayon has a population of 12,000 to 16,000 inhabitants. The large-panel houses have mostly 5, 9 or 16 storeys. Two- and three-storey row houses and 22- to 24-storey towers are included (Port 1969). The total planned residential area exceeded 3.9 million $\mathrm{m}^{2}$ (adhering to a density norm of $22.5 \mathrm{~m}^{2}$ per capita). 
Estonian housing estates and Finnish housing estates (such as Tapiola and Pihlajamäki) share elements of Finnish modernism (Dremaite 2013). However, Scandinavian modernism and Finnish and Swedish orientation are not easily traceable in the Lasnamäe planning scheme. The cosiness characteristic of Scandinavian new towns that, according to one expert (interview with $\mathrm{O}$. Zhemchugov, 2013), should have been expressed in Lasnamäe (through high-rise building blocks arranged to form inner courtyards) was lost due to the enormous scale of the housing estate.

One-third of the planned apartment houses in Lasnamäe (mikrorayons IX-XII) were not constructed; the spatial structure of the largest housing estate in Tallinn is functionally incomplete because the commercial centre of the district was never built (nor was the cultural-memorial centre). As usual, there were shortcomings in providing recreational facilities and shops, and greenery and parks are almost non-existent. The transport facilities essential for commuting are remarkably inadequate, as the high-speed light rail originally planned in a sunken motorway was not built.

\subsection{Challenges and Opportunities in Large Housing Estates in Soviet Estonia}

Two key themes emerge when we synthesise the findings of our detailed discussion of Tallinn's three large socialist housing estates. First, we demonstrate how international modernist ideals inspired local architects - to a greater extent than previously recognised-and influenced the development of housing estates in Soviet Estonia. Second, we explore the powerful role in Soviet Estonia-which perhaps departed from the norm in USSR republics - of local architects in town planning practice as revealed by first-hand accounts.

\subsubsection{International Knowledge Inspires Architects of Large Housing Estates}

Estonia's geographic position on the western periphery of communism (or 'inner abroad' in the USSR) made possible the preservation of close relations with neighbouring capitalist countries. Finnish and Swedish influences are consequently evident in city planning and architecture of the day in Estonia (interviews with D. Bruns, 2013; I. Raud, 2016) and international modernist ideas from the western world played an important role, too, in the design of large housing estates (interview with D. Bruns, 2013; O. Zhemzhugov, 2013). An adherence to modernist ideals can be detected in the 'clean sweep' urban development method-entailing 
the complete demolition of existing semi-urban space in order to build something new and boldly different-heretofore untested in Estonia (Hess and Hiob 2014).

Our findings suggest that the city planning system in the Soviet Union was not as controlled as previously assumed. The 1950s Khrushchëv thaw-often referred to in hindsight as a 'brilliant failure'-transformed certain aspects of the Soviet system (but not the system itself) and was highly significant for city planning (McCauley 1995). Liberalisation of state and foreign politics in the USSR influenced all aspects of life, including cultural landscapes (Peirumaa 2004). In the Baltic countries (and other USSR republics, although due to proximity and similarities in language, Estonians were perhaps more likely to participate), official study trips to Finland and Sweden were the manifestation of fostering international connections (and for Estonians, perfectly timed with concept development for Mustamäe). The trips became more frequent when, in 1965, direct ferry connection between Tallinn and Helsinki was restored (Kalm 2002). Upon return from the study trips, Estonian architects published articles about their experiences and impressions (in both public media and in professional outlets) in surprisingly candid ways, frequently debating the possibilities for urban planning practice and critiquing the planning of large residential districts. During the Khrushchëv period, social contacts with war-emigrant Estonians (mostly in Sweden and Germany) were enabled, permitting information from abroad to be easily delivered through family connections. An official slogan of the socialist system-'learning from the mistakes of capitalist countries'-was given special meaning in the way professional architectural knowledge was openly developed from foreign books and magazines (Eesti Projekt 1968). While the atmosphere of censorship was strict in the USSR, inhabitants of the northern part of Estonia were able to receive Finnish television signals, due to physical proximity, readily granting them exposure to visual depictions of modern cities and residential spaces across the Baltic Sea. For these reasons, we argue that Estonia is distinctive among the sister republics for its outward connections and influence and offers an intriguing array of interrelated modernist residential planning approaches.

Orientation towards Estonia's northern neighbours was a conceptual tendency in Estonian architecture and city planning that usurped the standard design models of the USSR (Kalm 2002) and encouraged 'Baltic exceptionalism' in architecture and city planning (Dremaite 2017). Compared to architectural design of individual buildings, the influence of Finnish and Swedish town planning innovation on site planning for large housing estates is more difficult to trace. The vast scale of socialist housing estates in Soviet Estonia amplified the drabness of the districts and at the same time diminished the comforting features of Scandinavian modernism, like natural terrain emphasis and use of existing trees to create 'tower in the forest' settings for new housing blocks.

However, parallels between the layout of housing estates in Estonia (from the Soviet years) and contemporaneous Nordic city planning can be easily detected from our analysis of original planning documents and statements made by chief architects of the plans (Kalm 2012; interviews with D. Bruns, 2013; I. Raud, 2016; O. Zhemchugov, 2013). This was unique in the USSR, although it was matched to a 
certain degree in Latvia (in Āgenskalna priedes in Riga) (Kalm 2002) and Lithuania (in Lazdynai in Vlinius) (Dremaitè 2013; Rimkutè 2014) and to some extent, in Russia. Both Estonian and Lithuanian housing districts received awards from all-Union architectural and planning competitions (Bruns 2007; Dremaitè 2013; Port 1983) and Estonia and Lithuania were the only republics that regularly fulfilled new housing construction quotas required by Soviet authorities in Moscow (Pesur 2003).

The design of Lithuania's Lazdynai, which, like the housing estates in Estonia, pushed the boundaries of Soviet design-and, in some senses, composed in opposition to a standard Soviet mass housing scheme-was later heralded by the communist party for its socialist design excellence (Dremaite 2010).

\subsubsection{Architects in Estonia Maintain a Consistently Strong Role in Town Planning Practice}

Since architectural education began in Estonia in the 1920s, local professional architects had gained several decades of experience prior to the socialist era. Estonia was one of the few republics in the FSU that preserved an independent site-planning design capability in its state planning and design apparatus (Eesti Projekt, EKE Projekt, Tööstusprojekt, Kommunaalprojekt), a practice that can be traced to a mature architectural tradition dating from the early twentieth century (interview with J. Lass, 2016). Professional self-awareness combined with institutional powers granted by the new regime encouraged Estonian architects to take an active role in city planning under state socialism. In other republics of the Soviet Union such as Belarus and Kazakhstan (interview with J. Lass, 2016), architectural and city planning were designed and implemented from central headquarters in Leningrad or Moscow (using only standard building and district designs), with virtually no involvement with local or national experts (Rimkute 2014; Ruseckaite 2010). Consequently, architects in Estonia maintained a considerable voice in shaping cityscapes. City planning practice in Estonia was thus not based solely on reproduction of centrally formulated urban design models or economically efficient engineering but was developed locally under the leadership of skilled Estonian architects. In municipal governance, an architectural department and architectural advisory board were important bodies, largely comprised of architects, and architectural commissions reviewed plans and projects issued by state planning and design institutes.

A strong tradition of architectural competitions in Estonia, originating in the 1930s, continued throughout the Soviet occupation, generating unique designs for significant buildings and site planning for new residential districts (Lapin 1981; Port 1983). As a result, a non-Soviet international influence is highly apparent in Estonian plans for large housing estates, a phenomenon that can be attributed, at least in part, to western knowledge and information about city planning from 
international sources. Notably, foreign architectural magazines were used in universities as teaching materials. Similar phenomena are recognised in Lithuania, where Dremaite argues that modernist aesthetics and western-oriented ambitions of Baltic architects were reflected during Soviet times in mass housing as architects sought to modernise cities and also declare their membership in an international cadre of modern architects (Dremaite 2010). We thus find support for a 'westward gaze' (Maciuika 1999, 23) among architects in Estonia, matching a pattern in the Baltics, as an expression during Soviet times of national and cultural identity.

This research confirms significant roles for bold and daring local architects in the Baltic republics in planning and designing large socialist housing estates. In the FSU, town planning was recognised as a critical function since it ensured the propagation of socialist ideology by translating collectivism to urban built environments which would endure. Our interviews with key architects of socialist housing estates revealed that clever interpretation of the norms and guidelines was required for architects to achieve a specific vision, and that experience and confidence helped architects to perfect the practice of creative interpretation of Soviet dicta. Architectural and planning officers in State Building Committees were known to avoid the commands of power, when possible, while working earnestly to improve the social space of cities (Oja 2009).

Our detailed investigation of mikrorayons in Tallinn demonstrates that professional architects were represented in almost all levels of official decision-making in town planning processes that produced large housing estates. The State Building Committees in the USSR republics - often referred to as the 'architectural KGB' (Oja 2009)—were traditionally led by a chief architect. The leader of the State Building Committee of Estonia from 1965 to 1988 has said that he accepted the position out of loyalty after being warned that if he did not assume it, a Russian would be imported to direct the institution. Undisturbed by voices of the public nor landowners, the chief architect of Soviet Tallinn was solely responsible for all decisions with spatial dimensions.

\subsection{Conclusion}

The massive scale of residential districts in socialist urban space required a comprehensive approach for an unprecedented scale of urban development. Chief architects, when designing mikrorayons, were tasked with designing myriad interrelated urban systems: proposing a road and traffic system, locating services and recreational areas, conducting mobility planning, establishing infrastructure and orchestrating the compositional structure of new urban fabric. We synthesise our findings to conclude that, in undertaking these enormous challenges, architects in socialist Estonia (as well as Latvia and Lithuania) can be considered visionary city builders who, when handed standard building designs for residential space, seized opportunities to innovate in site design and layout, embracing possibilities to create unique built environments in vast housing estates that influenced urban landscapes. 
We further find that architects appropriated the maximum authority they possibly could (and perhaps even overreached in certain cases) within the communist system, helping them to create state-of-the-art modernist living environments that shaped lives in important ways.

What resulted were distinctive modernist spaces that, although they contained standard Soviet residential buildings at their core (this could not be helped), were otherwise state of the art. Apartments in new housing estates provided coveted conveniences (for example, modern kitchens, comfortable toilets and washrooms, central heating) that were superior to amenities offered in contemporaneous pre-World War II housing (Hess 2011) and were thus quite prestigious (Kährik and Tammaru 2010). Individual apartments in new Estonian housing estates had grown larger during the Soviet era, and, by the late Soviet years, Estonians enjoyed the highest living space per capita at $\left(11.7 \mathrm{~m}^{2}\right)$ in the Soviet Union (the USSR average was $9.4 \mathrm{~m}^{2}$ ) (Bater 1989). Only budget constraints and notoriously cheap construction materials dampened the modernist vision that Soviet-era Estonian architects created for new residential space in Estonia's capital city (interviews with I. Raud, 2016; D. Bruns, 2013; O. Zhemzhugov 2013). If the conditions in Estonia that allowed town planning innovation that we describe in this article had not existed, built environments in housing estates could be of much lesser quality than those that endure today.

We also demonstrate a new perspective of Soviet-era city planning in Estonia by helping to correct inaccurate assumptions that architects' contributions to city planning practice were generally weak and strongly controlled by the Soviet system through unchallengeable designs and plans from the USSR central party. Based on analyses of original planning documents, we suggest that, regarding site planning for mikrorayons, the regulations issued in Moscow played a less important role in town planning outcomes in Estonia than previously assumed for USSR republics. While it was necessary for architects to strictly adhere to density norms, the physical structure and site planning of mikrorayons were, as a rule, the outcome of original design processes by local architects who were strongly inspired by modernist ideals popular at the time throughout the western world. We depict in this chapter a series of three large housing estates, built in the capital city during the socialist years, showing the relatively powerful position of Estonian architects in socialist city building processes and how, using more information from abroad than is often recognised, they gained expertise in modernist city planning techniques and produced original and state-of-the art designs. The process we describe produced more desirable housing estates in Estonia than would have resulted from strict adherence to system constraints. These events provided party leaders with exemplary town planning ensembles to support residential expansion, while Estonian architects experienced a supportive atmosphere (contrary to common assumptions about the USSR) to pursue modernist ambitions that they hoped would be admired beyond the borders of the Soviet Union. 
Acknowledgements This chapter is derived from an article published in Planning Perspectives (2018) (copyright Taylor and Francis), available online: http://www.tandfonline.com/doi/full/10. 1080/02665433.2017.1348974. Metspalu P, Hess D (2018) Revisiting the role of architects in planning large-scale housing in the USSR: the birth of three large housing estates in Tallinn, Estonia. Plan Perspect 33(3):335-361, DOI: https://doi.org/10.1080/02665433.2017.1348974. The research was supported with funding from the European Union's Horizon 2020 research and innovation programme under the Marie Skłodowska-Curie grant agreement No. 655601. When this research was conducted, Daniel Baldwin Hess was a visiting scholar in the Centre for Migration and Urban Studies at the University of Tartu, Estonia.

\section{References}

Andrusz G (1987) The built environment in Soviet theory and practice. Int J Urban Reg Res 11:478-598

Bater JH (1980) The Soviet city: ideal and reality. Edward Arnold, London

Bater JH (1989) The Soviet scene: a geographical perspective. Edward Arnold, London

Berman M (1982) All that is solid melts into air: the experience of modernity. Simon and Schuster, New York

Boyer MC (1994) The city of collective memory: its historical imagery and architectural entertainments. MIT Press, Cambridge

Bruns D (2007) Tallinna peaarhitekti mälestusi ja artikleid [The Memories of Tallinn Chief Architect]. Eesti Arhitektuurimuuseum, Greif OÜ

Bunkśe EV (1979) The role of the human environment in Soviet urban planning. The Geogr Rev 69(4):379-394

Charley J (2004) The concrete memory of modernity: excerpts from a Moscow diary. In: Hvattum M, Hermansen C (eds) Tracing modernity: manifestations of the modern in architecture and the city. Routledge, London, pp 195-214

Choay F (1970) The modern city: planning in the 19th century. G. Braziller, New York

Domański B (1997) Industrial control over the socialist town: benevolence or exploitation?. Praeger, New York

Dremaite M (2010) The (Post-)Soviet built environment: Soviet-Western relations in the industrialised mass housing and its reflections in Soviet Lithuania. Lith Hist Stud 15:11-26

Dremaite M (2013) Modern housing in Lithuania in the 1960s: nordic influences. In: Caldenby C, Wedebrunn, PO (eds) DOCOMOMO: survival of modern from cultural centres to planned suburbs, pp 80-91. Arkitektur B, Copenhagen

Dremaite M (2017) Baltic modernism: architecture and housing in Soviet Lithuania. DOM Publishers, Berlin

Eesti Projekt (1968) Väike-Õismäe makrorajooni detailplaneerimine [The detailed planning project for Väike-Õismä]. M. Port, M. Meelak (architects); L. Koemets (engineer). Commissioned by Tallinn City Proletariat Delegates Council Executive Committee Government for Architecture and Planning

Eesti Projekt (1970) Lasnamäe elurajooni generaalplaan [The General plan for Lasnamäe]. M. Port, M. Meelak (architects); L. Koemets (engineer). Commissioned by Tallinn City Proletariat Delegates Council Executive Committee Government for Architecture and Planning

Ericson R (1988) Priority, duality, and penetration in the Soviet command economy. RAND, Santa Monica

Estonprojekt (1959) Mustamäe elurajooni detailplaneerimise projekt [The detailed planning project for Mustamäe residential district in Tallinn]. Tihomirov, Ilves, Jansen, Tippel, Prahm (architects). Commissioned by Tallinna linna TSN Täitevkomitee Kapitaalehituse Osakond

French R (1987) Changing spatial patterns in Soviet Cities - planning or pragmatism? Urban Geogr 8(4):309-320 
French RA (1995) Plans, pragmatism, and people: the legacy of Soviet planning for today's cities. University of Pittsburgh Press, Pittsburgh

Gentile M, Tammaru T, van Kempen R (2012) Heteropolitanization: social and spatial change in Central and Eastern European cities. Cities 29(5):291-299

Hatherley O (2015) Landscapes of communism: a history through buildings. Allen Lane, London

Hausladen G (1987) Planning the development of the socialist city: the case of Dubna New Town. Geoforum 18(1):103-115

Hess DB (2011) Early 20th-century tenement buildings in Estonia: building blocks for neighbourhood longevity. Town Plan Arch 35(2):110-116

Hess DB (2017) Transport in Mikrorayons: accessibility and proximity in centrally planned residential districts during the socialist era, 1957-1989. J Plan Hist 17(3):184-204

Hess DB, Tammaru T, Leetmaa K (2012) Ethnic difference in housing in post-Soviet Tartu, Estonia. Cities Int J Urban Policy Plan 29:327-333

Hess DB, Hiob M (2014) Preservation by neglect in Soviet-Era Town planning in Tartu, Estonia. J Plan Hist 13(1):24-49

Hess DB, Tammaru T, van Ham M (2018) Lessons learned from a Pan-European study of large housing estates: origin, trajectories of change, and future prospects. In: Hess DB, Tammaru T, Van Ham M (eds) Housing estates in Europe: poverty, segregation, and policy challenges. Springer, Netherlands

Kährik A, Tammaru T (2010) Soviet prefabricated panel housing estates: areas of continued social mix or decline? the case of Tallinn. Hous Stud 25(2):201-219

Kalm M (2002) Saunapidu suvilas. Nõukogude eestlased Soome järgi läänt mängimas [Sauna-party in a Summerhouse. Soviet Estonians Playing "West" Following Finland]. In: Sarapik V, Kalda M, Veidemann R (eds) Kohandumise märgid. Underi ja Tuglase Kirjanduskeskus, Collegium litterarum 16, Tallinn

Kalm M (2012) An apartment with all the conveniences was no Panacea: mass housing and the alternatives in the Soviet period Tallinn. Architektúra \& Urbanizmus (J Arch Town Plan Theory) 47:189-202

Kovács Z, Herfert G (2012) Development pathways of large housing estates in post-socialist cities: an international comparison. Hous Stud 27(3):324-342

Kulu H (2003) Housing differences in the late Soviet city: the case of Tartu, Estonia. Int J Urban Reg Res 27:897-911

Lapin L (1981) Arengujooni Eesti seitsmekümndendate aastate arhitektuuris [The Development Paths of Estonian Architecture in 1970 s]. Ehituskunst, Eesti NSV Arhitektide Liidu kogumik. Tallinn: Kunst

Leetmaa K, Tammaru T, Hess DB (2015) Preferences towards neighbour ethnicity and affluence: evidence from an inherited dual ethnic context in post-Soviet Tartu, Estonia. Ann Assoc Am Geogr 105(1):162-182

Lehmann SG, Ruble BA (1997) From 'Soviet' to 'European' Yaroslavl: changing neighbourhood structure in post-Soviet Russian cities. Urban Stud 34(7):1085-1107

Lewin M, Elliott G (2005) The Soviet century. Verso, London

Liepa-Zemeša M, Hess DB (2016) Effects of public perception on urban planning: evolution of an inclusive planning system during crises in Latvia. Town Plan Rev 87(1):71-92

Lizon P (1996) East central Europe: the unhappy heritage of communist mass housing. J Arch Educ 50:104-114

Maciuika JV (1999) East Bloc, West view: architecture and lithuanian national identity. Tradit Dwell Settl Rev 11(1):23-35

McCauley M (1995) The Khrushchëv Era 1953-1964. Pearson Education Ltd., London

Meuser P, Zadorin D (2016) Toward a typology of Soviet mass housing: prefabrication in the USSR, 1995-1991. DOM Publishers, Berlin

Metspalu P, Hess DB (2018) Revisiting the role of architects in planning large-scale housing in the USSR: the birth of three large housing estates in Tallinn, Estonia. Plan Perspect 33(3):335-361 
Ofer G (1977) Economising on urbanisation in socialist countries: historical necessity of socialist strategy. In: Broan AA, Neuberger E (eds) Internal migration: a comparative perspective. Academic Press, New York, pp 219-244

Oja U (2009) Voldemar Herkel - oma aja arhitekt [Voldemar Herkel - an architect of his time]. Eesti Ekspress. http://ekspress.delfi.ee/areen/voldemar-herkel-oma-aja-arhitekt?id=27685001. Accessed 15 Jan 2009

Peirumaa R (2004) Hruštšovi aja "sula” ning muudatused ENSV kunstipoliitikas ja -elus 1950. aastate teisel poolel [Kruschev's Thaw and the Change in the Art Policy and Life in Soviet Estonia in 1950s]. Master's thesis, University of Tartu

Port M (1969) Linnade planeerimisest [About Urban Planning]. In: Parmas Heino (ed) Riiklik projekteerimise instituut Eesti Projekt 25-aastane. Valgus, Tallinn

Port M (1983) Architecture in the Estonian SSR. Perioodika, Tallinn

Pesur V (2003) Kuidas loodi Lasnamäe - intervjuu Mart Pordiga [How Lasnamäe Was Created an Interview with Mart Port]. Eesti Päevaleht. https://www.epl.ee/news/tallinn/kuidas-loodilasnamae-intervjuumart-pordiga.d?id=50965394. Accessed 30 Sep 2003

Power A (1997) Estates on the edge: the social consequences of mass housing in Europe. McMillan, London

Rimkute K (2014) Soviet mass-housing in Vilnius: exploring the consequences of the 1955 housing reform and the rebellion against architectural homogenization. Master's thesis, University of Edinburgh, Edinburgh School of Architecture and Landscape Architecture

Ruseckaite I (2010) Sovietiniu metu gyvenamieji rajonai Vilniuje: tipishkumo problema [Typical Problems In Soviet Residential Districts. The Case of Vilnius]. Urbanistika ir architektura (Town Plan Arch) 34(5):270-281

Shomina E (1992) Enterprises and the urban environment in the USSR. Int J Urban Reg Res 16 (2):222-233

Sild M (2014) Modernist city plans and their importance today, planning of pre-fabricated panel housing estates during the Soviet period: the case of Lasnamäe, Tallinn and Annelinn, Tartu. Master's thesis, University of Tartu, Tartu

Smith DM (1996) The Socialist City. In: Andrusz G, Harloe M, Szelènyi I (eds) Cities after socialism: urban and regional change and conflict in post-socialist societies. Blackwell Publishers, Oxford, pp 71-99

Stanilov K (2007) Nine housing trends in Central and Eastern European cities during and after the period of transition. In: Stanilov K (ed) The post socialist city. Urban form and space transformations in Central and Eastern Europe after socialism. GeoJournal library. Springer, Heidelberg, pp 173-190

Szelényi I (1996) Cities Under Socialism - and After. In: Andrusz G, Harloe M, Szelènyi I (eds) Cities after socialism: urban and regional change and conflict in post-socialist societies. Blackwell Publishers, Oxford, pp 286-317

Tammaru T (2001) Suburban growth and suburbanisation under central planning: the case of Soviet Estonia. Urban Stud 38:1314-1357

Tammaru T, Leetmaa K, Silm S, Ahas R (2009) Temporal and spatial dynamics of the new residential areas around Tallinn. Eur Plan Stud 17(3):423-439

Tosics I (2004) European urban development: sustainability and the role of housing. J Hous Built Environ 19:67-90

Turkington R, van Kempen R, Wassenberg F (2004) High-rise housing in Europe: current trends and future prospects. DUP Science, Delft University Press, Delft, Netherlands

Wassenberg F (2004) Large social housing estates: from stigma to demolition? J Hous Built Environ 19:223-232

Yanitsky O (1986) Urbanisation in the USSR: theory, tendencies, and policy. Int J Urban Reg Res 10(2):265-287

Zhuravlyev A, Fyodorov M (1961) The microdistrict and new living conditions. Russ Soc Sci Rev 2(4):37-40 
Open Access This chapter is licensed under the terms of the Creative Commons Attribution 4.0 International License (http://creativecommons.org/licenses/by/4.0/), which permits use, sharing, adaptation, distribution and reproduction in any medium or format, as long as you give appropriate credit to the original author(s) and the source, provide a link to the Creative Commons license and indicate if changes were made.

The images or other third party material in this chapter are included in the chapter's Creative Commons license, unless indicated otherwise in a credit line to the material. If material is not included in the chapter's Creative Commons license and your intended use is not permitted by statutory regulation or exceeds the permitted use, you will need to obtain permission directly from the copyright holder.

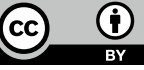




\title{
Chapter 8 \\ Socialist Ideals and Physical Reality: \\ Large Housing Estates in Riga, Latvia
}

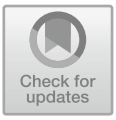

\author{
Sandra Treija and Uǵis Bratuškins
}

\begin{abstract}
Large housing estates represent a significant part of the existing housing stock in many Eastern European cities including Riga, the capital of Latvia. A considerable number of large housing estates were developed within the Soviet housing expansion plans in Riga. Based on social ideals and planned economic strategies for urban development, large housing estates seek their place in the context of other political and economic formations. Socialist ideals and a command economy influenced the principles of town planning and determined the pace and scale of construction. Large housing estates are a troublesome legacy of the previous period, which has become a reality in the housing situation of a significant part of the population of Riga. There are certain problems in this type of housing that are related both to the ageing of the housing fund and to the new social and economic conditions. Various processes that have occurred in recent decadeshousing reform, land reform, etc.-have produced significant changes in the way large-scale residential districts are managed and maintained. Despite the differences in spatial and structural solutions of housing estates constructed in various decades, they shared some common features according to the common planning principles used in their development. The study is focused on the spatial organisation of the estates-original ideas, development stages, current conditions and challenges for future redevelopment. Effective planning, financing, management and legal instruments are necessary for executing complex reconstruction projects. Finding solutions among parties with different interests is a complicated task due to changes that will directly affect real estate property rights.
\end{abstract}

Keywords Large housing estates - Social ideals - Spatial organisation - Riga, Latvia

\footnotetext{
S. Treija $(\bowtie) \cdot$ U. Bratuškins

Faculty of Architecture, Riga Technical University, Riga, Latvia

e-mail: Sandra.Treija@rtu.lv

U. Bratuškins

e-mail: Ugis.Bratuskins@rtu.lv

(C) The Author(s) 2019

D. B. Hess and T. Tammaru (eds.), Housing Estates in the Baltic Countries,

The Urban Book Series, https://doi.org/10.1007/978-3-030-23392-1_8
} 


\subsection{Introduction}

A significant number of large housing estates were developed within the Soviet housing expansion plans in Latvia between the late 1950s and early 1990s. As the leading paradigm of residential development after World War II, large-scale housing underwent certain transformations throughout the decades differing considerably in size, number, development density and urban layout. Despite the differences in spatial and structural solutions of housing estates constructed in various decades, they shared some common features according to the common planning principles used in their development. Large residential areas are mainly located in the outer perimeter of the city within easy-to-reach distances from the city centre. They usually have well-developed educational and service facilities as well as good recreation opportunities. Thus, large-scale housing estates remain popular urban areas which appeal to a very large number of inhabitants.

Transition from a state regulated to a free market economy in the last decade of the twentieth century fundamentally transformed property owner relationships in the region and the subsequent governmental reforms affected the real estate sector, social classes, etc. Large-scale housing estates still actively participate in the real estate market; small apartments have regained their popularity and are again in high demand. This is driving the modernisation of these buildings and living spaces while at the same time creating new issues such as shared responsibility for maintenance of the buildings and common areas.

This chapter provides an overview of the development of large housing estates in Riga. The study is focused on the physical organisation of the estates-original ideas, development stages, current conditions and challenges for future redevelopment. It describes the social and economic background, indicates the differences in spatial concepts of the estates and defines contemporary problems based on the process of housing reforms.

\subsection{Social and Economic Context of Housing Development in the USSR}

Large housing estates are a typical feature of many European cities. It is a post-World War II development which was carefully planned in view of the expected increase in population (Van Kempen et al. 2005). Although the motives leading to the construction of residential complexes were similar in many European countries-housing shortages, ongoing technological progress, new lifestyles, governmental support, functional zoning in urban planning - not all motives were equally important in all European countries (Krantz 1999; Turkington et al. 2004). Since Latvia was a member republic of the Soviet Union, a large socio-economic and political structure, these prerequisites and motives for construction were largely dictated by the policies of the USSR (Lejnieks 2005). 
In Western European countries, the housing problem was largely addressed by an economic recovery which allowed people to become more creditworthy and capable of choosing a higher standard of housing (Wallace et al. 2012). The situation was different in Eastern Europe where the construction of large housing estates continued until the beginning of the 1990s, thus becoming a significant portion of the housing stock (Palacin and Shelburne 2005). During this period in Riga, about $70 \%$ of the existing housing areas were built using prefabricated housing construction methods (Marana and Treija 2002).

Political ideology was the primary driver behind the impressive development of housing capacity in the USSR - the Soviet government had declared the goal of improving the housing conditions for a large number of people (Rubins 2004). Ideological considerations were accompanied by technical ones, that is, development of new construction technologies. Implementing these political directives required extensive construction. The most advanced form of construction to satisfy this demand was erection of prefabricated large-slab residential buildings (Rubīns 2004).

The strict state-controlled system of housing in the USSR, including Latvia, functioned until 1991. The system was based on the centralised planned construction process and low cost of housing. The major share of housing stock belonged to the state or municipalities and the apartments were rented to residents for an indefinite period. Residents had to cover only a symbolic part of the actual dwelling and service fees, while the remaining part was subsidised by the state or municipalities. Since the provisioning of housing was a politically defined priority and given intensive subsidies, apartments were affordable to a wide range of the population (Tsenkova and Turner 2004; Treija 2009).

The decision on industrialisation, quality improvement and cost reduction in the construction sector was adopted by the Communist Party and the Soviet Council of Ministers in 1956. It was followed by the resolution 'On the housing development in the USSR' in 1957. The resolution set a goal to make apartments available to a great majority of the population with the aim to provide each family with a separate apartment by the year 1980. The goal was not limited to quantity only; improvement of the quality of life was another important aspect. Providing bright and well-equipped buildings surrounded by green areas with services and facilities available nearby such as kindergartens, schools and retail stores were important steps towards implementing the vision of comfortable and high-quality living environments (Caldenby 2010).

Technological advances allowed the implementation of the ideological directive to proceed quickly and on a grand scale. Industrialisation and prefabrication in construction reached a high level; new working methods and building materials were introduced as well as new architectural designs of the buildings (Švidkovskis 1967). The occupant density and structural solutions of the buildings reflected new social requirements, and employed new construction techniques and new finishing materials (Šusts 1966).

According to historical data on the population distribution in Latvia during the considered period, most of the population was concentrated in Riga and its 
Table 8.1 Population and housing fund in Riga

\begin{tabular}{l|l|l|l}
\hline Year & Population in Riga & Housing fund (thousand $\left.\mathrm{m}^{2}\right)$ & Floor space per resident $\left(\mathrm{m}^{2}\right)$ \\
\hline 1940 & 353800 & 6800 & 19,20 \\
\hline 1945 & 228200 & 6100 & 26,70 \\
\hline 1950 & 482300 & 6500 & 13,50 \\
\hline 1960 & 588000 & 7333 & 12,50 \\
\hline 1970 & 731800 & 9970 & 13,60 \\
\hline 1980 & 843000 & 13477 & 16,00 \\
\hline 1990 & 909135 & 16419 & 18,00 \\
\hline
\end{tabular}

Source Rubīns (2004), Centrālā Statistikas pārvalde (2017)

surrounding area. The ongoing process of urban migration resulted in $70 \%$ of the population living in cities. In the 1980s, Riga was not only the administrative, political, industrial and cultural centre of the Latvian SSR but also the centre of many inter-republic functions of the entire Baltic economic area.

Such terms as 'minimal', 'normative' and 'average provision with residential space' were in use for a long time within the housing policy of the USSR. The minimum provision was set to $4 \mathrm{~m}^{2}$ per person while the normative one was 9$12 \mathrm{~m}^{2}$ per person in different decades (Table 8.1). The concept of a 'housing standard' as a figure characterising the number of rooms per household member came into use in the Soviet urban planning and housing programmes only in the 1980s after the slogan 'a separate apartment or private house for each Soviet family by the year 2000' was introduced. Standard 'n' was accepted as the preferred onethe total number of persons in the household should correspond to the number of rooms occupied (Melbergs 1989).

\subsection{The Development of Riga}

In accordance with urban development forecasts, territorial master plans (general plans) were developed in the cities and towns where rapid growth was predicted in both industrial and residential areas. Three territorial plans were developed in Riga in 1955, 1968 and 1984.

The Riga Master Plan of 1955 (architect Vasiljev, J. et al.) envisioned creating relatively independent residential areas in the peripheral parts of Riga connected to the city centre by modern motorways. The city had to find new territories for mass housing construction. The first areas to be built up were the areas where city utilities such as water supply, sewage, drainage, etc. could be provided without much additional investment. The territory on the left bank of the River Daugava was set as an important development area since the development potential of the territory on the right bank was considered to be limited due to the location of industrial zones and topographical conditions. Jugla District $\left(254,000 \mathrm{~m}^{2}\right.$ of living space), 
Dreilini $\left(164,000 \mathrm{~m}^{2}\right)$, Moscow Street area $\left(102,000 \mathrm{~m}^{2}\right)$ and Agenskalna Priedes $\left(52,000 \mathrm{~m}^{2}\right)$ are examples of the larger residential areas developed in that period (Валескалн and Васильев 1969).

The vicinities surrounding the city's peripheral industrial centres were intended for further expansion as residential areas. Development of the city was encumbered there because of the widespread construction of individual residential houses during the early post-war years which, on the one hand, helped to replenish the Riga housing stock destroyed during World War II but, on the other hand, blocked the development of the city in several important directions-westwards, southwestwards and south-eastwards.

The most important feature of this plan was that it simultaneously solved architectural, technical and social problems. This caused changes in the structure of the entire city. The use of standard projects in large-scale residential area development, a characteristic feature of that period, resulted in an approach which no longer emphasised only the expressiveness of the architectural design of a single building but also considered the expressiveness of an entire urban development complex. However, the limited number of standard projects did not provide sufficient means of expression to achieve good results in the creation of large-scale physical compositions.

In the Riga Master Plan of 1969 (architect Melbergs, G. et al.), preconditions were set for strict functional zoning of the city territory. For the first time, it also involved planning of the suburban areas in a radius of 50-70 km surrounding Riga.

The Riga city planning structure was based on ensuring the balanced and continuous development of all functional elements of the city, preserving the connection between work, residential and recreational areas. An important role in the territorial organisation was ascribed to functional zoning aimed at creation of preconditions for the development of complete industrial, management or residential units. Certain industrial zones were formed based on existing industrial enterprises, combining and developing them up to a certain natural or urban border. Further development of industrial enterprises in these zones was limited and could be implemented only by removing any building units which were inadequate to the zoning requirements. Four new industrial zones were planned for future development, envisioning mainly the construction of new facilities (Melbergs and Pučinšs 1969).

The construction of apartments in the future was planned mainly in the areas built up with low-rise buildings. The plan was to completely or partially demolish them and replace them with new prefabricated residential blocks. In each planning area, extra space was reserved for the construction of apartments. This approach had to ensure normal development of the city and improve the living conditions. Existing residential blocks in the central part of the city were reserved for the development of the public centre. Composition of the city centre was based on a wide range skyline visible from multiple locations along the River Daugava or from the city's main motorways, while the composition of residential areas focused on the spaces of inner courtyards (Krastiņš et al. 1998). 
In the Riga Master Plan of 1984 (architect Melbergs, G. et al.), Riga was defined as an important urban centre of the USSR. Considering the estimated number of employed persons in all sectors of economy as well as the expected natural growth and migration of the population and its demographic structure, the number of Riga inhabitants for the first stage of construction until 1990 was set at 920,000 people increasing to 1 million by 2005. According to the new Master Plan, the volume of housing construction was determined by considering an average increase of the provided living space per person up to $19-20 \mathrm{~m}^{2}$ of the total area, or by $23.4 \%$. Thus, by 2005, the intention was to build apartments with a total area of more than $8,000,000 \mathrm{~m}^{2}$. With regards to the environmental planning of the city, it should be noted that the modern territory of Riga with an area of 30,700 hectares allowed for the construction of apartments as well as cultural and communal buildings. To preserve the basic organisation principle of the social infrastructure of the city, 'work-life-rest', eight administrative planning districts were proposed which would combine social and administrative functions. This would facilitate creation of a unified, architecturally planned structure and facilitate control over execution of the Master Plan. Functional zoning of the city was based on the functional zones defined by the previous Master Plan without making any significant alterations. It was planned to complete construction in the residential areas under development by the end of the planning period and reacquire residential areas in several other districts (Krastinšs et al. 1998). It should be noted that the accommodation of inhabitants and the locations of residential areas were linked to optimisation indicators based on the availability of jobs, public centres and recreation areas. Also considered were building costs in the territory and the comparative free-time cost factor.

The new Master Plan of Riga city development was approved by the Riga Executive Committee (City Council) in 1984. However, approval was not granted by the Cabinet of Ministers of the Latvian SSR because the development plan for the city with a population potentially exceeding 1 million inhabitants did not envision the construction of an underground railway system which was required by provisions of the State Plan of the USSR (Melbergs 1993).

Implementation of the grand Riga city development plans required significant territorial resources. Some of the new construction projects were planned in the former built-up areas and envisioned the demolition of existing buildings while other projects were planned in areas close to Riga's administrative border (Fig. 8.1).

\subsection{Physical Organisation of Large Housing Estates}

Urban growth emphasising residential construction set the stage for contemporary urban development solutions. Architects focused mainly on entire building complexes rather than on separate buildings (Šusts 1966). Architect Švidkovskis stated the new concept: 'The notion of habitation begins to embody the concepts of both 


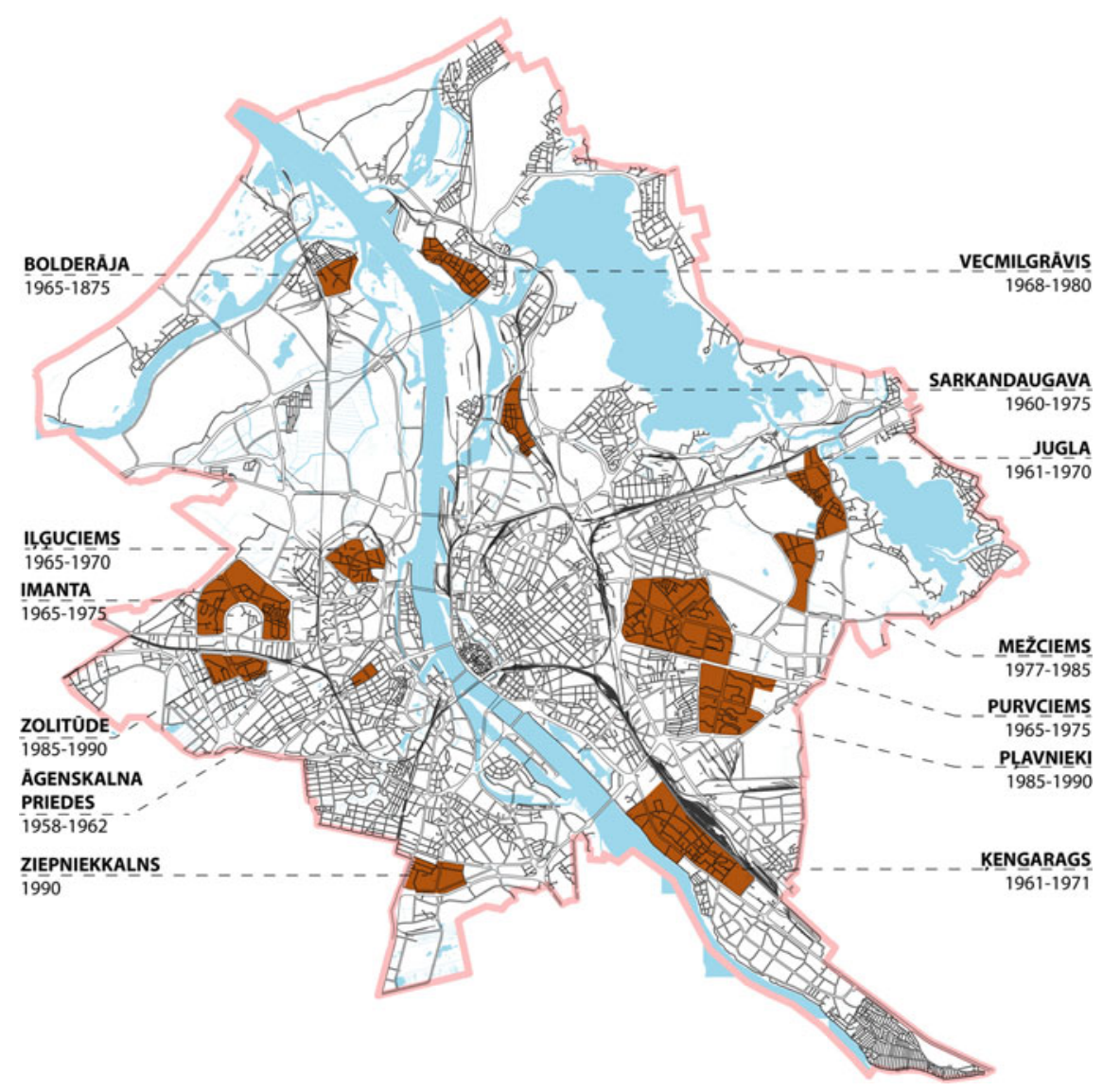

Fig. 8.1 Location of large housing estates in Riga. Source Sandra Treija

function and design of the entire building unit. For the first time, each separate building no longer represents a single decorative or compositional piece but becomes an element of the physical composition. Careful design of the layout of housing groups creates diversity and feelings of spaciousness while at the same time maintaining human scale in the surroundings' (Švidkovskis 1967).

The Microrayon (micro-neighbourhood) became the basic unit of the new large housing estate. It was a housing complex which also included essential services for the residents. Schools, kindergartens, grocery shops and other public services located in the microrayon expanded the concept of a habitat which exceeded the borders of a single apartment. An urban structure new in its content and shape emerged in the new complexes. Each inhabitant was provided with the access to all necessary everyday public services within the borders of the microrayon. The physical organisation of building groups in large housing estates was significantly influenced by the requirement to provide an optimal microclimate and hygienic 
regime in the apartments as well as sufficient outdoor recreation space near the housing. The traditional development with the lines of side-by-side buildings stretching along the corridor-shaped streets was replaced by freestanding buildings surrounded by plenty of green spaces which became an important element of the residential area (Švidkovskis 1967). Planted spaces were needed to create a good microclimate, ensure decent hygienic conditions and provide relaxation space while together forming an expressive urban landscape.

Open spaces in the planned courtyards were reserved for important household functions - drying laundry, beating carpets, access to waste containers, etc. Next to the entrance doors, several parking lots (about 6 to 10) were arranged. The rest of the courtyard area was landscaped to provide playgrounds for children and small rest areas equipped with benches (Treija et al. 2012).

Since green space in housing estates usually occupied $40-45 \%$ of the entirety, planning authorities wanted to find out how intensively they were used for the daily recreation needs and whether people were satisfied with the quality of the planted spaces and their facilities. A survey of inhabitants carried out as early as 1967 and 1968 showed that the inhabitants of the new microrayon did not fully utilise the green areas because they were not satisfied with the available facilities. It was concluded that large urban spaces which required considerable investment were not being used to full capacity (Lūse 1971).

As the leading paradigm of urban development for several decades, the spatial concept of large housing estates has undergone several transformations. Although the main setting remained unchanged, quick and inexpensive provisioning of the population with a high-quality residential environment, housing estates differed significantly in terms of size, occupant density and physical organisation (Treija and Bratuškins 2013). The development of large housing estates can be divided into several stages.

During the first decade after World War II, the first standard residential housing projects were developed in Riga and the first villages for factory workers were built. However, design and construction techniques did not keep pace with the rapid growth rate of the city which was stimulated by industrial development. Locating new villages for factory workers next to the industrial areas was a characteristic feature of the early stage of this period, which could be observed not only in Riga but also in many cities in the Soviet Union (Валескалн and Васильев 1969). Ву 1955, two-storey brick buildings dominated in the construction of residential buildings in Riga. Custom designed standard projects were created for this building type. The introduction of standard low-rise residential buildings created the necessary conditions for the development of housing construction methods on an industrial scale. This experience of planning and building residential complexes had an impact on the development of large-scale housing estates designed in subsequent years.

From the mid-1950s until the end of the 1960s, the principle of the free layout plan became the leading trend in the composition of residential areas. Large-scale residential areas in Riga generally followed this principle. The concept of 'free layout' in contrast to traditional building development along the streets includes 
various types of planning systems, the structure of which is determined by natural conditions (orientation, terrain, green areas, watercourses and water bodies) and the urban environment (street network and basic utilities). These practical factors were often combined with geometric ornamental schemes designed by architects. This period was characterised by a simplified architectural shape and layout of buildings limited by the requirements and needs of prefabrication, an excessive passion for ornamental arrangement of groups of buildings, and little attention paid to the use of different planning and vertical composition techniques for courtyard and motorway spaces. The development of large-slab manufacturing was the main characteristic during this period. Compared to brick house construction technology, large-slab technology made it possible to double productivity of the building industry (Rubīns 2004).

The next decade from 1965 to 1975 introduced more detailed techniques in the composition of microrayons or micro-neighbourhoods - their spaces became more intimate, as if focusing inwards. The main elements of the physical plan included green space in which residential buildings, public centres and boulevard corridors were combined into a coherent system. The unrestricted approach to nature and the maximum use of natural features were the main principles in the organisation of residential areas (Krastiņš et al. 1998). During this period, the principles of international modernism were developed and mastered by interpreting them in accordance with the available technical capabilities of industrialisation. Area plans gradually became more differentiated and intricate depending on social demand and location (Пиешиньш 1969).

During the last period of Soviet development, from 1975 to 1990, the rigidities of micro-neighbourhood planning gave way to more sophisticated solutions. Considering the flat terrain typical of Riga, much more attention was paid to the perception possibilities of the city's skyline (Strautmanis 1977). The importance of infrastructure was realised by developing such components as service facilities, street networks and equipment elements up to levels determined by the spatial structure of the area (Figs. 8.2 and 8.3). The role of colourful solutions in creating area identity was also emphasised.

Despite the differences in the physical and structural solutions in the large housing estates, there are also several common features that define their development principles. Examples include a wide spectrum of free layout structures used in area planning, the consideration of building location and height along main thoroughfares, and taking advantage of primary streets by the placement of public utilities and commercial areas along their routes. Other similarities of typical large housing estates are their inner courtyards and pedestrian paths separated from the street, large landscaped recreation spaces and vertically dominating elements that accentuate the intersections of main streets and residential centres.

Decades after their implementation, large housing estates have been criticised by different locals: architects, planners and even officials. The most common arguments against the approach of physical organisation are related to the excessive geometric structure which is not adaptable from a human perspective; the generic layout which causes orientation problems and the road structures which seem 


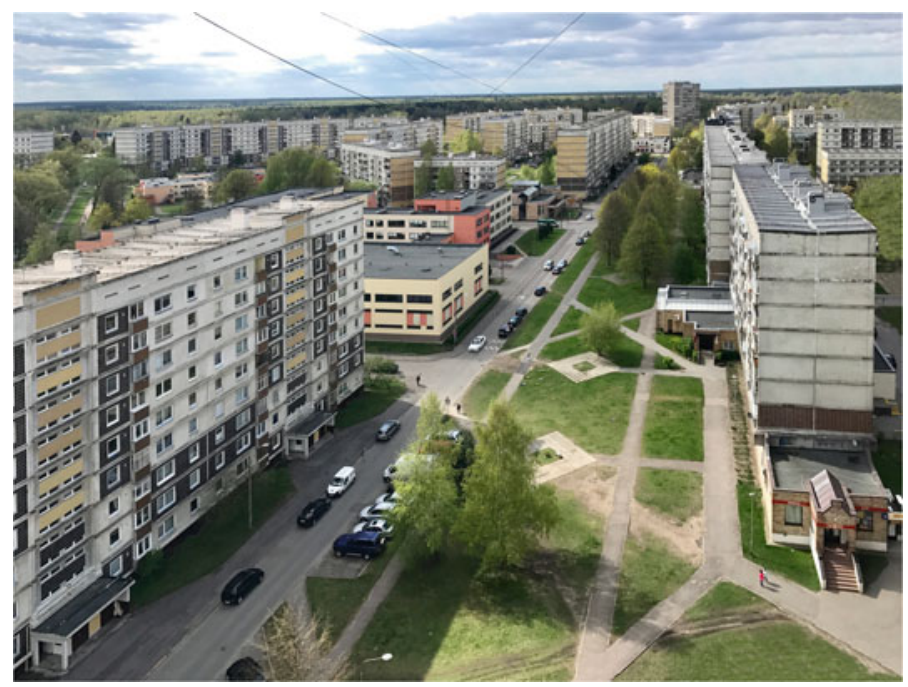

Fig. 8.2 Main inner street with pedestrian priority and services in mikrorayon Zolitūde I (arch. Berķe et al.). Source Sandra Treija

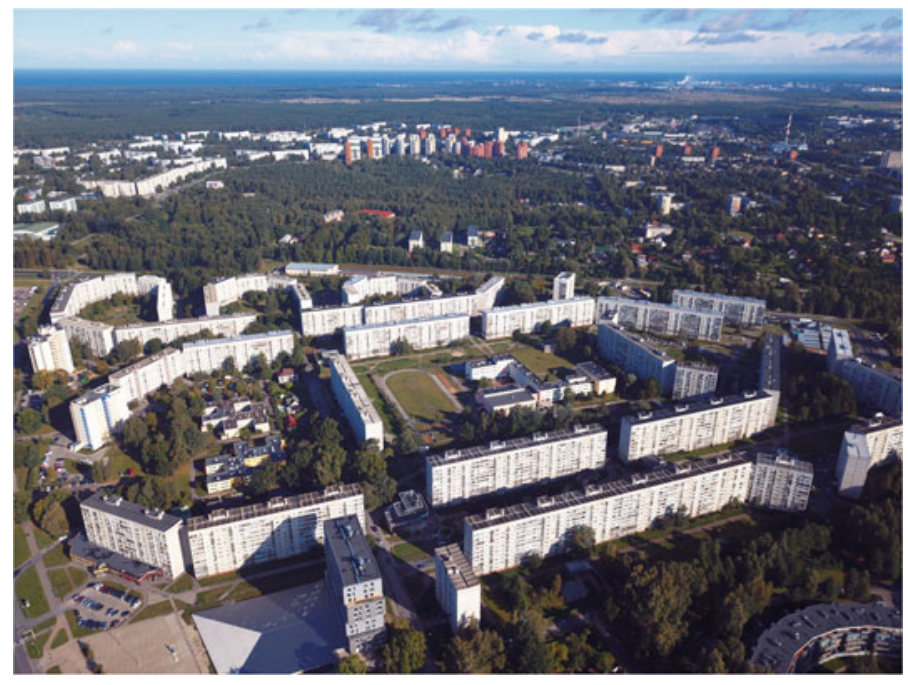

Fig. 8.3 Spatial organisation of mikrorayon Zolitūde II (arch. Berḳe et al.) with school and kindergarten at the core. Source Sandra Treija

chaotic (Strautmanis 1977). The courtyards were evaluated as hypertrophic and were not being fully utilised and the architecture was defined as an inexpressible, impoverished means of expression (Melbergs 1979; Piešiņš 1982). 


\subsection{Eras of Residential Development}

For 50 years until the beginning of the 1990s, large-slab buildings were erected in Riga according to a set of 11 standardised projects that differed in terms of exterior wall material, number of floors, number of apartments and useful floor area. Elements of the buildings were produced in many large-slab construction factories in Riga as well as in other major towns in Latvia (Brinkis 1996).

Separate stages in the development of residential buildings can be distinguished when older projects were replaced with newer ones. Housing types used immediately after World War II belong to the first generation of residential projects. The weak economic environment of the first post-war years was undoubtedly the major factor that had a considerable impact on the construction practices of that time. The first pre-industrial residential buildings were characterised by clear and simple multi-storey designs using white silicate brick construction. Flat wall surfaces were interrupted by regular window patterns in the living spaces alternated by different layouts of the staircases. As a design element, red bricks were used along windows and elsewhere in the otherwise light-coloured wall surfaces. The slopes of the gable roofs were covered with wavy slate plates.

Nevertheless, this generation of buildings provided a comparatively higher level of comfort with regard to basic utilities. Each apartment was equipped with running water and sewage mains, toilet and bath, and, where possible, access to central heating and hot water. Post-war housing ideology implied construction of small-sized apartments based on 'economic' standard projects with small living rooms and minimum auxiliary space. The hallway was designed as a narrow corridor, the kitchen area was around $6.0 \mathrm{~m}^{2}$ or less, the bathroom and toilet were installed in a single space taking up $2.0-2.5 \mathrm{~m}^{2}$ in which a bathtub just $1.5 \mathrm{~m}$ long could be placed. Integrated bathrooms were not equipped with sinks; those were available only in buildings with separate bathrooms. The kitchen and bathroom pipes were connected in one block. This saved plumbing costs but did not allow for making changes to the apartment layout. Many apartments consisted only of adjoining rooms. There were no outdoor spaces or they appeared in the form of very small balconies (Fig. 8.4).

The second phase, which began in the mid-1960s, can be considered as the period of residential building modernisation. Prior to that, only standard projects developed in the central offices of the USSR were allowed for construction. Starting with 1965, Latvian architects could adapt the USSR standard projects to local conditions which effectively allowed updates in many instances. This process started with five-storey large-slab buildings and was followed by those of nine storeys. A group of architects and civil engineers was awarded with a State Award of the Latvian SSR for their modernisations of the standard building project. Compared to the first generation, there were wider entrance halls and, in some designs, a built-in wardrobe. The kitchen area was increased and the toilet was removed from the bathroom and placed into a separate room; however, the short 


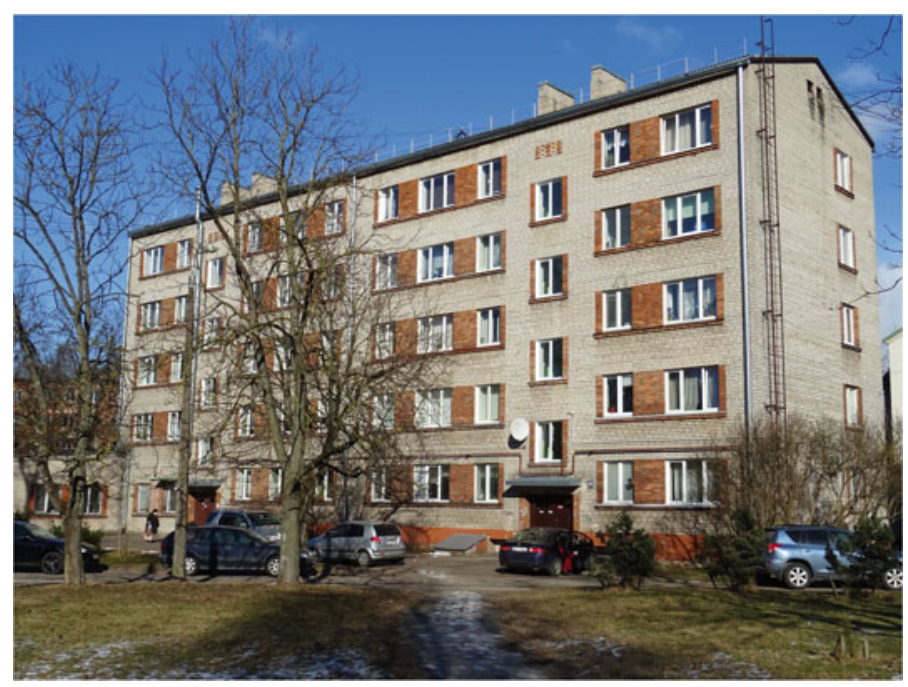

Fig. 8.4 Typical Khrushchëv-period dwelling house in Āgenskalna Priedes (1958-62). Source Uğis Bratuškins

bathtubs still remained. In some apartments, the number of adjoining rooms decreased. Loggias were erected instead of balconies (Piešiňš 1982).

In 1972, a second large-slab manufacturer was launched, the Riga Large-Slab Construction Plant. It produced building blocks for the standard nine-storey large-slab houses. Its capacity, $240,000 \mathrm{~m}^{2}$ per year, was about twice as large as the output of the first standard construction plant (Asaris 1976).

The third phase commenced in the mid-1970s. While work on future projects continued during the second-generation construction phase, it was necessary to wait several years until construction of the new generation of standard buildings could start. The initial third-generation buildings without construction difficulties appeared in the beginning of the 1970s. Third-generation apartments were about $5 \%$ more spacious than those of the second generation. An important feature appeared in the apartment layout. Larger apartments were equipped with separate guest toilet near the entrance while the bathroom and family toilet were placed in the private area of the apartment. The bathroom had a $1.7 \mathrm{~m}$ long bathtub and a place for a washing machine. The entrance was equipped with a double door to minimise heat loss and provide better sound insulation (Kazāks 1982). The buildings higher than five floors were equipped with garbage containers and buildings higher than six floors had an elevator. The buildings erected according to the latest standards had enlarged apartment spaces, entrance halls with daylight and strict apartment layouts. These qualities were included in the typical project series 119, developed by Latvian architects (arch. L. Plakane et al.), who received a gold medal at the USSR National Economic Achievement Exhibition (Piešiņš 1982) (Fig. 8.5). 


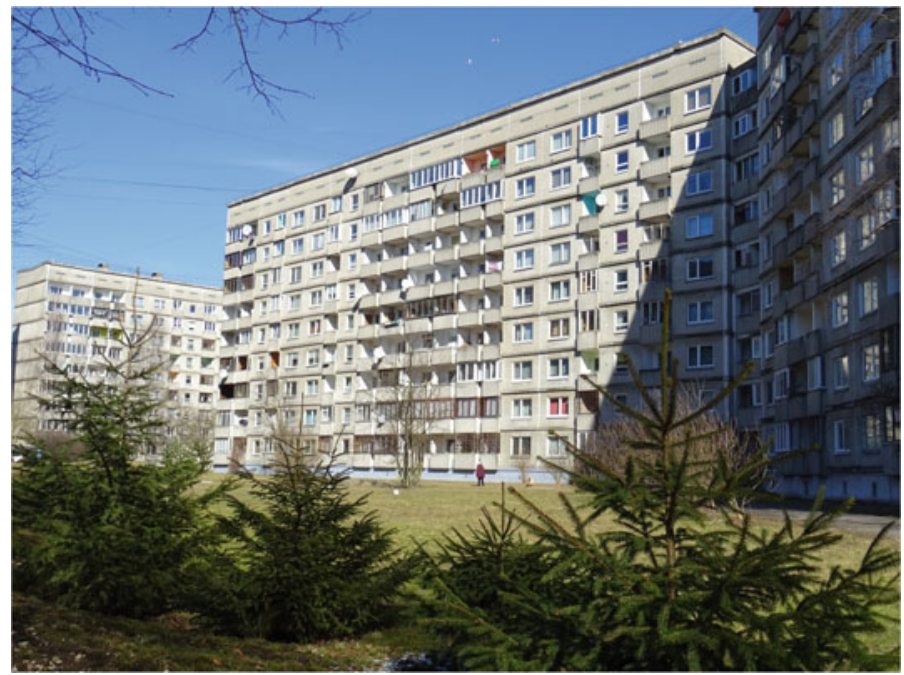

Fig. 8.5 Large 1980s apartment building (typical project series 119th, arch. Plakane, L. et al.) in Pḷavnieki (1985-90). Source Uğis Bratuškins

Although most of the residential buildings were built according to a series of standard projects, individually designed residential buildings were also constructed. These were usually separate buildings but occasionally were built in groups as well. Some of them were designed as experiments to test some of the project's improvements or spatial or technological innovations (Fig. 8.6). Often an individual

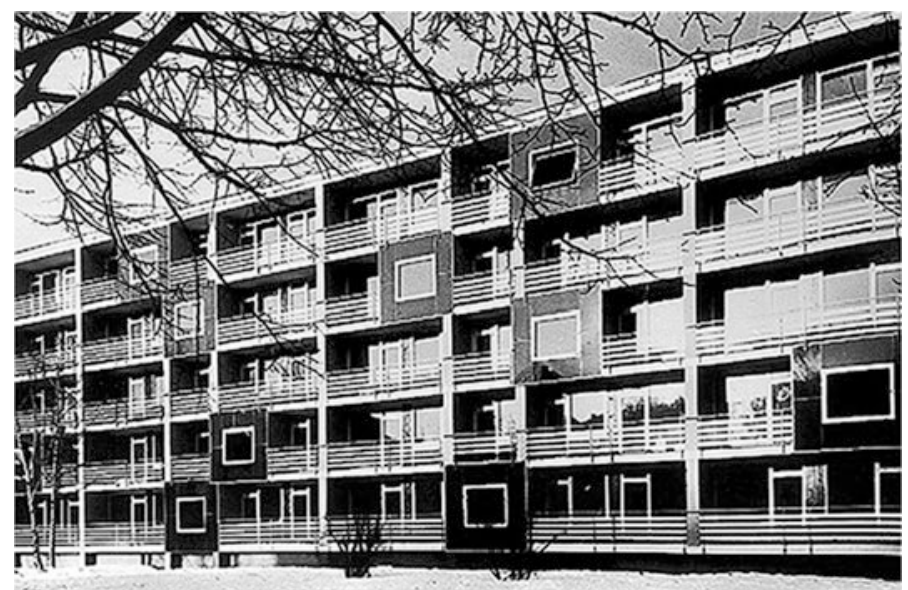

Fig. 8.6 Individually designed residential building in Brīvības street (arch. Staņa, M., Jākobsons, I., Kanders, H. 1967-1970). Scientific Collection of Latvian Museum of Architecture, S11-84. Source The Archive of Museum of Latvian Architecture 
design was for a special customer or the result of a collaboration of several creative associations.

Approximately 200,000 apartments were built in Riga from 1958 to 1990. Despite the remarkable growth of construction volume that culminated in 1987, the demand for separate living space for each household was not satisfied (Rubīns 2004). Riga had a significant apartment deficit at the time because the increase in construction speed and volume did not keep up with the increasing number of inhabitants. As a result, the average provision of residential living space did not increase. In 1940, the provision of useful living space per person in Riga was $19.2 \mathrm{~m}^{2}$ but at the end of the Soviet era at the beginning of the 1990s it was only $18 \mathrm{~m}^{2}$.

\subsection{Current Tendencies and Future Challenges}

The processes of the last decades, housing reform (denationalisation and privatisation of the housing stock), land reform, etc., have caused significant changes in the way large-scale residential districts are managed and maintained.

In Latvia, denationalisation of the apartment houses and privatisation of flats by their owners began in 1991. Almost $99 \%$ of the municipal and state-owned buildings were offered for privatisation. These buildings were divided into apartment properties, where each property contained parts and infrastructure common to the entire building, e.g. residential communal space, outside walls, roof, foundation, communal engineering and communications and the attached land plot (Tsenkova 2002). As a result of denationalisation and privatisation of real estate, the ownership structure of the housing stock has considerably changed in Latvia. In Riga, more than $80 \%$ of the housing stock is privately owned (Centrālā Statistikas pārvalde 2006) (Table 8.2).

This has led to a broad and complex structure of multiple stakeholders which significantly delays defining common interests, setting goals and collective decision-making (Saferagic 2002; Tsenkova and Turner 2004). Because most of the buildings have high energy consumption and low heat resistance that significantly affect the costs for each apartment owner (Berglund 2002), the gradual renovation of these buildings is a topical question.

Significant influence regarding the possibilities for any improvement projects in large housing estates depends on land reform. Following the privatisation of real estate and denationalisation of residential buildings when land was tied to each building, the current land ownership structure is complex and fragmented. The logic of establishing a microrayons is not compatible with the current configuration where majority of buildings cross land boundaries (Fig. 8.7).

Table 8.2 Privatisation of apartments in Riga

\begin{tabular}{l|l|l|l}
\hline & 1996 & 2000 & 2006 \\
\hline Privatised apartments & 2547 & 156232 & 192856 \\
\hline $\begin{array}{l}\% \text { of total number of } \\
\text { apartments }\end{array}$ & $1.2 \%$ & $68 \%$ & $85 \%$ \\
\hline
\end{tabular}

Source Centrāāā Statistikas pārvalde (2006) 


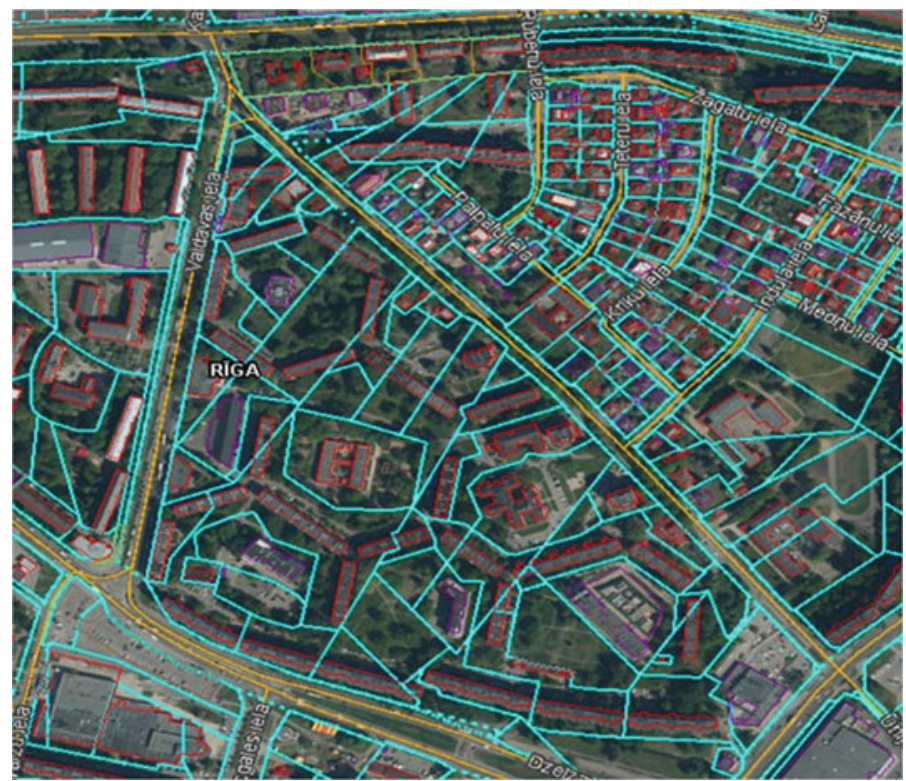

Fig. 8.7 Distribution of individual properties in the Purvciems housing estate. Source https:// www.kadastrs.lv/properties

The management system did not keep up with such rapid ownership reforms in the housing areas either. Observations of the current status of buildings and open spaces show that the existing housing management system fails to implement substantial renovations of the living environment resulting in a considerable part of the housing stock being exposed to the risk of degradation. In most cases, the decisions that enabled apartment tenants to become apartment owners were not made with full awareness of the resulting rights and responsibilities of multiple stakeholders (Slava and Geipele 2012). Since Latvia joined the EU, funding for renovation of these buildings has been made available. The Economic Ministry and other institutions responsible for the work have carried out an information campaign. New legislation concerning adjustments to the management of residential buildings was enacted to support renewal of the housing stock. However, the number of renovated residential houses is still very small. Interviews of apartment residents confirm that the main problem for inhabitants, landowners and managers is the shared property, i.e. land and/or buildings which are not owned by a single entity. Lack of understanding about the legal relations between landowners, managers and apartment owners as well as lack of knowledge about their mutual rights and responsibilities creates frustration and passivity with regard to maintaining and improving the housing environment (Kvartāla vides vērtējums iedzīvotāju un zemes īpašnieku skatījumā, SKDS 2013). A further complication is that sometimes these owner relationships are imposed artificially without taking into consideration the interests of all parties (Gruis et al. 2009; Csizmady et al. 2016). Taking into 
account the specific socio-demographics of large housing estates such as the elderly with specific interests and financial recources, the lack of active progress from the inhabitants is concerning.

Despite these significant problems, Riga's large housing estates are active parts of the city where most of the inhabitants live. Apartments are in active demand in the real estate market; their price is about $50-70 \%$ of the price of new apartments in the same district (Latio 2017).

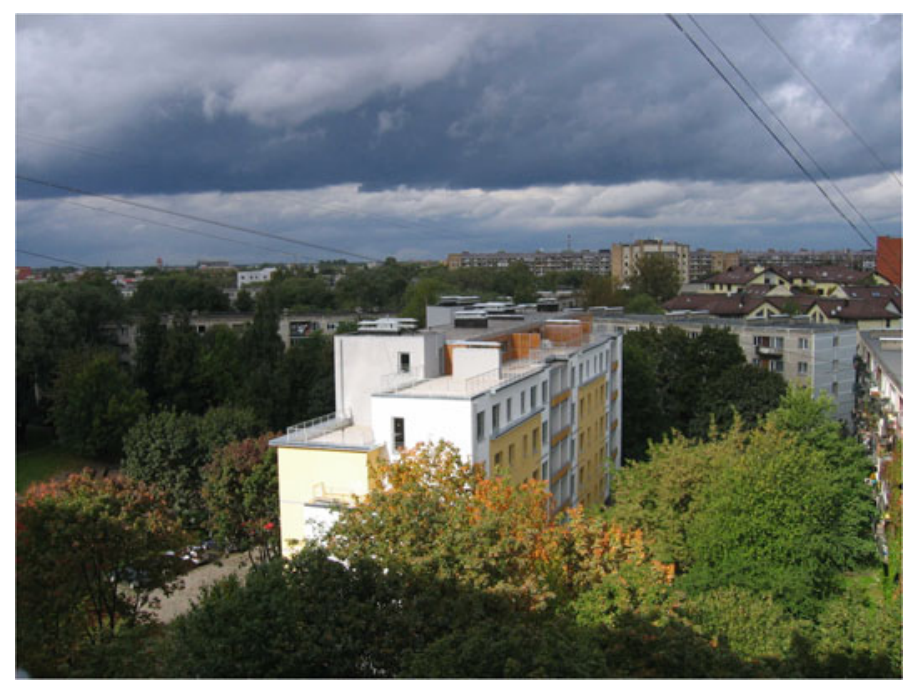

Fig. 8.8 New infill in large housing estate Purvciems. Source Sandra Treija

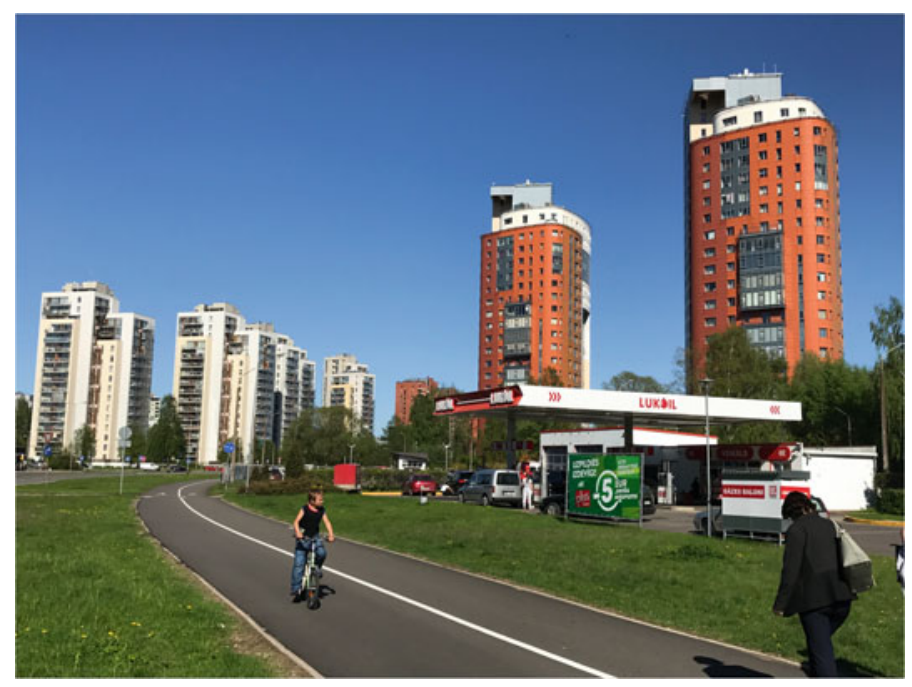

Fig. 8.9 New complex of high-rises in large housing estate Imanta. Source Sandra Treija 
Unused land plots that are not attached to privatised buildings are viewed by property owners as potential new building sites. Since the year 2000, around 60 new residential buildings have been built on the territories of large housing estates as well as a large number of buildings near their borders (Figs. 8.8 and 8.9).

Population surveys also show a high level of satisfaction. In various surveys, $70-90 \%$ of the population report that they are satisfied with the residential area (Iedzīvotāju aptauja par dz̄ivi apkaimē, Purvciems, Aptauju Centrs 2013; Imantas iedzīvotāju vērtējums dzīvei apkaimē, SKDS 2013; Zolitūdes iedz̄ivotāju vērtējums dzīvei apkaimē, SKDS 2013). However, it is important to consider the stability of this satisfaction. Public perception and the supply of alternative housing in the real estate market can strongly impact residents' opinion (Herfert et al. 2013).

\subsection{Conclusion}

The design and construction of new residential areas and separate buildings in Riga during the Soviet period strictly adhered to the prevailing housing construction ideology. The main essence of it was a strong, almost totalitarian centralisation of the development and implementation of this ideology in Moscow for the entire USSR. That led to designs of standard residential buildings that were approved and constructed in accordance with the requirements of the central authority. Since the official goal was to build more and more square metres of residential space, standard apartment buildings were the best solution. This resulted in mass implementation of prefabricated reinforced concrete products, large-slab structures and spatial elements in the construction of apartments. The adaptation of these dwellings to the needs and requirements of today's communities is a challenge for the development of many cities.

There are questions that should be discussed among a wider professional audience related to the future of functional and physical organisation of large housing estates. Are the original spatial organisation and architecture of buildings in large housing estates considered to have an architectural value as a piece of the Modernism period and, in this context, respected? Assuming that the original structures are to be respected and that new buildings must fit in, it can be concluded that it would be difficult to attain a harmonious environment; each courtyard is a self-contained, wholly sealed composition. The original architects did not anticipate the need to accommodate further additions and modifications.

Previous studies have shown that the causes of degradation in large-scale residential areas are related to shared land ownership and management problems as well as economic and social situations. In order to carry out complex reconstruction projects, effective planning, financing, management and legal instruments must be developed. Finding solutions among parties with different interests is a complicated task due to changes that will directly affect real estate property rights. 
So far, the balance between the quality of residential space in large housing estates and their market prices as well as the reputation and quality of the local educational institutions have kept the inhabitants in these areas. The limited financial capacity of the population, the lack of alternative residential areas and established social ties have been the main reasons which have allowed the large housing estates to remain an attractive choice for residents of the city. The main challenge is to maintain the attractiveness of these areas in the future. Improvements such as increasing energy efficiency, using renewable energy sources, changes in waste management and enhancing accessibility among other measures cannot be carried out without the support of all stakeholders.

\section{References}

Asaris G (1976) Kvalitātes plānošana. Māksla, Nr. 1. Māksla, Rīga, pp 4-6

Brinkis J (1996) A short historical review of large scale housing areas in Riga. Large scale housing areas in the Baltic Countries. Lund Centre for Habitat Studies, Lund, pp 65-70

Berglund U (2002) Privatisation, segregation and local engagement: a Latvian case study. Challenges and opportunities in housing: new concepts, policies and initiatives. CIB Publications, Riga, pp 33-49

Caldenby C (2010) From cradle to grave. In: Caldenby C, Wedebrunn O (eds) DOCOMOMO. Living and dying in the urban modernity. The Royal Academy of Fine Arts, Copenhagen, pp 5-17

Centrālā Statistikas pārvalde (2006) Housing privatisation by statistical region, city and district at the end of the year 1996-2006. Downloaded from Centrālā Statistikas Pārvalde electronic database. http://data.csb.lv/. Accessed 16 Oct 2017

Centrālā Statistikas pārvalde (2017) Housing stock by statistical regions, cities and districts at the end of the year 1990-2009. Downloaded from Centrālā Statistikas Pārvalde electronic database. http://data.csb.lv/. Accessed 12 Oct 2017

Csizmady A, Treija S, Fáczányi Z, Balogh P (2016) Participatory design processes for the development of green areas of large-scale housing: case studies from Budapest and Riga. Crit Hous Anal 3(2):17-25

Gruis V, Tsenkova S, Nieboer N (eds) (2009) Management of privatised housing. International policies and practice. Wiley and Blackwell, Chichester

Herfert G, Neugebauer CS, Smigiel C (2013) Living in residential satisfaction? insights from large-scale housing estates in Central and Eastern Europe. Tijdschrift voor economische en sociale geografie: TESG. Wiley and Blackwell, Oxford

Imantas iedzīvotāju vērtējums dzīvei apkaimē, SKDS (2013). http://www.sus.lv/sites/default/files/ media/faili/atskaite_imanta_12_2012.pdf. Accessed 14 Oct 2017

Iedz̄ivotāju aptauja par dzīvi apkaimē, Purvciems, Aptauju Centrs (2013). http://www.rdpad.lv/ wp-content/uploads/2014/12/1_apkaime_Purvciems_atskaite.pdf. Accessed 14 Oct 2017

Kazāks V (1982) Cik paaudzēs dzīvosim. Māksla 2(94):20-23

Krantz B (1999) Large scale housing estates in North-West Europe: problems, interventions and experiences. Delft University Press, Delft

Krastiņš J, Strautmanis I, Dripe J (1998) Latvijas arhitektūra no senatnes līdz mūsdienām. Baltika, Rīga 
Kvartāla vides vērtējums iedzīvotāju un zemes īpašnieku skatījumā, SKDS (2013). http://www. arhitekts.riga.lv/images/mikrorajonu-petijumi/socialais-audits/RBAB-Purvciems-DzI-2014_ papild.pdf. Accessed 8 Oct 2017

Lejnieks, J. (2005), Living in Latvia 1944-1991, Constructed Happiness. Domestic Environment in the Cold War Era, ed. Mart Kalm, Ingrid Ruudi (Tallinn: Estonian Academy of Arts): 222-227

Lūse M (1971) Latvijas pilsētu dzīvojamo kvartālu apstādījumu izmantošana. In: Tīlmanis O et al (ed) Latvijas PSR pilsētu arhitektūra. Zinātne, Rīga, pp 159-173

Marana I, Treija S (2002) Large housing estates: a challenging space. Challenges and opportunities in housing: new concepts, policies and initiatives. CIB Publications, Riga, 49-61

Melbergs G, Pučinšs E (1969) Rīgas jaunā generālplāna arhitektoniskā plānojuma principi. Arhitektūra un pilsētbūvniecība I. Rịgas Politehniskais institūts, Rīga, pp 88-94

Melbergs G (1979) Dažas mājokḷu celtniecības problēmas pilsētekoloğijas skatījumā. In: Buka O et al (ed) Latvijas PSR pilsētu arhitektūra. Zinātne, Rīga, pp 132-140

Melbergs G (1989) Dzīvoklis 2000. Māksla, Nr.6. Māksla, Rīga, pp 34-35

Melbergs G (1993) Rīga no otrās līdz trešajai atmodai. Māksla, Nr.3. Māksla, Rīga, pp 78-80

Palacin J, Shelburne CR (2005) The private housing market in Eastern Europe and the CIS. Discussion Paper series No 2005.5. UNECE, Geneva

Piešinš J (1982) Trešās paaudzes aplēse. Māksla, Nr. 2. Māksla, Rīga, pp 17-19

Residential market report Riga City and other regions, Latio (2017). http://latio.lv/en/services/ market-analysis-and-review-1/housing-market/153/eng-latio-residential-market-report-2017q4.pdf. Accessed 14 Feb 2018

Rubīns J (2004) Rīgas dzīvojamais fonds 20. gadsimtā. Jumava, Rīga

Saferagic D (2002) Housing quality - two faces of the same coin. The twin pursuits of satisfactory housing and housing satisfaction. CIB Publications, Tallinn, pp 179-195

Scientific Collection of Latvian Museum of Architecture, S11-84

Slava D, Geipele S (2012) Legal and economic problems of housing management in Latvia. Ekonomika un uzñēmējdarbība. RTU, Riga, pp 144-153

Strautmanis I (1977) Dialogs ar telpu. Liesma, Rīga

Šusts V (1966) Laikmetīgais mājoklis. In: Zakamennijs O et al (ed) Laikmetīgā arhitektūra Padomju Latvijā. Liesma, Rīga, pp 19-27

Švidkovskis O (1967) Dzīvojamā vide sociālistiskajā sabiedrībā. Māksla, Nr. 3. Māksla, Rīga, pp $16-20$

Tsenkova S (2002) Housing reforms in Riga: the politics of muddling though. Challenges and opportunities in housing: new concepts, policies and initiatives. CIB Publications, Riga, pp 3-33

Tsenkova S, Turner B (2004) The future of social housing in Eastern Europe: reforms in Latvia and Ukraine. http://www.urbancentre.utoronto.ca/pdfs/housingconference/Tsenkova_Turner_ Social_Hous.pdf

Treija S (2009) Housing and social cohesion in Latvia. In: Holt-Jensen A, Pollock E (eds) Urban sustainability and governance. Nova Science Publishers, New York, pp 197-207

Treija S, Bratuškins U (2013) Large-scale housing estates in Riga: from standardized design to market driven development. Survival of modern: from cultural centres to planned suburbs. The Royal Danish Academy of Fine Arts, Copenhagen, pp 102-119

Treija S, Bratuškins U, Bondars E (2012) Green open space in large scale housing estates: a place for challenge. J Arch Urban 36(4):247-254 (Routledge)

Turkington R, van Kempen R, Wassenberg F (2004) High-rise housing in Europe. Current trends and future prospects. Delft University Press, Delft

Van Kempen R, Dekker S, Hall S, Tosics I (eds) (2005) Restructuring large housing estates in Europe. University Press, Chichago

Wallace C, Pichler F, Haerpfer C (2012) Changing patterns of civil society in Europe and America 1995-2005: is Eastern Europe different? East Eur Politics Soc 26 
Zolitūdes iedzīvotāju vērtējums dzīvei apkaimē, SKDS (2013). http://www.sus.lv/sites/default/ files/media/faili/atskaite_zolitude_12_2012.pdf. Accessed 16 Oct 2017

Валескалн В, Васильев Ю (1969) Этапы развития архитектуры социалистической Риги. Архитектура и градостроительство. Рижский Политехнический институт, Рига, pp 57-93

Пиешиньш Я (1969) Тенденция развития основных принципов формирования функциональной структуры новых жилых комплексов города Риги. Архитектура $u$ градостроительство. Рижский Политехнический институт, Рига, pp 5-16

Open Access This chapter is licensed under the terms of the Creative Commons Attribution 4.0 International License (http://creativecommons.org/licenses/by/4.0/), which permits use, sharing, adaptation, distribution and reproduction in any medium or format, as long as you give appropriate credit to the original author(s) and the source, provide a link to the Creative Commons license and indicate if changes were made.

The images or other third party material in this chapter are included in the chapter's Creative Commons license, unless indicated otherwise in a credit line to the material. If material is not included in the chapter's Creative Commons license and your intended use is not permitted by statutory regulation or exceeds the permitted use, you will need to obtain permission directly from the copyright holder. 


\title{
Chapter 9 \\ Living in a Large Housing Estate: \\ Insider Perspectives from Lithuania
}

\author{
Viltė Janušauskaitė
}

\begin{abstract}
This chapter explores the concept of a particular type of living environment — a large socialist housing estate — and its daily life in Soviet times through the memories and narratives of its residents. The analysis compares experiences of those who moved into and lived in three Vilnius mikrorayons: Lazdynai (awarded the Lenin prize in 1974), Žirmūnai (awarded the State prize in 1968) and Karoliniškès, built when the euphoria of getting a new apartment of one's own was already dampened by increasing general criticism of mass housing. The research relies upon 29 in-depth qualitative interviews with people who, at the time, were newcomers to the newly built districts and who still reside there. Findings suggest differences in opinions about living environments between residents of Lazdynai and residents of the other estates, the former being strongly influenced by the Lenin prize and its echoes in public discourse. The analysis examines the shift in attitudes over time concerning this model of living environment together with particular aspects of it, starting with the earliest, often highly optimistic impressions back in the late 1960s and culminating in the defensive nostalgia prevailing in contemporary opinions.
\end{abstract}

Keywords Housing estates - Mass housing - Mikrorayon - Soviet daily life • Vilnius, lithuania

\subsection{Introduction}

Mass housing, a specific and unusual type of living environment at the time of the construction of the first mikrorayons, imposed a completely new way of organising everyday life. It is therefore of great importance to understand how the ideas of urban and architectural design incorporated in mass housing estates affected and

\footnotetext{
V. Janušauskaitė $(\bowtie)$

Department of History, Vilnius University, Vilnius, Lithuania

e-mail: vilte.jan@gmail.com

(C) The Author(s) 2019

D. B. Hess and T. Tammaru (eds.), Housing Estates in the Baltic Countries,

The Urban Book Series, https://doi.org/10.1007/978-3-030-23392-1_9
} 
influenced their residents' way of life while on the other hand, the strategies newcomers employed to make themselves feel at home in their new apartments.

Mass housing was a large-scale enterprise in Lithuania: Vilnius' housing stock multiplied nearly five times between 1945 and 1990 (Miškinis 1991: 92). At the beginning, these estates presented models of socialist living, but today housing estates are subject to growing criticism and an image of urban ghettos is taking hold (Caldenby 2010: 5, 16). Yet, the foundation of nearly all discussion concerning this topic is professional opinion that lacks consideration of resident attitudes. A similar trend afflicts contemporary research analysing Soviet-period housing in Lithuania or in other parts of the former Soviet Union. The scholarship can be classified into the categories of urban (Caldenby 2010), architectural (Dremaitè 2006) and design (Crowley 2002; Buchli 1997; Lakačauskaitė-Kaminskienè 2011) analysed from the perspective of professional outsiders (architecture, art and cultural historians) (for example, Drèmaitė et al. 2012 covers all three categories, including relevant social and political contexts).

On the contrary, this chapter analyses the built environment and residential space of socialist mass housing estates and daily life lived within them through memories and narratives of residents. The research presented herein has similarities with other relevant studies based on ethnographic methodology and data, including research about the Soviet housing experiment as experienced by residents (Buchli 1999). Gullestad (1984) explores democratic welfare state societies with a focus on living environments and the home-centred realm with relevance to large housing estate of the 1960s and 1970s around the Baltic Sea. The material aspects-for example, DIY and manual craft, of 'making a home' in the former Soviet Union - are richly explored by Reid (2014). This chapter both contextualises and extends previous scholarship by relying on qualitative interviews and emphasising material culture.

Representing the first attempt to enlarge the scope of scholarship about experiences in centrally planned housing within the Lithuanian context, this chapter compares experiences in three Vilnius mikrorayons: Lazdynai, which was the most praised (constructed between 1967 and 1974 and awarded the Lenin prize in 1974), Žirmūnai, less renowned but still well respected (constructed between 1962 and 1969 and awarded the State prize in 1968) and Karoliniškès (constructed between 1970 and 1976). Completion of the last of these occurred when the initial euphoria of acquiring a new apartment was already dampened by growing criticism both of centrally planned housing in general, and particular aspects of the style, such as poor building quality, incomplete construction and uniformity: 'Žirmūnai, Lazdynai are like the peaks of mass housing in Lithuanian cities. Meanwhile other complexes are still far off that level' (Miškinis 1991: 86).

In all three mikrorayons, newcomers were assigned to new apartments equipped with modern conveniences. Shops, schools and kindergartens designated for the inhabitants' daily needs were located nearby. Plans for public transport and new roads existed to connect the estates - proclaimed as being quiet and green - with the city centre and industrial areas. It might have seemed as if the newcomers were living out a dream, but they faced significant challenges. It is therefore important to represent memories of daily life from the perspective of insiders and to compare 
variations in the living conditions and opinions of residents of Žirmūnai, Lazdynai and Karoliniškès. This research exposes a shift in attitudes over time concerning standardised housing, beginning with the first, often optimistic impressions in the late 1960s and culminating in rather negative or, conversely, defensively nostalgic contemporary opinions (Janušauskaitė 2015).

\subsection{Data Collection}

The research presented in this chapter employs a qualitative approach. It consists of two techniques: in-depth interviews with fragments of participant observation and archival research (especially fonds No. 1036 and 1070 in the Vilnius Regional State Archive, where information concerning design and construction processes is preserved, and relevant press publications of the period). Two strictly quantitative pieces of sociological research conducted immediately after the construction of the districts, completed in 1974 in Lazdynai and in 1980 in Karoliniškès (Vanagas 1992), proved also to be a valuable source of information. A detailed survey, designed by urban planner and researcher Vanagas (1973), was intended to elicit feedback from new tenants and suggest guidelines for future mass housing projects. Respondents were selected using probability sampling based on the type and size of their apartment with responses generated from interviews. The survey covers a broad range of questions from urban design to the size of the kitchen or residents' preferred ways to spend their leisure; its data complements and confirms contemporary findings.

Ethnographic data has been collected using semi-structured qualitative interviews conducted between January 2013 and September 2017. Participants were selected according to the following criteria: they moved into the mikrorayons Žirmūnai, Lazdynai or Karoliniškès when newly built, and have resided there ever since, i.e. they identify themselves as 'original tenants'. There was no intention to study social circles within the framework of this research, but because the first interviewees who themselves were found through personal social networks provided further information on their neighbours or friends, and snowball sampling was used onwards to enlarge the interview base and to compare several attitudes towards objectively identical conditions or events. There were 29 interviews conducted in total, five with two interviewees (such as spouses or neighbours). For a detailed account of participants and their living conditions, see Table 9.1. All participants received information about the goals and methods of this research and gave their consent to participate. In addition, all the names mentioned in this text are pseudonyms and personal details, such as addresses and work positions, remain concealed.

The majority of the research participants have lived in the mikrorayons for more than 40 years. Residents belong to two generations: they either received the apartments as working people or they moved in with their parents. Most of the residents are now elderly, causing many of the interviews to take place in the setting 


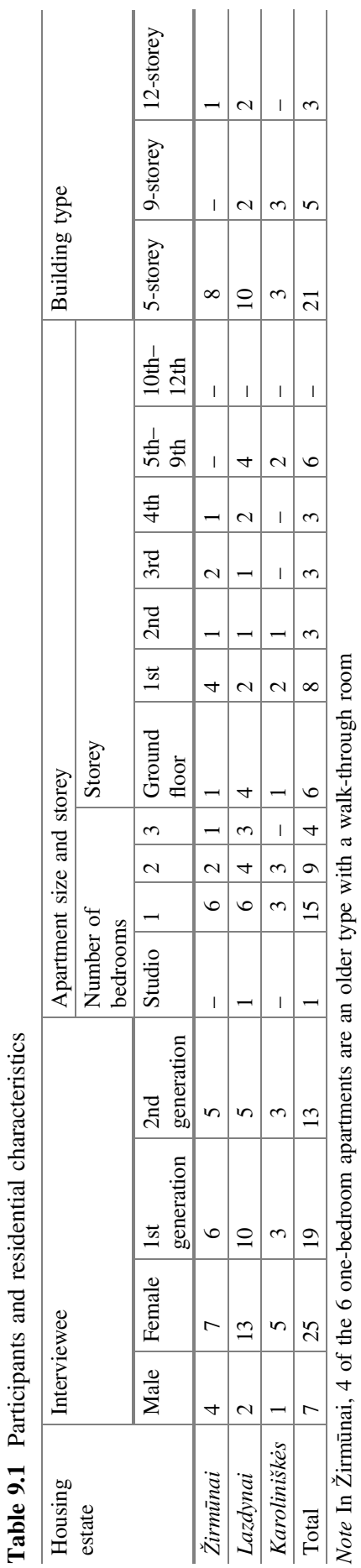


of their home, which provided additional non-verbal information concerning their living environment and daily routines. Conversations covered various topics (in chronological order), reflected in the organisation of this chapter: 'getting an apartment', moving in, settling in and dealing with defects and deficiencies, relations with neighbours, living conditions and daily life in Soviet times, opinions of various housing estates (including their place of residence), and finally changes in attitude over time as the socialist system collapsed and both people and buildings grew old.

\subsection{Acquiring a New Apartment}

'One family in one apartment', was an official goal established by the USSR Communist Party in 1957 (Dremaite 2006: 323). Yet getting a private, modern apartment was considered an immense achievement throughout the 1960s and 1970s. As Laima from Lazdynai emotionally recalled: 'When you don't have anything and you get an apartment, you feel as if you're in heaven'. There were three ways to get an apartment through the state-regulated housing allocation system: first, people could wait in a general housing queue; second, they could get an apartment from the organisation where they were employed (depending on the type of organisation: retail staff stood no chance in comparison to construction workers) and third, they could join a building cooperative. Waiting lists were long (though considerably shorter for cooperative housing), and the housing distribution system was never transparent causing many people to join cooperatives and pay for a new apartment themselves. Paying for cooperative housing was also the only officially permitted way to acquire more square metres per person than could be allocated according to the rules.

The most popular apartment type was a communal one-bedroom apartment (with a typical size of approximately $45 \mathrm{~m}^{2}$ ), which constituted $42.9 \%$ of all the apartments built in Lazdynai, and 50.7\% in Karoliniškès (Vanagas 1992: 44). These apartments were never referred to as 'one-bedroom apartments' but were instead known as two-room apartments because the rooms did not differ significantly in size or other qualities and usually served as multifunctional spaces. In Indré's opinion, this practice had a negative impact on the demographic composition of residences: 'virtually the whole block consisted of two-room apartments, so all the families on this staircase were single-child families'. Yet, a 1974 survey of the then prestigious Lazdynai revealed that in almost one-third of three-bedroom apartments, someone was regularly sleeping in the walk-through living room. In one-bedroom apartments, this number increased to nearly two-thirds (Vanagas 1992: 79). Therefore, design professionals promoted convertible furniture which was highly desired by tenants.

Most of the apartments were identical: thus, the main distinguishing feature, except for the apartment number, was its vertical location in the building. The first and second floors were almost uniformly recognised as the best options as they 
were elevated from the ground level but not too high, considering that five-storey buildings for economic reasons were still designed without an elevator. In the higher blocks, which were usually regarded as inferior for many reasons by those who lived in the lower buildings, opinions were divided between the lower and the upper floors, which offered stunning views (except for the very last floor which was notorious for its coldness in winter, heat in summer and constant leaking). There was common agreement that the ground floor was the worst for having no privacy (security issues emerged only a few decades later). It was possible to swap between floors, but this happened only in exceptional circumstances such as a sick or disabled person in a family needing to live on the ground floor. In cooperative buildings, the procedure of drawing lots was adopted to ensure a fair distribution process, but in many cases it introduced possibilities for corruption: 'it was discrimination because we all paid the same money but we drew different lots: all the philologists and teachers drew a lot with the ground or the fourth floor and a bad layout' (Elvyra, Žirmūnai).

\subsection{Moving In}

Newcomers were usually full of curiosity and excitement, so they tried to pay a visit as soon as possible. However, their initial impressions often proved to be somewhat controversial in all three housing estates as illustrated by the following conversation of a married couple:

Margarita recalls: 'I came here, it was still under construction, it was mud, it was a quagmire'.

Vladas retorts: 'And I could hear a cuckoo calling. As a country man, I really liked it'.

In fact, many residents drew a distinction between city people and 'rural children' as they called themselves. Apparently, those who came from a rural background more often appreciated nature and its benefits, which were obvious from the very first visits to all three estates, while others were horrified by the muddy surroundings that 'looked like trenches after the war' (Elvyra). Trees, which were later promoted as one of the most prominent features of effective modernist planning, were still very young or not even planted (see Fig. 9.1). Ona recalled how her elderly mother complained about Lazdynai: 'it was so empty, there wasn't a single tree, nothing... it was such a desert'.

Ironically, residents of Lazdynai, the estate proclaimed to be 'the most fully completed in the republic' (Vanagas 1973: 8), complained the most. The situation was so bad at one point during the autumn that a construction worker in big rubber boots had a special task: help remove people stuck in the mud near the central avenue. This was inconvenient since newcomers had to be quite creative to avoid material loss. For example, Nijole lost one of her shoes in the mud, and then someone told her to wrap her shoes with plastic bags. Her neighbour, Laima, 


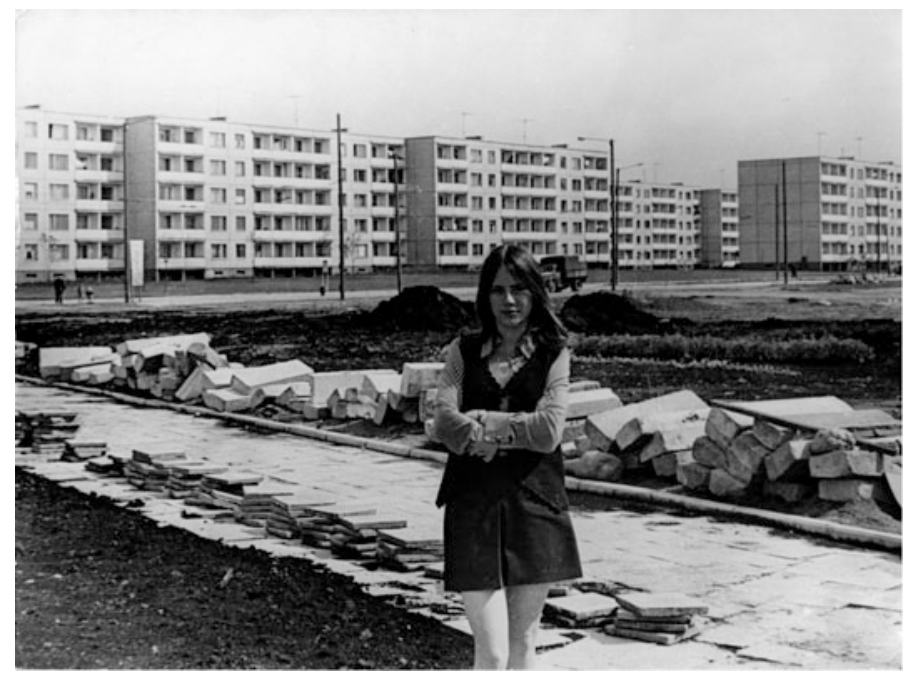

Fig. 9.1 Beginning a new life in Žirmūnai. Source V. Janušauskaite family archive

created a paved path from her entrance to the completed sidewalk using concrete tiles stacked nearby, but by the evening the tiles had sunk into the mud.

The new housing estates were still considered to be located somewhere far away and this image was reinforced by inadequate or incomplete transport connections that depended on bridges which had not yet been built. No 'main street' existed in Žirmūnai in 1965, and to reach public transport, newcomers travelled on foot approximately $1.5 \mathrm{~km}$ to the west to Dzeržinskis street. Aronas recalled that the first day he made his way home from school was horrible: it was far away, a long walk through puddles, and all he knew was the general direction (no accurate city maps were publicly available in the Soviet Union at the time, only very distorted, small-scale diagrams). On the other hand, there were two ferries from Žirmūnai to Antakalnis on the opposite bank of river Neris. The ferries only operated during the summer season, and thus the opening of Žirmūnai bridge in 1967 (for the jubilee of the Revolution) is remembered as 'a huge improvement' by Liudmila. Valakampiai bridge was completed later, but the time saving was so significant that Alma used to ignore the danger and cross this bridge while it was still under construction in order to get to her collective garden. The initial lack of asphalt also made journeys complicated. For example, at the beginning, the last bus to Lazdynai left at 9:00 PM and 'after that, you've had it. Taxi? Taxis didn't go to Lazdynai because of the bad roads; it was quite possible to get stuck' (Laima and Nijolè).

Built on the sites of former suburban villages, the new residents of the three housing estates could see remnants of the villages that were incongruent with the current socialist reality: an abandoned Jewish cemetery in Karoliniškès, overgrown orchards in Lazdynai, wooden cottages (Fig. 9.2) and the almost invisible remains of Calvary chapels marked with brick-lined flowerbeds in Žirmūnai. Children 


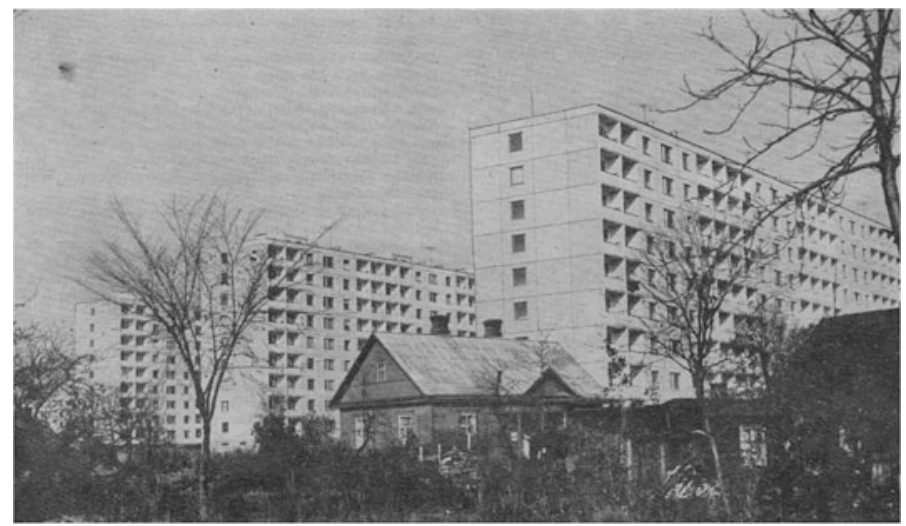

Fig. 9.2 Housing blocks drive out the Giedraičių street slums. Source Statyba ir architektūra, December 1968, used with permission

eagerly explored these places. The sites of the future - that is, large unfinished structures that surrounded already inhabited blocks - also peaked the interest of children. Every element of the new environment transformed into a resource. For example, 'playing home' required children to 'build' an apartment 'to live in', arranging the layout of it on the ground using paving slabs from nearby stacks of building material. Other popular activities included frequent visits to abandoned cottages or construction sites. Marius and his friends managed to climb onto a diving platform to look down upon the empty unfinished Lazdynai pool. Incomplete housing blocks became sites of play: it was fun for children to throw sticky black insulation material (for building panel joints) at other children. In Karoliniškès, children tried to wash the material to produce chewing gum, mostly unavailable in the USSR. Meanwhile, the adults had to deal with issues that are more practical: initially, the elevators in nine- and twelve-storey apartment buildings remained (intentionally) out of order to avoid possible damage from large furniture items, forcing residents to climb the staircases with all of their possessions.

\subsection{Deficiencies}

Most of the interviewees had never had their own personal apartment before, so almost any level of quality was still an improvement. Yet, there is a distinction between Lazdynai and the other two mikrorayons. Residents of Žirmūnai and Karoliniškès demonstrated a moderate attitude towards the quality of their apartments and instead emphasised their feeling of joy. One issue that bothered a significant part of Žirmūnai residents was the poor design of 'older type' one-bedroom apartments, containing two main living spaces, a larger walk-through room and a 
second very narrow room, 'like a corridor' (see Fig. 9.3 for the layouts of 'old' and 'new' one-bedroom apartment). Liudmila called this type of apartment the 'worst possible option'. Elvyra felt particularly disappointed because she had paid for new panels (with separated rooms) but was assigned to the older type apartment and only received reimbursement of one hundred roubles. It was a rather small sum of money: Antanina recalls that a two-bedroom apartment in Karoliniškès was worth 8,000 roubles in the early 1970s. Many immediately attempted to address the issue of walk-through room through 'do-it-yourself' efforts or hiring illegally paid labour. For Alma this attempt ended up in court: 'I found out that there was a workshop where Jewish people were working. They made walk-in closets which separated one room from another. When they were delivering the closet to me that I ordered, they were stopped by the militia. I was summoned to the court for interrogation and I was told that they were doing everything illegally and the material was confiscated. Later on, I got it back because it was already paid for'. Another sensitive aspect that is still highly contentious is bathroom layout. Some consider that a separate toilet is convenient for larger families while others argue that it is simply unhygienic with no sink for hand washing in a tiny toilet room. Indre's grandfather, who often came for the winter from a rural area, complained that it was too close to the kitchen: he felt that the proximity of food and toilet was inappropriate.

Despite the fact that there were similar small issues in all three estates, it was Lazdynai newcomers who immediately noticed and listed a series of defects of varying importance: bad quality of windows, doors, flooring and wall paint, residual dampness from the construction, even rotten wood under the linoleum flooring and 'not a single perpendicular wall' (Bronè). However, there was one
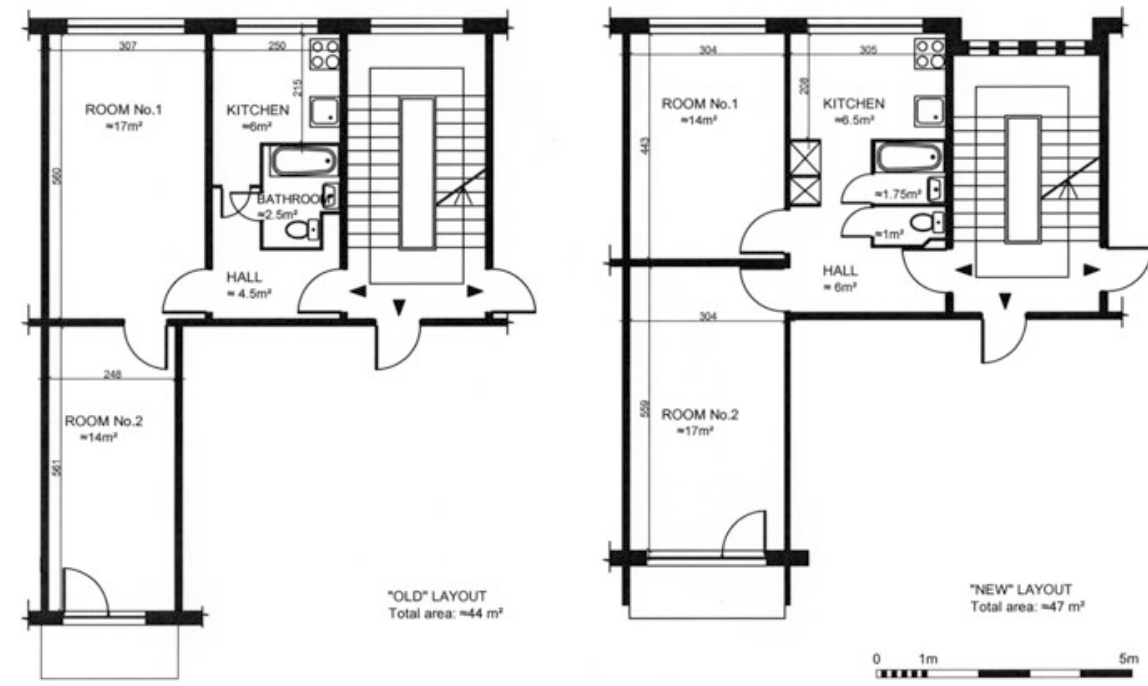

Fig. 9.3 Plans of 'old' and 'new' one-bedroom apartments. Source Drawing by V. Janušauskaite (2018), based on original plans 
defect on which all the interviewees uniformly agreed. Prefabricated apartment buildings were well known for their poor sound insulation: inner concrete walls were only $14 \mathrm{~cm}$ wide; consequently, Alma could hear her drunken neighbour snoring. These walls required residents to adapt various noise mitigation strategies: for example, Indrè's father in Žirmūnai wouldn't allow her to begin her piano practice without first covering all the electricity sockets in the room with cushions to muffle the sound.

Officially the certificate of building completion could not be approved without the signatures of all residents, confirming that all the defects had been resolved (this also suggests that defects were expected), but after Elvyra refused to sign, her signature was forged. Frustration due to constant shortages and poor quality of nearly all the elements of the living environment resulted in two opposite attitudes. For example, Petras considered it of no importance: 'I must confess, I'm not a craftsman myself. Those trivial things...' This is reminiscent of the spiritual ideal of the 1920s, described by V. Buchli in Narkomfin (Buchli 1999: 132) and revived in the second wave of modernisation (Buchli 1997: 161). This attitude was quite widely shared, because even those who chose the other extreme-'hunting' for better quality items and ordering individually made furniture - adopted this modernist aesthetic. Categorisation of taste even served to define the 'other': 'you can immediately distinguish the residents of these apartment buildings. They prefer colours such as bright yellow, green, pink...' (Nijolè).

\subsection{Neighbours}

The Soviet housing allocation system was found on social and ethnic mixing: a university professor should comfortably live beside a factory worker in an identical apartment. This tool intended to create an equal society but in reality, it did not encourage people to interact with neighbours with whom they did not share similar interests and values. This trend had been identified in the above-mentioned Vanagas' 1970 s survey, when only $13 \%$ of respondents attested to spending their leisure time with neighbours, compared to $39 \%$ spending time with family and relatives and 22\% with colleagues (Vanagas 1992: 60).

Physical integration served to increase psychological segregation. Liudas even pointed out that one of the advantages of a nine-storey building is that 'you can run away. You don't need to meet a neighbour and greet him'. Neighbours or even entire blocks were described according to nationality (Lithuanian, Russian, Polish, Jewish), social background (people of rural origin versus intelligentsia) and social position (white-collared employees versus workers). Interviewees in Lazdynai and Žirmūnai, who regarded themselves as members of the intelligentsia, emphasised that 'cultured people' populated their neighbourhood, thus classifying themselves too as 'special'. In particular, inhabitants of Žirmūnai strongly contradicted the stereotype of the blue-collar mikrorayon. This confirms that the social utopia of mixing different people was not successful: most of the residents made friends only 
with 'birds of the same nest' (Bronè). There were some exceptions in apartment buildings of more homogeneous social composition: whether the one in Žirmūnai populated by intelligentsia or the one in Lazdynai where people, mostly blue-collars, who relocated from the Naujininkai suburb had retained a sense of micro-community. The latter example confirms Vanagas' survey findings from the 1970s, showing that less educated people were usually more involved in neighbourhood-based relationships - up to $23.4 \%$ compared with only $8.3 \%$ among those with higher education (Vanagas 1992: 62).

It is therefore not a coincidence that the most important attribute of a good neighbour (for 56\% of residents in Lazdynai and 47\% in Karoliniškès in the 1970s Vanagas 1992: 64) was and continues to be, being quiet and polite. The issue of poor sound insulation became especially sensitive when people working for the KGB or similar secretive organisations inhabited any number of apartments. Regard for these residents was a mixture of dislike and fear, and sometimes self-created. For example, Bronè recalled how her neighbour, after getting drunk, used to tell them: 'I'll have you all like this' (clenching his fist). Vladas was certain that the KGB controlled their building in Žirmūnai, because many KGB employees lived there and 'behind our pantries in the basement there was a corridor with an eavesdropping device'.

Having a different ethnic and linguistic background seldom presented challenges. However, it was nearly always an attribute mentioned when discussing neighbours. The question whether there was a dominant daily language in these multilingual environments is worth further research. Many of the interviewees from all three mikrorayons mentioned what Indre and Sonata's discussion of their childhood communications stated succinctly: 'the Polish learned Lithuanian very quickly but the Russians never spoke it. Therefore, we [Lithuanians] learned Russian but not Polish'.

Overall, each person acknowledged that respectable and 'generally good' people populated apartment buildings, and/or staircase, with whom, in most cases, one had little contact. This was emphasised despite the fact that nearly everywhere there were several apartments that were or had been occupied by people who departed from socially appropriate behaviour patterns. Most often, excessive alcohol consumption and its consequences, sometimes murder, caused these patterns. Yet, there were stories of even more unusual crimes: for example, Vladas in Žirmūnai said 'there were graves of Napoleon soldiers... many were buried there with gold teeth... he used to bring [home] their skulls and pull out the teeth'.

\subsection{Daily Life}

All three housing estates resembled Scandinavian-type suburbs. Despite the fact that nearly all residents worked elsewhere, there was planning for various services according to a three-level system: a primary service centre within the distance of $150 \mathrm{~m}$, a secondary centre within $500 \mathrm{~m}$ and a third-level centre (designated for the 
entire estate) within $1200 \mathrm{~m}$ (Dremaitè et al. 2012: 166-167). Built first were the living quarters, due to the housing shortage, and new residents usually moved in while public and commercial buildings were still under construction. This situation resulted in many schoolchildren commuting back and forth on a daily basis to finish their school year in their previous schools in the city centre.

Shabby temporary wooden kiosks served initially as grocery stores. Later, modern buildings and self-service supermarkets replaced these. Žirmūnai residents also appreciated the Dzeržinskis market, where people went on foot or using trolleybus No. 5. There were several cafés in each of the estates, which served coffee (often remembered as of quite poor quality) and pastries. They are now long closed and older residents consider the lack of meeting places as one of the main disadvantages compared with the past. A restaurant on the first floor of the Minsk shopping centre in Žirmūnai was atypical, serving meals prepared according to special dietary requirements and for which patrons needed a doctor's prescription. The cream of the crop was Erfurtas, a restaurant and nightclub in Lazdynai, renowned in Lithuania and promoted to foreign guests, including official delegations (Liutkevičienė 2012: 94, 143-144). Locals too enjoyed being near it in various ways. Petras and Aldona, who lived in front of it, listened on their balcony for free to concerts of famous Lithuanian stars of the time, audible through the bar's open windows. Otherwise, it was not easy to get in unless one knew how to skip the long queues: 'If you took ten roubles and showed it through the window, you would get in immediately' (Nadia). Meanwhile, Marius used to go there after school because it offered a menu of the day for 'one rouble and you could eat more than enough for that'. It seems, however, that people from Žirmūnai and even from Karoliniškès seldom visited this famous place.

Interestingly, neither adults nor children from neighbouring Lazdynai and Karoliniškès interacted in their immediate natural surroundings - the former went down to the river and the latter favoured Lake Salote in the opposite direction or the same river bank but a little bit further away. Even more significant is the fact that people from different parts of Žirmūnai also identified themselves with their respective neighbourhood (unofficially called lower, middle/central and upper Žirmūnai). Indrè professed that a grocery store ten minutes' walk away was already considered 'not ours'. Nevertheless, leisure activities in all the mikrorayons appeared very similar-hiking around all year round, cross-country skiing in winter (see Fig. 9.4), camping, cycling, and bathing and sunbathing in summertime. Liudmila even managed to go down to the Neris River for a swim in the mornings before work. The surrounding area also provided natural resources: Laima pointed out that 'the forest was full of good things - mushrooms and berries... My husband used to get up early and pick fresh mushrooms for breakfast'.

Children used the neighbourhood surroundings for games as well. In all the housing estates, climbing on the roofs was a common activity. In Karoliniškès, the apartment building junctures allowed children to jump from the roof of one nine-storey block to another. The commonality of this behaviour and different perspectives on the limits of safe behaviour caused Sonata to recall: 'As for me, I too jumped... My mum was hanging out the laundry on the balcony on the sixth 


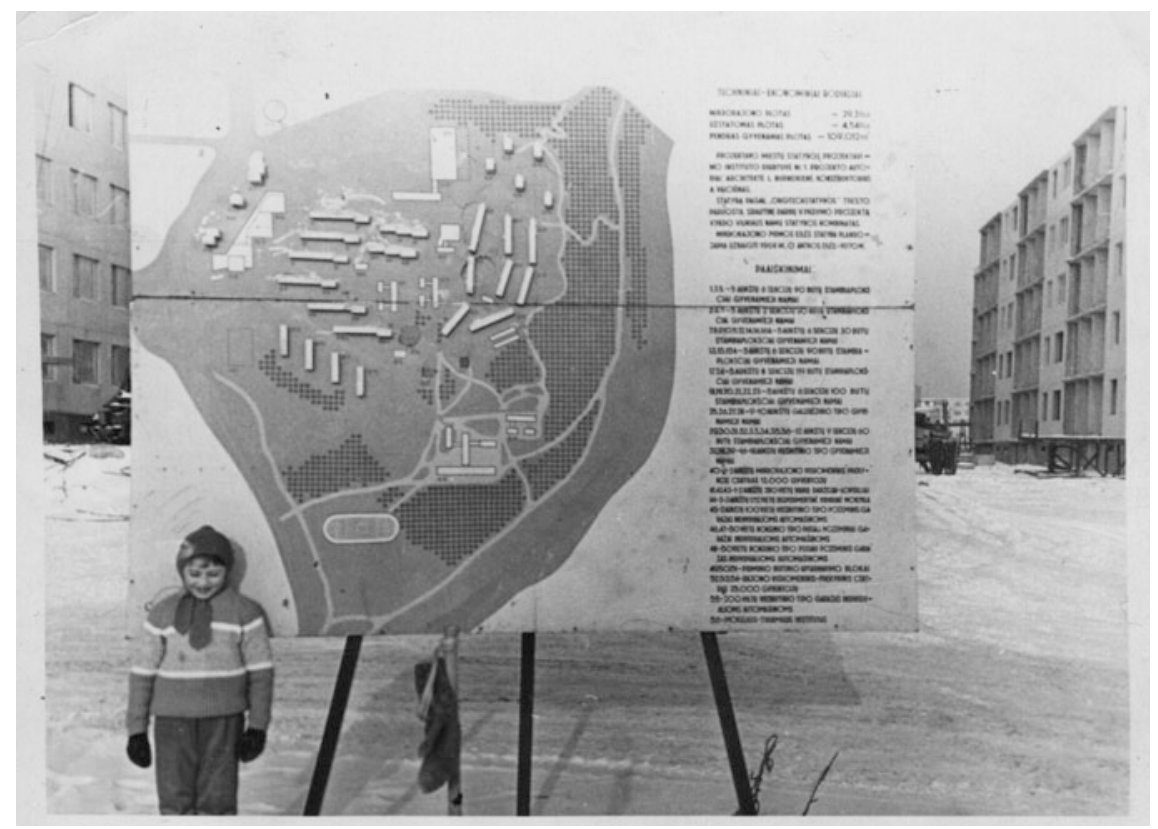

Fig. 9.4 A construction information sign and skiing in Žirmūnai before apartments are occupied. Source V. Janušauskaite family archive

floor. She just looked up and said nothing'. Nadia and her friends in Lazdynai often explored the underground labyrinth of corridors containing heating pipes, with entrance from the basements of their apartment building. Adults allowed children and teens to play alone in the surrounding grounds (Fig. 9.5), and most parents had no idea where or how far kids went. However, the teenage boys experienced the situation, described as very peaceful and secure by adults, somewhat differently.

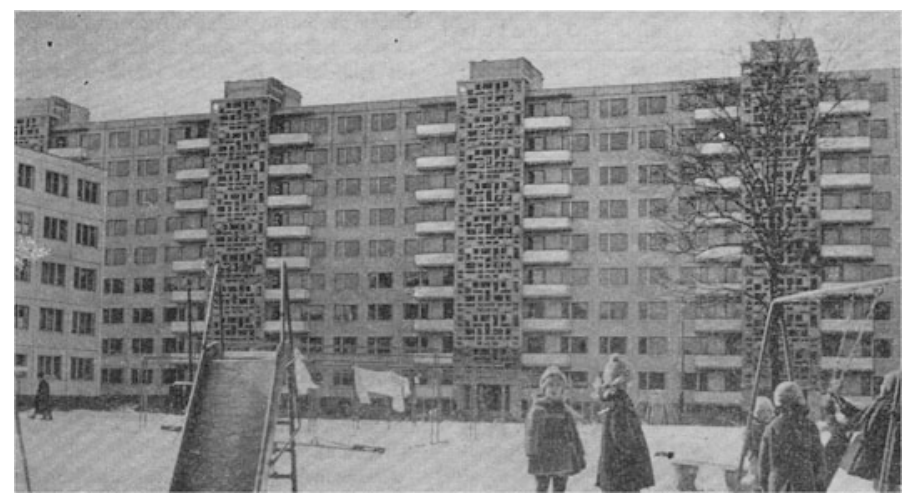

Fig. 9.5 Unattended children playing in the courtyard. Source Statyba ir architektūra, May 1968, used with permission 
Marius from Lazdynai and Liudas from Karoliniškès talked about gangs forming on a territorial basis by teenagers, mostly Russian speaking, who were 'not capable of continuing their education and engaged in drinking, smoking and stealing kopecks'. Liudas was sure that many of them were delinquents relocated away from Russian cities in advance of the 1980 Summer Olympics: however, there has never been any official confirmation of this popular urban myth.

\subsection{Comparisons and Evaluation}

'Lazdynai - the outpost of the new Vilnius' was the title of an article by Jurgis Vanagas (Vanagas 1973: 8-9), in which the author praised the district as a benchmark for the ideal future socialist city. Many similar publications followed. Sociological research statistics were used to bolster perspectives of housing estates; it was shown that $92 \%$ of residents declared that they would choose to live in Lazdynai, even if they had been offered an apartment in any other part of the city (correspondingly, 77\% in Karoliniškès) (Vanagas 1992: 69). After award of the State prize in 1968 to Žirmūnai, the reaction there was much more modest. An article in the professional press only briefly mentioned this achievement and instead elaborated on the predicted future glory of Lazdynai (Statyba ir architektūra 1968: 3-4).

Residents' evaluations mirror this trend. Most interviewees made a comparison between Žirmūnai and Lazdynai, usually in favour of the latter. Liudmila from Žirmūnai recognised that 'Lazdynai is an exceptional neighbourhood while Žirmūnai is functionally good but otherwise just rows of housing blocks'. Meanwhile, Nijolè from Lazdynai pointed out that 'they [the architects of Žirmūnai] also had a lot of space available but didn't do so well'. Raminta even assumed that the materials and equipment for the streets in Lazdynai had to be of better quality because it had to match the standard of the higher level award. The difference is also well illustrated by the fact that nearly all interviewees from Lazdynai mentioned the Lenin prize and often the names of the architects, despite the fact that today the award is considered controversial, because of its connection with the former regime. Interviewees from Žirmūnai needed prompting to recall the award (with the exception of Raminta). Most of them pointed out that they knew about it but that it was not important or wondered why this type of building district received an award. Only Elvyra mentioned the name of the main architect, Birute Kasperavičienè. Finally, no one from Karoliniškès mentioned the urban design or the architects, if one excludes Liudas' remark about 'houses grouped in crosses in a very silly way'.

In a sense, Lazdynai residents were living in a showcase and that undoubtedly had an impact. Nothing similar ever happened in the other two mikrorayons. There were no tours for tourists, no public events on the occasion of the Lenin prize (see Fig. 9.6), no monument commemorating it, no documentary where people could recognise their apartment buildings or even family members and no pressure to 


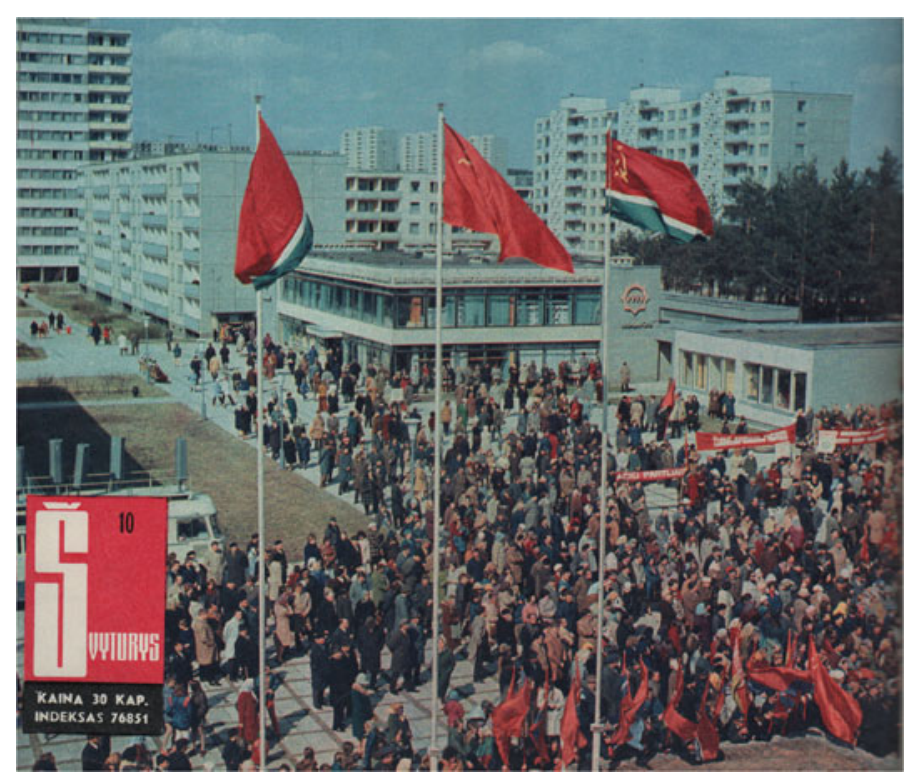

Fig. 9.6 People gather in Lazdynai on the occasion of the Lenin prize. Source Liudas Ruikas, Švyturys, 1974 No. 10

keep the representative appearance. Meanwhile, along the main avenue in Lazdynai, even the laundry visible on the balconies could 'damage the aesthetics of the façades' (Vanagas 1992: 93) — a situation similar to mid-1950s Warsaw (Crowley 2002: 185-186). Genute remembers this rule being observed: 'just put your laundry outside and someone from the local authorities comes and asks you to remove it'. The owner could even have been fined. Lazdynai residents thus learned by heart the positive public comments about the mikrorayon and after a while assimilated them as their own thoughts; today, they still argue that 'there is no better district than this one' (Laima).

In a sense, Lazdynai residents were living in a showcase and that undoubtedly had an impact. Nothing similar ever happened in the other two mikrorayons. There were no tours for tourists, no mass meeting on the occasion of the Lenin prize (see Fig. 9.6), no monument commemorating it, no documentary where one could recognise one's estate or even one's family members and no pressure to keep the representative appearance. Meanwhile, along the main avenue in Lazdynai, even the laundry visible on the balconies could 'damage the aesthetics of the façades' (Vanagas 1992) - a situation similar to mid-1950s Warsaw (Crowley 2002). Genute remembers this rule being observed - just put your laundry outside and someone from the local authorities comes and asks you to remove it' - the owner could even have been fined. Lazdynai residents thus learned by heart the positive public comments about the mikrorayon and after a while assimilated them as their own thoughts, nowadays still arguing why 'there is no better district than this one' (Laima). 


\subsection{Temporal Dimensions}

More than 50 years have passed since the first residents moved into Žirmūnai and nearly 40 since the last residents got their apartments in Karoliniškès. Naturally, the standards of the living environment have changed, and yet most of the interviewees would not like to move out of any of these three mikrorayons: some of them have actually returned after spending some years away. This echoes the results of previous sociological research (Vanagas 1992: 69). However, one may assume that the reasons behind this statement are somewhat different. Most of the interviewees make a distinction between the housing estates of the past rooted deeply in their memories and the housing estates of today criticised in public discourse: 'of course, we were young then, but the estate also grew old' (Janina, Lazdynai).

Today, almost no one describes mass architecture as 'nice' (however, 34\% of respondents formerly did, according to the Vanagas survey 1992: 72). This suggests that the concept of well-designed housing and the general idea of beautiful architecture have changed over time, even among the most enthusiastic original tenants. Even in Soviet times, it was recognised that residents' dissatisfaction had shifted from 'easily corrected defects (construction quality etc.) to permanent features which were impossible to improve, such as the size of the apartment, its layout etc.' Respondents particularly wished to have larger kitchens (approximately ten sq. m) because up to 99\% ate their meals there daily (Vanagas 1992: 77). Today, this issue is even more prominent: in some cases, mostly in Karoliniškès, it has evolved into the need for a bigger apartment. Vilma justified it by referring to a refrigerator attached to the wall at a particular height, so that a family of four could squeeze under it into the tiny kitchen and have their meals together. In a similar way to the reactions towards material culture during Soviet times, another group adopts a defensive attitude to make this issue psychologically easier: 'I just sleep here, all my activities are outside' (Dalia).

The perception of the distance to the city centre is one of the criteria that actually changed for the better. Initially, distances between housing estates and the city centre seemed far but today residents consider it close, not only because the original tenants are accustomed to the daily commute but also due to urban sprawl that appeared in later decades. Lazdynai and Žirmūnai, in particular, receive the proud description of, 'as good as being in the centre, only with fresh air' (Aldona). This is not the case with Karoliniškees: Liudas recalled that, when he moved to his wife's place in Žirmūnai, 'it was central. In Žirmūnai you go out and you can go where you want on foot. When my wife came to me, she said that she had moved from the centre to the periphery'. Nevertheless, the expression 'going to the city' remains used by most of the interviewees, thus maintaining the distinction between the city centre and 'dormitory estates'.

Consistent with the official view of the 1970s, housing estates are praised by their residents for being spacious and designed not in a 'window to window' style as most of the newer parts of the city. The topic of increasing density over time is also germane. While neutral remarks were expressed about the housing blocks that 
'filled all possible gaps' in Karoliniškès (Kotryna), the tall housing block close to Žirmūnai shopping centre was evaluated as being 'out of place' (Liudmila). In Lazdynai, a conspiracy theory was even developed: 'city authorities waited until the prize was awarded and then allowed the district to be spoiled' (Nadia). After all, the new construction erected in recent decades is widely considered to negatively impact urban design in housing estates: 'today they are spoiling Lazdynai by cramming these buildings into it' (Bronè).

Nature is another meaningful theme assimilated from official Soviet descriptions, which still plays an important role in many ways. Most commonly mentioned are the characteristics of fresh air, the greenery and forests around, proximity to the river and the stunning views from the windows of the upper floor apartments. Nature even serves as a means of comparison between housing estates: 'the Neris River is clean in Žirmūnai. Here it enters the city and in Lazdynai it flows out of it' (Juozas). Still, different opinions about housing estates are as dramatic now as they were forty years ago. 'In a sense, I am a patriot of Lazdynai' (Dalia); no such proud claim came from the other mikrorayons. On the contrary, Aronas expressed a more rational attitude using the same concept: 'I am not a great patriot of Žirmūnai, I just like living here'.

\subsection{Conclusion}

This research confirms that, despite many negative opinions in contemporary public discourse and the significant change in housing standards, large socialist-era housing estates are still viewed as good places to live by their long-term residents. These findings also contradict prevailing professional view defining large housing estates as places constructed and lived in out of necessity and not embraced by residents. There are several reasons why. First, the then newcomers came to newly built modern neighbourhoods that were organised to impose a certain way of life and, over time, to become a standard model for residential environments. Furthermore, over many years, housing estates became vital parts of people's lives and their memories. Even tenants who at the very beginning were longing for a socially and culturally vibrant Old Town atmospheres now describe a good housing estate as quiet and green; that is to say, they prefer the modernist model with separate work and recreational areas connected by convenient public transport. Highly appreciated green space in housing estates embodies the modernist ideal of an interesting mix of values and uses: in the very modern housing estate, most people welcome opportunities to enjoy ample nature. A key concern in all the housing estates is a possible increase in density (i.e. to make them less suburban and more 'city-like'), since residents nearly always regard high-density living negatively and appreciate and seek to preserve another significant feature of modernist planning - open space.

On the other hand, tenants have become more critical towards design and construction quality, especially when it concerns individual apartments. This shift 
of attitude applies both when considering the present and remembering the past. The incredible joy of getting an apartment is not forgotten but it is no longer sufficient. Construction defects or initial inconveniences, such as poor sound insulation or muddy surroundings, are reflected clearly in memories, especially in Lazdynai. In other housing estates, these memories accord less significance and tenants place more emphasis on clever personal solutions (for example, bookcases dividing shared rooms). It is the attitude towards defects and self-reliant improvement that positions Lithuania between the (replicated) Scandinavian suburbs and the grandiose and repetitive housing estates of the USSR. While DIY contributed to the creation of residential comfort in Nordic welfare society (Gullestad 1984), it was intrinsic in the context of constant shortages in the USSR. Still, it is was hardly imaginable that residents should contribute to the construction of their housing block (by digging the foundation, etc.) as was practiced in Russia (Reid 2014).

One of the aspects that has not changed at all (though not regarded as either a positive or a negative factor) is the carefully measured relationship with neighbours: intentional social diversity has never worked as a socially unifying tool, and the relationship has now become even more distant and superficially polite, especially when new people move in. The social experiment of imposed mixing ended up in explicitly expressed segregation.

In conclusion, several distinctions exist between the past and the present and between Lazdynai and other mass housing estates. The long-term residents living in housing estates since they were established witnessed a gradual decline in their material environment due to natural wear and tear and to partial neglect caused by limited financial resources and changing priorities. At the same time, they also absorbed the official, usually very positive, opinions expressed in the Soviet press and elsewhere and maintained these adopted views even in the context of negative changes. This is quite understandable: they have remained in the estate (or even returned to it) and therefore have to find the means to create and maintain a certain local identity. Therefore, one special feature of the nostalgia the residents express stands out: declaration of the official discourse of the 1970s as a personal opinion when the interviewees are talking about and reflecting upon their district, which they still love. This defensive nostalgia is more apparent among the residents of Lazdynai; meanwhile, the local narrative or myth of the housing estate has never been elaborated to that degree in Žirmūnai and there are no traces of it at all in Karoliniškès. This has also resulted in different initial attitudes and different memories - compared to Lazdynai, there were fewer complaints about the previous inconveniences, probably due to lower expectations. Now there is less euphoria and the transformation of (self) judgment is less significant.

Author's Note This chapter is written in memory of my grandfather who, as a family man in his late 30 s, was so overwhelmed with joy when he finally got the keys to his newly built apartment in Žirmūnai that he did a somersault in a still empty living room. 
Acknowledgements This research was funded by a grant (No. MOD-17-21) from the Research Council of Lithuania.

\section{References}

Buchli V (1997) Kruschev, modernism and the fight against "Petit-bourgeois" consciousness in the soviet home. J Des Hist 10(2):161-176

Buchli V (1999) An archaeology of socialism. Berg, Oxford

Caldenby C (2010) From cradle to grave. Living and dying in the urban modernity. In: Caldenby C, Wedebrunn $\mathrm{O}$ (eds) Living and dying in the urban modernity. Docomomo, Denmark, pp 5-17

Crowley D (2002) Warsaw interiors: the public life of private spaces, 1949-1965. In: Crowley D, Reid SE (eds) Socialist spaces. Sites of everyday life in the eastern bloc. Berg, Oxford, pp 181206

Drèmaitė M (2006) Pigiau, daugiau, greičiau. Masinė gyvenamoji statyba ir modernizmo kanonai. Naujasis židinys - Aidai 8:321-328

Drèmaitė M, Petrulis V, Tutlytė J (2012) Architektūra sovietinèje Lietuvoje. VDA leidykla, Vilnius

Gullestad M (1984) Kitchen-table society: a case study of the family life and friendship of young working-class mothers in urban Norway. Universitetsforlaget, Oslo

Janušauskaite V (2015) Can nostalgia save the district? The case study of Lazdynai in Vilnius, Lithuania. In: Jian Z, Weijue Z (eds) Proceedings of Community, Space and Governance. City and Society International Forum 2015 Shanghai China. Tongji University Press, Shanghai, pp $127-143$

Lakačauskaitė-Kaminskienė R (2011) Buities modernizacijos skatinimo kampanijos viešojoje erdveje. Menotyra 18(4):291-307

Liutkevičienè I (2012) Déjà vu. Vilnius 1974-1990. Inga Liutkevičienė, Vilnius

Miškinis A (1991) Lietuvos urbanistika: istorija, dabartis, ateitis. Mintis, Vilnius

Reid SE (2014) Makeshift modernity: DIY, craft and the virtuous homemaker in new soviet housing of the 1960s. Int J Hist Cult Modern 2(2):87-124

Statyba ir architektūra (1968) Miestų statybos projektavimo institutas. Statyba ir architektūra 8:3-6

Vanagas J (1973) Lazdynai - naujojo Vilniaus forpostas. Literatura ir menas 25(1386):8-9

Vanagas J (1992) Miesto gyvenamosios aplinkos formavimas: sociologinis aspektas. Technika, Vilnius

Open Access This chapter is licensed under the terms of the Creative Commons Attribution 4.0 International License (http://creativecommons.org/licenses/by/4.0/), which permits use, sharing, adaptation, distribution and reproduction in any medium or format, as long as you give appropriate credit to the original author(s) and the source, provide a link to the Creative Commons license and indicate if changes were made.

The images or other third party material in this chapter are included in the chapter's Creative Commons license, unless indicated otherwise in a credit line to the material. If material is not included in the chapter's Creative Commons license and your intended use is not permitted by statutory regulation or exceeds the permitted use, you will need to obtain permission directly from the copyright holder. 


\section{Part IV}

Exploring the Socio-Demographic and Ethnic Characteristics of Previous and Current Housing Estate Dwellers 


\title{
Chapter 10 Socio-economic and Ethnic Trajectories of Housing Estates in Tallinn, Estonia
}

\author{
Anneli Kährik, Karin Kangur and Kadri Leetmaa
}

\begin{abstract}
Housing estates consisting of Soviet-era large-scale multi-family housing hold a dominant position in the housing market of Tallinn; slightly less than two-thirds of residents resided there in 2011. These housing segments were attractive to mixed socio-economic status groups when initially built due to their high rent subsidies and prevalence of modern conveniences in apartments. The historical developments of housing estates intertwined with ethnicity, specifically the extensive in-migration flows during the Soviet era. In this chapter, we investigate how the socio-economic and ethnic position of housing estates changed over the course of the period of political and economic reforms (1989-2000) and the subsequent decade (2000-2011). The focus is interlinkages between social and ethnic patterns. Findings suggest a steady, downward trajectory in the social composition of these housing estates, excluding some centrally located neighbourhoods. The historical circumstances related to construction dynamics, flows of foreign immigration and allocation patterns explain residential dynamics. Ethnically minority-rich neighbourhoods are more likely to experience a downward social trajectory than housing estates with fewer ethnic minorities regardless of location.
\end{abstract}

Keywords Housing estates - Ethnic concentrations - Neighbourhood trajectories • Neighbourhood decline

\footnotetext{
A. Kährik $(\bowtie) \cdot$ K. Kangur $\cdot$ K. Leetmaa

Centre for Migration and Urban Studies, University of Tartu, Tartu, Estonia

e-mail: Anneli.Kahrik@ut.ee

K. Kangur

e-mail: Karin.Kangur@ut.ee

K. Leetmaa

e-mail: Kadri.Leetmaa@ut.ee

(C) The Author(s) 2019

D. B. Hess and T. Tammaru (eds.), Housing Estates in the Baltic Countries,

The Urban Book Series, https://doi.org/10.1007/978-3-030-23392-1_10
} 


\subsection{Introduction}

Estonia, as part of the Soviet Union from 1940 until 1991, inherited specific urban landscapes from the Soviet regime (Morton and Stuart 1984). From the 1960s to the early 1990s, the massive construction of large-scale housing estates, i.e. the uniform housing districts with large-scale multi-family buildings, took place in urban centres as well as in rural areas. Cities became spatially dense and compact with new extensive areas containing high-rise apartment buildings springing up on the urban outskirts (Smith 1996).

The construction of housing estates was the main instrument for the state to alleviate the acute housing shortage existing in urban areas after World War II. In addition to war damage on the housing stock, the housing shortage was further exacerbated by policies fostering fast industrialisation-led urbanisation in Estonia (Tammaru 2000). Extensive flows of foreign labour immigrants and their families arrived in Estonian urban areas from the other union republics of the Soviet Union, in addition to the natural increase and local rural-urban migration flows from the 1960s. These flows were mostly pushed to meet the labour-intensive needs of the recently established Soviet industrial enterprises and to contribute to the number of military personnel. These ethnic groups eventually grew in numbers due to family reunifications and demographic expansion (Tammaru 2002; Tammaru and Kulu 2003). By the end of socialist period in Estonia (1991), $71 \%$ of the country's population lived in urban areas with the external net migration contributing $36 \%$ to the total urban population growth since the post-World War II period (Tammaru 2002). The population of the Tallinn urban region increased by almost $70 \%$ between 1959 and 1989 (from 282,000 to 475,000 inhabitants) (Jauhiainen and Kährik 2005).

After Estonia lost its de facto independence under the Soviet occupation, housing tenure composition and foundations for housing allocation changed completely. The state confiscated existing dwellings from the private landlords. The state played the main role in housing redistribution, as it became the principal land and housing owner in Soviet Estonia. The pre-World War II housing stock owned by the state during the Soviet occupation received no investment or redevelopment, which led to its physical degradation and loss of popularity among young people and families, indicated by their ageing population structure (Temelová et al. 2016). In comparison, dwellings in newly constructed housing estates with modern facilities and highly subsidised rents became especially attractive for newly formed households and families. During the socialist period, private households built privately owned detached or semi-detached houses, but since this required considerable private investments they were less attractive than housing estates (Ruoppila and Kährik 2003).

Besides financing and constructing housing estates, the state assumed responsibility for the housing distribution mechanisms in Soviet Estonia. The state redistributed existing pre-World War II housing units among households. New apartment distribution utilised queuing lists managed by state-owned enterprises or 
local authorities, using priority lists and various allocation criteria (Gentile and Sjöberg 2006). With the construction of large uniform housing districts, the state pursued its ideological aim to build an egalitarian and just society (Bater 1986). In the case of Tallinn, management of socio-economic inequalities was quite successful, measured by a reduction in the socio-economic stratification by the end of the Soviet period (Tammaru et al. 2016). The new established uniform housing districts played a crucial role in this achievement. The central allocation mechanisms and conditions of deficiency, however, created other types of inequalities with certain occupational categories (such as managers, politicians, the military, workers in high-priority enterprises, among others) privileged when allocating the best-ranked public housing (Kährik and Tammaru 2010). Many 'non-priority' groups never received access to the modern apartments.

According to the 1989 Population and Housing Census (PHC), 61\% of inhabitants in Tallinn lived in housing estates at the end of the socialist period. One-fourth of the total population inhabited pre-World War II areas of the inner city, whereas only $12 \%$ lived in low-rise suburbs. Since the arrival of minority groups during Soviet times, there has been an over-representation of Russian-speaking minorities in housing estates. Housing estates differed by the age structure of residents as well, which was largely determined by the time of completion of the residential buildings. The prime target group for newly constructed state dwellings was families with children.

Rapid economic and political reforms during the 1990s introduced new, market-based foundations for the housing market. Estonia stands out for its radical institutional transition from being highly state-controlled to being one of the most neoliberal market-oriented system (Tammaru et al. 2016). During the ownership reform after the Soviet era, tenants could privatise their dwelling unit free-of-charge, unless the pre-World War II owners returned to their dwellings, as was the case with older housing stock (Kährik 2000). Overall, privately owned housing grew to 96 percent in Estonia by 2002 compared to just $36 \%$ prior to the ownership reform (Kährik and Kõre 2013). The rate of privatisation in housing estates in Tallinn was near $100 \%$. The flats became owner-occupied without further subsidies from the state for regular maintenance.

The distinctive Soviet historical legacies, described above, as well as the full privatisation of the market, set a different context for the evolution of social and ethnic trajectories of housing estates in Tallinn, as compared to the cities in Western European or post-Soviet Central European contexts (e.g. Dekker and Van Kempen 2004). In Western Europe, the typical social trajectory found in housing estates is downward with the infiltration of lower status groups and ethnic minorities (e.g. Andersson and Bråmå 2004; Musterd and Ronald 2007). This chapter expands upon the idea that historical patterns strongly influence contemporary neighbourhood dynamics. In this light, we aim to trace and interpret the specific socio-economic and ethnic trends that characterise the developments in housing estates in Tallinn. We investigate changes during the period of political and economic reforms (1989-2000) and the subsequent decade (2000-2011). The focus is interlinkages between social and ethnic patterns. Our primary hypothesis is that 
social trajectories of housing estates are rooted in ethnic processes. We believe that the overall lower social standing of Russian-speaking populations in Estonia and the over-representation of this group in certain housing estates translates to a downward social trajectory.

\subsection{Methods and Data}

In our empirical study, we define housing estates as urban neighbourhoods with at least 1,000 residents where the share of Soviet large-scale multi-family dwellings exceeds $80 \%$ of the housing stock. The neighbourhood units used in the analysis are statistical-administrative spatial units in Tallinn that follow urban and historical development and share similar street and building structures. In average, 8,400 inhabitants lived in those housing estates in 2000. The spatial scale for our defined housing estates was roughly equal to the size of Soviet microrayons - the planning units used during the period of the Soviet Union. A few neighbourhoods have microrayon names (e.g. Microrayon I). We make spatial generalisations based on the scale of urban districts of Tallinn. In our spatial terminology, we use the terms 'inner city' and 'outer city'. Inner city points to the more centrally located historical city from pre-1940 era with newer infills and the outer city is an outlying urban area within the administrative borders of Tallinn. Most housing estates were located in the outer city.

To determine the social and ethnic composition of neighbourhoods and their respective trajectories accurately, the analysis focuses on the economically active population. Calculation of population trends uses the Population and Housing Census (PHC) data from 1989, 2000 and 2011. The division of occupational (ISCO) groups served as a proxy for measuring social status. The ISCO 1-2 categories classify as 'high social status' groups, and the ISCO 5-6 and 9 are 'low social status groups'. The 1989 ISCO occupational categorisation was not the proxy for measuring the social hierarchy in 1989 , but this categorisation remains to trace the long-term socio-economic changes. For 2000 and 2011 the ISCO categorisation works relatively well with respect to the hierarchical order of prestige and income levels at that time. The analysis selected all individuals from the age group 1864 years for whom had a defined ISCO category. The basis for ethnic categorisation is the reported mother tongue of residents. For the analysis of ethnic distribution, three groups divided residents-Russian-speakers, Estonian-speakers and others. Estonian-speakers constituted 53\% and Russian-speakers $44 \%$ of the residents of Tallinn in 2011.

In order to identify neighbourhood types and trajectories, first, relative shares of each social group (low, middle, high) and ethnic group (Russian-speaking, Estonian-speaking, other) were calculated for each neighbourhood unit. A threshold level of $15 \%$ points over or under $100(100=$ average for the city $)$ was used to set the cut-off points for identifying the respective statuses for each neighbourhood. Based on the relative shares the following categories were constructed-low, mixed 
and high social status neighbourhoods based on social divisions, and ethnically minority-rich, mixed and minority-poor neighbourhoods based on ethnic divisions. For example, in order for a neighbourhood to be classified of 'low social status', it must fulfil the following criteria: the low social status group must be over-represented by at least $115 \%$ of the city average and the high-status group under-represented by less than $85 \%$ of the city average (see Temelová et al. 2016 for similar methodology). These cut-off points overlap with the standard deviation value level of 0.5 across neighbourhoods in the case of most categories and years.

These categorisations for each year are the basis of modelling and interpretation of neighbourhood trajectories. For better interpretation of the trajectories, we identified residential flows contributing to socio-economic change in Tallinn neighbourhoods (using a longitudinal dataset based on the HPC 2000 and 2010 data) (Kangur 2016). Based on this study, calculating the relative weights of these flows informed assessment of whether the 'dominating flow' of change in particular neighbourhoods was 'in situ change of social status' or 'residential mobility'.

\subsection{Urban and Housing Policy Conditions for Spatial Change in Housing Estates}

When Estonia incorporated into the Soviet Union after World War II, the most widespread form of new dwelling construction in Tallinn consisted primarily of large-scale prefabricated apartment buildings. These types of dwellings became highly dominant forms of housing, constituting slightly less than two-thirds of the overall housing supply in the city (Fig. 10.1). In Tallinn, 61.4\% of 470,000 residents resided in housing estates (defined according to the explanation presented above) by the eve of the Socialist era (1989). Housing estates were master planned following the microrayon planning structure (Smith 1996). Clusters of neighbouring microrayons formed larger urban districts. Some urban districts in Tallinn consist solely of large-scale apartment buildings (such as the Lasnamäe and Mustamäe districts, see Figs. 10.2 and 10.3).

Construction of the first microrayons occurred during the 1950s in the inner city district of Northern Tallinn. In the first new outer city area, Mustamäe (Figs. 10.2 and 10.3), construction began in the early 1960s (Kährik and Tammaru 2010). The oldest segments of housing estates consist of five-storey buildings with small apartments known as khrushchëvki. In the Haabersti district (Väike-Õismäe neighbourhood) the construction began in 1974. The quality of the apartments in this district improved and the flats were a more suitable size for families. The neighbourhoods' construction included pedestrian zones, green areas, social infrastructure and conveniently located groceries. The fourth and densest cluster of housing estate neighbourhoods followed from the 1980s to the early 1990s in the Lasnamäe district. This newer panel housing district has the most spacious apartments and good connectivity to the city; however, the population density is high in 
A. Kährik et al

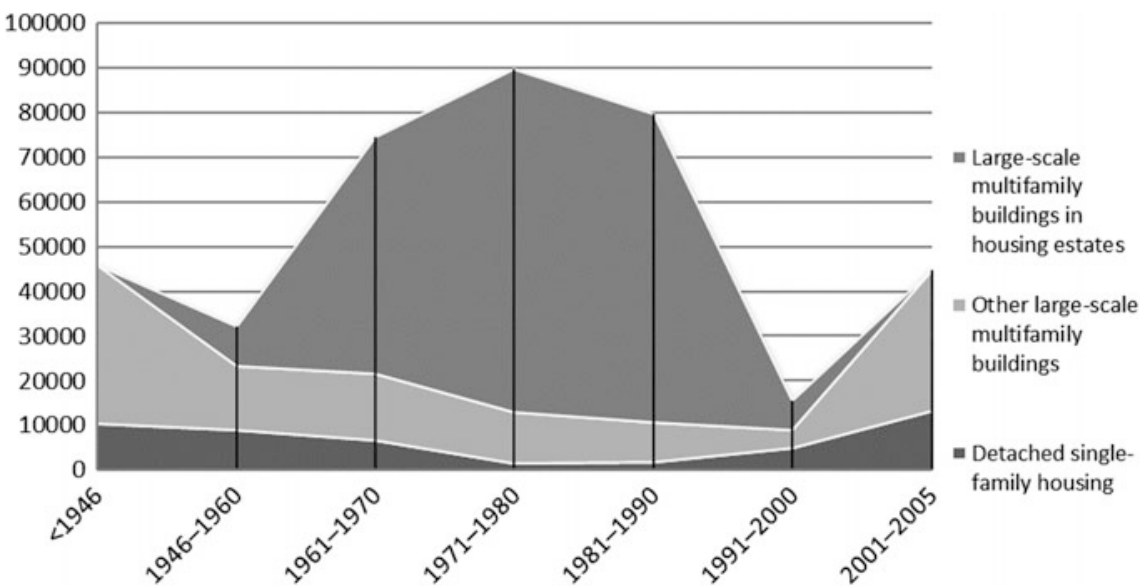

Fig. 10.1 Evolution of housing stock by dwelling type in Tallinn. Source Database from statistics Estonia

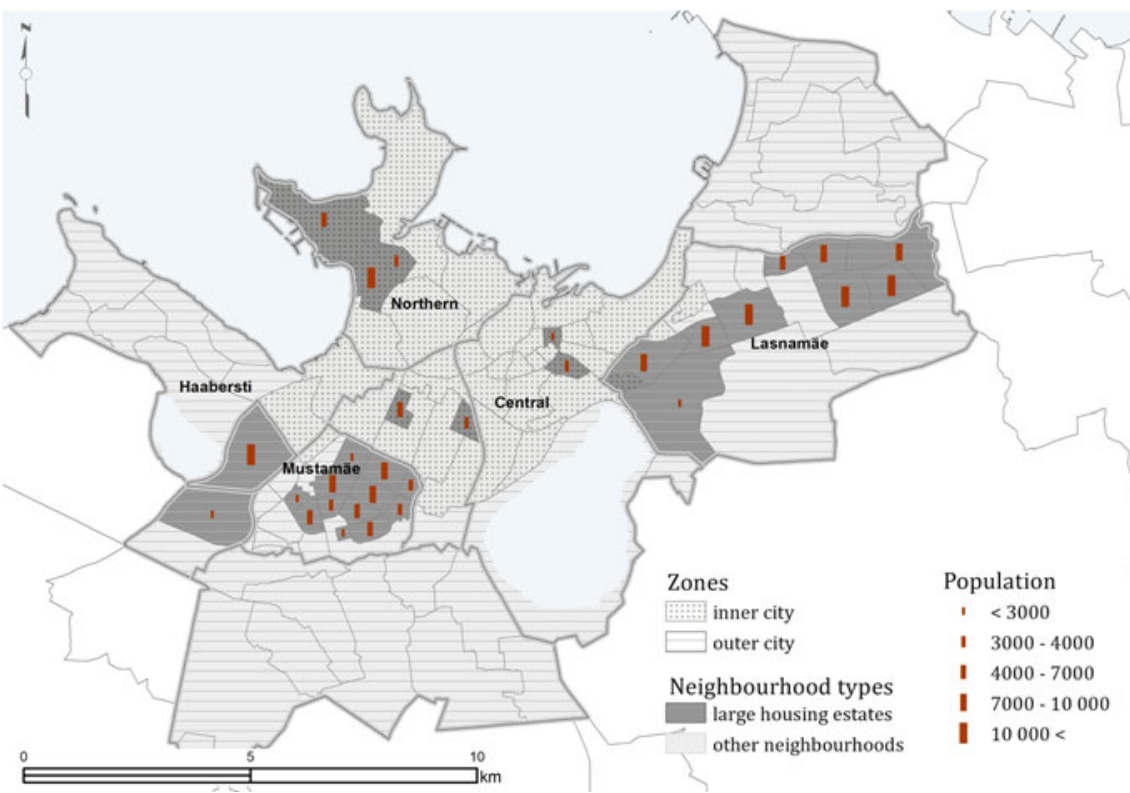

Fig. 10.2 Locations and population size of housing estates. Source Database from housing and population census 2000; map layers: Land Board of Estonia, Tallinn city government

this district. It is comprised of roughly 100,000 inhabitants, which constitutes roughly $25 \%$ of the total city population. In Tallinn's central city, small-scale housing estates generally functioned as infill construction within the existing urban fabric (Fig. 10.2). 


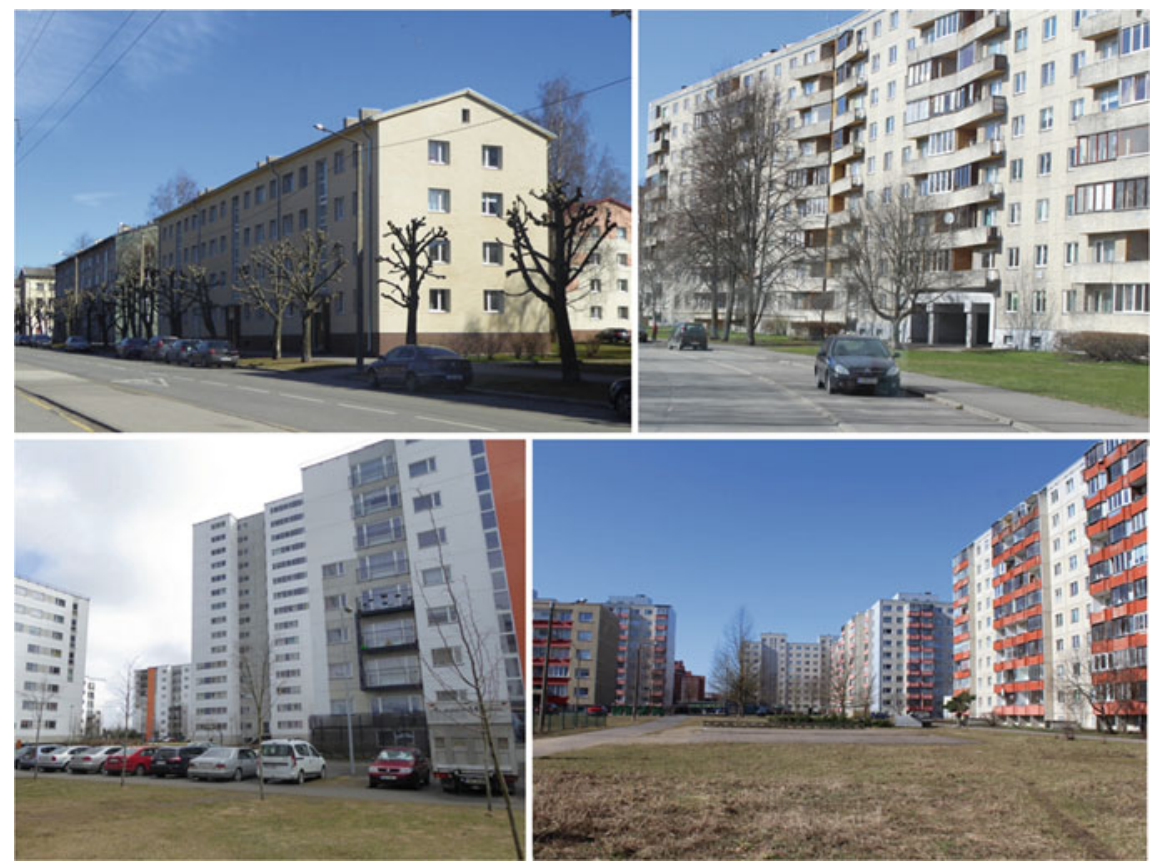

Fig. 10.3 Selection of housing estates in Tallinn (top left: Northern Tallinn, top right: Mustamäe, bottom left: Lasnamäe (new social housing), bottom right: Lasnamäe). Source A. Väiko, A. Kährik

The high rate of foreign net migration from 1960 to 1990 drove the development of housing estates (Tammaru 2002). As mostly Russian-speaking immigrant groups needed housing upon their arrival, the central administrations allocated them to the new panel housing districts (see Gentile and Tammaru 2006). Immigrants, who were over-represented in the industrial sector, had priority access to new housing over the native population (Kõre et al. 1996; Org 1989; Sommer 2012). As a result, with a few exceptions, there was ethnic skewing in housing estate neighbourhoods. Ethnic minorities made up 56\% of the resident populations of housing estates by the end of the Soviet era, despite these ethnic groups consisting of slightly less than half the total urban population (Table 10.1). The Russian-speaking blue-collar immigrant workers became the most concentrated in the district of Lasnamäe (arriving during the 1970s and 1980s) (Nerman 1998).

The Estonian population, on the other hand, was primarily located in pre-World War II dwellings in the inner city, which were often dilapidated and rundown (Ruoppila and Kährik 2003). The most striking concentration of Estonian-speaking populations took place in the low-rise suburbs: only one-fourth of the population in these suburban areas was Russian-speaking (Table 10.1). Previous research explores the issues related to high rates of ethnic segregation and housing market 
segmentation in Estonian cities (Hess et al. 2012; Kulu 2003; Raitviir 1987; Tammaru et al. 2016).

Housing estates in general remained socially heterogeneous in Tallinn as the place of residence for the socialist 'middle class' (Kährik and Tammaru 2010). When initially built, the estates were attractive to young families, contributing to a rather young population composition at the time.

After the completion of the privatisation process, tenants got the legal right to sell or exchange their dwelling in the housing market, allowing households to more easily relocate. Since then, property values fluctuated across different housing and neighbourhood types with housing estates placing at the lower end of the price range. Residential properties in the Lasnamäe district had the lowest pricing in Tallinn (Padrik 2016). After 2000, the size of private rental stock grew (Hussar 2018; Lux et al. 2012). Based on data from the 2011 census, owner-occupied housing constituted about $80 \%$ of the total housing stock in Tallinn, whereas the share of rental housing stock was around $20 \%$ (incl. 1.8\% public rental units). With such high rate of homeownership, the situation in Tallinn contrasts the Northern and Western European cities where often social rental tenure dominates in housing estates.

Since 2000, construction of new private multi-family buildings is occurring in housing estates. As the property prices of these dwellings are far above the average for housing estates, these new developments are likely to have an impact on the existing social structure of housing estates (Hess et al. 2018 forthcoming). To address problems related to the lack of affordable, modern living space in the city, the city government implemented new social housing programmes between 2003 and 2013 in the districts of Lasnamäe and Northern Tallinn. All together, these public initiatives increased the housing supply in Tallinn by nearly 2\% (Kährik and Kõre 2013). Although the new housing is equipped with all modern amenities and is of relatively good standards, its location is likely to lead to severe consequences, most notably the further spatial segregation of the population with lower social standing.

Recent studies reveal an increasing stigma and unpopularity among Estonian-speakers associated with certain kinds of housing estates based on ethnic grounds. These housing estates are still the most preferred type of residence for Russian-speakers, who prefer the locations due to the available Russian-language social infrastructure (kindergartens, primary and secondary schools), and proximity to the similar ethnic groups (Kährik and Tammaru 2010; Leetmaa et al. 2015). Estonian-speakers are more likely to leave housing estates as compared to Russian-speaking minorities (Kährik and Tammaru 2010, 2008; Tammaru et al. 2013).

The economic restructuring after Estonia regained independence, which included a shrinkage of the industrial and agricultural sectors, affected the Estonian-speaking and Russian-speaking minorities differently. This reflects the changing in situ social patterns of Tallinn's neighbourhoods. The 'professionalisation' of the labour force involved more Estonians than the minorities (Tammaru et al. 2016). After the structural and economic reforms, Estonians more frequently found work among the 
top ISCO categories, while the opposite is true for ethnic minorities, further highlighting the growing gap between the two ethnic categories from 2000 to 2011. Arguably, Russian-speaking minorities in Estonia were at a disadvantage in the labour market since societal restructuring, leading to decreased opportunities for upward social mobility (e.g. Aasland and Fløtten 2001). The insufficient level of Estonian-language proficiency adds an extra risk factor for their labour market integration (Leppik and Vihalemm 2015; Lindemann and Kogan 2013). In addition, unemployment levels hit Russian-speaking minorities harder, since being over-represented in the large industrial enterprises that largely shut down during the course of the reforms. This may explain the increasing correlation between areas of high Russian-speaking population and the relative social decline of neighbourhoods (due to in situ processes).

\subsection{Socio-economic and Ethnic Trajectories of Neighbourhoods}

The intra-urban spatial patterns, as inherited from the Soviet past, clearly reflect the over-representation of Russian-speakers in the panel housing areas of Tallinn. In total, $40 \%$ of all housing estates in the city were classified as ethnically 'minority-rich', and slightly less than half as ethnically mixed by the end of the Soviet period in 1989 (Fig. 10.4). Regarding population trends during the times of political and economic reforms, the 1990s marked a dramatic decline in the total population, with the number of inhabitants shrinking by $15 \%$ in Tallinn (Table 10.2). Most influential to this decline was the negative net migration rate and low birth rates, which lasted throughout the decade. About one-fourth of all Russian-speaking minorities left Estonia by the early 1990s. The net migration rate for this group remained in decline until 2011 (Anniste and Tammaru 2014), increasing the overall share of Estonian-speakers in the city.

Despite this decrease in the overall numbers of Russian-speakers, the overall share of Russian-speaking minorities increased in housing estates with Russian-speakers making up nearly $60 \%$ of the total housing estate population by
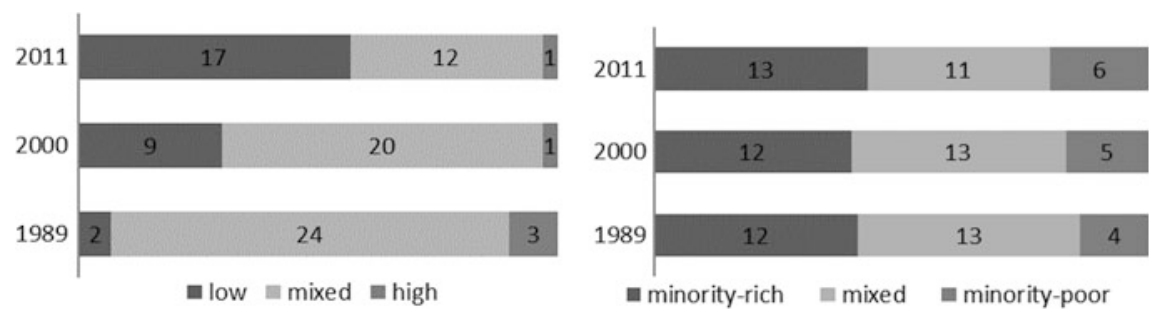

Fig. 10.4 Distribution of housing estates by socio-economic and ethnic status. Source Database from housing and population censuses 1989, 2000 and 2011 
Table 10.1 Average shares of social and ethnic groups (by percentage) and mean age (in years) across neighbourhood types in Tallinn in 1989, 2000 and 2011

\begin{tabular}{l|l|l|l|l|l|l}
\hline & $\begin{array}{l}\text { City } \\
\text { total }\end{array}$ & \multicolumn{3}{l}{ Housing estates } & $\begin{array}{l}\text { Inner city } \\
\text { (excl. HEs) }\end{array}$ & $\begin{array}{l}\text { Suburbs } \\
\text { (excl. HEs) }\end{array}$ \\
\hline & Total & Total & $\begin{array}{l}\ldots \text { in } \\
\text { inner city }\end{array}$ & $\begin{array}{l}\ldots \text { in } \\
\text { suburbs }\end{array}$ & Total & Total \\
\hline $\begin{array}{l}\text { High social status, } \\
1989\end{array}$ & 26.1 & 26.2 & 23.0 & 27.0 & 24.6 & 29.1 \\
\hline $\begin{array}{l}\text { High social status, } \\
2000\end{array}$ & 31.3 & 28.0 & 25.5 & 28.5 & 34.4 & 41.1 \\
\hline $\begin{array}{l}\text { High social status, } \\
2011\end{array}$ & 32.2 & 23.7 & 24.2 & 23.5 & 41.6 & 46.0 \\
\hline $\begin{array}{l}\text { Low social status, } \\
1989\end{array}$ & 14.5 & 12.6 & 15.8 & 11.9 & 16.2 & 21.1 \\
\hline $\begin{array}{l}\text { Low social status, } \\
2000\end{array}$ & 23.2 & 24.6 & 25.8 & 24.4 & 22.4 & 17.9 \\
\hline $\begin{array}{l}\text { Low social status, } \\
2011\end{array}$ & 22.6 & 26.8 & 28.1 & 26.5 & 18.7 & 14.8 \\
\hline $\begin{array}{l}\text { Russian-speakers, } \\
1989\end{array}$ & 48.1 & 55.6 & 60.7 & 54.4 & 41.7 & 23.5 \\
\hline $\begin{array}{l}\text { Russian-speakers, } \\
2000\end{array}$ & 43.2 & 53.0 & 28.1 & 63.5 & 32.8 & 16.5 \\
\hline $\begin{array}{l}\text { Russian-speakers, } \\
2011\end{array}$ & 44.1 & 58.9 & 23.9 & 62.1 & 27.5 & 18.9 \\
\hline \begin{tabular}{l} 
Mean age, 1989 \\
\hline Mean age, 2000
\end{tabular} & 36.3 & 35.2 & 36.4 & 34.8 & 36.2 & 37.1 \\
\hline Mean age, 2011 & 40.3 & 42.1 & 42.3 & 42.0 & 38.9 & 34.9 \\
\hline
\end{tabular}

Source Database from housing and population censuses 1989, 2000, 2011

2011. Although this trend minimally affects the overall number of 'minority-rich' housing estates, it reflects the growing concentration of ethnic minority groups in the housing estates (Fig. 10.4). From this, we can assume that the increase of ethnic minorities in housing estates has been spatially selective, leading to the accumulation of this group in neighbourhoods that already possessed an over-representation of Russian-speaking population. The greatest increase in the share of ethnic minorities occurred in the outer city housing estates where the share of Russian-speakers peaked in 2000 with some areas reaching as high as two-thirds of the population. The inner city housing estates experienced growth in the Estonian-speaking population (Table 10.1). The largest relative loss of Russian-speakers took place in pre-World War II housing in the inner city, with the share of the minority group decreasing its presence from 42 to only 28\%. Previous research points out the role of Estonian-speakers in gentrification (Kährik et al. 2015). This relates partly to their distinctive neighbourhood and housing type preference patterns as compared to Russian-speaking minorities (Hess et al. 2012; Leetmaa et al. 2015). In total shares, 
Table 10.2 Comparative population dynamics for neighbourhood types in Tallinn, 1989-2011

\begin{tabular}{|c|c|c|c|c|c|c|}
\hline & \multirow{2}{*}{ City total } & \multicolumn{3}{|c|}{ Housing estates } & \multirow{2}{*}{$\begin{array}{l}\begin{array}{l}\text { Inner city } \\
\text { (excl. HEs) }\end{array} \\
\text { Total }(\%)\end{array}$} & \multirow{2}{*}{$\begin{array}{l}\begin{array}{l}\text { Outer city } \\
\text { (excl. HEs) }\end{array} \\
\text { Total }(\%)\end{array}$} \\
\hline & & $\begin{array}{l}\begin{array}{l}\text { Total } \\
(\%)\end{array} \\
\end{array}$ & $\begin{array}{l}\ldots \text { in inner } \\
\text { city }(\%)\end{array}$ & $\begin{array}{l}\ldots \text { in outer } \\
\text { city }(\%)\end{array}$ & & \\
\hline $\begin{array}{l}\text { Population in } \\
1989 \text { (tho. inh.) } \\
\text { Distribution }\end{array}$ & $\begin{array}{l}\mathrm{n}=469.6 \\
100 \%\end{array}$ & 61.4 & $\ldots 11.9$ & $\ldots 49.4$ & 26.6 & 12.0 \\
\hline $\begin{array}{l}\text { Population in } \\
2000 \text { (tho. inh.) } \\
\text { Decline } \\
\text { (1989=100) } \\
\text { Distribution }\end{array}$ & $\begin{array}{l}\mathrm{n}=400.4 \\
-14.7 \% \\
100 \%\end{array}$ & 62.9 & $\ldots 10.8$ & $\ldots 52.1$ & 23.2 & 13.9 \\
\hline $\begin{array}{l}\text { Pop in } 2011 \text { (tho. } \\
\text { inh.) } \\
\text { Decline } \\
(1989=100) \\
\text { Distribution }\end{array}$ & $\begin{array}{l}\mathrm{n}=392.7 \\
-16.4 \% \\
100 \%\end{array}$ & 57.9 & $\ldots 9.7$ & $\ldots 48.2$ & 24.1 & 18.0 \\
\hline
\end{tabular}

Source Database from housing and population censuses 1989, 2000, 2011

the rate of Russian-speaking minorities is the smallest in low-density suburbs; however, this tendency is historically rooted.

Our findings suggest that 'Soviet-style' neighbourhoods can be an attractive option for Estonian-speakers if these places provide residents with good access to inner city locations and are ethnically less minority-dense. Astonishingly, Estonian-speakers are highly over-represented in inner city housing estates compared to the pre-World War II inner city housing stock.

During the late Soviet period, housing estates had a largely mixed socio-economic composition (Table 10.1). In 1989, 24 out of 29 housing estates could be classified as 'socially mixed' (Fig. 10.4). This attribute is a side effect of the central planning system that existed in Soviet Estonia, since, as described previously, market-based redistributions did not occur in Tallinn before the mid-1990s. Until the collapse of the Soviet Union, housing estates were considered attractive housing for various population categories (Tammaru et al. 2016). The socio-economic disparity was less drastic in the older, pre-World War II sections of the inner city. Only the low-rise outer city stood out by the over-representation of low-skilled workers up until 1989. The social dynamics occurring in two periods (1989-2000 and 2000-2011) reveal a trend of gradual social degradation of housing estates in Tallinn. In 2000, one-third of housing estates were low socio-economic status, i.e. with over-representation of unskilled labourers. By 2011, the share of low social status neighbourhoods rose to cover $50 \%$ of all housing estates (Fig. 10.4).

Figures 10.5 and 10.6 depict the dynamics in intra-urban geography of social status and ethnic groups. Most housing estates in the outer city district Lasnamäe show loss of socio-economic status since 1989. Decrease of social status takes place 


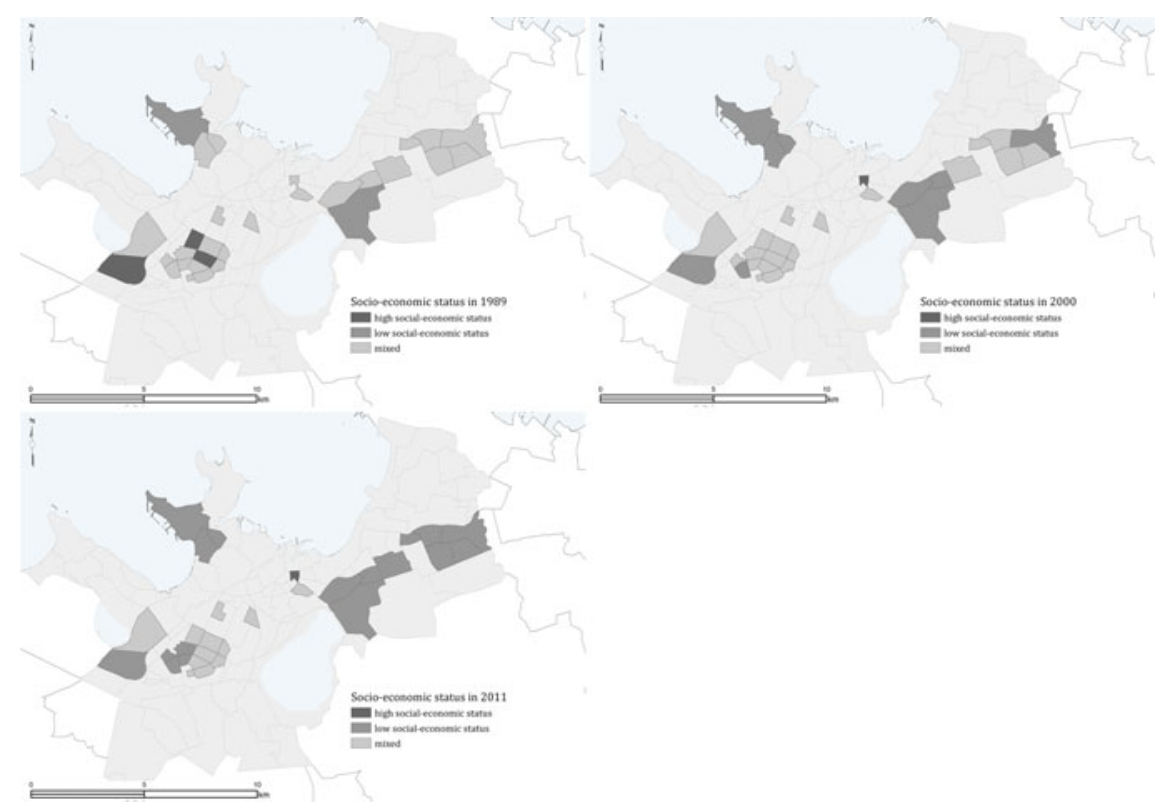

Fig. 10.5 Socio-economic status changes in housing estates in Tallinn, 1989, 2000 and 2011. Source Database from housing and population censuses 1989, 2000 and 2011; Map layers: Land Board of Estonia, Tallinn city government

in other districts, as well with the exception of housing estates located in Central Tallinn. Mustamäe and Haabersti districts differ only in regards to their initial social status, as some of these neighbourhoods enjoyed conditions that were more favourable before 1990 compared to Lasnamäe or Northern Tallinn. Concerning ethnic distributions, the entire district of Lasnamäe and housing estate neighbourhoods in Northern Tallinn were distinguished by high shares of Russian-speakers in 1989. The other outer city areas as well as Central City housing estates were mostly ethnically mixed or, to a smaller degree, 'minority-poor'.

Overall, ethnic change in the urban fabric of the city is less remarkable compared to changes in social dynamics. The neighbourhoods of Mustamäe continue to be mixed or largely Estonian-speaking communities, especially in locations near Tallinn Technical University. Seemingly, only the housing estates in Haabersti district (Väike-Õismäe) became 'minority-rich' over time.

Further insight into the social and ethnic trajectories of housing estates emerges when we investigate overlaps between social and ethnic dimensions of panel housing areas (Figs. 10.7 and 10.8). Our hypothesis suggested a positive relationship between social decline and ethnic concentrations. We predicted that social degradation is more likely to happen in the 'minority-rich' neighbourhoods. Figure 10.7 extracts the distinctive social and ethnic trajectories. 'Upgrade', 'downgrade', or 'stable' trajectory refers to the situations where the housing estate 


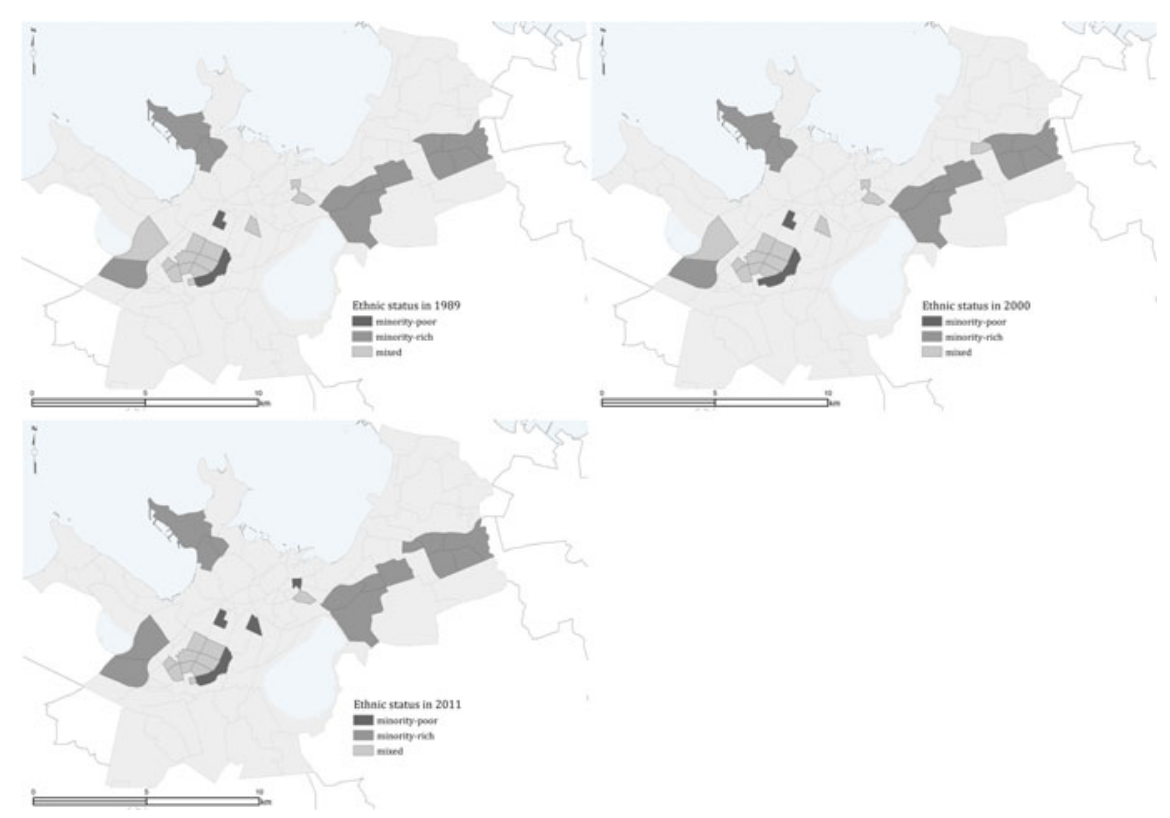

Fig. 10.6 Ethnic status changes in housing estates in Tallinn, 1989, 2000 and 2011. Source Database from housing and population censuses 1989, 2000 and 2011; map layers: Land Board of Estonia, Tallinn city government

either moved from one neighbourhood status to another or remained stable, during the two observational decades. If the neighbourhood experienced mobility during the first phase (1989-2000) we call it respectively the 'early' upgrader or downgrader, whereas the change during the second decade (2000-2011) refers to a 'late' upgrade or downgrade.

As shown in Fig. 10.6, 'minority-rich' areas have a much greater tendency to experience 'stable low', 'early downgrade', or 'late downgrade' social cycles. Barely any such housing estate continued to stay mixed, and none experienced social upgrade. Likewise, none of the 'minority-poor' housing estates fell into the 'stable low' or 'social downgrade' cycles. It seems having a larger share of Estonian-speakers in a neighbourhood is a key factor in fostering the social stability in housing estates. Although certain overlap between the social and ethnic factors in the spatial fabric is clear, there is a share of ethnically mixed neighbourhoods that followed the 'low stable' or the 'downward' social trajectory during the two independence decades. Hence, the social degradation processes hide more than the ethnic and historical components and require attention when analysing the causes behind the decrease in popularity and status in housing estates.

Both the social and ethnic risk factors are associated with Lasnamäe. Lasnamäe has the highest concentration of Russian-speaking ethnic minorities across all neighbourhoods, as well as a gradual decline in socio-economic conditions 


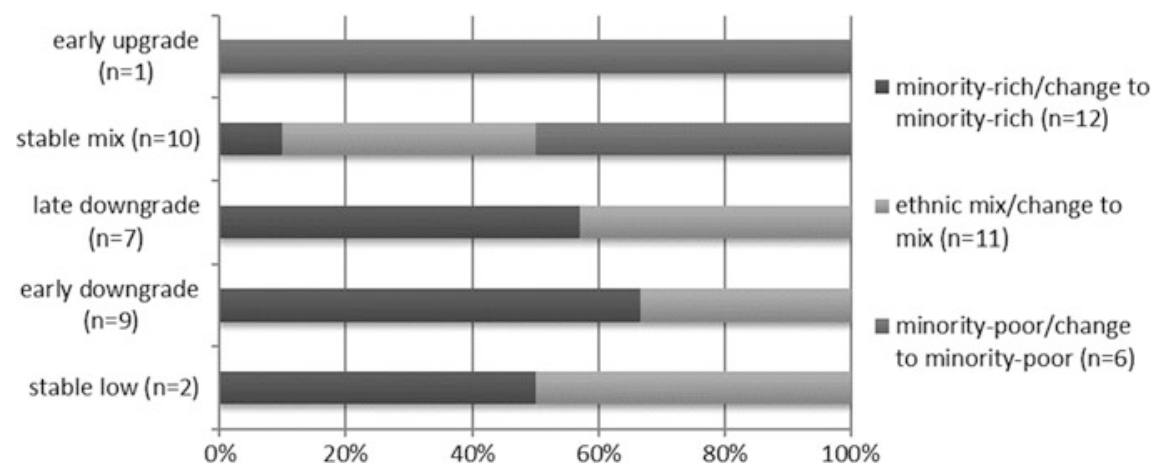

Fig. 10.7 Decomposition of social dynamics in Tallinn housing estates by ethnic distribution between 1989 and 2011. Source Database from housing and population censuses 1989, 2000 and 2011

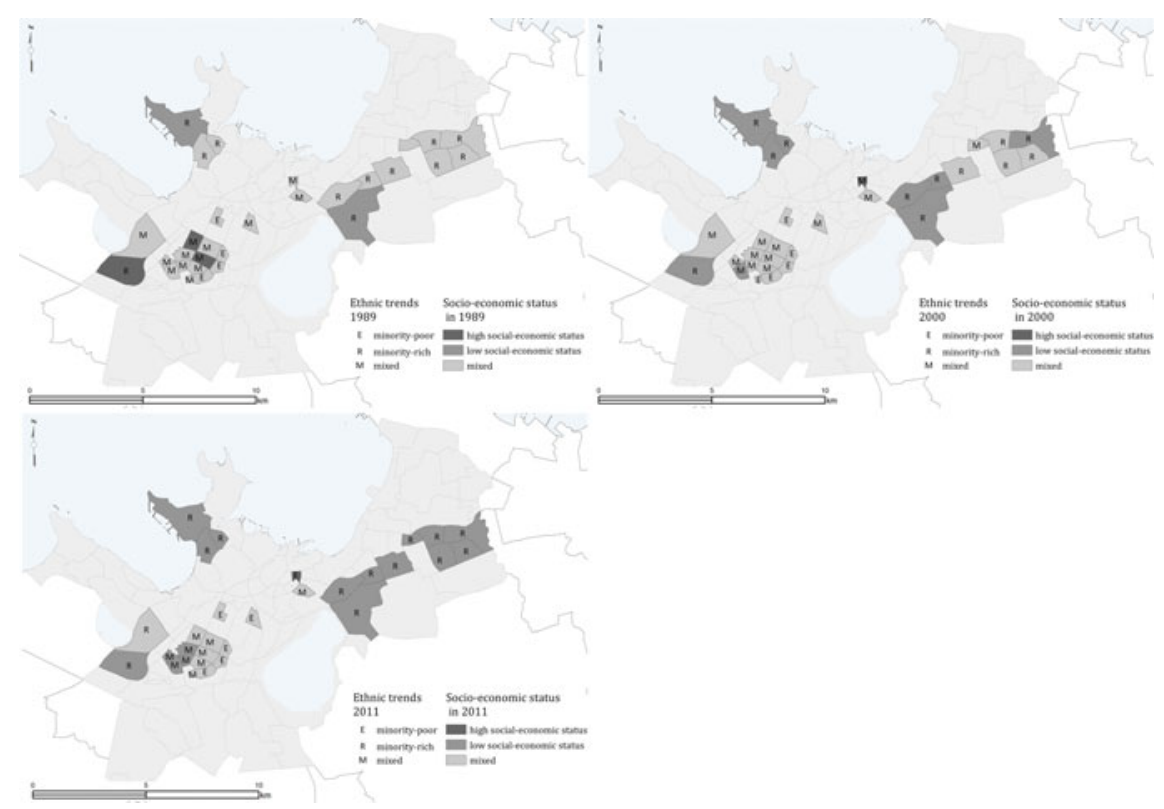

Fig. 10.8 Interaction of social and ethnic dynamics (trends) within housing estates, 1989, 2000 and 2011. Source Database from Housing and Population Censuses 1989, 2000 and 2011; map layers: Land Board of Estonia, Tallinn city government

(Fig. 10.8). The spatial scale of the district, which has a high population density comprising one-fourth of all Tallinn's residents, further undermines its prospects. Additionally, neighbourhoods in Lasnamäe are relatively distant from the city centre, which adds a further risk factor, despite readily available and low-cost 
public transport connections. The social environment of the neighbourhood does play an important role in explaining the ethnic preferences and growth of Russian-speaking communities in Lasnamäe (i.e. as said social infrastructure, and representatives of the same ethnic groups further attract ethnic minorities). The neighbourhood in Lasnamäe where construction of new social dwellings occurred during the 2000s first experienced social and ethnic mixing followed by social decline along with the growth of Russian-speaking minorities.

The housing estates of Northern Tallinn are distinguished by low-status socio-economic conditions and high percentages of Russian-speakers, which led to some controversial developments in the area. Despite occupying a coastal area with beach access, which is an attractive feature for other gentrifying areas (Temelová et al. 2016); this district retained its lower status populations. Establishment of the Russian-speaking population in this area was largely due to the location of several Soviet industrial plants within the region. This further establishes the connection between the population allocation patterns of the Soviet era, and recent ethnic/social trends, as the historical factors tend to keep back gentrification processes. The other smaller scale inner city housing estates located in Central Tallinn largely preserved their social mix with a small-scale increase in the overall Estonian-speaking population.

In examining the age composition of the districts, we can see that the period of construction for panel housing areas influenced the overall age composition of the respective area. During the Soviet era, residential mobility was rather modest, as housing shortages tied most people to their apartments. The population composition of different housing estates is reflective of the time at which they were constructed (Tammaru et al. 2016). The age of housing estates positively correlates with the age of the population, such that in older housing estates the age structure is more biased towards elderly (Mustamäe, Northern Tallinn). The proportion of younger individuals was the highest in Lasnamäe. The mean age increased in housing estates more rapidly than the city average: the mean age of 42 years in 2011 in housing estates (compared to 40 years in all of Tallinn) is higher than in all other neighbourhood types (pre-World War II inner city low-rise suburban districts) (Table 10.1).

Different population mechanisms can correspond with changes in the social dynamics of neighbourhoods. Change in the population structure of these areas can occur because of in situ changes (e.g. selective upward or downward social mobility without moving the place of residence), also due to actual displacement or replacement of some population categories because of residential mobility. By cross-comparing with the results of a recent study conducted by Kangur (2016), covering the period 2000-2010, we conclude that social change in housing estates in Tallinn has been induced by residential mobility rather than in situ change. According to the results of the aforementioned study, social decline in Mustamäe and Haabersti is shown to be directly associated with the outflow of higher social status residents (as post-2000 suburban developments are likely to attract them in the nearby surroundings). In Lasnamäe and Northern Tallinn, the picture is less clear. For example, half of the housing estates in Northern Tallinn followed the 
decline path because of the inflow of low social groups, while the other half downgraded due to the outflow of high social status groups. However, this finding does not diminish the overall importance related to in situ processes on the social trajectories of neighbourhoods, such as the relative lowering of social status position of Russian-speakers as compared to Estonian-speakers in society.

\subsection{Discussion and Conclusion}

Several complex factors affect social and physical degradation processes in large housing estates, as pointed out in Western European urban contexts. The density of social housing and the high concentration of immigrants from less wealthy countries, who usually hold a lower social position in society than native populations, deserve the most attention. The context of Tallinn differs somewhat from Western European cities. In the post-Soviet context of Tallinn, the interplay between distinctive Soviet historical legacies and new housing market mechanisms is shaping the neighbourhood trajectories for the large housing estates. The almost full-extent privatisation of dwellings and the issue that housing estates play such a predominant position in the housing market reveal the main differences compared to Western contexts. Tallinn's high percentage of Russian-speaking ethnic minorities makes the role of ethnic factor a central focus. While these minorities are less distinguishable from the Estonian-speaking population as compared to the minorities of Western European cities, the trend of minority ethnic groups holding a less favourable economic position in society as compared to the majority populations still holds true. The concentration of Russian-speakers in housing estates remains an important issue hampering the social integration of ethnic minorities in Tallinn.

The findings from this chapter raise warnings about the spatially selective but large-scale social degradation tendencies taking place in housing estates of Tallinn. On one hand, we identified a trend towards the over-representation of elementary occupations (i.e. low social status categories) in these areas during the two decades after Estonia regained its independence, on the other hand, we see that the overall strengthening in the position of ethnic minorities in housing estates is taking place. These trends indicate a step towards narrowing the gap between the differences in the housing estates of post-socialist Eastern and Western cities.

The social dynamics in housing estates connect to the specifics of the ethnic fabric established by Soviet housing allocation policy. It is clear from the analysis that the areas most suffering from social degradation are those with the highest concentrations of Russian-speaking minorities. The lower socio-economic resources of the ethnic minorities living in Estonia, as compared to natives, affected the social downward mobility of neighbourhoods. Nevertheless, the processes of social degradation do not stop with in situ change. The historical patterns of ethnic distribution continue to reproduce themselves based on residential location decisions. This is due to already established perceptions, community networks and ethnic 
infrastructure present in housing estates but often absent in other types of neighbourhoods. Residential mobility in housing estates led to further ethnic and social sorting in Tallinn (Kährik and Tammaru 2010). Estonian-speakers are much more likely to opt for gentrifying areas in the inner city or less dense outer low-rise suburbs than Russian-speakers (Kährik and Tammaru 2008; Kährik et al. 2012; Tammaru et al. 2016). Housing estates are the most preferred type of neighbourhoods for Russian-speaking minorities (i.e. the cultural preferences explanation of residential separation/integration patterns holds true in Tallinn) (Leetmaa et al. 2015; Mägi et al. 2016). Assumingly, the most attractive locations are those where a considerable size of minorities already settled, such as the district of Lasnamäe.

As these residential processes develop, certain socio-ethnic 'hierarchies' are highlighted across various housing estates. The higher share of Estonian-speakers in combination with more attractive locations seem to yield prospects that are more favourable. In this respect, the small-scale housing estates of the Central City, and some neighbourhoods in suburban area Mustamäe, seem to be placed in the upper levels of this 'hierarchy'. Some of these areas retained a social and ethnic mix, while others became largely Estonian-speaking over time. This suggests that it is not solely the 'Soviet-style' urban form that determines the socio-economic disadvantage per se, but rather the function of historical conditions and related allocation patterns, and the specific locational features (planning, natural surroundings and other characteristics). The neighbourhoods in Mustamäe and Haabersti (VäikeOismäe) stand out with more successfully implemented neighbourhood plans, with more developed recreational areas and greenery, which all adds to the upkeep of social stability and attractiveness. These more developed environments still seem to hold popularity among Estonian-speakers, whereas in the suburban Lasnamäe district a 'tipping point' in terms of 'Estonian-speaker flight' seems reached. Many factors drive the unattractive position of this district in the eyes of Estonian-speakers, for example, the ethnic character of the district, dense building structure, distant locations in some cases and lack of natural attractions.

The prospects for other housing estates located in Northern Tallinn are less clear, given its dense population of ethnic minorities. Regardless of the attractive location in terms of natural surroundings and access to the inner city, historical trends seem to hinder the social regeneration of these areas. Existing research shows minimal or no interaction between the communities of these housing estates with the surrounding pre-World War II, gentrifying neighbourhoods (Tammaru et al. 2017). Rather, the areas function as two parallel worlds within close physical proximity that are otherwise socially segregated. Both a high share of homeowners, which led to a more stagnant resident population, and the existing socio-ethnic image of the areas presumably contribute to maintaining the low social status. Additionally, the physical characteristics of the housing (relatively small apartments in $k h r-$ uschtschovka type of buildings) do not match with the neighbourhood preferences of potential gentrifiers. As the course of gentrification evolves, the inertia of trends rooted in the socialist times will likely be broken, which would lead to change in the residential composition. 
The effects of regeneration initiatives and the construction of multi-family housing on the overall socio-ethnic composition in housing estates, is a point of interest. The effects of such urban restructuring have not clearly manifested in socio-economic patterns. According to a study conducted by Hess et al. (2018), the renovation of existing buildings has yet to affect the socio-economic structure of residents, whereas another study (Hess et al. 2018) noted that there are inevitable effects on the social environment when new apartment buildings are built in neighbourhoods. The current study did find that the implementation of municipality-initiated housing projects worsened the accumulation of social disadvantage in Lasnamäe.

To conclude, the fact that none of the 'minority-poor' housing estates experienced downward mobility while the majority of 'minority-rich' housing estates have revealed deeper concerns. This manifests the idea that exclusion from economic capital leads to spatial exclusion, e.g. that lower socio-economic position translates into lower spatial resources (note that the real estate values are the lowest in Lasnamäe). These processes build upon one another as the increase in ratios of lower social status and ethnic minorities further accelerate socio-economic 'flight' and the relocations of Estonian-speakers. As these processes build and become cemented, they become more difficult to address, especially when a certain 'tipping point' is reached.

Tallinn still has many strengths including the high homeownership rate in housing estates (making owners more responsible and motivated with regards to housing upkeep and neighbourhood maintenance), the prevalent role the housing estates play in the housing market, their good connectivity to the city centre, as well as good infrastructure available. These factors allow for tackling of the issues at hand somewhat more easily compared to many Western cities. Applying a targeted urban policy could still lead to the reversal of social and ethnic trends in the at-risk areas. For example, undertaking physical restructuring projects could diversify the existing homogeneous urban fabrics. The inclusions of mixed ethnic and middle-class status families into the neighbourhoods can contribute to the overall transformation of the neighbourhood environment, making these areas more attractive and liveable, as well as encouraging a sense of community spirit. Some of the initiatives, such as developing community activism, community gardening, developing public spaces and subsidies to housing renovations, among others, are already on the way (Leetmaa et al. 2018) with more still to do.

Acknowledgements This article was prepared with the support of the research grants IUT2-17 and PUT PRG306 of the Estonian Research Council, the Marie Curie fellowship FP7-PEOPLE-2012-IEF Grant No 332265. 


\section{References}

Aasland A, Fløtten T (2001) Ethnicity and social exclusion in Estonia and Latvia. Eur-Asia Stud 53(7):1023-1049

Andersson R, Bråmå Å (2004) Selective migration in Swedish distressed neighbourhoods: can area-based urban policies counteract segregation processes? Hous Stud 19(4):517-539

Anniste K, Tammaru T (2014) Ethnic differences in integration levels and return migration intentions: a study of Estonian migrants in Finland. Demogr Res 30:377

Bater JH (1986) Some recent perspectives on the Soviet city. Urban Geogr 7(1):93-102; Clapham D (1995) Privatisation and the East European housing model. Urban Stud 32(45):679-694

Dekker K, Van Kempen R (2004) Large housing estates in Europe: current situation and developments. Tijdschrift voor economische en sociale geografie 95(5):570-577

Gentile M, Sjöberg Ö (2006) Intra-urban landscapes of priority: the Soviet legacy. Eur-Asia Stud 58(5):701-729

Gentile M, Tammaru T (2006) Housing and ethnicity in the post-Soviet city: Ust'-Kamenogorsk, Kazakhstan. Urban Stud 43(10):1757-1778

Hess DB, Tammaru T, Leetmaa K (2012) Ethnic differences in housing in post-Soviet Tartu, Estonia. Cities 29(5):327-333

Hess DB, Tammaru T, Väiko A (2018 forthcoming) Segregation effects from new and renovated housing in a super homeownership state. Centre for Urban and Migration Studies, Estonia

Hussar A (2018) Estonia: prospects for steady improvement. In: Hegedüs J, Lux M, Horváth V (eds) Private rental housing in transition countries. Palgrave Macmillan, London, pp 211-233

Jauhiainen JS, Kährik A (2005) Estonia (Chap. 7). In Urban issues and urban policies in the new EU countries. Ashgate Publishing, Aldershot, pp 131-154

Kangur K (2016) Muutused Tallinna naabruskondade sotsiaalmajanduslikus koosseisus aastatel 2000-2011 [Changes in socioeconomic composition of neighbourhoods in Tallinn from 2000 to 2011]. MSc, University of Tartu

Kulu H (2003) Housing differences in the late Soviet city: the case of Tartu, Estonia. Int J Urban Reg Res 27(4):897-911

Kõre J, Ainsaar M, Hendrikson M (1996) Eluasemepoliitika Eestis 1918-1995 [Housing policy in Estonia 1918-1995]. Akadeemia 10:2133-2163

Kährik A (2000) Housing privatisation in the transformation of the housing system-the case of Tartu. Estonia. Norsk Geografisk Tidsskrift 54(1):2-11

Kährik A, Kõre J (2013) Estonia: residualization of social housing and the new programs. In: Hegedüs J et al (eds) Social housing in transition countries. Routledge, Oxon och New York, pp 163-179

Kährik A, Tammaru T (2010) Soviet prefabricated panel housing estates: areas of continued social mix or decline? The case of Tallinn. Hous Stud 25(2):201-219

Kährik A, Leetmaa K, Tammaru T (2012) Residential decision-making and satisfaction among new suburbanites in the Tallinn urban region, Estonia. Cities 29(1):49-58

Kährik A, Novák J, Temelová J, Kadarik K, Tammaru T (2015) Patterns and drivers of inner city social differentiation in Prague and Tallinn. Geografie 120(2):275-295

Kährik A, Tammaru T (2008) Population composition in new suburban settlements of the Tallinn metropolitan area. Urban Stud 45(5-6):1055-1078

Leetmaa K, Tammaru T, Hess DB (2015) Preferences toward neighbor ethnicity and affluence: evidence from an inherited dual ethnic context in post-Soviet Tartu, Estonia. Ann Assoc Am Geogr 105(1):162-182 
Leetmaa K, Holvandus J, Mägi K and Kährik A (2018) Population shifts and urban policies in housing estates of Tallinn, Estonia. In: Hess DB, Tammaru T, Van Ham M (eds) Housing estates in Europe. Springer, Cham, Switzerland, pp 389-412

Leppik M, Vihalemm T (2015) The paradox of national language acquisition: Russian speakers' labor market positions in Estonia. J Balt Stud 46(4):471-496

Lindemann K, Kogan I (2013) The role of language resources in labour market entry: comparing Estonia and Ukraine. J Ethn Migr Stud 39(1):105-123

Lux M, Kährik A, Sunega P (2012) Housing restitution and privatisation: both catalysts and obstacles to the formation of private rental housing in the Czech Republic and Estonia. Int $\mathbf{J}$ Hous Policy 12(2):137-158

Mägi K, Leetmaa K, Tammaru T, van Ham M (2016) Types of spatial mobility and change in people's ethnic residential contexts. Demogr Res 35(41):1161-1192

Morton HW, Stuart RC (eds) (1984) The contemporary Soviet city. ME Sharpe, Armonk

Musterd S, Ronald VK (2007) Trapped or on the springboard? Housing careers in large housing estates in European cities. J Urban Aff 29(3):311-329

Nerman R (1998) Lasnamäe. Ajalugu [The History of Lasnamäe]. Eesti Entsüklopeediakirjastus. Tallinn

Org A (1989) Korteriolud [Housing conditions], In: Pavelson M (Ed) Tallinna taastootmismehhanism ja arengustrateegia [Renewal and development strategy of Tallinn]. Tallinna Linnauurimise Instituut Tallinn)

Padrik J (2016) Tallinna elamufondi füüsiline regeneratsioon ja seosed sotsiaalsete muutustega naabruskondades [Physical regeneration of the housing fund of Tallinn and its relation with the social changes in neighbourhoods]. MSc, University of Tartu

Raitviir T (1987) Tallinna factor-ökoloogiline struktuur [The factor-ecological structure of Tallinn] Eesti teadus- ja tehnikainformatsiooni ning majandusuuringute instituut. Tallinn

Ruoppila S, Kährik A (2003) Socio-economic residential differentiation in post-socialist Tallinn. J Hous Built Environ 18(1):49-73

Smith DM (1996) The socialist city. Cities after socialism: urban and regional change and conflict in post-socialist societies, pp 70-99

Sommer S (2012) Soviet housing construction in Tartu: the era of mass construction (1960-1991). MSc, University of Tartu

Tammaru T, van Ham M, Leetmaa K, Kährik A, Kamenik K (2013) The ethnic dimensions of suburbanisation in Estonia. J Ethn Migr Stud 39(5):845-862

Tammaru T (2000) Differential urbanisation and primate city growth in Soviet and post-Soviet Estonia. Tijdschrift voor economische en sociale geografie 91(1):20-30

Tammaru T, Kindsiko E, Holvandus J, Leetmaa K, Pastak I, Väiko A (2017) Dealing with urban diversity. The case of Tallinn

Tammaru T (2002) Universal and specific features of urbanization in Estonia under socialism: the empirical evidence of the sources of urban and rural population growth. Prof Geogr 54(4):544556

Tammaru T, Kulu H (2003) The ethnic minorities of Estonia: changing size, location, and composition. Eurasian Geogr Econ 44(2):105-120

Tammaru T, Kährik A, Mägi K, Novák J, Leetmaa K (2016) The 'market experiment': Increasing socio-economic segregation in the inherited bi-ethnic context of Tallinn. In: Tammaru $\mathrm{T}$ et al (eds) Socio-economic segregation in European capital cities. Taylor \& Francis, Oxon och New York, pp 333-358

Temelová J, Novák J, Kährik A, Tammaru T (2016) Neighbourhood trajectories in the inner cities of Prague and Tallinn: what affects the speed of social and demographic change? Geografiska Ann Ser B Hum Geogr 98(4):349-366 
Open Access This chapter is licensed under the terms of the Creative Commons Attribution 4.0 International License (http://creativecommons.org/licenses/by/4.0/), which permits use, sharing, adaptation, distribution and reproduction in any medium or format, as long as you give appropriate credit to the original author(s) and the source, provide a link to the Creative Commons license and indicate if changes were made.

The images or other third party material in this chapter are included in the chapter's Creative Commons license, unless indicated otherwise in a credit line to the material. If material is not included in the chapter's Creative Commons license and your intended use is not permitted by statutory regulation or exceeds the permitted use, you will need to obtain permission directly from the copyright holder.

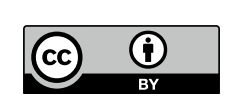




\title{
Chapter 11 \\ Residential Change \\ and Socio-demographic Challenges \\ for Large Housing Estates in Riga, \\ Latvia
}

\section{Zaiga Krišjāne, Māris Bērziṇš, Guido Sechi and Jānis Krūmiṇš}

\begin{abstract}
Large housing estates from the socialist era are a characteristic feature of the built environment in the cities of Central and Eastern Europe. Many urban researchers are increasingly interested in residential changes in these areas, showing how demographic and socioeconomic processes interact with the decline or upgrading of this distinct type of housing. In Europe, the debate concerning large housing estates is largely related to a declining and ageing population, as well as to housing conditions. In Latvia, the underdeveloped housing market and the massive privatisation of the housing stock to sitting tenants have contributed, since the late-Soviet period, to inherited socio-spatial structures. During the 2000 s, the second decade of post-socialist transition, the increasing residential mobility of affluent people was observed. However, the issue of its impact on residential composition in the large housing estates remains ambiguous. This chapter discusses the patterns of population change and composition in the most distinctive type of housing in the capital city, Riga. We draw our empirical evidence from there due to the widely acknowledged fact that the most notable social changes and the fastest economic growth have tended to be concentrated and much more advanced in capital cities. Moreover, a significant number of city residents continue to live in mass housing built in the Soviet period.
\end{abstract}

Keywords Large housing estates - Population decline - Socio-spatial change • Riga

\footnotetext{
Z. Krišjāne $(\bowtie) \cdot$ M. Bērziņ̌̌ $\cdot$ G. Sechi $\cdot$ J. Krūmin̦š

Department of Human Geography, University of Latvia, Riga, Latvia

e-mail: zaiga.krisjane@lu.lv

M. Bērziňš

e-mail: maris.berzins@lu.lv

G. Sechi

e-mail: guidosechi78@gmail.com

J. Krūmiñš

e-mail: kruminsjanis3@gmail.com

(C) The Author(s) 2019

D. B. Hess and T. Tammaru (eds.), Housing Estates in the Baltic Countries,

The Urban Book Series, https://doi.org/10.1007/978-3-030-23392-1_11
} 


\subsection{Introduction}

Urban residential areas in Central and Eastern Europe have experienced substantial physical and social transformation since the 1990s. Recent patterns of urban residential change are affected by the socio-demographic outcomes of deindustrialisation, suburbanisation, gentrification and growing income inequality, thus downgrading or upgrading the social status of some residential areas while retaining a relatively good image and social mix in others. For nearly five decades, a massive construction of large housing estates took place all across the Former Soviet Union. This socialist mass housing was an experiment in urban living not only in Riga - where more than $70 \%$ of inhabitants today reside in this type of housing - but also in most urban areas in Central and Eastern Europe. It shaped the social lives and everyday activities of conspicuous numbers of Soviet citizens and still affects the culture of urban living for many dwellers. In fact, socialist mass housing is a unique phenomenon that facilitated the policies of a relatively fast urbanisation and industrialisation as well as fulfilling an enormous social role - providing millions of families with their own apartments throughout the Former Soviet Union. During the socialist regime from the late 1940s to the late 1980s, the urban population in Riga increased significantly-from 228,200 to 910,455 by 1989. The massive construction of large housing estates occurred mainly on the outskirts of the city. Along with the industrialisation and urbanisation processes, these large housing estates became an important destination for the mainly Russian-speaking immigrants from other Soviet republics. Within this context, it is somewhat unexpected that there should be so few studies addressing these densely inhabited and symbolic areas of the post-Soviet city. Moreover, to the present day, no detailed studies on residential change in large housing estates in Riga exist. Similarly, despite the common legacies, the age of the Soviet-era urban fabric in Riga remains diverse and various characteristics of the socialist past have had a lasting influence on the residential composition of apartment blocks in large housing estates. In this study, we focus on identifying the evolving local patterns of demographic, ethnic and socio-economic change in these large housing estates during the first decade of the twenty-first century, discussing the residential change that has occurred in the most distinctive type of housing in Riga. This chapter seeks to analyse how the patterns of residential composition differ between the large housing estates in terms of construction periods. A further goal is to clarify whether the estates have been affected by residential change in a light of systemic transformation and economic restructuring, and whether the socio-demographic and ethnic trajectories differ between them depending on construction period or location. 


\subsection{Setting the Scene: Socio-economic and Spatial Transformation in Riga}

Riga is both the capital and the largest city in Latvia. In 2017, it was home to 641,423 inhabitants or around $33 \%$ of the country's nearly 2 million people. There are three historical layers that define the contemporary urban fabric and spatial structure of Riga, as depicted in Fig. 11.1. These same layers can be found in a great majority of cities in Central and Eastern Europe (Kovács and Herfert 2012; Sýkora 2009). After World War II, Latvia was annexed by the Soviet Union, resulting in a new and distinct layer in the urban fabric of Riga. The construction of large housing estates was part of the ideal of building an egalitarian Soviet society. However, despite the fact that under the central planning system, the state sought to ensure satisfactory and equal living standards for all, previous studies have found significant levels of residential differentiation under Soviet rule (Enyedi 1998; French and Hamilton 1979; Kornai 1992). There is a general consensus in the literature that the administrative allocation of housing under socialism was more egalitarian in theory than in practice (Szelényi 1983). The socialist system contained key mechanisms that sorted the population according to housing quality and size (Gentile and Sjöberg 2013; Rubīns 2004). When apartments in the newly built large housing estates in Soviet cities were allocated, preference was given to the Russian-speaking workforce who, most often, arrived through 'organised channels' of migration (Gentile and Tammaru 2006; Kulu 2003). Thus, immigration was part of a deliberate political and ideological agenda in the Soviet Union. And in Latvia, where the Soviet period resulted in further industrialisation, this agenda was used to disperse the predominately Russian-speaking population (Lewis and Rowland 1979; Riekstinšs 2004). Moreover, during the Soviet period, the formation of ethnic minorities was shaped by the interrelated policies of industrialisation, immigration and urbanisation (Gentile and Sjöberg 2010). Approximately half of all Soviet-era immigrants came from the present territory of the Russian Federation, and during the 1970s and 1980s, the share of Belarusian and Ukrainian immigrants in Latvia increased (Monden and Smits 2005). The immigrants were mostly located in the largest industrial cities with their own ethnic infrastructure and became over-represented in the newly built large housing estates (Hess et al. 2012; Kährik and Tammaru 2010). Thus, a considerable population increase, reaching almost one million by 1989 and accompanied by high levels of ethnic housing segmentation, characterised late-Soviet Riga.

Following Latvia's independence, political and economic restructuring took place and Riga experienced a population loss due to low birth rates and out-migration. As a result, according to national statistics, the share of ethnic minorities, even today, exceeds $50 \%$ of the city's population, as shown in Table 11.1. Apart from Russians, other large ethnic groups are Belarusians and Ukrainians, who mostly speak Russian. The societal changes and economic reforms of the 1990s have placed minorities in a new situation that substantially alters the patterns of labour market and housing segmentation inherited from the Soviet 


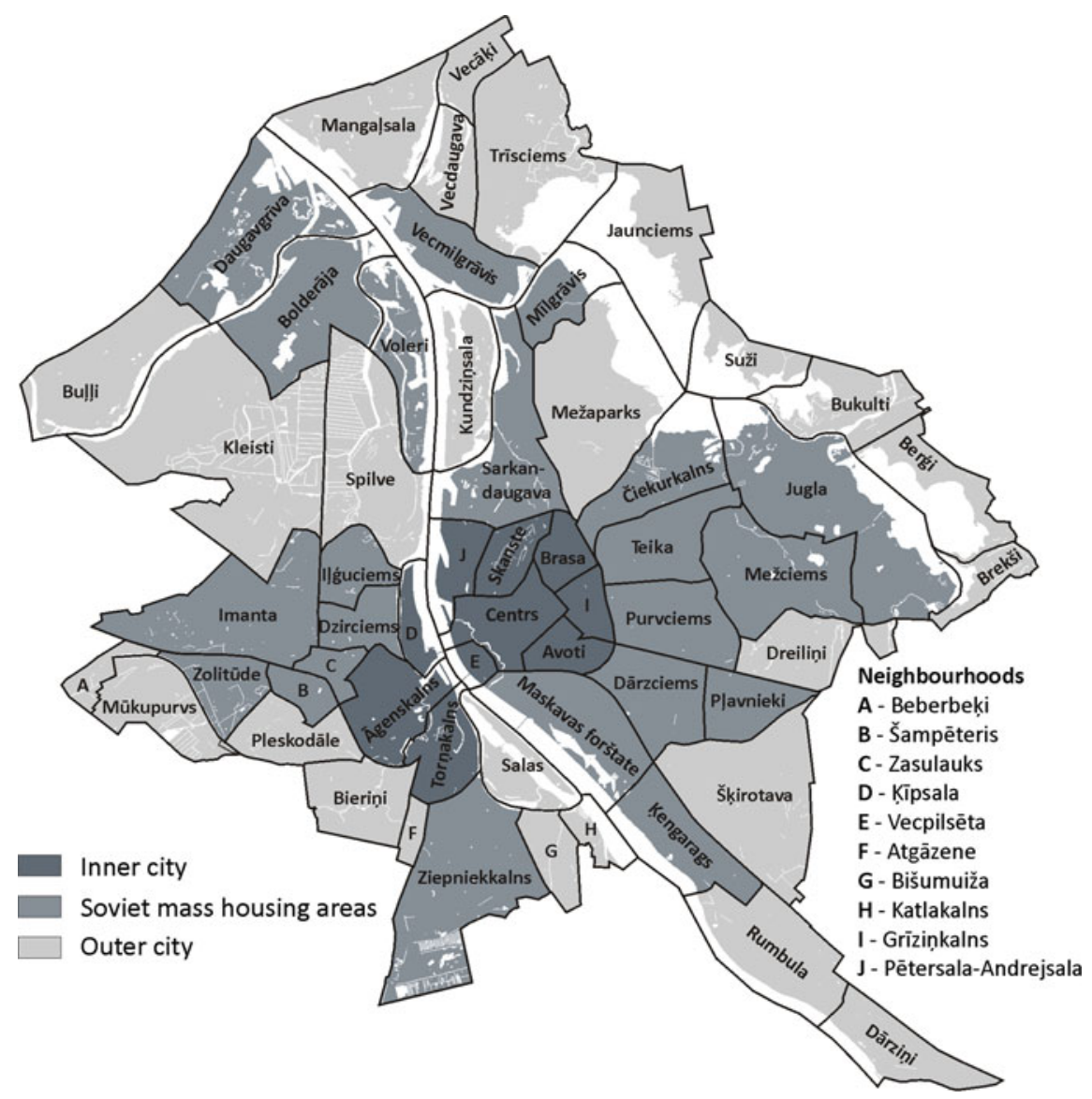

Fig. 11.1 Neighbourhood units divided by urban zone in Riga. Source Authors' figure, Riga City Council

period. Studies have confirmed that the members of the Russian-speaking minority in Latvia have adjusted less well to economic restructuring and suffered more from employment losses in the various industrial sectors in which they were over-represented (Aasland 2002; Lindemann 2013; Muižnieks et al. 2013). Today, more than $70 \%$ of Riga's urban dwellers live in apartments in large Soviet-era housing estates.

The 25 years of post-Soviet transition have added a new layer of housing in Riga, mainly in the inner and outer parts of the city. This in-fill development of new and very expensive apartments provides homes for the higher income groups in the population. Growing suburbanisation due to the construction of detached and semi-detached houses in the urban periphery contributed to the increase of dwelling size measured per person. In general, the outer city is the most diverse with respect to the housing stock. This urban zone covers neighbourhoods with detached 
Table 11.1 Population and housing characteristics in Riga, 2000, 2011 and 2016

\begin{tabular}{l|l|l|l}
\hline & 2000 & 2011 & 2016 \\
\hline Total population & 764,329 & 658,640 & 639,630 \\
\hline Population change $(1989=100 \%)$ & 84.0 & 72.3 & 70.3 \\
\hline Net migration per year & $-8,748$ & $-7,210$ & 2,952 \\
\hline Share of ethnic minorities (\%) & 59.1 & 53.7 & 53.8 \\
\hline Population by urban zone (\%) & & & \\
\hline Inner-city neighbourhoods & 21.5 & 17.1 & 16.9 \\
\hline Soviet mass housing neighbourhoods & 73.7 & 75.9 & 75.3 \\
\hline Outer-city neighbourhoods & 4.8 & 7.0 & 7.8 \\
\hline Population by dwelling type (\%) & \multicolumn{4}{l}{} & \\
\hline Detached house & 4.7 & 6.8 & $4.9^{(2015)}$ \\
\hline Semi-detached house & 1.3 & 1.9 & $1.8^{(2015)}$ \\
\hline Flat in apartment block & 94.0 & 91.3 & $93.3^{(2015)}$ \\
\hline Owner-occupied housing (\%) & 63.6 & 74.5 & $80.2^{\text {Latvia) }}$ \\
\hline Total area of dwelling space per person & $21 \mathrm{~m}^{2}$ & $28 \mathrm{~m}^{2}$ & $30 \mathrm{~m}^{2(2015)}$ \\
\hline
\end{tabular}

Source Authors' analysis of census datasets and the statistical database of the Central Statistical Bureau

housing, including pre-Soviet villas and summer cottages, Soviet-era dacha settlements and extensive territories of allotment gardens. There are also large lakes, wetlands and marshes, as well as nature reserves along the sea coast. During the 1990 s, and especially the 2000s, the outer suburbs experienced an increase in the construction of owner-occupied housing and commercial structures (office buildings, shopping centres, warehouses etc.). As a result of the mass privatisation of the housing stock in the 1990s, along with the restitution of housing to its pre-war owners, the municipal sector today owns only an insignificant part of the housing stock. Owner-occupied housing increased substantially between 2000 and 2016 from 64 to $80 \%$ of the housing stock. During the large-scale privatisation of housing, sitting tenants were given their apartments in exchange for vouchers or virtually free of charge. Thus, large numbers of sitting tenants, mostly in the Soviet-era housing estates, became owner-occupiers. People who lived in the restituted apartments could not privatise or buy their flats but instead, became tenants of those to whom the ownership was returned. At the same time, caps were set to avoid a potential sharp increase in rents for tenants in pre-war housing. Other support measures were also introduced for the most vulnerable among the urban dwellers. By 2007, during the peak of a construction boom, rent regulation was abolished; however, rents have not risen substantially since then. This can partly be explained by the subsequent economic recession from 2008 to 2012 (Liepa-Zemeša and Hess 2016). Over the past decade, Riga has initiated municipal (social) housing construction programmes to accommodate tenants who had been living in housing now restituted to previous owners and other socially vulnerable groups. However, the share of rented housing is still negligible and housing policy is more oriented towards supporting home ownership. 


\subsection{Data and Methods}

The data used in this chapter are derived from the 2000 and 2011 rounds of the population census. Census data are cross-sectional because they capture geographical population patterns as they exist at the particular moments in time when the census is taken. Despite some inconsistencies, these statistics are the most reliable data on population composition in Latvia. Unlike many other secondary data sources, which provide only administrative data, the resolution of census datasets is the best available in terms of details released about individuals and the spatial scale at which the data are geocoded. Moreover, the coding of variables used in the 2000 and 2011 census datasets enables comparison of these statistics. This study proceeds in two stages. First, we investigate the city-wide patterns of residential change that took place in the first decade of the twenty-first century and the differences between Soviet-era apartment blocks and other types of housing. In the second stage, we explore the internal differences between the housing estates constructed in successive periods. The census data were used both to compare people living in Soviet-era apartment blocks with those living in other types of housing, and to trace any differences in the demographic and socio-economic composition of people living on the different estates. We adopt particular apartment blocks built during the Soviet period as an appropriate structural and spatial unit of observation. Initially, not only were pre- and post-Soviet housing and detached and semi-detached types of dwelling excluded from individual-level census datasets but also apartment blocks with fewer than six flats over less than two storeys were excluded. Unfortunately, we could not link each selected apartment block to a particular housing estate since most of them were built in several stages and therefore different construction generations are found. We thus refer to the term 'Soviet-era housing estates' as meaning all the blocks of flats erected in this period that meet the previously selected criteria.

\subsection{Soviet-Era Housing Estates in Riga}

The context-related issues affecting the pace of post-Soviet transformations play an important role in explaining the local level reality of the post-Soviet city. In light of this argument, it is crucial to clarify not only the general trends in residential change in the Soviet-era housing estates, but also the residential restructuring in different generations of construction and in various locations. The most intense construction of apartment housing in Riga, as depicted in Fig. 11.2, took place after World War II and lasted until the demise of the Soviet Union in 1991 (with some apartments completed by 1995). Flats in these modernist, standardised and mainly prefabricated apartment buildings were allocated, through the centrally organised system, to certain population categories: the working middle class and professionals (especially those in high priority enterprises), politicians or nomenklatura. 


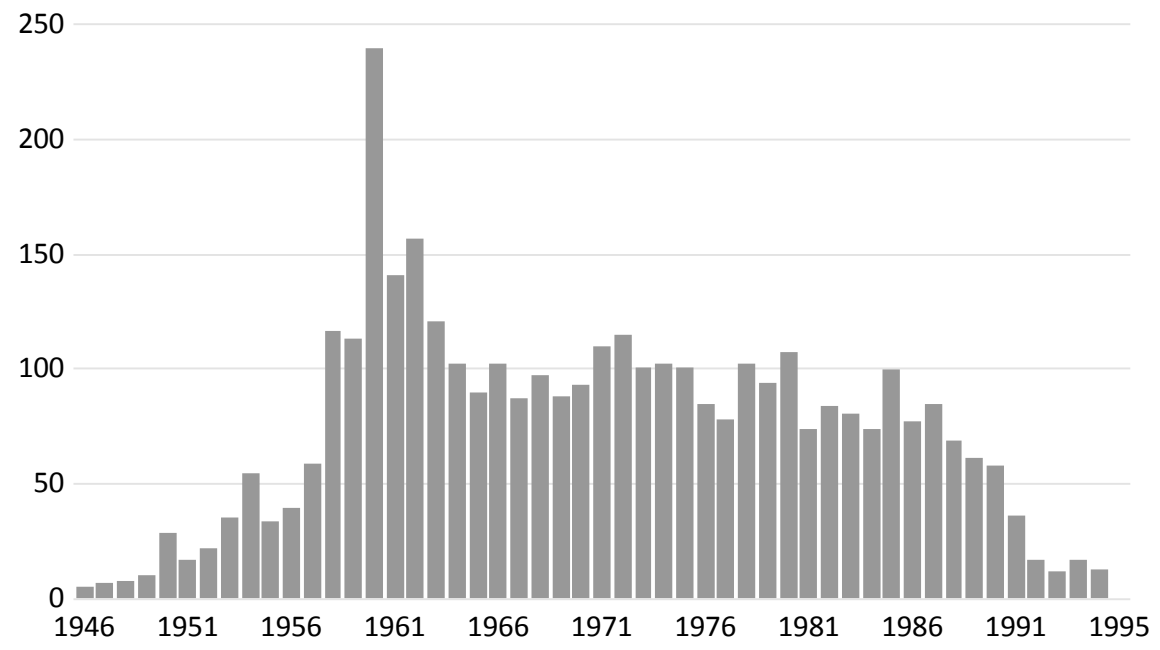

Fig. 11.2 Annual construction of Soviet-era apartment buildings in Riga, 1946-1995. Source Authors' analysis of census datasets

The military and the intellectual and cultural elite had better access and better quality housing (Smith 1989). Another characteristic feature of the Soviet period was low residential mobility, as most people were tied to their apartments due to housing shortages (Szelényi 1996). Thus, the composition of the population in the different types of Soviet-era mass housing is also attributed to the epoch at which the particular apartment block was constructed (Turkington et al. 2004).

The Soviet modernist townscapes in Riga were largely established in empty spaces or in open fields, mainly on the urban fringe, however, Soviet-era apartment blocks are also visible in inner-city areas. State socialism came with the adoption of central planning and the political hegemony of the Communist party (Gentile 2015). This explains the priority of urban investment in industry, especially during the Stalinist regime in the first decade under Soviet power in Latvia. In the 1940s and early 1950s, little new housing was built in Riga. The apartment blocks that were built at that time were typical solid stone buildings in neoclassical style or so-called Socialist Classicism, as shown in Fig. 11.3. Starting from the late 1950s, the development of large-scale residential zones became a critical issue for the Soviet Union under Khrushchëv's regime. A central element of this development was the Communist Party's 1957 statement that it would provide every Soviet family with their own individual apartment (Drèmaite 2017). Consequently, the year 1957 is marked as the beginning of an era of prefabricated mass production of housing. During the late 1950s and early 1960s, Riga experienced a rapid increase in its housing stock. Between 1958 and 1963, a total of 889 apartment blocks or 22,278 dwellings were built in Riga. Compared to the period 1946-1955, as depicted in Fig. 11.2, the number of dwellings constructed between 1958 and 1963 was almost seven times greater. The development of Soviet-era mass housing is 
strongly related to the evolution of construction norms. Regulations approved in 1955, known as the Construction Norms and Rules (SNiP for short, in translation from Russian), served for years as a means to control residential housing development. In the period from 1955 to 1991, the SNiP rules dealing with mass housing were thoroughly revised only four times-in 1957, 1962, 1971 and 1985 (Meuser and Zadorin 2015). Thus, only four generations of construction can be identified in the course of Soviet-era mass housing development (Drėmaite 2017). In Riga, Soviet-era prefabricated apartment blocks represent every generation of construction and occupy vast areas on the fringes of the inner city (Fig. 11.4). The height of the prefabricated apartment blocks and the size and quality of the dwellings increased with each successive generation (Smith 1996; Treija and Bratuškins 2014). The first generation of the epoch of Soviet mass housing is epitomised by the notorious type of khrushchëvka, as shown in Fig. 11.3, a poorly built low-quality, usually three- or five-storey, brick building hosting many small apartments with small rooms and tiny premises for amenities (French 1995).

Since the late 1950s, prefabricated-panel technologies were applied by the construction industry, thus increasing productivity and quality. In Latvia and Riga, the construction of prefabricated-panel housing estates began in 1959 (Rubins 2004) and the first large-scale panel housing micro-district in Riga was built in Agenskalns. A new phase of state socialist urban-life organisation was the micro-district (mikrorayon, a kind of Soviet self-contained neighbourhood unit. Thus, the new residential housing was grouped together into large, functionally

(a)

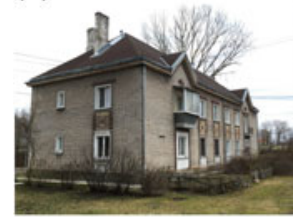

(e)

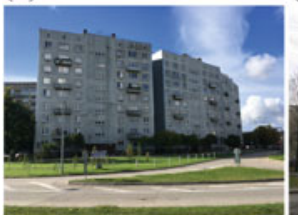

(b)

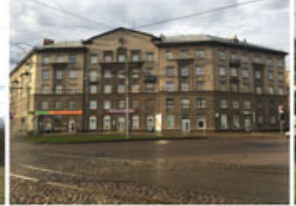

(f)

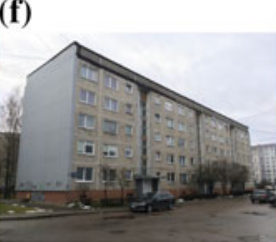

(c)

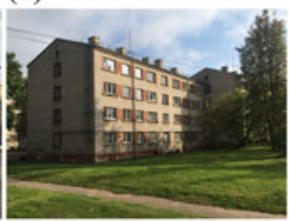

(g)

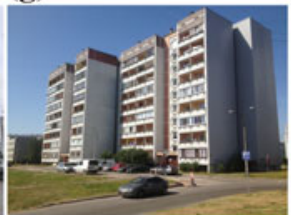

(d)

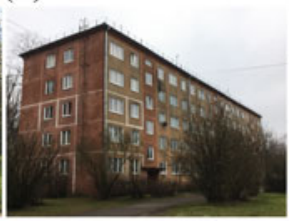

(h)

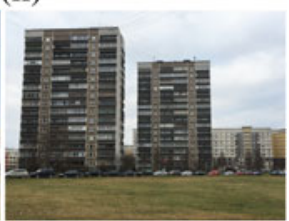

Fig. 11.3 Various types and series of Soviet-era apartment buildings in Riga. Note a typical two-storey apartment house built in the late 1940s; b solid stone building of the early 1950s in the Stalinist era, representing the architecture of Socialist Classicism; $\mathbf{c}$ typical apartment block of the Khrushchëv era in the late 1950s; d one of the first prefabricated-panel houses built in the early 1960s; e originally designated in Leningrad (Saint Petersburg); however, later, the apartment blocks of this series, the construction of which was widespread in the 1970s, became tied to Riga; f typical five-storey apartment block of the Brezhnev era in the 1970s; g nine-storey prefabricated-panel house of the 1980s; $\mathbf{h}$ the newest high-rise panel blocks of the late-Soviet period from the 1980 s and early 1990 s 
zoned mikrorayons each comprising 9,000 to 12,000 inhabitants (Drèmaitė 2017). At that time, the mikrorayon approach was extremely attractive for rapidly growing cities like Riga. Generally speaking, there are 13 large mikrorayons or housing estates in Riga which largely overlap with the boundaries of the existing neighbourhoods, as shown in Fig. 11.4 and Table 11.2. The largest housing estate is Purvciems, which stretches across several present-day neighbourhoods, with almost 60,000 inhabitants living in the Soviet-era apartment blocks in 2011. Conversely, the smallest housing estate is located in the neighbourhood of Daugavgriva with its more than 8,000 inhabitants.

By the 1970s, the state socialist system was solidly established in Latvia and all the largest industrial cities, including the capital, Riga, were a destination for

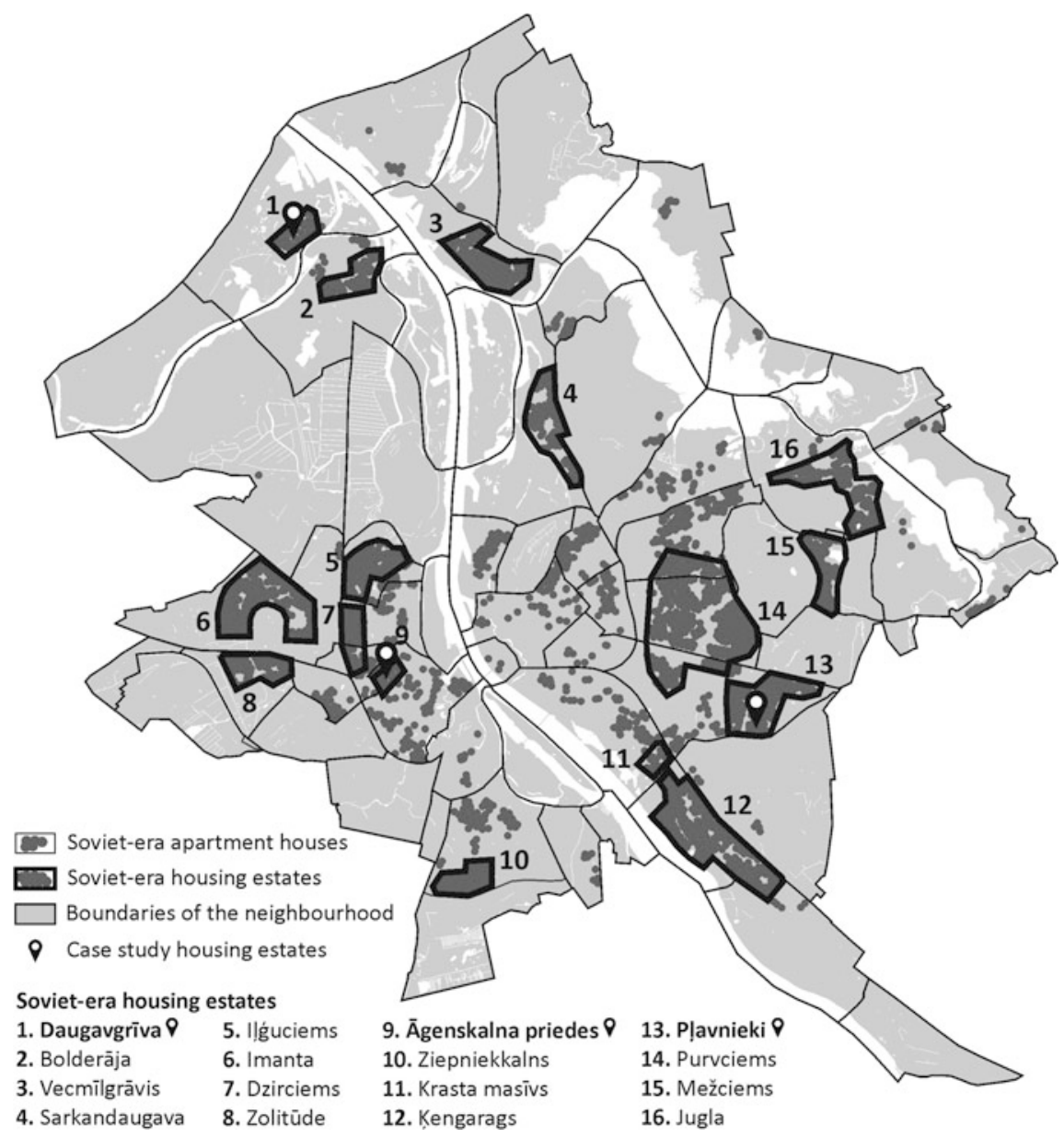

Fig. 11.4 Location of all Soviet-era apartment blocks and largest housing estates, including the three case-study areas. Source Authors' analysis of census datasets 
Table 11.2 Largest housing estates by neighbourhood in Riga

\begin{tabular}{|c|c|c|c|c|}
\hline & \multirow{2}{*}{$\begin{array}{l}\text { Period of } \\
\text { construction }\end{array}$} & \multirow{2}{*}{$\begin{array}{l}\text { No. of } \\
\text { dwellings, } \\
\text { '000s }\end{array}$} & \multicolumn{2}{|c|}{ Population, '000s (2011) } \\
\hline & & & Total $^{\mathrm{a}}$ & $\begin{array}{l}\text { Soviet-era } \\
\text { apartment blocks }\end{array}$ \\
\hline \multicolumn{5}{|c|}{ Largest housing estates by neighbourhood } \\
\hline Purvciems & 1965-1975 & 24.9 & 59.3 & 53.2 \\
\hline Ķengarags & 1961-1971 & 23.5 & 50.4 & 48.4 \\
\hline Plavavnieki & 1985-1995 & 17.9 & 44.8 & 42.4 \\
\hline Imanta & 1966-1975 & 18.7 & 46.6 & 40.8 \\
\hline Ziepniekkalns & 1985-1995 & 12.1 & 33.6 & 27.5 \\
\hline İğguciems & 1965-1970 & 10.3 & 24.0 & 22.6 \\
\hline Vecmīlgrāvis & $1968-1980$ & 9.0 & 22.7 & 21.6 \\
\hline Jugla & 1961-1970 & 10.4 & 25.1 & 21.5 \\
\hline Zolitūde & 1985-1995 & 6.2 & 18.6 & 16.3 \\
\hline Sarkandaugava & $1960-1975$ & 6.4 & 18.1 & 13.5 \\
\hline $\begin{array}{l}\text { Āgenskalns } \\
\text { (Āgenskalna priedes) }\end{array}$ & 1958-1962 & 6.8 & 26.8 & 12.8 \\
\hline Mežciems & 1977-1985 & 5.3 & 15.3 & 12.7 \\
\hline Bolderāja & $1955-1975$ & 4.6 & 13.0 & 10.7 \\
\hline \multicolumn{5}{|c|}{ Other housing estates by neighbourhood ${ }^{\mathrm{b}}$} \\
\hline $\begin{array}{l}\text { Teika (part of } \\
\text { Purvciems) }\end{array}$ & $1955-1965$ & 10.1 & 28.9 & 20.3 \\
\hline $\begin{array}{l}\text { Dārzciems (part of } \\
\text { Purvciems) }\end{array}$ & $1971-1990$ & 6.7 & 21.0 & 14.9 \\
\hline $\begin{array}{l}\text { Maskavas forštate } \\
\text { (Krasta masīvs) }\end{array}$ & 1967-1986 & 5.8 & 27.2 & 12.9 \\
\hline Dzirciems & 1966-1975 & 4.5 & 12.1 & 9.2 \\
\hline Daugavgrīva & 1966-1985 & 3.4 & 9.0 & 8.5 \\
\hline Total & 1955-1995 & 186.6 & 658.6 & 457.8 \\
\hline
\end{tabular}

Note ${ }^{\text {a }}$ Total population of the neighbourhood, including residents living in detached and semi-detached buildings as well as those living in pre-war- and post-1991-built houses

${ }^{\mathrm{b}}$ Some of these housing estates are among the largest, while others are usually not recognised as housing estates

Source Authors' analysis of data derived from the 2011 census

Russian-speaking immigrants. The supply of newly built housing continued to follow the trend of mass production introduced by Khrushchëv. However, despite a significant imprint in the urban fabric, housing shortages existed-largely inherited from previous decades - and cities still did not manage to meet the demand for accommodation (Andrusz 1984; Gentile and Sjöberg 2013). The late-Soviet period of post-1976 was when most of the Soviet-era apartment blocks were built across the city, and as a result, the housing shortages slowly declined so that the late-Soviet period is represented by very attractive and qualitative mass housing. With some exceptions in the cases of Ägenskalns and Maskavas forštate, the 
neighbourhoods and housing estates listed in Table 11.2 have an absolute majority of residents living in Soviet-era apartment blocks. Those built on the largest housing estates and all across Riga represent the first three generations of housing construction. The high-rise apartment buildings corresponding to the fourth generation were constructed as separate monolithic concrete towers on several housing estates in Riga.

With respect to its housing supply, the choice and diversity in housing stock of present-day Riga have changed considerably since the Soviet period. However, the Soviet-era standardised apartment buildings still house a considerable proportion of urban dwellers. The dominance of large-scale housing estates implies that the city of Riga was spatially relatively compact until the end of the 1990s. The process of suburbanisation of more affluent households accelerated only at the beginning of the 2000s (Krišjāne and Bērziņš 2012).

\subsection{Demographic, Ethnic and Socio-economic Trajectories of Large Housing Estates in Riga}

Based on 2000 and 2011 census data, it is possible to assume that analysis of the demographic, ethnic and socio-economic variables captures not only the situation at certain moments in time but also the changes during the transition. As of 2011, the average age of the residents on Soviet-era mass housing estates had increased in comparison to 2000. In 2011 the highest share of inhabitants aged 65 and older lived in neighbourhoods dominated by the oldest Soviet-era housing stock, as shown in Fig. 11.5. In 2011, too, the percentage of ethnic Latvians moderately increased in comparison to 2000, whereas there has been a moderate decrease in the share of East Slavic ethnic minorities. Overall, East Slavic residents represent an absolute majority in Soviet-era housing estates. As of 2011, in most neighbourhoods, it is the Russian-speaking minorities who still constitute an absolute majority, with the exception of two of the oldest ones (Ägenskalna priedes and Jugla), mikrorayons characterised by early (first-generation) mass housing developments, which have witnessed a sharp increase in the share of ethnic Latvians since 2000 .

Our findings concerning demographic, ethnic and socio-economic change in large housing estates compared to other types of housing in Riga are summarised in Table 11.3. The percentage of single-person households has substantially increased, whereas there has been a substantial decrease in the number of households of three or more persons in Soviet-era apartments. The proportion of residents with higher education and a managerial or professional occupation has increased, whereas the share of residents with low education levels has substantially decreased. In 2011, as in 2000, a substantial majority of the residents were women, the ratio being slightly higher than for Riga city overall. In terms of family status, there has been a 

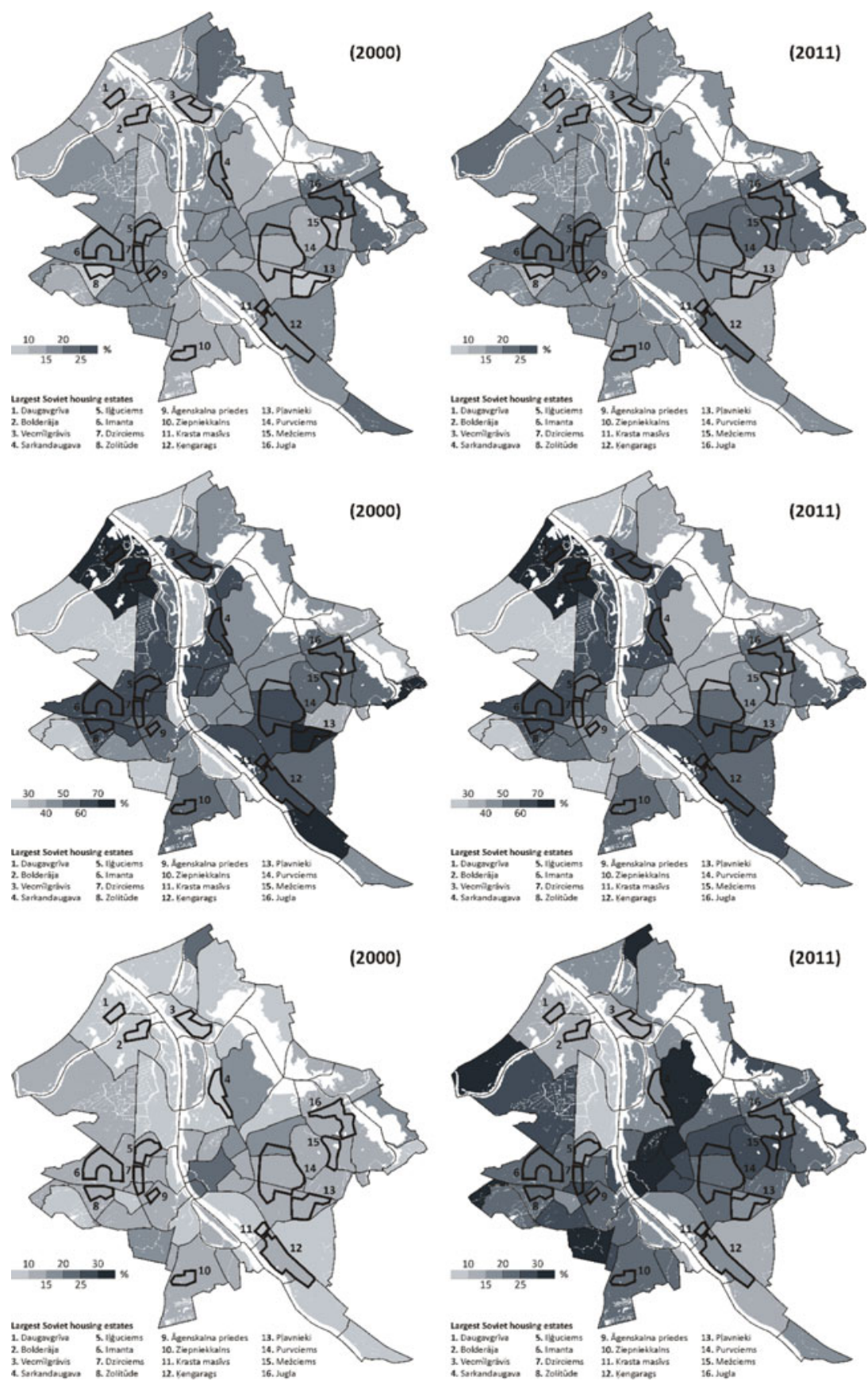

Fig. 11.5 Distribution of various population groups (aged 65+ ; ethnic minorities; managers and professionals) by neighbourhoods of Riga. Source Authors' analysis of data derived from the census 
Table 11.3 Demographic, ethnic and socio-economic characteristics of residents living in Soviet-era apartments and other types of housing in Riga, 2000 and 2011

\begin{tabular}{|c|c|c|c|c|c|}
\hline & & \multicolumn{2}{|l|}{2000} & \multicolumn{2}{|l|}{2011} \\
\hline & & $\begin{array}{l}\text { Soviet-era } \\
\text { apartment } \\
\text { blocks }\end{array}$ & $\begin{array}{l}\text { Other } \\
\text { housing }\end{array}$ & $\begin{array}{l}\text { Soviet-era } \\
\text { apartment } \\
\text { blocks }\end{array}$ & $\begin{array}{l}\text { Other } \\
\text { housing }\end{array}$ \\
\hline & Population & 543,892 & 220,437 & 457,841 & 200,799 \\
\hline & $\%$ & 71.2 & 28.8 & 69.5 & 30.5 \\
\hline \multirow[t]{2}{*}{ Gender } & Male & 44.4 & 45.3 & 43.2 & 46.0 \\
\hline & Female & 55.6 & 54.7 & 56.8 & 54.0 \\
\hline \multirow{3}{*}{ Age group } & $0-18$ years & 20.4 & 21.9 & 15.2 & 19.0 \\
\hline & 19-64 years & 63.9 & 62.4 & 64.4 & 66.6 \\
\hline & $65+$ years & 15.7 & 15.7 & 20.4 & 14.4 \\
\hline \multirow{5}{*}{$\begin{array}{l}\text { Ethnic } \\
\text { group }\end{array}$} & Latvian & 34.5 & 57.5 & 38.8 & 63.5 \\
\hline & Russian & 48.9 & 31.2 & 46.2 & 26.5 \\
\hline & Belarusian & 5.5 & 2.6 & 4.7 & 2.0 \\
\hline & Ukrainian & 4.9 & 2.4 & 4.1 & 1.9 \\
\hline & Other & 6.2 & 6.3 & 6.2 & 6.1 \\
\hline \multirow{3}{*}{$\begin{array}{l}\begin{array}{l}\text { Household } \\
\text { status }\end{array} \\
\end{array}$} & Single & 37.3 & 40.7 & 37.6 & 45.5 \\
\hline & Married & 47.0 & 41.4 & 39.9 & 34.0 \\
\hline & $\begin{array}{l}\text { Widowed/ } \\
\text { Divorced }\end{array}$ & 15.7 & 17.9 & 22.6 & 20.5 \\
\hline \multirow{3}{*}{$\begin{array}{l}\text { Household } \\
\text { size }\end{array}$} & 1 person & 9.1 & 11.1 & 15.4 & 18.0 \\
\hline & 2 persons & 24.0 & 20.3 & 26.2 & 21.9 \\
\hline & $3+$ persons & 66.9 & 68.6 & 58.4 & 60.1 \\
\hline \multirow[t]{3}{*}{ Education } & Primary & 30.4 & 34.3 & 18.9 & 22.8 \\
\hline & Secondary & 49.2 & 47.2 & 51.3 & 46.7 \\
\hline & Tertiary & 20.4 & 18.6 & 29.9 & 30.5 \\
\hline \multirow[t]{4}{*}{ Occupation } & $\begin{array}{l}\text { Managers/ } \\
\text { Professionals }\end{array}$ & 10.8 & 11.4 & 14.8 & 18.1 \\
\hline & $\begin{array}{l}\text { All other } \\
\text { occupations }\end{array}$ & 36.6 & 35.7 & 30.0 & 25.9 \\
\hline & Unemployed & 6.9 & 7.6 & 8.7 & 8.9 \\
\hline & Inactive & 45.7 & 45.3 & 46.5 & 47.1 \\
\hline
\end{tabular}

Source Authors' analysis of census datasets

substantial decrease in the percentage of married residents and a substantial increase in the share of widowed or divorced ones.

More specifically, we were interested in the patterns of residential composition of large housing estates in terms of their construction period, as shown in Table 11.4. Residents living in Soviet-era housing built between 1956 and 1975 
Table 11.4 Demographic, ethnic and socio-economic characteristics of residents living in Soviet-era housing estates built during various eras, 2011

\begin{tabular}{|c|c|c|c|c|c|c|}
\hline & & $\begin{array}{l}1946- \\
1955\end{array}$ & $\begin{array}{l}1956- \\
1965\end{array}$ & $\begin{array}{l}1966- \\
1975\end{array}$ & $\begin{array}{l}1976- \\
1995\end{array}$ & $\begin{array}{l}1946- \\
1995\end{array}$ \\
\hline & Population & 10,193 & 77,486 & 153,045 & 217,117 & 457,841 \\
\hline & $\%$ & 2.2 & 16.9 & 33.5 & 47.4 & 100.0 \\
\hline Mean age & & 40 & 44 & 44 & 42 & 43 \\
\hline \multirow[t]{2}{*}{ Gender } & Male & 45.3 & 42.2 & 42.5 & 44.0 & 43.2 \\
\hline & Female & 54.7 & 57.8 & 57.5 & 56.0 & 56.8 \\
\hline \multirow[t]{3}{*}{ Age group } & $0-18$ years & 17.5 & 14.5 & 15.1 & 15.4 & 15.2 \\
\hline & 19-64 years & 66.9 & 62.6 & 60.2 & 67.8 & 64.4 \\
\hline & $65+$ years & 15.6 & 22.8 & 24.7 & 16.8 & 20.4 \\
\hline \multirow[t]{5}{*}{ Ethnic group } & Latvian & 38.3 & 43.8 & 40.9 & 35.5 & 38.8 \\
\hline & Russian & 47.1 & 43.1 & 45.1 & 48.1 & 46.2 \\
\hline & Belarusian & 4.5 & 4.0 & 4.4 & 5.2 & 4.7 \\
\hline & Ukrainian & 3.7 & 3.3 & 3.6 & 4.8 & 4.1 \\
\hline & Other & 6.4 & 5.8 & 5.9 & 6.5 & 6.2 \\
\hline \multirow{3}{*}{$\begin{array}{l}\text { Household } \\
\text { status }\end{array}$} & Single & 40.5 & 38.2 & 36.9 & 37.6 & 37.6 \\
\hline & Married & 37.6 & 36.0 & 38.9 & 42.1 & 39.9 \\
\hline & $\begin{array}{l}\text { Widowed/ } \\
\text { Divorced }\end{array}$ & 21.8 & 25.8 & 24.2 & 20.3 & 22.6 \\
\hline \multirow{3}{*}{$\begin{array}{l}\text { Household } \\
\text { size }\end{array}$} & 1 person & 14.4 & 19.2 & 15.7 & 13.9 & 15.4 \\
\hline & 2 persons & 22.9 & 28.6 & 26.8 & 25.0 & 26.2 \\
\hline & $3+$ persons & 62.8 & 52.2 & 57.5 & 61.0 & 58.4 \\
\hline \multirow[t]{3}{*}{ Education } & Primary & 22.5 & 20.4 & 19.6 & 17.7 & 18.9 \\
\hline & Secondary & 51.1 & 51.4 & 51.5 & 51.1 & 51.3 \\
\hline & Tertiary & 26.4 & 28.2 & 28.9 & 31.3 & 29.9 \\
\hline \multirow[t]{4}{*}{ Occupation } & $\begin{array}{l}\text { Managers/ } \\
\text { Professionals }\end{array}$ & 14.0 & 14.0 & 13.9 & 15.8 & 14.8 \\
\hline & $\begin{array}{l}\text { All other } \\
\text { occupations }\end{array}$ & 29.4 & 29.3 & 28.8 & 31.1 & 30.0 \\
\hline & Unemployed & 10.7 & 8.9 & 8.1 & 8.8 & 8.7 \\
\hline & Inactive & 45.9 & 47.8 & 49.2 & 44.2 & 46.5 \\
\hline \multirow[t]{3}{*}{ Dwelling size } & Less than $49.9 \mathrm{~m}^{2}$ & 43.8 & 73.3 & 58.6 & 40.1 & 52.0 \\
\hline & $50.0-79.9 \mathrm{~m}^{2}$ & 42.4 & 24.3 & 40.8 & 55.4 & 45.0 \\
\hline & More than $80.0 \mathrm{~m}^{2}$ & 13.8 & 2.3 & 0.6 & 4.5 & 3.0 \\
\hline \multicolumn{2}{|c|}{ Mean dwelling size } & 56.9 & 45.9 & 49.1 & 54.9 & 51.5 \\
\hline
\end{tabular}

Source Authors' analysis of data derived from the 2011 census

had a higher mean age. Similarly, the share of Latvians was higher in housing estates built throughout the late 1950s to the mid-1970s. The female-to-male ratio is found to be higher among residents of housing estates built between 1956 and 1965 . 
The highest share of elderly residents is found in housing estates built in the 19661975 period, whereas the lowest share is found in 1946-1955 estates. The highest share of residents of less than 18 years of age is found in these 1946-1955 estates, the lowest in those built between 1956 and 1965. Finally, the highest share of residents aged 18-64 is found in the fourth-period estates and the lowest in those of the third period. The highest share of ethnic Latvians is found in estates built between 1956 and 1965, whereas the highest share of East Slavic minorities is found in 1976-1995 estates. The oldest housing stock has the highest share of single residents. The largest households live in both the oldest and the newest housing stock of Soviet-era apartment blocks. The largest share of highly educated residents and residents with a managerial or professional occupation is found in estates built between 1976 and 1995, while the highest share of residents with primary education is found in those from 1946 to 1955; the highest combined share of inactive and unemployed residents is found in estates built from 1966 to 1975 . The highest average dwelling size is found on estates constructed between 1946 and 1955, and the lowest among 1956-1965 estates. An absolute majority of residents in blocks built between 1956 and 1975 and a relative majority of residents in 19461955 blocks lives in apartments of less than $50 \mathrm{~m}^{2}$, whereas an absolute majority of residents in fourth construction-period estates lives in apartments of between 50 and $80 \mathrm{~m}^{2}$.

Table 11.5 shows the socio-demographic composition of three selected neighbourhoods, which differ in terms of location and construction period. Ägenskalna priedes is located in the inner city, with its mix of historical and Soviet-era apartment houses, whereas the other two are peripherally located housing estates, the first of which-Plavnieki-is one of the largest and the newest, connected relatively close to the city centre. However, the second housing estateDaugavgriva - is relatively small and the most distant residential area in the city. All the selected housing estates were built in different construction periods. Agenskalna priedes is a typical example of buildings from the Khrushchëv period. Plavnieki is one of the newest housing estates built in the late 1980s, while Daugavgriva was built over a span of 20 years, under the rule of Brezhnev. Among these three neighbourhoods, Agenskalna priedes has the higher share of managers or professionals and of residents with tertiary education. Among the two other housing estates, Plavnieki (more recent and with better infrastructure and location) seems to be more attractive than Daugavgriva to these categories of residents. Agenskalna priedes also has the highest share of singles and one-person households, as well as the highest share of residents aged over 65. In terms of ethnic composition, Ágenskalna priedes has a relative majority of ethnic Latvians, whereas the two other housing estates have an absolute majority of Russian-speaking residents. 
Table 11.5 Demographic, ethnic and socio-economic characteristics of residents living in selected Soviet-era housing estates, 2011

\begin{tabular}{|c|c|c|c|c|}
\hline & & \multirow{2}{*}{$\begin{array}{l}\text { Inner-city location } \\
\overline{\text { Agenskalna priedes }} \\
(1958-1962)\end{array}$} & \multicolumn{2}{|c|}{ Peripheral location } \\
\hline & & & \begin{tabular}{|l|} 
Plavnieki \\
(1985-1995)
\end{tabular} & $\begin{array}{l}\text { Daugavgrīva } \\
(1966-1985)\end{array}$ \\
\hline & Population & 12,779 & 42,407 & 8,492 \\
\hline & $\%$ & & & \\
\hline \multirow[t]{2}{*}{ Gender } & Male & 41.2 & 44.1 & 45.1 \\
\hline & Female & 58.8 & 55.9 & 54.9 \\
\hline \multirow[t]{3}{*}{ Age group } & $0-18$ years & 14.0 & 15.3 & 16.7 \\
\hline & 19-64 years & 63.8 & 71.1 & 67.2 \\
\hline & $65+$ years & 22.3 & 13.6 & 16.1 \\
\hline \multirow{5}{*}{$\begin{array}{l}\text { Ethnic } \\
\text { group }\end{array}$} & Latvian & 46.4 & 30.5 & 21.2 \\
\hline & Russian & 41.3 & 51.7 & 58.0 \\
\hline & Belarusian & 3.6 & 5.7 & 6.7 \\
\hline & Ukrainian & 3.3 & 4.8 & 6.5 \\
\hline & Other & 5.3 & 7.3 & 7.6 \\
\hline \multirow{3}{*}{$\begin{array}{l}\text { Household } \\
\text { status }\end{array}$} & Single & 39.3 & 37.6 & 37.7 \\
\hline & Married & 35.8 & 42.4 & 41.3 \\
\hline & $\begin{array}{l}\text { Widowed/ } \\
\text { Divorced }\end{array}$ & 24.8 & 20.0 & 21.0 \\
\hline \multirow{3}{*}{$\begin{array}{l}\text { Household } \\
\text { size }\end{array}$} & 1 person & 20.9 & 13.2 & 10.7 \\
\hline & 2 persons & 27.9 & 24.1 & 23.6 \\
\hline & $3+$ persons & 51.1 & 62.8 & 65.7 \\
\hline \multirow[t]{3}{*}{ Education } & Primary & 18.6 & 17.8 & 22.6 \\
\hline & Secondary & 48.2 & 53.4 & 56.3 \\
\hline & Tertiary & 33.2 & 28.8 & 21.1 \\
\hline \multirow[t]{4}{*}{ Occupation } & \begin{tabular}{|l|} 
Managers/ \\
Professionals
\end{tabular} & 16.9 & 14.7 & 9.5 \\
\hline & $\begin{array}{l}\text { All other } \\
\text { occupations }\end{array}$ & 28.0 & 33.3 & 34.5 \\
\hline & Unemployed & 8.3 & 10.1 & 11.0 \\
\hline & Inactive & 46.8 & 41.9 & 45.0 \\
\hline
\end{tabular}

Source Authors' analysis of census datasets

\subsection{Conclusion}

Since 1991, Latvia, and Riga in particular, have experienced deep economic and social change on the path from state socialism to democracy and a market-oriented housing system. Large-scale housing estates are the most visible spatial structures 
created during the Soviet period. Similarly, Soviet-era apartments make up a considerable proportion of the urban housing stock in Riga. Thus the Soviet legacy is evident, as the housing structures that it created still shape the cityscape and house a majority of urban dwellers. However, the patterns of population change and composition in the most distinctive types of housing have evolved over the past two decades and are a topic of high importance in post-Soviet urban studies. The detailed analysis of this particular type of housing in contemporary cities contributes to a better understanding of post-Soviet urban transformations in terms of population ageing and the physical and social downgrading of housing estates. Deep socio-economic reforms are the reasons why we should expect changes in the socio-spatial distribution of the population in urban areas. In comparison to other studies, historically contextual factors have been important in shaping residential differentiation (Musterd and Kovács 2013). In this chapter, we have provided evidence - through the analysis of 2000 and 2011 census data - of how the residential composition of Soviet-era housing estates has evolved and transformed in Riga. Besides emphasising the demographic and socio-economic composition needed to understand residential change, we have added the construction period as an important dimension which, at its best, illustrates inner differentiations between distinct types of Soviet-era housing estates. Finally, comparative case studies within the city context help to identify important variations at the local level. The pattern of multilayered development of the Soviet-era heritage has resulted in variation in housing associated with social diversity and overall neighbourhood development.

It has been a long time since urban areas have been characterised by a geographically expressed intra-urban social order, and the cities of the Former Soviet Union are no exception. Building on an empirical base of the most recent evidence that brings together both the effects of the Soviet legacy and the conditions of post-1991 transformations, this chapter demonstrates that various aspects of the socialist past have had a lasting influence on residential composition in Soviet-era apartment buildings, measured through housing inequalities in terms of the different generations of construction. The data used in this study present the situation as it was 10 and 20 years after the demise of the Soviet Union. The timeframe used reveals that the process of systemic socioeconomic change had come to an end by the early 2000s, while more pronounced exposure to globalisation has introduced liberalisation and a restructuring of economies in post-socialist countries (Smith and Timár 2010). Thus, the first decade of the twenty-first century is more characterised by a spatial manifestation of the systemic transition (Sýkora and Bouzarovski 2012). This has brought about more distinctive patterns of intra-urban socio-spatial divisions based on ethnicity, class and income. Many authors assumed that the large-scale housing estates - and especially, the older ones - would start to lose the relatively high status they enjoyed under Soviet rule. Eventually, this might cause these Soviet-era apartment blocks to become ghettos and slums, trapping ethnic minorities and low-income social groups, as is the case in many Western European cities (Szelényi 1996; Turkington et al. 2004). However, the main results of our analysis reveal that Soviet-era housing estates in Riga are still characterised by a strong social mix and do not show clear signs of decline. In terms of demographic 
and socio-economic composition, with the exception of ethnicity, the Soviet-era apartments in Riga are not much different from the average apartment in the city, although the residential composition and its change varies to a certain extent, depending on the history, location and construction period of the estate. The trajectories of ethnic composition reflect a general trend towards a moderate increase in the share of ethnic Latvians, while Russian-speaking inhabitants still constitute a majority in large housing estates, with a few exceptions. There is a moderate trend towards ageing in the Soviet-era housing estates, reflecting similar trends in the city and the country. The share of the elderly population is significantly higher in housing estates built in the late 1950s and early 1960s.

A comparative analysis of three housing estates with different geographical scales and historical backgrounds has enabled more detailed explanations of residential change in various locations within the city and thus enriched our overall knowledge of socio-spatial development in the post-Soviet city of Riga. In general, our chapter has demonstrated that housing estates in Riga are not homogeneous residential areas. Some of them are at risk of physical decay and social exclusion, while others are more stable in terms of residential composition. By applying an intra-urban comparison, the demographic and socio-economic composition of particular housing estates is mainly affected by the interplay between historical legacies of housing construction and geographical location. In general, these latter have resulted in a high concentration of housing estates on the outskirts of the city, close to the socialist industrial areas. The socio-economic success and residential attractiveness of these housing estates during the post-Soviet transformation largely depended on their access advantages, distance from the city centre and quality of housing. The newest housing estates, representing the third and fourth generations of construction in the course of Soviet-era mass housing development, are in a better position. In particular, post-1976 apartment blocks, with their better quality of housing and more convenient dwelling space, have a higher share of residents with tertiary education in white-collar, predominantly high-income socio-occupational categories (managers or professionals). Looking at the selected housing estates in more detail, the most attractive for the university educated and high-income socio-professional groups as well as for Latvians is Ägenskalna priedes, which is located in the inner city. This is a neighbourhood with a mixed historical background - a pre-Soviet residential development in an attractive location close to the city centre with a significant in-fill of Soviet-era apartment buildings from the late 1950s and early 1960s. The specific features of this neighbourhood are its ongoing regeneration and gentrification dynamics that have also impacted Soviet-era housing estates. However, the observed gender differences and greater presence of an elderly population, as well as single-person and small households, reveals the effects of ageing. In contrast, the most extreme situation in terms of residential composition is demonstrated by the Daugavgriva housing estate - the smallest and most distant from the city centre in Riga with a considerable share of Russian-speaking minorities and over-represented by low socio-economic status groups; however, it is more gender and demographically balanced compared to Agenskalns. Further social exclusion of this housing estate may lead to local 
degradation and the creation of a spatial poverty trap. The risk of physical and social decay could be partly overcome by municipal level regeneration initiatives. As the case study of Plavnieki has shown, this estate stands somewhere in the middle between the more advanced inner city and the least attractive peripheral locations. This area suggests that the direction of future socio-spatial development is not yet set in many housing estates in Riga. Nevertheless, they all face demographic ageing that could be balanced by the in-migration of young people. At the same time, the incomers could retain the socially mixed structure of the housing estates but may also lead to a more polarised socio-economic composition in Riga (Krišjāne et al. 2016). Generally speaking, the micro-geographical approach illustrates that, in Riga, socio-spatial poverty traps could, instead, be attributed more to the level of particular apartment blocks than to entire housing estates or neighbourhoods.

Acknowledgements The authors are grateful to the book editors for their insightful comments and valuable suggestions. We would also like to acknowledge the Population Census section of the Central Statistical Bureau of Latvia and personally Maranda Behmane, Uldis Ainārs and Dāvis Kḷaviņš. This study was supported by the National Research Programme Project No. VPP-IZM-2018/1-0015.

\section{References}

Aasland A (2002) Citizenship status and social exclusion in Estonia and Latvia. J Balt Stud 33 (1):57-77

Andrusz GD (1984) Housing and urban development in the USSR. SUNY Press, New York

Dremaite M (2017) Baltic modernism. Architecture and housing in Soviet Lithuania. DOM, Berlin

Enyedi G (1998) Transformation in Central European postsocialist cities. In: Enyedi G (ed) Social change and urban restructuring in Central Europe. Akademiai Kiado, Budapest, pp 9-34

French A (1995) Plans, pragmatism, and people: the legacy of Soviet planning for today's cities. University College London Press, London

French R, Hamilton F (eds) (1979) The socialist city. Spatial structure and urban policy. Wiley, Chichester

Gentile M (2015) The 'Soviet' factor: exploring perceived housing inequalities in a midsized city in the Donbas, Ukraine. Urban Geogr 36(5):696-720

Gentile M, Sjöberg Ö (2010) Soviet housing: who built what and when? The case of Daugavpils, Latvia. J Hist Geogr 36(4):453-465

Gentile M, Sjöberg Ö (2013) Housing allocation under socialism: the Soviet case revisited. Post-Sov Aff 29(2):173-195

Gentile M, Tammaru T (2006) Housing and ethnicity in the post-Soviet city: Ust'-Kamenogorsk, Kazakhstan. Urban Stud 43(10):1757-1778

Hess DB, Tammaru T, Leetmaa K (2012) Ethnic differences in housing in post-Soviet Tartu, Estonia. Cities 29(5):327-333

Kährik A, Tammaru T (2010) Soviet prefabricated panel housing estates: Areas of continued social mix or decline? The case of Tallinn. Hous Stud 25(2):201-219

Kornai J (1992) The socialist system: the political economy of communism. Oxford University Press, Oxford

Kovács Z, Herfert G (2012) Development pathways of large housing estates in post-socialist cities: an international comparison. Hous Stud 27(3):324-342 
Krišjāne Z, Bērziņš M (2012) Post-socialist urban trends: new patterns and motivations for migration in the suburban areas of Riga, Latvia. Urban Stud 49(2):289-306

Krisjane Z, Berzins M, Kratovits K (2016) Occupation and ethnicity: patterns of residential segregation in Riga two decades after socialism. In: Tammaru T, Marcinczak S, van Ham M, Musterd S (eds) Socio-economic segregation in European capital cities. East meets west. Routledge, New York, pp 287-312

Kulu H (2003) Housing differences in the late Soviet city: the case of Tartu, Estonia. Int J Urban Reg Res 27(4):897-911

Lewis RA, Rowland RH (1979) Population redistribution in the USSR: its impact on society, 1897-1977. Praeger, New York

Liepa-Zemeša M, Hess DB (2016) Effects of public perception on urban planning: evolution of an inclusive planning system during crises in Latvia. Town Plan Rev 87(1):71-92

Lindemann K (2013) The school performance of the Russian-speaking minority in linguistically divided educational systems: a comparison of Estonia and Latvia. In: Windzio $M$ (ed) Integration and inequality in educational institutions. Springer, Dordrecht, pp 45-69

Meuser P, Zadorin D (2015) Towards a typology of Soviet mass housing: prefabrication in the USSR, 1955-1991. DOM, Berlin

Monden CW, Smits J (2005) Ethnic intermarriage in times of social change: the case of Latvia. Demography 42(2):323-345

Muižnieks N, Rozenvalds J, Birka I (2013) Ethnicity and social cohesion in the post-Soviet Baltic states. Patterns Prejud 47(3):288-308

Musterd S, Kovács Z (2013) Place-making and policies for competitive cities. Wiley-Blackwell, Oxford

Riekstiņš J (2004) Migranti Latvijā, 1944-1989. Dokumentu Krājums. [Migrants in Latvia, 19441989. Collection of documents]. Latvijas Valsts Arhīvs, Riga

Rubīns J (2004) Rīgas Dzīvojamais Fonds 20. Gadsimtā [Housing stock of Riga in the 20th Century]. Jumava, Riga

Smith A, Timár J (2010) Uneven transformations: Space, economy and society 20 years after the collapse of state socialism. Eur Urban Reg Stud 17(2):115-125

Smith DM (1989) Urban inequality under socialism: case studies from Eastern Europe and the Soviet union. Cambridge University Press, Cambridge

Smith DM (1996) The socialist city. In: Andrusz G, Harloe M, Szelenyi I (eds) Cities after socialism. Urban and regional change and conflict in post-socialist societies. Blackwell, Oxford, pp 70-99

Sýkora L (2009) New socio-spatial formations: places of residential segregation and separation in Czechia. Tijdschrift voor Economische en Sociale Geografie 100(4):417-435

Sýkora L, Bouzarovski S (2012) Multiple transformations: Conceptualising the post-communist urban transition. Urban Stud 49(1):43-60

Szelényi I (1983) Urban inequalities under state socialism. Oxford University Press, Oxford

Szelényi I (1996) Cities under socialism - and after. In: Andrusz G, Harloe M, Szelenyi I (eds) Cities after socialism. Urban and regional change and conflict in post-socialist societies. Blackwell, Oxford, pp 286-327

Treija S, Bratuškins U (2014) Rīgas lielmēroga dzīvojamo rajonu identitāte un attīstība [Identity and development of Riga's mass residential areas]. In: Rozenvalds J, Zobena A (eds) Daudzveid̄̄gās un Main̄̄gās Latvijas Identitātes [Multiple and changing latvian identities]. LU Akadēmiskais Apgāds, Riga, pp 347-361

Turkington R, van Kempen R, Wassenberg F (eds) (2004) High-rise housing in Europe: current trends and future prospects. Delft University Press, Delft 
Open Access This chapter is licensed under the terms of the Creative Commons Attribution 4.0 International License (http://creativecommons.org/licenses/by/4.0/), which permits use, sharing, adaptation, distribution and reproduction in any medium or format, as long as you give appropriate credit to the original author(s) and the source, provide a link to the Creative Commons license and indicate if changes were made.

The images or other third party material in this chapter are included in the chapter's Creative Commons license, unless indicated otherwise in a credit line to the material. If material is not included in the chapter's Creative Commons license and your intended use is not permitted by statutory regulation or exceeds the permitted use, you will need to obtain permission directly from the copyright holder.

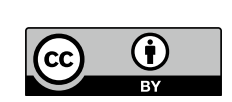




\title{
Chapter 12 Soviet Housing Estates in Vilnius, Lithuania: Socio-ethnic Structure and Future(-Less?) Perspectives
}

\section{Donatas Burneika, Rūta Ubarevičienė and Aušra Baranuskaitė}

\begin{abstract}
This study is focused on Soviet housing estates in Vilnius. The aim of the chapter is to gain more insight into the social and ethnic profile of the residents and to highlight the trajectories of change. The analysis is based on Lithuanian census data from 2001 to 2011. Results suggest that although Soviet housing estates are less segregated than other parts of Vilnius, considerable socio-economic differences exist among residents belonging to different ethnic groups. Soviet housing estates are definitely not the most attractive residential areas, and more affluent groups increasingly prioritise residing in other parts of the city. However, that has not turned them into the neighbourhoods with the highest concentration of the least affluent population. Thus, the Soviet housing estates maintain a rather neutral position in the current residential structure of Vilnius.
\end{abstract}

Keywords Soviet housing estates · Socio-ethnic structure $\cdot$ Housing • Vilnius

\subsection{Introduction}

The post-war era of rapid industrialisation and economic growth corresponded with a massive wave of urbanisation in Central and Eastern European (CEE) countries. This took place under the communist Soviet regime. The pace of urbanisation was

D. Burneika $(\bowtie) \cdot R$. Ubarevičienè · A. Baranuskaitè Institute of Human Geography and Demography, Lithuanian Social Research Centre, Vilnius, Lithuania e-mail: donatas.geo@gmail.com
A. Baranuskaitè
e-mail: baranauskaite.ab@gmail.com
R. Ubarevičienè
Faculty of Architecture and the Built Environment, Department of Urbanism, Delft University of Technology, Delft, The Netherlands
e-mail: r.ubareviciene@tudelft.nl
(C) The Author(s) 2019
D. B. Hess and T. Tammaru (eds.), Housing Estates in the Baltic Countries,
The Urban Book Series, https://doi.org/10.1007/978-3-030-23392-1_12 
especially rapid in Lithuania. If the rate of urbanisation was as low as $30 \%$ in the pre-war period, it reached $68 \%$ by the end of the 1980s. As a consequence, a large proportion of the population of major Lithuanian cities lived in Soviet housing estates at the end of the socialist period. Since the 1990s, when the transition to a market-based economy began, the socio-spatial development of Lithuania has been characterised by several important facets: shrinkage of population, metropolitanisation, suburbanisation and increasing segregation. All of these processes have had an effect on the residential structure of Soviet housing estates.

Today, in this rapidly shrinking country, Vilnius is the main metropolitan city in Lithuania that still has potential to grow, despite the population of its central areas having dropped during the last decade (Ubarevičienè et al. 2016). In Vilnius, as in other CEE cities, the housing market was only weakly influenced by public housing policies, and, since the introduction of the market economy, cities have expanded through the process of a weakly planned and unregulated residential suburbanisation (Borén and Gentile 2007; Gentile et al. 2012; Sýkora and Ouředníček 2007). Significant spatial transformations of the whole Vilnius metropolitan region were accompanied by major changes in social structure, such as an increase in social and ethnic segregation (Valatka et al. 2016). Recent research has shown a clear relationship between the ethnic and socio-economic status of Vilnius residents (Burneika and Ubarevičienè 2016). On the other hand, these findings showed that Soviet housing estates form the most stable neighbourhoods in Vilnius city, experiencing only minor changes in their ethnic and socio-economic structure. Moreover, segregation levels were found to be relatively low in Soviet housing estates. In this chapter, we hypothesise that this stability may hide a steady downgrading of Soviet housing estates, especially in the context of the development of the city as a whole. We also expect that the trends could vary in different places, because despite their apparent uniformity, Soviet housing estates differ in terms of metropolitan location, year of construction and quality. In addition, the residential structure in Soviet housing estates should also vary, because different periods of construction corresponded to different immigration flows from other Soviet Republics and from within Lithuania.

This study is focused on Soviet housing estates in Vilnius. The aim of the chapter is to gain more insight into the social and ethnic profile of their residents and to highlight the trajectories of change. In order to get a better insight into the processes of residential differentiation, we also compare Soviet housing estates with the rest of the city. We use Lithuanian census data from 2001 to 2011. Aggregate data is used to illustrate the social and ethnic structures and to observe their changes. Data on the individual level is used to explore the interrelationships between individual characteristics. 


\subsection{Soviet Housing Estates and the Housing Structure of Vilnius}

In this study, Soviet housing estates are defined as collections of high-rise apartment buildings (mostly 5-12 storeys) built during the Soviet period (1946-1990), when intensive industrialisation followed by immigration of Russian speakers (mainly from Russia) prompted a desperate need for new housing in Vilnius. High-rise apartment buildings were a dominant type of housing built during that period (Fig. 12.1). The General Plan of Vilnius, which was part of the Lithuanian regional planning scheme approved in 1967 (Šešelgis 1996), foresaw the construction of new housing estates in massive neighbourhoods planned as separate city districts (the current administrative units, 21 in total) (Čiurlionienè 2008). The first Soviet housing estate districts appeared near the central part of the city, as well as in more distant areas, located beyond natural barriers such as forested slopes of the Neris river valley. Today, Soviet-era apartments accommodate around $62 \%$ of the Vilnius population (compared to $71.5 \%$ in 2001) and are scattered throughout the city (based on 2001 and 2011 censuses). The empirical part of this study is focused on residential areas - larger sets of Soviet housing estates - in which the absolute majority (at least 90\%) of the residents live in Soviet-era apartments. These residential areas are mostly located in the middle-west part of the city and accommodate one-third of the total population. In this study, we refer to these residential areas as housing estate districts (seven in total, Fig. 12.2) and housing estate neighbourhoods (17 in total, Fig. 12.7), depending on the spatial level used in the analysis.

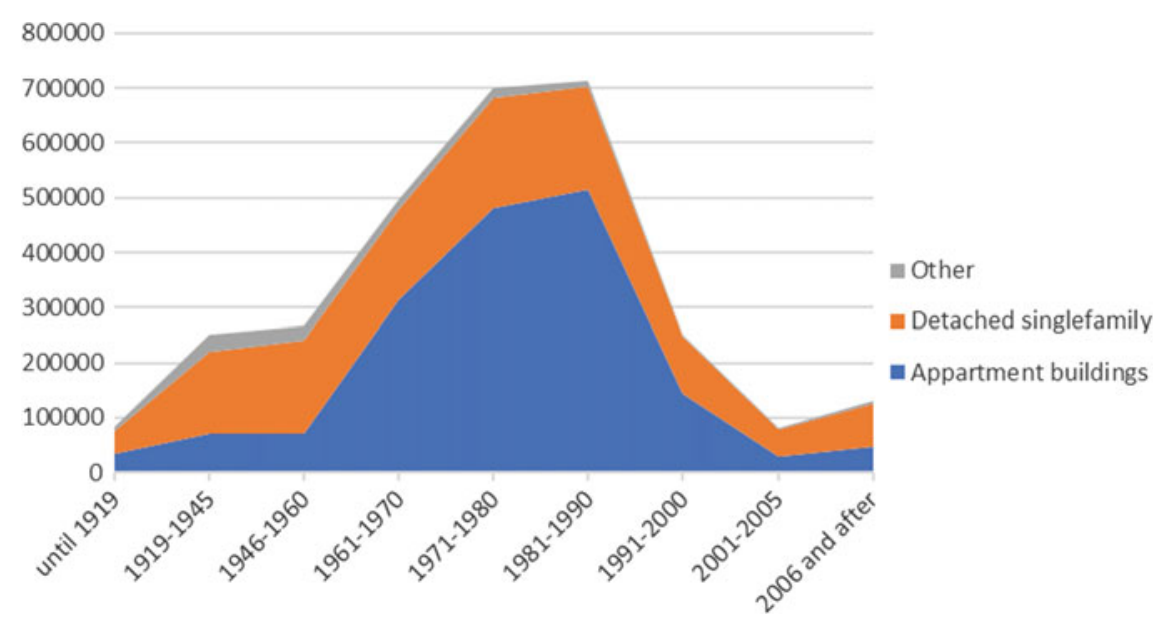

Fig. 12.1 Residential construction periods in Vilnius by housing types. Data source 2011 Lithuanian census 


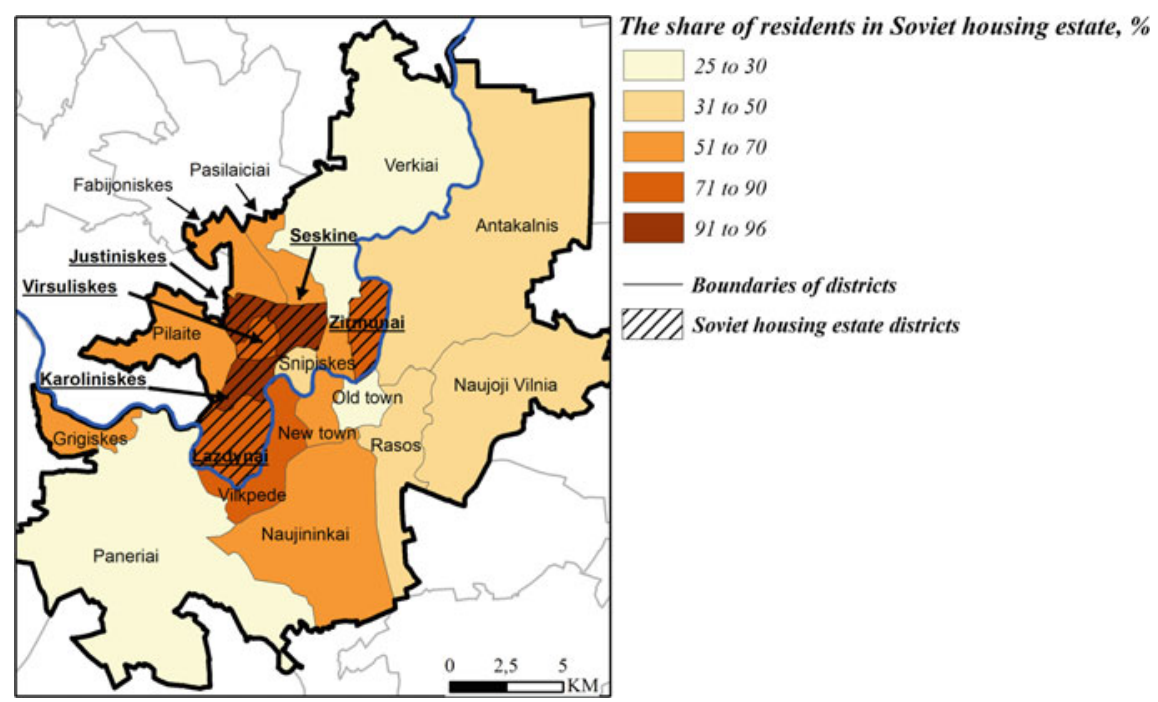

Fig. 12.2 Vilnius districts and share of residents in Soviet housing estates, 2011. Data source 2011 Lithuanian census

The quality of the housing in Soviet housing estates improves and the age decreases with distance from the city centre. As a result, their price levels are quite similar. There are a few blocks of more distant and older Soviet apartment buildings located near former industrial satellite towns. Distance from the city centre and poor physical quality make these apartment buildings the least attractive in the Vilnius housing market. Previous studies have also shown that these areas are characterised by the lowest social status and a high non-Lithuanian population (Burneika et al. 2017). Although these particular housing estates do not form large residential neighbourhoods, they may significantly affect the average indicators of some districts of Vilnius, which also incorporate more affluent suburban neighbourhoods. Furthermore, in recent decades, new housing estates have been built near Soviet-era housing districts in various parts of Vilnius. Therefore, the housing supply and residential structure of many neighbourhoods has been in flux. Soviet housing estate districts such as Karoliniskes, Justiniskes and Seskine (Fig. 12.2) were fully built up during the Soviet period, and there was hardly any room for post-Soviet development. Meanwhile, Zirmunai and Lazdynai were the districts where most of the post-Soviet construction took place in the post-reform period (Burneika 2008), thus their residential structure should have been strongly affected by mobility processes characterised by the inflow of higher social status groups.

The city centre of Vilnius consists of the Old Town (Senamiestis), New Town (Naujamiestis), former working-class neighbourhoods and some prestigious residential areas built at the end of the nineteenth century. An important feature of the Soviet housing era is working-class dormitories, which are scattered around the central parts of the city near "traditional" Soviet high-rise apartment buildings. The 
dormitories were privatised and can now be described as the low-quality housing in Vilnius. However, because they are scattered and not numerous, they do not form large areas of poverty.

The outer city forms a wide ring around the city centre and large housing estates. This zone extends both within and beyond the city limits. It has a relatively fragmented socio-economic structure and includes large, newly suburbanised areas, old collective gardens ("dacha"), former satellite industrial towns, other industrial areas and even rural settlements (some of them recently incorporated into the city limits). In Vilnius, there is a great division between the southern industrialised part, which includes former rural and suburban settlements with relatively low-quality housing, and the northern part, where new and more expensive single-family dwellings dominate. In general, the current character of the outer city is a result of post-Soviet suburbanisation. The districts where most of the post-Soviet development took place are distinguished by population growth and a decreasing share of residents in Soviet housing estates (Fig. 12.3).

Soviet housing estate districts were among the fastest shrinking districts in Vilnius (Fig. 12.3). Furthermore, the share of residents in Soviet-era apartments dropped significantly in Vilnius as a whole, as well as in each housing estate. A greater drop in population was also observed in the central pre-war working-class districts, where many wooden slums equipped with minimal communal facilities are located; however, the processes of gentrification have already changed this situation. The decline of the population in housing estates is mostly associated with the ageing population and negative net migration (due in part to suburbanisation).

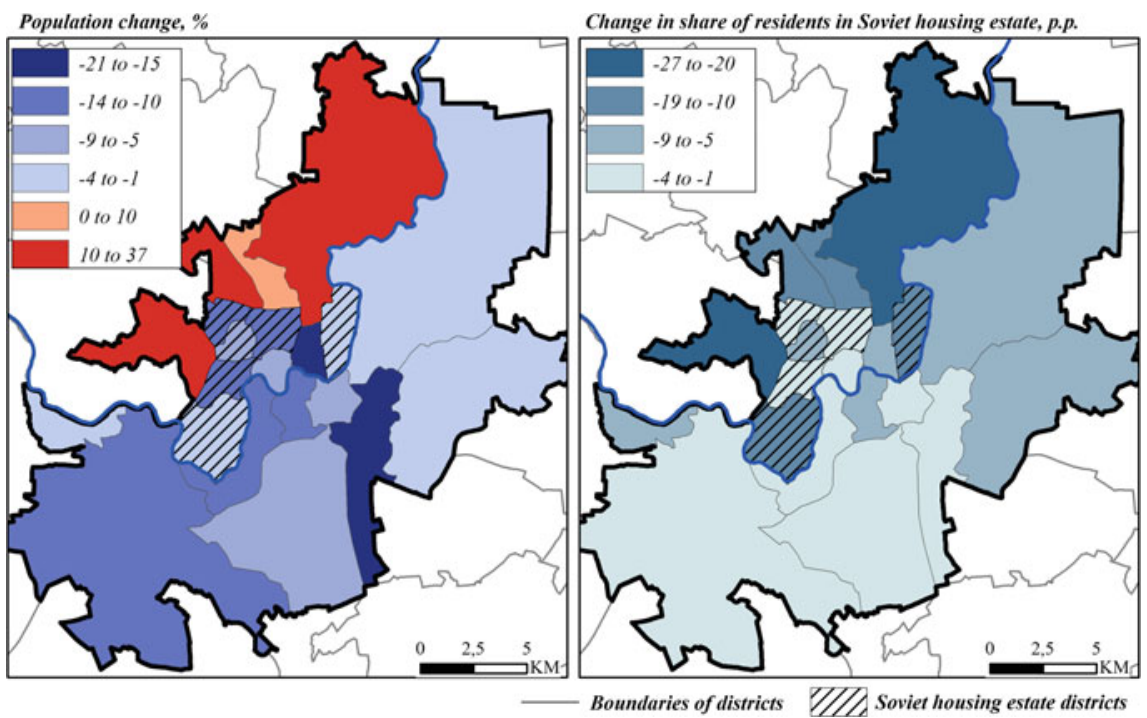

Fig. 12.3 Population change (left panel) and change in resident share in Soviet housing estates (right panel), 2001-2011. Data source 2001 and 2011 Lithuanian censuses 
A small inflow of newcomers to Soviet housing districts may be explained by two factors: limited purchasing power and varying housing preferences. It could also be associated with a limited supply of available dwellings; the household size in Soviet apartments decreases (as well as the number of residents), but the majority remain occupied. There may be a third reason: an inability of population registers to cope with the shadow rental market. In that case, we should assume that the actual social structure of housing estates might be different to that shown by the official statistics, because it is mostly young persons and families who take part in the rental market.

\subsection{Brief Overview of Previous Studies}

In this paper, we use the concept of socio-ethnic structure to determine residential differentiation, which is based on two parameters of a group: social status and ethnicity (similar to Andersson and Kährik 2016). Accordingly, we focus mainly on the parameters of age, level of education, occupational status and ethnicity. The concept of socio-ethnic inequality describes "the condition" when various ethnic groups have different social positions even if they live in the same spaces. Two main reasons for socio-ethnic inequality are mentioned in many studies, especially those in which North American and Western European cities are analysed. First, ethnic minorities often have fewer resources, which limits their ability to acquire housing. Second, discrimination in the housing market might restrict their choices (Bolt and van Kempen 2010; Semyonov and Glikman 2009). Although the processes of spatial differentiation of ethnic minorities in North American and West European cities have been studied for several decades, their findings provide little help in understanding ethnic landscapes in post-Soviet cities. At present, ethnic diversity in Western cities is often regarded as a result of postcolonial processes, while in the post-Soviet cities, particularly in the Baltic countries, ethnic diversity can mostly be deemed the result of colonialism. Ethnic minorities that migrated to Baltic cities during the Soviet period were not in disadvantaged socio-economic positions. This is likely to have changed after post-communist reforms were introduced, which included property restitution and the strengthening of the position of national languages in public and institutional life.

In Lithuania, one of the first attempts to gain more insights into the social and ethnic structure of housing estates was made by Vanagas (1996). He presented the results of sociological surveys that illustrated differences of place identities among the residents of various districts in Vilnius. Vanagas' studies showed differences in the attractiveness of centrally planned housing districts, with Antakalnis, Zirmunai and Lazdynai ranked among the most attractive districts (together with the city centre), while districts that were further away from the city centre and of later construction were ranked the least attractive. Unfortunately, these surveys did not analyse the social or ethnic profile of the residents. More recent survey-based research of Krupickaite (2014) showed that residents of typical Soviet-era high-rise apartments (Karoliniskes district was used as a case study) are the most dissatisfied 
with their dwellings, compared to residents of other parts of Vilnius. The findings of Krupickaite (2014) suggest that faster social degradation is expected in housing estates, as their population is ageing and has lower levels of education and income. In addition, the residents of Soviet housing estates are the least mobile, which means that their social structure changes slowly. Although a few other studies on residential differentiation in Vilnius have been carried out (Tereškinas et al. 2013; Žilys 2013), they did not focus exclusively on Soviet housing estates, and thus their results provide little insight into the social and ethnic structure of the housing estates and differences between neighbourhoods. Most studies mentioned in this overview find that the ethnic and social composition is quite homogenous in housing estates compared to other parts of Vilnius.

\subsection{Data and Methods}

The empirical part of this chapter is focused on residential areas in Vilnius in which the absolute majority (at least 90\%) of the residents live in Soviet-era apartments. Analysis is based on a data from 2001 to 2011 Lithuanian censuses. District-level (Seniūnija or LAU 2 statistical regions) data is used to analyse socio-ethnic structure and its changes between 2001 and 2011. Data aggregated on smaller (neighbourhood) level ${ }^{1}$ is used to analyse 2011 census data in more detail. Finally, individual-level data is used to explore the relationships between individual characteristics. Aggregate data is mostly analysed using cartographical techniques, with logistic regression used for individual-level analysis. The following variables describing the population structure are included in the analyses: age, ethnicity, level of education and occupational group. The combination of cartographical and statistical methods gives a good insight into the residential structure of Soviet housing estates and allows us to uncover trends in their changes.

We use self-reported data on ethnicity to analyse residential differentiation of Lithuanian, Polish and Russian ethnic groups. These are the main ethnic groups in Vilnius and in Lithuania overall. Occupational groups, according to the ISCO categories, ${ }^{2}$ are used as a proxy for socio-economic status, with managers and professionals representing groups with higher socio-economic status, and unskilled and low-skilled workers representing groups with lower socio-economic status. Although occupation does not always reflect social status or income, the national labour force survey of 2010 (Statistics Lithuania 2014) confirmed that the differences in incomes between occupational groups are substantial in Lithuania.

\footnotetext{
${ }^{1}$ This is an intermediate level between census tracts and districts in Vilnius. Based on the prevailing housing type, we created 65 smaller neighbourhoods in Vilnius. These were the smallest possible territorial units for which we could request Statistics Lithuania provide us with individual-level data, which they could only do for the 2011 census.

${ }^{2}$ We use the International Standard Classification of Occupations (ISCO) provided by the International Labour Organization (2012).
} 


\subsection{Socio-ethnic Differentiation and Trajectories of Change in Vilnius}

This section discusses the socio-ethnic structure of housing estates in Vilnius. Four indicators are analysed: ethnic, age, level of education and occupational structure.

\subsubsection{Ethnic Structure}

Currently, Lithuanians comprise $63.3 \%$ of the total population in Vilnius, and the largest ethnic minority groups are Poles (16.5\%) and Russians (11.9\%) (based on the 2011 Lithuanian Census). All together, the seven housing estates that we analyse in this chapter have the same proportion of Lithuanians, a slightly smaller proportion of Poles (16.0\%) and a higher proportion of Russians (13.1\%) than city average. It can be seen in Fig. 12.4 that although the share of Lithuanians has been increasing throughout the districts of Vilnius since 2001, this increase has been smaller in housing estates. Meanwhile, the most visible increase in the share of Lithuanians was observed in the city centre (due to gentrification processes) and in the suburban zones. These are the areas where the most post-Soviet development took place. Consequently, ethnic segregation on a city-wide scale-Soviet housing estates districts versus the rest of the city-is growing. Among housing estates, the highest increase of Lithuanians was observed in Zirmunai-the most centrally located Soviet housing districts-where large housing projects were developed during recent decades. Therefore, it is difficult to assess how much of this change in the ethnic composition of Zirmunai has been determined by changes in the Soviet-era apartments themselves.

Russians are overrepresented in all Soviet housing estates compared to the city average. However, Russians are mostly concentrated in the southern industrial districts of mixed housing (housing estates, dilapidated pre-war working-class dwellings, and Soviet dormitories). Poles are also concentrated in the southern part of the city, but unlike the Russians, their share is not high in Soviet housing districts. The share of both Russian and Polish minorities is decreasing throughout the districts of Vilnius (at the expense of a growing share of Lithuanians). However, there is one exception: an increase in the share of Poles in Karoliniskes, which is likely to be related to lower levels of Lithuanian newcomers; it is the oldest among analysed housing estate (of similar age and housing design to Zirmunai and Lazdynai) with a relatively unfavourable location. Moreover, both Zirmunai and Lazdynai received prizes for urban design in the Soviet era, which probably makes Karoliniskes the least attractive place for more affluent, middle-class newcomers. Given that Poles occupy the worst positions in the Vilnius labour market (Burneika and Ubarevičienè 2016), this increase possibly indicates that the district attracts the least affluent, lower middle-class newcomers to housing estates. 
12 Soviet Housing Estates in Vilnius, Lithuania ...

Share of Lithuanians, \%

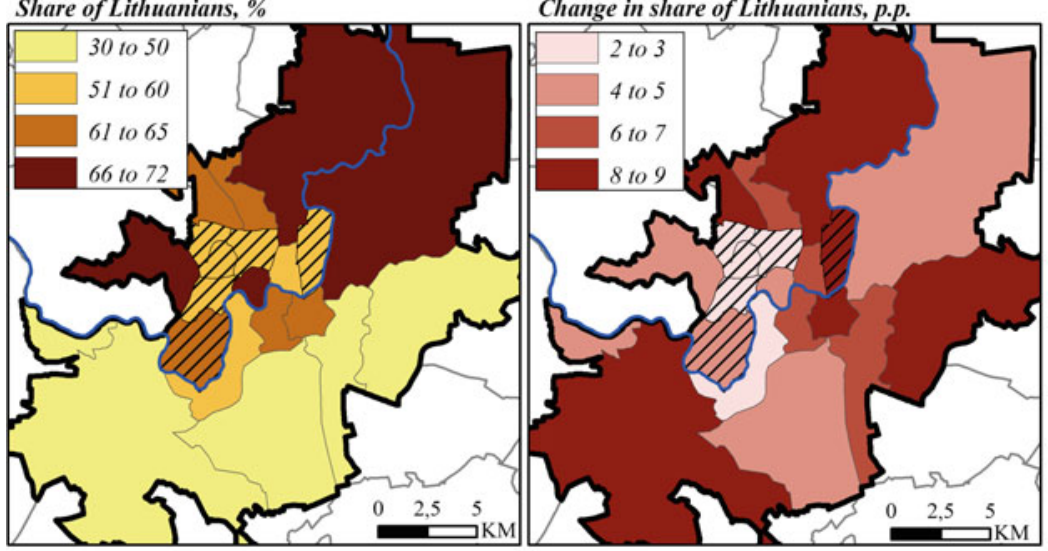

Share of Russians, \%

Change in share of Russians, p.p.
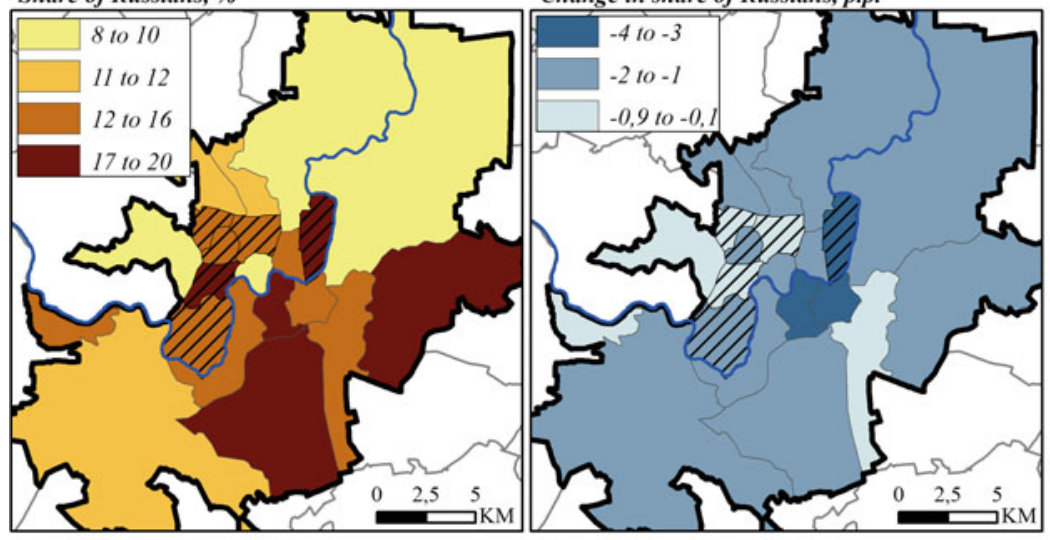

Share of Poles, \%

Change in share of Poles, p.p.

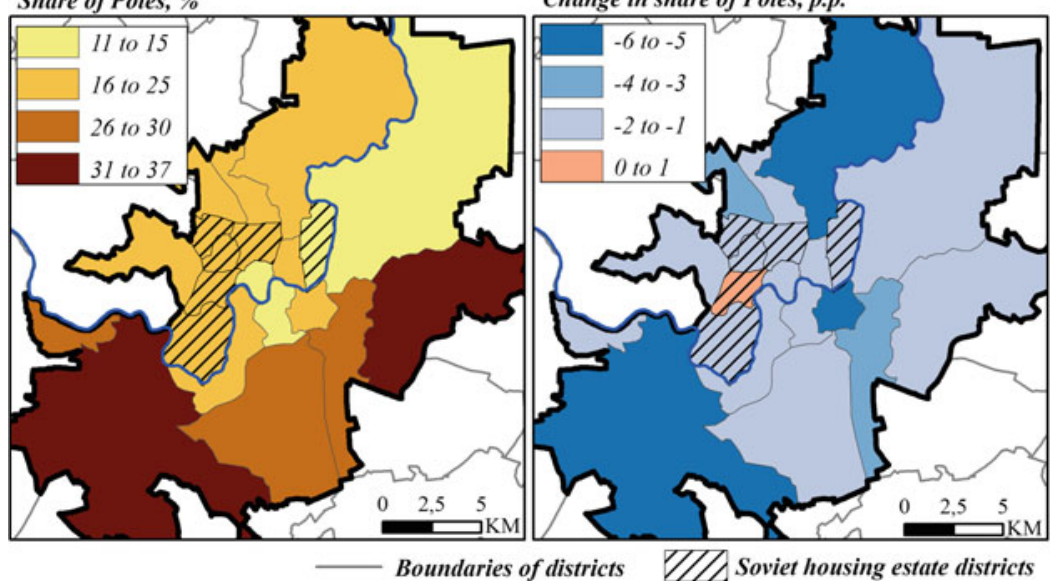

Fig. 12.4 Ethnic landscape of Vilnius: Lithuanians, Russians and Poles, 2001-2011. Data source 2001 and 2011 Lithuanian censuses 


\subsubsection{Age Structure}

Figure 12.5 demonstrates that in 2001 the highest share of the working-age population could be found in the northern part of Vilnius, while pensioners were overrepresented in the more central districts. To a large extent, this fragmentation persisted in 2011. In housing estates, the share of working-age population was quite high in 2001, but the decrease in this share has been the fastest. Soviet housing districts also experienced an abrupt increase in their share of the elderly population. In 2001 the highest share of pensioners could be found in the oldest and more centrally located housing estates. Meanwhile (unsurprisingly), the lowest share of pensioners
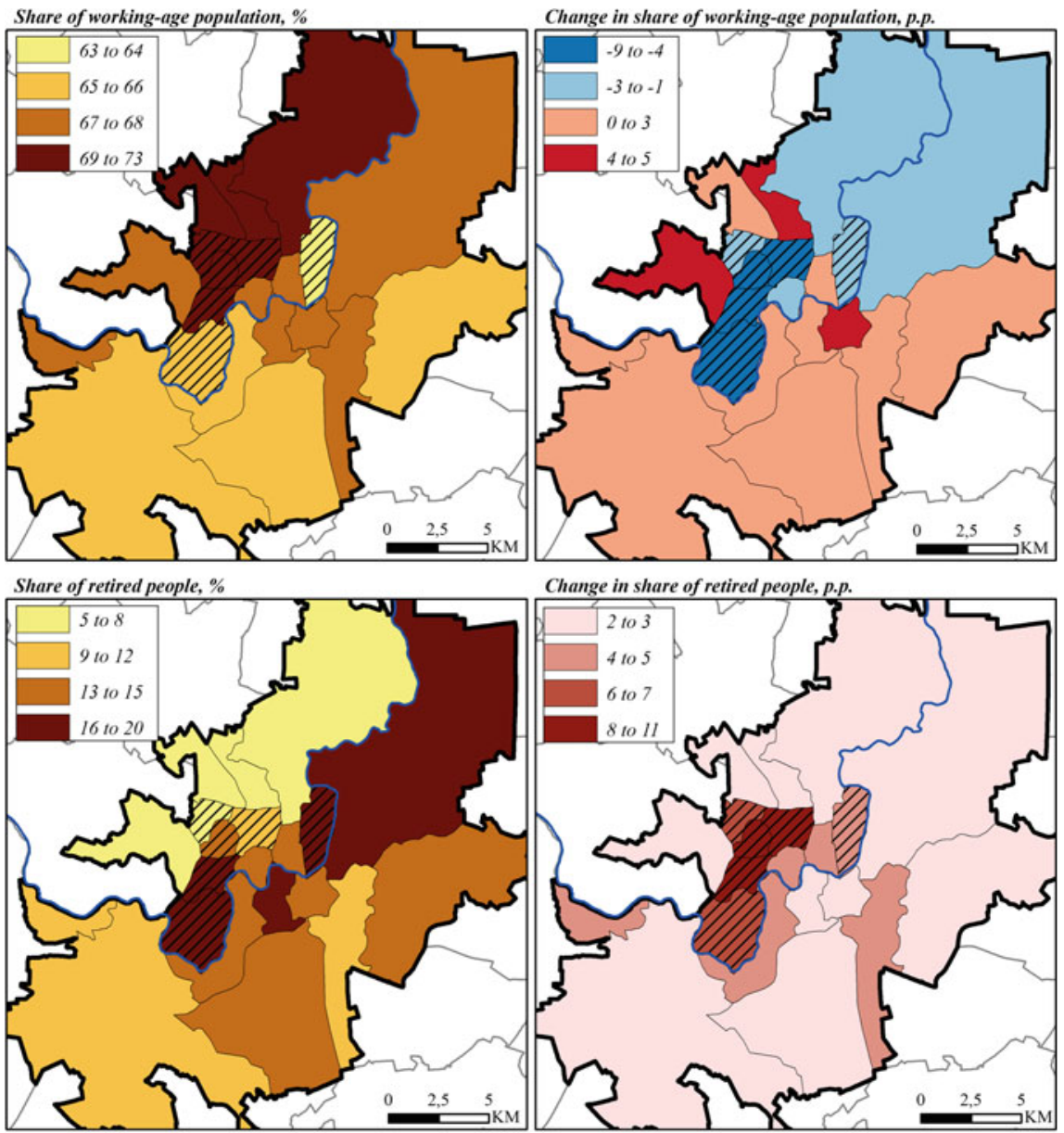

Change in share of retired people, p.p.

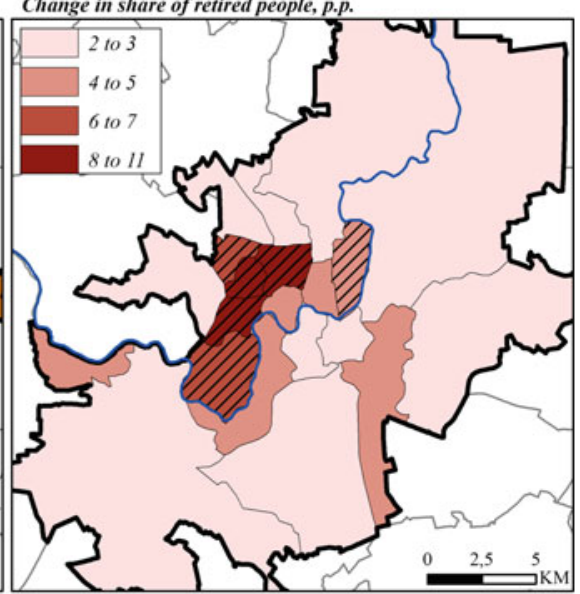

Boundaries of districts DID, Soviet housing estate districts

Fig. 12.5 Age structure of Vilnius: working-age adults and pensioners, 2001-2011. Data source 2001 and 2011 Lithuanian censuses 
could be found in the newest housing estates, located to the north-west of city centre. We can state that changes in age structure were greater than changes in ethnic composition in housing estates. Therefore, this confirms our earlier expectations that it is the immobile and "ageing in place" population that primarily determines socio-ethnic changes in housing estates. However, we may expect more profound changes in socio-ethnic composition in housing estates in the coming decades, when residential differentiation will be facilitated by a natural population decline.

\subsubsection{Educational Attainment}

The level of education (measured by educational levels among residents aged 10+) can also indirectly characterise the social structure of a population. Figure 12.6 illustrates that the residents of housing estates are distinguished by a relatively high level of education, whereas residents with lower education levels are overrepresented in the southern part of the city. Therefore, in terms of the social environment, it could be assumed that more educated and prosperous groups should find housing estates quite attractive to live in. However, the change in the share of residents with tertiary education indicates that housing estates are less attractive for highly educated newcomers compared to the post-Soviet spaces. The lowest increase in the share of residents with tertiary education was detected in Karoliniskes, confirming our previous suggestions concerning the low desirability of this older Soviet housing district. Our results suggest that all Soviet housing estates can be characterised as slowly deteriorating areas, although a fairly large proportion of well-educated residents remain, especially when compared with the southern part of the city.

\subsubsection{Occupational Structure}

Figure 12.7 illustrates that the higher occupational groups tend to concentrate in the northern part of the outer city and in the inner city. Meanwhile, the lower occupational groups tend to concentrate on the southern part of the city. Soviet housing estates do not stand out in terms of concentration of higher- or lower occupational groups, thus they can be characterised as having a fairly average occupational structure. According to census data, between 2001 and 2011 the number of Vilnius residents with higher occupational status increased by $41 \%$ (from 83.4 to 117.8 thousand). However, it can be seen in Fig. 12.6 that the increase was smaller in housing estates (it must be noted that Soviet housing estates, like many other districts, experienced declining concentrations of residents with lower occupational status). This means that Soviet housing estates have a relatively declining structure of occupational status in the context of the whole city. We can state that neither immigration nor social mobility upgrades the social status of housing estates. This is consistent with our previous findings. 


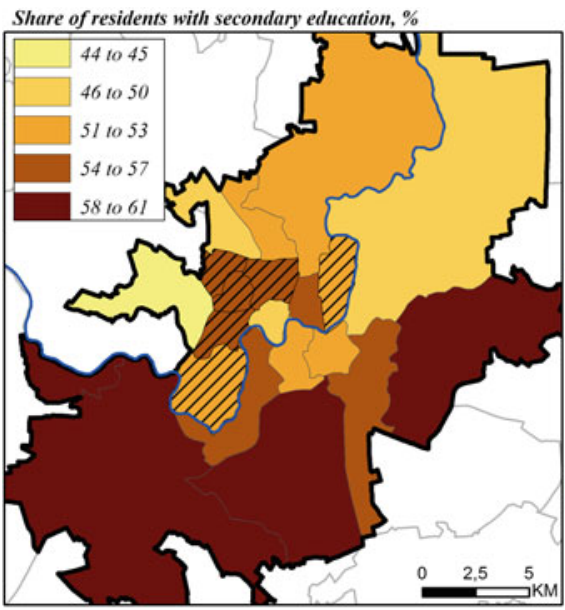

Change in share of residents with secondary education, p.p.

Share of residents with tertiary education, $\%$
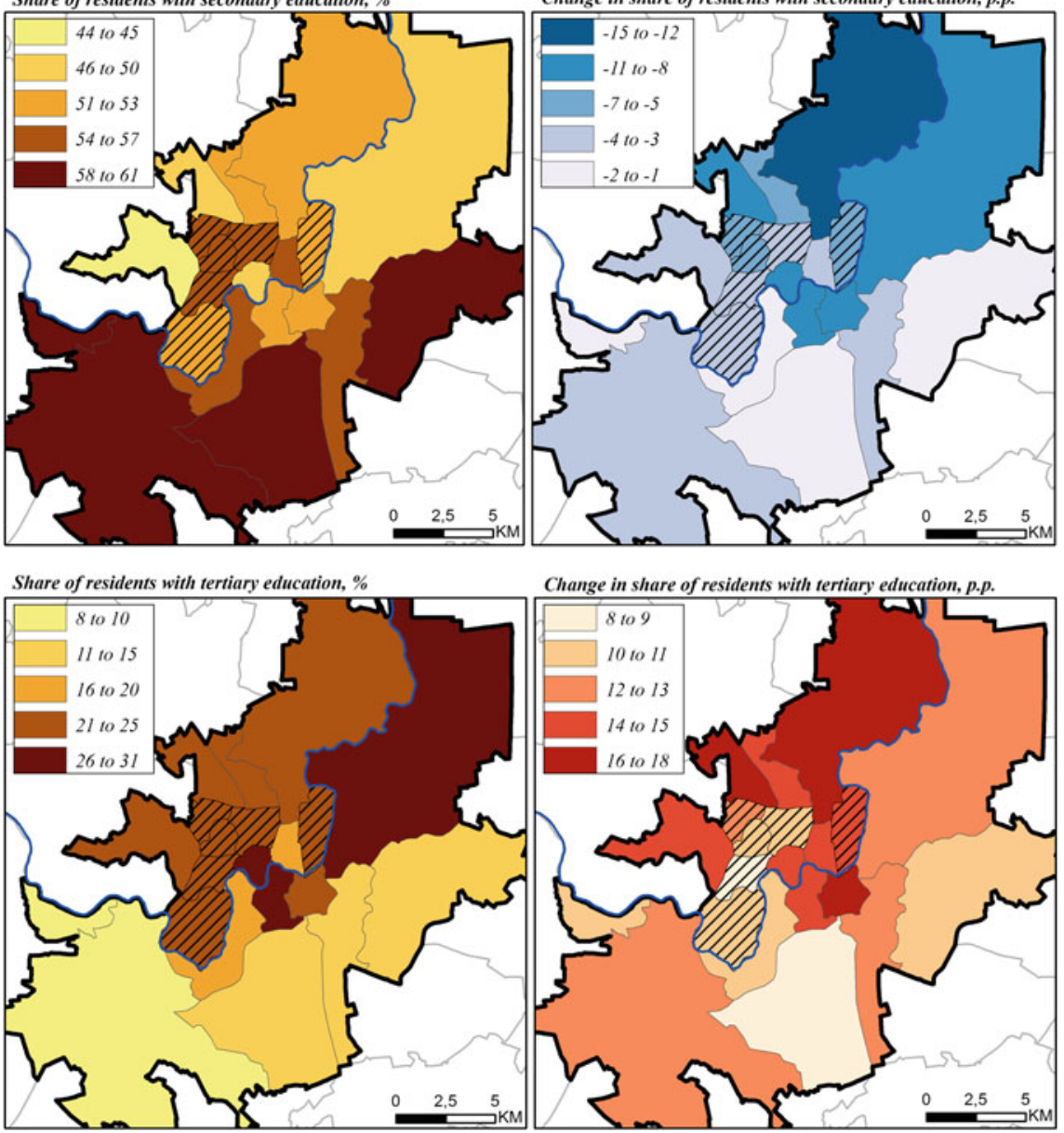

Change in share of residents with tertiary education, p.p.

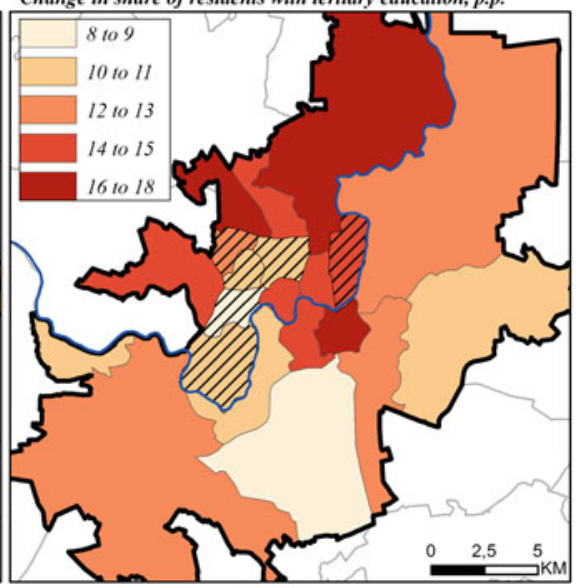

Boundaries of districts D/D, Soviet housing estate districts

Fig. 12.6 Educational structure of Vilnius: secondary and tertiary education, 2001-2011. Data source 2001 and 2011 Lithuanian censuses

To sum up, we may state that all indicators: ethnicity, age, level of education and occupational structure indicate limited residential mobility ('in-' and 'out-' flows) in housing estates. Although Soviet housing estates have become less attractive for the younger population and higher socio-economic status groups, they are not the poorest residential areas of Vilnius. We observe a slow social decline in housing estates compared to the whole city, where the social structure is improving faster due to immigration and social mobility. It should be noted that the social decline in housing estates is relative and most of them have a fairly average social structure on a city-wide scale, whereas the most prosperous and least affluent population groups are overrepresented in other parts of Vilnius. The cost of living in Soviet housing 


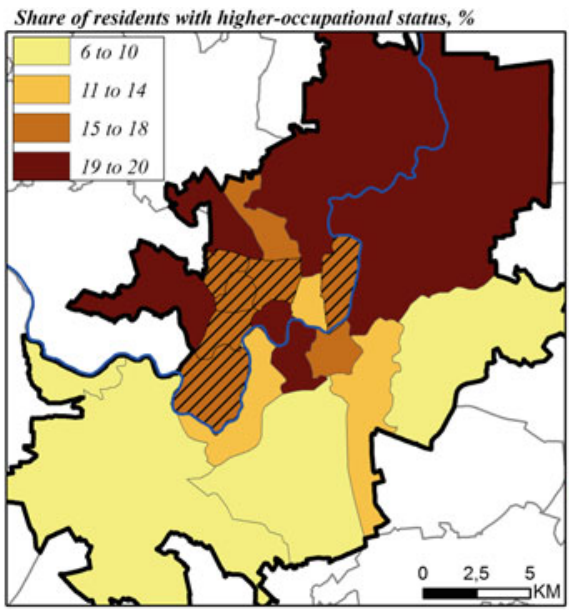

Change in share of residents with higher-occupational status, p.p.

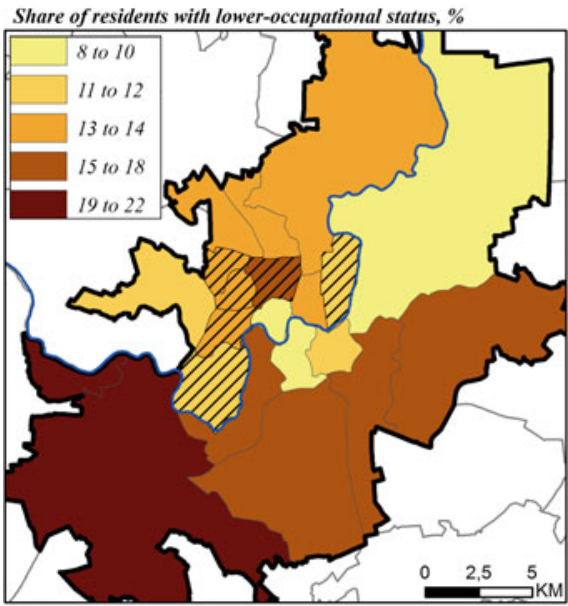

Change in share of residents with lower-occupational status, p.p.

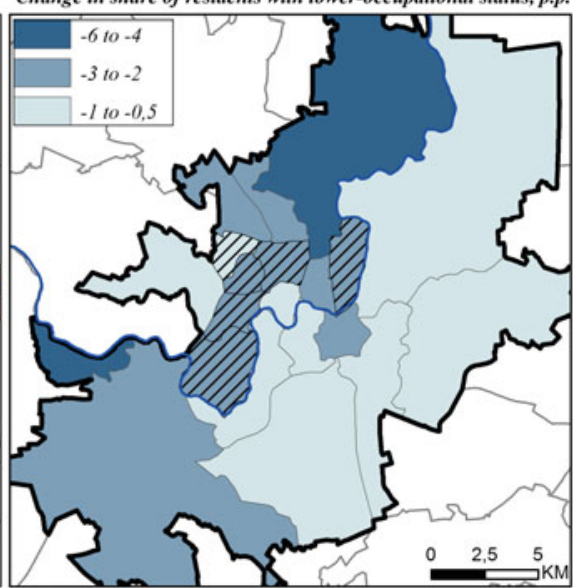

- Boundaries of districts $\mathrm{VIV}$ Soviet housing estate districts

Fig. 12.7 Higher and lower occupational groups in Vilnius, 2001-2011. Data source 2001 and 2011 Lithuanian censuses

estates is likely to be too high for the lowest-income households to move in. On the other hand, existing heating cost compensation - an instrument of state social policy ${ }^{3}$ - and the ageing population's preference to remain in place, frame the socio-economic and ethnic structure of these districts.

\footnotetext{
${ }^{3}$ According to the policy, households should not spend more than $20 \%$ of their income on heating costs. Otherwise for low-income households (e.g. pensioners) in older apartments, built during the Soviet period, heating costs would exceed their income in winter time. As a result of this compensation, lower income groups can afford to live in relatively expensive and large apartments.
} 


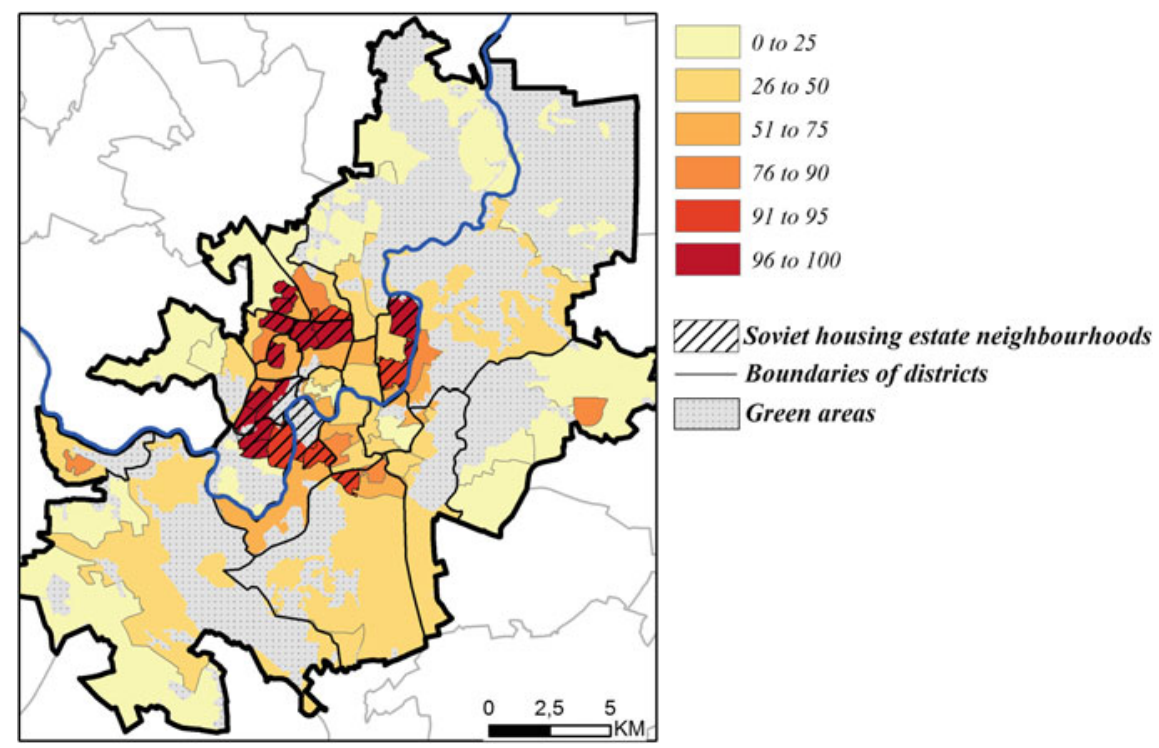

Fig. 12.8 Share of residents in Soviet apartment buildings in Vilnius by neighbourhood, 2011. Data source 2011 Lithuanian census

\subsection{Detailed Spatial Level Analysis: Socio-ethnic Composition in 2011}

The results above suggest that in many cases housing estates do not stand out significantly from the overall context of Vilnius. However, there are many smaller residential areas that do not form separate districts, but where the absolute majority of residents live in Soviet-era apartments. More detailed spatial level analysis should help to gain more insight into socio-ethnic differentiation and to better access the characteristics of housing estate residents within the city. In addition, detailed spatial level analysis should help us to understand to what extent changes in socio-ethnic composition of housing estates are related to the post-Soviet infill of residential development and to what extent they are determined by renovation within apartment buildings. Therefore, we will now use neighbourhood-level ${ }^{4}$ data to give an overview of the socio-ethnic structure of Soviet housing neighbourhoods.

Figure 12.8 illustrates the share of residents in Soviet-era apartment buildings across 65 neighbourhoods in 2011. It also indicates housing estate neighbourhoods - areas in which at least $90 \%$ of residents live in Soviet housing estates. There are almost no pre- and post-Soviet residential buildings in the majority of housing estates and there is little space for new construction. The majority of new buildings

\footnotetext{
${ }^{4}$ Described above in Data and Methods section.
} 
were built in spaces outside housing estates. The development of the city has been mostly in a westbound direction since the nineteenth century, therefore the distance between the Old Town and the various Soviet housing neighbourhoods varies greatly. In Zirmunai district the nearest housing estates are reachable by foot, whereas these neighbourhoods are a few kilometres away from the Karoliniskes and Lazdynai districts, separated by a river valley and having only two transport junctions for the city centre.

\subsubsection{Ethnic Structure}

Figure 12.9 illustrates the ethnic landscape of Vilnius in 2011 in more detail. Although clear ethnic segregation can be seen at the city level, housing estates do not differ from the general context of the city, especially in the case of Lithuanians and Poles. There are very small variations in the share of these two groups in housing estates (analysed in previous sections). The greatest differences are in southern, more industrial neighbourhoods in Vilkpede and, especially, Naujininkai, which include a lot of dormitories, some khrushchëvka, and even older Soviet buildings that cannot be separated from typical Soviet housing estates in our analysis. It is the least Lithuanian Soviet apartment space in Vilnius. The share of Russians, on the other hand, is somewhat higher and varies more inside Soviet housing districts. Russians are overrepresented in the older housing estates (in the Zirmunai, Lazdynai and, especially, Karoloniskes districts) and more central locations, which are close to the industrial areas. The distribution of Russians is most likely related to historical factors as these neighbourhoods were established during a time of intense industrialisation. It can be said that the newer the housing

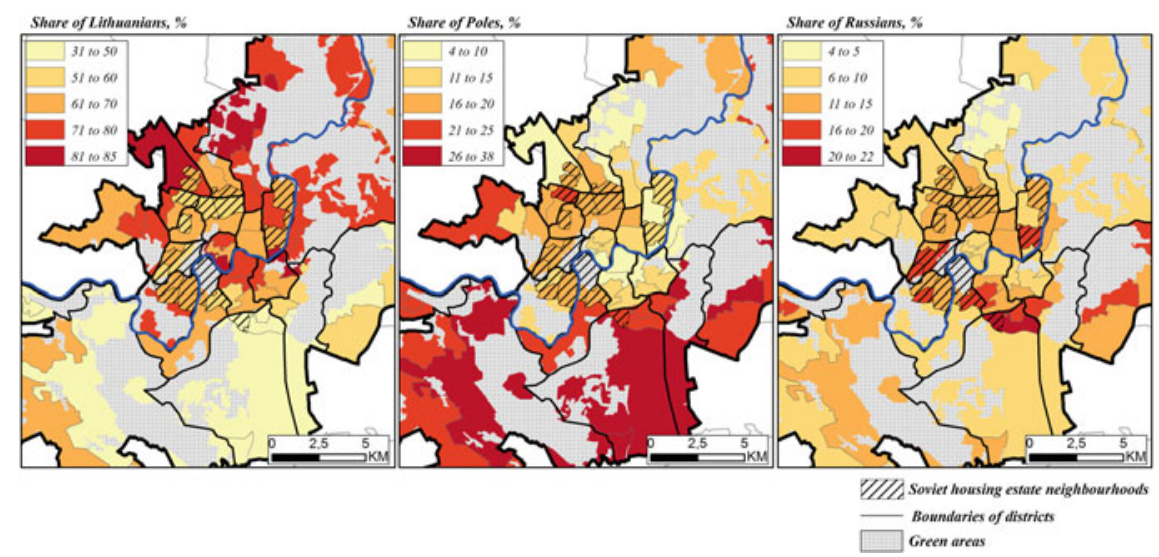

Fig. 12.9 Ethnic landscape in Vilnius by neighbourhood, 2011. Data source 2011 Lithuanian census 
estate, the lower the share of Russians. Post-Soviet spaces built in between the Soviet housing districts are overrepresented by Lithuanians, who have dominated among the newcomers since 1991. In general, these findings are in line with the findings of other Baltic studies (Tammaru et al. 2016; Krišjāne et al. 2016), though the share of minorities is much lower in Vilnius. There are no typical housing estate neighbourhoods in Vilnius, i.e. those in which the two main ethnic minorities would form the majority of population.

\subsubsection{Age Structure}

In Soviet housing estates, the spatial distribution of the population by age correlates with the construction period of the neighbourhoods. Figure 12.10 shows that the oldest residents concentrate in the oldest Soviet housing neighbourhoods (right panel), residents who just exceed retirement age are overrepresented in more distant housing estates (middle panel), and young groups dominate outside of these neighbourhoods, mostly in the inner city and suburbs (left panel). The pattern of such distribution illustrates the construction cycles of the city in the post-war period. Neighbourhood-level analysis shows that districts with mixed housing types (e.g. in Zirmunai or Lazdynai) have experienced more profound changes in their ethnic and age structures, due, above all, to the new post-Soviet development. In general, housing estates within a district share similar compositions of population, which confirms the hypothesis that construction age is a decisive factor.

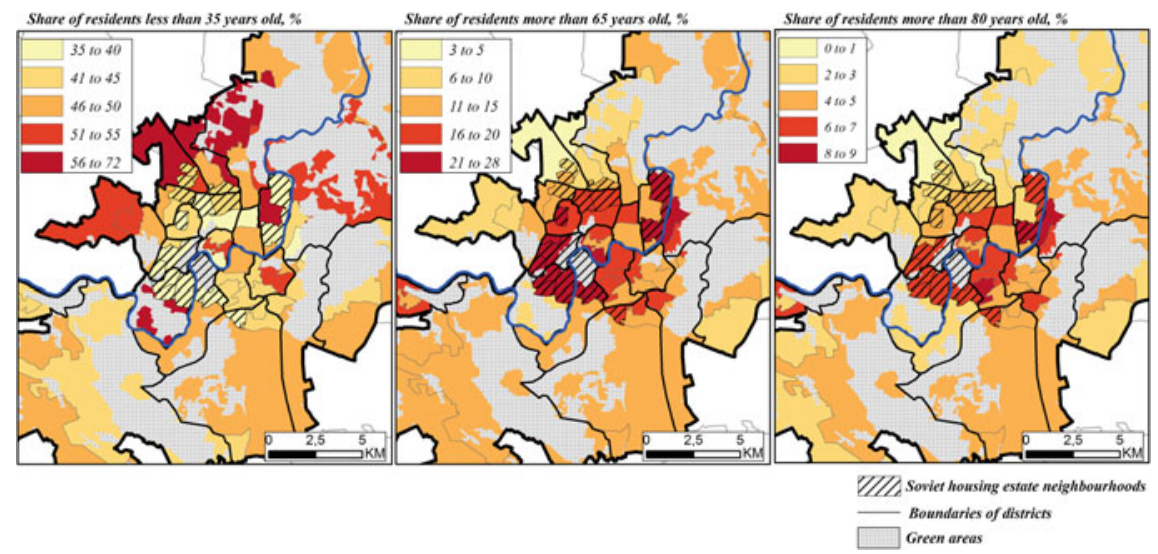

Fig. 12.10 Age groups in Vilnius by neighbourhood, 2011. Data source 2011 Lithuanian census 


\subsubsection{Educational and Occupational Structure}

In terms of share of residents with tertiary education, housing estates have an average position in Vilnius (Fig. 12.11, left panel). There is a significant overrepresentation of highly educated residents in the inner city. The higher share is observed in the most centrally located housing estate in Zirmunai, and underrepresentation is detected in the southern part of the city. The spatial distribution of higher occupational groups (right panel) overlaps, in most cases, with the distribution of residents with tertiary education. Soviet housing estates are also not exceptional in terms of the share of residents with lower occupational status: none of them has a particularly high or low proportion of lower occupational groups (middle panel). In addition, our analysis showed (maps not shown) that in terms of employment by economic sector (industry, traditional services and business services) Housing estates again do not stand out from the overall context of Vilnius. On the contrary, some other urban areas have rather clearer "specialisations".

The results of the neighbourhood analysis reaffirm that housing estates occupy relatively average positions in terms of the social composition of Vilnius. The more outstanding feature of these areas is an overrepresentation of older population groups. The elderly, who are the least mobile group of the residents prevent possible inflow of other population groups, resulting in slower changes to the social composition of Soviet housing estates. Age composition may also have an impact on the development of housing estates in the future-e.g. the initiation of renovation projects depends on the activity and support of the local population (though the main initiator of renovation projects has been the city government since the reform of 2013). A recent study by Ščerbinskaitė and Krupickaitė (2017) demonstrates that the spatial distribution of renovation projects in Vilnius is highly uneven. There are more renovation projects being implemented in Soviet apartment

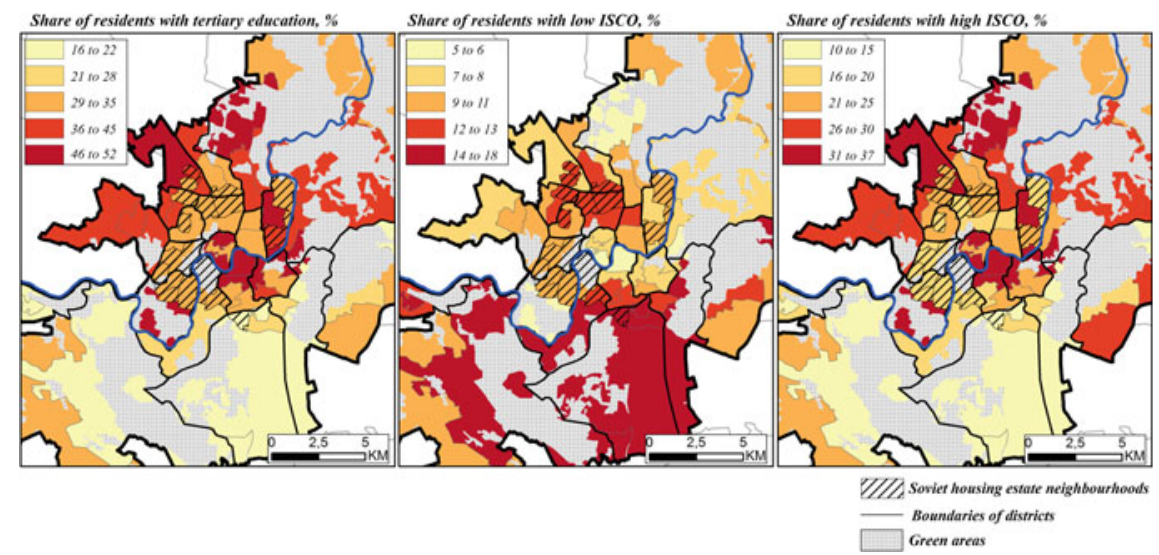

Fig. 12.11 Tertiary education and occupational groups in Vilnius by neighbourhood, 2011. Data source 2011 Lithuanian census 
buildings that is situated close to the city centre (i.e. in Zirmunai or Antakalnis). Very few houses of similar age and design were renovated in Karoliniskes and neighbouring areas; the share of renovated buildings is five to six times lower there.

\subsection{Individual-Level Analysis: Social Dimensions of Ethnic Differentiation in Soviet-Era Apartments}

A large proportion of Vilnius residents live in Soviet-era apartments that do not form part of the larger neighbourhoods or districts that have been analysed in previous sections. Although, our aim was to gain more insight into the profile of the residents in those homogenous and large Soviet estates, it would also be interesting to know whether the residents of Soviet-era apartments are different from those living in other types of housing in Vilnius. Many previously analysed areas have at least a small proportion of non-Soviet buildings. Therefore, in this section we will analyse data that is not linked to districts or neighbourhoods; using individual-level data, we will explore the characteristics of residents according to their housing type of residence (residents that live in Soviet-era apartments versus other housing types). We expect that individual-level analysis will reveal greater differences between the residents.

First, we aggregated individual-level data to show the profile of residents that lived in Soviet-era apartments and those that lived in other types of housing in Vilnius in 2011 (Table 12.1). Results show that on average, there are more females, more elderly people, fewer ethnic Lithuanians and more Russians, as well as less educated, less skilled and more unemployed residents in Soviet-era apartments compared to the rest of the city. Although, these results are in line with the findings of the previous sections, the differences here are more pronounced.

To further explore the socio-spatial differentiation within Vilnius, we present the results of binary logistic regression models that estimate the probability that a Vilnius resident lives in Soviet-era apartments rather than other housing types (Table 12.2). Census data from both 2001 and 2011 are analysed.

First, the model for 2011 shows that the probability of living in Soviet-era apartments strongly increases with age: residents over 65 years old are 3.1 times more likely to live in Soviet-era apartments than in a different type of dwelling. It also shows that controlling for other characteristics, Lithuanians are less likely and Russians more likely to live in Soviet-era apartments. Moreover, highly educated people are less likely to live in Soviet-era apartments. In addition, the model shows that with increasing occupational status the likelihood of living in Soviet-era apartments decreases, while there is a higher probability of being unemployed if living in a Soviet-era apartment. In general, the residents of Soviet-era apartments are slightly less socially affluent and more ethnically mixed than the Vilnius average.

The second model shows the residential differentiation in 2001. The comparison of the two models highlights some important trajectories of change in the social and ethnic profile of the residents in Soviet-era apartments compared to the rest of the 
Table 12.1 Composition of the population of Soviet-era apartments and of Vilnius as a whole, 2011

\begin{tabular}{|c|c|c|c|}
\hline Category & $\begin{array}{l}\text { Soviet housing } \\
\text { estates, \% }\end{array}$ & Other types of housing & Vilnius total, \% \\
\hline Male & 43.6 & 46.6 & 44.7 \\
\hline Female & 56.4 & 53.4 & 55.3 \\
\hline Age up to 35 & 39.0 & 53.4 & 44.4 \\
\hline Age $35-49$ & 20.0 & 22.6 & 21.0 \\
\hline Age $50-64$ & 21.0 & 15.3 & 18.8 \\
\hline Age above 65 & 20.1 & 8.8 & 15.8 \\
\hline Lithuanians & 59.6 & 69.2 & 63.3 \\
\hline Poles & 17.4 & 15.1 & 16.5 \\
\hline Russians & 14.2 & 8.2 & 11.9 \\
\hline Primary education & 9.1 & 9.8 & 9.4 \\
\hline Secondary education & 56.1 & 46.5 & 52.6 \\
\hline Tertiary education & 34.7 & 43.7 & 38.0 \\
\hline Low-occupational status ${ }^{*}$ & 22.7 & 15.8 & 20.0 \\
\hline Middle-occupational status ${ }^{*}$ & 25.2 & 21.6 & 23.8 \\
\hline High-occupational status ${ }^{*}$ & 37.0 & 50.2 & 42.2 \\
\hline Unemployed $^{*}$ & 15.1 & 12.3 & 14.0 \\
\hline
\end{tabular}

Data source 2011 Lithuanian census. *From economically active population

city. First, the model for 2001 shows that although, as in 2011 , the probability of living in Soviet-era dwellings increases with age, the likelihood of the older age groups living in such apartments was not as high in the past. Apparently, a large proportion of the population approached retirement age just prior to 2011. This also corresponds to the period of construction of the Soviet housing estates (mostly late $60 \mathrm{~s}-80 \mathrm{~s}$ ). The model also shows that ethnic minorities were relatively less likely to live in Soviet-era dwellings than they were in 2011. In addition, Soviet-era apartments had a relatively more favourable socio-economic structure: residents were more likely to have tertiary education and higher occupational status in 2001 compared to 2011; the likelihood of living in Soviet-era dwellings decreased the most for the higher occupational groups, illustrating that Soviet-era apartments are losing their most affluent populations.

The results of the regression models confirmed our previous observations and gave us more insight into the relationships between individual characteristics. In addition, the results clearly show the direction of change and that residential differentiation (specifically, differentiation between the residents living in Soviet-era apartments and those living in other dwelling types) is significantly and rapidly increasing. This increase is to the disadvantage of Soviet-era dwellings.

Next, we ran multinomial logistic regression to explore the differences between individuals belonging to particular ethnic groups in Soviet-era apartments in 2011 (Table 12.3). In this model, the dependent variable indicates the ethnic group: 
Table 12.2 Logistic regression model of Soviet housing estate residents in Vilnius, 2011 and 2001, at the individual level

\begin{tabular}{|c|c|c|c|c|c|c|}
\hline \multirow[b]{2}{*}{ Variables } & \multicolumn{3}{|l|}{2011} & \multicolumn{3}{|l|}{2001} \\
\hline & B & SE & EXP (B) & B & SE & EXP (B) \\
\hline \multicolumn{7}{|c|}{ Gender $($ reference $=$ male $)$} \\
\hline Female & 0.083 & 0.006 & 1.087 & 0.068 & 0.006 & 1.070 \\
\hline \multicolumn{7}{|c|}{ Age (years) $($ reference $=$ up to 35$)$} \\
\hline $35-49$ & 0.137 & 0.008 & 1.147 & -0.169 & 0.008 & 0.844 \\
\hline $50-64$ & 0.544 & 0.009 & 1.723 & 0.449 & 0.010 & 1.566 \\
\hline Above 65 & 1.132 & 0.010 & 3.101 & 0.616 & 0.011 & 1.852 \\
\hline \multicolumn{7}{|c|}{ Ethnicity (reference $=$ Lithuanian) } \\
\hline Polish & 0.081 & 0.008 & 1.084 & -0.256 & 0.008 & 0.774 \\
\hline Russian & 0.487 & 0.010 & 1.628 & 0.250 & 0.010 & 1.284 \\
\hline \multicolumn{7}{|c|}{ Education (reference $=$ primary) } \\
\hline Secondary & 0.077 & 0.012 & 1.080 & -0.109 & 0.010 & 0.896 \\
\hline Tertiary & -0.149 & 0.013 & 0.862 & 0.015 & 0.013 & 1.015 \\
\hline \multicolumn{7}{|c|}{ Occupational status (reference $=$ non-participating) } \\
\hline Low & 0.329 & 0.011 & 1.389 & 0.500 & 0.011 & 1.649 \\
\hline Middle & 0.245 & 0.010 & 1.277 & 0.574 & 0.011 & 1.775 \\
\hline High & -0.111 & 0.009 & 0.895 & 0.267 & 0.012 & 1.307 \\
\hline Unemployed & 0.263 & 0.012 & 1.301 & 0.313 & 0.013 & 1.368 \\
\hline Constant & 0.051 & 0.011 & 1.052 & 0.679 & 0.009 & 1.971 \\
\hline $\mathrm{R}^{2}$ (Negelkerke) & \multicolumn{3}{|l|}{0.070} & \multicolumn{3}{|l|}{0.033} \\
\hline$-2 \mathrm{LL}$ & \multicolumn{3}{|l|}{680,494} & \multicolumn{3}{|l|}{645,015} \\
\hline
\end{tabular}

Data source 2001 and 2011 Lithuanian censuses

Notes

$\mathrm{N}_{\text {total }}$ in $2011=533505, \mathrm{~N}_{\text {total }}$ in $2001=550441$

$\mathrm{N}_{\text {Soviet housing estates }}$ in $2011=330582, \mathrm{~N}_{\text {Soviet housing estates }}$ in $2001=393621$

Significance levels are not provided because the complete population sample is analysed

Lithuanian (reference category), Polish or Russian. We used the same set of independent characteristics. The results show that in Soviet-era apartments, ethnic minorities (especially Russians) are likely to be older compared to Lithuanians. It is likely that this also indicates that Lithuanians are more common among the newcomers. Ethnic minorities have a lower probability of having higher education (especially Poles). In addition, ethnic minorities are more likely to have lower occupational status or to be unemployed, and less likely to have higher occupational status than Lithuanians. It can be stated that in terms of socio-economic status, Russians are more similar to Lithuanians, while Poles occupy the most disadvantaged social positions in Vilnius Soviet-era apartments. It is interesting that when the same model is run for the rest of Vilnius population (table not shown), the differences between the ethnic groups are even higher. For example, ethnic minorities are more likely to be older (this probability is higher for Poles), they are more likely to be less educated (especially Poles) and to have more unfavourable positions in the 
Table 12.3 Multinomial logistic regression model of the Soviet housing estate population in Vilnius by ethnicity, 2011, at the individual level

\begin{tabular}{|c|c|c|c|c|c|c|c|c|}
\hline \multirow[b]{2}{*}{ Variables } & \multicolumn{4}{|l|}{ Poles } & \multicolumn{4}{|c|}{ Russians } \\
\hline & B & SE & \begin{tabular}{|l} 
EXP \\
(B)
\end{tabular} & $95 \% \mathrm{CI}$ & B & SE & $\begin{array}{l}\text { EXP } \\
\text { (B) }\end{array}$ & $95 \% \mathrm{CI}$ \\
\hline \multicolumn{9}{|c|}{ Gender $($ reference $=$ male $)$} \\
\hline Female & 0.222 & 0.010 & 1.249 & $1.224-1.274$ & 0.095 & 0.011 & 1.100 & $1.077-1.123$ \\
\hline \multicolumn{9}{|c|}{ Age (years) $($ reference $=$ up to 35) } \\
\hline $35-49$ & 0.473 & 0.015 & 1.605 & $1.559-1.651$ & 0.460 & 0.016 & 1.584 & $1.535-1.635$ \\
\hline $50-64$ & 0.551 & 0.014 & 1.734 & $1.687-1.783$ & 0.831 & 0.015 & 2.296 & $2.231-2.363$ \\
\hline Above 65 & 0.408 & 0.014 & 1.503 & $1.462-1.546$ & 0.685 & 0.015 & 1.984 & $1.926-2.044$ \\
\hline \multicolumn{9}{|c|}{ Education (reference $=$ primary) } \\
\hline Secondary & -0.279 & 0.017 & 0.757 & $0.732-0.782$ & 0.218 & 0.022 & 1.244 & $1.192-1.298$ \\
\hline Tertiary & -1.323 & 0.021 & 0.266 & $0.256-0.277$ & -0.087 & 0.024 & 0.916 & $0.875-0.960$ \\
\hline \multicolumn{9}{|c|}{ Occupational status (reference $=$ non-participating) } \\
\hline Low & 0.627 & 0.017 & 1.872 & $1.812-1.933$ & 0.290 & 0.018 & 1.336 & $1.289-1.385$ \\
\hline Middle & 0.162 & 0.016 & 1.176 & $1.139-1.215$ & -0.071 & 0.018 & 0.931 & $0.899-0.965$ \\
\hline High & -0.273 & 0.019 & 0.761 & $0.733-0.790$ & -0.533 & 0.019 & 0.587 & $0.565-0.609$ \\
\hline Unemployed & 0.399 & 0.020 & 1.491 & $1.435-1.549$ & 0.445 & 0.020 & 1.561 & $1.500-1.623$ \\
\hline Intercept & \multicolumn{4}{|l|}{-1.214} & \multicolumn{4}{|l|}{-1.975} \\
\hline
\end{tabular}

Data source 2001 and 2011 Lithuanian censuses

Notes

Lithuanians constitute the reference category

$\mathrm{N}_{\text {total }}=301701, \mathrm{~N}_{\text {Lithuanians }}=197067, \mathrm{~N}_{\text {Poles }}=57593, \mathrm{~N}_{\text {Russians }}=47041$

-2 Log-likelihood final $=6307.051 . \mathrm{R}^{2}$ (Nagelkerke) $=0.088$

Significance levels are not provided because the complete population sample is analysed

labour market. More detailed analysis by housing type would help to gain further insights into residential differentiation in Vilnius. The model for 2001 (table not shown) suggests that differences between the main ethnic groups have tended to decline in recent decades. For example, the probability of Poles having higher occupational status increased from 0.619 to 0.761 and for Russians, it increased from 0.454 to 0.587 . Similarly, the probability of having tertiary education increased from 0.201 to 0.266 for Poles and from 0.893 to 0.916 for Russians.

Summarising, we find that the social structure of Soviet-era apartment buildings is marked by a relative decline. They are becoming more ethnically mixed but differences between ethnic groups are decreasing. These trends are logical trends in light of the share of Soviet-era dwellings in the housing stock, the minimal differences in its attractiveness and the available alternatives (both positive and negative). 


\subsection{Discussion and Conclusion}

In this chapter, we sought to learn more about the social and ethnic profile of the residents of Soviet housing estates in Vilnius and to highlight the trajectories of change. Our results show that in terms of their socio-ethnic structure Soviet housing estates are more homogenous spaces compared with the rest of the city. The results also show that the socio-ethnic structure of these residential areas varies depending on their location and construction period. On the other hand, there are significant socio-economic differences between ethnic groups in Soviet housing estates, although these have been gradually decreasing in recent decades. Most likely these differences, especially the positions of ethnic minorities in the labour market, were inherited from the Soviet period. We assume that similar housing conditions and locations, nowadays, play their role in reducing residential differentiation in Soviet housing estates (attracting residents of similar purchasing power). Although socio-ethnic differentiation is also decreasing on a city-wide scale, this decrease is faster in Soviet housing estates.

Soviet housing estates tend to maintain ethnically mixed populations, whereas the city as a whole is becoming more Lithuanian. We may expect that this ethnic differentiation will continue in the decades to come. There are no signs that Soviet housing estates could become ethnically segregated, but such trends are visible in some working-class neighbourhoods, which are becoming the last place of choice for the residents.

Our results also show that the demographic and socio-economic composition of Soviet housing estate districts and neighbourhoods is tending to deteriorate in relation to the rest of the city. One of the most outstanding features of these areas is an increasing overrepresentation of older population groups. While the most prosperous and younger population groups prefer to live in other parts of the city, older residents are 'ageing in place' in Soviet housing estates; as a result, new residents have limited opportunities to move in. Although we do not predict any major changes in socio-ethnic composition in Soviet housing estates, it might start to change when the rapidly ageing population starts to pass away. In addition, the majority of Vilnius residents live in Soviet-era apartments; thus, it is unlikely that there will be a sudden social downturn. Soviet housing estates do not differ significantly in their attractiveness, but somewhat faster negative trends are evident in older and more distant areas.

There are several reasons that explain why Soviet-era housing estates do not devolve into the least attractive residential areas in Vilnius: (1) their dominance of the housing stock; (2) lower quality housing in the working-class neighbourhoods, dormitories and industrial suburbs; (3) minimal differences in the attractiveness and prices of dwellings in Soviet housing estates (preventing the concentration of low-income groups in particular areas); (4) the current social structure of Soviet housing estates; (5) the relatively low share of ethnic minorities in Soviet housing estates and in the city; (6) the decreasing number and share of low-skilled and unemployed residents in Vilnius. 
A new development tool, the "Neighbourhoods programme", presented by the city government in 2017, aims at revitalisation initiatives for Soviet-planned areas (Vilnius City Municipality 2018) and 1288 neighbourhoods, consisting of Soviet-era apartment buildings, were defined. Financial aid is provided to those neighbourhoods, whose communities actively cooperate. This programme is in its initial phase and therefore, it is difficult to predict its success and effect. The older population composition of Soviet-era apartments may have a negative effect on revitalisation projects because the participation of active local communities is very important. The uneven spatial distribution of renovation projects also indicates the presence of residential (social) differentiation among the residents in Soviet housing estates. In Vilnius, the revitalisation of Soviet housing estates could be facilitated by the active involvement of city government in the development of infrastructure; For example, additional car parking places, improvement of transport junctions, creation of sites attractive for small businesses and group renovation of housing.

\section{References}

Andersson R, Kährik A (2016) Widening gaps: segregation dynamics during two decades of economic and institutional change in Stockholm. In: Tammaru $\mathrm{T}$ et al (eds.) Socio-economic segregation in European capital cities. East meets west. Routledge, London, pp 110-131

Bolt G, van Kempen R (2010) Ethnic segregation and residential mobility: relocations of minority ethnic groups in the Netherlands. J Ethn Migr Stud 36(2):333-354

Borén T, Gentile M (2007) Metropolitan processes in post-communist states: an introduction. Geografiska Ann Ser B Hum Geogr 89(2):95-110

Burneika D, Ubarevičienè R (2016) Socio-ethnic segregation in metropolitan areas of Lithuania. Czech Sociol Rev 52(6):795-819

Burneika D (2008) Post-Soviet transformations of urban space in Vilnius. Ann Geogr 41(1-2):1425

Burneika D, Ubarevičienė R, Valatka V, Baranauskaitė A, Pociūtė-Sereikienė G, Daugirdas V, Krupickaitė S (2017) Lietuvos metropoliniai regionai. Gyventojų rezidencinè diferenciacija XXI a. pradžioje [The metropolitan regions in Lithuania. Residential differentiation in 21st century]. LSTC, Vilnius

Čiurlionienė I (2008) Vilniaus miesto planavimo raida: kai kurie estetinių aspektų ypatumai [The evolution of Vilnius city planning: some peculiarities of the aesthetic aspect]. In: K. Šešelgio skaitymai [K. Šešelgis readings] conference. VGTU, Vilnius

Gentile M, Tammaru T, van Kempen R (2012) Heteropolitanization: social and spatial change in central and East European cities. Cities 29(5):291-299

International Standard Classification of Occupations. http://www.ilo.org/wcmsp5/groups/public/dgreports/—dcomm/—publ/documents/publication/wcms_172572.pdf. Accessed 9 May 2016

Krupickaitė D (2014) Vilnius - between persistence and socio-spatial change. Eur Reg 19(34):21-31

Krišjāne Z, Bērziņš M, Kratovitš K (2016) Occupation and ethnicity: Patterns of residential segregation in Riga two decades after socialism. In: Tammaru $\mathrm{T}$ et al (eds) Socio-economic segregation in European capital cities: east meets west. Routledge, London, pp 287-312

Ščerbinskaitė S, Krupickaite D (2017) Daugiabučiu renovacijos Vilniaus mieste teritoriniai ypatumai [Territorial features of renovation of apartment buildings in Vilnius]. Geografijos metraštis 50:21-40 
Semyonov M, Glikman A (2009) Ethnic residential segregation, social contacts, and anti-minority attitudes in European societies. Eur Sociol Rev 25(6):693-708

Šešelgis K (1996) Teritorijų planavimo raida Lietuvoje [Development of regional planning in Lithuania]. Urbanistika Ir Architektūra 21(1):4-19

Statistics Lithuania (2001) Census data, on special request

Statistics Lithuania (2011) Cendus data, on special request

Sýkora L, Ouředníček M (2007) Sprawling post-communist metropolis: commercial and residential suburbanization in Prague and Brno, the Czech Republic. In: Razin E et al (eds) Employment deconcentration in European metropolitan areas. Springer, Dordrecht, pp 209-233

Tammaru T, Kahrik A, Magi K, Novák J, Leetmaa K (2016) The 'market experiment': increasing socio-economic segregation in the inherited bi-ethnic context of Tallinn. In: Tammaru $\mathrm{T}$ et al (eds) Socio-economic segregation in European Capital cities: East meets West. Routledge, London, pp 333-358

Tereškinas A, Žilys A, Indiliūnaitė R (2013) Pilietiškumas ir tapatumas šiuolaikinėje visuomenėje: Socialinè atskirtis ir socialinè segregacija Lietuvos didmiesčiuose [Citizenship and identities in contemporary society: Social exclusion and social segregation in Lithuanian cities]. Vytauto Didžiojo Universiteto Mokslo Klasteriai 2:171-185

Ubarevičienė R, van Ham M, Burneika D (2016) Shrinking regions in a shrinking country: the geography of population decline in Lithuania 2001-2011. Urban Stud Res 1-18

Valatka V, Burneika D, Ubarevičiené R (2016) Large social inequalities and low levels of socio-economic segregation in Vilnius. In: Tammaru $\mathrm{T}$ et al (eds) Socio-economic segregation in European capital cities: east meets west. Routledge, London, pp 313-332

Vanagas J (1996) Miesto sociologijos pagrindai [Basics of urban sociology]. Technika, Vilnius

Žilys A (2013) Rezidencinè diferenciacija ir skirtumai Lietuvos moderniajame mieste: (po) sovietinis ar Vakaru miestas? [Residential differentiation in Lithuanian modern cities: Is it a (post-)Soviet or Western city?] Socialinių tyrimų žurnalas 4(2): 67-101

Vilnius City Municipality (2018) About the Neighbourhoods programme. https://www.vilnius.lt/ kaimynijos. Accessed 13 Mar 2018

Open Access This chapter is licensed under the terms of the Creative Commons Attribution 4.0 International License (http://creativecommons.org/licenses/by/4.0/), which permits use, sharing, adaptation, distribution and reproduction in any medium or format, as long as you give appropriate credit to the original author(s) and the source, provide a link to the Creative Commons license and indicate if changes were made.

The images or other third party material in this chapter are included in the chapter's Creative Commons license, unless indicated otherwise in a credit line to the material. If material is not included in the chapter's Creative Commons license and your intended use is not permitted by statutory regulation or exceeds the permitted use, you will need to obtain permission directly from the copyright holder. 


\section{Part V \\ Complexities of Built Environments in Housing Estates}




\title{
Chapter 13 \\ Incomplete Service Networks \\ in Enduring Socialist Housing Estates: \\ Retrospective Evidence from Local \\ Centres in Estonia
}

\author{
Kadri Leetmaa and Daniel Baldwin Hess
}

\begin{abstract}
Scholarly literature frequently refers to the incompleteness of service infrastructure in socialist housing estates. This has been considered a major failing of socialist residential landscapes that were planned and built according to scientific principles offering a high quality of life to residents through rational and technical design standards. This chapter presents visual and context-based evidence to illustrate how compromises in the service networks of newly built modernist housing estates were made during the socialist years. To do so, we investigate contemporaneous circumstances and decisions that delayed or (indefinitely) postponed the construction of neighbourhood services and community infrastructure. We ground our arguments in the evolution of Väike-Õismäe, a 1970s-era housing estate in Tallinn, Estonia. Findings suggest that even in one of the most admired residential districts, recognised with a prestigious architectural award from the Soviet state, the initial visions of the architect were unrealised and adjustments to plans were made in the earliest phases of implementation before construction began.
\end{abstract}

Keywords Housing estates - Mikrorayon - Socialism - Scarcity of resources • Service networks $\cdot$ Urban planning $\cdot$ Estonia

\footnotetext{
K. Leetmaa

Centre for Migration and Urban Studies, University of Tartu, Tartu, Estonia e-mail: kadri.leetmaa@ut.ee

D. B. Hess $(\square)$

Department of Urban and Regional Planning, University at Buffalo, State University of New York, New York, USA

e-mail: dbhess@buffalo.edu

(C) The Author(s) 2019

D. B. Hess and T. Tammaru (eds.), Housing Estates in the Baltic Countries,

The Urban Book Series, https://doi.org/10.1007/978-3-030-23392-1_13
} 


\subsection{Introduction}

Within the vast Soviet urbanisation programme between World War II and the late 1980s, a planned hierarchical system for creating rationalised townscapes was key to furthering the growth of socialist urban-industrial centres. There was an urgent need to address deficits in residential space in cities, and large modernist housing estates, designed with egalitarian principles as their foundation, were the response. The system provided highly subsidised apartments for Soviets in new standardised apartment buildings situated within carefully planned mikrorayons. The latter became the main 'building block' of socialist residential landscapes: all services were to be provided at prescribed walking distances to offer supreme efficiency and high quality of life.

It is widely agreed, however, that in socialist cities, the service networks were only partially provided relative to the prescribed levels in initial visions. A failure to provide living environments with ample modern conveniences is seen as one of the major failings of socialist housing estates. This is usually attributed to the crushing demand for building new housing units elsewhere in the city, because services came to be viewed as noncritical amenities that could be added later. Consequently, housing estates almost never reached their full functional potential. Although scholarly literature frequently refers to this reality, these arguments tend to remain vague and abstract without clearly demonstrating how mikrorayon service networks evolved during the planning, construction and occupation of new estates.

The ambition of this chapter is to bring more clarity and visual analysis to these statements. The article focuses on a 1970s-era residential district, Väike-Õismäe (Little Blossom Hill in translation) in Tallinn, Estonia. As this chapter is written, Väike-Õismäe celebrates its 50th anniversary (its first detailed plan was approved in 1968). Although we present Väike-Õismäe as an archetypical incomplete housing estate, it received the Soviet State Architectural Award in 1986, a recognition that only a few districts achieved in the entire Soviet Union.

Archival documents and images, written debates among architects and opinion leaders in the 1970s, other texts written by the key planners of Soviet Estonia during socialist years and later, and a retrospective interview (carried out in 2017) with the former (1960-1980) Chief Architect of Tallinn are used to trace how the services were planned and implemented.

\subsection{Planned Residential Districts in Socialist Cities}

Centrally planned systems and government ownership of all land in the Soviet Union made possible a unified vision of urbanisation and its on-the-ground realisation. The economy was meticulously planned by central authority (Hegedüs and Tosics 1983) to reach the industrial ambitions of fast-growing cities. Public provision of housing and carefully designed residential districts were intended to be a 
vital aspect of the socialist regime. A remarkable share of pre-World War II housing stock was destroyed during the war; after nationalisation, many people resided in inadequate conditions in communal apartments (Tsenkova 2009) and explosive industrial growth worsened the situation. Housing systems became firmly embedded in larger political and economic structures in the socialist regime (Marcuse 1996; Liepa-Zemeša and Hess 2016). It was believed that equally high living standards for all residents could be achieved through central planning. The universal right for housing was even written in the Soviet Constitution.

Town planning was performed by trained architects (Wright 1958) during Soviet times. Architects employed by the government at various levels (in state bureaus, municipal governments, design institutes in republics) sought to establish integrated residential districts designed to cleverly rationalise internal organisation of cities. A primary component of the spatial organisation of socialist cities was a pre-fabricated apartment building. Apartment buildings were to be aggregated into standardised units known as mikrorayons, envisioned as self-contained neighbourhoods. In theory, mikrorayons could house 5,000-9,000 people focused around an elementary school (Perry 1926; Bruns 2007, 34). Mikrorayons were in turn aggregated to produce larger planned housing estate districts (even for 100,000 or more residents) (Bater 1980; Miliutin 1974; Robinson 2009; Smith 1996; Stanilov 2007). The districts were mostly located on greenfields on the urban periphery. Although the ambition was to replace the entire urban housing stock with modern apartments, a permanent shortage of dwellings prohibited the demolition of older quarters (Hess and Hiob 2014).

Ideologies supporting modernist residential planning 'travelled' from country to country in the early and mid-twentieth century (Dahir 1947; White 1980). In the Soviet Union, planning for mikrorayons borrowed principles from British new towns (Kaufmann 1936; Goss 1961), planned unit developments in the United States (Perry 1929, 1926), and Scandinavian tower-in-the-forest suburban settlements (Cinis et al. 2008). Travel reports and books written by young Soviet architects who later became key figures in designing modernist housing areas in Soviet Estonia (Port 1966) suggest that Soviet architects had professional ties with their Western colleagues (Shenker 1971). The usual spatial organisation of the districts followed a superblock approach and incorporated the principle of co-mingling housing and services, thereby exploiting proximity opportunities by creating neighbourhoods which stressed accessibility (and a scientific approach for ensuring minimum distances) (Hall 1988; Lu 2006).

A key element of spatial plans of modernist mikrorayons was the provision of green space. Green buffer areas were intended to enclose industrial zones and delineate housing estate districts. It has been argued that in socialist cities, such open space would allow for even 'more recreational opportunities than in capitalist cities’ (Hall 1987, p 263). In addition, an organised system of pathways provided walking access for commuting to work, to schools, to service, commercial and leisure centres, and to public transport stations (Obraztsov 1961). Importantly, green areas and pathways, and traffic relegated to perimeters of mikrorayons 
provided apartment dwellers with convenient walking access to community resources and safe environments for children to walk and play unaccompanied.

Within the building process, the design of building elements, including wall panels, stairways, and doors, was standardised through industrial processes. This was the most rational solution for building quickly and in large quantities. The components were manufactured in factories and assembled on-site. Mechanisation delivered completed tower blocks which were at first unsophisticated; with maturation of the programme, however, complete mikrorayons (standard projects for apartment blocks but also for mikrorayon service centres) were industrially produced (Andrusz 1984). Uniformity and disciplined repetition-with a reduced role for artistry and organicism in design - produced an identical and anonymous built environment (Hatherley 2016; Monclús and Díez Medina 2016). We demonstrate that although architectural uniformity was deemed necessary to support equality, the criticism towards regularity of built structures began to emerge immediately after the first mikrorayons were erected.

\subsection{Service Networks Offer Function and Convenience}

Each mikrodistrict will have one school, two pre-school children's establishments, a food shop, a personal service shop, a cafeteria, club, and building maintenance office. Here the radius of servicing does not exceed 400 meters (Obraztsov 1961, p 35).

When standardisation in planning and housing construction started to gather momentum in socialist cities, the mikrorayon approach was widely discussed among urban experts. The prime qualities to be offered were 'access' and 'proximity' to services and daily necessities and 'efficiency' in urban mobility. The number and type of services provided were precisely calculated (or, in socialist parlance, 'allocated') by administrators based on per-capita standards (DiMaio 1974; French and Hamilton 1979). This (scientific) approach was considered an improvement over organic demand-based appearance of services, offering $20 \%$ efficiency savings over traditional organisation of street space (Obraztsov 1961).

Community services were located in the most interior space of mikrorayons, segregating playgrounds and outdoor socialisation space from vehicle traffic. Most important was that the schools were situated at a walkable distance and walking paths were safe. In Soviet Estonia, the double-mikrorayon concept for 12,000 inhabitants and 2 schools was implemented; due to immigration, Estonian cities became bilingual and a mikrorayon needed to contain both an Estonian and Russian language school (Leetmaa 2017, interview with Dmitri Bruns).

Services were organised hierarchically into 'layers' (Marozas 2009) with everyday needs located conveniently for the residents of one mikrorayon, and higher order services walkable or accessible via public transport for several mikrorayons (Hess 2018). Each residential district should have a planned main or 
higher order centre. Within approximately 400 metres from every residence, an everyday service centre ('ABC centre') had to be located (Obraztsov 1961). Services visited less frequently-department stores, health clinics, cinemas, social clubs, a House of Culture-were planned for the main centre, still saving residents from a need to travel regularly to the city centre.

Naturally, given the cost of providing community facilities, Soviet architects were expected to provide the smallest amount of services possible and still satisfy norms. The multilayered plan for service networks called for designing appropriate mikrorayon service centres. The latter usually contained pavilions and one- to two-storey low-rise buildings set in a walkable environment. Besides functionality, the sculptures, fountains, and benches were part of the spatial composition of centres suggesting that this designed space should be used for meeting and socialising (Šiupšinskas and Lankots 2019). The Baltic architects gathered inspiration for service centre design from multifunctional satellite settlements surrounding Nordic capitals_-Vällingby (Stockholm, Sweden) and Tapiola (Helsinki, Finland) - that they visited on state-sponsored study trips (Metspalu and Hess 2018; Šiupšinskas and Lankots 2019). In reality, even when architects proposed original concepts for mikrorayon centres, budget pressures often caused the simplification and standrdisation of public buildings.

\subsection{Service Networks Fall Short of Promises}

Although convenient access - to consumer services, healthcare, education, and recreation - served as a founding principle for mikrorayons, new districts were in practice often poorly equipped with services (Gentile and Sjöberg 2006; Hausladen 1987; Kalm 2012; Svetlichnyi 1960; Temelová et al. 2011; Cinis et al. 2008). A significant share of the service component was delayed or never built (De Decker and Newton 2009; Gentile 2004; Sjöberg 1992). For this reason, the Soviet urban experience differed significantly from idealistic visions.

During the implementation of carefully drawn plans for housing estates, service networks were viewed as providing noncritical amenities and secondary to the raison d'etre of mikrorayons: to provide housing for industrial workers (DiMaio 1974). A general expectation existed that after a higher welfare level is achieved in the future, society will be positioned to enrich all aspects of citizens' lives. From a practical point of view, the provision of housing and services were the responsibilities of different ministries, and the funding for these tasks came from separate budgets and was typically uncoordinated (Bruns 2007, 38).

To compensate for an absence of nearby neighbourhood services, residents adapted and managed their daily needs in other ways; for example, they used existing, often overloaded, infrastructure of neighbouring residential districts. But this could be challenging since the planned public transport connections with the rest of the city were also unfinished (Hess 2017). Usually, only schools and child care facilities were developed in accordance with initial plans (Bruns 2007, 39); 
grocery stores, retail outlets, health clinics, catering, cultural and household service establishments, however, significantly lagged behind the plans (Shaw 1991). Consequently, even when ambitious plans for service networks helped to justify peripheral locations for new residential districts, housing estate residents still remained dependent, out of necessity, on city centres.

Plans for the socialist-era expansion of Tallinn confirm that all larger housing estate districts were designed to have one main centre, while embedded mikrorayons would also have a commercial centre; in reality, none of the higher order centres was built. Delays in providing planned services and often indefinite postponements of establishing mikrorayon centres were endemic to all socialist cities. Next, we present the story of Väike-Õismäe district in Tallinn to illustrate these tendencies with visual materials and description of circumstances and decisions made at the time the district was planned and constructed.

\subsection{Väike-Õismäe-An Unfinished Macrorayon}

\subsubsection{The Mikrorayon Takes Shape as a Planning Unit}

In Tallinn, then the capital of the Estonian Soviet Republic, mass housing construction was launched in the late 1950s. After Khrushchëv criticised excess in residential construction, housing construction became increasingly industrialised in the Soviet Union. In the late 1950s and early 1960s, standard apartment buildings using brick construction, khrushchëvki, were built in small groups as in-fill in unbuilt or war-demolished areas relatively close to city centres. The advantages of using factory produced panels and standard building projects were soon realised. The first pilot panel buildings were erected in Tallinn in 1961 and the practice quickly became prevalent.

In urban planning the mikrorayon concept was gradually adopted in the same period. In the first larger modernist districts of Soviet Tallinn (Pelguranna, built in the late 1950s) apartment buildings were arranged in rows, not closed yards, and service networks were less developed. In the 1960s, when Mustamäe housing estate district was built (preceding Väike-Õismäe district), the mikrorayon approach had already become prevalent in residential planning. Mustamäe consisted of nine mikrorayons in which the principles of self-contained neighbourhoods were followed.

According to the General Plan of Tallinn (adopted in 1968), after Mustamäe was constructed, the focus of residential construction should shift to Väike-Õismäe, situated atop bare agricultural land in the western part of the city (Bruns 1993, 148150). By that time the mikrorayon concept had been practiced throughout the Soviet Union for 10 years. Originally, Väike-Õismäe district, with three mikrorayons, was intended to become a logical continuation of the adjacent Mustamäe mikrorayons. The planning process of Väike-Õismäe, however, elevated the mikrorayon concept to a new level. 


\subsubsection{From Mikrorayon to Makrorayon: Initial Planning Task for Väike-Öismäe}

The official planning task for Väike-Õismäe district was issued in 1967. The idea was to plan a housing estate at the intersection of two main streets (Paldiski and Ehitajate roads) (Fig. 13.1). The Tallinn Executive Office for Architecture and Planning commissioned Eesti Projekt, the central planning institute of the republic, to compile the detailed plan of Väike-Õismäe. The draft plans submitted by the planning team (lead architect Mart Port with collaborators Malle Meelak, Kalju Luts and Inessa Põldma) included four alternative versions of spatial plans for mikrorayons in VäikeÕismäe (Fig. 13.2). The team preferred an innovative solution that formed a single large integrated makrorayon rather than three separate mikrorayons (Fig. 13.2, image 3). The prime reason for this decision stemmed from consideration for the location of the new district: planners feared that vehicular traffic would take shortcuts between Ehitajate and Paldiski road; large traffic flows, however, were not intended to drive through housing estates. To avoid this, a circular street connecting mikrorayons but not enabling through traffic was proposed.

The planners demonstrated that important elements of the mikrorayon concept were achievable in the makrorayon configuration. Three major commercial and service centres were placed at the outer corners of the circular street; these, together with smaller groceries, had to ensure that the walking distance from homes to shops and service points would not exceed 550 metres. Public transport would function circularly to ensure that bus stops are close to service centres and homes.

The full detailed plan of Väike-Õismäe was submitted to the city administration in Spring 1968, after which it had to travel through the approval process of various republic and city departments. Somewhat surprisingly, the innovative spatial approach was welcomed rather warmly by the bureaucracy of Soviet Estonia, and the first detailed plan of the district was approved in late 1968 (Fig. 13.3). The shift from mikrorayon to makrorayon is reflected in the handwritten revisions made throughout the typed manuscript of the 1968 Detailed Plan: the word 'mikrorayons' (plural) has been replaced with the word 'makrorayon' (singular).

The 9-storey residences were located inside the circular street and 5-storey buildings were located outside of it. Taller towers added visual accents: single 16-storey apartment towers were placed between 9-storey apartment buildings, and 22-storey apartment towers demarcated the location of service centres outside the circular road. The 1968 plan also proposed a small number of 1-storey and 2-storey residential buildings. These smaller buildings were to be financed through cooperative housing funding schemes. By introducing various building heights, planners aimed to bring variety into an otherwise monotonous area. They also proposed to introduce more innovative individual building projects or at least new standard projects for towers, schools and kindergartens, and service centres.

The area within the circular street was designed for children and recreation. In the middle of the green pedestrian park, an artificial pond surrounded by a 


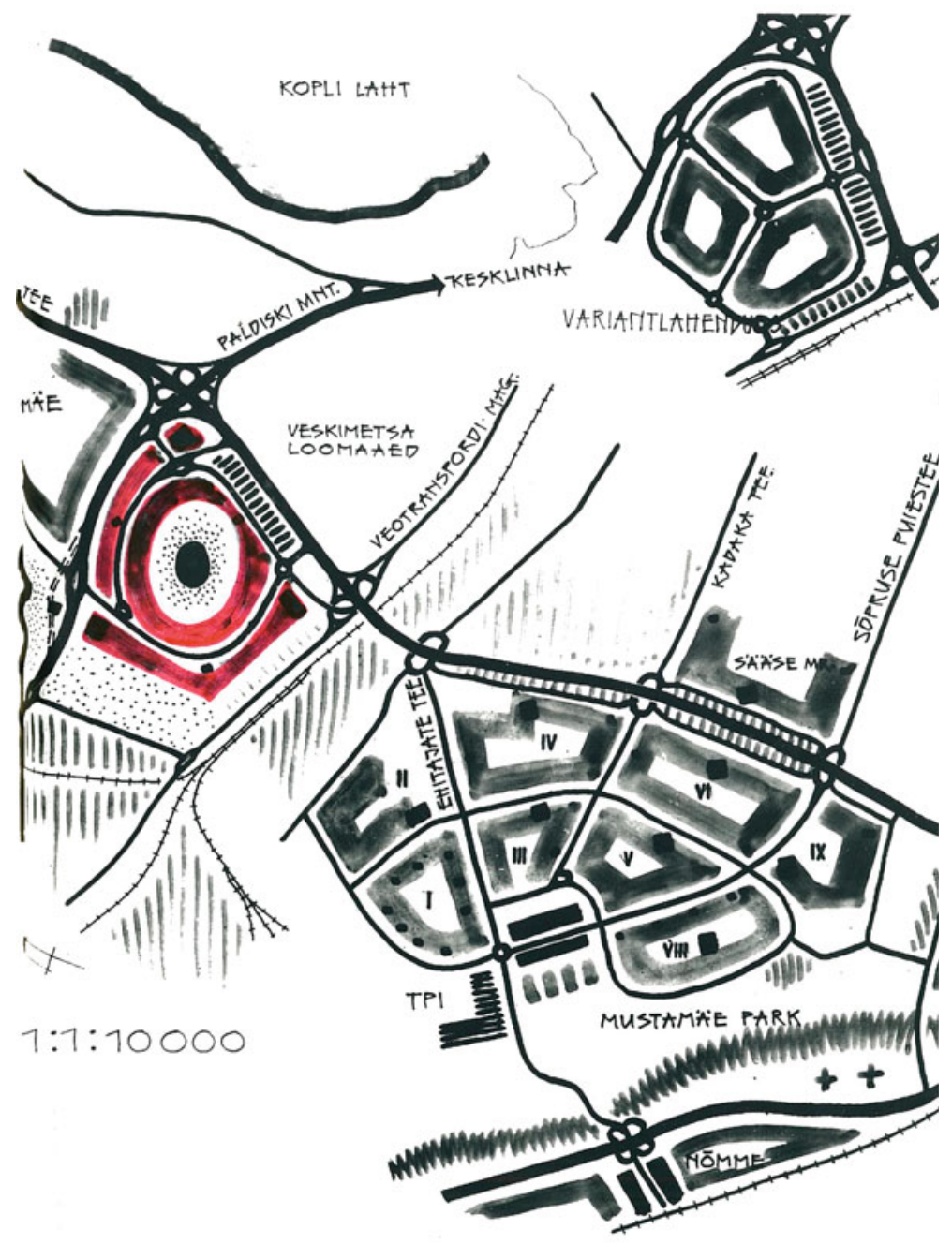

Fig. 13.1 Location of Väike-Õismäe district, 1968 detailed plan Source Archive of the Tallinn city planning department. Used with permission 


\section{Variantlahenduste arhitekturursed skeemid}

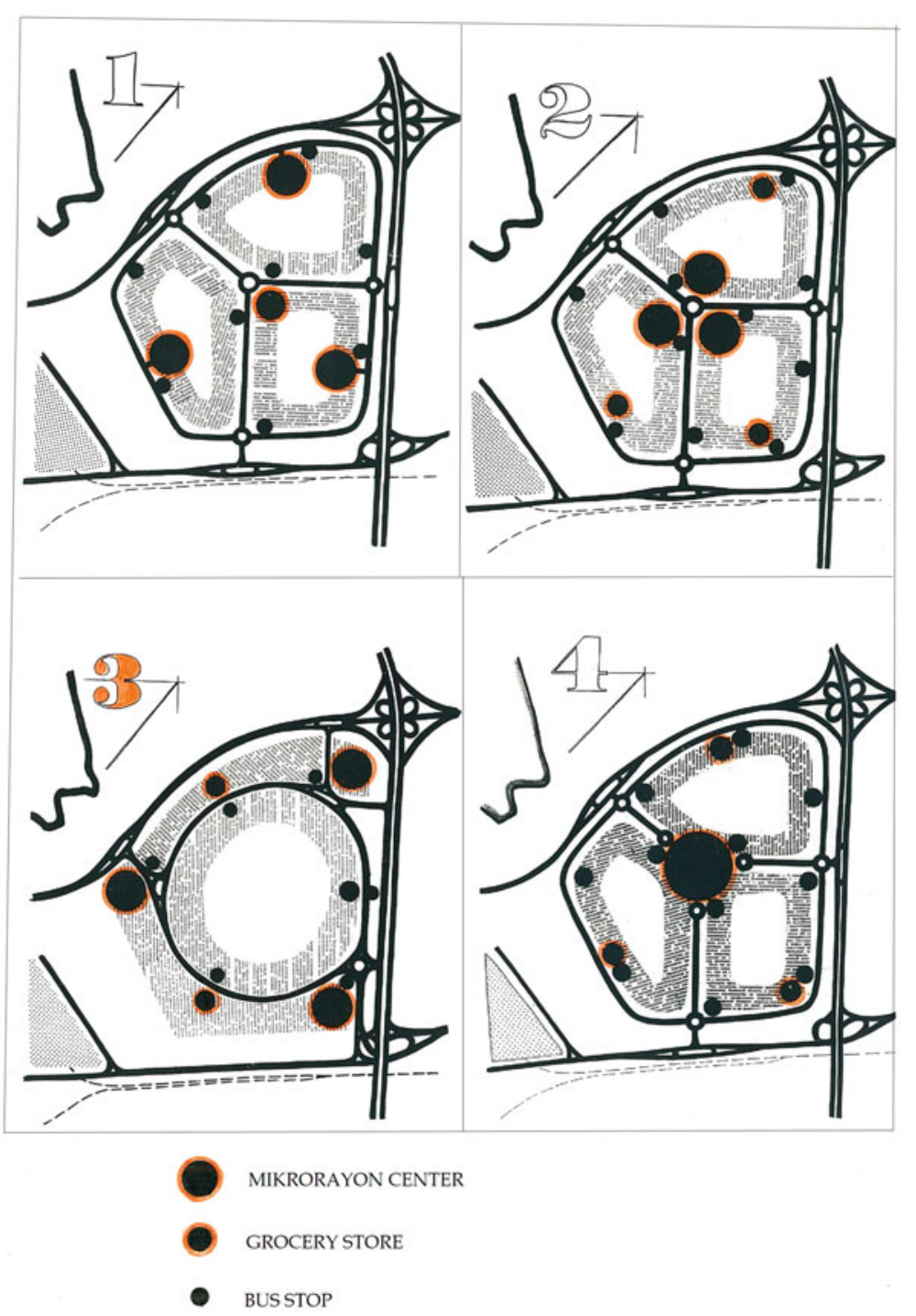

Fig. 13.2 Four alternative configurations of Väike-Õismäe housing estate, 1968 detailed plan Source Archive of the Tallinn city planning department. Used with permission

'sunbathing lawn' was planned. All four schools (both Estonian and Russian schools) and kindergartens (10 buildings), alternating with small car-free parks and play areas, were inside the circle. In this way, most school-age children, except 


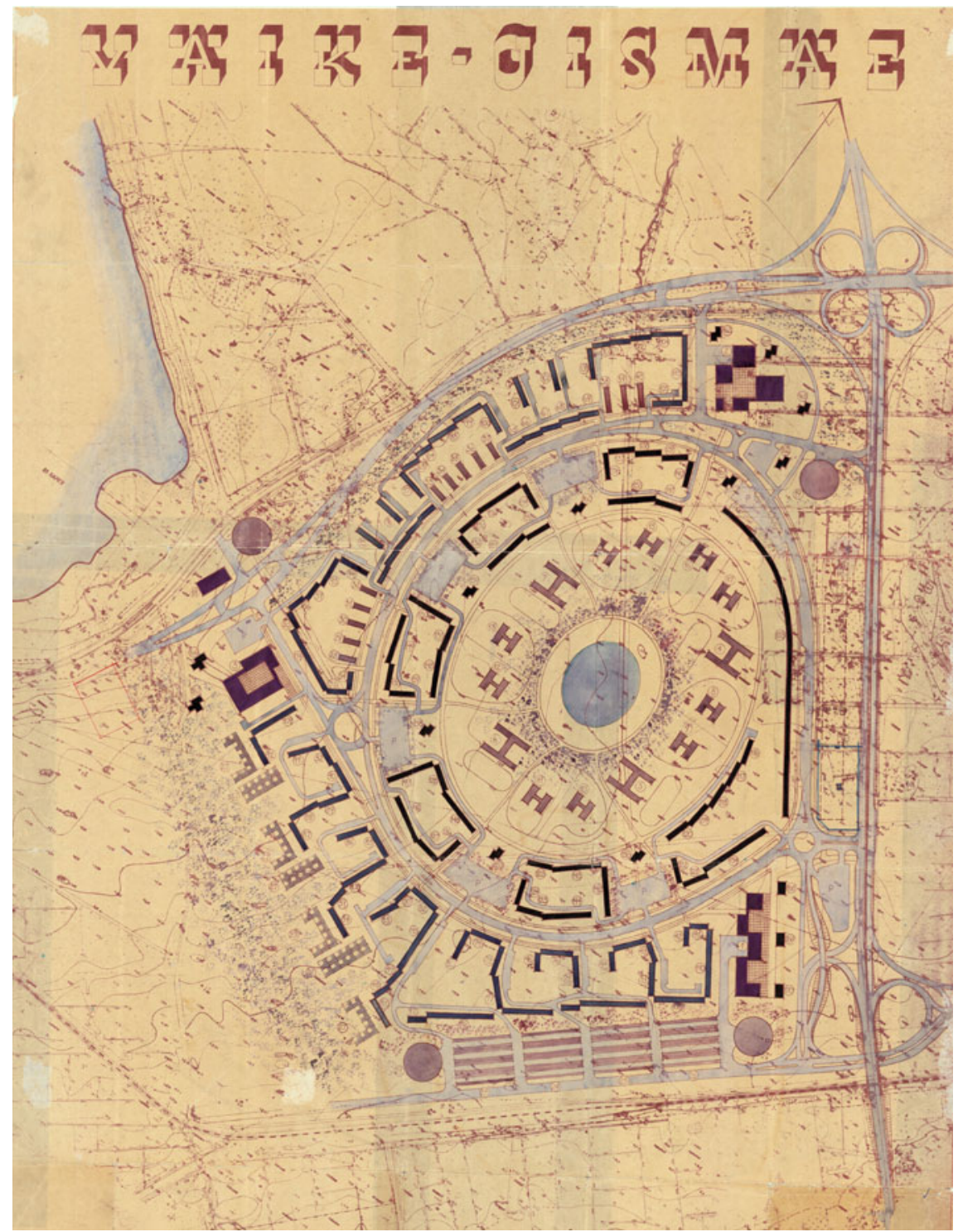

Fig. 13.3 General planning scheme of Väike-Õismäe, 1968 detailed plan Source Tallinn city planning department archive. Used with permission

those living outside the circular street, could walk to schools without crossing major streets. This was also one of the few critical points that was highlighted by city and state administrations: an alternative was to place some schools outside the circle. 


\subsubsection{Planned Service Network of the 1968 Detailed Plan}

The district as a whole had to meet similar norms and quality standards as other housing estates consisting of mikrorayons. The initial detailed plan of 1968 proposed three service centres: Centre No. 1 in the corner where Paldiski and Ehitajate roads intersect; Centre No. 2 in the corner adjacent to Mustamäe; Centre No. 3 close to Harku Lake. All three major service centres were located outside of the circular main street. The centres were more or less located symmetrically at equal distances from each other; to ensure the proximity of a convenience store to all residences, three auxiliary groceries were placed between these centres.

The 1968 Detailed Plan carefully prescribes the composition of the service centres. Table 13.1 presents the planned service network. Centre No. 1 became the main centre where higher order services important to the entire Väike-Õismäe district were envisioned.

Naturally, the construction process had to start somewhere. The 1968 plan suggested the initial construction order to enable habitation of the first parts of the district while subsequent construction occurred. Certain buildings had to be erected first: two courtyards with 9-storey and grouped 5-storey residential buildings, one school, three kindergartens and one of the planned service centres. Interestingly, Centre No. 2 became the first that was built. The rationale to start construction activities in this sector of the new district was its proximity to Mustamäe. Although Mustamäe was not yet finished, its infrastructure and utilities could be used; for example, the initial dwellings in Väike-Õismäe could temporarily be heated from boilers from Mustamäe (until the heating system for Väike-Õismäe was complete).

In reality, major investments related to the physical preparation of the construction site became the prerequisites without which housing construction could not be launched in Soviet Tallinn. The first Väike-Õismäe plan paid a great deal of attention to infrastructure: power supply, central heating, water, sewage, and stormwater sewers. It was clearly stated, for example, that construction in VäikeÕismäe could not begin before sewage collector No. 3 had been installed.

Housing construction was scheduled to begin in Väike-Õismäe in 1971. This was postponed, however, due to unexpected technical obstacles (especially challenges with soil conditions) that appeared during the early stages of water and sewage system installation. Consequently, construction of Väike-Õismäe was postponed to 1973. As the centralised construction industry could not be stalledbuilding factories in Tallinn produced building components for housing estates at top production-two mikrorayons (Siili and Sääse) were spontaneously erected near existing parts of Mustamäe, and Mustamäe itself was densified with more apartment buildings, even though the service networks of Mustamäe were still unfinished. 
Table 13.1 Composition of Väike-Õismäe service centres according to the 1968 detailed plan

\begin{tabular}{|c|c|c|c|c|}
\hline Type of service & $\begin{array}{l}\text { Centre no 1. Main } \\
\text { centre (Paldiski Road) }\end{array}$ & $\begin{array}{l}\text { Centre no. } 2 . \\
\text { (Ehitajate } \\
\text { Road) }\end{array}$ & $\begin{array}{l}\text { Centre No. } 3 . \\
\text { (Lake Harku/ } \\
\text { Järveotsa) }\end{array}$ & Total \\
\hline Pharmacy & 1 & 1 & 1 & 3 \\
\hline $\begin{array}{l}\text { Milk supply } \\
\text { station }\end{array}$ & 1 & 1 & 1 & 3 \\
\hline $\begin{array}{l}\text { Club rooms and } \\
\text { library }\end{array}$ & 200 visitors & 200 visitors & 200 visitors & \begin{tabular}{|l}
600 \\
visitors
\end{tabular} \\
\hline $\begin{array}{l}\text { Widescreen } \\
\text { cinema }\end{array}$ & 600 visitors & - & - & \begin{tabular}{|l}
600 \\
visitors
\end{tabular} \\
\hline Canteen & $\begin{array}{l}200 \text { visitors } \\
\text { (usable as café } \\
\text { restaurant in the } \\
\text { evenings) }\end{array}$ & 100 visitors & 100 visitors & \begin{tabular}{|l|}
400 \\
visitors
\end{tabular} \\
\hline Grocery stores & 25 employees & 25 employees & 25 employees & $\begin{array}{l}75 \\
\text { employees }\end{array}$ \\
\hline $\begin{array}{l}\text { Industrial good } \\
\text { stores }\end{array}$ & 4 employees & 4 employees & 4 employees & $\begin{array}{l}12 \\
\text { employees }\end{array}$ \\
\hline $\begin{array}{l}\text { Housing } \\
\text { administrative } \\
\text { office }\end{array}$ & 1 & 1 & 1 & 3 \\
\hline Shoe repair & 25 employees & - & - & $\begin{array}{l}25 \\
\text { employees }\end{array}$ \\
\hline Tailor & 68 employees & - & - & $\begin{array}{l}68 \\
\text { employees }\end{array}$ \\
\hline Photography & 3 employees & - & 2 employees & \begin{tabular}{|l|}
5 \\
employees
\end{tabular} \\
\hline $\begin{array}{l}\text { Metal equipment } \\
\text { and clock repairs }\end{array}$ & 15 employees & - & - & $\begin{array}{l}15 \\
\text { employees }\end{array}$ \\
\hline Hairdressers & 20 employees & 5 employees & 5 employees & $\begin{array}{l}30 \\
\text { employees }\end{array}$ \\
\hline Rental station & - & - & 1 employee & $\begin{array}{l}1 \\
\text { employee }\end{array}$ \\
\hline $\begin{array}{l}\text { Laundry } \\
\text { reception desk }\end{array}$ & 1 employee & 1 employee & 1 employee & $\begin{array}{l}3 \\
\text { employees }\end{array}$ \\
\hline $\begin{array}{l}\text { Dry cleaner } \\
\text { reception desk }\end{array}$ & 1 employee & 1 employee & 1 employee & $\begin{array}{l}3 \\
\text { employees }\end{array}$ \\
\hline $\begin{array}{l}\text { Self-service } \\
\text { laundry }\end{array}$ & 1 employee & 1 employee & 1 employee & $\begin{array}{l}3 \\
\text { employees }\end{array}$ \\
\hline Sauna & 200 visitors & - & - & \begin{tabular}{|l|}
200 \\
visitors
\end{tabular} \\
\hline $\begin{array}{l}\text { Service bureau } \\
\text { office }\end{array}$ & 1 employee & - & - & $\begin{array}{l}1 \\
\text { employee }\end{array}$ \\
\hline $\begin{array}{l}\text { Telephone central } \\
\text { station }\end{array}$ & - & 1 & - & 1 \\
\hline
\end{tabular}

Source Tallinn city planning department archive 


\subsubsection{The 1974 Revision of Väike-Õismäe Detailed Plan and the Construction Process}

For some years, the 1968 Detailed Plan of Väike-Õismäe stood at a standstill. In 1973, in parallel with the beginning of housing construction, a new planning task was issued for the 'Revision' of the initial detailed plan. This was partly related to fast modernisation: more automobile parking and more landline telephone connections were needed. In many aspects, the plan also needed greater specification. For example, the purpose of the central plan was not clarified in the 1968 plan: should it be possible to swim there, and how it should be regularly cleaned and supplied with water? The important decisions were needed about pedestrian safety while crossing the circular street. Most importantly, however, a final executive decision was needed about which projects to finance and in which order. The project in Väike-Õismäe demonstrates the need for a realistic programme that clarifies what to build, what not to build, and what to postpone. This need emerged very early during construction.

Low-rise buildings were left out of implementation plans without discussion (Table 13.2), even though they nicely diversified the housing composition of the area, since it was understood that 1- and 2-storey buildings would not help solve housing shortages. Nonetheless, Väike-Õismäe was envisioned to have a diverse cityscape due to its varying building heights.

A general principle was that Väike-Õismäe should accommodate more living space than originally envisioned in the 1968 plan. Additional land was allocated for housing construction (Fig. 13.4). Initially, the area outside the circular road between Centres No. 1 and 2 was reserved for small enterprises (for adding more services and jobs in the future), but in the revised plan this area included 5-storey apartment buildings. West of the makrorayon, additional housing was planned that included educational facilities and formed a separate mikrorayon (likely following the advice of some experts in 1968 that certain educational buildings should also be placed

Table 13.2 Comparison of housing composition, 1968 detailed plan and 1974 revision

\begin{tabular}{l|l|l}
\hline \multirow{2}{*}{} & \multicolumn{2}{l}{$\begin{array}{l}\text { Living space, sq. m (share of total housing } \\
\text { stock) }\end{array}$} \\
\cline { 2 - 3 } & 1968 detailed plan & 1974 revision \\
\hline 1-storey houses & $3,840(1.1 \%)$ & - \\
\hline 2-storey apartment buildings & $7,040(1.9 \%)$ & - \\
\hline 5-storey apartment buildings & $135,725(38.0 \%)$ & $138,429(34.7 \%)$ \\
\hline 9-storey apartment houses & $165,218(46.3 \%)$ & $196,727(49.4 \%)$ \\
\hline 16-storey towers & $45,000(12.7 \%) *$ & $43,355(10.9 \%)$ \\
\hline 22-storey towers & & $20,000(5.0 \%)$ \\
\hline Total & $356,823(100.0 \%)$ & $398,511(100.0 \%)$ \\
\hline
\end{tabular}

Source Tallinn city planning department archive

Note 16- and 22-storey apartment buildings are not differentiated 


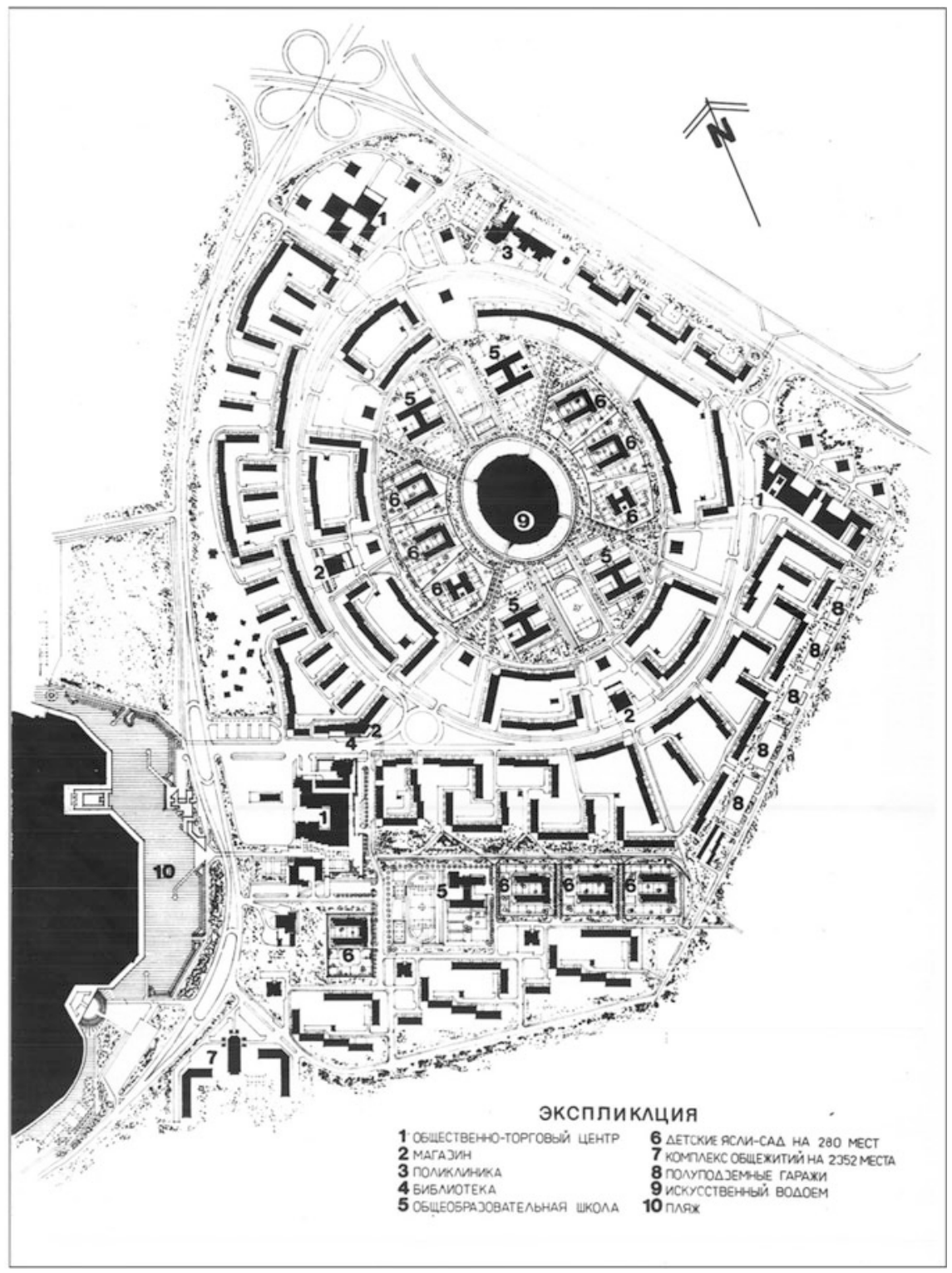

Fig. 13.4 General plan of Väike-Õismäe district, 1974 revision plan Source Tallinn city planning department archive. Used with permission

outside the circle). Although 10 kindergartens and 4 schools were initially planned in the pedestrian park, the revised plan included 6 kindergartens and 4 schools within the circle (making the pedestrian park less dense). Four more kindergartens and 1 school were allocated to the new mikrorayon. 
The most relevant compromises were made in service networks. In order to adapt to changes, a new service network was proposed (Table 13.3) in which services in the planned main centre were substantially reduced. Some services were moved to other locations, other service centres, or elsewhere on undeveloped land. The hierarchical principle that service centre No. 1 should be a higher order centre now disappeared. The most important services in Väike-Õismäe, however, had to be built somewhere. A public sauna, intended to be part of Väike-Õismäe centre No. 1 was shifted to the category 'outside the service centres' (Table 13.3), and specific sizes were indicated for small shops 'outside the service centres' (these were the planned auxiliary groceries allocated between service centres in 1968). Clearly, a more realistic plan was created because residents had by then started to move in and needed primary services.

The 1974 Revision modernised, complemented, and specified the initial detailed plan. A district fire station, a service station for buses and trolleybuses, and a policlinic were added to the district plan, locating them outside the service centres. Experts were invited to analyse whether and how to build the pond. Visually it was attractive, but when the start of construction approached, critics argued that Tallinn is a coastal town and digging artificial ponds is ridiculous. An interesting discussion unfolded: architects argued that Tallinn has positive experiences in integrating artificial water with urban design, referring to the eighteenth century Kadriorg castle and park. (Socialist housing estates surprisingly were compared with classical architecture.) The final decision to construct the pond was related to the rationality arguments: planners demonstrated that the soil from the pond area could be used in a cost-saving way as fill on housing construction sites.

A debate unfolded in relation to pedestrian safety and more specifically, how the circular street should be crossed. In the 1970s, urban planning principles were constantly refined. In Lasnamäe, a Tallinn housing estate area that was in the planning phase when the construction work in Väike-Õismäe was underway, pedestrians were separated from motorised traffic through physical design. The revision of Väike-Õismäe plan was sent back several times to the planners' desk with the requirement to address pedestrian crossings with bridges or tunnels (instead of pedestrian safety islands and zebra crossings). 'Planners argued that the proposals were expensive and it was too late to introduce new configurations when preparatory work had already been finished. The final decision was that, if needed, traffic signals would be installed at critical spots.

The housing construction of Väike-Õismäe indeed started in the nearest corner of Mustamäe, and Centre No. 2 was built along with the first buildings. As expected, and similar to all other housing estate districts in Tallinn, the planned main Centre No. 1 was never started. The construction of housing in Väike-Õismäe occurred between 1973 and 1978. During this period, two auxiliary groceries (a planning strategy for reducing walking distances for those living further from proper centres) were finished on the plots reserved for parking.

At the same time, the centres were renumbered in order to give an impression of completeness. Figure 13.5 shows one of the small groceries that now (instead of the main centre) was numbered as 'Õismäe 1'. Centre No. 2 in the initial plan now was 
Table 13.3 Composition of Väike-Õismäe service centres, 1974 revision plan

\begin{tabular}{|c|c|c|c|c|c|}
\hline Type of service & $\begin{array}{l}\text { Centre No. } 1 . \\
\text { Main centre } \\
\text { (Paldiski Road) }\end{array}$ & $\begin{array}{l}\text { Centre } \\
\text { No. } 2 . \\
\text { (Ehitajate } \\
\text { road) }\end{array}$ & $\begin{array}{l}\text { Centre No. } 3 . \\
\text { (Lake Harku/ } \\
\text { Järveotsa }\end{array}$ & $\begin{array}{l}\text { Outside } \\
\text { planned } \\
\text { service } \\
\text { centres }\end{array}$ & Total \\
\hline Pharmacy & 1 & 1 & 1 & - & 3 \\
\hline $\begin{array}{l}\text { Milk supply } \\
\text { station }\end{array}$ & 1 & 1 & 1 & - & 3 \\
\hline $\begin{array}{l}\text { Widescreen } \\
\text { cinema }\end{array}$ & 600 visitors & - & - & - & 600 visitors \\
\hline $\begin{array}{l}\text { Canteen, } \\
\text { restaurant }\end{array}$ & 200 visitors & $\begin{array}{l}180+30 \\
\text { visitors }\end{array}$ & 100 visitors & - & 510 visitors \\
\hline Grocery stores & $650 \mathrm{~m}^{2}$ & $710 \mathrm{~m}^{2}$ & $650 \mathrm{~m}^{2}$ & $\begin{array}{l}300+300+ \\
300 \mathrm{~m}^{2}\end{array}$ & $2910 \mathrm{~m}^{2}$ \\
\hline $\begin{array}{l}\text { Industrial good } \\
\text { stores }\end{array}$ & $300 \mathrm{~m}^{2}$ & $\begin{array}{l}4 \\
\text { employees }\end{array}$ & 4 employees & $500 \mathrm{~m}^{2}$ & $\begin{array}{l}4 \\
\text { employees }+800 \\
\mathrm{~m}^{2}\end{array}$ \\
\hline $\begin{array}{l}\text { Housing } \\
\text { administrative } \\
\text { office }\end{array}$ & 1 & 1 & 1 & - & 3 \\
\hline $\begin{array}{l}\text { Militia (internal } \\
\text { affairs) and } \\
\text { passport office }\end{array}$ & 1 & - & - & - & 1 \\
\hline Shoe repair & 25 employees & $\begin{array}{l}2 \\
\text { employees }\end{array}$ & - & - & 27 employees \\
\hline Tailor & 67 employees & - & - & - & 67 employees \\
\hline Photography & 3 employees & - & 2 employees & - & 5 employees \\
\hline $\begin{array}{l}\text { Metal } \\
\text { equipment, } \\
\text { clock repair }\end{array}$ & 15 employees & - & - & - & 15 employees \\
\hline $\begin{array}{l}\text { Metal } \\
\text { equipment, } \\
\text { clock repair } \\
\text { (reception) }\end{array}$ & - & $\begin{array}{l}2 \\
\text { employees }\end{array}$ & - & - & 2 employees \\
\hline Hairdressers & 18 employees & $\begin{array}{l}5 \\
\text { employees }\end{array}$ & 5 employees & - & 28 employees \\
\hline Rental centre & - & 1 & - & - & 1 \\
\hline $\begin{array}{l}\text { Service bureau } \\
\text { office }\end{array}$ & $50 \mathrm{~m}^{2}$ & - & - & - & $50 \mathrm{~m}^{2}$ \\
\hline $\begin{array}{l}\text { Laundry } \\
\text { reception desk }\end{array}$ & 1 & 1 & 1 & - & 3 \\
\hline $\begin{array}{l}\text { Dry cleaner } \\
\text { reception desk }\end{array}$ & 1 & 1 & 1 & - & 3 \\
\hline $\begin{array}{l}\text { Self-service } \\
\text { laundry }\end{array}$ & 1 & - & - & - & 1 \\
\hline $\begin{array}{l}\text { Post office, } \\
\text { bank }\end{array}$ & 1 & 1 & 1 & - & 3 \\
\hline
\end{tabular}


Table 13.3 (continued)

\begin{tabular}{l|l|l|l|l|l}
\hline Type of service & $\begin{array}{l}\text { Centre No. 1. } \\
\text { Main centre } \\
\text { (Paldiski Road) }\end{array}$ & $\begin{array}{l}\text { Centre } \\
\text { No. 2. } \\
\text { (Ehitajate } \\
\text { road) }\end{array}$ & $\begin{array}{l}\text { Centre No. 3. } \\
\text { (Lake Harku/ } \\
\text { Järveotsa }\end{array}$ & $\begin{array}{l}\text { Outside } \\
\text { planned } \\
\text { service } \\
\text { centres }\end{array}$ & Total \\
\hline $\begin{array}{l}\text { Urban } \\
\text { sanitation office }\end{array}$ & - & 1 & - & - & 1 \\
\hline Public toilet & 1 & 1 & 1 & - & 3 \\
\hline Health clinic & - & - & - & $\begin{array}{l}1(1600 \\
\text { patients per } \\
\text { day) }\end{array}$ & 1 \\
\hline Newsstands & 2 employees & 3 & 1 employees & 2 employees & 8 employees \\
\hline Flower shop & - & 1 & - & - & 1 \\
\hline $\begin{array}{l}\text { Bus stop } \\
\text { pavilions }\end{array}$ & 1 & 1 & 1 & 1 & 4 \\
\hline Fire station & - & - & - & 1 & 1 \\
\hline $\begin{array}{l}\text { Public transport } \\
\text { service station }\end{array}$ & - & - & - & 1 & 1 \\
\hline $\begin{array}{l}\text { Telephone } \\
\text { central station }\end{array}$ & - & - & - & 1 & 1 \\
\hline Sauna & - & - & - & 300 visitors & 300 visitors \\
\hline
\end{tabular}

Source Tallinn city planning department archive

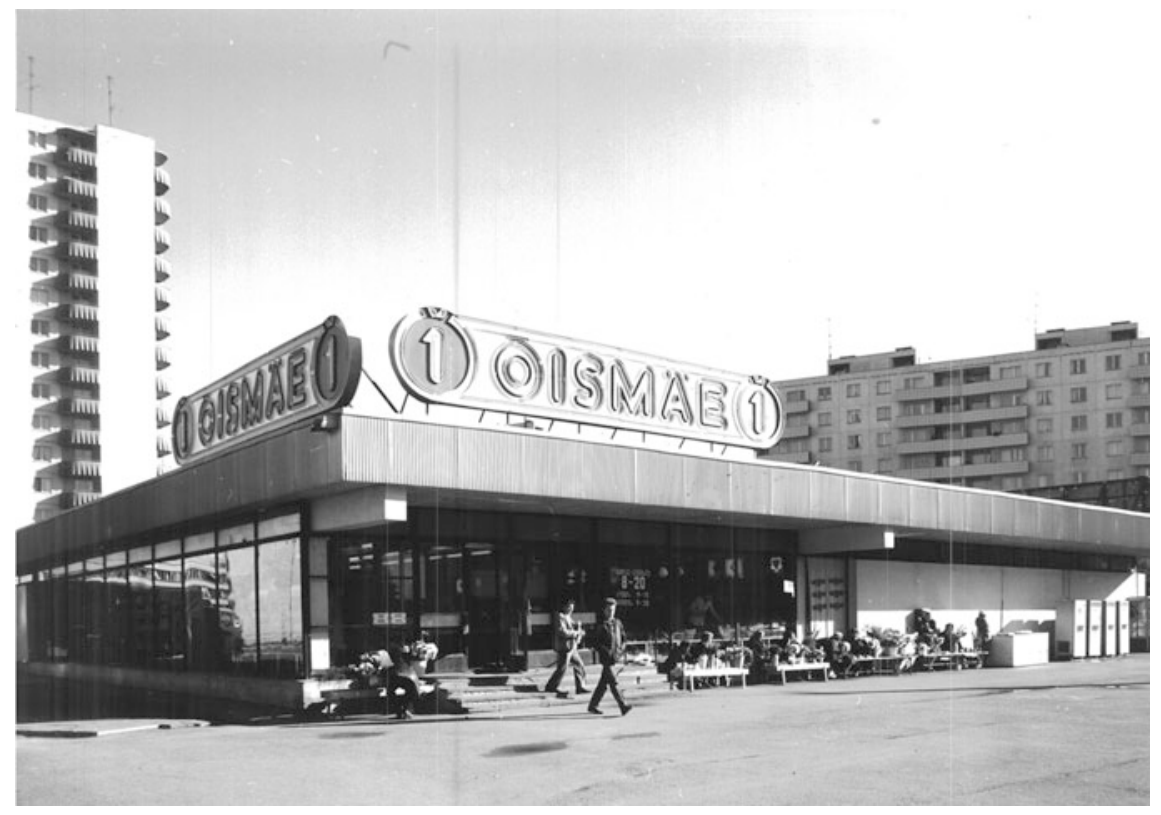

Fig. 13.5 Planned auxiliary shop, later renamed 'Õismäe 1', included in materials submitted for a 1985 architectural award competition Source Tallinn city planning department archive. Used with permission 
given the name 'Õismäe 2'. Another auxiliary grocery was named 'Õismäe 3', and the original Centre No. 3 (later known as Järveotsa Centre in reference to nearby Lake Harku) was completed considerably later. The missing services were gradually integrated with the new network of services (Port 1987). Centre No. 2, the first and only planned centre built, became the main administrative centre of the makrorayon.

\subsubsection{Debates About Socialist Urbanism in the 1970s}

By the late 1970s, half of the residences in Tallinn were built within the previous 15 years. Although new housing construction gradually solved the urgent shortage of living space, the emerging dense and monotonous built environment was something that the residents had never before experienced. Promised service networks remained unfinished, and criticism towards housing estates gained momentum. Despite the limited freedom of expression, the need to complete new residential districts was a topic of public debate in the late 1970s, especially as the city was one of the sites for competitions in the Moscow Olympic games (1980) and the quality of the urban environment was therefore of particular importance. These discussions are best expressed in a series of articles entitled 'City Where We Live' published between 1977 and 1979 in the culture and arts-oriented weekly newspaper 'Sirp ja Vasar'.

Mart Port, one of the most influential architects in Soviet Estonia, argued that 'it is high time to finish our new building complexes without dispersing funding' (Anupõld 1977). He was referring to the incompleteness of Mustamäe and the lack of resources to build needed service centres in Väike-Õismäe. He was of the position that mere rationalisation does not lead to the high quality: 'high level architecture occurs when a good project, builders with good skills, good materials and appropriate funding meet'. He continues 'Also the cars are not sold without wheels. Why, then, should our new residential districts lack public centres, sport facilities, and meeting places? We should give architectural works to people so that they are perfect, finished, and worthy of our era' (Port 1977).

Liimets (1978), an engineer and later a diplomat, is also critical: 'we are already launching housing construction in Lasnamäe, when Väike-Õismäe and even Mustamäe still lack the elementary sport, cultural and service facilities. By 1978, only 5 out of 9 planned mikrorayon centres in Mustamäe have been built'. According to him, certain services are with utmost priority for those population groups who are more confined to their immediate surroundings (children, youth and pensioners).

Fjuk (1979), an architect and journalist and 1990s politician, admits that free planning was a core topic in the twentieth century, but that the socialist countries absorbed only one aspect of it: rationalisation. He argues: 'people naturally seek shelter and safety, however 'wideness' does not offer this quality. An attractive environment should contain contrasts, diversity, surprises and entertainment'. 
According to Fjuk, 'technology prevails' in the Soviet Union: building factories are inflexible, and after production units have been installed, it is difficult to change what they produce. He further claims that the plots between blocks are like 'no-man's-land, an uncivilised milieu, a place of chaos' and that 'the measure of architecture should always be human scale'.

Many opinion leaders called for a more systematic approach to diversify urban housing stock. In 1970, Port (1970) drew attention to the fact that people need dwellings appropriate to various stages of their lifecourse; standards prescribed in plans might therefore be difficult to meet in the future. He proposes that factories should produce building details that could be later reorganised into smaller or larger apartments.

The enemy of ambitions to diversify housing was typically rationalisation. Pihlak (1978), an economic geographer and planner, criticises the decision to omit lower-rise apartment buildings in Väike-Õismäe and condemns criticism of larger dwellings: 'we have only a few large families, and standard apartments in housing estates are not suitable for them'. Also, Paalberg (1978), an economist, advocates the need to accept building single family homes, so that people could contribute to housing construction. Nobody dared to question the system of industrial housing construction. It was proposed that standard projects and rational production of building details should be used for privately constructed single family homes (Bruns 1978a); as the priority was to solve 'the apartment problem', however, the main focus should remain on the construction of high-rise apartment buildings.

Understandably, those responsible for urban development in city offices had a difficult task: they could not ignore the 'rules of the time', but at the same time they were in charge of influential decisions at a period when city grew fast. Chief architect Dmitri Bruns explained (Leetmaa 2017, interview with Dmitri Bruns) how he had to argue with the authorities that Tallinn does not need new factories, since factories would trigger new immigration and additional pressure on already scarce urban housing. But Port also needed to consider the professional critics of his time.

Bruns firmly defended the principle of industrial housing construction (Bruns 1978b): 'the task is to supply residents with apartments and we need to do that consistent with the level of economic development of our society'. He also argues that important aims have been achieved: new apartments contain modern facilities, internal planning of apartments has been improved, families do not share apartments, and equality is considered. According to him, the next crucial updates in quality would be achieved in 1985 within reconstruction of a Housing Construction Factory. Bruns convinces the contemporaries (Bruns 1978a) that the most important challenge is to inspire architects to work together with engineers: 'When architects do not know the logic of production, they only choose from ready-made solutions'. Forty years later, in a retrospective interview, he argues: 'this was not architecture, engineers took over the tasks of architects, partly because the latter were only able to produce houses with pillars and did not adjust to the time' (Leetmaa 2017, interview with Dmitri Bruns).

The Chief Architect admits that the speed of building new service networks has been too slow (Bruns 1978a): 'we are successfully fulfilling the plans as regards 
educational infrastructure, while other services clearly lag behind, most importantly cultural and leisure facilities'. Bruns mentions three reasons for this schism (Bruns 1978c): first, an apartment shortage still exists; second, the capacity of building organisation in the republic has not been increased enough; and third, service buildings are less standardised and more time and workforce is needed to construct them. Bruns offers hope that in time, the ideal service networks will be finished (Bruns 1978c): 'give us some time. Do not demand everything at once'.

\subsubsection{An Incomplete Residential Area Wins the Soviet State Architectural Prize}

A high point for Väike-Õismäe occurred in 1986, when the district was awarded a prestigious Soviet State Architectural Prize. For the competition (Materials Submitted to the Soviet State Architectural Award Competition 1985), VäikeÕismäe was presented as a completed district. Figure 13.6 presents a series of illustrations submitted to the competition. The aerial views of the district were emphasised in various images: the spatial form of the makrorayon, diverse building heights, and reflections of silhouettes in the pond. Organised car parking is situated between residential blocks and public transport uses the circular road.

The award nomination materials include references to both finished and unfinished elements. The educational facilities within the circle - and also district Centre No. 1-are indicated on the scheme. The district milieu is depicted as human scale, with green areas for walking and fishermen angling at the pond or boating in the lake. Kids' activities, relaxation, and everyday activities occur between the residential blocks (rather than parking lots). A healthy mix of nature and urban amenities created an ideal milieu for families.

Mart Port, the head of the Väike-Õismäe planning team, commented in 1987 on the success of the district in the competition: 'the time factor cannot be ignored in the assessment of urban construction. There is always the risk that the solution that seemed persuasive, even unique at the start of the design, turns out to be one of the many and annoying. With Väike-Õismäe, the story was opposite' (Port 1987, 3). According to Port the plan of Väike-Õismäe had opponents, but the exceptions applied were to the benefit of the district. He refers to the makrorayon approach that enabled resource economy; visually appealing and pedestrian-friendly atmospheres; a return to the closed yard design that met the sunlight norms for apartments; use of water features in urban design, etc. Most importantly, Port argues that during the preceding 20 years, urban planning principles changed and this 'worked in favor of Little Oasis Garden' (a nickname that the grand architect gave to Väike-Õismäe) (Port 1987, 6).

Chief Architect Bruns considered how it became possible that an unfinished district won such a prestigious award: 'by this time, of course, quite a lot was finished' (Leetmaa 2017, interview with Dmitri Bruns). Consequently, the 


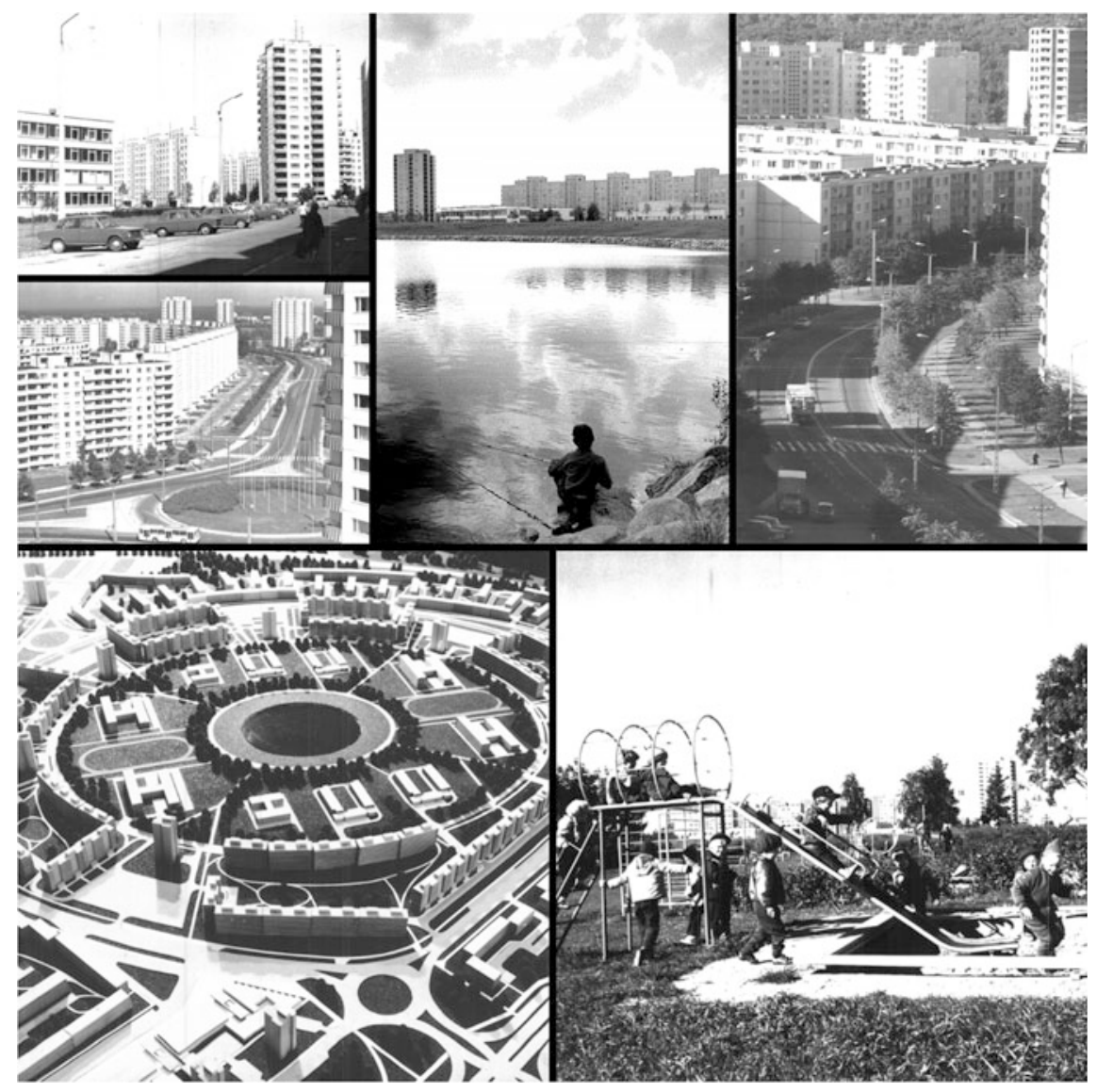

Fig. 13.6 Images of Väike-Õismäe, included in materials submitted for a 1985 architectural award competition Source Tallinn city planning department archive. Used with permission

(in)completeness of socialist housing areas should be considered in relative terms. In his comments on the changes applied in the 1974 Revision compared to the 1968 Detailed Plan, Bruns even diminished the contrasts between two plans, explaining that this was simply an ongoing planning process of a district that started from visions and continued with specifications (Leetmaa 2017, interview with Dmitri Bruns). It follows that at the heyday of socialist housing construction the compromises in the initial plans were de rigueur; with a scarcity of resources, architects' plans still required implementation. 


\subsubsection{Väike-Öismäe Service Networks After the System Change}

When the socialist system collapsed in 1991, Väike-Õismäe, like many other housing estate districts, remained unfinished. No resources were available to complete the plans. Soon, privatisation was initiated and sitting tenants became flat owners and assumed responsibility for care of the buildings and surrounding land.

Väike-Õismäe was a rather prestigious residential environment in the 1990s. Everything created in the previous decades, even if fewer buildings were built than appeared on plans, was new. The decision to locate attractions in this part of Tallinn worked to the benefit of Väike-Õismäe: Rocca al Mare Open Air Museum was opened in 1964 and the Tallinn Zoo was moved adjacent to the district in the 1980s. Compared to Mustamäe, Väike-Õismäe was an advancement in planning principles: apartments had better internal planning, and the structure of the district was logical. The next housing estate district, Lasnamäe (three times larger than Väike-Õismäe), suffered from budget cuts even more and due to intensive immigration also became a symbol of russification.

In 1994, a new revision of Väike-Õismäe district plan (Revision of the District Master Plan of Haabersti, Tallinn, 1994) was adopted, during a time when nobody was able to predict Tallinn's investment capacity. The most striking addition to the district infrastructure was a church building that understandably was not part of typical socialist community networks. The proposed location of the prospective church was iconic - on an island in the middle of the pond (Fig. 13.7). The accompanying note written by the Bishop of the Estonian Evangelic Lutheran Church approves the location but declare that 'in the foreseeable future, no financial tools are available for construction'. The ideas remained on paper only, although in recent years church construction in housing estates became a reality: in 2013, a new orthodox church was opened in Lasnamäe and a brand-new Lutheran church is scheduled to open soon in Mustamäe.

The quest to rename Väike-Õismäe service centres continued into the early 1990 s and reflected an attempt to erase socialist symbols. Instead of simple sequential numbering, the shops were now given names of flowers-Õismäe 1 was renamed Kullerkupu (Trollius europaeus), Õismäe 2 was renamed Nurmenuku (Primula veris), and Õismäe 3 was renamed Meelespea (Myosotis alpestris). These revisions justified the name of Väike-Õismäe district, Little Blossom Hill—and also helped to create the perception that the district is completed.

Today, large commercial chain stores have taken over the commercial space in the makrorayon centres. In addition, one of the largest shopping malls in Tallinn, Rocca al Mare Centre, is located in the corner of the makrorayon where Centre No. 1 was initially planned. A butterfly interchange at this intersection, indicated in the 1968 Detailed Plan, was opened in June 2018. Many other services - a concert hall, car shops, sport halls, cafeterias and pubs - can now be found in the shopping mall or nearby, attracting people from all over the region, but functionally serving 


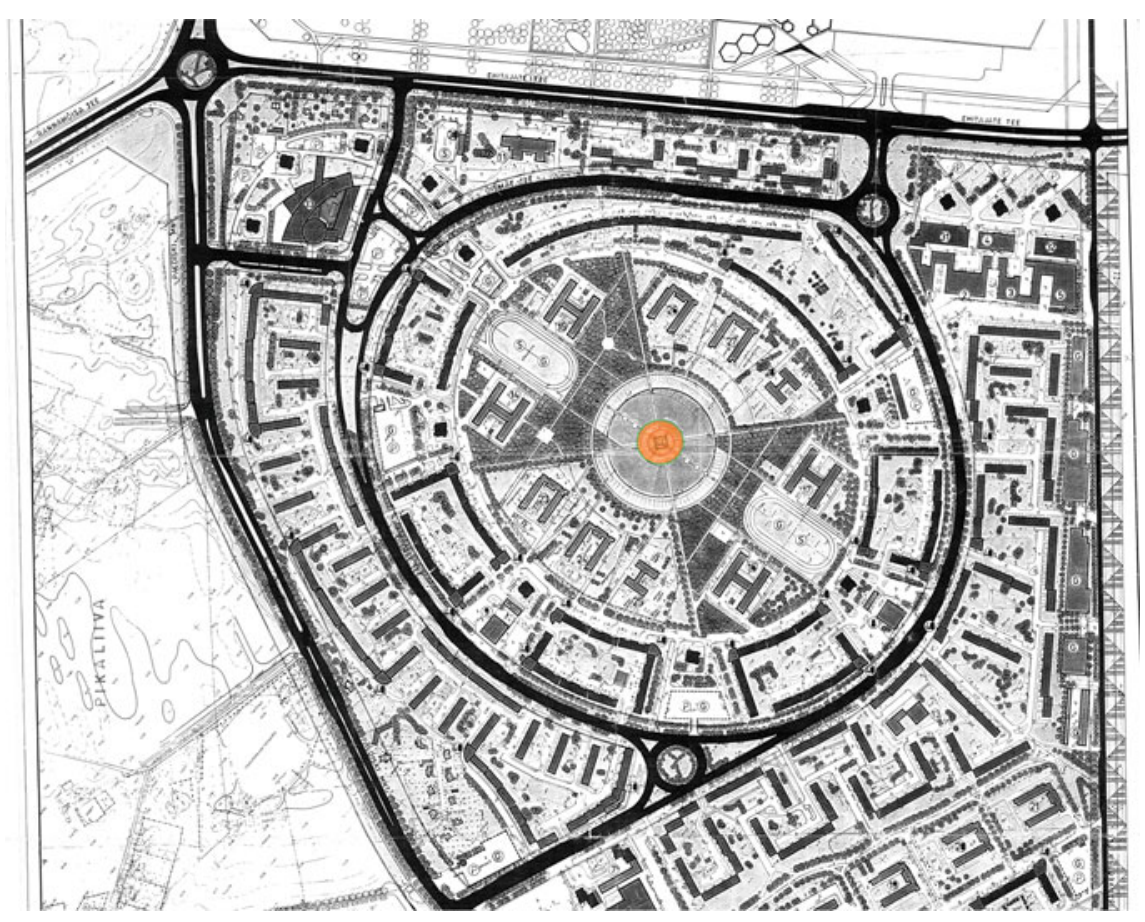

Fig. 13.7 Revision of the district master plan of Haabersti, 1994. Note: No. 44 indicates a proposed church Source Tallinn city planning department archive. Used with permission

also as a contemporary main centre for Väike-Õismäe and nearby fast-growing suburban settlements.

Despite the political system and changing planning ideas, the main centre was eventually established close to its planned location. The only criticism that we can make today is the impacts of these trends to the walkability of the district: higher order services around the districts are accessible today primarily by cars. It seems that the Väike-Õismäe service network has reversed itself over time. The educational infrastructure is still located within the district, as initially planned and realised, but a remarkable share of commercial services, cultural and sport facilities are outside the makrorayon, encouraging car use rather than walking.

Today, housing estates compete with other residential environments in formerly socialist countries (Kovács and Herfert 2012). Although public investments may be directed to housing estates (where a large proportion of the electorate lives) it is increasingly difficult to maintain the relative prestige of these districts (Hess et al. 2018). People with more financial resources prefer gentrifying neighbourhoods or suburbs (Hess et al. 2017; Tammaru et al. 2016) because small and outdated apartments no longer satisfy expectations. The target market for living in housing estates is limited today (Kährik et al. 2019): mostly, younger households at the beginning of their housing careers (usually renters) and older residents who enjoy 
familiar environments. Walkability, service availability, greenery, recreation spaces, and even its socialist past could help Väike-Õismäe maintain its social status, provided that a systematic approach is made by contemporary planners to make good use of these aspects. Still, a pedestrian experience in Väike-Õismäe today can give an impression of urban abandonment.

\subsection{Conclusion}

A hallmark of the Soviet Union was that many promises of better lives ahead for Soviet citizens were in reality unfulfilled. The same phenomenon occurred in city planning - initial visions for urban plans were not fully realised. Although there was an ambition to build cities with complexity and scientific rationale, many Soviet citizens lived in 'unfinished cities' due to resource limitations and other inefficiencies of the Soviet system. But the problem is not unique to specific places (the republics of the Soviet Union) or times (the era of state socialism); we live today within a market economy in which we masterplan cities without being able to predict the interests of investors and long-term outcomes.

From the evolution of Väike-Õismäe-from approval of its plan in 1968 through construction and residence to today, nearly three decades since the end of state socialism - we learn that compromises in service networks were made in the very first phases of implementation of plans before construction activity was launched. While previous scholarly literature argues that approved plans for housing estates simply remained unfinished, this study clarifies circumstances and outcomes: initial detailed plans merely demonstrated the professionalism of Soviet architects, while subsequent revisions of plans adopted the realities of the socialist urban economy and funding realities.

The planning and construction of Väike-Õismäe suggests that other socialist housing estates likely faced similar limitations. Otherwise, an unfinished housing estate could not have been awarded one of the most prestigious architectural prizes in the Soviet Union. We conclude that (in)completeness vis-à-vis initial visions was not an argument during the award of architectural prizes. Instead, the honour of an award recognised the skills of key persons to oversee the construction of housing estates under budgetary restrictions in an inflexible system so that the resulting environment will still become a coherent whole. Another interpretation is that recognition in the Soviet Union-expressed through the honour of architectural prizes - also enabled the legitimisation of modernist housing estates and communicated to Soviet citizens that newly erected housing estates were residential environments suitable for housing workers and their families and accommodated the ideological aims of state socialism including homogeneity, classlessness, and equality. 
Acknowledgments This project has received funding from the European Union's Horizon 2020 research and innovation programme under Marie Skłodowska-Curie grant agreement No. 655601. The authors are grateful to Mr. Dmitri Bruns, the Chief Architect of Tallinn 1960-1980, whose retrospective memoirs and interpretations of the socialist urban planning led us to a deeper understanding of the era that we have not had chance to experience personally. The authors acknowledge helpful contributions to the research from Pille Metspalu, Johanna Holvandus and Annika Väiko.

\section{References}

Andrusz G (1984) Housing and urban development in the USSR. SUNY Press, Albany, New York Anupõld E (1977) A group discussion about new city. City Where We Live. Sirp ja Vasar 7 (1):89

Bater JH (1980) The Soviet city: ideal and reality. Edward Arnold, London, UK

Bruns D (1978a) To continue the debate. City Where We Live. Sirp ja Vasar 27(4):16

Bruns D (1978b) To continue the debate... City Where We Live. Sirp ja Vasar 13(4):8-9

Bruns D (1978c) To continue the debate... City Where We Live. Sirp ja Vasar 20(4):16

Bruns D (1993) Tallinn urban development. Valgus, Tallinn

Bruns D (2007) Tallinna peaarhitekti mälestusi ja artikleid. Eesti Arhitektuurimuuseum, Tallinn

Cinis A, Dremaite M, Kalm M (2008) Perfect representation of Soviet planned space: mono-industrial towns in the Soviet baltic republics in the 1950s-1980. Scandanavian J Hist 33(3):226-246

Dahir J (1947) The neighbourhood unit plan: its spread and acceptance. Russell Sage Foundation, New York, NY

De Decker P, Newton C (2009) At the fall of Utopia. Urban izziz/Urban Chall 20:74-82

DiMaio AJ (1974) Soviet urban housing: problems and policies. Praeger, New York

Fjuk I (1979) Understanding new urbanism. City Where We Live. Sirp ja Vasar 1(5):16

French RA, Hamilton FEI (1979) The socialist city: spatial structure and urban policy. Wiley, London

Gentile M (2004) Former closed cities and urbanisation in the FSU: an exploration in Kazakhstan. Eur-Asia Stud 56(2):263-278

Gentile M, Sjöberg Ö (2006) Intra-urban landscapes of priority: the Soviet legacy. Eur-Asia Studies 58(5):701-729

Goss A (1961) Neighbourhood units in British new towns. Town Plan Rev 32(1):66-82

Hall DR (1987) Emerging residential structures of socialist cities. Contemp City Ecol 6:257-278

Hall P (1988) Cities of tomorrow. An intellectual history of urban planning and design in the twentieth century. Basil Blackwell, Oxford

Hatherley O (2016) Landscapes of Communism: a history through buildings. The New Press, England

Hausladen G (1987) Planning the development of the socialist city: the case of Dubna New Town. Geoforum 18(1):103-115

Hegedüs J, Tosics I (1983) Housing classes and housing policy: some changes in the Budapest housing market. Int J Urban Reg Res 7(4):467-494

Hess DB (2017) Decrypting Fareless Public Transport in Tallinn, Estonia. Case Stud Transp Policy 5(4):690-698

Hess DB (2018) Transport in Mikrorayons: accessibility and proximity to centrally planned residential districts during the socialist era, 1957-1989. J Plan Hist 17(3):184-204

Hess DB, Hiob M (2014) Preservation by neglect in Soviet-era town planning in Tartu, Estonia. J Plan Hist 13(1):24-49 
Hess DB, Iacobucci E, Väiko A (2017) Network connections and neighborhood perception: using social media postings to capture attitudes among twitter users in Estonia. J Archit Urban Plan 13:67-77. https://doi.org/10.1515/aup-2017-0010

Hess DB, Tammaru T, van Ham M (2018) Lessons learned from a Pan-European study of large housing estates: origin, trajectories of change, and future prospects. In: Hess DB, Tammaru T, Van Ham M (eds) Housing estates in Europe: poverty, segregation, and policy challenges. Springer, Dordrecht, The Netherlands

Kalm M (2012) An apartment with all conveniences' was no panacea: mass housing and the alternatives in the Soviet period in Tallinn. Architektura and Urbanizmus 46(3-4):194-207

Kaufmann EC (1936) Neighbourhood units as new elements of town planning. J R Inst Br Archit 44:165-175

Kovács Z, Herfert G (2012) Development pathways of large housing estates in post-socialist cities: an international comparison. Hous Stud 27(3):324-342. https://doi.org/10.1080/02673037. 2012.651105

Kährik A, Kangur K, Leetmaa K (2019) Socio-Economic and ethnic trajectories of housing estates in Tallinn, Estonia. In: Hess DB, Tammaru T (eds) Housing estates in the Baltics: the legacy of central planning in Estonia, Latvia, and Lithuania. Springer, Dordrecht, The Netherlands

Leetmaa K (2017) Interview with Dmitri Bruns-Tallinn chief architect in the years 1960-1980

Liepa-Zemeša M, Hess DB (2016) Effects of public perception on urban planning: evolution of an inclusive planning system during Crises in Latvia. Town Plan Rev 87(1):71-92

Liimets E (1978) Phenomena associated with urbanisation. City Where We Live. Sirp ja Vasar $11(8): 12$

Lu D (2006) Travelling urban form: the neighbourhood unit in China. Plan Perspect 21(4): 369-392

Marcuse P (1996) Privatization and its discontents: property rights in land and housing in the transition in Eastern Europe. In: Andrusz G, Harloe M, Szelènyi I (eds) Cities after socialism: urban and regional change and conflict in post-socialist societies. Blackwell Publishers, Oxford

Marozas M (2009) Post-Socialist city: adaptation of USSR-Made urban structures in Lithuania. Delft University of Technology, The Netherlands

Materials Submitted to the Soviet State Architectural Award Competition (1985) Archive of the Tallinn city planning department

Metspalu P, Hess DB (2018) Revisiting the role of architects in planning large-scale architects in planning large-scale housing in the USSR: the birth of socialist residential districts in Tallinn, Estonia, 1957-1979. Plan Perspect 1-27

Miliutin NA (1974) Sotsgorod: the problem of building socialist cities. MIT Press

Monclús J, Díez Medina C (2016) Modernist housing estates in Europe-an cities of the Western and Eastern Blocs. Plan Perspect 31(4):533-562

Obraztsov A (1961) What will our future cities look like? Sov Rev 2(4):34-37

Paalberg H (1978) The problems of the development of Tallinn. Eesti Raamat, Tallinn

Perry CA (1926) The local community as a unit in the planning of urban residential areas. In: Perry CA (ed) The urban community. University of Chicago Press, Chicago, pp 238-241

Perry CA (1929) Regional survey of New York and its environs, vol VII. Neighborhood and community planning. vol VII. Committee on regional plan of New York and its Environs, New York, NY

Pihlak Ü (1978) City where we live. Sirp ja Vasar 1(9):9

Port M (1966) England through the eyes of an architect. Eesti Raamat, Tallinn

Port M (1970) Architecture needs science! Sirp ja Vasar 15(5):3

Port M (1977) Speeches of a plenum. Sirp ja Vasar 28(10):7-8

Port M (1987) Väike-Õismäest ja Ajategurist. Ehitus ja Arhitektuur 2

Robinson J (2009) The Post-Soviet city: identity and community development. Paper presented at the city futures in a globalising world: an international conference on globalism and urban change, Madrid, Spain

Shaw DJB (1991) The past, present, and future of the Soviet city plan. Plan Perspect 6:125-138

Shenker I (1971) City surprising to four Russian architects. New York Times, New York 
Sjöberg Ö (1992) Underurbanisation and the zero urban growth hypothesis: diverted migration in Albania. Geografiska Annaler Ser B Hum Geogr 74(1):3-19

Smith DM (1996) The Socialist City. In: Andrusz G, Harloe M, Szelènyi I (eds) Cities after socialism: urban and regional change and conflict in post-socialist societies. Blackwell Publishers, Oxford

Stanilov K (2007) Nine Housing Trends in Central and Eastern European Cities During and After the Period of Transition. In: Stanilov K (ed) The Post Socialist City. Urban form and space transformations in central and eastern Europe after Socialism, Springer, Heidelberg, pp 173-190

Svetlichnyi B (1960) Soviet town planning today. Probl Econ 111(8):29-36

Šiupšinskas M, Lankots E (2019) Collectivist ideals and consumer spaces: microrayon centres in Vilnius and Tallinn. In: Hess DB, Tammaru T (eds) Housing estates in the Baltics: the legacy of central planning in Estonia, Latvia, and Lithuania. Springer, Dortrecht, The Netherlands

Tammaru T, Marcińczak S, van Ham M, Musterd S (2016) Socio-Economic segregation in European capital cities: east meets west. Routledge, New York/London

Temelová J, Novák J, Ouředníček M, Puldová P (2011) Housing estates after socialism: various trajectories and inner differentiation. Urban Stud 48(9):1811-1834. https://doi.org/10.1177/ 0042098010379279

Tsenkova S (2009) The legacy of socialist housing systems. In: Tsenkova S (ed) Housing policy reforms in post socialist Europe: lost in transition. Physica-Verlag, Heidelberg, Germany

White PM (1980) Soviet urban and regional planning. St. Martin's Press, London, UK

Wright HM (1958) A visit to Russia. Town Plan Rev 29(3):162-178

Open Access This chapter is licensed under the terms of the Creative Commons Attribution 4.0 International License (http://creativecommons.org/licenses/by/4.0/), which permits use, sharing, adaptation, distribution and reproduction in any medium or format, as long as you give appropriate credit to the original author(s) and the source, provide a link to the Creative Commons license and indicate if changes were made.

The images or other third party material in this chapter are included in the chapter's Creative Commons license, unless indicated otherwise in a credit line to the material. If material is not included in the chapter's Creative Commons license and your intended use is not permitted by statutory regulation or exceeds the permitted use, you will need to obtain permission directly from the copyright holder.

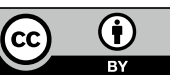




\title{
Chapter 14 \\ Collectivist Ideals and Soviet Consumer Spaces: Mikrorayon Commercial Centres in Vilnius, Lithuania and Tallinn, Estonia
}

\author{
Matas Šiupšinskas and Epp Lankots
}

\begin{abstract}
This chapter focuses on Soviet mikrorayon centres-multifunctional social, and commercial centres - built in large housing estates in Vilnius, Lithuania and Tallinn, Estonia from the 1960s to the 1980s. In both countries, ensuring proper services to modern citizens was initially based on the conceptual model of a multistage domestic service system with small shops integrated into the urban fabric next to homes, and larger mikrorayon centres with self-service supermarkets reachable by foot without crossing wide roads. Mikrorayon centres also represented a novel type of urban space. New pedestrian commercial centres, influenced by the Vällingby centre in Stockholm and Tapiola centre near Helsinki, operated as a simulation of traditional city centres in sparse, freely planned new settlements. We argue that the theoretical model of multistage domestic services, as well the ideological and communal mission of the centres, was quickly reworked into a type of space that embraced consumption and individual behaviour within the framework of collectivism. The study shows how the architectural form and visual aesthetic of the centres had a specific role in this. As such, the Soviet mikrorayon centres were the product and defining part of the hybrid nature of late Soviet society and represent a peculiar type of spatiality where conflicting value systems do not exclude each other but instead interact.
\end{abstract}

Keywords Housing estates - Mikrorayon centres • Soviet modernism • Late-socialist architecture

\footnotetext{
M. Šiupšinskas $(\bowtie)$

Department of History, Vilnius University, Vilnius, Lithuania

e-mail: mr.matas@gmail.com

E. Lankots

Institute of Art History and Visual Culture, Estonian Academy of Arts, Tallinn, Estonia e-mail: epp.lankots@artun.ee

(C) The Author(s) 2019

D. B. Hess and T. Tammaru (eds.), Housing Estates in the Baltic Countries,

The Urban Book Series, https://doi.org/10.1007/978-3-030-23392-1_14
} 


\subsection{Introduction}

The post-war decades through the mid-1970s were the worldwide golden age of new towns and mass-produced housing estates. The biggest urban utopian movement of the twentieth century introduced new habitation models in vast homogeneous housing estates that brought about changes in everyday routines including household provisioning. During the 1970 s, new social and commercial centreswhere residents could socialise and find most necessary services and goods - were planned in the mikrorayons of pre-fabricated housing estates in the Baltic countries. In order to develop a network of services, a multistage domestic service system was introduced in Lithuania, Latvia and Estonia, with small shops integrated into the urban fabric next to homes, and larger mikrorayon centres reachable by foot without crossing wide roads. Mikrorayon centres also represented a novel type of urban space. New pedestrian commercial centres operated as a simulation of traditional city centres in sparse, freely planned new settlements. Their architectural form combined with commercial signs on the facades, etc., helped to create a specific sense of belonging. The mikrorayon centres like ABC-5 in Tallinn, Žirmūnai in Vilnius, Imanta and Minsk in Riga, and several other shopping centres across the Soviet Union became symbols of new urban life and received publicity in architectural and propaganda press (Deveikienè 1980; Gaižutis and Grubevicius 1985; Ikonnikov 1975; Orentaite 1977; Pangsepp and Korp 1978; Tomberg 1975; Минкявичюс 1987; Страутманис et al. 1987).

This study focuses on mikrorayon centres built in post-war mass housing estates in Lithuania and Estonia, specifically Lazdynai and Šeškinè in Vilnius and Mustamäe in Tallinn. We argue that the theoretical model of multistage domestic services, as well the ideological and communal mission of the centres, was quickly reworked into a hybrid type of space embracing consumption and individual behaviour within the framework of collectivism.

Consumerism in the Soviet Union did not only appear on the symbolic level (like human desires or visual representation) but arose as a new direction in Brezhnev's party policy in the 1970s (Chernyshova 2013, 2016; Paretskaya 2012). Prime Minister Aleksei Kosygin had indicated the importance of accumulating reserves of consumer goods when he introduced economic reform in 1965. Likewise, Brezhnev declared during the Congress of the Communist Party in 1971 that Soviet citizens no longer had to sacrifice material comfort, and, with the promise of an abundance of consumer goods he indicated the replacement of the former ascetic discourse with a more consumer-oriented one, as depicted in Fig. 14.1 (Paretskaya 2012). To improve production efficiency, the government was offering workers material incentives (among other things) in the form of increased wages and rewards (Harrison 2002). In order to prove efficient, these incentives had to be matched by better stocked shops (Chernyshova 2016).

This chapter examines Soviet mikrorayon centres as historically and culturally situated spaces, suggesting that the modernist centres were the product and defining part of the hybrid nature of late-socialist society, imbued as it was with 

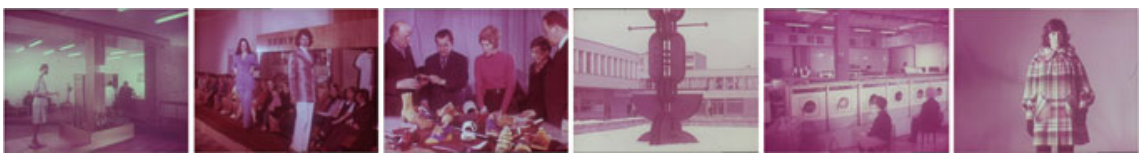

Fig. 14.1 Films promoting service centres in Lithuania. Stills from the movies 'I žiburèli', 'Juzè žengia per Lietuvą' and 'Sostinès servisas', 1970s. Created by Nota Liubošic in 1973 at Lietuvos kino studija. Source Lietuvos kino centras, used with permission

controversies and consistent ideological appropriations. Buildings and the built environment serve as important epistemological vehicles, therefore visual/ architectural material (including photos, plans, architectural sketches and drawings, etc.) form a primary source material for our research. Additional sources include archival material, brochures and propagandist picture albums. The wider meaning of the phenomenon of mikrorayon centres as Soviet consumer spaces emerges when placing the material in the context of general intellectual discussion and scholarly research on the late-socialist period in historical and cultural studies (see Yurchak 2006; Fürst 2010; Klumbyte and Sharafutdinova 2012; Chernyshova 2013; Feinberg and Kalinovsky 2016).

\subsection{From Neighbourhood Planning and ABC Towns to Soviet Mikrorayon Centres}

The first freely planned mass housing districts in the Soviet Union were drafted and planned in the second half of the 1950s - the experimental quarter of Novye Cheremushki in Moscow built between 1956 and 1958 being the first one-while the production lines of housing plants were running at full capacity from the $1960 \mathrm{~s}$ onwards. The new planning ideology introduced a unit-based approach at every scale. The planning of the whole districts and its constitutive micro-districts (known as mikrorayons in the Soviet Union), with schools, kindergartens, shops, primary services and entertainment facilities, were planned for 5000-10,000 residents. Small flats were organised according to a square metre-based standard of living space per person.

The roots of Khrushchëv's city planning policy branched in various directions: it contained both pre-Second World War Russian avant-garde ideas about urbanisation with the building as the social container (Charley 2004), as well as Western concepts which linked the concepts of garden cities and Clarence Perry's work on the neighbourhood unit (Perry 1929), the functional zoning of the city according to CIAM principles and state-subsidised development of social structures (Ojari 2004). Although Perry's reforms in city planning had some currency in the 1930s, they became the core of the "return to order" on both sides of the block in the post-war reconstruction years (Wakeman 2016). Yet there was a clear difference in emphasis. While the bedrock for social life in Western new towns was the young 
nuclear family, the homogenous, yet diffuse urban qualities of mikrorayons and small flats with existenzminimum kitchens served the ideals of (class) collectivity in the Soviet Union while preventing group differentiation and withdrawal into family privacy. However, in both Western and Soviet contexts, modernist mass housing estates could be considered as a strategy of political stabilisation (Ojari 2004; Wakeman 2016).

The first direct source from which Soviet city planning obtained theoretical examples was the International Union of Architects (UIA) Congress, held in Moscow in 1958, on the theme of reconstructing cities (Ojari 2004). The congress and the active cultural exchange that started in the late 1950s and included numerous architects' study trips to Finland, Sweden, England, etc., and subscriptions to Western architectural and planning journals in libraries, suggests that the principles of Soviet town planning were largely based on 'ready-made' examples. The design model of that time was the planning of Greater London in 1944, and in the Baltic republics, the Swedish and Finnish planning practices were especially influential.

An important source for planning local mikrorayon centres in the Soviet Union were ABC towns, a model which arose in Sweden in the 1950s. Arbete, Bostad, Centrum ('work, living, centre'), as it was known in Swedish, referred to a multifunctional satellite city that combined housing with workplaces and a local centre. The principle of ABC towns was first formulated by Sven Markelius in 1945, who applied the housing scheme in the spirit of British New Towns that featured diverse housing centred around a local centre (Poom 2005; Rudberg 1998). The idea was first put into practice in the Vällingby residential district (1950-1954, architect Sven Markelius) in western Stockholm. The Vällingby centre (1953-1955, architects Sven Bäckström and Leif Reinius) was also the first district centre in Northern Europe to introduce the commercial pedestrian precinct based on the model of Lijnbaan in Rotterdam (built 1948-1953). Vällingby fostered a building ideology based on the enthusiasm for collective living, which sprouted in 1930s Sweden. Even so, Vällingby remained an experiment. Providing sufficient work opportunities turned out to be a real problem as the distance from Stockholm-the main attraction in the region — was too small (Poom 2005). Farsta — the next satellite city that came out of Markelius' desk - was already a BC town ('Bostad, Centrum') in essence, as the residents worked in the city while the district centre mainly included commercial uses similar to North American shopping malls (Rudberg 1998).

The Swedish ideal of collective living — based on the idea of equality, according to which everybody was to be guaranteed equally high living standards-was more appropriate for the Soviet housing ideology than the Dutch or English models, which mainly involved building social housing that in the long run produced serious problems of segregation (Ико́нников 1978). Beyond a doubt, Vällingby, together with the Tapiola centre near Helsinki (design 1953-1955, completed 1961, architect Arne Ervi) that repeated the spatial and functional solution of the former, had an iconic position in the Soviet Union, and they were often reproduced in Soviet architectural literature published during the 1960s and 1970s (Васильев 1960; Васильев et al. 1958; Ико́нников 1967; Ико́нников 1978). These two 
housing estates, especially Tapiola, were frequently visited in the 1960 s by Estonian, Latvian and Lithuanian architects, and thus became the most significant model for mikrorayon centres in new housing estates in the Baltics (Bruns 1961; Drèmaitė et al. 2012; Hallas-Murula 2005; Mirov 1965; Mačiulis 2008; Ojari 2004; Väljas 2016).

While the Vällingby and Tapiola centres served as architectural role models for mikrorayon centres, the idea of self-service supermarkets became topical in the Soviet Union after Khrushchëv's visit to the United States in 1959. The rationalising impetus behind opening self-service supermarkets (universams) in the Soviet Union was similar to the retail trade in the capitalist economies: savings on staff costs and more efficient and quicker shopping for larger amounts of goods by the consumer. Yet, the phenomenon of supermarkets was more about a transnational transfer of culture and practice rather than an Americanisation of shopping, as retail experts from Eastern Europe also gathered knowledge about self-service and supermarkets during the trips to West Germany, Switzerland and Sweden (Trentmann 2012).

For the functional planning of the mikrorayon centres, the scientific organisation of service provision became a part of the technocratic rhetoric at that time. Experts were responsible for selecting how to organise supply and how to plan service infrastructure. Everything was calculated, measured and divided into different hierarchical levels. Such an approach was used not only for mikrorayon planning, but for the whole city and even the country. For example, cities and towns were divided by importance (state significance, regional significance). Based on the size of the city and its level of importance, infrastructures of different sizes and typesi.e. hotels, theatres, service centres-were planned and financed. A similar approach was used when planning housing districts.

In the early 1960s, a 'multi-stage domestic service system' was used to designate subsidiary functions planned in the housing estates in Lithuania and Estonia (Arman 1963; Aronas 1969; Tippel 1963). The network of public services was organised by dividing service buildings into several levels as shown in Fig. 14.2. Kindergartens and nurseries, schools, self-service shops, bakeries, and stores selling household goods were considered services of everyday use. It was a requirement to ensure a quick and safe pedestrian route from housing to these service places. The second category with periodic use consisted of workers' clubs with theatre halls, cinemas, bank and post offices, hairdressing salons, universal shops, music and art schools, libraries, sport complexes, outpatient (poly) clinics, pharmacies, laundries and dry cleaners. These functions were usually grouped into mikrorayon centres, or main centres that were easily accessible by foot or by public transport (one or two stops) (Tippel 1963; Vanagas 2008). The third group included institutions, enterprises and cultural buildings, which were usually concentrated in the city centre and accessible from the districts' transport nodes in half an hour by using public transport.

In essence, the multiple stages of domestic services meant the planning of services according to the primary and secondary needs on the district or micro-district scale (rayon and mikrorayon). For example, Lithuanian urbanist Jurgis Vanagas 
2.14 pav. Gyvenamosios zonos modelis, sudarytas pagal laips. nišką aptarnavimo sistemą:

1 - mikrorajon 4 centrai, 2 - gyvenamuju rajony centrai, 3-miesto centras, 4-pramonés rajono centras, 5- poilsio zonos centras, 6 specializuoti centrai

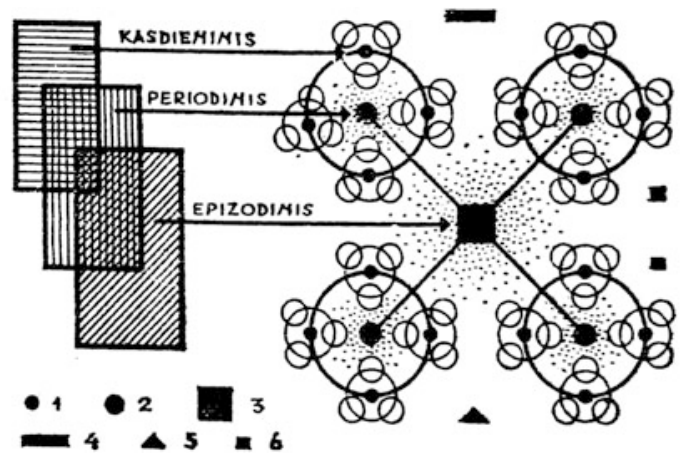

Fig. 14.2 Schematic of multistage domestic service system. Source Kazimieras Šešelgis, Rajoninio planavimo ir urbanistikos pagrindai, Vilnius: Mintis, 1975

described rayon as a territory composed of several mikrorayons, a park, a sport stadium and rayon centre with multistage domestic services (Vanagas 2008). A public or rayon centre was an important element, not only functionally but also compositionally: the main public space was located around it, often with representational symbols (a sculpture, a fountain or a square). The maximum distance from the most distant apartment building to the rayon centre could be $800-1000$ metres and 400-500 metres from the mikrorayon centre (Vanagas 2008). Of course, such a strict division was possible only in theory and in locations where topography is quite simple. In reality, the rayon centres were in many cases never realised (Mustamäe, Lazdynai) as the building efficiency proved too low. There was constant pressure to erect more residential buildings as the shortage of flats was not alleviated due to steady immigration, and there were not enough time and resources to spend on finishing all the planned subsidiary functions.

\subsubsection{Mikrorayon Centres in Vilnius-From Žirmūnai to Šeškine}

During the Soviet years, Vilnius became the main testing ground for local architects and planners. The housing needs of city professionals and industry workers was growing, the city was expanding and more people were coming from smaller towns to study or work. As an answer to the general housing problem, the first groups of panel housing (series No. 1605A) were erected in the Naujamiestis eldership (the smallest administrative division in Lithuania), and later in Antakalnis and other parts of the city (Mikučianis 2000). Žirmūnai, the first full-scale mass housing district in Vilnius and Lithuania, was constructed from 1962 to 1969. In 1964, a new series of panel houses (No. I-464) was introduced (Čerbulènas and Glemža 1985) and thus the construction of new housing blocks became completely 
standardised (Reklaitė and Leitanaitè 2011). Together with a new wave of mass housing districts, a multistage domestic service system was put into use in Lithuania after 1962 (Balčiūnas 1974). The first mikrorayon centre was built in Panevėžys, with more built later in Kaunas and Klaipeda (Aronas and Balčiūnas 1969). The mikrorayon centre of Žirmūnai, built in 1969, was the first one built in Vilnius (architects A. Aronas, V. Ivanova and A. E. Paslaitis) (Petrauskas 1966). The main elements of the complex were a commercial centre with shops on the ground floor, and a restaurant, universal hall and library on the second floor (Čerbulènas and Glemža 1985). Behind it was a separate block with a tailor's shop, hairdresser, savings office, post office and domestic services. It was extended to one side, making the composition more dynamic and asymmetrical. This type of complex with its slight facade and functional modifications was repeated three times in the Žirmūnai neighbourhood (the centres Žirmūnai, Minskas and Šaltinèlis), twice in Lazdynai (the centres Lazdynai and Erfurtas) and in other cities as well.

Žirmūnai featured a sculpture called "Joy” (sculptor Kazys Kisielis). The interior of the post office was decorated, as was a restaurant where sculptor Teodoras Kazimieras Valaitis created an abstract mural from copper (Petrauskas 1966). All the attempts to decorate the centre show its role as a representational space for the district. A similar approach was implemented in other centres. For example, the most iconic pictures of the Lazdynai and Žirmūnai neighbourhood were taken in mikrorayon centres where the urban space was decorated with water ponds and sculptures, and was connected to pedestrian walkways as shown in Fig. 14.3. The restaurants located on the second floor of mikrorayon centres in Lazdynai and Žirmūnai were promoted as modern, fancy and desirable places and were photographed for albums and tourist brochures. Buildings and sculptures next to mikrorayon centres were part of the symbolism of new, modern Vilnius used for souvenirs.

The reason for such extensive publicity was partly because both Žirmūnai and Lazdynai were awarded for their designs. In 1968, the designers (architects Birute Kasperavičienè, Bronislovas Krūminis, engineers Vaclovas Zubrus and Smuelis Liubeckis) of the Žirmūnai central mikrorayon received the USSR State Prize and in 1974 the designers of Lazdynai (architects Vytautas Čekanauskas, Vytautas Brèdikis, Vytautas Balčiūnas, Gediminas Valiuškis and engineers Algimantas Kleinotas and Vincentas Šileika) were awarded the Lenin Prize. It was the first time a mass housing district received such recognition. As a neighbourhood influenced by Scandinavian examples (e.g. Tapiola), Lazdynai was presented as an example of how local architects were able "to subtly protect the beauty of nature and to find a harmonious relation between building volumes and the topography of the place" (Vileikis 1986, p. 45). Compared to Mustamäe in Tallinn, Lazdynai covers almost an equal area, but was planned for a much smaller population. In Lazdynai, the buildings were placed between the pine trees, while in Mustamäe the final configuration of the mikrorayons was determined by the logic of moving the cranes around the construction site (Kalm 2001).

Lazdynai, a district for 30,000 inhabitants, was almost fully planned according to the requirements of a multistage domestic service system with all three stages in 


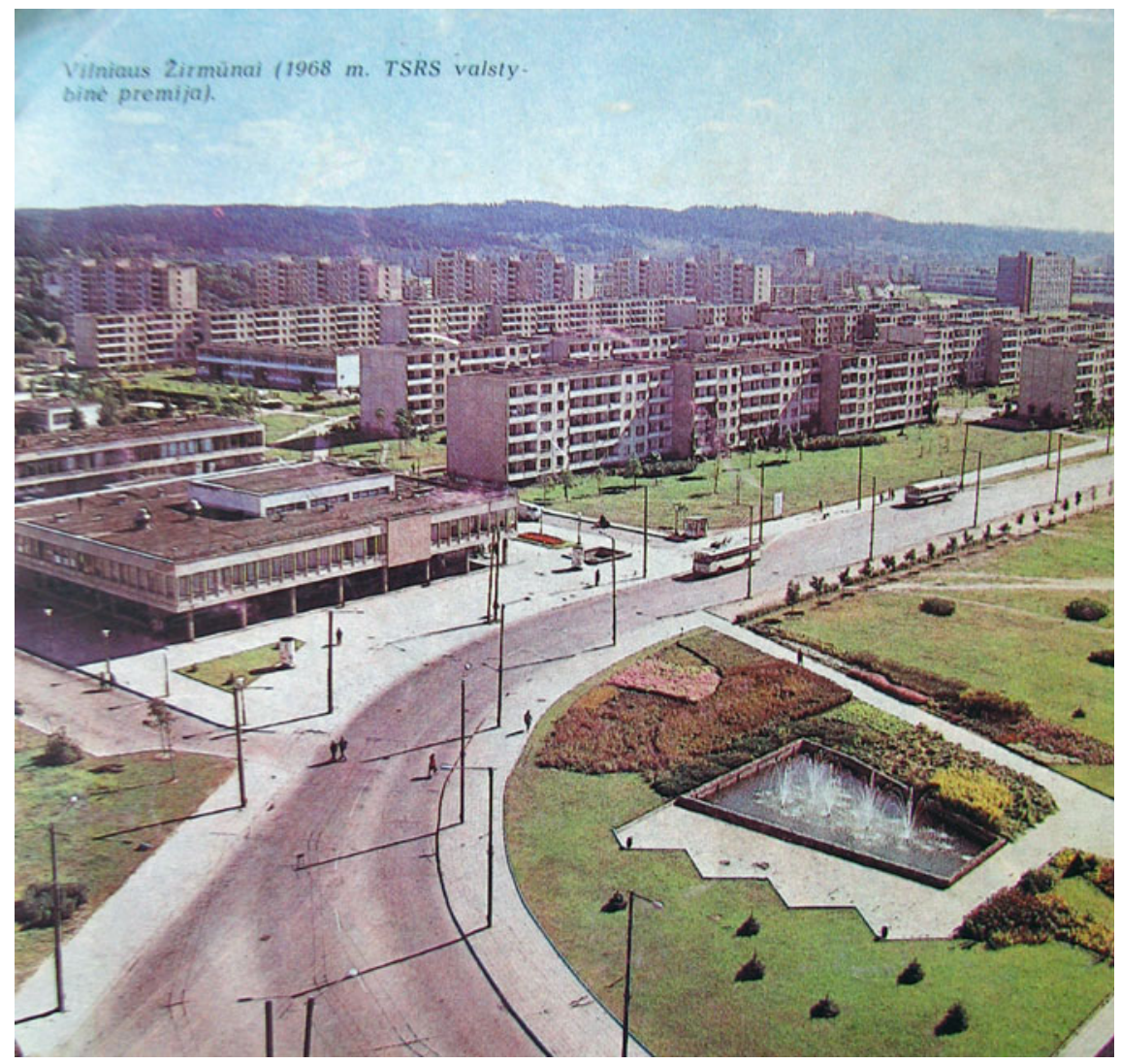

Fig. 14.3 Žirmūnai neighbourhood and the mikrorayon centre "Šaltinèlis", 1980s. Source Journal Statyba ir architektūra, used with permission

mind. Smaller shops were planned inside the neighbourhoods close to one's home, then bigger mikrorayon centres were planned next to inner micro-district streets, and finally, the main rayon centre (architect Česlovas Mazūras, 1966) was envisioned in the very middle of the whole housing area and close to public transport routes. Its impressive structure rising above the main road was reminiscent of the Vällingby centre, but it was too challenging and expensive to build so it was never realised (Grunskis and Šiupšinskas 2012). Two main mikrorayon centres (Erfurtas and Lazdynai) were built using modifications of the same standardised project as in Žirmūnai (standard project No. 3779_5). The third mikrorayon centre was replaced by housing blocks and the fourth one was a smaller and less elaborate building based on standard project No. LG 272-31-46, designed by architect Arūnas Eduardas Paslaitis (together with Aleksandras Aronas and engineer Maryte Kaklauskienè) (Buivydas 2000). It was almost a structuralist approach (Buivydas 2006) that consisted of several modular blocks with different functions. The 
modules made it possible to create multiple combinations or expand the centre in further stages (Balčiūnas 1970).

The multistage domestic service system that was used in Žirmūnai and Lazdynai looked nice in theory, though criticism began quite soon. First of all, it was hard to adapt standard projects to different needs and to use them together as one complex (Girčys 1971). Bigger commercial centres were often redesigned to fit a specific place, and that brought up the question of whether to use a standard project if it requires serious updates. At the same time, the theory on planning the locations of different services was already failing. First of all, the planners started to recognise that a mikrorayon is not a closed system and these centres are partly servicing other mikrorayons and housing districts (Girčys 1971). Second, it was more economical to maintain bigger centres rather than a number of smaller shops. Initially building smaller places of 'primary services' - where inhabitants could place their orders, use vending machines, and which contained a small canteen, meeting spaces, childrens' spaces and workshops - was attempted for different groups of houses (Aronas and Balčiūnas 1969). It was based on the idea that an individual apartment was used only for the most private of needs with all other services planned as communal.

However, this idea did not function as intended and the trend shifted towards more concentrated service centres. It was not only the planning that failed, but the distribution and the supply system, as well. Jokes about queuing next to a shop without knowing what they were selling were widespread. The dispersive domestic service system attracted more and more criticism over the years (Čaplikas 1987). For example, it was claimed that separate shops were too small and so it was hard to provide a full range of products which left customers with a limited choice. The most radical attempt to concentrate public functions appeared in the Šeškine district (built 1979-1985, architect Kazimieras Rimantas Balènas) (Bielinis 1988), where only one main rayon centre (built in 1981-1986, designed by multiple architects) was designed and built for all six mikrorayons and without any individual mikrorayon centres at all. Thus, the mikrorayon centres and separate service buildings were almost completely removed from the design.

The buildings in the Šeškinè centre were oriented towards the inside, where an internal square, shown in Fig. 14.4, with clock tower and a water basin were placed. The centre was planned as an organic urban structure that would change and evolve depending on needs (Mačiulis 2009). The idea of the building as a freestanding object in space was rejected, and designers tried to create a complex composition with shopping passages and elevated galleries with different levels of public space. The red brick, new triangular floor slabs and glued wood beams that were used in the designs were not easily available, which shows that the Šeškinè rayon centre was considered an important project. In its attempt to go beyond the usual practice of service centre design (Kulikauskas 1986), the project received a lot of attention and was awarded the Prize of the Council of Ministers of the USSR in 1987 (Reklaite and Leitanaite 2011). Despite the fact that the concentrated rayon centres built in Šeškinè and Justiniškès were considered successful practices to be 


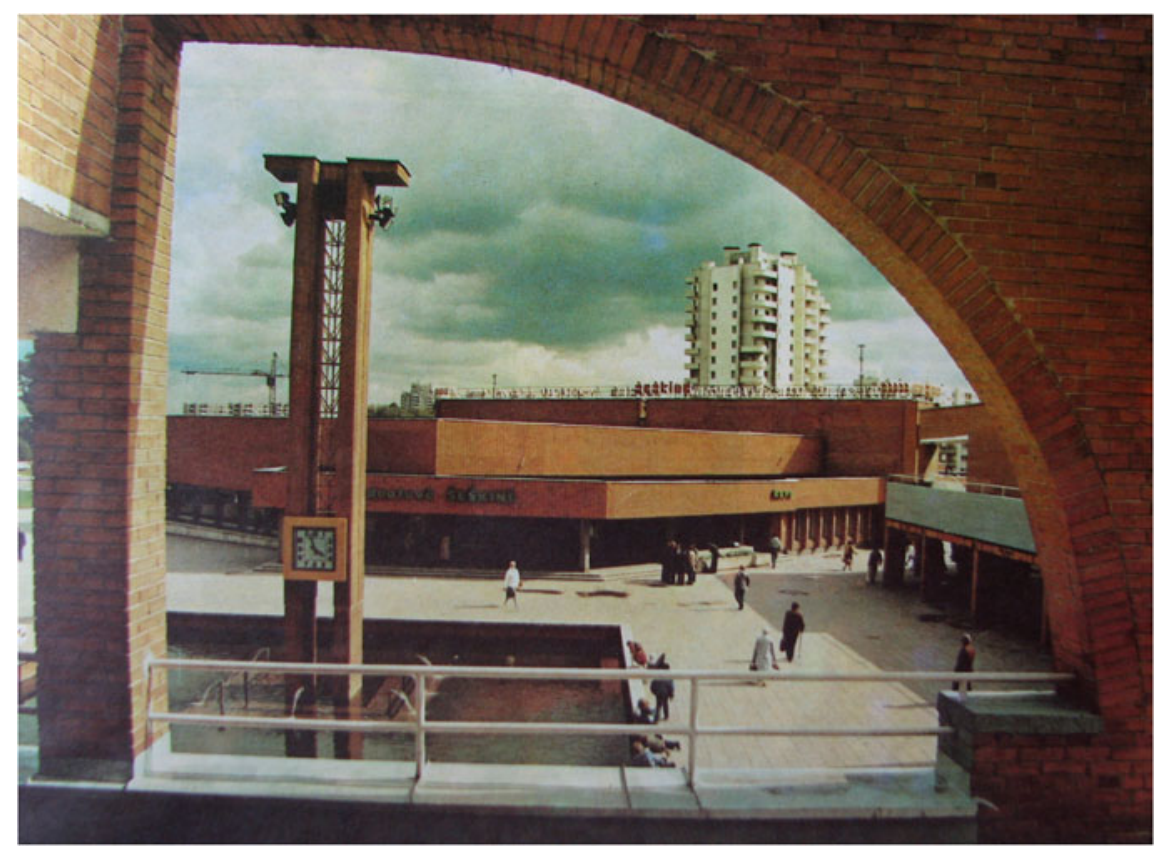

Fig. 14.4 Clock tower and fountain in the Šeškinè rayon centre, 1980s. Source Journal Statyba ir architektūra, used with permission

continued in future districts (Vèlyvis 1988), Pašilaičiai and Fabijoniškès were never fully completed because of ascendant political and economic changes.

The development of rayon and mikrorayon centres in Vilnius mark the transition from the theoretical and technocratic idea of a multistage domestic service system to more concentrated, bigger commercial centres where a greater variety of products and services were available. At the same time, it shows how different ideas from outside were shaping the value system of local professionals. Scandinavian modernism and planning practices were used as a progressive role model until the poor and limited local construction industry turned it into a cliché. Also, the priorities were slowly moving towards exceptional aesthetics and individuality.

\subsection{ABC Centres in Mustamäe and Other Housing Estates in Tallinn}

As in the general building history of the USSR, the story of mikrorayon centres in new residential districts in Estonia is similarly marked by changing and partly unrealised ideas. Mustamäe in Tallinn was one of the first modernist housing estates in the Soviet Union based on the ideas of free plan and pre-fabricated concrete 
construction. The competition for the area took place in 1958 (winning architects Voldemar Tippel, Lidia Pettai, Toivo Kallas and engineer Aleksander Prahm) and the building of the district that was planned for 60,000 inhabitants started in 1962 and lasted for ten years. In the 1970s, Väike-Õismäe (planned in 1968 by Mart Port and Malle Meelak), a district for 40,000 inhabitants based on the idea of a circular town, was built. The third large housing estate in Tallinn, Lasnamäe (master plan 1970-1976 by Mart Port, Malle Meelak et al.) was established for 200,000 inhabitants and would be divided into 11 double-size mikrorayons (with 12,000 18,000 people each) with large centres located near the thoroughfare with pedestrian overpasses and stops for public transport. Several of Lasnamäe's new planning ideas and none of the mikrorayon centres were completed as intended.

In terms of architectural history, Mustamäe mikrorayon centres are important as they set a model for a whole new building typology and corresponding architectural aesthetic in Estonia. Similar low-rise supermarkets with cubic volumes and glass walls covered with horizontal roof plates and projecting cornices were erected during the 1970s and the early 1980s in several Estonian cities and kolkhoz settlements in the countryside. In 1966, the plan for the public houses in Mustamäe prescribed the functional and spatial use of the centres that provided a vision of the routine and lifestyles of Soviet citizens. By 1966, the first mikrorayons were completed, emphasising shortcomings in services and architectural solutions that in turn led to a decision to abandon the idea of the so-called separate pavilions of primary services and instead integrated different functions. These included grocery and household stores, services (shoe repair, laundry, hairdresser, etc.), as well as ideological education and social activities (the so-called "red corners"). The design of the mikrorayon or the so-called ABC centres was part of the detailed planning and building process of mikrorayons, though the numbers (ABC-2, ABC-3, etc.) did not necessarily indicate the actual order of completion of mikrorayons or their centres. Completing the centres took altogether nearly 20 years. The main reasons were the forced construction of residential houses that pushed public buildings to the background and the shortage of materials and different resources that resulted in a loss of building capability in the 1970s.

Initially planned as standardised buildings, the ABC centres were nevertheless built according to individual designs. Their common visual and architectural identity was constructed through a recognisable spatial and visual form: a compact public space surrounded by low-built volumes, and pedestrians moving between different shops and services (food and everyday products, culinary or takeaway food, hairdressers, shoe makers, photo studios, dry cleaning shops, the municipal housing office, as well as different social functions like a universal hall used for sports or gatherings, a café or a restaurant). Their architectural vocabulary included rational form, and the buildings were fitted with red brick facades covered with flat roofs with wide overhanging cornices. The facades adjoining the pedestrian precinct had huge windows, so walking by was similar to passing a shop window in traditional urban centres. The main public area was decorated with a pool or fountain, or an abstract sculpture in some cases. The new urban collective life was to be fully epitomised in a new centre for the entire Mustamäe district (the 1964 
competition was won by Toivo Kallas and Raine Karp, with the final design made by Raine Karp in 1972). It was planned to house, in addition to everyday services and shops, a 1000-seat cinema, a dance club, and various eating establishments from diners to restaurants. In the spirit of commercial centres in Vällingby and Tapiola housing estates, the composition of the winning design for Mustamäe emphasised the contrast of low-rise buildings in the shopping centre with a tall adjoining tower block. Various staircases provided access to multilevel vertical spatial arrangements, and covered inner courtyards formed compact, self-contained urban spaces (Mustamäe elamurajooni ühiskondliku keskuse projektide võistlusest 1965; Ojari 2000).

As the main district centre was planned in a neighbouring area at the same time, only the small, primary service pavilions were built in the first two mikrorayons (No. 1 and No. 3) in Mustamäe. The first multifunctional social and commercial centre in Mustamäe was built in the mikrorayon No. 2; it had a low rectangular U-shaped volumetric solution with a brick-façade and a flat roof with a wide, dark painted cornice-elements influenced by Scandinavian modernism that would prevail in later ABC centres. There was a grocery store (not a self-service supermarket yet), different services and a restaurant as well as a house of games-a bigger hall serving as the communal gathering spot and housing different events and activities for children and adults. The first ABC-centre was an oasis to some extent, although the open area leading to one of the main streets in Mustamäe did not permit a more enclosed space as in the centres designed later. ABC-4 (1965-1969, architects Paula Koido, Enno Talgre), shown in Fig. 14.5, contained the first supermarket built in Tallinn and it also was the first centre to be named an ABC centre. The layout has an exceptionally outgoing character, resembling a classic urban living quarter: various sections of buildings are placed with their 'backs' together, forming in this case a closed technical courtyard inside the 'quarter' while leaving the public area scattered along the perimeter of the whole complex.

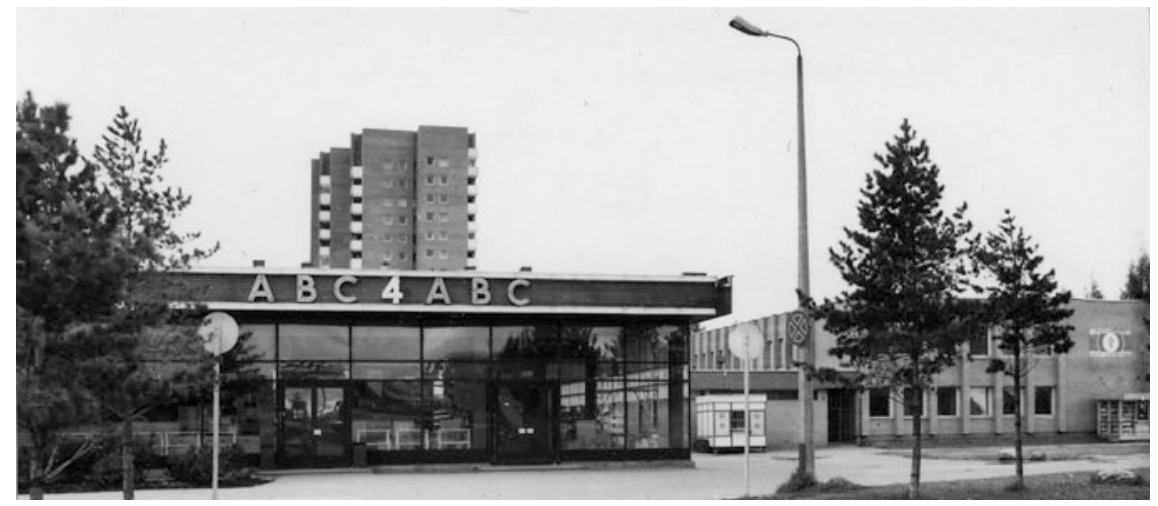

Fig. 14.5 ABC-4 in Mustamäe, Tallinn. Architects Paula Koido and Enno Talgre, built 19651972. Photo from the 1980s. Source Museum of Estonian Architecture, used with permission 
The visual and architectural parameters of $\mathrm{ABC}$ centres reached their height with ABC-5 (1963-1970, architect Peep Jänes), considered to be the most representative one in Soviet Estonia. Wide stairs placed on a sloping terrain led from a bus stop on a main street to a busy pedestrian area lined by low buildings placed freely under flat roof 'plates'. The centre was comprised of different stores (food, household, culinary), services, a universal hall and a famous restaurant Kännu Kukk. The outer perimeter of the centre had blind brick walls and emphasised the idea of an enclosed island in the midst of a monotonous built environment. The inner urban street, with open glass walls and its consumer aesthetics with different signs (bread, milk, gastronomy, etc.), shown in Fig. 14.6, invited social interaction.

A new approach to urban life in Mustamäe can be seen in ABC-6 (designed 1968, completed in the early 1980s, architect Miia Masso), which was probably the first building in Estonia to play with the Team-X idea of multilayered urban space and life on various levels. ABC- 6 is a complete structure that contains a complicated organism. The lower volume of the supermarket intersects with the higher volume of the services building, where smaller shops and workshops are located on an open shopping street, which is on the upper level of the building.

ABC-8 (1970, architects Tiiu Argus and Vivian Lukk), continued the motif of a building raised on a slope, as in the case of $\mathrm{ABC}-5$, yet here the one-directional elongated low structure formed a public area in front of the building enhanced by pine trees, a pool and a sculpture. The open public area in front of the building was, likewise, one of the main features of two later and smaller ABC centres (ABC-3,

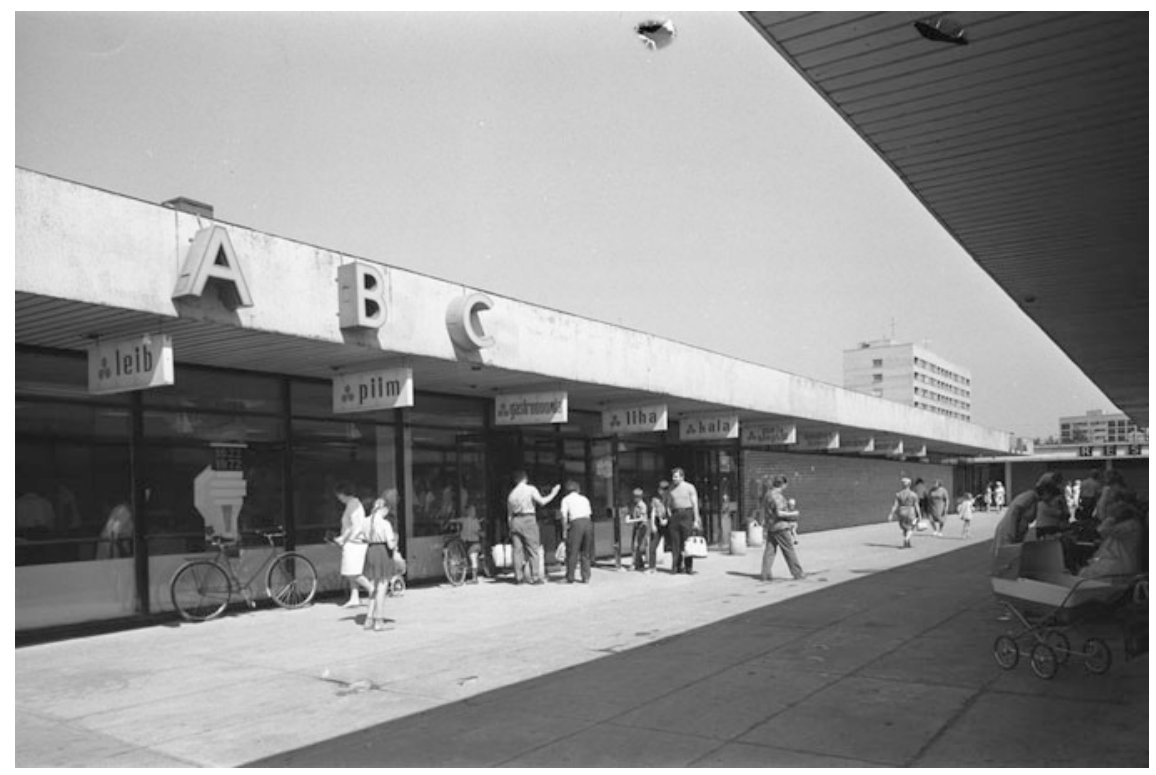

Fig. 14.6 Pedestrian area of ABC-5 in Mustamäe, Tallinn. Architect Peep Jänes, built 1963 1970. Photo by J. Budakov (1972). Source Estonian Film Archives, used with permission 
ABC-7) that were architecturally less impressive than the earlier ones. As the next mass housing estate built in Tallinn, Väike-Õismäe, was one large macro-district instead of several micro-districts, three smaller social and commercial centres were planned in the area-Õismäe-1 (1975, architect Lembit Aljaste) being the most representative one. The architectural aesthetic, as in the first mikrorayon centre in Lasnamäe (1978, architect Helje-Reet Aurik), was derived from Mustamäe's ABC centres that by the end of the 1970s was aesthetically outdated. The next supermarkets in Lasnamäe, built in mikrorayons No. 2 and No. 3 (named Kotka and Leningrad, respectively) and both designed by Lembit Aljaste in the early 1980s, introduced a new architectural logic. As they were meant to be part of the large mikrorayon centres stretched on both sides of the main traffic artery bridged by pedestrian overpasses and marked by adjoining tower blocks, as depicted in Fig. 14.7, their more compact yet more massive architectural solution derived from the idea of a complex urban nodal point that is accessible from different levels. Although none of the mikrorayon centres was completed as planned in Lasnamäe, the idea of large centres - double the size of Mustamäe's ABC centres - introduced a new approach to planning services in the district. The three-stage domestic service model was considered to be out of date when planning Lasnamäe, and the concept of a 'functional service scheme' was introduced instead (Meelak 1976). This meant that periodic services like the cinema, library, sauna, clubhouse, etc., were brought into the mikrorayon centre. The new approach retained the 500-m service radius and increased the number of inhabitants in the mikrorayon to 18,000. This, in turn, meant planning fewer but larger centres that would help to lower the costs and at the same time enlarge the assortment in the shops and introduce new services (Meelak 1976).

The designs for ABC centres and other mikrorayon centres, as well as the actual built and visual environment in Mustamäe, Väike-Õismäe and Lasnamäe, illustrate not only the transformation and shifting emphasis of neighbourhood planning ideas in Estonia, but also the imagery and changing scenery of urban practices like shopping and socialising.

\subsection{Conclusion: Mikrorayon Centres Function as Soviet Consumer Spaces}

The mikrorayon centres in Lithuania and Estonia connected with changes in lifestyle that emerged on the level of simple everyday habits and routine, e.g. buying food products in self-service shops. The centres were the first to introduce self-service supermarkets in Estonia and one of the first in Lithuania where all food and household products could be purchased from one place instead of a series of small specialty shops. In addition to everyday changes, the transformative role of the mikrorayon in Estonian and Lithuanian centres can be seen on the level of 


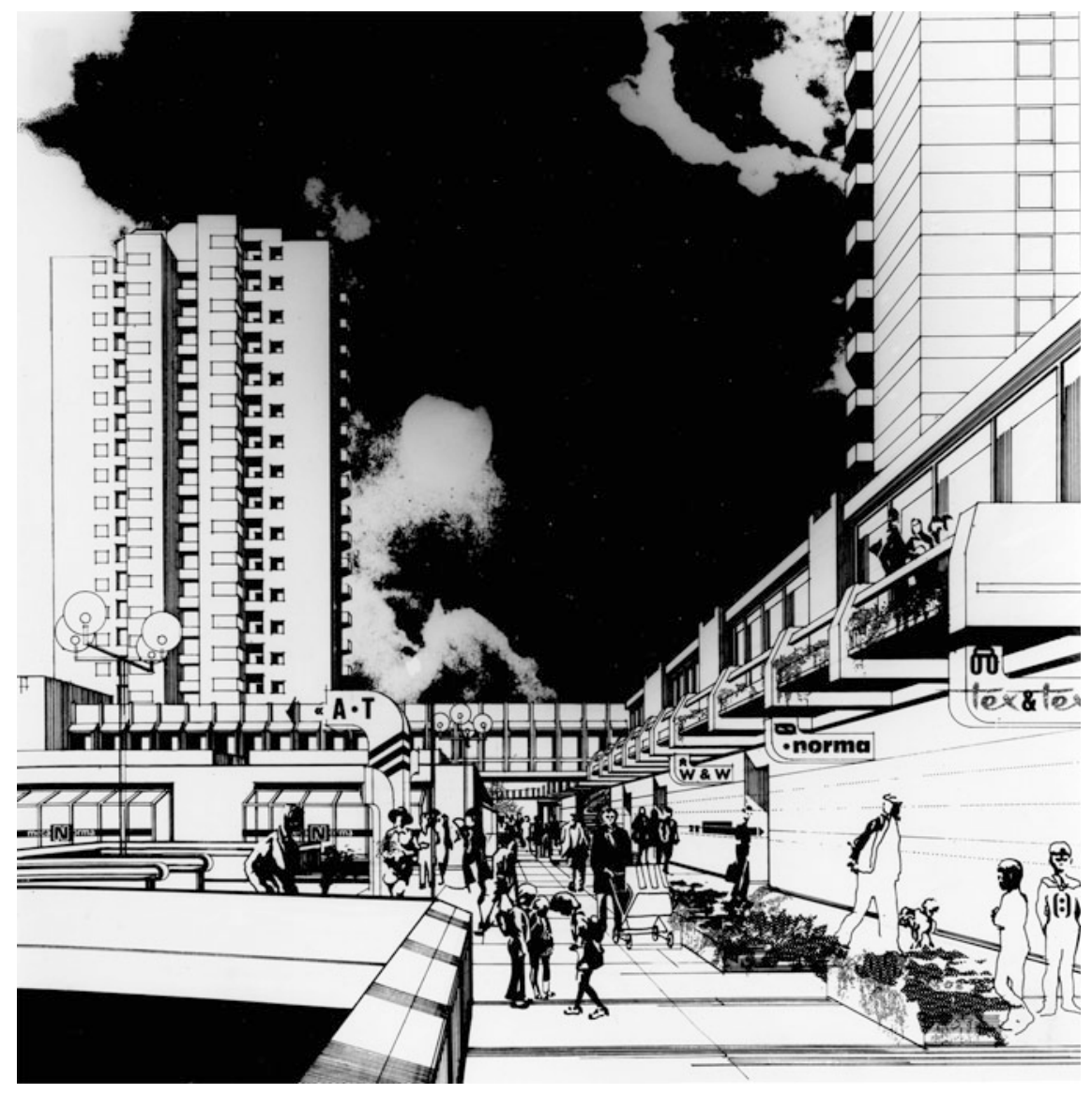

Fig. 14.7 Mikrorayon centre in Lasnamäe, Tallinn. Drawing by Mart Port. Source Museum of Estonian Architecture, used with permission

representation: architecture, urban landscape design, as well as specific building materials (e.g. red brick), had a specific importance in image creation.

In both countries, ensuring proper services to modern citizens was initially based on the conceptual model of a multistage domestic service system. Thus, the differences between the two cities appear on architectural rather than ideological grounds. In Vilnius, the construction of the first centres in Žirmūnai and Lazdynai was in accordance with the demands of industrialisation and rationalisation, as they were built according to standard designs based on module systems, while all the centres in mass housing estates in Tallinn used individual designs that were influenced by organic Scandinavian modernism. The Scandinavian influences appeared in Vilnius in the planning schemes and general milieu (e.g. Lazdynai), as the architectural solutions of mikrorayon centres applied more functionalist and structuralist approaches. The aura of novelty that surrounded the newly built centres 
in Tallinn in the late 1960s and early 1970s was not so much about architectural innovation, but was rather due to the whole new approach to the everyday living environment and the fact that the architectural aesthetics that were known from exceptional public buildings (e.g. the Helsinki-Tallinn Ferry Terminal or the Flower Pavilion) were brought into the everyday environment. By the late 1970s, Scandinavian modernism was already obsolete, and the centres in Väike-Õismäe are examples of a stereotypical approach in supermarket design. The 1980s marked a shift in the architecture of mikrorayon centres that were perhaps more evident in Vilnius. The Šeškinè centre was exceptional in rethinking the idea of a communal service building and the practice of shopping with novel structural solutions, while the mikrorayon centres built in Lasnamäe in Tallinn merely illustrate the shortcomings of the new paradigm that tried to go beyond the three-stage domestic service system.

Despite these different architectural specificities, the mikrorayon centres in both cities differ from the unified industrial appearance of district apartment buildings, and as such acquired a symbolic function as urban signs. As there were no other meaningful places in the homogenous environment consisting of pre-fabricated housing, the centres, both architecturally and functionally different from the rest of the urban settlement, were also ascribed a new kind of meaning. The role of mikrorayon centres as locales of identity (i.e. places where people mentally anchor themselves) has emerged from the memories of the people living in Mustamäe at the time and who emphasise the role of $\mathrm{ABC}$ centres in their cognitive maps of the district (Lankots and Sooväli 2008).

Identity formation in idealistic spaces like Soviet mikrorayon centres is related to complex tension between the public and the private in a socialist state. One of the main differences between Soviet and capitalist consumer spaces, in spite of their common simulative urban qualities, was the visibility of their ideological content. Capitalist commercial spaces can be described as semi-public, urban-like spaces that seemingly allow the experience of freedom or sense of public place in an area controlled by private interests (Lahti 2003). In a communist state, consumer space, a public area in its essence, could be described as overtly ideological and prescribing collective behaviour but at the same time encouraging individuality on a symbolic level through architecture and visual aesthetics. David Crowley and Susan Reid (2002) have suggested the shifting meanings of public and private within socialism, where not only the private is contested by the public (e.g. tearing down fences in the historic areas of Tallinn and liquidating private courtyards), but also the public sphere took on various social meanings apart from ideological ones. Collective consumption that was detached from the direct political meaning of collectivity is one example. In reality, the consumer experience turned out to be somewhat different from the rhetoric of the party promise of the coming abundance of consumer goods. Yet, as Paretskaya notes, it was not the goods themselves that mattered but the lifestyles they represented and encouraged (Paretskaya 2012). Thus, we believe, the spatial features and visual aesthetics of the mikrorayon centres embody socialist consumer culture according to a specific logic that differs from Western consumer society. As Crowley notes: "What defines a modern 
[Socialist] consumer society is not access to consumer goods but knowledge of them. In this regard, the role of advertisements, magazines and other forms of publicity is key" (Crowley 2017). Although access to branded goods, fashionable clothes or luxury products, like cars, was limited, people were aware of the aesthetic codes which accompanied modern consumerism. Accordingly, 'socialist consumerism' across the Eastern Bloc was a phenomenon found largely in the realm of images rather than things (Crowley 2017).

As such, mikrorayon centres represent socialist spaces that go beyond an ideological understanding of space and are described by a shifting and multilayered interaction between spatial organisation, expression and use (Crowley and Reid 2002). Consequently, the mikrorayon centres - while marking the ideological programme and changing trajectories of planning thought and habitation modelsrepresent a peculiar type of spatiality where conflicting value systems do not exclude each other but instead interact. Mikrorayon centres, both in Lithuania and Estonia, were built as public collective spaces and at the same time, through architectural imagery and visual codes, encouraged individual behaviour and values based on consumption and self-determination. When correlating the social and economic transformations of the last 15 years, the symbolic and functional importance of the mikrorayon centres in Vilnius and Tallinn has changed considerably. Besides being inaccessible to car traffic or with limited parking possibilities, poor maintenance and a partially reconstructed and partially deteriorating physical state reflect the divided ownership of the buildings. Similarly, the new functional scheme containing stores like budget supermarkets, second-hand clothing stores, pawn shops and casinos are rather illustrative of their present marginal position. Yet, the marginalisation of $\mathrm{ABC}$ centres cannot automatically be related to the deficiencies of modernist housing estates, for which identities are in transition today. As school and kindergarten networks as well as health and medical services are well developed in these residential districts, housing estates still remain important living areas in Vilnius and Tallinn.

Today, new shopping centres with gyms, cinemas, restaurants and speciality shops have been built near the main roads leading through the housing estates and are making efforts to acquire not only the status of district centres, but function as attractive entertainment centres for a larger part of the city. The former mikrorayon centres have remained in use mainly by first-generation residents of the housing estates, who are now retired. Transformed shopping practices in Soviet mass housing estates illustrate the shift from fulfilling the primary needs of Soviet citizens to the lifestyle and entertainment practices of post-socialist society.

Acknowledgements The research was funded by the Estonian Research Council [grant no. IUT32-1]. 


\section{References}

Arman H (1963) Elamurajoonidest ja elamukompleksidest. Linnaehituse küsimusi Eesti NSV-s. Eesti NSV Ministrite Nõukogu Riiklik Ehituse ja Arhitektuuri Komitee, Tallinn, pp 31-36

Aronas A, Balčiūnas V (1969) Mikrorajonų visuomeniniai-prekybiniai centrai. Statyba ir architektūra 11:7-9

Balčiūnas V (1970) Naujas kompleksas miestų mikrorajonams. Statyba ir architektūra 11:1-3

Balčiūnas V (1974) Apie gyventojų aptarnavimo sistemas ir kompleksus. Statyba ir architektūra $2: 2-5$

Bielinis J (1988) Lietuvos TSR istorijos ir kultūros paminklų sąvadas 1. Vyriausioji enciklopedijų redakcija, Vilnius

Bruns D (1961) Tapiola. Eesti NSV arhitektuur. Artiklite kogumik. Riiklik Ehituse ja Arhitektuuri Komitee, Tallinn, pp 46-50

Buivydas R (2006) Architektūra: pozityvai ir negatyvai. Ex Arte, Vilnius

Čaplikas V (1987) Prekybos centrai Vilniuje. Klaidos kartojamos. Statyba ir architektūra 9:20-21

Čerbulènas K, Glemža J (1985) Vilniaus architektūra. Mokslas, Vilnius

Charley J (2004) The concrete memory of modernity: excerpts from the Moscow diary. In: Hvattum M, Hermansen C (eds) Tracing modernity: manifestations of the modern in architecture and the city. Routledge, London, pp 195-213

Chernyshova N (2013) Soviet consumer culture in the Breznev era. Routledge, London, New York

Chernyshova $\mathrm{N}$ (2016) Consumers as citizens: revisiting the question of public disengagement in the Brezhnev era. In: Feinberg D, Kalinovsky AM (eds) Reconsidering stagnation in the Brezhnev era: ideology and exchange. Lexington Books, Lanham, pp 3-20

Crowley D (2017) 'Consumer art' and other commodity aesthetics in Eastern Europe under communist rule. https://faktografia.com. Accessed 3 Oct 2017

Crowley D, Reid SE (2002) Socialist spaces: sites of everyday life in the Eastern bloc. Berg, Oxford, New York

Deveikienè O (1980) Vilnius. Mintis, Vilnius

Drèmaitė et al (2012) Architektūra sovietinèje Lietuvoje. Vilniaus dailès akademijos leidykla, Vilnius

Feinberg D, Kalinovsky AM (eds) (2016) Reconsidering stagnation in the Brezhnev era: ideology and exchange. Lexington Books, Langham

Fürst J (2010) Stalin's last generation: soviet post-war youth and the emergence of mature socialism. Oxford University Press, Oxford

Gaižutis A, Grubevičius A (1985) Vilnius. Mintis, Vilnius

Girčys G (1971) Dẻl prekybos objektų nomenklatūros. Statyba ir architektūra 12:6-8

Grunskis T, Šiupšinskas M (2012) Tarybinio laikotarpio viešujų erdvių transformacijos Lietuvoje. Vilniaus Žirmūnų ir Lazdynų atvejis. J Arch Urban 36:209-221. https://doi.org/10.3846/ 20297955.2012.732492

Hallas-Murula K (2005) Soome-Eesti: sajand arhitektuurisuhteid. Eesti Arhitektuurimuuseum, Tallinn

Harrison M (2002) Economic growth and slow-down. In: Bacon E, Sandle M (eds) Brezhnev reconsidered. Palgrave MacMillan, Basingstoke, pp 38-67

Ikonnikov A (1975) Soviet architecture of today: 1960s-1970s. Aurora Art Publishers, Leningrad

Kalm M (2001) Eesti 20. sajandi arhitektuur. Prisma Prindi Kirjastus, Tallinn

Klumbyte N, Sharafutdinova G (2012) Soviet society in the era of late socialism, 1964-1985. Lexington Books, Lanham

Kulikauskas P (1986) Šeškinès centras - bendravimas su žaviu kaprizingu vaiku. Statyba ir architektūra 6:10-12

Lahti J (2003) Tapionraitti - the backbone of the pedestrian precinct. In: Tuomi T (ed) Tapiola. Life and architecture. Building Information Ltd., Helsinki, pp 59-82

Lankots E, Sooväli H (2008) ABC-keskused ja Mustamäe mikrorajoonide identiteedid. Kunstiteaduslikke Uurimusi/Stud Art Arch 17(4):88-113 
Mačiulis A (2008) Permaningi metai. Architekto užrašai, Vilniaus dailès akademijos leidykla, Vilnius

Mačiulis A (2009) Kęstutis Pempè: architekto biografija. Archiforma 2:42-48

Meelak M (1976) Lasnamäe projekteerimistöödest. Ehitus ja Arhitektuur 2:12-17

Mikučianis V (2000) Noréjau dirbti Lietuvoje. Vilniaus dailès akademijos leidykla, Vilnius

Mirov B (1965) Arhitekti tähelepanekud Soome reisilt. Ehitus ja Arhitektuur 1:41-43

Mustamäe elamurajooni ühiskondliku keskuse projektide võistlusest (1965) Ehitus ja Arhitektuur $2: 31-37$

Ojari T (2000) Modernismi parameetrid: Mustamäe kujunemisest. In: Hallas K (ed) Kümme. Eesti Arhitektuurimuuseumi Aastaraamat. Eesti Arhitektuurimuuseum, Tallinn, pp 49-64

Ojari T (2004) Elamispind. Modernistlik elamuehitusideoloogia ja Mustamäe. Kunstiteaduslikke Uurimusi/Stud Art Arch 13(2):42-65

Orentaite B (1977) Vilnius. Mintis, Vilnius

Pangsepp R, Korp M (1978) Nõukogude Eesti. Eesti Raamat, Tallinn

Paretskaya A (2012) A middle class without capitalism? Socialist ideology and post-collectivist discourse in the late-soviet era. In: Klumbyte N, Sharafutdinova G (eds) Soviet society in the era of late socialism, 1964-1985. Lexington Books, Lanham, pp 43-66

Perry C (1929) The neighborhood unit: a scheme of arrangement for the family-life community. Regional Plan of New York and Its Environs, New York

Petrauskas J (1966) Visuomeninis prekybinis centras. Statyba ir architektūra 8:28

Poom J (2005) Housing policy in Sweden 1945-2000. In: Kalm M, Ruudi I (eds) Võistlevad õnned. Elukeskkond külma sõja sõja perioodil/Constructed happiness: domestic environment in the cold war era. Eesti Kunstiakadeemia, Tallinn, pp 239-252

Reklaitė J, Leitanaitė R (2011) Vilnius 1900-2012. Naujosios architektūros gidas, Baltos lankos, Vilnius

Rudberg E (1998) Building the welfare of the Folkhemmet 1940-60. In: Caldenby C et al (eds) Sweden: 20th century architecture. Prestel-Verlag, München

Tippel V (1963) Suur-Tallinna probleemidest. Linnaehituse küsimusi Eesti NSV-s. Eesti NSV Ministrite Nõukogu Riiklik Ehituse ja Arhitektuuri Komitee, Tallinn, pp 39-44

Tomberg T (1975) Таллин/Tallinn. Планета, Москва

Trentmann F (2012) Consumer society revisited: affluence, choice, and diversity. In: Langer L, Jessen R (eds) Transformations of retailing in Europe after 1945. Ashgate, Farnham, pp 19-32

Vanagas J (2008) Urbanistikos pagrindai. Technika, Vilnius

Vèlyvis J (1988) Mūsų medžiagos pèdsakais. Prekybos centrai Vilniuje. Klaidos kartojamos. Statyba ir architektūra 3:21

Vileikis A (1986) Vilnius - Tarybų Lietuvos sostinè. Mintis, Vilnius

Väljas M (2016) Karp, an architect with character. In: Karp R, Väljas M (eds) Arhitekt Raine Karp. Eesti Arhitektuurimuuseum, Tallinn, pp 9-36

Wakeman R (2016) Practicing utopia: an intellectual history of the new town movement. University of Chicago Press, Chicago

Yurchak A (2006) Everything was forever until it was no more. The last Soviet generation. Princeton University Press, Oxford

\section{Literature in Cyrillic Script}

Васильев Б. Л et al (1958) Города - спутники: Харлоу. Визеншо. Веллингбю: из опыта градостроительства за рубежом. Госстройиздат, Ленинград

Васильев Б (1960) Градостроительная практика и жилищное строительство в скандинавских странах: приемы планировки и застройки новых жилых районов. Госстройизда, Ленинград

Ико́нников А (1967) Хельсинки. Стройиздат, Ленинград

Ико́нников А (1978) Современная архитектура Швеции. Стройиздат, Москва 
Минкявичюс ЙК (1987) Архитектура советской Литвы. Стройиздат, Москва

Страутманис ИА et al (1987) Архитектура Советской Латвии. Architecture of the Soviet Latvia. Стройиздат, Москва

\section{Archival Materials}

Mustamäe ühiskondlike hoonete mahu paigutuse skeem (1966) Eesti Projekt, Tallinn (Estonian National Archives, ERA.T-14.4-6. 8818)

Open Access This chapter is licensed under the terms of the Creative Commons Attribution 4.0 International License (http://creativecommons.org/licenses/by/4.0/), which permits use, sharing, adaptation, distribution and reproduction in any medium or format, as long as you give appropriate credit to the original author(s) and the source, provide a link to the Creative Commons license and indicate if changes were made.

The images or other third party material in this chapter are included in the chapter's Creative Commons license, unless indicated otherwise in a credit line to the material. If material is not included in the chapter's Creative Commons license and your intended use is not permitted by statutory regulation or exceeds the permitted use, you will need to obtain permission directly from the copyright holder.

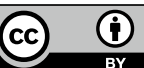




\title{
Chapter 15 \\ Between Community and Private \\ Ownership in Centrally Planned \\ Residential Space: Governing Parking \\ in Socialist Housing Estates
}

\section{Tauri Tuvikene}

\begin{abstract}
This chapter examines the problems of governing shared aspects of housing estates under the conditions of extensive privatisation in originally centrally planned and organised urban space. The management of car parking in housing estates illustrates the mismatch between initial planning ideas and contemporary governing of housing estates. Instead of the municipality replanning areas to deal with the 'parking problem', the municipality merely allocates parcels of its land for long-term lease to function as parking lots, with partial funds channelled for the formalisation of informal parking areas. On the one hand, the accommodation of individual cars in housing estates marks a departure from the neighbourhood unit principles that housing estates were meant to have. On the other hand, the responsibility of the city is also diminishing and that of lower level governing actors-flat-owners' associations (FOAs) - increasing. Nevertheless, due to their form, wherein streets, green spaces and buildings are interwoven, housing estates would require more central systems of governing than FOAs could provide, which is the reason 'governing through community' is on the rise. This paper discusses the questions through the case of Mustamäe in Tallinn, but many of the insights would be applicable for various other housing estates not just in Tallinn but also elsewhere in the formerly socialist world having a similar physical form and facing the challenge of accommodating parked cars.
\end{abstract}

Keywords Parking - Neoliberalism - Flat-owners associations - Housing estates • Tallinn

T. Tuvikene $(\bowtie)$

Centre for Landscape and Culture, School of Humanities, Tallinn University,

Tallinn, Estonia

e-mail: tauri.tuvikene@tlu.ee

(C) The Author(s) 2019

D. B. Hess and T. Tammaru (eds.), Housing Estates in the Baltic Countries,

The Urban Book Series, https://doi.org/10.1007/978-3-030-23392-1_15 


\subsection{Introduction}

The challenges of centrally planned housing estates in Europe extend beyond social problems. This is because housing estates are everyday living environments requiring typical maintenance including mowing grass, cleaning courtyards and sorting out mundane concerns, such as finding space to park cars. In societies where the principal form of urbanisation occurred through the construction of housing estates, such everyday worries become prominent. It is thus not surprising that the increasing challenge of accommodating automobile parking in housing estates, which has been exacerbated by rampant motorisation, has led to a condition described as the 'parking problem'. This condition is often felt as one of the most prominent concerns within housing estates, as illustrated in this chapter's case study of Mustamäe in Tallinn, Estonia (Heidmets and Liik 2012), and throughout the former Soviet Union (Vihavainen 2011).

In Estonia, as elsewhere in the former Soviet Union, private automobiles have turned from objects that are hard to acquire to a ubiquitous element within urban environments, with ownership trebling during the post-Soviet years from 161 cars per 1000 inhabitants in 1991 to 520 cars per 1000 inhabitants today (2017). Urban spaces have proved incapable of accommodating the increasing number of individual cars in existing parking spaces. In housing estates, this has meant the provision of additional parking spaces in unorganised ways, not overseen or managed by governmental authorities. Namely, residents have parked their cars on what used to be grass, thereby collectively transforming it into parking space (Fig. 15.1). Eventually, the city has supported such gradual and informal adaptation of land by legalising and formalising those parking spaces. Thus, the adaptation of the neighbourhood to cars and the city's support for it has generated a new vision of space in housing estates, whereby instead of the auto-mobility restrictions devised in the Soviet years, cars now hold a more prominent position.

The underlying design logic of housing estates was to restrict cars entering the courtyards by locating motor vehicle infrastructure, including parking lots, at the edges of super-blocks. Nowadays, it is common that cars are parked in rows alongside the front of the buildings or alongside the edges of green spaces. In this way, cars are driving frequently around at the inner courtyards. Yet some suggestions to move back to the Soviet ideas have also been proposed as ways to tackle the 'parking problem' in the Mustamäe General Plan (2006; see Fig. 15.2). Nevertheless, even though this plan was exhibited in the General Plan, it was never implemented in this spot and has not become a general guiding principle for the future practice of governing the area. Instead, 'parking problem' has remained to be solved by individual apartment buildings, and thus by small-scale solutions, which even so receive guidance and governing from city authorities.

Using the example of a 'parking problem' in housing estates, we see ways in which the centralised organisation of housing estates contradicts the conditions of privatisation. Since the privatisation of buildings and much of the land in housing estates, Estonia has not relied on large housing associations but opted for 


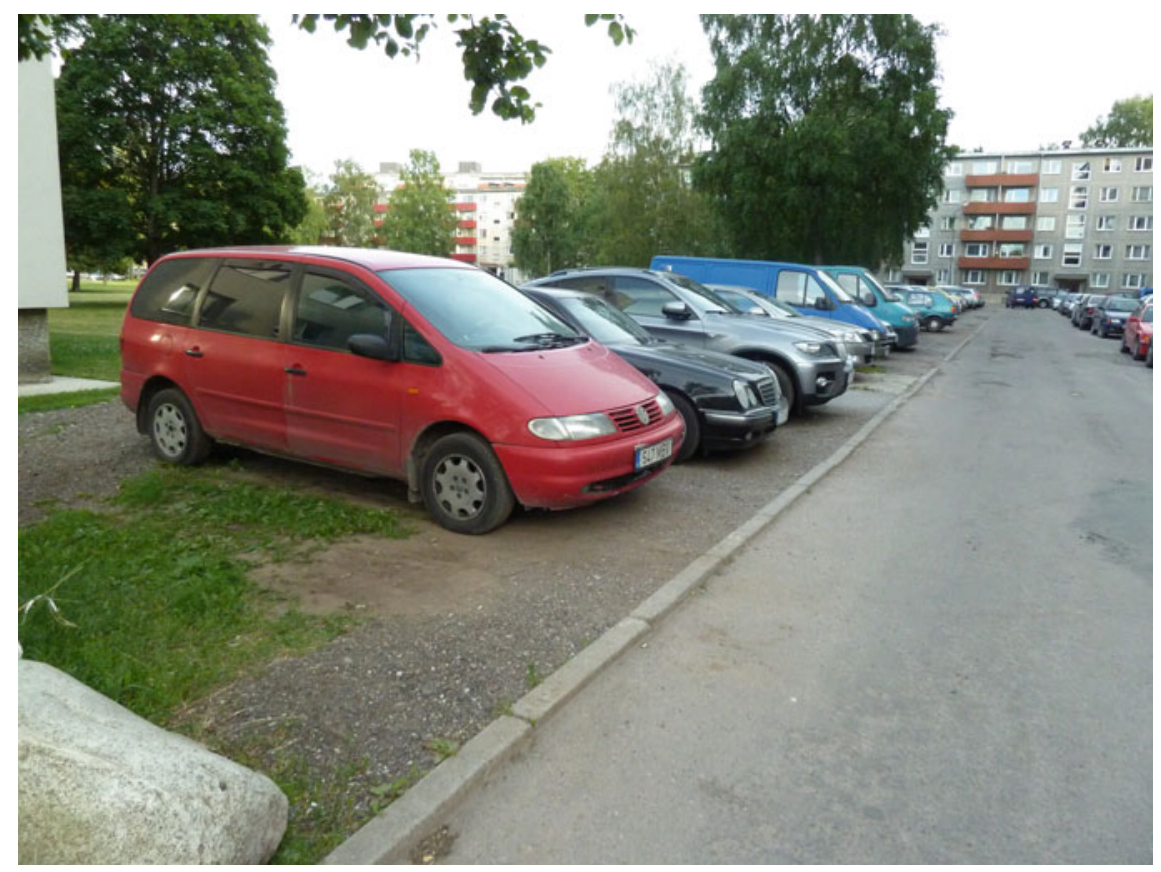

Fig. 15.1 Cars parked upon greenspace. Source T. Tuvikene (photo made in 2013)

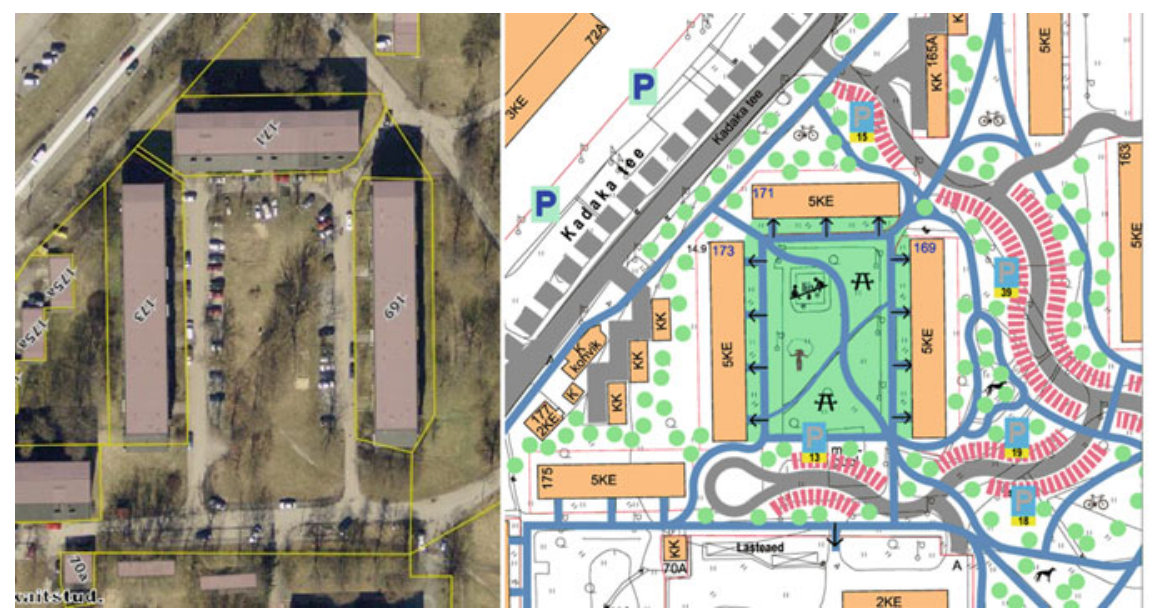

Fig. 15.2 Current configuration of parking space (left) and in the 2006 Mustamäe General Plan (right). The image on the left also highlights how cars are parked on shared spaces and not on the land owned by the FOAs. Sources Maa-amet, 2018 (https://xgis.maaamet.ee/maps/XGis, accessed 25 May 2018) (left; permission not required) and Mustamäe General Plan 2006 (right, permission not required) 
flat-owners' associations (FOAs) formed based on single apartment buildings as primary responsible actors not just dealing with their own building but also land beyond it. Provision and management of parking have become one of their duties. Nevertheless, the local state has remained active in direct solutions to the 'parking problem'. Yet the state acts only through the active involvement of citizens wherein communities form principal actors of governing (Cruikshank 1996; Mowbray 2011; Rose 1999; Tally 1999). The governing of housing estates takes place by 'governing through community' (Cheshire et al. 2009; Lanz 2013; Raco and Imrie 2000; Rose 1999). However, while usually claimed to be the result of shifting ideas on the modes of government reflecting historical emergence of neo-liberal sentiments, this paper also highlights that the way housing estates are planned has a role in the mode of governing that is utilised. Planning for parking has shifted from comprehensive mobility planning to a fragmented approach due to 'rolling path-dependencies,' (Bouzarovski et al. 2016) where early decisions to privatise form conditions for action in later stages. With this chapter, I show the ways in which housing estates necessitate centralised planning, where even in the condition of a fragmented approach the role of the active state has remained crucial, except now limited to act through apartment buildings.

This chapter focuses on Mustamäe, the oldest of the three major housing estates in Tallinn, constructed between 1964 and 1972, and today home to 68,000 residents in 11 micro-districts. My fieldwork in Mustamäe took place in 2012 as part of a wider research project on parking governance in Tallinn. I interviewed four city officials responsible for governing various aspects of parking, had conversations with a vice-mayor, and interviewed the Head of the Estonian Union of Cooperative Housing and six heads of flat-owners' associations. In 2014, I conducted a project on neighbourhood activism in Mustamäe, resulting in 16 interviews including 10 with heads of flat-owners' associations, which supported the claims in this paper. Living in Mustamäe in 2014 and 2015 contributed to the knowledge of the neighbourhood. For the historical part about Mustamäe, I have investigated original planning documents. Additionally, media reports and information on governmental tools in official documents provide a basis for analysis.

\subsection{Centrally Managed Housing Estates: Vehicular Mobility Restriction Plans}

If the aim was merely to provide as much housing as possible, buildings could have been aligned in rows in housing estates. Instead, building location and arrangement were carefully considered and the solution was 'micro-districts' which are the principal building blocks of housing estates. The principles of micro-districts are discussed comprehensively elsewhere in the book, but it is important to note here that they are not only inspired by Le Corbusier but parallel other neighbourhood utopias, such as the 'neighbourhood unit' proposed by Clarence Perry in the USA 
(see Ojari 2004). The planning ideas that housing estates draw from have a basis on three points: offering a significant amount of accessible greenery; spacing and arranging buildings such that dwellings receive ample sunlight, and planning traffic to improve safe pedestrian mobility. Such ideas were combined into the concept of the 'super-block' that proposed a significant expansion of the street block in order to maximize spaces for pedestrians and increase the green space that residents can access, especially without crossing a street (Panerai et al. 2004). Thus, micro-districts in housing estates are tackling important questions of providing healthy amounts of light for residents and offering easily accessible green spaces, but the design is considerably about traffic circulation, as well.

Housing estates considered transport in the way they were positioned within the urban spatial system, but also in the ways in which the inner courtyards were planned (Hess 2018). Following general transport planning principles of housing estates, the physical plan of Mustamäe set out to restrict the movement of cars inside residential quarters. On the one hand, the number of cars entering a block was limited by using the superblock/neighbourhood unit structure with wider streets at the outskirts and only small roads inside a block. On the other hand, blocking the possibility of driving through a superblock directly restricted vehicular mobility. To achieve this, some roads in the micro-districts were designed as cul-de-sacs (Southworth and Ben-Joseph 2004) that made it physically impossible to drive through. The first planning documents for Mustamäe from the early-1960s designated the cul-de-sacs (even though they were not called cul-de-sacs but rather 'dead-end streets'). While streets leading to the groups of apartment buildings were

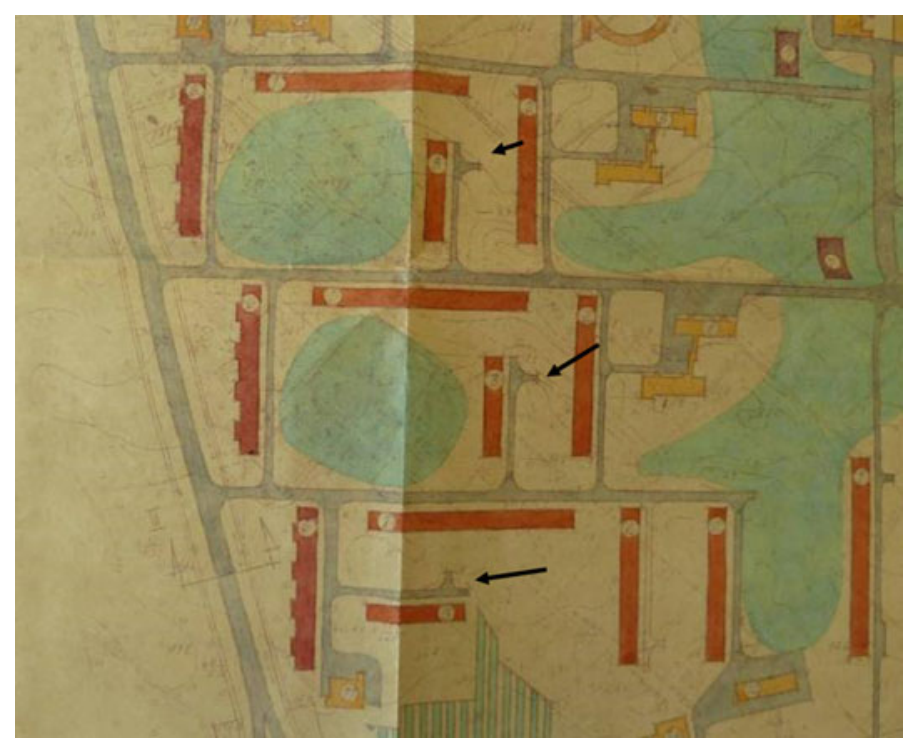

Fig. 15.3 Cul-de-sacs (shown with black arrows) are depicted in an earlier Mustamäe plan. Source National Archives of Estonia (Eesti Projekt 1964), permission not required 
designated to be $5.5 \mathrm{~m}$ wide, other streets leading to individual dwellings were merely 3.5 or $2.5 \mathrm{~m}$ wide. Streets that were $3.5 \mathrm{~m}$ wide were meant to have broader sections for overtaking and turnaround (Eesti Projekt 1964; see also Fig. 15.3).

In addition to the dead-end streets, the plan regulated automobile use by narrowing streets so that parking on them would not be possible (or would be possible only for a limited number of vehicles). Plans placed parking in garages at the outer parts of the micro-district. The wide streets surrounding superblocks, then, were intended to contain vehicular traffic, only entering close to the buildings infrequently to deliver something to an apartment or to take residents on board. A later plan for a refurbishment project in 1985 more thoroughly conceptualised the traffic management of cul-de-sacs.

\begin{abstract}
With the new traffic organisation, the aim has been to reduce driving through the micro-district. Vehicle traffic that would endanger pedestrians and children playing around buildings on streets in front of the apartment buildings is reduced... [W]ith the new traffic plan, dead-end streets are created in front of buildings. In order to curtail traffic, metal bollards are planned to be fitted into the road tarmac. (Kommunaalprojekt 1985, p. 5; author's translation)
\end{abstract}

In addition to cul-de-sacs, pedestrian circulation was not confined to the roads, but people could walk via direct routes through the courtyards and between buildings. This kind of pedestrian movement exhibits the thinking of Le Corbusier and Perry for whom the superblock form provided freedom for people on foot.

Thus, some of the ideas that housing estates embody in their material form of governing are more forward-looking than often discussed. Planning for pedestrians and restricting car mobility are important principles within the 'sustainable mobilities paradigm' (Banister 2008). I agree here with Dekker et al. (2005, p. 5) who propose that not only is it premature to claim that housing estates in Europe have reached the limits of their 'useful existence', but that 'large estates have an important part to play in promoting sustainable urban development more broadly, given their compact morphology, abundant open space, and their potential to benefit from public transport links and the development of green heating and energy systems'.

Housing estates expressed a comprehensive vision of mobility in accordance with Marxist-Leninist views of shared resources (Hess 2018). While Hess notes many inconsistencies with those principles already in the Soviet years, the shared vision was particularly altered with privatisation. The appearance and functioning of courtyards have remained a significant problem. The Development Plan for Housing notes:

The problem of multi-apartment residential areas is the upkeep of the areas between apartment buildings. While apartments are usually in private ownership and apartment buildings are managed by associations then courtyards between buildings are owned by local government or central state (or they are still on unreformed state land) and the associations do thus not have direct right, obligation or motivation to take care of those areas. Because of this, there is often a lack of landscaping, children playgrounds and resting places. (Majandus-ja Kommunikatsiooniministeerium 2008, p. 32; author's translation) 
The mismatch between the layout of housing estates and governing forms emerging with privatisation is a challenge that the city authorities seek to overcome through modes of governing through FOAs.

\subsection{Governing Housing Estates Through FOAs: The Challenges of Parking}

Housing estates on both sides of the Iron Curtain have been subject to privatisation and a general reduction of state control (e.g., Marcuse 1996; Murie et al. 2005). Such shifts, however, echo wider trends in societies. The diminishing state role has largely been captured by the notions of 'roll back' neoliberalism (Peck and Tickell 2002) wherein privatisation, deregulation and marketisation result in more freedom as well as responsibility leveraged on individuals. Yet, privatisations are also accompanied by the forms of 'roll-out' neoliberalism (Peck and Tickell 2002) meaning the extension of state capacities to spheres they were not an integral element of before. However, in modern societies governing is unable to direct the behaviour of individuals to the full extent but has to take into consideration their needs and wishes (see in particular Barry et al. 1996; Burchell et al. 1991; Dean 1996; Rose 1999; Rose and Miller 1992). A stream of research on governmentality has elaborated on governing techniques that rather than working against freedom, govern through freedom (Rose 1999). According to such interpretations of liberal governmentality, citizens are responsible for improving their own lives and bettering their conditions, while also improving society as a whole. Using these governing approaches, the state tries to accomplish its goals while investing less time and money in the welfare of individuals.

Estonia's strategy in terms of privatisation was a rapid transfer of assets from state ownership to that of individuals: in the case of housing estates, this was not done through restitution (see Feldman 1999) but vouchers given based on working years, through which former tenants of apartments could purchase their dwelling on very affordable terms (Kährik et al. 2004). Whereas $29 \%$ of dwellings were privately owned at the beginning of 1994, 5 years later in 1999, the percentage was already $93 \%$ (Statistikaamet n.d.). The shift was thus from the almost complete state ownership of housing at the end of the Soviet time (in 1991) to more than $97 \%$ of private ownership today (2014). Eventually, apartment buildings were transformed into condominiums with each tenant owning their apartment and a share of the land under the building and around it. Those two privatisations - dwelling and landhowever, were not coterminous, with the transfer of dwellings taking place sooner than the transfer of the surrounding territory. Nevertheless, with the two privatisations and diminishing tax bases of municipalities, the capacity for city authorities to initiate change and govern has been reduced.

With the central government decision to move towards private ownership and FOAs in the 1990s, individual apartment buildings have become the primary actors 
to take the responsibility of their living environment. It has been an understandable move from governmental authorities to attach other responsibilities to their agenda. The FOAs' field of responsibility has increased with the expectation that the organisation renovates the buildings and cares for parking lots, as well.

The neo-communitarian governing procedures, as they are conceptualised in political theory, follow 'roll-out neoliberalism' as outlined above and call for the third sector to act in improving economic development, social welfare and social cohesion (Fyfe 2005). These shifts in the UK and beyond, under frameworks of the Third Way or Big Society or other similar community-oriented state actions, call for the devolution of service functions to the 'third sector' by local state policies (Mowbray 2011). Rosol (2012), for instance, shows community volunteering in the case of community gardens as a neo-liberal strategy by local governors to provide green infrastructure, without needing to do the actual work, yet remaining in control of the situation. Similarly, FOAs in Estonia are formally third sector non-governmental organisations, a category that also includes citizen initiatives advancing political causes. Yet, in their function, FOAs fulfil a task that someone must do anyway (that is, maintain the building and take care of surrounding sites).

The conditions for the emergence of the 'neo-liberal' model of governing housing estates, with two components - active state and active individuals - present, are provided by the materiality of housing estates, as well as governmental pragmatism where almost all buildings (97\%), and large swathes of land are privatised: lacking finances and capacity to take lead in the management of public spaces in housing estates, the city government relies on time, money and organisational capacities of FOAs. While most of the buildings have privatised at least a certain portion of land, the privatisation of land has not led to a neat correspondence between spatial elements and their owners. That is, if the efforts by apartment buildings are not coordinated, problems will occur. First, the vast green space is not clearly belonging to one apartment building or another. The greenery is intermediary space in between apartment buildings belonging to everyone by the initial planning ideas. Formally, it mostly still does so today in Estonia as the greenery between buildings remains an unreformed property managed by district government or is fully municipalised. Thus, all the new borders drawn in the public space of housing estates appear as problematic in relation to the way it has functioned for decades. Second, designating a land plot around apartment buildings to belong to the FOA also means the inclusion of street sections providing access to other buildings (depicted in Fig. 15.4), which produces at least two problems: vehicular and pedestrian mobility to other buildings is compromised and responsibility for repair and maintenance of the road section is unclear. In the case of street privatisation, it then must be clearly designated who, under what conditions, can pass through the property to prevent ongoing conflicts between the residents of different buildings. If street sections for public use are privatised to FOAs, each FOA will have only a limited incentive to renovate and maintain the street, as many other buildings will benefit as well. An FOA would be funding services for other buildings from its own budget collected from the flat-owners. The research interviews with heads of FOAs indicated problems even with getting people within a 


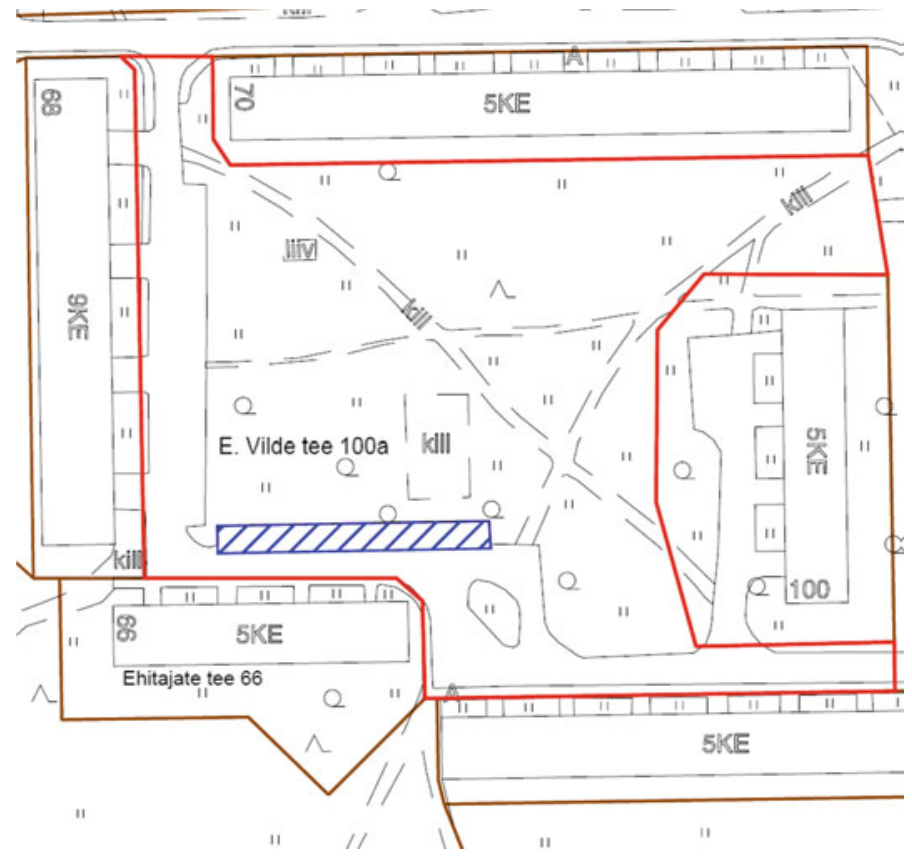

Fig. 15.4 An example of isiklik kasutusõigus [personal use right] for an apartment building, shown as striped areas. Note that street space is omitted. Source Tallinn City Government 2011b, permission not required

single FOA to accept costs of parking lots construction for own building use, making it even more problematic when the circle of users for those plots would be wider.

Streets inside blocks were not municipalised as 'transport land', as in other areas of the city, but were instead combined either with the building (rare option) or with the courtyard (more common). Land parcels are usually not gated as is usual in older city districts. The individualising use of various spatial elements thus extends beyond the mainly scant amount of land linked to one's apartment building (e.g. cutting branches of trees or maintaining flowers/bushes that are officially on the city land or parking informally on the green that legally belongs to the local government). Commenting on the privatisation process when the borders were being drawn, a councillor at the Mustamäe borough argued that in the superblock form of urban plan every piece of land belongs to everyone and it cannot be simply privatised (Hagelberg 1999). Thus, while the privatisation of housing and the Land Reform generated the context, whereby residents are organised into collectives based on apartment buildings with residents usually being the owners of their flats, much of the land in the neighbourhood has remained in collective use and in many cases in collective ownership (represented by the district government). Such physical space has required a wider level of intervention than current practice by the district government. 
The Development Plan for Housing (Majandus-ja Kommunikatsiooniministeerium 2008) cited above notes the mismatch between those who are and who city governors urge to be active in housing estates (that is FOAs) and the legal designation of land. Pragmatically, then, FOAs in housing estates are centres of deliberation, decision-making and activity inside these park-like structures, capable of showing interest and acting in the areas around them. With the number of flats usually around one hundred (if not more), such FOAs are quite powerful actors in governing and have emerged as pragmatic targets for taking over some of the responsibilities of governing housing estates. The state informs residents that addressing car parking - as well as many other issues in the housing estate - is their problem, but still intervenes in many ways to support their (pro-)activity. The city of Tallinn possesses a vision whereby FOAs lead the decision-making, not only in terms of their own buildings but also the surrounding land, whereas the vision includes that guidance is provided by the city authorities.

\subsection{Three Measures of Intervention in Parking in Housing Estates}

In recent years, the city of Tallinn has devised three measures that tackle the housing estate 'parking problem': (1) policy intervention; (2) funding support for parking provision; and (3) privatisation of the use of land. What is significant in all three measures is the way in which the city acts, doing so only through the proactive engagement of FOAs who are expected to be self-governing and responsible actors, following neo-communitarian and neo-liberalism principles.

The first of those measures - a particular policy scheme-was put together in 2012 by the city government to organise the provision of parking lots in residential areas. Even though it might look like a planning document that forms an agreement between different parties in terms of how and where the parking lots would be provided, it was merely an internal government document aimed to coordinate practices between departments to create parking lots. What is more significant, however, is the nature of the Scheme for Parking Provision (Tallinn City Government 2012). To my question as to whether the city prefers specific locations for the parking lots, officials at Mustamäe district government showed me a planning document ordered from a private company that mapped planned parking lots around apartment buildings (Interview 3). This document was prepared for less than one-third of the Mustamäe territory and it also did not show where parking lots should be built, but merely pointed out all the places where parking lots could potentially be constructed. As municipality officials stressed during an interview, parking spaces will be provided where FOAs requests them to be provided. Thus, even though the city had a specific policy for dealing with the parking problem (and no more recent policies have emerged as stated in follow-up phone interview, 
Interview 6), the policy was not the blueprint for action, but instead merely an idea that could be transformed into practice when FOAs show initiative.

The second measure applied by the city is funding provided for parking lot construction. The most important of those financing measures is a programme Hoovid Korda (direct translation is 'courtyards into order'). Since 2006, the programme annually supports approximately 70 applicants to carry out a diverse range of projects in courtyards. Projects range from locked sheds for garbage collection to providing children's playgrounds, and more recently including locked storage spaces for bicycles and murals on walls. The range of funded courtyard improvements has thus gradually expanded. The programme has also been important for funding the refurbishment of parking spaces, which is reportedly one of the key developments to be supported through this measure (Interview 6). Despite the funding by the city, however, a significant portion still needs to be provided by city residents. The programme covers no more than $70 \%$ of applicants' construction costs, with the funding percentage often much lower, even as low as $18 \%$ (Interview 6). Moreover, there is a cap on the funding amount of 15,980 EUR per year per applicant and no more than 39,950 EUR in three consecutive years. The average funding received by FOAs remains about three times lower than the maximum amount of annual funding (5,643 EUR in 2016). Parallel to the funding programmes for energy efficiency renovations for apartment buildings, this funding programme assumes that each FOA is capable of securing finances among the apartment owners of the building. The programme, moreover, is competitive. While in 2010, the number of successful applications for the whole city was $68 \%$ (with 22 projects from 30 that applied in Mustamäe got funding), a year later the share for the whole city had dropped to $43 \%$ (with only 7 projects from 31 funded in Mustamäe) (Tallinn City Government 2011a). In 2016, there were 128 applications and 90 projects that received funding, equivalent to a $70 \%$ success rate for applications. The total budget for projects has gradually increased and is now more than a half million EUR. In response to my question as to how the selection of applicants is done and whether there is an underlying principle about where parking lots should be provided in the housing estate, the officials claimed the decisions were based on the merits of the application rather than the logics of urban planning (Interview 5). In advancing their parking options, hence, apartment buildings can compete for the city funding which requires at least one-third of self-funding.

The third measure for the municipality to be involved in 'easing the parking problem' of FOAs, as the vice-mayor claims in the local borough newspaper (Vorrk 2012), is by offering the use of municipal land to individual FOAs. Namely, the city has opened the opportunity to enclose a portion of land for the exclusive use of a single building (Rattus 2012). While some apartment buildings decided and managed to privatise a larger land plot around their buildings, including parking lots and would thus not need land from the city, other FOAs have now acquired the 'personal right to use' on the city land. 'Personal right to use' is a freely-given 15-year rental agreement with the city for the utilisation, including maintenance and renovation of parking space (only, and not including street; see Fig. 15.4). The existence of such a governmental tool, as city authorities (Interview 3) have claimed, is 
a result of the demands of FOAs. Either those FOAs that had formalised their parking lots and financed it fully or half from their own budgets, felt it unjustified that cars from other buildings could also use the land (Interview 3). FOAs, having received the right from the city to use a land plot exclusively for a particular apartment building, then hired private companies to enforce parking. In this way, following Vihavainen's (2011) claims, FOAs have created a 'club good' out of 'common good'. By the end of 2017, Tallinn personal right to use has been set for 71 parking lots for 1,800 parking spaces in total (Kesknädal 2017).

While the city constructs some parking spaces in the course of road renovations, the main form for parking provision in housing estates remains through FOAs with plans, advice, partial funding and right to use city owned land offered. In practice, then, parking spaces that cars have already taken over are formalised with various helping measures from city authorities. As cars are considered unavoidable inside the blocks by city authorities the organisation and understanding of the physical space moves further away from the underlying planning ideas of Mustamäe and those of the 'neighbourhood unit'. The Scheme for Parking Provision (Tallinn City Government 2012; author's translation; no page number) states that the construction of '[a]dditional parking spaces adjacent to dwellings takes place by reducing greenery and increasing somewhat the traffic in the residential quarter.' Moreover, new projects for parking lot renovation often contain pavements for pedestrians, suggesting an increase of elements that, according to the superblock planning ideas, are not even necessary: traffic should be scarce enough that pedestrians and cars can share the interior street space. Thus, the state involvement has not so much meant a comprehensive re-drawing of informally generated mobility practices but rather accommodated them. Nevertheless, as was argued here, despite the individualised and fragmented measures, the state still administers developments by not allowing extensive private encroachments (gates and fences are forbidden, for instance) and by slightly nudging the process of improvements.

\subsection{Conclusion}

This chapter showed that while there are policies and measures by the city to deal with the parking problem, these governing tools expect FOAs to be in many ways 'entrepreneurial, self-responsible' actors (Larner 2003, p. 511) who manage their own matters themselves. The city thus has policies that resemble neo-liberal tools of governing. The arts of governing car parking in Mustamäe involve techniques such as governing at the distance and through the freedom of individual actors. Nevertheless, it is in many ways a pragmatic response to the physical conditions of housing estates in a situation, wherein most of the buildings and land under buildings are privatised and governments are cut short of financial means. Housing estates were initially state projects organised around centralised governing modes in either welfare states or communist governments. The space in micro-districts is difficult to parcel due to the way in which public and private spaces are intertwined, 
even if the intention is to move towards increasing individual governing. The large swathes of land between buildings fall under city ownership in Mustamäe and requiring actions by some actors on more general scale than individual buildings. The city must act somehow, but pragmatically, action is only possible through FOAs.

Through privatisation of residential blocks, FOA decision-making becomes a pragmatic governing solution. The city is not providing parking lots in a top-down way because it does not have to (FOAs have been created and are capable in taking over the tasks) and because it cannot do so (as there are no finances that would match the tasks). Hence, the introduction of the schemes for parking regulations devised by the city authorities and enacted through the actions of FOAs.

The materiality of the physical space mattered in this chapter in at least three ways. First, the materiality led to a problem - the 'parking problem' - as the physical plan could not accommodate increasing car ownership levels. Soviet housing estates-and Mustamäe as the oldest housing estate in Tallinn in particular - were planned for low car-use and utilised a model whereby large numbers of cars were not planned to operate inside superblocks. An increase in car use in Tallinn that creates a new, car-oriented reality in housing estates, radically transforms the original concept of the superblock. Such a model, generated by the recurring activities of cars, has also received backing from the local government who devise policy and offer funding and land for parking lots. Secondly, the physical reality of housing estates necessitates at least some forms of centralised governing. Site layouts make laissez-faire approaches impossible and require responsible actors on a more encompassing scale than a single building. Buildings, streets and courtyards are all enmeshed so that privatising a building with the land beneath it can be done, but privatising more than that leads to immediate conflicts with other buildings because streets and courtyards are for collective use. This actor, on a more encompassing level in Tallinn, has been local authority and mainly its district branch. Thirdly, the way buildings are positioned - as centres in vast green areasalso makes them possible centres for decision-making and action. The members of FOAs routinely show interest in their surroundings even if it is not the land they own: trees, bushes, green plots and parking spaces around a particular apartment building all fall within the area that residents from that FOA actively use.

This chapter draws attention to the necessity of governing modes that are on a more encompassing level than individual apartment buildings for managing housing estates. Currently in Tallinn, this governing mode is relying on certain centralised policies with funding and assistance, but with the main activities carried out by FOAs. Yet, there could be alternative means of achieving the same ends. For instance, new non-governmental organisations responsible for one micro-district could be formed as a true manifestation of neighbourhood-based governing (Somerville et al. 2009). Indeed, Perry (2001 [1929]) envisioned his neighbourhood units of 1920s as platforms for fostering citizenship. Some change in moving towards new means of more collective forms of governing is manifested by citizen initiatives, including non-governmental organisations such as Lasnaidee, in the newest socialist housing estate in Tallinn. Similarly, roundtables for FOAs in 
various housing estates have emerged enabling heads of FOAs to share experiences and enhance mutual learning. Studies I carried out about neighbourhood activism in Mustamäe in 2014 also revealed some small initiatives of cross-FOAs cooperation, such as building a children's playground and finding ways to collectively manage the task of mowing grass in a shared courtyard. Nevertheless, there is much to be done to achieve a better balance between the physical form and the institutional forms of housing estates governance.

\subsection{List of Interviews}

Interview 1 (14 March 2012) — a former municipality official in environmental matters and architect (one of the Mustamäe General Plan authors)

Interview 2 (7 May 2012) — an official in the urban planning department (an expert in general planning)

Interview 3 (9 July 2012) - a city official in Mustamäe city district government Interview 4 (17 July 2012)-Head of Estonian Union of Cooperative Housing Interview 5 (23 August 2013) - Two city officials dealing with the programme Hoovid Korda ('Courtyards into order')

Interview 6 (16 March 2018) - Phone interview with city official dealing with the programme Hoovid Korda ('Courtyards into order').

Acknowledgements The research was supported by the Archimedes Foundation, CEELBAS and Estonian Research Council grant PRG398.

\section{References}

Banister D (2008) The sustainable mobility paradigm. Transp Policy 15(2):73-80. https://doi.org/ 10.1016/j.tranpol.2007.10.005

Barry A, Osborne T, Rose N (1996) Foucault and political reason. The University of Chicago Press, Chicago

Bouzarovski S, Sýkora L, Matoušek R (2016) Locked-in post-socialism: rolling path dependencies in Liberec's district heating system. Eurasian Geogr Econ 57:624-642. https://doi.org/10.1080/ 15387216.2016.1250224

Burchell G, Gordon C, Miller P (1991) The foucault effect: studies in governmentality. The University of Chicago Press, Chicago

Cheshire L, Rosenblatt T, Lawrence G, Walters P (2009) The governmentality of master planning: housing consumption, aesthetics and community on a new estate. Hous Stud 24(5):653-667

Cruikshank B (1996) Revolutions within: self-government and self-esteem. In: Barry A, Osborne T, Rose $\mathrm{N}$ (eds) Foucault and political reason: liberalism, neo-liberalism and rationalities of government. The University of Chicago Press, Chicago, pp 231-252

Dean M (1996) Foucault, government and the enfolding of authority. In: Barry A, Osborne T, Rose N (eds) Foucault and political reason: liberalism, neo-liberalism and rationalities of government. The University of Chicago Press, Chicago, pp 209-230 
Dekker K, Hall S, Van Kempen R, Tosics I (2005) Restructuring large housing estates in European cities: an introduction. In: Van Kempen R, Dekker K, Hall S, Tosics I (eds) Restructuring large housing estates in Europe. The Policy Press, Bristol

Eesti Projekt (1964) Mustamäe IV mikrorajooni hoonestamise eskiisprojekt (Available in the archive: The National Archives of Estonia, ERA.T-14.4-6.8748)

Fyfe NR (2005) Making space for "neo-communitarianism"? the third sector, state and civil society in the UK. Antipode 37:536-557. https://doi.org/10.1111/j.0066-4812.2005.00510.x

Hagelberg T (1999) Korter tuleb hauda kaasa võtta [The apartment must be taken to the grave with you]. Luup, 6(89)

Heidmets M, Liik K (2012) Mustamäe arenduspiirkonna (I, II ja III mikrorajoon) elanike hoiakud ja valmisolek osalemiseks piirkonna ümberhoonestamisel. Tallinn University

Hess DB (2018) Transport in mikrorayons: accessibility and proximity to centrally planned residential districts during the socialist era, 1957-1989. J Plan Hist 17(3):184-204. https://doi. org/10.1177/1538513217707082

Kährik A, Lux M, Kõre J, Hendrikson M, Allsaar I (2004) Eluasemepoliitika üleminekuriikides [Housing policy in transitional countries]. Praxis, Tallinn

Kesknädal (2017) Eha Võrk: Pealinn teeb korteriühistutega tõhusat koostööd. http://www. kesknadal.ee/est/uudised?id=29491, 15 March 2018

Kommunaalprojekt (1985) Mustamäe II mikrorajooni kapitaalremondi tööprojekt (Available in the archive: Riigiarhiiv, ERA.T-2.4.1.10904)

Lanz S (2013) Be Berlin! governing the city through freedom. Int J Urban Reg Res 37:1305-1324. https://doi.org/10.1111/j.1468-2427.2012.01195.x

Larner W (2003) Neoliberalism? Environ Plan D: Soc Space 21(5):509-512

Majandus-ja Kommunikatsiooniministeerium (2008) Eesti eluasemevaldkonna arengukava 20082013. https://www.mkm.ee/et/eesmargid-tegevused/ehitus-ja-elamumajandus/elamumajandus, 8 Oct 2017

Marcuse P (1996) Privatization and its discontents: property rights in land and housing in the transition in Eastern Europe. In: Andrusz G, Harloe M, Szelenyi I (eds) Cities after socialism. urban and regional change and conflict in post-socialist societies. Oxford, Blackwell, pp 119191

Mowbray M (2011) What became of the local state? neo-liberalism, community development and local government. Commun Dev J 46:1132-i153. https://doi.org/10.1093/cdj/bsq051

Murie A, Tosics I, Aalbers M, Sendi R, Černič Mali B (2005) Privatisation and after. In: Van Kempen R, Dekker K, Hall S, Tosics I (eds) Restructuring large housing estates in Europe. The Policy Press, Bristol, pp 85-103

Mustamäe General Plan (2006) Mustamäe linnaosa üldplaneering. Tallinn: Tallinna Linnaplaneerimise Amet (prepared by E-Konsult and AB Koot and Koot). https://www. tallinn.ee/est/ehitus/Mustamae-linnaosa-uldplaneering-Kehtestatud, 25 May 2018

Ojari T (2004) Elamispind. Modernistlik elamuehitusideoloogia ja Mustamäe [Floor space: the modernist residential housing ideology and Mustamäe]. Kunstiteaduslikke Uurimusi (Studies on Art and Architecture) 13(2):42-70

Panerai P, Castex J, Depaule J-C (2004) Urban forms: the death and life of the urban block. Architectural Press, Oxford, Auckland, Boston, Johannesburg, Melbourne, New Delhi

Peck J, Tickell A (2002) Neoliberalizing space. Antipode 34(3):380-404

Perry C (2001) The neighbourhood unit. Routledge/Thoemmes Press, London

Raco M, Imrie R (2000) Governmentality and rights and responsibilities in urban policy. Environ. Plan. A 32:2187-2204. https://doi.org/10.1068/a3365

Rattus S (2012). Ühistud saavad parkla ehitamiseks tasuta maad. Pealinn, p 8

Rose N (1999) Powers of freedom: reframing political thought. Cambridge University Press, Cambridge, UK

Rose N, Miller P (1992) Political power beyond the state: problematics of government. Br J Sociol 43(2):173-205

Rosol M (2012) Community volunteering as neoliberal strategy? green space production in Berlin. Antipode 44:239-257. https://doi.org/10.1111/j.1467-8330.2011.00861.x 
Somerville P, Beckhoven EV, Kempen RV (2009) The decline and rise of neighbourhoods: the importance of neighbourhood governance. Int J Hous Policy 9(1):25-44. https://doi.org/10. 1080/14616710802693557

Southworth M, Ben-Joseph E (2004) Reconsidering the cul-de-sac. Access: Transp Res Univ Calif 1(24):28-33

Tallinn City Government (2011a) An answer to the request of information regarding Hoovid Korda programme by Urmas Mardi (LV-1/8195; 20 Nov 2011). https://aktal.tallinnlv.ee/static/ Aruparimised/Dokumendid/apvdok1016.pdf, 21 July 2014

Tallinn City Government (2011b) The city ordinance no. 367-k. Tallinna linna omandis olevale Eduard Vilde tee 100a kinnisasjale isikliku kasutusõiguse seadmine korteriühistu Kosmos kasuks [Setting private use right for FOA Kosmos on a city of Tallinn property with an address Eduard Vilde tee 100a] (14 Mar 2011)

Tallinn City Government (2012) Elamukvartalitesse lisaparkimiskohtade rajamise kava, Order no. 467

Tally J (1999) The agonic freedom of citizens. Econ Soc 28(2):161-182

Vihavainen R (2011) Common and dividing things in homeowners' associations. In: Kharkhordin O, Alapuro R (eds) Political theory and community building in post-soviet Russia. Routledge, London, pp 139-163

Võrk E (2012) Üheksakümmend uut parkimisala korrusmajadele [90 new parking areas for apartment buildings]. Mustamäe Leht, p 4

Open Access This chapter is licensed under the terms of the Creative Commons Attribution 4.0 International License (http://creativecommons.org/licenses/by/4.0/), which permits use, sharing, adaptation, distribution and reproduction in any medium or format, as long as you give appropriate credit to the original author(s) and the source, provide a link to the Creative Commons license and indicate if changes were made.

The images or other third party material in this chapter are included in the chapter's Creative Commons license, unless indicated otherwise in a credit line to the material. If material is not included in the chapter's Creative Commons license and your intended use is not permitted by statutory regulation or exceeds the permitted use, you will need to obtain permission directly from the copyright holder. 


\section{Part VI \\ Imagining the Future Lives of Housing \\ Estates}




\title{
Chapter 16 \\ State-Subsidised Refurbishment \\ of Socialist Apartment Buildings \\ in Estonia
}

\author{
Kalle Kuusk and Jarek Kurnitski
}

\begin{abstract}
Apartment buildings in large urban housing estates constitute a large share of the housing supply. Most apartment buildings that are located in housing estates are over 30 years old and, for the most part, only minor refurbishment work has been carried out on them so far. Common problems for these apartment buildings are high energy consumption levels and poor indoor climate conditions. Although research has shown that the condition of load-bearing constructions is satisfactory, some problems do exist which are related to the degradation of facades and balconies. When it comes to restoring these buildings, two different approaches have been discussed in Estonia: demolishing the old buildings and replacing them with brand new apartment buildings; or refurbishing the existing buildings. The vision which prefers the demolition of the old apartment buildings and the construction of new buildings has not been realised in practice thanks to the high costs involved, and also due in part to the apartments being privately owned. The economic and environmental reasons favour an intensive refurbishment of the existing buildings. The costs involved in such an intensive level of refurbishment work are approximately three or four times lower than they would be for putting up a brand new apartment building. From the environmental aspect, rebuilding is also not particularly reasonable thanks to the much higher energy and carbon footprint involved in the use of new building materials. Refurbishment has also generated positive effects on the macroeconomic level, as quantified in terms of job creation and tax returns. In practical terms, refurbishment has been the only feasible solution when it comes to modernising apartment buildings.
\end{abstract}

Keywords Apartment buildings • Refurbishment • Demolition • Energy efficiency

\author{
K. Kuusk $(\square) \cdot$ J. Kurnitski \\ Department of Civil Engineering and Architecture, Nearly Zero Energy Buildings Research \\ Group, Tallinn University of Technology, Tallinn, Estonia \\ e-mail: kale.kuusk@ttu.ee \\ J. Kurnitski \\ e-mail: jarek.kurnitski@ttu.ee \\ (C) The Author(s) 2019 \\ D. B. Hess and T. Tammaru (eds.), Housing Estates in the Baltic Countries, \\ The Urban Book Series, https://doi.org/10.1007/978-3-030-23392-1_16
}




\subsection{Refurbishment Motivators}

There are various approaches to renovating apartment buildings in housing estates. Three main scenarios have been proposed for discussion in Estonia (Terk and Keskpaik 2015):

- Demolition and rebuilding by building groups and a redesign of the common space between the buildings.

- Complete modernisation by building groups via the retention of the current load-bearing structures by following the example shown by east Berlin. Floor planning can be updated and extensions can be added (involving lifts, balconies, sanitary facilities, common areas, etc.).

- Carry out refurbishment work on a building-by-building basis. During such work, windows are replaced and additional thermal insulation is applied to the external walls and the roof, along with an upgrade being carried out on building service systems.

The first two scenarios are both expensive and inconvenient for the apartment inhabitants. Demolition also brings up the subject of economic viability and environmental issues. The experience of the Dutch shows that the transformation of the existing housing stock is a much more environmentally efficient way to achieve the same result that demolition and rebuilding would deliver (Itard and Klunder 2007). In Estonia, where apartments are mainly privately owned, demolition is particularly difficult. The condition of the existing building structures means that demolition is not the optimum solution. The results of research covering the current technical condition of old Estonian housing stock refers to it being in a satisfactory condition in terms of load-bearing constructions (Kalamees et al. 2011a, b). Nevertheless, the agenda of the Tallinn Vision Council contained the proposal to demolish a total of 103 of the oldest prefabricated concrete large-panel apartment buildings on Tallinn's oldest large housing estate, that of Mustamäe (Sarv 2013). The concept was to buy apartments from their owners, demolish the buildings, and build new ones. After that, the previous inhabitants could buy new apartments in new apartment buildings. That vision has not been further developed because it was seen as being highly expensive and, in practice, it would be very difficult to buy apartments from their owners on a one-by-one basis.

Demolition is a plausible solution when a particular area is marked for complete rebuilding. At higher volumes, the construction costs would be lower and a larger macroeconomic impact would also be an important factor, but here further detailed analysis is required. On a single building level, refurbishment work is substantially cheaper than erecting a brand new construction. The number of apartment buildings on housing estates makes refurbishment the more favourable solution due to the enormous construction capacity required for a new build. Therefore, the refurbishment of existing apartment buildings has been the aim of the housing policy in Estonia. In order to promote refurbishment projects, state-subsidised refurbishment 


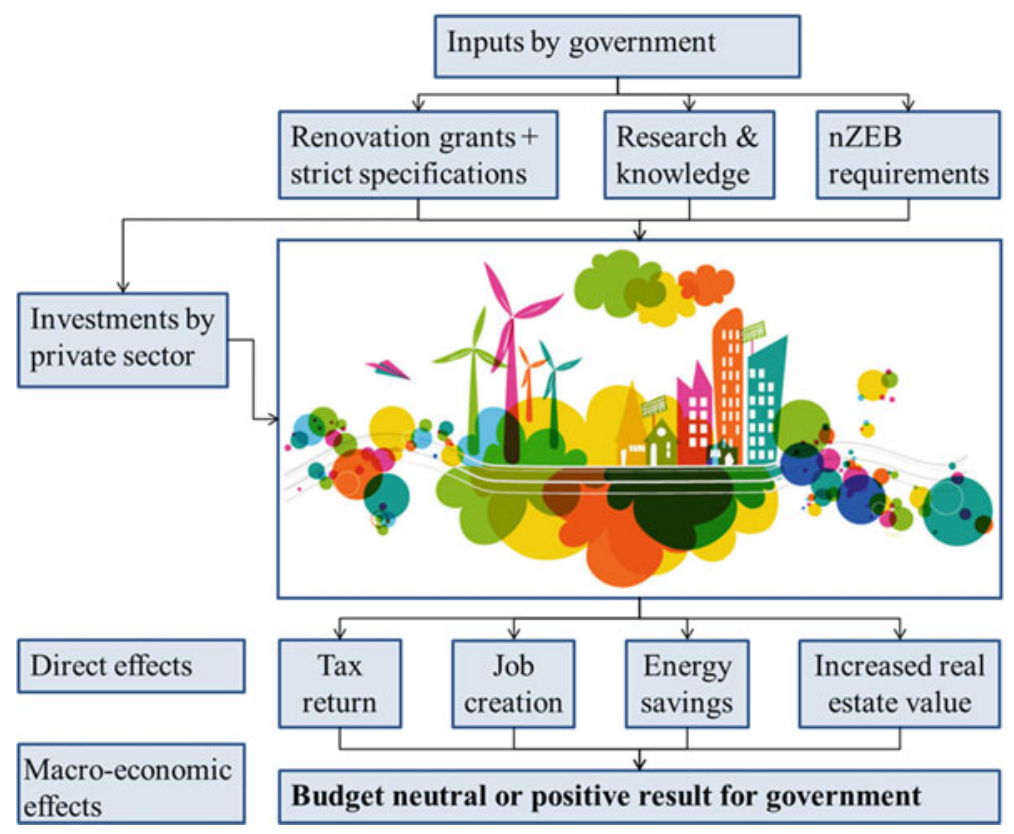

Fig. 16.1 Impacts of renovation plans

programmes have been initiated. The results from grant schemes have shown that state-managed grants have a large number of impacts, as shown in Fig. 16.1.

The main opportunity being provided by a state-managed refurbishment scheme is the ability to be able to guide the refurbishment processes towards the desired direction. The grant scheme allows the creation of energy-efficient building policies through technical research-based requirements for the refurbishment work. The grant scheme also has macroeconomic effects in terms of tax returns and job creation. Another important factor is the mobilisation of private-sector investments. The grant support schemes have, over the years, significantly raised apartment owners' contributions towards energy refurbishment targets. The average investment made by apartment associations has increased by more than double. The increase of private-sector investments is the outcome of the different levels of the extent of refurbishment work. Minor refurbishment work has gradually been replaced by extensive refurbishment work.

\subsection{Estonian Apartment Building Stock}

According to Statistics Estonia, there are 23,600 apartment buildings in Estonia. Most of these apartment buildings were built during the industrialised construction period between 1960-1990, as shown in Fig. 16.2. Large housing estates were the 


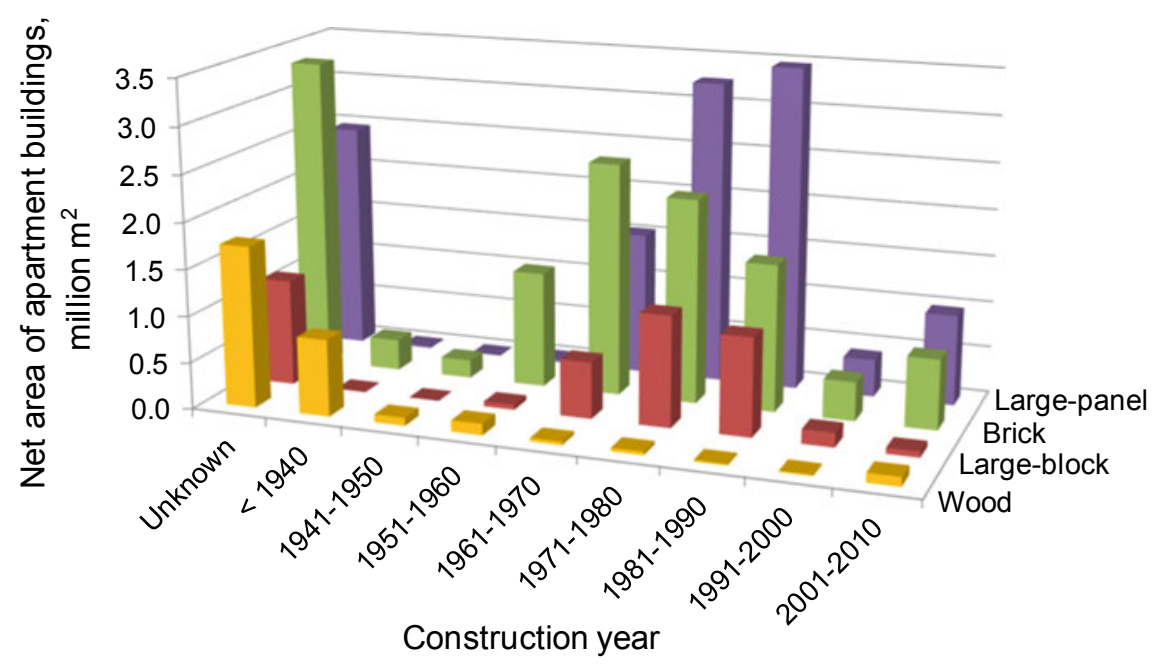

Fig. 16.2 Distribution of apartment buildings in Estonia according to age and construction type

main outcome of the large-scale construction programmes of that era. For example, three main housing estates in Tallinn can be categorised into this way (Table 16.1). Based on the primary construction materials in use, it can be seen that there are four main apartment building types in Estonia: wood; autoclaved, aerated large concrete blocks; brick; and prefabricated, reinforced large concrete panels. The majority of the wooden apartment buildings were built before World War II. After World War II, the construction of wooden apartment buildings decreased significantly and was pretty much finished after the 1960s (Arumägi 2015). Nowadays, those districts which have wooden apartment buildings are being nominated as historically valuable areas. Aerated large concrete block buildings are composed, as may be suggested, of large blocks. These are mainly two- to five-storey buildings, and in architectural terms, they are visually similar to the smaller types of brick apartment buildings. Brick apartment buildings have an inner, load-bearing layer of 250$630 \mathrm{~mm}$ in thickness, $60-120 \mathrm{~mm}$ of low-quality thermal insulation, and a $120 \mathrm{~mm}$ external layer. Both buildings types have been used in smaller towns and villages and also on larger housing estates (Fig. 16.3).

Prefabricated large concrete panel apartment buildings are the most common building type to be used on large housing estates. The panels of the external walls

Table 16.1 Number of apartment buildings in Tallinn housing estates

\begin{tabular}{l|l|l|l|l}
\hline & $\begin{array}{l}1961- \\
1970\end{array}$ & $\begin{array}{l}1971- \\
1980\end{array}$ & $\begin{array}{l}1981- \\
1990\end{array}$ & Total \\
\hline Mustamäe & 246 & 90 & 30 & 366 \\
\hline Õismäe & 6 & 193 & 38 & 237 \\
\hline Lasnamäe & 68 & 123 & 321 & 512 \\
\hline
\end{tabular}



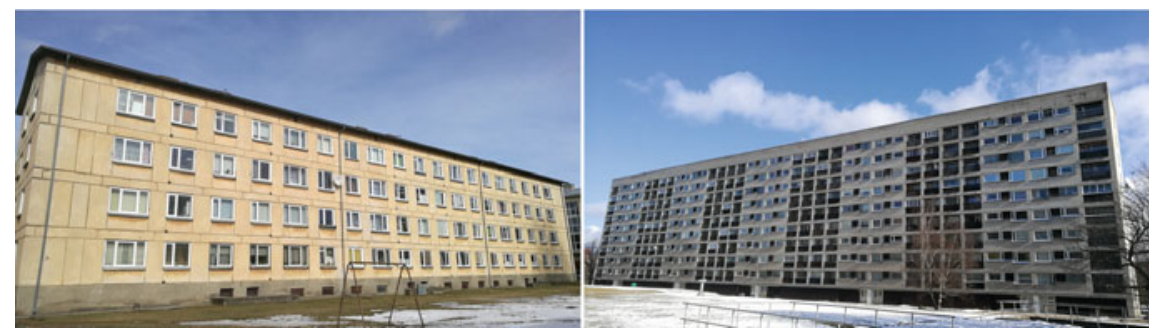

Fig. 16.3 Large block (left) and brick (right) apartment buildings in Tallinn housing estates

are composed of two layers of reinforced concrete (a 50-125 $\mathrm{mm}$ inner layer and a $30-70 \mathrm{~mm}$ outer core) with low-quality thermal insulation of $100-150 \mathrm{~mm}$ in between. Typological series 1-464 apartment buildings in Mustamäe (Fig. 16.4) have five (Type A) or nine (Type D) storeys. A single 1-464 typology building consists of between four and eight sections in a row, each having one staircase. One of the key shortcomings of the five-storey concrete apartment buildings is the absence of lifts. Those buildings which were erected in the Õismäe and Lasnamäe districts were of series 121 . The main difference when comparing them to series 1-464 is the design which focuses on sections instead of an entire building. A building may be composed of several sections that differ from one another. In addition, apartment buildings of series 133 and 66 have been used in various cities around Estonia.

The Estonian housing market is characterised by a high rate of private ownership of housing stock (97\%) and a high rate of owner-occupancy (about $82 \%$ of non-vacant conventional dwellings) (National Report on Estonia, TENLAW). Such an ownership structure is the result of the privatisation process, which in Estonia took place in the 1990s after the collapse of the Soviet Union. During the Soviet Union period, property such as dwelling units in apartment buildings was in public ownership. The private ownership of every apartment makes any large-scale and systematic process of renovating and refurbishing apartment buildings a complicated one. Apartment buildings are generally managed by apartment associations. All apartment owners are members of the apartment association and are responsible

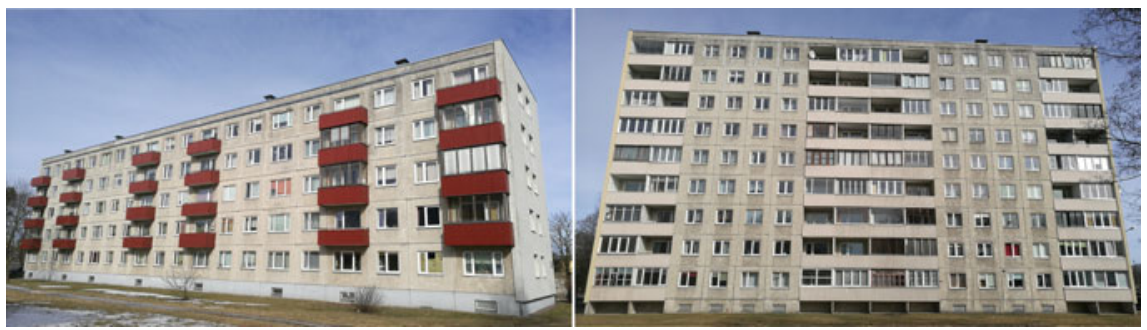

Fig. 16.4 Large-panel apartment buildings in Mustamäe: 1-464A (left) and 1-464D (right) 
for decisions and payments. This means that more than $50 \%$ of apartment owners in each building must agree on the scope of any refurbishment work and also on the budget for any such work.

\subsection{Energy Efficiency and the Current Technical State of Estonian Apartment Building Stock}

Energy efficiency levels in buildings are expressed through primary energy usage. Primary energy takes into account the energy used in buildings (space heating, ventilation, domestic hot water and all electricity loads), and the environmental impact, with weighting factors according to the energy carrier. Residential buildings are divided into eight 'Energy Performance Certificate' (EPC) classes (as shown in Fig. 16.5), in which Class A denotes the highest energy efficiency levels (the nZEB level), and Class $\mathrm{H}$ the lowest level. Existing apartment buildings are usually EPC Class F or G. All modernist apartment buildings from the industrialised construction era have similar thermal transmittance levels. As energy prices were very low at the time, the thermal transmittance of the building envelope was high. The low quality of the construction work and the variations in the materials used and in their parameters were also important factors for the high thermal transmittance of the building envelope. Thermal transmittance values for the external walls of the apartment buildings were as follows:

- prefabricated concrete large-panel wall $\mathrm{U} \approx 0.8-1.2 \mathrm{~W} /\left(\mathrm{m}^{2} \cdot \mathrm{K}\right)$;

- brick wall (without insulation) $\mathrm{U} \approx 1.6-2.0 \mathrm{~W} /\left(\mathrm{m}^{2} \cdot \mathrm{K}\right)$;

- brick wall (with $60 \mathrm{~mm}$ of insulation) $\mathrm{U} \approx 0.8-1.2 \mathrm{~W} /\left(\mathrm{m}^{2} \cdot \mathrm{K}\right)$;

- autoclaved aerated concrete block wall $\mathrm{U} \approx 0.6-0.8 \mathrm{~W} /\left(\mathrm{m}^{2} \cdot \mathrm{K}\right)$.

Building structures at that time contained significant thermal bridges (Ilomets et al. 2017), so the thermal transmittance of the building envelope as a whole is
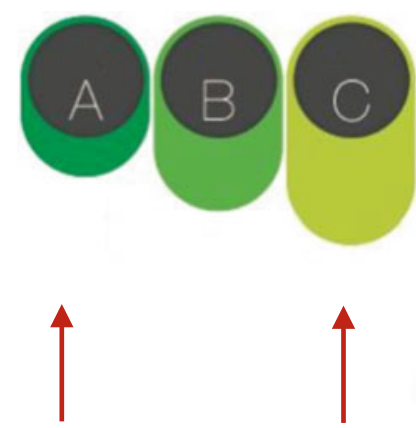

nZEB

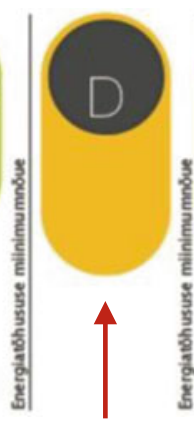

Major renovation

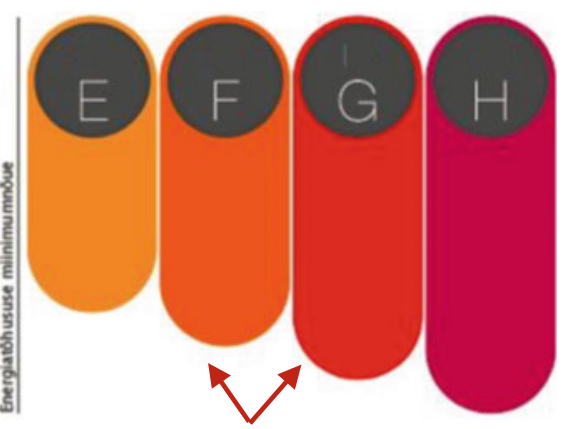

Existing buildings

Fig. 16.5 Energy performance certificate classes for apartment buildings 
actually higher than the thermal transmittance of its single parts. By comparison, the modern recommendation for thermal transmittance in an external wall is $\mathrm{U} \approx 0.15 \mathrm{~W} /\left(\mathrm{m}^{2} \cdot \mathrm{K}\right)$. Approximately, $70 \%$ of flats in Estonia are located in low-energy-efficiency apartment houses (Pittini et al. 2015). The average heating energy consumption level for apartment buildings in Estonia is approximately 140$150 \mathrm{kWh} /\left(\mathrm{m}^{2} \cdot \mathrm{a}\right)$ (Kuusk 2015) which is higher than the average Northern European heating energy consumption level (cf. Balaras et al. 2005; Engvall et al. 2014; Paiho et al. 2015).

Apartment buildings in Estonia are heated mainly by means of district heating and have a one-pipe heating system with hydronic radiators and no thermostats. The indoor temperature is regulated only in heating substations. The ventilation system is natural passive stack ventilation with mechanical kitchen hoods installed by apartment owners. Common problems which are related to building service systems include insufficient ventilation, mould growth due to that insufficient ventilation, uneven indoor temperatures, and insufficient thermal comfort levels.

High energy consumption levels and poor indoor climate are not the only problems when it comes to existing apartment buildings. Research has shown that although the condition of load-bearing constructions is satisfactory, there exist problems which are related to degradation of facades and balconies. Additional external thermal insulation together with the improvement of ventilation is advised in order to eliminate critical thermal bridges and to stop degradation mechanisms (Ilomets 2017). The temperature of the external layer of an old facade after applying external thermal insulation remains above $+10{ }^{\circ} \mathrm{C}$ throughout the year, meaning no more freeze-thaw damage.

\subsection{Refurbishment Grant Schemes in Estonia}

The investment capabilities of apartment associations are not sufficient to be able to cover the cost of crucial repair work and to significantly improve the building's energy efficiency levels. The analysis showed that the apartment owners' capability of being able to invest in energy efficiency is lower than that necessary to meet current energy efficiency requirements. Apartment owners' own funds often allow only for single refurbishment measures and often do not result in any significant change in energy use. Even worse, such repairs have typically neglected ventilation completely and have led to a deterioration of indoor climate with potential adverse health effects upon the occupants. Therefore, financial support is required in order to be able to carry out refurbishment work in apartment buildings in order to achieve future energy efficiency targets and to assure adequate indoor climate conditions. Without grants being made available, the annual cost (in terms of energy costs and refurbishment loan repayments) after any refurbishment work is carried out would be too high for apartment owners to be able to afford, and this would make it difficult for the apartment association to make a decision in favour of major refurbishment work. Subsidies increase the interest of apartment owners in investing in energy efficiency improvements. 
During the 2010-2014 period, a total of 663 apartment buildings underwent refurbishment work in Estonia under the umbrella of a support scheme that was joint-financed by Assigned Amount Unit trading and a government budget, with the administration of the scheme being handled by Fund KredEx (http://kredex.ee/en/). In addition to the refurbishment grant, a refurbishment loan was also made available at a low interest rate and with a long repayment period. The refurbishment loan was financed by European Structural Funds. Total investments from apartment associations and the grant scheme amounted to 151 million euros, of which 38 million euros were grants. Average energy savings for each apartment building were at $43 \%$, and the total annual energy saving was approximately 60 GWh (Lauri 2014).

A total of 102 million euros from the European Union Structural Funds was used in the new grant scheme for 2015-2017. Under the new scheme, technical requirements and the application process were further developed and were more detailed. A $15 \%$ grant can be applied when an Energy Performance Certificate (EPC) of Class E (covering minor refurbishment work) is achieved after the completion of any refurbishment work, while a $25 \%$ grant can be applied when EPC Class D (covering the energy efficiency requirement for major refurbishment work) is achieved after the completion of any refurbishment work, and a $40 \%$ grant can be applied when EPC Class C (covering the energy efficiency requirement for new apartment buildings) is achieved after the completion of any refurbishment work.

In addition to the EPC class, requirements are also in place for thermal transmittance in the building envelope, the heating system, and the ventilation system. A $15 \%$ refurbishment grant does not come with any additional requirements for the building envelope because this grant share is used mainly for minor refurbishment work and improving the indoor climate, areas which may not include the refurbishment of the entire building envelope. Although there are no specific requirements for the building envelope, a heating energy reduction of at least $20 \%$ is required. The main difference between the 25 and $40 \%$ grants is the fact that the $40 \%$ grant also has a requirement for the window and external wall thermal bridge. In order to be able to fulfil these requirements, windows must be moved into the insulation layer. Another option is to insulate the window jamb with an insulation layer that is at least $50 \mathrm{~mm}$ thick, which in practice is often impossible. Fulfilling the thermal transmittance requirements for external walls usually means the creation of an insulation layer that is between 150 and $200 \mathrm{~mm}$ thick. Fulfilling the thermal transmittance requirements for the roof usually means $300-400 \mathrm{~mm}$ of insulation layer. The requirements for windows are only for those windows that are going to be replaced and only for old wooden-framed windows that have not so far been replaced and which certainly do have to be replaced.

The heating system has only two requirements: the system must be balanced and radiators have to be equipped with thermostats in order to allow room-based indoor temperature control.

Ventilation and indoor air quality were the main problems in the previous refurbishment grant scheme (Kõiv et al. 2014). Therefore, special attention was paid to ensure that refurbishment work would include the installation of the ventilation 
system, and that the requirements and the compliance of the ventilation system could be met. Continuous average ventilation (for each apartment in total) should be $0.51 / \mathrm{h}$. Supply or intake air flow rates are required to be at least $101 / \mathrm{s}$ in bedrooms, with living rooms exhibiting sound levels that are no more than $25 \mathrm{~dB}$ (A). Extract air flow rates are required to be at least 101/s in the WC, 151/s in the bathroom and 81/s in the kitchen (or 101/s in the bathroom and 61/s in the kitchen in one room flats). A $40 \%$ grant required that the ventilation system utilise heat recovery. A supply and extract ventilation system with an apartment-based air handling unit and an exhaust ventilation system with an exhaust air heat pump for heat recovery were previously used in standard refurbishment work practices. A new solution in Estonia which evolved from new ventilation requirements involves the central air handling unit with ventilation ducts inside the facade insulation layer, as shown in Fig. 16.6. This solution has become one of the main ventilation solutions in the current refurbishment work grant scheme.

In order to pay more attention to the preparation and commissioning process, the new grants scheme has three main differences when compared to the previous measure. The first innovation is the technical consultant for apartment associations. These individuals have undergone specialist training which focuses on the problems involved in the refurbishment of apartment buildings and the solutions that can be applied. The purpose of technical consultants is to help apartment associations make the right choices and to steer a rather complex refurbishment process that involves a good many parties (such as the board and members of the apartment association, the energy auditor, the designer, the contractor, and the bank). The second innovation is the review process for a developed design by third-party experts in order to ensure that all technical requirements are fulfilled and design documents are prepared to an adequate level of quality. A summary of the review process report is also often required by commercial banks as part of the refurbishment grant process in order that a refurbishment loan may be issued. The third innovation is the commissioning process. A measuring protocol for ventilation airflows must be drawn up in order to confirm that the required ventilation rates are achieved. Results showed that the commissioning of ventilation requirements, and an obligation to present the airflow rate measurement protocol in order to confirm
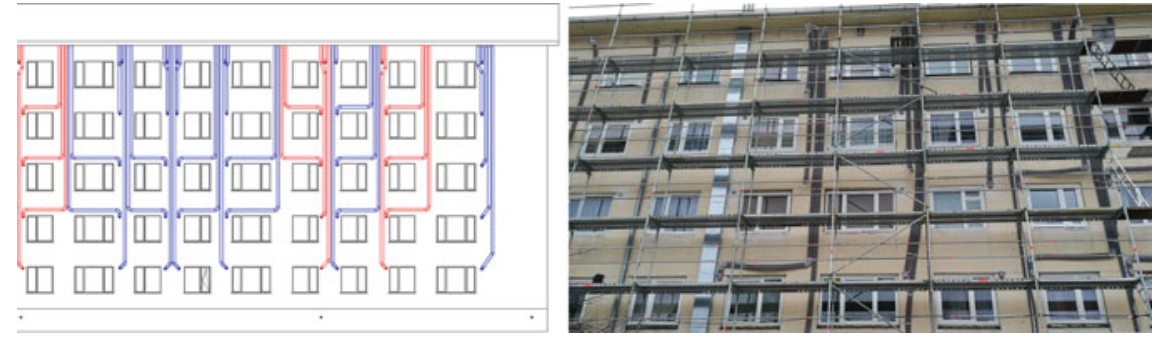

Fig. 16.6 Ventilation ducts in façade insulation layers: schematic view with red supply air ducts and blue exhaust air ducts (left), and photo (right) 

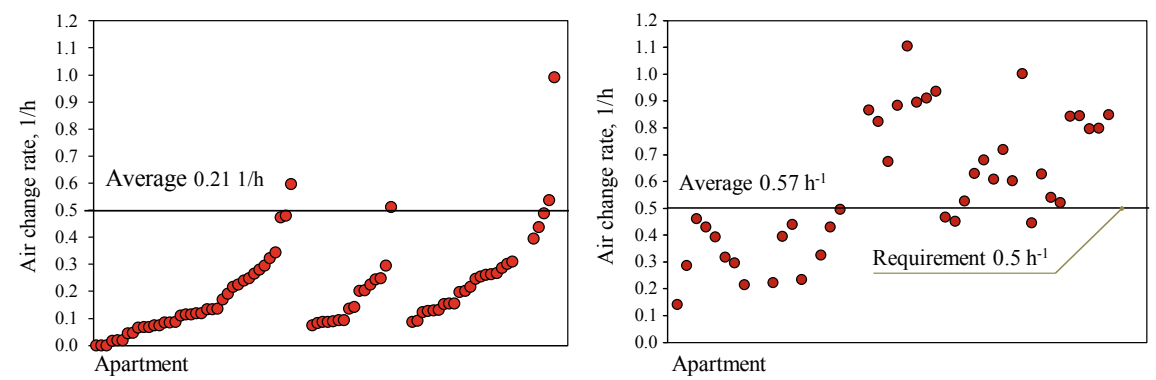

Fig. 16.7 Measured average ventilation air change rates: previous grant scheme (left) and new grant scheme (right)

that the required ventilation rates are achieved, has significantly improved ventilation air change rates in apartment buildings that have already undergone refurbishment work. Average ventilation air change rates which have been measured operationally - as shown in Fig. 16.7—-serve to illustrate the effects of compliance procedures. Under the new grant scheme, even in operational situations in which airflow rates may have been reduced by the inhabitants of apartments, the ventilation system provided values that were close to or higher than $0.51 / \mathrm{h}$.

Although various stakeholders were, at the start of this process, pessimistic when it came to the new technical requirements, the results showed that the grant scheme has worked better than expected. Approximately, $90 \%$ of applications were received for the $40 \%$ grant, which refers to extensive integrated refurbishment work. This shows that with the help of a financial incentive, apartment owners are willing to invest in order to carry out extensive integrated refurbishment work.

\subsection{The Economic Impact Involved in Refurbishment Work on Apartment Buildings - National Economic Impact}

Large-scale refurbishment programmes have a significant impact at the macroeconomical level. Pikas et al. (2015) analysed refurbishment projects in order to discover the tax revenue and job generation for each one million euros of investment. Figure 16.8 summarises the distribution of construction costs. The projects were analysed on the basis of the project budget, while costs were classified into three different categories. On average, $12 \%$ had been spent on project management costs. Labour costs account for $34 \%$ of construction costs, and material costs totalled $54 \%$.

The distribution of project costs was used to calculate job creation and tax revenues for each one million euros of investment (directly) into the construction site and (indirectly) into the consultancy and manufacturing sectors. The average 
Fig. 16.8 Distribution of projects costs

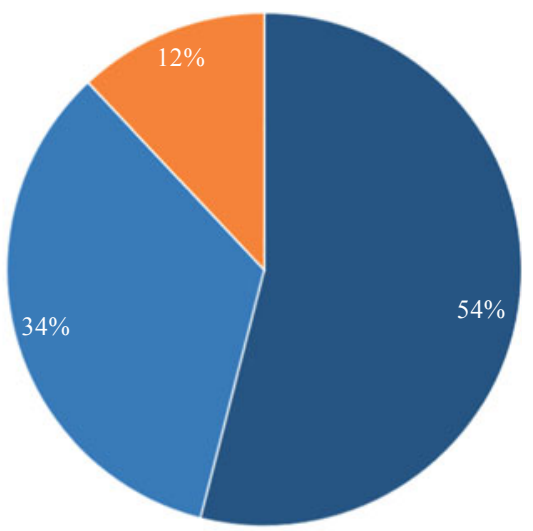

- Material costs, $€ \quad$ - Labor costs for employer, $€$

- Project management costs, $€$

total tax revenue from the refurbishment projects was between 32 and $33 \%$, including VAT and direct and indirect employment taxes (Fig. 16.9). Employment tax revenue included social security tax, unemployment insurance, funded pension contributions and unemployment insurance. The average total tax revenue for each one million euros of investment was $324,000 €$. The average direct tax revenue from construction was $28 \%$, whilst the average indirect tax revenue was $1 \%$ from consultancy and $3 \%$ from manufacturing. Tax revenue from manufacturing only included employment-related taxes, as VAT is paid during the construction phase, making the tax revenue from construction the highest of all of the options. If the objective is to balance tax revenue against government investment then a suitable subsidy for project costs would be between 32 and 33\%, because an average of $28 \%$ from construction and $4 \%$ from manufacturing and consultancy are remitted. In

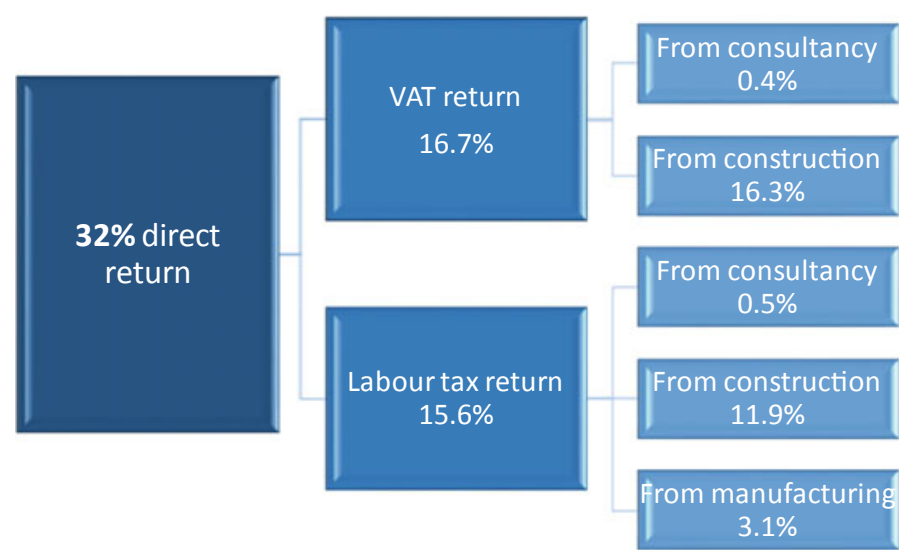

Fig. 16.9 Distribution of tax revenue 
addition to tax revenue, an average of 17 jobs was created for each one million euros of investment.

\subsection{The Impact upon Households of Refurbishment Work}

The main concerns of apartment owners (in Estonia, apartments are occupied mainly by their owners) tends to relate to investment costs and total costs (in terms of loans, maintenance, and energy) after the refurbishment work has been completed. Total cost and energy savings are important factors when a decision is made regarding refurbishment work. An analysis of refurbished apartment buildings showed that the average cost for an intensive refurbishment is approximately $260 € / \mathrm{m}^{2}$. Extensive refurbishment work provides an approximate reduction of $50 \%$ in terms of heating energy. A reduction in heating energy should be even higher but a change in the consumption habits of the inhabitants (in terms of a higher indoor temperature after the refurbishment work has been completed) tends to decrease the energy savings. Electricity consumption increases between 10 and $20 \%$ due to the electricity being used in the newly installed mechanical ventilation system.

A cost analysis for refurbishment work showed heating costs being at $60 €$ / MWh (including VAT), and an electricity price of $113 € / \mathrm{MWh}$ (including VAT), and for the funding of the refurbishment work a loan period of 20 years and an interest rate of $3 \%$. The results of the cost analysis as shown in Fig. 16.10 allows the conclusion to be drawn that, although work for extensive refurbishment requires fairly high initial investment levels, the reduction in heating energy use and the

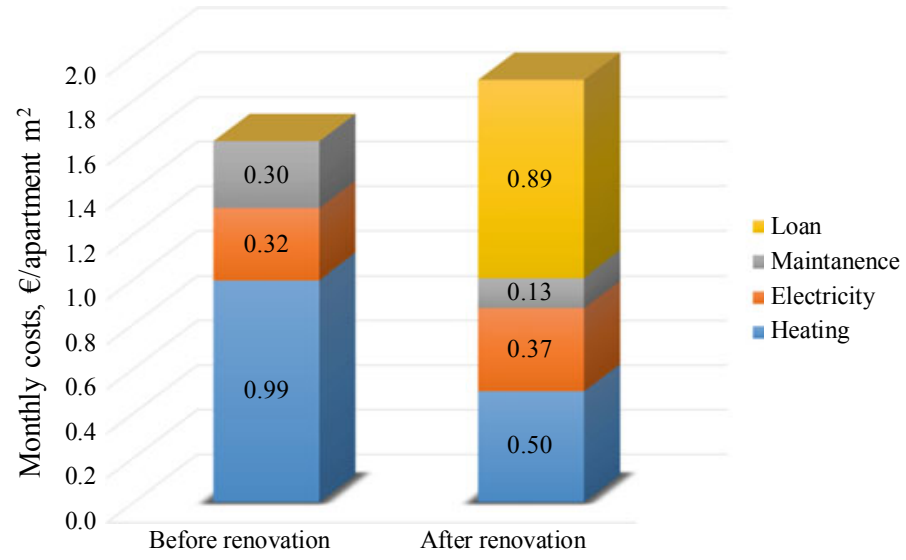

Fig. 16.10 Monthly costs for households before and after renovation (measured for $\mathrm{m}^{2}$ of living space in apartments) 
financial help from the grant scheme will keep the monthly costs for apartment owners at a fairly reasonable level. Monthly average costs together with loan payments are approximately $20 \%$ higher when compared to the situation before the refurbishment scheme had been carried out.

Considering current property values, an analysis of property-related transaction prices for apartments in refurbished apartment buildings when compared to the prices for apartments in non-refurbished apartment buildings in the same area showed that refurbishment work may, albeit not necessarily, increase the value of the property in question (Allekand 2014). As a result of refurbishment work having been carried out, the statistical average value of property increased by $9 \%$.

A survey which was carried out across 40 households in apartment buildings that had already undergone refurbishment work found positive satisfaction results from the occupants (Kalamees et al. 2017), reporting that almost all households were satisfied with the results of the refurbishment work in terms of energy savings, thermal comfort levels, and indoor air quality. A modest increase in monthly payments was highlighted by $30 \%$ of households, but the occupants commented that they could keep room temperatures at between 22 and $23{ }^{\circ} \mathrm{C}$ thanks to well-insulated buildings and relatively small energy bills, which serves to indicate that occupants who are in apartments which have poor thermal quality levels prefer their thermal comfort to be on the warm side. The benefits from refurbishment work, such as a better living environment, better indoor climate and smaller energy bills, were all reported, fully compensating for the slightly increased monthly costs which included loan payments to the bank.

\subsection{Refurbishment Bottlenecks}

The refurbishment of an apartment building usually involves measures that are designed to improve the condition of the building envelope and its service systems. Public spaces between buildings and apartment layouts are not changed. Tallinn Vision Council has pointed out that the floor planning for these old dwellings is unsuitable for families (Sarv 2013) because the bathrooms and kitchens are too small. In addition, in the five-storey buildings, narrow staircases and the absence of lifts restrict the movement of families with small children and elderly or disabled people. Living standards have changed and conditions in apartments on housing estates are no longer considered to provide the best living environment. Lõoke (2016) studied the 1-464 series large-panel apartment building, and proposed four possible solutions for problems that were related to living conditions:

- Major work - to change all of the apartments in the same way and, for the most part, to a considerably major extent. For example, adding a new room to all apartments which are positioned at the end of the apartment building.

- Variable - the layout of the apartments in the 1-464 series is rather rigid, and there are not that many ways in which they can be improved. By building a new 
communications shaft through all of the apartments it is possible to change the layouts, but if this is positioned correctly then it will not considerably change the apartment for anyone who prefers not to have such a change.

- Communal - those operations that do not change the apartments themselves but which add some form of function or amenity to the apartment building which can be used by all of the apartment owners. For example, a sauna on the roof of the building.

- Repartitioning the apartments - there is a lack of apartments in the building stock which have a large number of rooms. In order to correct this, it is possible to merge apartments together, forming larger apartments. Usually merging two apartments together will result in an apartment that is too large, so it's reasonable to merge three apartments together instead of in order to form two larger ones that are still reasonably sized.

Refurbishment work will affect the architectural appearance of the buildings. Housing estates have generally been built as homogenous environments. Taking a building-by-building approach to the refurbishment of apartment buildings has changed that (Fig. 16.11). Every building has its own architectural design and the initial modern homogenous environment is often not followed anymore. Guidance for local the municipality or for a general refurbishment plan for an entire group of buildings would help to prevent that problem.

Although there already exist buildings on housing estates that have undergone refurbishment work, that refurbishment work has been too slow for the desired renewal of housing stock. The current refurbishment rate for apartment buildings in Estonia is approximately $1 \%$ per year ( 200 buildings). Refurbishment schemes have shown that a higher refurbishment rate raises the construction cost due to the

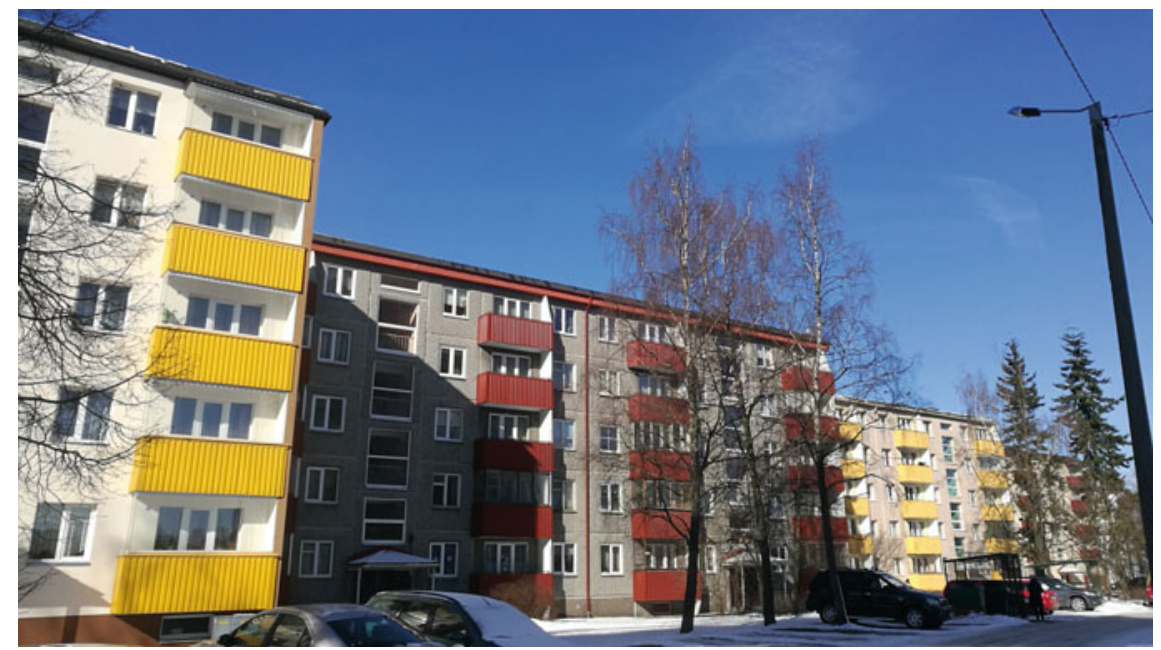

Fig. 16.11 Various façade treatments on adjacent apartment buildings 


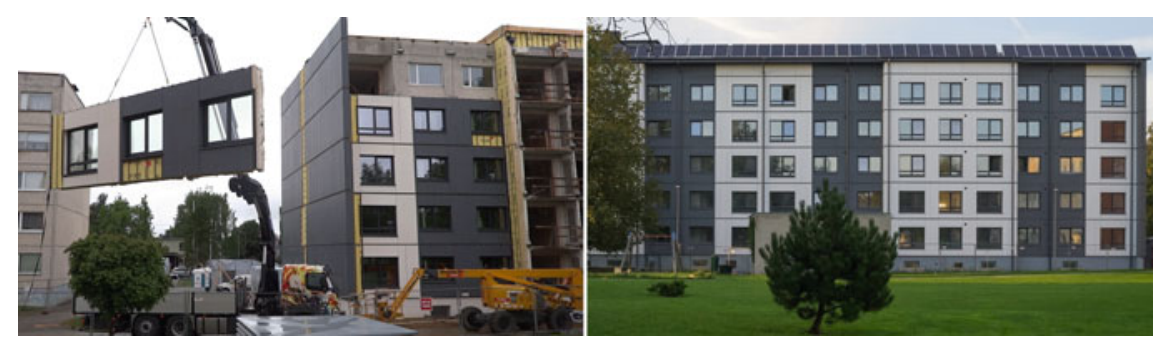

Fig. 16.12 Installation of modular wall panels (left) and the finished building (right)

higher demand for and limited number of construction workers. Current refurbishment work mainly uses labour-intensive refurbishment technologies. Refurbishment work on one apartment building takes approximately 6 months. In order to increase the rate at which refurbishment work takes place, new technologies are needed. One possible solution is to handle refurbishment work using prefabricated modular panels. The concept of using prefabrication in the refurbishment process involves timber frame external wall elements with insulation, a façade cover, and windows all being pre-assembled at the factory. The quality of the work is higher and installation onsite does not require scaffolding. In 2017, a large-panel apartment building, which was used as a dormitory for Tallinn University of Technology, underwent refurbishment work using prefabricated walls and roof modular panels (Fig. 16.12). The prefabrication solution would allow for a significantly shorter time being taken to handle such refurbishment work. The estimated installation time for external wall elements is 2 weeks for one apartment building. So far this building is the only pilot project in Estonia to undergo refurbishment work using prefabricated façade elements.

\subsection{Conclusions}

Apartment buildings in large urban housing estates are essential to ensure a housing supply. There are visions which involve the demolition of old apartment buildings and building new ones. Although this approach would theoretically supply a complete resolution of the problems regarding public space between the buildings and regarding the apartment layouts, the economic and environmental reasons favour the extensive integrated refurbishment of existing buildings. In the case of privately owned and occupied Estonian apartments, refurbishment work with governmental grants seems to be the solution that works. Today around 1,100 existing apartment buildings out of about 20,000 in the total stock have undergone refurbishment work. Energy efficiency increases and an indoor climate condition which is comparable to modern apartment buildings have been achieved following the application of an intensive refurbishment process. At the same time, the cost of 
an intensive refurbishment is approximately three or four times lower than it would be for putting up a new apartment building. From the environmental aspect, rebuilding is also considered as being unreasonable due to the much higher embodied energy and carbon footprint of building materials.

Large-scale refurbishment work has generated positive effects at the macroeconomic level, something which can be quantified in terms of job creation and tax returns. In all, seventeen jobs for each one million euros of investment in refurbishment work had been created both directly and indirectly per year in Estonia. Tax revenue from refurbishment projects has been quantified to be between 32 and $33 \%$. Therefore, evidence from Estonia suggests that a state-subsidised refurbishment programme has, in practical terms, been budget-neutral with direct financial supports of $25-40 \%$ in use during the past 10 years.

Acknowledgements This research was supported by Resource Efficient Smart Buildings and Districts, ZEBE, grant 2014-2020.4.01.15-0016 sponsored by the European Regional Development Fund.

\section{References}

Allekand I (2014) Kortermaja rekonstrueerimine ei pruugi selle väärtust tõsta (in Estonian). https:// domuskinnisvara.ee/2014/10/09/kortermaja-rekonstrueerimine-ei-pruugi-selle-vaartust-tosta/

Arumägi E (2015) The refurbishment of historic wooden apartment buildings. Doctoral thesis, Tallinn University of Technology

Balaras CA, Droutsa K, Dascalaki E, Kontoyiannidis S (2005) Heating energy consumption and resulting environmental impact of European apartment buildings. Energy Build 37:429-442

Engvall K, Lampa E, Levin P, Wickman P, Öfverholm E (2014) Interaction between building design, management, household and individual factors in relation to energy use for space heating in apartment buildings. Energy Build 81:457-465

Ilomets S, Kuusk K, Paap L, Arumägi E, Kalamees T (2017) Impact of linear thermal bridges on thermal transmittance of renovated apartment buildings. Journal of Civil Engineering and Management 23(1):96-104

Ilomets S (2017) Refurbishment need and performance of envelopes of concrete apartment buildings in Estonia. Doctoral thesis, Tallinn University of Technology

Itard L, Klunder G (2007) Comparing environmental impacts of renovated housing stock with new construction. Build Res Inf 35:252-267

Kalamees T, Ilomets S, Arumägi E, Alev Ü, Kõiv T-A, Mikola A, Kuusk K, Maivel M (2011a) Indoor hygrothermal conditions in Estonian old multi-storey brick apartment buildings. In: The 12th international conference on indoor air quality and climate, Indoor Air, Austin, Texas, pp 5-10

Kalamees T, Õiger K, Kõiv T-A, Liias R, Kallavus U, Mikli L, Lehtla A, Kodi G, Arumägi E (2011b) Technical condition of prefabricated concrete large-panel apartment buildings in Estonia. In: International Conference on Durability of Building Materials and Components. Porto, Portugal, pp 973-981

Kalamees T, Hamburg A, Mikola A, Kurnitski J (2017) Rekonstrueeritud korterelamute sisekliima ja energiakasutuse analüüs (in Estonian). http://kredex.ee/public/Uuringud/Rekonstrueeritud_ korterelamute_sisekliima_ja_energiakasutuse_analuus.pdf 
Kõiv T-A, Hamburg A, Mikola A, Kiil M, Tukia A, Rohula T, Siim G, Palmiste Ü (2014) Rekonstrueeritud korterelamute sisekliima ja energiatarbe seire ja analüüs ning nende vastavus standarditele ja energiaaudititele (in Estonian). http://www.kredex.ee/public/Uuringud/ Rekonstrueeritud_korterelamute_uuring.pdf

Kuusk K (2015) Integrated cost-optimal refurbishment of apartment buildings toward nearly zero-energy buildings. Doctoral thesis, Tallinn University of Technology

Lauri M (2014) Korterelamute renoveerimisturu ülevaade ja perioodi 2010-2014 korterelamute rekonstrueerimistoetuse mõju analüüs (in Estonian). http://www.kredex.ee/public/Uuringud/ Korterelamute_analuus_030914.pdf

Lõoke T (2016) Kuidas kaasajastada paneelmaju?. Magistritöö, Eesti Kunstiakadeemia

National Report on Estonia, TEN LAW. http://www.tenlaw.uni-bremen.de/

Paiho S, Pinto Seppä I, Jimenez C (2015) An energetic analysis of a multifunctional facade system for energy efficient retrofitting of residential buildings in cold climates of Finland and Russia. Sustain Cities Soc 15:75-85

Pikas E, Kurnitski J, Liias R, Thalfeldt M (2015) Quantification of economic benefits of refurbishment of apartment buildings as a basis for cost optimal 2030 energy efficiency strategies. Energy Build 86(2015):151-160

Pittini A, Ghekiere L, Dijol J, Kiss I (2015) The state of housing in the EU 2015

Sarv M (2013) Mustamäe maha, püsti uus Mustamäe! Eesti Päevaleht. http://epl.delfi.ee/news/lp/ mustamae-maha-pusti-uusmustamae.d?id=65551478 (in Estonian)

Terk E, Keskpaik A (2015) Tallinn's housing scenarios and the future of districts (Tallinna elamispinnastsenaariumid ja „magamislinnaosade“ tulevik) final report (in Estonian), Tallinn University. http://uuringud.tallinnlv.ee/document.aspx?id=11538

Open Access This chapter is licensed under the terms of the Creative Commons Attribution 4.0 International License (http://creativecommons.org/licenses/by/4.0/), which permits use, sharing, adaptation, distribution and reproduction in any medium or format, as long as you give appropriate credit to the original author(s) and the source, provide a link to the Creative Commons license and indicate if changes were made.

The images or other third party material in this chapter are included in the chapter's Creative Commons license, unless indicated otherwise in a credit line to the material. If material is not included in the chapter's Creative Commons license and your intended use is not permitted by statutory regulation or exceeds the permitted use, you will need to obtain permission directly from the copyright holder.

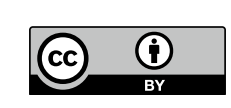




\title{
Chapter 17 \\ Retrofitting Soviet-Era Apartment \\ Buildings with 'Smart City' Features: \\ The H2020 SmartEnCity Project \\ in Tartu, Estonia
}

\author{
Rein Ahas, Veronika Mooses, Pilleriine Kamenjuk \\ and Raimond Tamm
}

\begin{abstract}
The retrofitting and renewal of modern-era socialist housing estates is a prominent issue throughout the world. There are different political choices to deal with dilapidated socialist housing estates. The transformation of such estates in post-socialist cities has so far focused primarily on improving their physical conditions and increasing the energy efficiency building-by-building. However, an integrated and area-based regeneration approach would have greater potential to influence the entire neighbourhood, as well as the inhabitants' environmental behaviour. The Smart City is a concept that can achieve environmental sustainability ambitions as well as large housing estate regeneration goals. This chapter describes the implementation of the Smart City concept to the renovation of a Soviet-era apartment buildings area, based on the example of the SmartEnCity project in Tartu, Estonia.
\end{abstract}

Keywords Retrofitting - Socialist housing estate - Area based - Smart city • Estonia

\footnotetext{
R. Ahas

Mobility Lab, Department of Geography, University of Tartu, Tartu, Estonia

V. Mooses $(\bowtie) \cdot$ P. Kamenjuk

Mobility Lab, Department of Geography, University of Tartu, Tartu, Estonia

e-mail: veronika.mooses@ut.ee

P. Kamenjuk

e-mail: pilleriine.kamenjuk@ut.ee

R. Tamm

Tartu City Government, Tartu, Estonia

e-mail: Raimond.Tamm@raad.tartu.ee

(C) The Author(s) 2019

D. B. Hess and T. Tammaru (eds.), Housing Estates in the Baltic Countries,

The Urban Book Series, https://doi.org/10.1007/978-3-030-23392-1_17
} 


\subsection{Introduction}

Socialist housing estates are obsolete, often stigmatised as socially problematic neighbourhoods that face issues of vacancy, social decline and crime (Musterd and Van Kempen 2007; Kovacs and Herfert 2012). Buildings erected in the post-WWII era are nearing the end of their service life. Many of these structures no longer meet the needs of modern lifestyles, or requirements of technological progress and environmental sustainability (Serrano-Lanzarote et al. 2016; Guerra-Santin et al. 2017).

There are various political choices to tackle the issues of such estates for application in the modern era. First, there is the option to take no action and let the estates continue to deteriorate. Second, it is possible to demolish the apartment buildings, as is planned in Moscow: in Russia's capital, authorities want to raze about 4,500 buildings that are home to around $10 \%$ of the city's population. [If the plan is realised it will be Moscow's largest urban resettlement programme in recent history (Watson et al. 2017).] Third, there is the possibility to demolish old apartment buildings and replace them with new construction, such as in St. Petersburg, Russia (Trumbull 2014). Fourth, there is the option to renovate, refurbish or retrofit old apartment buildings.

Most socialist housing estates have a high share of owner occupation following widespread privatisation in the 1990s. The estates have diverse social structures: in many cases, inhabitants are of lower economic earning power and more vulnerable, e.g. pensioners, young people and lower income earners (Martinaitis et al. 2007). Buildings designed at a time when energy was inexpensive are often now characterised by problematic energy performance. Despite low-priced living spaces, the heating costs are relatively high (Martinaitis et al. 2007). The different social structures and issues can complicate retrofitting processes. Tenants and owners can be resistant to changes and providing the investments needed for undertaking major work.

Engineering and technical challenges also contribute to the difficulty of retrofitting and modernization processes. Renovation is often more complicated, and therefore more expensive, than building new structures. Renovations in post-socialist cities have followed a similar path to Western countries during the 1980s, where the physical conditions of the buildings receive upgrades (Tosics 2005; cit. Muliuolyte 2013). However, this costly upgrading only provides a temporary relief to larger problems. This process revealed that refurbishing the housing structures is insufficient if the goal is to improve the living environment of the area's entirety (Muliuolyte 2013). An integrated approach to retrofitting that focuses on the district holistically can yield better results (Muliuolyte 2013).

Smart City is a concept that is gaining popularity for its holistic and cross-sectoral approach to urban regeneration. This concept focuses on the use of technologies and social innovation to develop a more creative society and better living environments. The Smart City concept in use has created new urban spaces (e.g. Songdo, South Korea) and transformed existing spaces (e.g. Barcelona, Spain). 
A new challenge worldwide is the use of this concept in retrofitting housing stocks, such that it can contribute to achieving sustainability goals and improving living environments.

This chapter describes the implementation (planning, design, and financial scheme) of the Smart City concept to the renovation of Soviet-era apartment buildings based on the example of the SmartEnCity project in Tartu, Estonia. The SmartEnCity ('Towards Smart Zero $\mathrm{CO}_{2}$ Cities Across Europe') project is an EU Smart Cities and Communities initiative, through which city districts and neighbourhoods in Vitoria-Gasteiz (in Basque County, Spain), Sønderborg (Denmark) and Tartu (Estonia) will be transformed into lighthouse demonstrations. In Tartu, 22 khrushchëvka-type apartment buildings will undergo renovation to become energyefficient, modern dwellings, i.e. "smartovkas." Khrushchëvki are a specific type of apartment building constructed in the 1950s and 1960s, during the rule of Nikita Khrushchëv (and continuing into the 1970s). The terms of reference established by Tartu are ambitious and focus on energy performance in residential premises. The goal is to reduce energy consumption in dwellings of this type in the Tartu pilot area from the current $270 \mathrm{kWh} / \mathrm{m}^{2} / \mathrm{y}$ to a nearly zero-energy building (nZEB) level. This means a maximum energy consumption of $90 \mathrm{kWh} / \mathrm{m}^{2} / \mathrm{y}$, which therefore achieves the energy efficiency rating 'A'. Achieving the project's goal will require establishment of construction technology requirements and surmounting of several social barriers, with people actively engaged and trained throughout the process.

\subsection{The Smart City Approach}

Although the Smart City concept has no single definition (Angelidou 2015; Caragliu et al. 2011), its key elements are the use of information and communication technologies (ICT), increased energy performance, reduction of greenhouse gases and boosts to social innovation, new business models and creative industries. One premise is that the smart city technologically integrates the concepts of a creative city with sustainable development (Ahvenniemi et al. 2017).

The EU's approach to smart cities focuses primarily on implementing technology to address environmental challenges and reduce greenhouse gas emissions (European Commission 2017). The use of innovative (green) technologies assists with resource conservation and precise data collection, ultimately informing and improving planning decisions. This provides information and feedback on the urban environment and its services, as well as individuals' consumption patterns (Khansari et al. 2014). Such that environmental problems are partially rooted in individual consumer behaviour (Vlek and Steg 2007), increasing and influencing Europeans' environmental awareness and understanding the motivations of people's behaviour is vital. Technological solutions are unlikely to solve environmental problems alone; individuals must contribute through social solutions, such as reducing consumption, developing environmental consciousness, and taking action 
to make informed decisions (Abrahamse et al. 2005; Alfredsson 2004; Steg and Vlek 2009).

The renovation of the Soviet housing estate in Tartu city centre follows an area-based approach utilising the Smart City interventions and solutions. The regeneration approach stresses that to achieve its goals development must incorporate elements area-wide, beyond the physical upgrading of buildings. These elements include the modernisation of public and private transportation systems; upgrades to outward appearance; neighbourhood adaption to new lifestyles; creation of new uses and activities; and place-making (Muliuolyte 2013). The realisation of this strategy relies on the incorporation of integrated planning practices. Integrated planning is holistic, cross-sectoral and participatory-process oriented (Rotmans et al. 2000; Hull 2005), whereby stakeholders jointly resolve relevant urban problems. The processes are often interdisciplinary in nature involving participants from different sectors, spatial scales, stakeholders, technologies and finance instruments.

Integrated planning in smart cities pools resources from both hard and soft domains. Technology is a tool that can help resolve problems fast and effectively to raise the quality of life in cities. For example, big data from sensors and intelligent solutions is an important dynamic input for various urban services (Kitchin 2014; Hashem et al. 2016). Regarding soft domains, the integrated planning framework stresses the importance of cooperation between various parties (the so-called 4P: Public-Private-People Partnership) and creates favourable opportunities for social innovation. 'Social' in this context refers to the nature of the value generated by innovation: this value relates to topics such as quality of life, solidarity and well-being as opposed to profit (BEPA 2010). Social innovation benefits society by increasing its capacity for learning, to become more knowledgeable and take informed action to resolve social problems.

\subsection{Retrofitting the SmartEnCity Housing Estate Districts in Tartu}

\subsubsection{Overview of the SmartEnCity Project in Tartu}

In the SmartEnCity project, plans to renovate khrushchëvki use an integrated and sustainable urban regeneration approach that will tackle energy efficiency in apartment buildings, while jointly developing integrated infrastructure solutions that address building energy performance and sustainable mobility. Figure 17.1 displays an example of a building to undergo the retrofitting process.

The project area covers the city centre of Tartu. The pilot area in the Tartu city centre is $0.39 \mathrm{~km}^{2}$ (Fig. 17.2). There are 43 khrushchëvka-style apartment buildings in the pilot area (1,779 flats total), of which retrofitting plans address 22 buildings or approximately 800 flats. The pilot area is home to nearly 4,000 


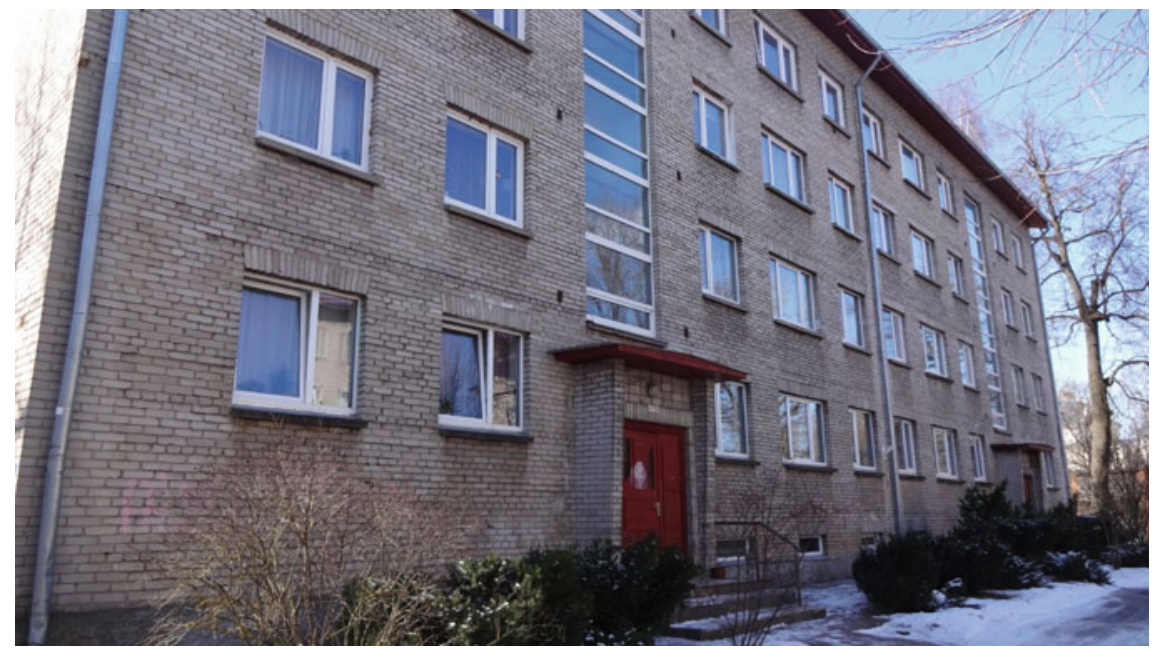

Fig. 17.1 A khrushchëvka apartment building in Tartu, Estonia prior to renovation (Tiigi 7, Tartu): a 4-storey, 32-unit building with $1,350 \mathrm{~m}^{2}$ total floor space (an estimated 80 inhabitants live in the building). Source Photo by authors

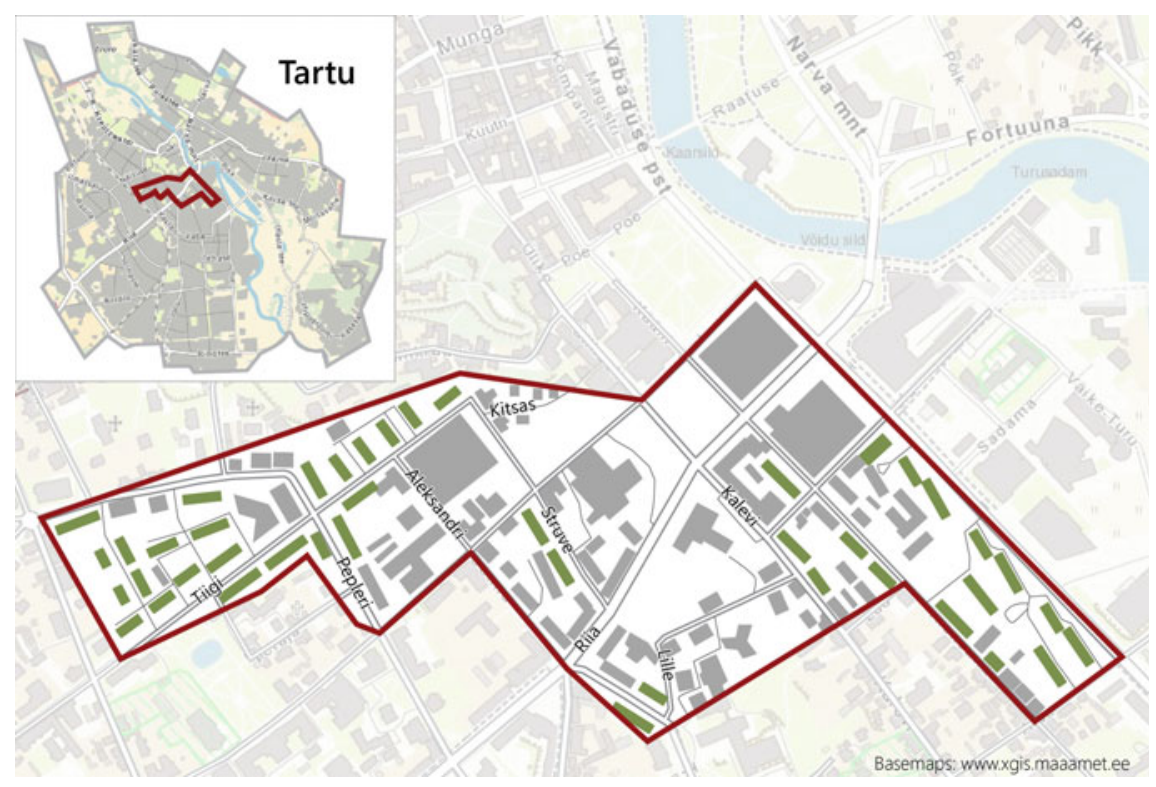

Fig. 17.2 Project pilot are in Tartu, Estonia. Green buildings: there are approximately 40 apartment buildings (khrushchëvki) in the pilot area, among which approximately 20 are being retrofitted (although not all area khrushchëvka-type buildings) 
inhabitants. Retrofitting efforts will directly affect about 2,100 inhabitants. The planned timespan of the project is five and a half years during which retrofitting of the apartment buildings will occur with simultaneous energy consumption monitoring for two years. The project began in 2016 and the expected completion date is 2021 .

An integrated urban planning approach is crucial for developing a smart city. Most Soviet housing estate districts are densely populated. Combined with the largely planned interior areas of estate districts, this limits the ability to make major changes to the physical environment, such as developing buildings and infrastructure. The project activities in Tartu, shown in Fig. 17.3 and outlined in Sect. 17.3.2, reflect this limitation. The activities focus primarily on retrofitting buildings and their surroundings pursuant to modern norms, as well as supplementing and renewing the transportation infrastructure that will extend beyond the pilot area. For example, transportation initiatives attempt to solve the shortage of parking spaces in prefabricated housing blocks, congestion and the decrease of urban air quality due to the growth in private car use. The transition to natural-gas-powered buses is an important step in Tartu, where there is intent to purchase 64 new gas buses; the electric car-charging network will be upgraded with 5 fast chargers in the city centre; including the development of a bike sharing

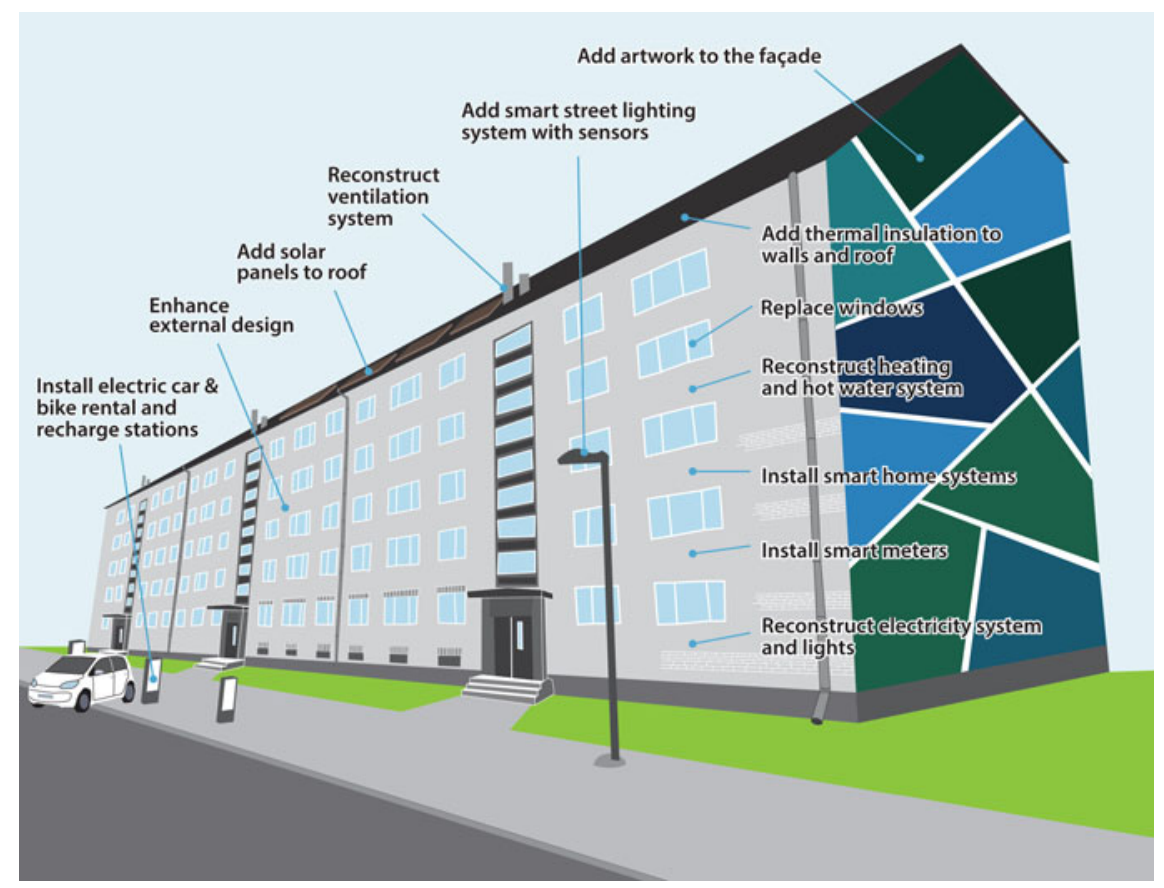

Fig. 17.3 Apartment building renovation plans in the Tartu pilot area: retrofit, mobility improvements and street lighting 
system for a new network of 750 public electric and regular bikes and 69 stations. Tartu's aim is to transition the city's bus fleet to $100 \%$ natural gas fuel in 2019 . The bike sharing system will include public city bikes, parking lots with safety locks and a software system for managing the bike rental system. These efforts will address electric car battery recycling, as well. H2020 sources will assist to fund the development of electric car charging stations and, in part, the bike sharing system.

Furthermore, the development of a district cooling system that returns residual heat from cooling to the district heating network will contribute to the infrastructure solutions. In 2016, with support from SmartEnCity, Estonia built its first district cooling plant in Tartu city centre. SmartEnCity will also see a move to an intelligent street lighting system that uses wireless mesh technology. More than 300 LED luminaires installed throughout the pilot area expected to generate an energy savings of $138,730 \mathrm{kWh}$ per year. Additionally, infrastructure projects will include installation of various sensors, such as movement detectors with cameras, noise and road surface sensors, and environmental sensors, to monitor $\mathrm{CO}_{2}, \mathrm{NO}_{\mathrm{x}}$ and $\mathrm{PM}$.

As part of the SmartEnCity project in Tartu, development of a City Information Open Platform (CIOP) will enable traditional and IoT-based data exchanges. The sensor technologies and CIOP will enable environmental monitoring, data collection and the control of the smart system. The platform concerns the buildings that will undergo retrofitting (e.g. monitoring energy use), district cooling, street lighting and transport systems. The platform must be flexible for integrating and implementing different sensors and control systems and be compatible with other systems.

Several parties shoulder the financial scheme of the retrofitting of the apartment buildings: funding for the activities is a combination of H2020 funding, a national support scheme for renovation activities (KredEx) and loans taken by the dwelling owners themselves. The estimated price of $1 \mathrm{~m}^{2}$ of space in these flats before renovation is 1,400-1,900 EUR and a 2-room $38 \mathrm{~m}^{2}$ standard apartment costs $60,000-80,000$ EUR. The estimated cost of retrofitting is $400 \mathrm{EUR} / \mathrm{m}^{2}$. The city of Tartu supports retrofitting the pilot area buildings by a total of 3,978,000 Euros (i.e. $102 \mathrm{EUR} / \mathrm{m}^{2}$ ) from EU H2020 funds. Additionally, apartment owner associations can apply to KredEx for a financial grant of up to $40 \%$ of the total cost of renovation provided. KredEx is a financing institution that, besides providing financial support to enterprises, helps Estonians improve their living conditions by offering loans, guarantees and grants for energy efficiency action. The KredEx reconstruction grants receive financing from the European Union Cohesion Fund for the period 2015-2020. Third, apartment owners represented by the apartment associations must invest individually. Apartment owner associations will likely cover their own contribution by taking a bank loan with a repayment period of 1520 years. Theoretical calculations show that post-retrofit building utility costs will presumably decrease by $60 \%$ and the apartment price will rise by up to $10 \%$. In comparison, B-level renovations of apartment buildings in Estonia cost on average 300-350 EUR/ $/ \mathrm{m}^{2}$. The maximum KredEx grant is $40 \%$ of the price and therefore apartment owner associations must pay $60 \%$ of the costs. In the SmartEnCity project, self-financing is about $30 \%$ of the cost. 


\subsubsection{Retrofit Plans for Apartment Buildings}

The SmartEnCity retrofitting of apartment buildings is technically 12 different categories of activity, as shown in Table 17.1. These stem from the project's terms of reference and the SmartEnCity objectives to achieve a nearly zero-energy level, increase life quality and encourage more sustainable consumer behaviour. The EU Directive 2010/31/EU on energy performance of buildings defines an nZEB as a building that has a very high energy performance. Energy from renewable sources should cover to a significant extent the near zero or very low amount of energy required, including energy from sources produced on-site or nearby (EU Directive 2010/31/EU Energy Performance of Buildings). According to the best construction practices in Estonia, a nZEB requires construction using technically reasonable, energy efficient and renewable energy technologies, with an energy performance indicator greater than $0 \mathrm{kWh} / \mathrm{m}^{2} / \mathrm{y}$ and, in the case of an Estonian apartment buildings, to a maximum of $100 \mathrm{kWh} / \mathrm{m}^{2} / \mathrm{y}$ (Minimum Requirements for Energy Performance Act 2015). The average energy consumption of khrushchëvki is currently about $270 \mathrm{kWh} / \mathrm{m}^{2} / \mathrm{y}$ and the target level is $90 \mathrm{kWh} / \mathrm{m}^{2} / \mathrm{y}$, requiring a reduction in energy consumption of more than 66-percent. Despite an area-based

Table 17.1 Retrofit plans for apartment buildings

\begin{tabular}{l|l}
\hline Activity & Details \\
\hline Insulation of outer walls & $\begin{array}{l}\text { Add ca. } 20 \mathrm{~cm} \text { insulation material, reinforcement, plastering, } \\
\text { painting }\end{array}$ \\
\hline $\begin{array}{l}\text { Replacement and } \\
\text { repositioning of windows }\end{array}$ & $\begin{array}{l}\text { New triple-glazed energy-efficient windows installed flush } \\
\text { with window insulation. Integrated thermal transmittance } \\
\text { level will be } \mathrm{U} \leq 1.0 \mathrm{~W} /\left(\mathrm{m}^{2} \cdot \mathrm{K}\right)\end{array}$ \\
\hline Insulating the roof & $\begin{array}{l}\text { Insulate attics and roofs to achieve thermal transmittance of } \\
\mathrm{U} \leq 0.12 \mathrm{~W} /\left(\mathrm{m}^{2} \cdot \mathrm{K}\right)\end{array}$ \\
\hline $\begin{array}{l}\text { Renovation of heating } \\
\text { systems }\end{array}$ & $\begin{array}{l}\text { Heating systems will be rebuilt as two-pipe systems that can } \\
\text { be regulated in each room, and smart thermostat valves } \\
\text { equipped with temperature limiters will be installed on } \\
\text { radiators, allowing temperatures to be set in the range of } 18- \\
\text { 23 }{ }^{\circ} \mathrm{C}\end{array}$ \\
\hline $\begin{array}{l}\text { Renovation of the hot water } \\
\text { system }\end{array}$ & $\begin{array}{l}\text { Will be replaced with a central system powered by district } \\
\text { heating. Local boilers will be eliminated }\end{array}$ \\
\hline Renovation of ventilation \\
system & $\begin{array}{l}\text { Installation of new system, either (a) intake-exhaust } \\
\text { ventilation systems with heat recovery, or (b) an exhaust } \\
\text { ventilation system with a heat pump and heat recovery, } \\
\text { which is equipped with devices for pre-heating and filtering } \\
\text { ambient air. The technical system must allow the ventilation } \\
\text { to be regulated separately in each apartment: } \\
\text { (a) automatically pursuant to the CO } \mathrm{CO}_{2} \text { concentration in the } \\
\text { indoor apartment air, (b) for a limited time interval at } \\
\text { maximum and minimum capacities, and to ensure the } \\
\text { required exchange of air in the common areas }\end{array}$ \\
\hline
\end{tabular}


Table 17.1 (continued)

\begin{tabular}{|c|c|}
\hline Activity & Details \\
\hline $\begin{array}{l}\text { Installation of smart home } \\
\text { systems }\end{array}$ & $\begin{array}{l}\text { Establish preconditions for installation of smart home } \\
\text { systems (weak-current-based). Smart home systems must be } \\
\text { installed in every apartment to enable residents to (a) track } \\
\text { their energy consumption, (b) modify their behaviour } \\
\text { towards greater environmental conservation. The smart home } \\
\text { system is planned so that homeowners can use the control } \\
\text { panel installed in their apartments (or other smart device } \\
\text { connected to the internet) to view dynamic energy } \\
\text { consumption and other information, and control heating and } \\
\text { ventilation in their apartments. Smart home systems will be } \\
\text { procured and installed using SmartEnCity project funds, i.e. } \\
\text { the apartment owner associations will not have to pay. } \\
\text { However, the housing associations will have to perform the } \\
\text { necessary preparations for installation of the system }\end{array}$ \\
\hline Installation of smart meters & $\begin{array}{l}\text { Automatic-read meters are to be installed in apartments and } \\
\text { buildings to measure the following volumes: household } \\
\text { water, heating, hot water heating, electricity for common } \\
\text { areas, electricity for the ventilation system and gas. The } \\
\text { meters must allow for monitoring of the energy expenditure } \\
\text { on a running basis, transmission of data, control of building } \\
\text { energy use and invoice preparation }\end{array}$ \\
\hline $\begin{array}{l}\text { Video intercom buzzers for } \\
\text { entrance hall doors }\end{array}$ & $\begin{array}{l}\text { It is recommended to install, for entrance hall doors, a video } \\
\text { intercom system (equipped with power supply and internet } \\
\text { cables) that is compatible with the smart home system }\end{array}$ \\
\hline Building electrical systems & $\begin{array}{l}\text { Electrical system will undergo renewal, controllable LED } \\
\text { lighting will be installed in building common areas (e.g. } \\
\text { motion detector, time relay, switch) }\end{array}$ \\
\hline Solar panels & $\begin{array}{l}\text { Solar panels will be installed on the buildings' roofs so that } \\
\text { renewable energy can be generated locally, with residual } \\
\text { energy sold to the power grid. Even in Estonia's climate, a } \\
100 \mathrm{~m}^{2} \text { roof can on average generate } 15,000 \mathrm{kWh} \text { of power } \\
\text { per year }\end{array}$ \\
\hline Exterior design & $\begin{array}{l}\text { Visually appealing artwork will be added to the façade, } \\
\text { designed to increase the attractiveness of the urban space. An } \\
\text { international art competition has been carried out as part of } \\
\text { the project and apartment associations will be able to select } \\
\text { from artists and works chosen in the competition }\end{array}$ \\
\hline
\end{tabular}

approach and comprehensive goals of nZEBs, the technical outcomes of retrofitting are different, individual buildings may vary somewhat in design and material choices. It is noteworthy that external conditions, i.e. climate affect building energy performance as well. In Estonia, the average annual temperature is $5.2{ }^{\circ} \mathrm{C}$ due to a wide range of seasonal variability: the average temperature in February is $-5.7^{\circ} \mathrm{C}$ and the average in July is $16.4^{\circ} \mathrm{C}$. 


\subsubsection{SmartEnCity Stakeholders}

Achieving the lofty ambitions of a project like SmartEnCity requires multifaceted organisational, technical and social engagement, and cooperation. A conclusion drawn after the first 2 years of the project is that the key to such a complicated task lies in the ability to engage various parties and harness their skills.

The first group consists of apartment owners, apartment owner associations, companies operating on the building premises, non-profits and city inhabitants. The most critical stakeholders from the project's standpoint being the apartment owners. The apartment owner association operates pursuant to the Apartment Association Act and is the legal person that represents all apartment owners in the building. The apartment owner associations organise, maintain, repair, manage and cover other everyday organisational aspects of the building. The apartment owner association functions through a collectively elected chairman, board, and often a maintenance company. Since only the general meeting may adopt major decisions, the decision regarding participation in the SmartEnCity project, contracting design and renovation work, taking a bank loan and other important decisions require adoption consideration during the general meetings of the apartment owners associations. Without interest and cooperation between residents, owners, the associations and tenants, it would be difficult to implement the project. The overall incentives for residents and homeowners to participate in the retrofitting are the increase in energy performance, lower utility costs, improved interior climate and an increase in the quality of life.

The second major group of stakeholders is the local consortium in Estonia. The team led by Tartu City Government makes a significant contribution through its legal services, public outreach and organising of the local team, and the Tartu Regional Energy Agency (TREA) that steers the retrofitting topic. In addition, the Institute of Baltic Studies, the University of Tartu, Telia Estonia and Tartu Smart City Lab all contribute to different topics from social innovation and replication to the implementation of smart technologies.

The third major stakeholder group includes technical support partners in Estonia, who contribute to their field through developing and supplying technologies. Telia Estonia provides the data communication platform, Fortum Tartu provides district heating and cooling energy solutions, and Elektritakso LTD is responsible for electric car batteries recycling solutions. TREA also serves as a technical partner, with a key role in selecting the relevant solutions, integrating them on the building level and monitoring the energy use. Technical consultants are also an important stakeholder. The technical consultants are people with relevant education and work experience whose task, based on the specifics of each building, is to assist in compiling the terms of reference and provide consultation to the apartment owner associations and design developers. The apartment owner associations hired this group to prepare the groundwork for the construction projects.

The fourth group of stakeholders is SmartEnCity's external partners from Spain and Denmark, who, similarly to Tartu, develop local solutions to fulfil the projects 
general goals. The international consortium had an important role in developing the ideology and technological solutions for the entire project, finding specific solutions, resolving problems that arose, providing advisory services and taking care of the exploitation, dissemination and communication of the results. Precisely the existence of the international cooperation network allows the implementation of such a project within the defined scope.

\subsection{Social Considerations of the SmartEnCity Project}

Residents and apartment owner associations will play a key part in achieving SmartEnCity's ambitious $90 \mathrm{kWh} / \mathrm{m}^{2} / \mathrm{y}$ goal in Tartu. For this reason, a major part of the project activities ties in with social innovation, engagement and training. Three significant aspects are relevant here.

First, residents need active education and training. Energy performance and ease of living in buildings retrofitted with smart solutions depend greatly on the residents' user skills and consumption patterns. Technology alone will not yield a significant effect; rather, behaviours and lifestyles also must change.

Engagement is additionally important because the changes related to buildings' renovations are significant and people must invest significantly themselves. Many less financially secure households may find it hard to contribute, but the building conditions are already quite poor in the 40-50-year-old structures, which inevitably require major improvements. It is important that residents understand the need for retrofitting. However, the retrofitting in general is comprehensive and long-term. Façade insulation, window replacement and the ventilation and heating systems means long and arduous inconvenience for people living in the building. Most people do not have anywhere else to move to while repairs are underway for up to a year. Experiences in Tartu have shown that residents have given negative feedback for renovations of apartment buildings that lasted an entire year. Various activities related to engagement may help people accept the renovation-related inconveniences more easily.

Finally, in the context of social learning and technical and organisational complexity, explaining the technical details of the project to residents and apartment association activists is very important to ensure they understand and can use the new technical solutions. In cooperation with different project partners from Estonia, SmartEnCity will train residents and enthusiasts whose task will be to start familiarising others on the activities and technologies. In addition, the project activities include collective experiments promoting environmental conservation principles to evaluate people's motivations for consumption behaviour. The intent is to stimulate individuals and residents toward more sustainable energy use patterns. This kind of collective learning and experimentation could be effective in spreading practical knowledge and skills for using the technology, realising the building's 'smart' qualities, and changing consumption behaviours and people's 
environmental conservation ethos in general. Ideally, this will stimulate intriguing and beneficial ecological or social innovations.

To evaluate sentiment regarding the project before the start of the retrofitting activities in the pilot area, a questionnaire (available both in the Internet and paperback) was conducted (213 respondents). Semi-structured in-person, in-depth interviews (15 interviewees, see Table 17.2) probed familiarity with the retrofitting process and overall goals of the SmartEnCity project among the residents of the pilot area. The authors of this chapter conducted the interviews, whilst other members of the SmartEnCity Tartu project team led the questionnaire survey. Participation in both studies was voluntary. People could receive a gift card as compensation for participating in the interviews. Despite the efforts, low levels of participation were a problem. The survey response rate was low and it was difficult and time-consuming to find the interviewees.

The predominant attitude towards the project among the residents of the pilot area leaned towards the positive. Most of the survey respondents (89\%) said they were interested in the apartment association investing in retrofitting and installing the smart home system in the building. Likewise, all interviewees supported the participation of their own apartment association in the project. The positive aspects and expected results of the project fall into four categories of responses based on the analysis of interviews: personal expenses, convenience and quality of life, aesthetics and environmental conservation.

Table 17.2 Characteristics of interviewees

\begin{tabular}{l|c}
\hline Gender & 5 \\
\hline Male & 10 \\
\hline Female & 4 \\
\hline Age group & 8 \\
\hline$\leq 30$ & 3 \\
\hline $31-60$ & \multicolumn{2}{l}{} \\
\hline $60 \leq$ & 9 \\
\hline Employment status & 1 \\
\hline Employed & 2 \\
\hline Self-employed & 2 \\
\hline Student & \\
\hline Retired & 12 \\
\hline Education & 2 \\
\hline Higher & 1 \\
\hline Vocational & \\
\hline General & 12 \\
\hline Flat ownership structure & 2 \\
\hline Belongs to member(s) of the household & 1 \\
\hline Tenant & \\
\hline Belongs to relative & \\
\hline &
\end{tabular}


In both the survey and the interview, most people considered the project's greatest positive aspect to be the financial gains in terms of savings on utility costs. A total of $69 \%$ of the survey respondents said they were hoping for a decrease in household costs and 38\% expected their real estate value to rise, as depicted in Fig. 17.4.

Well, if insulating a building from the outside has such an effect, perhaps all the expenses could become even lower. (male, 38)

"..." there would be a big leap in savings on my expenses in terms of energy saving due to smart home devices and renovation. (female, 63)

Another reason cited for the positive attitudes is an expected rise in quality of life and added convenience generated during and after the project activities. Following renovation, such citations include improvements in living conditions, rise in the quality of the buildings, rise in the level of user convenience associated with new technologies, and a reduction in the use of personal automobiles.

For one thing, my life will become much easier. I won't have to report any meter readings at the right time. It will be done for me. (female, 63)

The project is a factor promoting the development and image of the entire city of Tartu. Above all, this will be through an improvement in the exterior appearance of the buildings and the city centre, which was the third most important reason cited in the survey as well (43\% of respondents).

It's a great and unique opportunity for Tartu's development, really. And for shaping the city centre's appearance. (female, 63)

The interviews revealed that only a few people who placed major value on the natural environment cited environmental conservation as a reason. The project is a

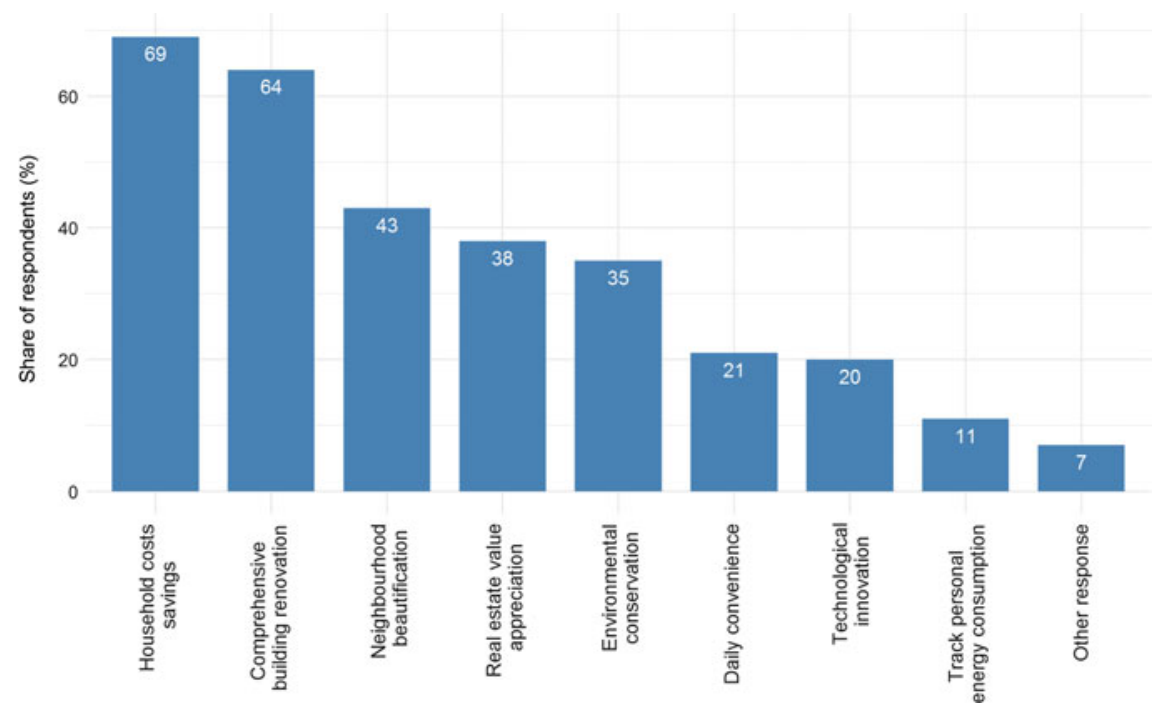

Fig. 17.4 Support for project investments: questionnaire results 
way of affecting society's consumption patterns and encouraging people to lead an environmentally sustainable lifestyle. Only one-third of respondents (35\%) said they prioritised environmental conservation-related aspects.

I like the general idea that we consume less and produce more. (female, 30)

Because such projects “...” can impact society's behavioural and consumption patterns in the long run. (male, 32)

Interviewees expressed a certain scepticism as to the potential increase in health risks related to technological solutions implemented in project activities (e.g. increase in electromagnetic radiation (EMR) and noise-level stemming from equipment installed and data communication), unforeseen financial costs and the technical smart home solution to be installed. Concern over the rise in the level of EMR was also expressed in the Tartu project website's forum.

Well, let's say there are ways I might die of cancer faster due to it. For example, the noise level could also grow in connection with this thing. (male, 32)

Some kind of smart home management system is being constructed. How it will exactly be realised, no one knows yet. It's a bit of a risk. (male, 39)

Overall, most interviewees view the topic of a smart home as fairly remote and unfamiliar, which is understandable, as smart home solutions are not yet widespread in Estonian households. The interviewees' knowledge about the devices installed was modest and they were vague on some aspects. People had hesitations about the nature of smart home and there was some uncertainty about their skills for using the technology: a perspective shared among adults (40-50) and pensioners. Nevertheless, most interviewed people were positively inclined toward readiness to use smart homes ('ready to use', 'ready to try'). Some were also negatively predisposed ('I won't use it') and neutral ('don't know'). Some positive aspects of using the smart home solutions cited were the increase in convenience and comfort, the possibility of monitoring one's own consumption behaviour and the possibility of adding other necessary applications, which in turn could expand the spectrum of services. People predominantly took a wait-and-see attitude to the magnitude of the effectiveness of the smart home solution, specifically whether it would have an actual impact on consumption patterns. Highlighted reasons include that the interviewees did not know the type of information collection, whether they could change their own behaviour based on the information without too much effort, whether everyone would be capable of using smart home solutions, and how the solution would function in practice.

At the moment, it seems like an exciting toy. (male, 38)

I think it depends on the information I'll get from there. Maybe something surprising will come out of it and I'll be totally willing to change my [consumer] behaviour. (female, 47)

I might consider it necessary in the short term for the project to generate feedback about itself, so to speak; in the long term, I don't see much of a point to it. (female, 30) 


\subsection{Discussion and Conclusion}

Khrushchëvka-style apartment buildings are home to many people in Eastern Europe. Since these buildings exceed their life span or are even unsafe and do not meet the current lifestyle standards, it is evident that such neighbourhoods need change. The primary question concerns the expediency and scale of such renovations. Technically and probably financially speaking, it is questionable to renovate these 50-year-old apartment buildings. At first glance, it would be easier to demolish them and build new modern buildings. Yet, social aspects generally sway toward a path of preservation and renovation. Such estates can offer affordable living spaces for lower socio-economic groups and for the people who are at the start of the housing ladder (Kovacs and Herfert 2012). People are also, of course, sentimentally and emotionally attached to these residential buildings. However, the chosen strategy depends on the technical condition of the building and the feasibility of the retrofitting. There are cases where the structure is dilapidated, living there is dangerous and the renovation is too complicated. Besides the aspects of finance and purposefulness, stakeholders must understand in which direction the city wants to develop. As regards sustainability, socialist housing estates as compact urban settlements present a far more preferred form of European idea about sustainability than suburban low-density settlements (Tosics 2005; cit. Muliuolyte 2013).

In the case of preservation, given the age and lifespan of these buildings, a full renovation will inevitably be required in the near future. Any renovation undertaken should be major, ambitious and concurrent, as the building utility systems generally require replacement in their entirety and a patchwork approach will soon require further repairs. It is particularly complicated if the renovation has taken place at the owners' own initiatives: one apartment at a time (i.e. changing windows, radiators). Once a general, proper retrofitting begins, such people would stand to lose their investments. Thus, often they are the most ardent opponents of a full retrofitting. Yet it is not possible to retrofit a building one apartment at a time and achieve optimum energy efficiency and quality results.

The same approach is applicable on a larger spatial scale, such as neighbourhoods. A building-by-building renovation strategy has shown its incapability to resolve the bigger social issues (whether related to neighbourhood's social decline or energy efficiency etc.) in socialist housing estates in the Western countries that were already present during the 1980s (Tosics 2005; cit. Muliuolyte 2013). In addition to this, the current building-by-building policy leaves apartment associations relatively alone to deal with the vital actions necessary for efficient reconstruction, i.e. understanding the technical specificities of the building and necessary renovation, choosing a construction company, agreeing on the terms of reference and dealing with the possible consequences. For example, several cases from Estonia have shown that sometimes the retrofitting is only carried out halfway (e.g. not installing a proper ventilation system), with the aim of cutting down on expenses. Thus, apartment associations need relevant advice on which activities to 
pursue and which company to hire. The first examples of companies' bankruptcy while reconstruction works were still ongoing have already occurred. In such cases, the associations are in a difficult situation regarding how to manage the financing and finish the renovation works. An area-based approach more efficiently addresses these issues, where the local municipality is actively involved and can offer support in the process.

However, such area-based strategies require new implementation schemes regarding the involvement and cooperation of different stakeholders, sectors and fiscal instruments. SmartEnCity project is a good example of a realisation of such a strategy, but there is necessity for institutional changes and alternative financing schemes to sustain the spillover effect to other municipalities. Local governments need to learn how to manage the process and communication with stakeholders and to be actively involved in guiding the area-based retrofitting process and finding additional financial resources to support the works. In the SmartEnCity project Tartu pilot area, the funding originates from three sources (KredEx, H2020 and bank loans of apartment owner associations) and targets the khrushchëvki to achieve an energy efficiency rating of $90 \mathrm{kWh} / \mathrm{m}^{2} / \mathrm{y}$. Without the financial support of Tartu city (from H2020 funds) and KredEx, it would have been difficult to target such an energy performance level. Additionally, the integrated and area-based approach targets other complicated issues in cities such as transportation, area-based heating systems, etc., that require cooperation between stakeholders from different sectors. SmartEnCity revealed that the existence of engineers, architects and technical consultants with relevant backgrounds is extremely important. The expectation is that the competence of construction companies and other stakeholders will rise during the project within the framework of SmartEnCity, as the monitoring, design, procurement, preparation and processing takes place for 22 buildings.

Another important aspect is the active engagement and empowerment of homeowners and apartment owner associations. The Tartu project concludes that it is complicated to undertake such work without having the support of apartment owner associations. Recommendations suggest that legislators and local governments develop an organisational framework for supporting and promoting cooperative activity, a role suited for apartment owner associations or, in the case of state-owned apartments, some other institutions (e.g. housing administrations). They could include all residents and owners in the decision-making process, as the population living in apartment buildings is very diverse and the success of the retrofitting depends on everyone.

Consideration should be made for investing in the installation of smart home systems, if the aim is to achieve higher energy efficiency. Even if today's users resist the technologies now, it will be necessary to ensuring optimal energy use and indoor climate control and safety for the entire building. A central smart home system is also necessary for collecting data and analysing performance. Our experience is that residents initially question and resist smart home systems. People hesitate because of a lack of knowledge and skills and are afraid of the EMR from smart home equipment and data transmissions. When new technologies emerge, 
people must primarily learn to use the solutions offered, integrate them into their daily lives and change their behaviour accordingly (Zhang et al. 2016). In such cases, social learning and educating people in technology are key to keeping such projects from being a failure. Studies have shown that social learning can make people's consumption patterns more sustainable (Buenstorf and Cordes 2008). As part of the Tartu SmartEnCity project, installation of a smart home system with different sensors to measure consumption. It is important to study how people both response to and adopt to them, and what is the efficiency of these devices and systems. As a result, a smart city can bring services closer to people, but if people are unable to reach the services then it is of no use. Additionally, there might also be a negative social impact such as increasing the digital gap by integrating technological systems such. As mentioned in Sect. 17.4, interviewed people were afraid of using the smart home system due to their lack of skills. Thus, marginalisation of groups already disadvantaged (disabled people, pensioners, etc.) could increase.

People living in Soviet-era housing estates are socially heterogeneous. In Tartu, both young families and students live in the city centre buildings, alongside older people who have been living there since construction and who are now retired. There are high-income, middle-income and low-income families, as well as both international residents and locals (including ethnic minorities and majority groups). The financial investments necessary for retrofitting have different impacts on all of them. Thus, such initiatives may not be affordable to all socio-economic groups and the size of investments will certainly curtail options for the less well off. This is one possible negative social impact that requires consideration for such projects. Yet segregation is not discernible in these buildings; our preliminary study of sociodemographic data and interviews showed the buildings have a varied demographic makeup. On one hand, there is a reason to believe that the social diversity of residents will increase as retrofitted buildings in the city centre will become more attractive, and that such intermingling is beneficial for both the housing estate districts and all of Tartu. On the other hand, since the area under intervention is located in the city centre, increasing real estate prices and the value of apartments can force the outmigration of pensioners, students and low-income earners. Khrushchëvki generally were affordable residences in the city centre, but this may change following retrofitting.

The diverse population also poses a challenge in terms of teaching and training people how to live in the smart building. Achieving energy efficiency rating " $A$ " requires more than construction foam and technologies; it requires a change in consumer attitudes and behaviours. Results from our survey and interviews showed that the basis for motivation of residents to participate in the development of smart city, above all, is the need for retrofitting and saving on costs. Very few people think about environmental problems and personal responsibility in this field, which is quite different from the noble objective of the EU-planned programme for reducing GHG emissions. Thus, there is always a possibility that people will not adapt to technological solutions aimed at decreasing the carbon footprint of buildings as expected. Because of this, education efforts will be key during this 
project in Tartu. This work is often complicated since the target groups are diverse and need individualised engagement approaches.

There are several ambitious goals of the SmartEnCity project and there is much to learn from both the lighthouse projects as well as from the smart city developments to sustain and spread their impact. Will technological innovation help to achieve the aims of sustainable development and environmental conservation or will it be a failure? Certainly, the condition of at least part of the city will be better and the quality of life in the district should improve. For many, this is precisely what is important.

Acknowledgements The authors of this chapter participated in preparing the SmartEnCity project proposal and are currently actively taking part in the implementation phase. This study has received funding from the European Union's Horizon 2020 research and innovation programme under grant agreement No. 691883.

\section{References}

Abrahamse W, Steg L, Vlek C, Rothengatter T (2005) A review of intervention studies aimed at household energy conservation. J Environ Psychol 25(3):273-291

Ahvenniemi H, Huovila A, Pinto-Seppä I, Airaksinen M (2017) What are the differences between sustainable and smart cities? Cities 60:234-245

Alfredsson EC (2004) "Green" consumption-no solution for climate change. Energy 29(4): 513-524

Angelidou M (2015) Smart cities: a conjuncture of four forces. Cities 47:95-106

BEPA (2010) Empowering people, driving change: social innovation in the European Union. Bureau of European Policy Advisers, European Commission

Buenstorf G, Cordes C (2008) Can sustainable consumption be learned? A model of cultural evolution. Ecol Econ 67(4):646-657

Caragliu A, Del Bo C, Nijkamp P (2011) Smart cities in Europe. J Urban Technol 18(2):65-82

Directive 2010/31/EU Energy performance of buildings. OJ L 153 18.06.2010, pp 13-35

European Commision (2017). http://ec.europa.eu/eip/smartcities/about-partnership/what-is-it/ index_en.htm. Accessed 15 Mar 2018

Guerra-Santin O, Boess S, Konstantinou T, Herrera NR, Klein T, Silvester S (2017) Designing for residents: building monitoring and co-creation in social housing renovation in the Netherlands. Energy Res Soc Sci 32:164-179

Hashem IAT, Chang V, Anuar NB, Adewole K, Yaqoob I, Gani A, Ahmed E, Chiroma H (2016) The role of big data in smart city. Int J Inf Manag 36(5):748-758

Hull A (2005) Integrated transport planning in the UK: from concept to reality. J Transp Geogr 13(4):318-328

Khansari N, Mostashari A, Mansouri M (2014) Conceptual modeling of the impact of smart cities on household energy consumption. Procedia Comput Sci 28:81-86

Kitchin R (2014) The real-time city? Big data smart urbanism. GeoJournal 79(1):1-14

Kovács Z, Herfert G (2012) Development pathways of large housing estates in post-socialist cities: an international comparison. Hous Stud 27(3):324-342. https://doi.org/10.1080/02673037. 2012.651105

Martinaitis V, Kazakevičius E, Vitkauskas A (2007) A two-factor method for appraising building renovation and energy efficiency improvement projects. Energy Policy 35(1):192-201

Minimum requirements for energy performance Act (2015) Riigi Teataja I, 05 Sept 2012, p 4 
Muliuolyte J (2013) Rediscovering large scale housing estates in post socialist cities. J Architect Urban 37(1):51-58. https://doi.org/10.3846/20297955.2013.781180

Musterd S, Van Kempen R (2007) Trapped or on the springboard? Housing careers in large housing estates in European cities. J Urban Aff 29:311-329. https://doi.org/10.1111/j.14679906.2007.00345.x

Rotmans J, van Asselt M, Vellinga P (2000) An integrated planning tool for sustainable cities. Environ Impact Assess Rev 20(3):265-276

Serrano-Lanzarote B, Ortega-Madrigal L, García-Prieto-Ruiz A, Soto-Francés L, Soto-Francés VM (2016) Strategy for the energy renovation of the housing stock in comunitat Valenciana (Spain). Energy Build 132:117-129

Steg L, Vlek C (2009) Encouraging pro-environmental behaviour: An integrative review and research agenda. J Environ Psychol 29(3):309-317

Tosics I (2005) Large housing estates in the west and in the east: what can we learn?. In: Ljubljana: RESTATE

Trumbull NS (2014) Restructuring socialist housing estates and its impact on residents' perceptions: "Renovatsiia" of khrushchëvki in St.Petersburg, Russia. GeoJournal 79:495-511. https://doi.org/10.1007/s10708-014-9534-1

Vlek C, Steg L (2007) Human behaviour and environmental sustainability: problems, driving forces, and research topics. J Soc Issues 63(1):1-19

Watson I, Ilyushina M, Lister T, Etzler T (2017) Russians protest plans to demolish Soviet-era apartment buildings. CNN. http://edition.cnn.com/2017/05/29/world/russia-moscow-apartmentbuildings-protest/index.html, 12 Mar 2018

Zhang T, Siebers PO, Aickelin U (2016) Simulating user learning in authoritative technology adoption: An agent based model for council-led smart meter deployment planning in the UK. Technol Forecast Soc Chang 106:74-84

Open Access This chapter is licensed under the terms of the Creative Commons Attribution 4.0 International License (http://creativecommons.org/licenses/by/4.0/), which permits use, sharing, adaptation, distribution and reproduction in any medium or format, as long as you give appropriate credit to the original author(s) and the source, provide a link to the Creative Commons license and indicate if changes were made.

The images or other third party material in this chapter are included in the chapter's Creative Commons license, unless indicated otherwise in a credit line to the material. If material is not included in the chapter's Creative Commons license and your intended use is not permitted by statutory regulation or exceeds the permitted use, you will need to obtain permission directly from the copyright holder. 


\section{Index}

A

Aalto, Alvar, 84, 101, 109

Āgenskalns, 232, 234, 235, 239, 242

Aldona, 192, 196

Algimantas, 78

Aljaste, Lembit, 314

Altstadt, 124

Amsterdam, 97

Annelinn, 17

Antakalnis, 187, 252

Antanina, 189

Apartment building associations, 3, 4, 6, 10, $13,14,16,18,19,21,22,73,75,77,81$, 100, 108, 140, 177, 188, 190, 191, 194, 204, 207, 230, 231, 235, 241, 242, 249, 250, 260, 264, 267, 269, 274, 275, 278, 283, 285, 291, 316, 322, 324, 326-331, $333,339-348,350-353,357-360$, $362-364,367,371,372$

Apartment buildings, 3, 4, 10, 13, 14, 17, 19-22, 91, 130, 173, 177, 188, 190-194, 207, 230, 232, 235, 241, 242, $249,250,260,263,267,269,274,275$, $278,283,285,306,322,325-333,339$, 340, 342-347, 350-354, 358-364, 371, 372

Architectural influences, 13, 71, 96, 98

Architecture, 9, 13, 16, 17, 53, 72, 73, 76, 78, $83,84,90,91,95,96,98-101,105,106$, $108-113,117,118,122,123,129,130$, $132,139,148,150-153,170,177,182$, 196, 232, 290, 291, 312, 315, 316

avant-garde style, 106, 303

Baltic modernism, 72, 118
Stalin baroque, 9,53

Areas-based planning, 22, 23, 357, 360, 364, 372

Argus, Tiiu, 313

Aronas, Aleksandras, 187, 197, 308

Aurik, Helje-Reet, 314

B

Bäckström, Sven, 304

Balčiūnas, Vytautas, 307

Balėnas, Kazimieras Rimantas, 309

Baltic countries, 3-6, 8-11, 13, 15, 16, 21-23, $31,32,34-38,40,41,43,45-47,153$, 252,302

Banjica, 133

Bavaria, 40

Belarus, 15, 67

Belov, Mikhail, 100

Berlin, 97, 122, 123

Berlin Wall, 5, 10

Bessarabia, 34

Bezirke, 121

Blokovi, 134

Brasilia, 133, 134

Bratislava, 125

Brèdikis, Vytautas, 73, 78, 84, 86, 123, 307

Brezhnev, Leonid, 14, 99, 111, 232, 239, 302

Britain. See United Kingdom (UK)

British, 98, 99

Brīvības, 173

Bronè, 191, 197

Bruns, Dmitri, 104

Bucharest, 10, 130, 131

large housing estates, 10 
Budapest, 119-121, 123, 126, 127

distribution of housing estates, 211

large housing estates 1970s, 120, 121, 125, 130 1980s, 120, 127

Built environment, improvement of, 5, 14, 15, $17,23,95,98,99,107,113,119,155$, $182,225,276,290,313$

Bulgaria, 117, 119-121, 130

C

Ceaușescu, Nicolae, 117, 130, 131

Čekanauskas, Vytautas, 73, 77-79, 83, 86, 123, 307

Central and Eastern Europe, 117-119

Central Asia, 118

Central planning, 9, 53, 54, 119, 140, 213, 227, $231,275,279$

Cibas, Albertas, 77

Ćirković, Vera, 133

City planning, 9, 13, 15, 16, 74, 139-142, 146, 152-154, 156, 165, 282, 284, 296, 303, 304

Civil war, 53, 134

Common good, 332

Communal life, 23

Community activism in neighbourhoods, 220

Congrès Internationaux d'Architecture Moderne (CIAM) architects, 97

Connectivity, 3, 22, 23, 207, 220

Cuba, 119

Czechoslovakia, 99, 119, 120, 122, 125 See also Prague

\section{D}

Daugava, 164, 165

Daugavgrīva, 233, 239, 242

Daugavpils, 51, 56-62, 64-66

Demography, 32

Demolition, 3, 4, 6, 20, 21, 56, 131, 153, 166, $275,339,340,353$

Denmark

population developments, 32

Density, 6, 32, 42, 87, 120, 127, 131, 133, 134, $141,142,146,147,151,156,162,163$, $168,196,197,207,213,216,218,371$

Displacement, 217

Dmitry, 77

Do-it-yourself urbanism, 5

Dokšas, Zigmas, 124

Dreilini, 165

Dubrovnik, 134

Dzeržinskis, 187, 192
E

East Berlin

large housing estates, formation of, 340

Eastern Bloc, 97

Eastern Europe, 123, 125

Eastern Minsk, 86

East Germany, 117, 119, 124, 125, 127, 129

Ecological footprints, 23

Economic development, 31, 36, 291, 328

Eestiprojekt, 133

Ehitajate, 279, 283

Elektrènai, 85, 124

Energy efficiency, 21-23, 178, 331, 344-346, $353,359,360,363,371-373$

England. See United Kingdom (UK)

Erfurtas, 192, 308

Ervi, Aarne, 84, 101, 102, 304

Estonia, 3, 5-8, 10, 11, 13, 15, 17, 18, 21-23, $31-46,73,74,82,83,90,91,95-97$, $100,101,104,106-108,111,112,119$, $122,123,125,139,143-145,150$, 151-156, 204-208, 210, 211, 213-215, 218, 273-276, 279, 290, 301, 302, 305, $310,311,313,314,317,322,325,327$, $328,339-343,345-347,350,352-354$, 357, 359, 361, 363-367, 371 See also Tallinn

Estonian, 72, 86, 353

Ethnic concentrations, 214

Europe, 97, 322

European Structural Funds, 346

F

Fabijoniškès, 310

Finland, 11, 13, 14, 32, 34, 83, 84, 95-97, 100, 101, 104-109, 111, 112, 119, 122, 146, 153, 277, 304 See also Helsinki

Finnish, 98, 104, 105, 112, 146, 152, 153

Flat-owners' associations, 21

Floreasca, 130

France, 11, 40, 99, 123 See also Paris large housing estates, 4, 162, 163

Friluftsstaden, 101

G

Gdańsk, 117, 128

Germany, 33, 34, 40, 122, 305 See also Berlin; East Berlin; West Berlin large housing estates, 3, 5, 10, 13, 23, 72 Plattenbau, 129

Gheorghiu-Dei, Gheorghe, 130

Giedraičiu, 188

Gomułka, Władysław, 120 
Gorbachev, Mikhail, 35

Gothenburg, 98

Gradov, Georgei, 98

Grands ensembles , 123, 131

\section{H}

Haabersti, 207, 214, 217, 219

Halle-Neustadt, 124

Havanna, 119, 121

Helamaa, Erkki, 104

Helamaa, Kirsti, 104

Helsinki, 11, 13, 14, 98, 101, 104-106, 109, $111,112,122,153,277,301,304,316$ See also Finland

neighbourhood unit plan, 122

spatial social mixing in post-World War II housing estates, 4, 98 socio-economic and demographic changes, 31

tenure, 210

Herkel, Voldemar, 104

Herttoniemi, 98

Hervanta, 112

Hitler, 34

Honecker, Erich, 121, 125

Housing allocation, 16, 31, 42, 43, 46, 51, 52, $57,64-68,185,190,204,218$

Housing construction, 9, 14, 15, 39, 45, 51-54, $58,59,68,71,74,91,99,108,112,121$, 144, 154, 164, 166, 168, 177, 229, 235, 242, 276, 278, 283, 285, 287, 290, 291, 293

Housing estates. See Large housing estates

Housing policies, 131, 142, 164, 207, 229, 248, 340

Housing shortage, 42, 51, 52, 54, 58, 63, 64, $68,97,99,144,162,192,204,217,231$, 234,285

Housing stock

management of, 21

Howard, Ebenezer, 97

Hoyerswerda, 123, 125

Hungary, 117, 119-123, 125, 130 See also Budapest

15-year housing development programme, 121

\section{I}

Imanta, 176, 302

Income inequality, 226

International Standard Classification of Occupation (ISCO), 206, 211, 253

Iron Curtain, 5, 10, 13, 21
$\mathbf{J}$

Jänes, Peep, 313

Jasinskas, Algirdas, 79

Jugla, 164, 235

Juknaičiai, 124

Justiniškès, 250, 309

Jyväskylä, 106

K

Kádár, János, 121

Kadriorg, 287

Kaklauskienè, Maryte், 308

Kallas, Toivo, 75, 110, 122, 144, 311, 312

Käpylä, 98

Karoliniškès, 19, 181-183, 185, 187-189, 191, 192, 194, 196, 197, 250, 252, 257, 261, 264

Karp, Raine, 312

Karu, H., 149

Kasperavičienè, Birutè, 84, 85, 307

Kaunas, 34, 307

Kazakhstan recruitment of initial residents, 154

Kelenföld, 123, 125, 126

Ķengarags, 19

Kharitonov, Max, 100

Khrushchëvki, 4, 15, 207, 261

demolition of, 278

renovation of, 359

Khrushchëv, Nikita, 52, 56, 58-60, 72, $73,98,172,231,232,234$, $278,303,305$

Khrushchëv Thaw, 95

Kiel, 106

Kiev, 10

Kivinen, Olli, 101

Kivi, Raul-Levroit, 104

Klaipeda, 33, 34, 82, 307

Kleinotas, Algimantas, 307

Koido, Paula, 312

Komonen, Markku, 97, 106

Korhonen, Esko, 109

Kornai, Janos, 54

Kosygin, Aleksei, 302

Kotka, 106

Kotryna, 197

KredEx, 22, 346, 363, 372

Krūminis, Bronius, 81, 85, 86, 307

Künnapu, Vilen, 106

L

Laima, 185-187, 192, 195

Lake Harku, 283, 284, 288-290 
Large housing estates, 3-6, 8, 10, 13, 14, 16, $17,20,23,46,71-73,82,86,87,90,91$, 95, 109, 111-113, 139-141, 144, 145, 152-156, 161-163, 167-169, 174, 176-178, 182, 197, 218, 225-227, 235, 237, 242, 251, 301, 311, 340-342, 357 ageing problem in, 161 distribution of, 8, 211 location of , 145, 167 physical decay, 242 position on housing ladder, 152 post-socialist transition of, 225 prefabricated, 77, 122, 163, 316, 362 private, 37

private ownership of, 343

reputation of, 23, 91, 178

roots of, 51-53

segregation ethnic, 210

residential, 209

social, 210 socio-economic, 210

size distribution, 185, 196, 206-208, 227, 252

social change in, 235

social composition, 260

spatial distribution, 241, 262, 263

Lasnamäe, 14, 15, 19, 119, 133, 144, 207, 209, 210, 213-217, 219, 220, 287, 290, 294, $311,314-316,343$

Latvia, 3, 5-8, 10, 11, 21, 31-37, 39-46, 57, $65,73,83,154,155,161-163,171$, $174,175,225,227-233,240,243,302$

Lazdynai, 8, 14, 19, 71, 82, 83, 86, 87, 89-91, $122,123,127,132,133,154,181-198$, 250, 252, 254, 261, 262, 302, 306-309, 315

Le Corbusier, 141, 324, 326

Leningrad, 11, 83, 108, 118, 134

Liepāja, 58

Lijnbaan, 304

Lindgren, Armas, 96

Lithuania, 3, 5-8, 10, 11, 21, 31-37, 39-46, $71,73,76,77,81-86,91,124,127,143$, $154,155,181,182,192,198,248,252$, $253,301-303,305-307,314,317$

Lithuanian, 71, 73, 77, 79, 82-84

Lithuania, population developments, 8, 32, $41-43,248$

Liubeckis, Šmuelis, 85, 307

Liubošic, Nota, 303

Liudas, 190, 194, 196

Liudmila, 187, 189, 192, 194, 197

Livonia, 33
London, 97, 304

Lõoke, 351

Lukić, Mirjana, 133

Lukk, Vivian, 313

\section{M}

Makariūnas, Jaunutis, 78

Marius, 188, 192, 194

Markelius, Sven, 17, 304

Marzahn, 123

Maskavas forštate, 234

Mass housing, 14, 52, 58, 59, 71, 72, 74, 75, $78,84-86,90,91,96,99,105,106,109$, $112,113,117-120,130,132,134,154$, $155,164,181-183,198,225,226,231$, $232,234,235,242,278,302-304,306$, $307,314,315,317$

Masso, Miia, 82

Matinkylä, 112

Maunula, 98

Mazūras, Česlovas, 87, 127

Meelak, Malle, 128, 147, 149

Meri, Lennart, 106

Meurman, Otto-Iivari, 101

Meuser, Philipp , 118

Mikrorayon, 10, 16-19, 55, 63, 64, 74-77, 84-87, 90, 91, 95, 99, 109-111, 113, 118, 122-124, 140-142, 144, 146-148, $151,152,155,156,167-169,174$, 181-183, 188, 190-192, 194-197, 206, 207, 232, 233, 235, 274-279, 283, 285, 286, 290, 301-312, 314-317

Minskas, 307

Mitrović, Mihajlo, 134

Modernism, 5, 11, 72, 83, 84, 95, 96, 102, 105, $106,112,118,122,123,127,130,132$, $139,141,152,153,169,177,310,312$, 315,316

Moldova, 34, 57

Moscow, 4, 10, 36, 38, 39, 41, 54, 60, 61, 74, $82,84,86,99,105,106,108-110,130$, $134,139,142,144,154,156,165,177$, 290, 303, 304, 358 See also Russia

demolition of apartment buildings, 166, 339 socio-spatial stratification of, 5,55

Multi-family housing, 203

Multi-storey flats, 121

Mustamäe, 13, 14, 19, 75, 77, 83, 104, $105,108,109,119,122,123,144$, 146, 147, 207, 209, 214, 217, 219, 278, 283, 290, 294, 302, 307, $310-314,340,343$

Mustamär, 312

Myyrmäki, 112 
$\mathbf{N}$

Nasvytis, Vytautas, 78-80

Naujamiestis, 250, 306

Naujininkai, 191, 261

Navoii, 86

Neighbourhoods decline of, 4, 211 population composition of, 269 unit, $14,17,74,97,101,122,123,206$, $232,303,321,324,325,332$

Neighbourhood trajectories, 207, 218

Neoliberalism, 327, 328

Neris River, 187, 192, 197, 249

The Netherlands, 11, 32

Neubrandenburg, 127, 129

Nord, Erfurt, 123

Nordic, 72, 78, 83, 99

Norra Guldheden, 98, 101

Novi Beograd, 117, 133, 134

Novye Cheremushki, 99, 303

Nowa Huta, 122, 123

O

Óbuda, 123

\section{$\mathbf{P}$}

Padrik, Ain, 106

Paldiski, 279, 283

Pallasmaa, Juhani, 97, 104, 106

Panevėžys, 307

Parking, 20, 147, 150, 168, 269, 285, 287, 292, $317,321-324,326,328-333,362,363$

Pašilaičiai, 310

Periphery, 143, 152, 196, 228, 275

Perry, Clarence, 14, 97, 275, 303, 324, 326, 333

Pettai, Lidia, 75, 110, 311

Piaţa Gării de Nord, 130

Pietilä, Reima, 84

Pihlajamäki, 11, 101, 103, 108, 109, 112

Plattenbau, 129

Pḷavnieki, 19, 173, 239, 243

Poland, 33, 34, 99, 117, 119-122, 127, 128

Population change, characteristics of, 241

Population decline, 58, 257

Population developments, 8, 42

Pormeister, Valve, 125

Port, Mart. , 122, 128, 144, 147, 149

Post-Soviet period of construction, 226, 228, 230, 250

Post-transformation development, 230, 241, 242

Post-war housing development, 118, 171

Poverty, 23, 243, 251
Poznań, 117

Prague, 125

large housing estates in, 152

Prahm, Aleksander, 110, 311

Prefabrication, 22, 72, 97, 101, 113, 133, 169, 353

Private housing developments, 37, 118, 130

Private ownership of apartments, 326, 327, 343

Privatisation of apartments, 21, 39, 174, 205, $322,328,329,343$

Pruitt-Igoe housing estate, 21

Prussia, 33, 40

Przymorze, 128

Public housing developments, 118

Public-private partnerships, 360

Purvciems, 175, 176, 233

$\mathbf{R}$

Refurbishment, 326, 331, 339-341, 344-354

Reinius, Leif, 304

Relocated households, reconcentration of, 191, 194

Rendelis, Nikolajs, 77

Renewal, 175, 352, 357, 365

Residential change, 225, 226, 230, 241, 242

Residential segregation, 22, 43, 57, 69

Restoration of urban space, 36, 44, 105, 111

Retrofitting, 22, 357-360, 362-368, 371-373

Revell, Viljo, 101

Rietdorf, Werner, 122, 123

Riga, Latvia, 6, 8, 14, 17, 19, 23, 36, 40, 43, $58,61,77,83,106,154,161-169,171$, $172,174,176,177,225-237,240-243$, 302

local housing market, characteristics of, 171,178

Roihuvuori, 109

Romania, 117, 119, 130, 131, 134 population developments, 130

Rostock, 123

Rotterdam, 304

Rovaniemi, 106

Różański, Stanisław, 128

Ruoppila, S., 108

Ruskeasuo, 98

Russia, 14, 15, 33, 34, 36, 40, 42, 67, 132, 154, 198, 249, 358 See also Moscow contemporary urban life, 134

\section{$\mathbf{S}$}

Saarinen, Eliel, 96

Sääse, 283

Salin, Edgar, 122

Šaltinèlis, 307 
Sargelis, Vidas, 82

Scandinavia, 83, 119

high-rise estates, 152

Scarcity of resources, 293

Scotland, 40

Second wave of Soviet housing construction, 190

Segmentation, internal, 210, 227

Senamiestis, 250

Seniūnija, 253

Šeškinè, 250, 302, 306, 309, 310, 316

Sharing economy, 23

Shevchenko, 86

Siili, 283

Šileika, Vincentas, 307

Silvennoinen, Lauri, 109

Siren, Heikki, 101

Siren, Kaija, 101

Slums, 188, 241, 251

Smart city, 22, 357-360, 362, 366, 373, 374

Sniečkus, 124

Social cohesion, 328

Social degradation, 47, 213-215, 218, 253

Social deprivation, 53

Social housing, 11, 97, 120, 210, 218, 304 defined, 207

Social ideals, 161

Socialism, 4, 5, 11, 39, 44, 53, 57, 58, 132, $134,140,142,154,227,231,240,296$, 316

Socialist housing estate, 4, 63, 143, 152, 153, $155,181,273,274,296,333,357,358$, 371

Social polarisation, 118

Social rental housing, 210

Social space, 155

Socio-economic changes of housing estates Helsinki, 31

Socio-economic segregation, large housing estates impact on, 16

Socio-economic status, 16, 242

Socio-ethnic structure, 252-254, 260, 268

Socio-spatial change, 5

Socio-spatial differentiation, 51, 68, 264

Sønderborg, 359

South Belgrade, 133

Soviet daily life, 16, 17, 181, 185

Soviet Estonia, 105

Soviet housing estates, 68, 141, 247-251, 253, $254,257-263,265,266,268,269,333$

Soviet Union. See Russia

Soviet West, 118

Spain, 358, 359, 366 See also Madrid
Spatial organisation, 6, 16, 161, 177, 275, 317

Stadt, Karl Marx, 123

Stalin, Joseph, 9, 34, 38, 52, 53, 56, 59, 98

State-socialism, 154, 231, 240, 296

St. Louis, Missouri, 21

Stockholm, 11, 17, 98, 106, 277, 301, 304 See also Sweden large housing estates, 11

St. Petersburg, 41, 232

local housing market, characteristics of, 10

Sustainability, 22, 23, 357-359, 371

Svoboda, Josip, 134

Sweden, 13, 14, 32, 33, 83, 87, 98, 109, 123, 153, 277, 304, 305 See also Stockholm housing estates in, 305

Switzerland, 32, 305

Systematisation, 130, 131, 133

\section{T}

Talgre, Enno, 312

Tallinn, 4, 6, 8, 11, 13-15, 17, 19, 23, 35, 36, $38,43,45,74,75,86,90,95,96$, 104-106, 108-111, 119, 122, 123, 127, $128,133,139,143-145,148-153,155$, 203-220, 273, 274, 278, 279, 282-285, 287, 289-291, 294, 295, 301, 302, 307, $310-317,321,322,324,330-333,340$, $342,343,351,353$

larger housing estates in apartment associations, building, 3, 10, 13, 18, 21, 22, 204, 207, 274, 275, 291, 316, 331, 333, 339-345, 352, $353,357,359,364,367$

Mustamäe estate, 111 privatisation of apartments, 39, 205, 328,343

social composition of, 203 social degradation, 47, 213-215, 218 spatial and socio-spatial reality in, 162

Tamm, Väinö, 104

Tapiola, 11, 14, 16, 83, 84, 86, 101, 102, 104, 108-110, 112, 122, 277, 301, 304, 305, 312

Tartu, 17, 18, 22, 123, 143, 361, 362, 368, 369, 372,373

Tashkent, 118

Tenure, 51, 52, 55, 119, 121, 204, 210

structure, 56, 210

Tippel, Voldemar, 75, 110, 122, 144, 311

Tiškus, Gytis, 82

Tito, 131-134

Togliatti, 86 
$\mathbf{U}$

Újpalota, 127

Ukraine, 15, 40 high-rise estates, 15

Umbrasas, Algimantas, 82

Underurbanisation, 51-54, 56, 58, 64

Union of Soviet Socialist Republics (USSR), 4-6, 8, 10, 11, 13, 31, 34, 35, 37-39, 41, $42,46,56,72,73,84-86,99,118-122$, $124,125,129,132,139,141-144,148$, $152,153,155,156,162-164,166,171$, $172,177,185,188,198,307,309,310$

United Kingdom, 11

United States, 123

large housing estates, 14, 20, 275

Urban differentiation, 23

Urban infrastructure, 10, 53

Urban planning, 5, 10, 11, 14, 68, 71, 74, 75, $77,91,98,101,130,140,142,153,162$, $164,278,287,292,331,362$

Urban policies, 53,220

Urban regeneration, 358,360

Urban renewal

in France, 40

policies, 140, 220, 226

Urban revitalisation, 21

V

Väike-Õismäe, 8, 45, 86, 90, 91, 119, 127, 128, 144, 147, 148, 207, 214, 273, 274, 278-288, 290-296, 311, 314, 316

Valaitis, Teodoras Kazimieras, 307

Valakampiai, 187

Valiuškis, Gediminas, 74, 79, 307
Vällingby, 11, 12, 17, 83, 122, 301, 304, 305, 308,312

Vienna, large housing estates, 97

Vilkpede, 261

Vilma, 196

Vilnius, 8, 14, 17, 19, 20, 23, 34, 35, 43, 71, $73-76,78,79,81-85,87,90,122,127$, 133, 181-183, 194, 247-269, 301, 302, 306, 307, 310, 315-317

local housing market, characteristics of, 6 , $8,71,73,86,182,247,250,253,254$, 262-264, 266-269, 301, 306

Vitoria-Gasteiz, 359

von Hertzen, Heikki, 101

Võrno, R., 149

\section{W}

Wales, 40

Warsaw, 195

Wassenberg, F., 23

Western Europe, 134

Y

Yugoslavia, 117, 119, 130-134

$\mathbf{Z}$

Zalotay, Elemér, 127

Zelenograd, 86

Zhemchugov, O. , 149

Žirmūnai, 8, 17, 82, 84-86, 91, 181-184, 186-188, 190-194, 196-198, 250, 252, 261-264, 302, 306-309, 315

Zubrus, Vaclovas, 82, 85, 307

Zurich, 106 